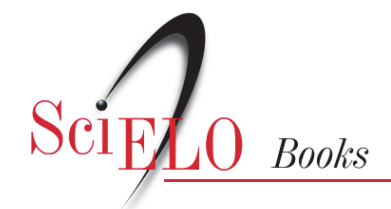

\title{
Tópicos em malacologia médica
}

\author{
Frederico Simões Barbosa \\ org.
}

BARBOSA, FS., org. Tópicos em malacologia médica [online]. Rio de Janeiro: FIOCRUZ, 1995. 314 p. ISBN 85-85676-13-2. Available from SciELO Books $<$ http://books.scielo.org $>$.

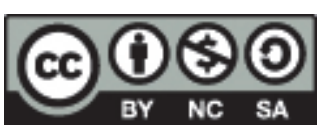

All the contents of this work, except where otherwise noted, is licensed under a Creative Commons Attribution-Non Commercial-ShareAlike 3.0 Unported.

Todo o conteúdo deste trabalho, exceto quando houver ressalva, é publicado sob a licença Creative Commons Atribuição Uso Não Comercial - Partilha nos Mesmos Termos 3.0 Não adaptada.

Todo el contenido de esta obra, excepto donde se indique lo contrario, está bajo licencia de la licencia Creative Commons Reconocimento-NoComercial-CompartirIgual 3.0 Unported. 


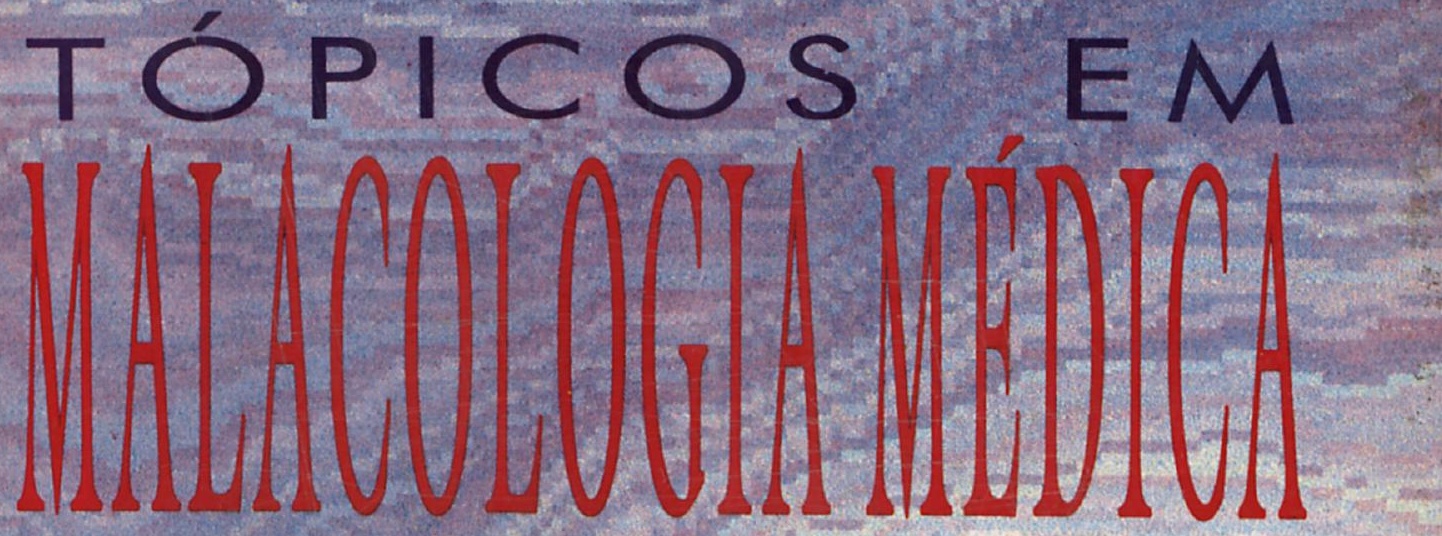

\section{Frederico Simōes Barbosa (Organizador)}
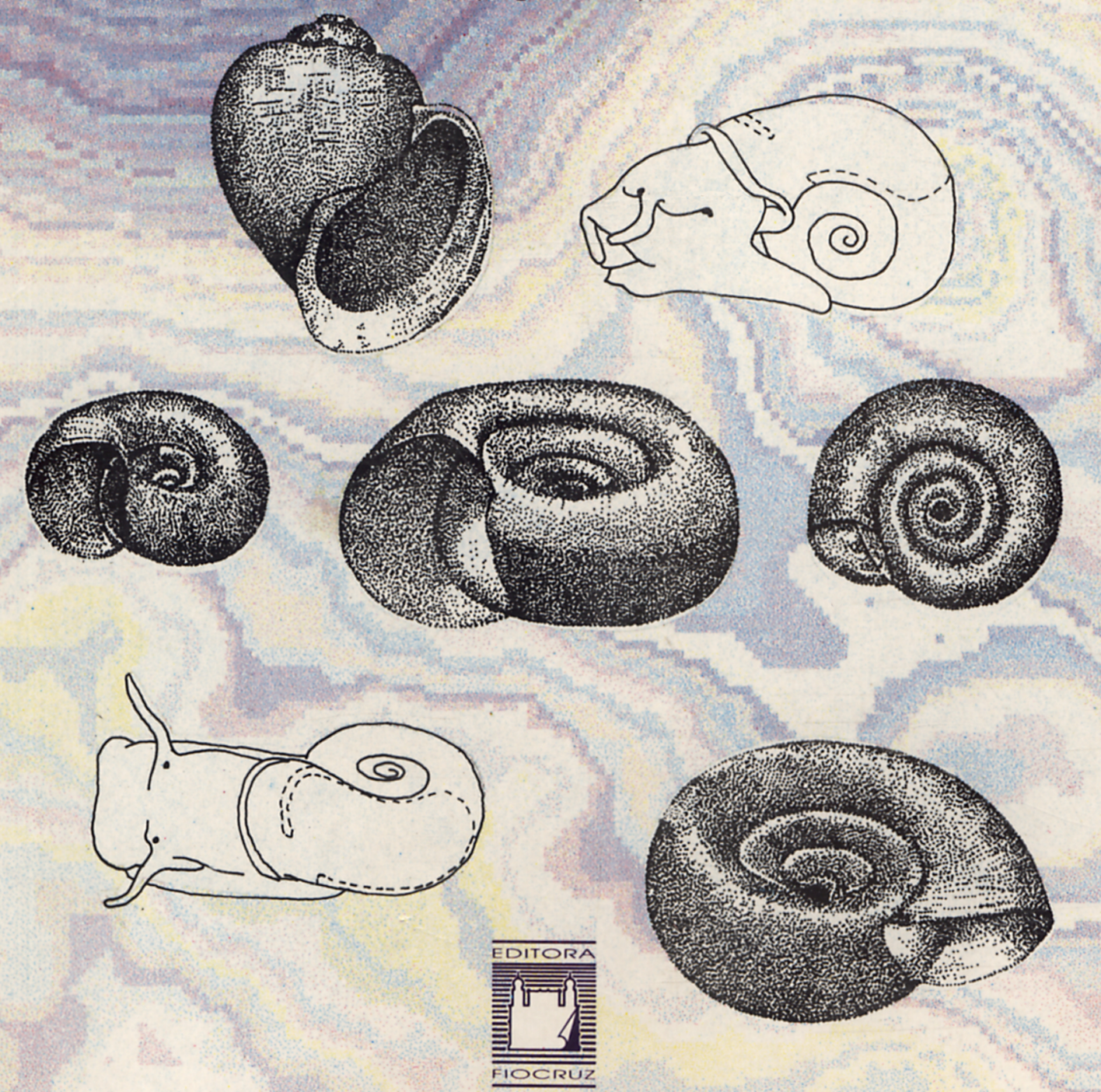


\section{TÓPICOS EM MALACOLOGIA MÉDICA}




\section{FUNDAÇÃO OSWALDO CRUZ}

Presidente

Carlos Médicis Morel

Vice-Presidente de Ensino e Informação

Paulo Marchiori Buss

\section{EDITORA FIOCRUZ}

Coordenador

Paulo Marchiori Buss

Conselho Editorial

Carlos E. A. Coimbra Jr.

Charles Pessanha

Hooman Momen

José da Rocha Carvalheiro

Luiz Fernando Ferreira

Paulo Gadelha

Paulo M. Buss

Sergio Goes de Paula

Zigman Brener

Coordenador Executivo

Francisco Edmilson M. Carneiro 


\section{TÓPICOS EM MALACOLOGIA MÉDICA}

Frederico Simões Barbosa

(Organizador) 
Copyright $\odot 1995$ by Frederico Simões Barbosa

Todos os direitos desta edição reservados à

EDITORA FIOCRUZ

ISBN: $85-85676-13-2$

Projeto Gráfico e Ilustrações de Capa: Lúcia Pantojo - SDE/ENSP

Revisão Técnica: Reinaldo $S$. dos Santos - SDE/ENSP

Revisão: Cláudia Cristiane Lessa Dias - SDE/ENSP

Marcionilio Cavalcanti de Paiva

Catalogação na Fonte

Centro de Informação Científica e Tecnológica

Biblioteca Lincoln de Freitas Filho

B $238 \mathrm{t}$ Barbosa, Frederico Simðes (Org.)

Tópicos em Malacologia Médica/Organizado por Frederico

Simões Barbosa - Rio de Janeiro: Fiocruz, 1995.

314 p. il. tab.

Inclui bibliografia

1. Moluscos. I. Título.

CDD - 20. ed. - 594

Rua Leopoldo Bulhões, 1480 - Térreo - Manguinhos

21041-210 - Rio de Janeiro - RJ

Tel.: 590-3789 r. 2009 Fax: (021) 280-8194 


\section{Sumário}

$\begin{array}{ll}\text { Prefácio } & 7\end{array}$

Introdução 11

1. Sistemática e Biogeografia

1.1 Morfologia Geral dos Moluscos, em particular da Classe Gastropoda José Luiz Moreira Leme

1.2 Família Pilidae Connoly, 1927 (Ampulariidae Gray, 1824) Silvana Thiengo

1.2.1 Gênero Pomacea (Perry, 1810) - Silvana Thiengo 53

1.2.2 Gênero Marisa (Gray, 1824) Antonio Carlos Marini \& Maria Dalva A. Mello

1.3 Famílias Chilinidae, Ancylidae, Physidae e Lymnaeidae Lais Clark Lima

1.4 Família Planorbidae - Lais Clark Lima

1.4.1 Espécies e subespécies do Gênero Biomphalaria Lais Clark Lima

1.4.2 Espécies hospedeiras de Schistosoma mansoni no Brasil Lais Clark Lima

2. Etologia

2.1 Catálogo Comportamental de Biomphalaria glabrata (Say, 1818) Pedro Jurberg, Rodolfo Armando da Cunha, Júlio Vianna Barbosa, Marisa da Silveira Soares, Virgínia Torres Schall \& Mário Jorge de Araújo Gatti

3. Embriologia

3.1 Embriologia - Toshie Kawano

\section{Relação Molusco/Parasita}

4.1 Ciclo Biológico do Parasita no Molusco - Paulo M. Zech Coelho

4.2 Resistência e Suscetibilidade à Infecção por Schistosoma mansoni em Caramujos do Gênero Biomphalaria - Paulo M. Zech Coelho

5. Controle

5.1 Controle Biológico dos Moluscos Transmissores da Esquistossomose: A Competição Interespecífica Biomphalaria glabrata x Biomphalaria straminea - Constança S. Barbosa \& Frederico S. Barbosa

5.2 Perspectivas no Controle Ambiental dos Moluscos Vetores da Esquistossomose - Otávio S. Pieri

6. Técnicas Malacológicas

6.1 Coleta; Remessa de Exemplares Vivos; Fixação e Dissecção Silvana Thiengo

6.2 Coleção Malacológica - Silvana Thiengo 
6.3 Infecção de Moluscos em Laboratório - Frederico S. Barbosa

6.4 Métodos e Técnicas Empregadas para o Estudo do Comportamento de Biomphalaria glabrata - (Say, 1818), (Gastropoda; Planorbidae), Caramujo Vetor da Esquistossomose - Pedro Jurberg,

Rodolfo Armando da Cunha \& Marcelo Luis Rodrigues

6.5 Cultivo em Massa de Biomphalaria straminea Constança S. Barbosa

6.6 Alimentação

José Rabelo de Freitas \& Mairy Barbosa Loureiro dos Santos 


\section{Prefácio}

É muito bem-vindo este livro de malacologia na atual conjuntura das Ciências Biológicas e da Saúde Pública do Brasil. Pensado e materializado no seio da Fiocruz e da Universidade, ele retrata uma vocação da comunidade científica brasileira para com suas doenças endêmicas, uma tradição consolidada desde Oswaldo Cruz e Carlos Chagas, no início deste século. Frederico Simões Barbosa e seus companheiros dão aqui seqüência a esta caminhada, trabalhando com os moluscos que, em nosso país, apresentam a sua maior importância quando veiculam a esquistossomose mansoni. Estimando-se que acometa pelo menos 10 milhões de brasileiros, a esquistossomose tem origens históricas nas fortes correntes da migração afro-brasileira dos tempos da escravidão, alcançando nosso país pelo Nordeste e encontrando possibilidades de transmissão em três espécies de moluscos brasileiros.

A par do grande interesse biológico e acadêmico que permeia a vida dos caramujos, é a esquistossomose em si o principal propulsionador do estudo destes moluscos entre nós. Disseminada por meio de migrações internas, a doença no Brasil sempre esteve ligada à maneira e à intensidade com que o homem se relaciona com as coleções naturais de água doce onde se encontram os caramujos do gênero Biomphalaria. Uma série de outros elementos epidemiológicos, de natureza bioecológica, política e social intervêm decisivamente neste ciclo, onde o caramujo é o vetor, e o homem, tanto quanto vítima, o principal protagonista. A esquistossomose aqui se determina basicamente sobre populações pobres e marginais cujas definições epidemiológicas mais visíveis são a falta de saneamento básico e um tipo de vida que induz ao contato com águas naturais poluídas. Desconforto, dores, baixa produtividade, disfunção hepática e intestinal, uma série enorme de formas exóticas e as temíveis conseqüências das formas hepatoesplênicas avançadas cobram o preço social da doença, muitas vezes desapercebido pelas elites dirigentes. Técnicos do próprio Ministério da Saúde do Brasil já referiam, em 1994 que "apenas $69,7 \%$ da população residente nos estados endêmicos para esquistossomose dispõem de água encanada. No Nordeste, região onde a doença apresenta as maiores prevalências e está mais disseminada, o suprimento de água é bem mais precário, atingindo apenas $49,2 \%$ da população. Praticamente inexiste suprimento de água nas áreas rurais. Esta medida, se adotada, produziria grande impacto na transmissão da esquistossomose, uma vez que no Japão essa providência reduziu em $72 \%$ as doenças intestinais. Com relação à população suprida com esgoto sanitário, o quadro 
é ainda pior..." Altos índices de analfabetismo, desnutrição, parcos salários e muito baixa capacidade de organização e reivindicação política são outras características das populações mais expostas à esquistossomose. O modelo político-econômico desprivilegia totalmente essas populações, oferecendo-lhes como estratégia de sobrevivência as migrações internas e a urbanização. Vão junto os esquistossomas e os caramujos, espraiando a dỏnça pelo País e urbanizando sua transmissão. Hoje já se conhecem importantes focos de esquistossomose com transmissão ativa em várias metrópoles brasileiras, coincidentemente acometendo as populações excluídas, mal assalariadas e desprovidas de educação, de água e de esgoto. Neste contexto e nesta história, os moluscos transmissores da esquistossomose no Brasil têm-se revelado bastante competentes, aprendendo a adaptar-se às mais distintas condições ambientais e a sobreviver ou recuperar suas populações em meio ambiente, provocada pelos resíduos industriais, por pesticidas agrícolas e mesmo por potentes moluscicidas. Visto até pouco tempo como o elo mais vulnerável da cadeia epidemiológica da esquistossomose, o caramujo mostrou-se um formidável adversário da Saúde Pública, sendo plenamente justificáveis os esforços para conhecê-lo melhor. Neste sentido, a malacologia brasileira teve o seu maior desenvolvimento a partir dos anos 50, quando bons grupos de investigação se iniciaram em Minas Gerais, em Pernambuco, na Bahia, em São Paulo e no Instituto Oswaldo Cruz. Nomes como Lobato Paraense e Simões Barbosa muito cedo se destacaram entre os grandes pesquisadores mundiais. Nos anos 60 , as áreas finalísticas do Ministério da Saúde ligadas à esquistossomose mantinham excelente interface com os centros de investigação e tinham mesmo sua própria massa crítica de pesquisa, desenvolvimento e vigilância sanitária concentrada no Instituto Nacional de Endemias Rurais (INERu). Na década de 70, no bojo do regime militar e de uma série de perseguições aos investigadores, a malfadada Reforma Rocha Lagoa fez desaparecer o INERu e enfraquecer bastante as relações entre os serviços e a investigação. Houve mesmo episódios de confronto, como aquele em que pesquisadores brasileiros foram pejorativamente tachados de "mandarins da esquistossomose" por autoridades ministeriais. Não obstante, iniciativas como o Programa Integrado de Doenças Endêmicas (PIDE), do CNPq, e os emergentes cursos de pós-graduação em algumas universidades reforçam as investigações sobre a esquistossomose. Desta época, o maior produto no âmbito da parasitose foi indubitavelmente a radical modificação de sua abordagem programática, advinda da descoberta de drogas esquistossomicidas como a Oxamniquine e o Praziquantel, capazes de controlar efetivamente as formas graves da doença. Pari passu, uma nova perspectiva de atenção à saúde se formatava em Alma-Ata, em busca das ações

\footnotetext{
*Amaral, R. S. \& Porto, MAS, 1994. Evolução e situação atual do controle da esquistossomose no Brasil. Revista da Sociedade Brasileira de Medicina Tropical, 27 (Suplemento III): 73-90.
} 
descentralizadas e da melhoria da atenção primária à saúde. O Brasil, que até então concentrava suas ações contra a esquistossomose no combate aos caramujos, pôde então desenvolver a moderna estratégia baseada no tratamento do infectado. Cessado o período de exceção, a VIII Conferência Nacional de Saúde levou à Constituinte uma nova lógica social, e os programas contra a esquistossomose no nível das populações afetadas começaram realmente a deslanchar. As ações diretas sobre os moluscos transmissores passaram a ser executadas em volume muito menor, somente justificadas em condições focais de extrema pressão de transmissão. Os recursos destinados às enormes quantidades de moluscicidas passaram a ser racionalizados em termos do diagnóstico da parasitose e seu tratamento, com o complemento de saneamento básico e de mobilização comunitária. Dados atuais da FNS de Minas Gerais, onde este programa se implantou em mais de 240 municípios nos últimos três anos, está demonstrando, através de avaliações periódicas, uma drástica redựção das formas graves da esquistossomose. Mas está demonstrando, também, que o uso de moluscicidas decaiu enormemente, sem efeito negativo sobre as taxas de prevalência, que também apresentam significativa redução em praticamente todas as áreas trabalhadas. Está demonstrando, enfim, que o programa pode ser responsavelmente conduzido em nível municipal, e que as pequenas obras de saneamento são possíveis e eficazes.

Com tais considerações poderia parecer incongruente retomar-se o vetor, na perspectiva deste livro. Em recente reunião da Sociedade Brasileira de Medicina Tropical (Salvador, 1994), a comunidade científica latino-americana procurou analisar a perda progressiva da "expertise" em vetores das nossas doenças endêmicas. Esta perda foi sentida como de grande intensidade, entendendo os especialistas que suas consequiências a médio e longo prazos se refletem negativamente na própria qualidade dos programas de controle. A grande biodiversidade e as inúmeras possibilidades de determinação da doença entre nós advertem pela prudência, pelo enfoque transdisciplinar e pela contínua vigilância epidemiológica. É ainda viva a lembrança do descaso, em São Paulo, de algumas autoridades sanitárias quando advertidas dos riscos de implantação da endemia, nos anos 40 , porque "os caramujos locais (Biomphalaria tenagophila) não eram sensíveis às cepas nordestinas de Schistosoma mansoni...". A manutenção da pesquisa em malacologia hoje se justifica plenamente. Novas situações epidemiológicas e a consolidação da luta antiesquistossomótica estão a exigir contínuo aperfeiçoamento dos técnicos, das estratégias e dos insumos pressupostos no programa. Como em várias outras doenças metaxênicas, os resíduos epidemiológicos são difíceis de extinguir e podem propiciar novas possibilidades de transmissão. A vigilância epidemiológica é o horizonte perceptível para a esquistossomose no Brasil, a demandar atenção e monitoramento contínuo sobre os principais elos da cadeia epidemiológica da doença. Além do mais, o controle do caramujo é ainda importante nos dias de hoje e se reconhece que os insumos utilizados ainda não são os ideais. 
Refira-se ainda que a fauna malacológica é muito rica e importante na biocenose de nossas águas, havendo muito por explorar e reconhecer.

Como mencionado, Frederico Simões Barbosa há muitos anos vem contribuindo na pesquisa, no ensino e na resolução de nossos grandes problemas de saúde, notadamente da esquistossomose. Sua vocação é estar permanentemente indagando, cercado de gente idealista, a dizer as suas coisas e a palmilhar sertões e povoados. Não estranha, pois, mais este livro, eminentemente prático e essencialmente dirigido à formação de técnicos e de alunos. Desde os primeiros textos da Sistemática e da Biogeografia, percebe-se a inquietação em contextualizar a malacologia brasileira numa projeção ao serviço. A Etologia, a Embriologia e a relação molusco-parasita abrem campo e caminho à discussão do controle. Esta se faz numa perspectiva ecológica, como se deveria esperar dos autores deste livro. Ao final, uma importante série de aspectos práticos compõe seis itens sobre técnicas malacológicas, destinadas ao estudante, ao técnico de campo e ao iniciante à pesquisa. Aqui se manifesta uma vez mais a sintonia dos autores com as questões éticas mais fundamentais para aqueles que estudam as coisas da Saúde Pública: o objeto a serviço do homem, na construção de uma sociedade em que as doenças não separem demasiadamente os homens. Num sentido prático, eles dividem o seu saber e o colocam a serviço da sociedade, no presente livro.

Há cerca de três lustros, Simões Barbosa me dizia pessoalmente na Ensp que acreditava numa Saúde Pública responsável e compartida, com bases sólidas nas próprias regiões endêmicas, fruto de uma epidemiologia local pronta e eficiente, voltada eminentemente para os agravos mais importantes. Era preciso preparar as pessoas para essa nova realidade. Hoje, professores e técnicos de serviço vivemos esta mesma busca, em especial depois que o País optou por uma nova ética social que norteou-se pelo desafio da saúde para todos. A construção desta saúde passa pelos ideários e pelos sonhos de gente como Frederico, assim como passa pela edição de obras que democratizem e que expandam o conhecimento como forma de liberação social. Sem dúvida, pelos caramujos também se pode chegar ao ser humano...

João Carlos Pinto Dias*

Belo Horizonte, agosto de 1995.

\footnotetext{
*Pesquisador Titular da Fiocruz e Professor Titular da Faculdade de Medicina da UFMG. Atual Coordenador da Fundação Nacional de Saúde em Minas Gerais.
} 


\section{Introdução}

A primeira impressão que se poderia ter desta publicação é a de que se trata de mais um manual de malacologia semelhante aos demais, surgidos em momento próprio, quando a malacologia se situava como campo de estudo aplicado e instrumento eficaz no controle da esquistossomose. Puro engano. A presente publicação tem como objetivo resgatar o vasto e valioso conhecimento, produzido particularmente neste país, no campo específico da malacologia médica e desenvolvido por pesquisadores brasileiros, a quem se fica a dever essa enorme riqueza contribuitiva à Ciência Nacional.

Os estudos de malacologia médica foram intensamente estimulados nas décadas de 50 a 70, período no qual os pesquisadores, apoiados por organizações nacionais e internacionais, sustentavam a opinião de que o uso dos moluscicidas era de substancial importância no controle da esquistossomose. Trabalhos de Farooq (Bulletin of the World Health Organization, 35: 331-338, 1966) e de outros muitos autores cimentaram estas idéias. Entretanto, uma avaliação independente do trabalho acima citado, feita por Gilles et al. (Annals Tropical Medicine and Parasitology, 67: $45-65,1973)$, mostrou que os resultados obtidos por Farooq não eram consistentes. Pesquisa a longo prazo (1966-1978), realizada no Nordeste do Brasil por Barbosa et al. (Annals of Tropical Medicine and Parasitology, 75: 41-52, 1981), evidenciou o valor muito restrito dos moluscicidas no controle daquela endemia.

O surgimento de novos quimioterápicos específicos, capazes de reduzir a prevalência da infecção e das formas hepatosplênicas da doença esquistossomótica, veio colocar o problema do controle das endemias em outros termos.

A incapacidade, não-confessada, de controlar a esquistossomose, utilizando-se os meios tecnológicos clássicos aplicados verticalmente nas regiões endêmicas, veio mostrar, mais uma vez, que a natureza tem razões que o homem procura desconhecer.

Com as evidências acima e o fato bem-estabelecido de que a erradicação da esquistossomose só foi possivel em país desenvolvido (caso específico do Japão), foram criadas várias abordagens, procurando-se envolver as comunidades e aceitando-se como importante a incorporação do controle da endemia nas estruturas dos serviços de saúde em nível local. Estava criado um modismo que veio para ficar, enquanto o caso da esquistossomose for tratado dentro do conceito da Ciência Autosustentada, criticamente analisado por Kloetzel (Cadernos de Saúde Pública, 8: 204206, 1992).

Não que se pretenda negar ò valor da Ciência, mas que se procure dignificar o homem como o alvo de todos os nossos interesses. 
Kloetzel cita que a esquistossomose pode ser controlada por processos simples e investimentos modestos (Parasitology Today, 5: 388-391, 1989), desde que se procure entender como se passam os processos mórbidos no contexto sociocultural, econômico e político das sociedades subdesenvolvidas, como comentado por Barbosa \& Coimbra (Memórias do Instituto Oswaldo Cruz, 87, Supl. IV: 215-220, 1992).

A malacologia médica teve seu apogeu. O Brasil produziu substancial quantidade de trabalhos de incontestável mérito, voltados particularmente para a sistemática, a distribuição geográfica, a Biologia, a Ecologia, a Etologia, a relação hospedeiro/parasito e o controle dos moluscos. A Fundação Oswaldo Cruz sedia o Laboratório Internacional de Referência em Malacologia Médica. O primeiro manual de malacologia médica foi criado neste país por Barbosa et al. (Manual de Malacologia Médica, 1960).

Tópicos em Malacologia Médica contou com renomados especialistas brasileiros que desempenharam a árdua tarefa de escrever os tópicos relacionados com a vida, o comportamento e os possíveis métodos alternativos de controle dos moluscos, distribuídos em seis capítulos. O sexto e último trata de assunto prático, envolvendo as técnicas de manejo dos caramujos transmissores da esquistossomose.

Diante deste magnífico acervo científico e ante as evidências de que o controle da esquistossomose passa por outros caminhos distantes das obsoletas estratégias operacionais, utilizadas no passado, poder-se-ia perguntar se ainda haveria espaço para investigações no campo da malacologia médica.

A resposta é seguramente positiva. Os avanços da Biotecnologia indicam uma série de investigações particularmente voltadas para: manipulação genética; genética de populações e cruzamentos interespecíficos; mecanismos responsáveis por superioridade competitiva de cepas de caramujos em testes de deslocamento competitivo; descoberta de novos competidores; estudos quantitativos sobre dinâmica populacional; pesquisas abrangentes de campo sobre Ecologia; e o comportamento dos moluscos, que são, entre outros, assuntos da maior relevância para a compreensão de mecanismos a fim de que se possa chegar ao desenvolvimento de metodologias alternativas de controle dos transmissores da esquistossomose.

A leitura atenta dos diversos tópicos desta publicação indicará ao leitor muitos outros caminhos atraentes para o desenvolvimento de pesquisas, principalmente na área básica: morfologia e sistemática, fisiologia, embriologia e.relações molusco/parasito.

Tem, assim, a malacologia médica extraordinário campo de trabalho aberto aos investigadores.

Aos colaboradores que nos honraram com suas contribuições, nossos agradecimentos. Tópicos em Malacologia Médica reflete o elevado nível da comunidade científica do país neste campo específico. Lamentamos a ausência de alguns colaboradores convidados que, por motivos diversos, não puderam atender a nossa solicitação.

Aos leitores, nossa expectativa de que estes Tópicos possam lhes dar apoio e valiosas sugestões de pesquisa. 
Sistemática e Biogeografia 


\subsection{Morfologia Geral dos Moluscos, Em Particular da Classe Gastropoda}

\section{INTRODUÇÃO}

Considerando a característica da obra como um todo e as limitações estabelecidas para a inclusão deste capítulo, minha intenção foi dividir em duas partes a matéria a ser apresentada.

$\mathrm{Na}$ primeira delas procurei introduzir generalidades sobre os moluscos, através de um texto livre e contínuo, evitando ao máximo notas, citações e referências a Figuras; procurando, assim, prender o leitor ao raciocínio apresentado e não remetê-lo ao exame de preconceitos que o mesmo preteritamente deveria possuir. Por esta razão o estudo dos gastrópodes foi deliberadamente deixado para o fim e não colocado no ponto que lhe cabia pelas interpretações sistemáticas e filogenéticas. Fui procurando sempre colocar as informações cabíveis dentro da melhor fluência do texto; às vezes ferindo as sequiências tradicionais do tratamento da matéria, mas sempre procurando a melhor transmissão do conhecimento.

$\mathrm{Na}$ segunda parte, a pretensão foi apresentar um estudo comparado dos caracteres diferenciais das diversas categorias sistemáticas tratadas, através de um relacionamento direto do texto com as ilustrações.

\section{PHYLUM MOLLUSCA}

\section{Parte Geral}

Os moluscos constituem um dos grupos mais dificilmente definíveis do Reino Animal, graças à extraordinária variabilidade de forma e às adaptações funcionais e ambientais apresentadas pelos seus representantes. Encontram-se entre os Celomata Bilateria, sendo a assimetria e a redução do celoma, encontradas em grande número de famílias e ordens, uma alteração secundária adquirida ao longo da evolução do filo.

Os demais caracteres normalmente destacados nas definições dos filos apresentam em Mollusca tão grande diversidade que torna indispensável a discussão das exceções sempre que uma qualquer característica é mencionada e definida.

Quanto ao número de espécies conhecidas cientificamente, mais de $110 \mathrm{mil}$ (Russell-Hunter, 1969); esse ramo só é suplantado pelo filo Arthropoda. Os registros paleontológicos acusam espécies de moluscos encontradas desde o pré-Cambriano, 
sendo notável o desenvolvimento dos Cephalopoda até o fim do Cretáceo, quando muitas de suas familias e ordens foram extintas.

Originados no mar, os moluscos conquistaram todos os ambientes naturais, mesmo os mais especializados micronichos ecológicos. Foram encontradas espécies desde as mais profundas depressões marinhas até as grandes altitudes montanhosas, em regiões áridas e desérticas e até em planícies geladas duramente atingidas pela longa duração do inverno.

Também o elevado desenvolvimento do sistema nervoso, da visão e da capacidade de aprendizagem dos Cephalopoda, tanto como o do sistema renal dos Gastropoda terrestres, são dados que constatam a grande importância dos moluscos no Reino Animal.

De outro lado encontramos espécies de moluscos adaptadas ao parasitismo com extrema redução dos órgãos e sistemas.

Ainda no aspecto da importância deve-se aqui mencionar a utilização de espécies de moluscos para a alimentação do homem desde a pré-história até hoje; na confecção de utensílios domésticos e de adorno, nas artes, nas religiões, etc.

Os moluscos compreendem os caramujos, os caracóis, as lesmas, os polvos, as lulas, as "lebres do mar", os mariscos, as ostras, etc.

Tal dificuldade de definição geral dos moluscos levou os especialistas a idealizarem um arquétipo ideal que teria as condições de dar origem às formas conhecidas. A descrição de tal arquétipo, que foge ao objetivo deste texto, pode ser facilmente encontrado na maioria dos livros de texto.

Apenas para facilidade didática vamos reunir todos os moluscos primeiramente em dois grupos, as classes maiores ou principais e as menores, perfazendo um total de oito classes, como é atualmente aceito na sistemática do filo.

As classes maiores, mais conhecidas e exploradas em todos os livros de texto de todos os níveis de ensino, são: Gastropoda, Bivalvia e Cephalopoda, sendo a última constituída por moluscos exclusivamente marinhos, a intermediária por espécies exclusivamente limitadas ao meio aquático e a primeira, que reúne o maior número de espécies viventes, habita todos os ambientes.

As cinco classes menores abrangem espécies limitadas ao ambiente marinho. São elas: Caudofoveata, Solenogastres, Monoplacophora, Poliplacophora e Scaphopoda.

Propositadamente foi deixado para o final desta parte introdutória tudo o que se refere a concha, que é o esqueleto do animal, geralmente de carbonato de cálcio e que pode ser externa, interna ou faltar completamente, tendo tais condições alternativas diferentes conotações sistemáticas, dependendo do táxon onde tal situação ocorre.

O importante, a nível de classe, é se conhecer e interpretar a relação entre a concha e as partes moles do animal. Em outras palavras, qual a utilização da concha pelo animal nas diferentes classes. 
Seguindo, ainda, o objetivo da facilitação didático, vamos introduzindo os conceitos de relação concha/partes moles à medida que formos definindo cada uma das classes, numa seqüência não obrigatoriamente filogenética, mas naquela de melhor entendimento do texto por parte do leitor. A seqüência será apresentada mais adiante.

O aprofundamento nos detalhes morfológicos, biológicos, ecológicos e filogenéticos será realizado na classe Gastropoda que é o foco principal desta obra.

\section{Classe Caudofoveata (Figuras 1-4)}
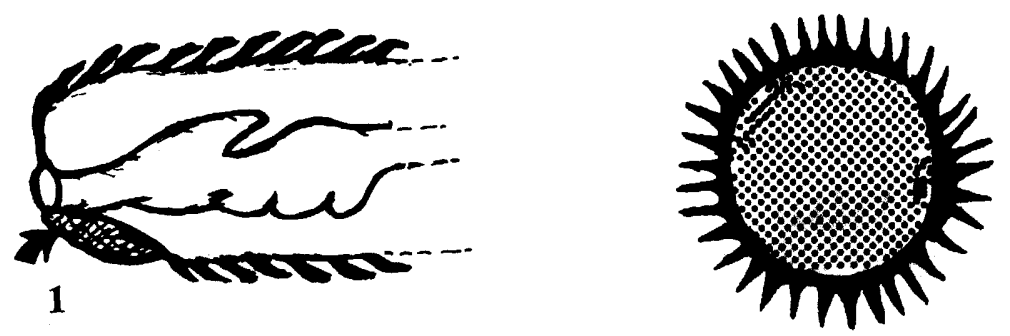

2

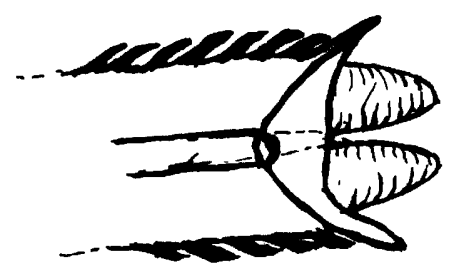

3

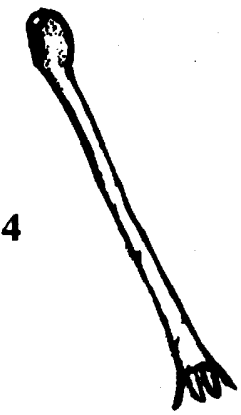

Reúne moluscos marinhos de corpo vermiforme mais ou menos alongado, de secção cilíndrica, com 2 a 140 milímetros de comprimento, desprovido de concha na fase adulta, mas com o manto coberto por uma cutícula quitinosa com escamas ou espículas imbricadas. Cabeça maldefinida, protegida por um escudo cuticular, oral-pedioso, que delimita anteriormente a boca; rádula bi-partida, intestino-reto; cavidade palial pósteroterminal, um par de ctenídeos (brânquias) bipectinados, prolongados para o exterior. Coração com um ventrículo e um par de aurículas pobremente desenvolvidas; sem órgãos excretores definidos. Sexos separados, fecundação externa, gônadas liberando seus produtos através de um ducto pericardial e sem gonoduto especializado.

São bentônicos, escavadores e alimentam-se de microorganismos e detritos.

São conhecidas cerca de 70 espécies, colocadas em sete gêneros e três famílias, nenhuma ocorrendo no Brasil. 


\section{Classe Solenogastres (Figuras 5-8)}

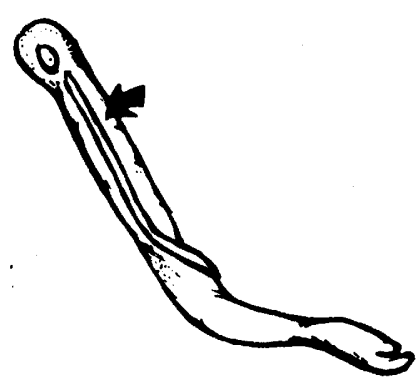

5

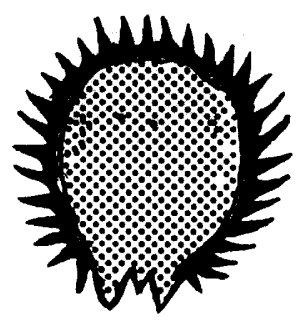

7

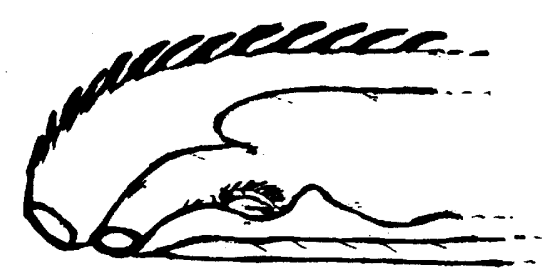

6

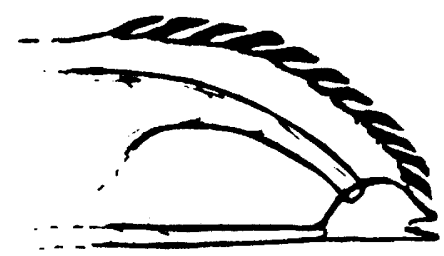

8

Moluscos de corpo vermiforme mais ou menos alongado e lateralmente comprimido, com 1 a 300 milímetros de comprimento; primitivamente sem concha ou placas, com o integumento palial, envolvendo todo o corpo com exceção de uma goteria ou sulco longitudinal ventral, o sulco pedal, característica principal da classe e razão do seu nome (solem = goteria + gaster $=$ ventre $)$. Secundariamente a cutícula sobre o integumento pode ser coberta por escamas ou espículas. Intestino reto, cavidade palial posterior subterminal sem ctenídeos (brânquias), podendo apresentar estruturas respiratórias secundárias, com lamelas, pregas ou papilas. Hermafroditas, com aparelho copulador presente, fecundação interna.

A classe abriga espécies marinhas de vida livre e epibiótica em sedimentos ou epizóicas sobre cnidários, como predadores. Reúne quatro ordens, 21 famílias, 60 gêneros e 180 espécies. Recentemente foi assinalada a ocorrência de uma espécie dessa classe no Rio Grande do Sul (Rios, 1985).

Os Caudofoveata e os Solenogastres eram reunidos na subclasse Aplacophora nas classificações mais antigas, como a apresentada por Wilbur \& Yonge (1964). Em alguns trabalhos de compilação, até mais recentes, como os de Abbott \& Boss (1989) e Rios (1985), Aplacophora tem status de classe. 


\section{Classe Monoplacophora (Figuras 9-11)}

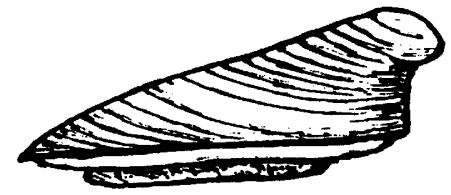

9

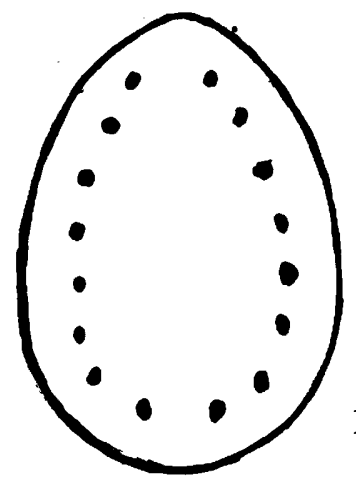

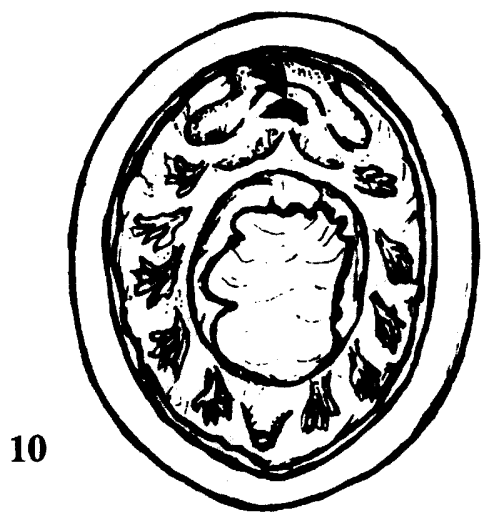

Moluscos bilateralmente simétricos com pé ventral, intestino reto com ânus medianamente terminal. Manto totalmente coberto por uma concha univalva oval não- enrolada e cavidade palial limitada a um par de fendas laterais rasas, contendo cinco pares de brânquias unisseriadas. Dois pares de aurículas, um par de ventrículos, dois pares de gônadas, descarregando seus produtos com cordões nervosos longos e paralelos.

A classe reúne oito espécies marinhas de profundidade entre 200 metros e depressões abissais. Não ocorre no Brasil.

A principal característica de classe é a segmentação muscular que deixa uma série de cicatrizes na superfície interna da concha. A descoberta da espécie Neopilina galathea (Lenche, 1957), com tais caracteres, motivou uma revisão geral na caracterização do filo Mollusca, adaptando-a para a inclusão da nova espécie segmentada. As cicatrizes musculares já eram conhecidas em conchas fósseis cuja classificação sistemática foi impossível até o encontro do primeiro exemplar vivo e a interpretação das mesmas. 


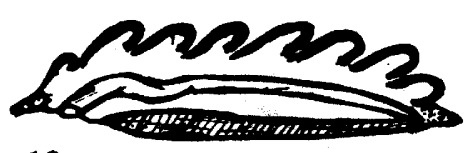

12
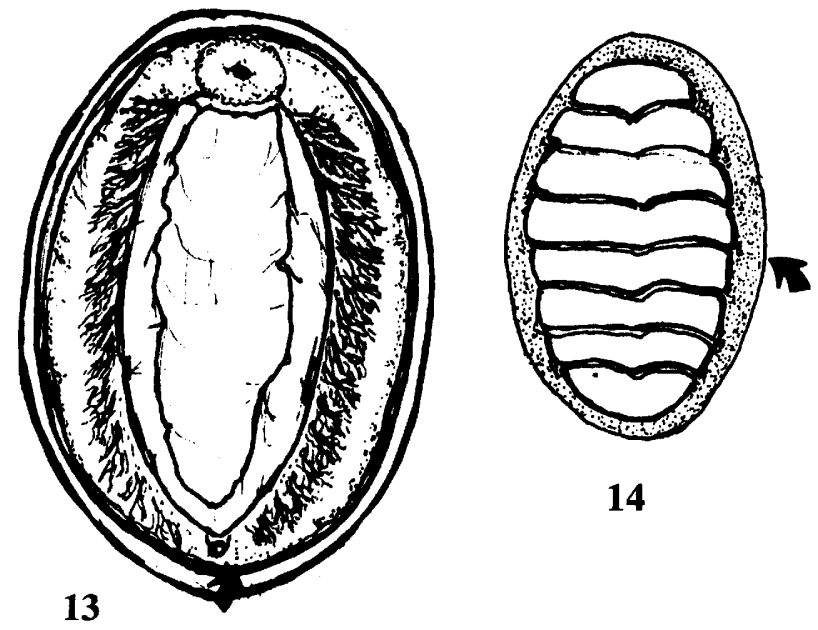

14
15
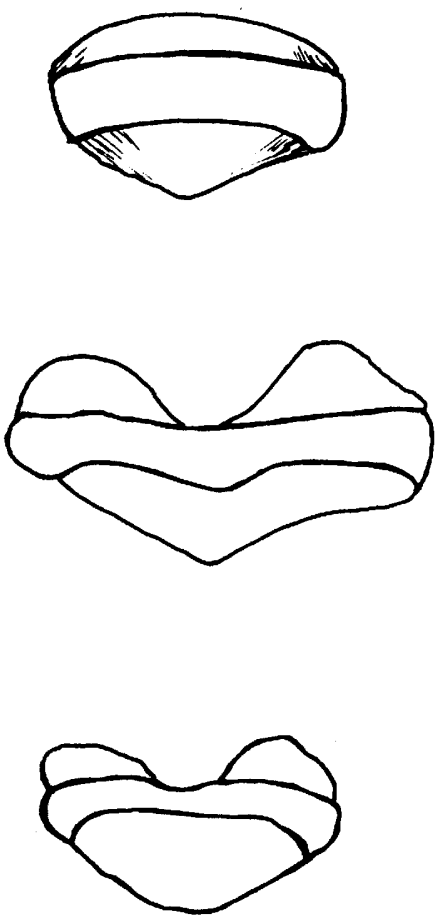

A principal característica dessa classe é a presença de uma concha oval, deprimida, bilateralmente simétrica, formada por oito placas imbricadas, circundadas e unidas por um cinturão coberto por escamas, espinhos, espículas ou cerdas calcárias ou quitinosas.

A concha protege dorsalmente todo o corpo do animal, que é alongado e deprimido, com as aberturas oral e anal diametralmente opostas.

A cabeça não é diferenciada e o pé é circundado pela cavidade do manto transformado em um sulco periférico que abriga de 6 a 88 pares de brânquias. A sola alargada, adaptada à fixação por sucção em substratos rochosos.

O coração possui um ventrículo e um par de aurículas simétricas e os rins apresentam ramificações e formas variadas.

Os sexos são separados e a fecundação é externa.

A classe reúne espécies marinhas bentônicas e herbívoras, geralmente de águas rasas, embora tenham sido encontradas espécies em até 7.000 metros de profundidade. Todas as espécies recentes são agrupadas na subclasse Neoloricata, tendo sido assinaladas para o Brasil 16 espécies. 
Os Polyplacophora, juntamente com os Aplacophora, eram reunidos, nas classificações mais antigas, na classe Amphineura, devido às peculiaridades do sistema nervoso.

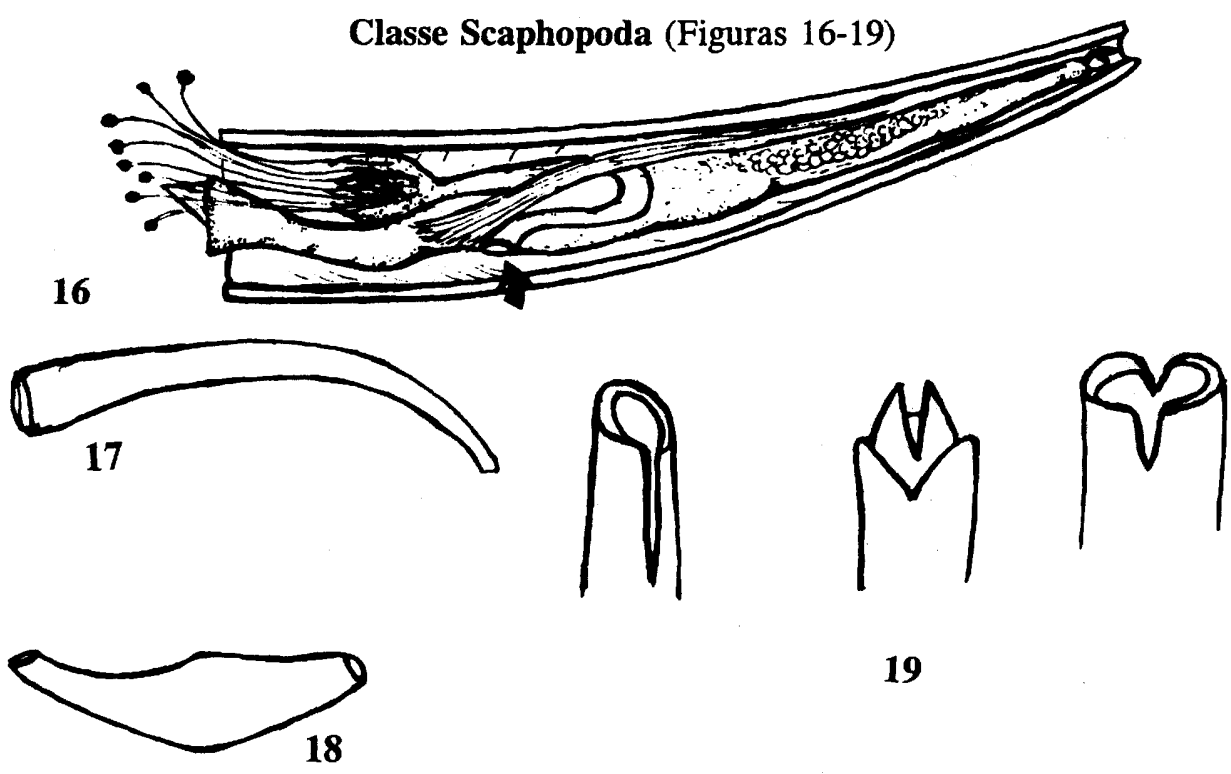

A classe reúne espécies bentônicas marinhas bilateralmente simétricas que apresentam corpo cilíndrico alongado, protegido por uma concha tubiforme aberta nas duas extremidades, sendo a anterior, ou basal, mais larga e a posterior um simples orifício geralmente continuado por uma fenda ou entalhe apical, com a face dorsal côncava e a ventral convexa, tomando o aspecto de um dente de elefante que motiva o nome do seu principal gênero, Dentalium.

Os Scaphopoda não apresentam cabeça diferenciada, sendo a região cefálica resumida a uma massa bucal que contém interiormente o aparelho radular e é circundada por um anel de prolongamentos finos tentaculiformes, captácula, adaptados à apreensão e transporte de partículas até a boca, e às funções tácteis. $\mathrm{O}$ pé é pontiagudo, adaptado à perfuração do solo arenoso. Também não possuem brânquias, sendo a respiração exercida por uma dobra da parede interna do manto; o coração é reduzido, sem aurículas, representado apenas por um fraco desenvolvimento do pericárdio. Apresentam um par de nefrídios lobados que se abrem na cavidade do manto através do ânus. Os sexos são separados e a gônada única, não se prolongando em oviduto ou qualquer órgão de cópula. A fecundação é externa, e a passagem dos gametas realizada através do seu rim direito.

São animais bentônicos, que vivem desde o sublitoral até profundas depressões além de 6.000 metros. 
São conhecidas aproximadamente 350 espécies, sendo 30 assinaladas na fauna brasileira.

Classe Bivalvia (Figuras 20-22)

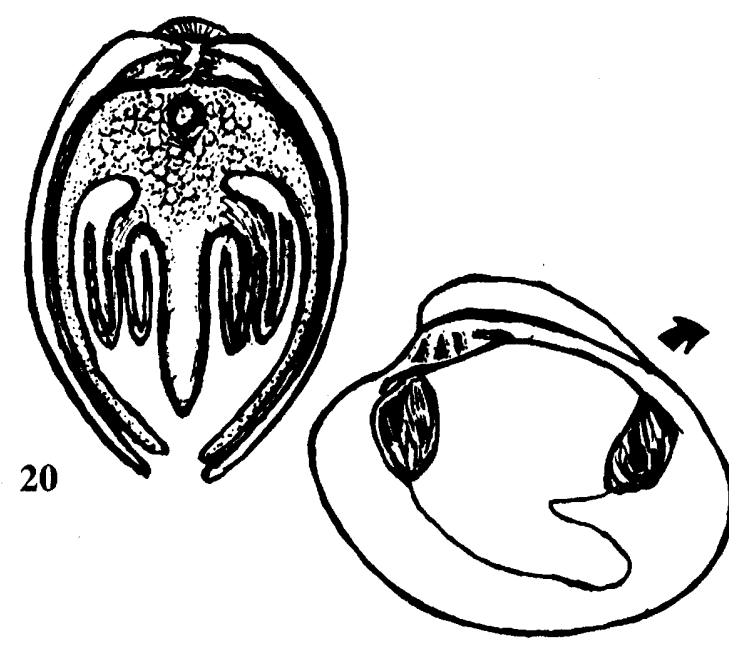

22

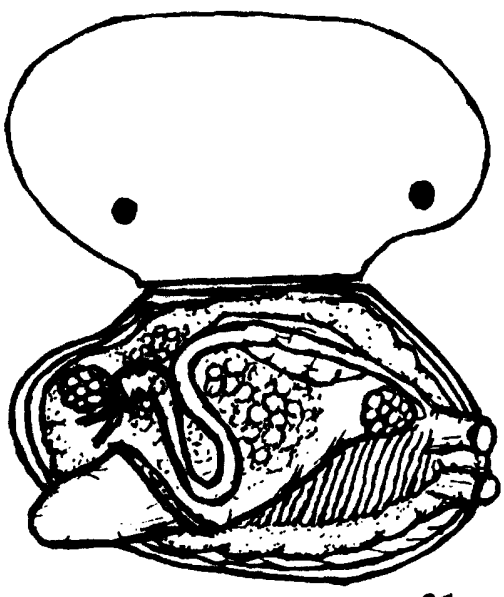

21

Essa primeira classe, dentre as maiores na propositura inicial deste texto, é constituída por moluscos bilateralmente simétricos limitados ao meio aquático, cujo corpo inteiro é geralmente envolvido por uma concha formada por duas valvas articuladas pela região dorsal e com a região cefálica extremamente reduzida sem apresentar cabeça, tentáculos, olhos e rádula. As brânquias apresentam, geralmente, um grande desenvolvimento e distribuem-se em forma de lâminas expandidas sob os dois lobos do manto que forram totalmente a superfície interna das valvas. Tal expansão das brânquias já valeu à classe o nome de Lamellibranchia ou Lamellibranchiata, nas classificações mais antigas. Da mesma forma a adaptação do pé em forma de cunha para a penetração e estabilização no solo deu à classe o antigo nome Pelecypoda (do grego, pelekys $=$ machadinha + podos $=$ pé $)$. Ainda, devido a ausência total de cabeça, essa classe foi também chamada Acephala.

Para fins descritivos podemos dividir o corpo de um Bivalvia em quatro partes: Massa visceral, pé, manto e brânquias.

A massa visceral ocupa toda a região entre os dois lobos do manto e abriga os sistemas de órgãos digestivos, circulatórios, excretores, reprodutores e nervosos.

O tubo digestivo se inicia anteriormente pela boca que é geralmente precedida por um par de palpos labiais, dotados de cílios que tem por função orientar as correntes de partículas para a fenda bucal. Nunca apresenta rádula e o esôfago é curto, sendo o desenvolvimento do estômago e do intestino bastante variável e relacionado ao hábito alimentar. Um par de glândulas digestivas envolve o estômago 
e grande parte do intestino, o ânus pode se abrir diretamente para o exterior na região posterior ou se alojar junto ao sifão exalante nas espécies mais evoluídas.

$\mathrm{O}$ aparelho circulatório apresenta uma uniformidade em todos os Bibalvia, com exceção dos Septibranchia onde é extremamente simplificado. Constitui-se de um coração dorsal com um ventrículo e duas aurículas laterais, envolvidos por um pericárdio que também envolve o reto.

O sistema excretor é constituído por um par de rins tubulares em forma de $\mathrm{U}$, abertos no pericárdio através de um conduto ciliado, que descarrega, além dos excretos nitrogenados, os gametas produzidos em um par de gônadas.

$\mathrm{Na}$ grande maioria das espécies os sexos são separados, mas alguns são hermafroditas, geralmente, apresentando protandria. Em algumas as larvas são livres natantes, em outras são parasitas de peixes e outros organismos aquáticos.

O sistema nervoso inclui três pares de gânglios (cerebropleural, visceral e pedal) com fibras interconectantes, órgãos fotossensíveis, nas margens de manto e algumas estruturas sensoriais.

O pé, que é uma expansão muscular antero-ventral que pode se estender além das margens ventrais das valvas quando estas estão afastadas, é usado para a locomoção e perfuração do solo. Nas espécies adaptadas à vida sedentária, como as do gênero Mitylus, por exemplo, o pé é reduzido, sendo a fixação ao substrato feita através de prolongamentos proteicos, retráteis chamado bissus, produzido por células especializadas, as glândulas bissógenas. Outras se fixam de forma definitiva pela cimentação de uma das valvas ao substrato como acontece com as ostras.

Nas espécies adaptadas à perfuração de madeiras ou de rochas o pé também se apresenta bastante modificado.

Nos Bivalvia o manto é dividido em dois lobos que se aderem à superfície interna de cada uma das valvas. Podemos interpretá-lo como uma delgada lâmina de tecido conjuntivo revestida em suas faces por tecido epitelial, sendo a interna forrada por cílios e substrato de apoio para a base das brânquias.

O lobos paliais podem apresentar seus bordos inteiramente livres ou fundidos em uma, duas ou três regiões, podendo a região posterior ser prolongada em sifões livres ou reunidos por uma banhia. A presença e o desenvolvimento dos sifões indicam o hábito do animal penetrar mais ou menos no substrato.

Os músculos adutores ultrapassam os limites do manto e se fixam nas faces internas das valvas, deixando nestas cicatrizes amplamente utilizadas na identificação específica e supra-específica.

As brânquias oferecem os mais valorosos caracteres para a interpretação sistemática dos Bivalvia a nível supragenérico.

A concha, que pode se modificar muito em casos especiais de adaptação ambiental, chegando até a ser interna ou faltar na fase adulta de algumas espécies, apresenta um grande número de caracteres taxonômicos na sua estrutura e na escultura da superfície externa. 
Também na superfície interna das valvas são encontrados caracteres utilizados na taxonomia, deixados pelas impressões das outras partes moles além dos músculos adutores, tais como: a linha palial impressa pelos bordos livres do manto; o sinus sifonal, marcado pela situação do sifão em posição de retração, e o sinus bissal.

Os principais caracteres estruturais da face interna das valvas são os apresentados pela charneira que é a região de articulação do bordo dorsal das valvas, que apresenta dentes, fossetas e entalhes carcterísticos.

A classe abriga cerca de 8.000 espécies, separadas em cinco subclasses, amplamente representadas no Brasil.

Esta classe reúne moluscos marinhos bilateralmente simétricos com um elevado desenvolvimento da cabeça que é circundada por uma coroa de oito ou dez tentáculos (ou braços) musculares extremamente móveis e geralmente dotados de ventosas preensis. O sistema nervoso é altamente desenvolvido e cefalizado por uma cápsula cartilaginosa; os olhos são semelhantes aos dos vertebrados, com retina $\mathrm{e}$ cristalino; órgãos de equilíbrio apresentam canais alojados no interior de cápsulas cartilaginosas também semelhantes aos canais semicirculares do ouvido interno dos vertebrados.

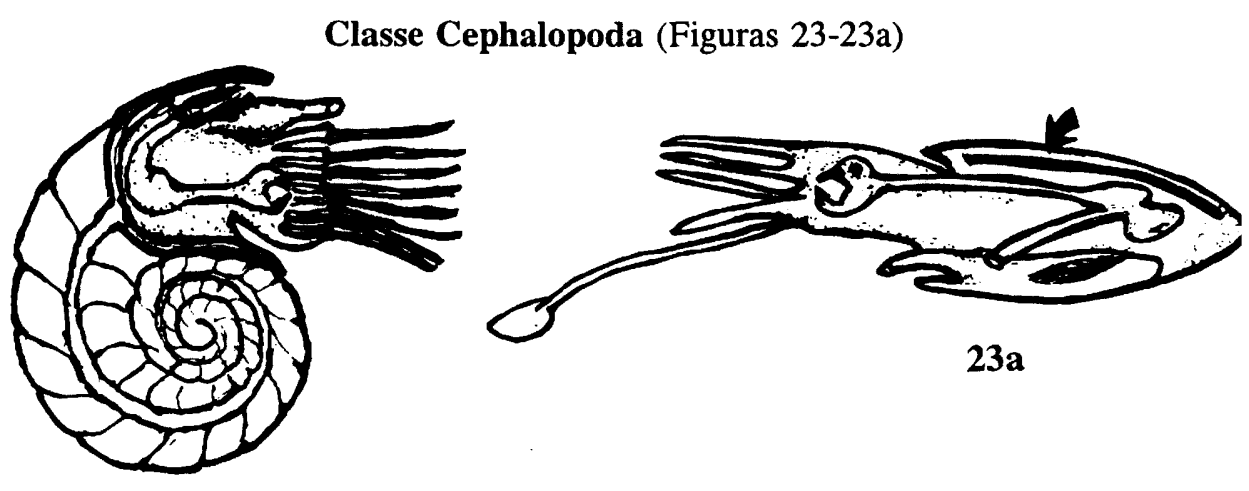

23

O manto envolve praticamente todo o corpo, deixando livres apenas a cabeça e o sifão, ou funil, que é o órgão de propulsão do animal resultante da transformação do pé, no entender de alguns especialistas, enquanto para outros é um prolongamento da borda do manto. A água da cavidade do manto é expelida através da ação muscular do funil, cuja abertura pode ser dirigida para frente ou para trás, orientando o deslocamento do animal em sentido contrário ao do jato.

A fenda bucal é protegida por um par de mandíbulas em forma de bico de papagaio, e a massa bucal abriga o aparelho radular. O tubo digestivo é curto e em forma de $\mathrm{U}$ com o ânus abrindo-se junto à base do funil. 
O sistema circulatório é complexo em relação ao das demais classes, chegando a ser fechado, apresentando um ou dois pares de aurículas e um ventrículo mediano, além de corações acessórios na base das brânquias.

O número de brânquias, um ou dois pares, é caráter importante nas categorias altas da sistemática dos Cephalopoda. A subclasse Nautiloidea (=Tetrabranchiata) é representada atualmente por um único gênero Nautilus, que é também o único que apresenta concha típica externa.

No gênero Argonauta (dibranquiado) a fêmea produz, por meio de glândulas de massa cefalopediosa, uma pseudoconcha incubadora. $O$ número de rins é relacionado ao número de brânquias. Os sexos são separados, a gônada é ímpar com um par de gonodutos nas fêmeas e um gonoduto nos machos. A fecundação é interna e os espermas são envolvidos em espermatóforos que são transportados para as fêmeas por meio de um braço modificado chamado hectocótilo. O desenvolvimento é direto, sem larva.

\section{Os Cephapoda são nectônicos e carnívoros.}

A concha externa em Nautilus é bilateralmente simétrica, enrolada planispiralmente, formada por voltas internamente separadas por septos, que deixam passar pelo seu centro um canal, o sifúnculo, que estabelece contacto entre todas as câmaras e auxilia o deslocamento vertical do animal pelo controle da pressão interna. As partes moles são alojadas apenas na última e maior câmara, que por isso é chamada de volta do corpo.

Os Cephalopoda dibranquiados (Coleoidea) ou não apresentam concha, como os polvos, ou possuem concha interna, de constituição calcária, como nos gêneros Sepia e Spirula, ou córnea, como no gênero Loligo (lulas).

A subclasse Coleoidea (=Dibranchiata) reúne quatro ordens: Sepiida (Sepia e Spirula); Teuthida (Decapoda); Vampiromorpha e Octopoda; com cerca de 600 espécies viventes, sendo 26 assinaladas na fauna brasileira.

Mais detalhes de definições e descrições das sete classes até aqui tratadas podem ser encontradas em Boss, 1982; Hyman, 1967; Morton \& Yonge, 1964; Purchon, 1968.

\section{Classe Gastropoda}

Esta última classe a ser estudada é a mais importante, quer pelo aspecto numérico, quer pelo aspecto evolutivo e, principalmente, pelo extraordinário êxito na conquista ambiental e na diversidade morfológica. Quanto a essa última condição, a classe Gastropoda transcende os limites do filo, estando entre os mais bem adaptados invertebrados, no que diz respeito a resistência às variações extremas de: 
temperatura, profundidade no ambiente marinho; altitude no ambiente terrestre; pressão de água ou ar; salinidade no meio aquático e umidade no meio terrestre.

Isso se deve a grande variação morfológica observada nos sistemas respiratórios, excretor, digestivo e reprodutor, dos mais diferentes grupos que constituem a classe.

O nome Gastropoda, que vem do grego Gaster $=$ Ventre + podos $=$ pé, devese a expansão musculosa de superfície ventral achatada em forma de sola que propicia a locomoção do animal por meio de desligamento, a qual se convencionou chamar de pé. Essa massa musculosa é fundida com a cabeça, formando uma peça, às vezes dificilmente delimitada, o cefalopódio ou massa cefalopediosa.

O cefalopódio é a única região do animal que se expande para fora do limite da concha quando o animal se apresenta em atividade. $O$ restante do corpo, que constitui a massa visceral, é constantemente protegido pela concha, na grande maioria das espécies que possui tal esqueleto externo.

A relação concha/corpo diferencia de maneira absoluta os Gastropoda das demais classes já analisadas.

Antes de explicar essa relação, é importante que se informe aqui que, ao longo da evolução, várias espécies sofreram transformações que levaram à redução e até ao desaparecimento da concha, enquanto, em outras, essa peça esquelética migrou para o interior das partes moles.

A concha univalva enrolada típica dos gastrópodes (caracol) é constituída por voltas que deixam um espaço contínuo interno desde o ápice até a abertura, no qual se expande ou se contrai a massa visceral, dotando-os de sui generis sistema de locomoção músculo-hidráulico. Expansão através de aumento da pressão hidráulica e retração através de contração muscular.

Nesse sistema hidráulico, a hemolinfa (sangue) tem mais uma importante função além daquela exercida dentro da fisiologia do sistema circulatório, a função de locomoção.

Basicamente estas características acima descritas distinguem esta classe de todas a demais, ressaltando-se que atualmente os cefalópodos do gênero Nautilus apresentam o corpo protegido por uma concha enrolada como a dos gastrópodes. Todavia, uma diferença básica fundamental é notada. O corpo do Nautilus é abrigado apenas no espaço da última volta, sendo as demais segmentadas por tabiques. 
MORFOLOGIA GERAL DOS MOLUSCOS

\section{Classe Gastropoda (Figuras 24 a 78)}
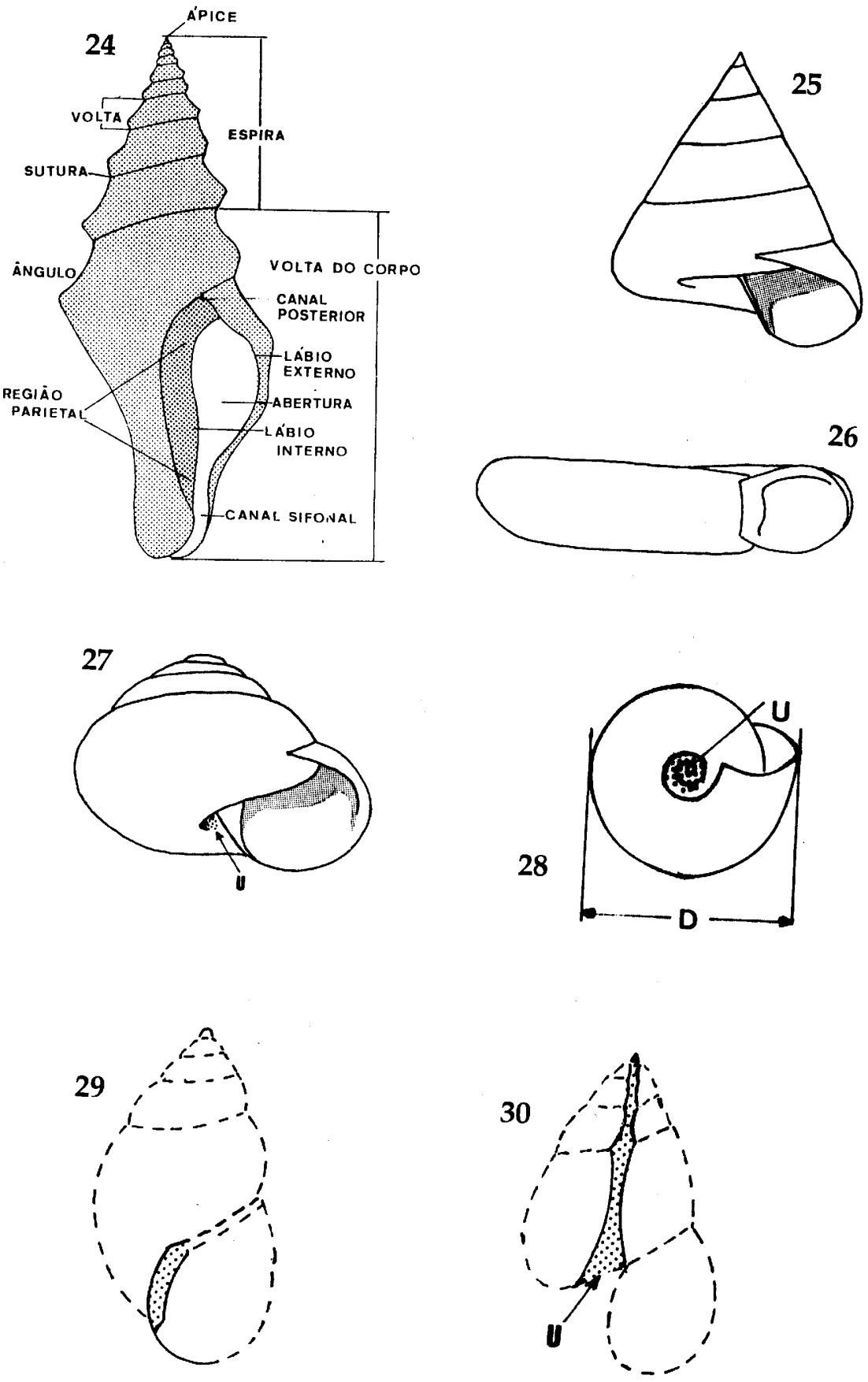
TÓPICOS EM MALACOLOGIA MÉDICA
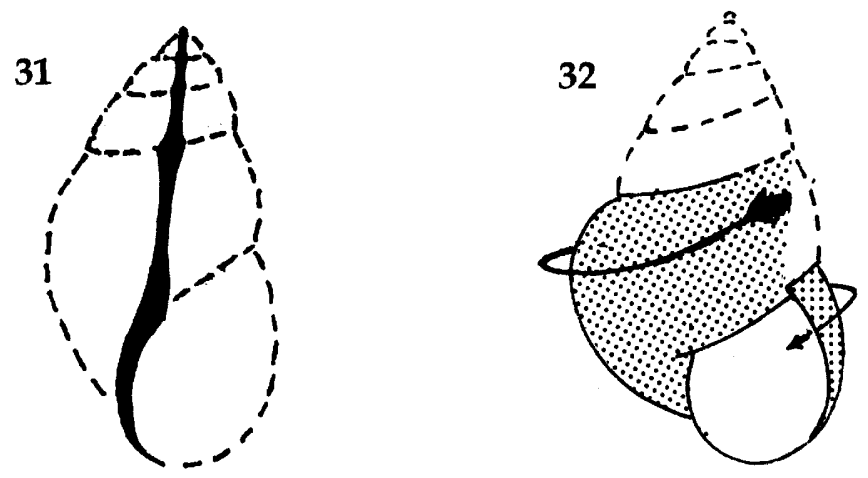

33 a 38

\section{$10 \mathrm{~mm}$}
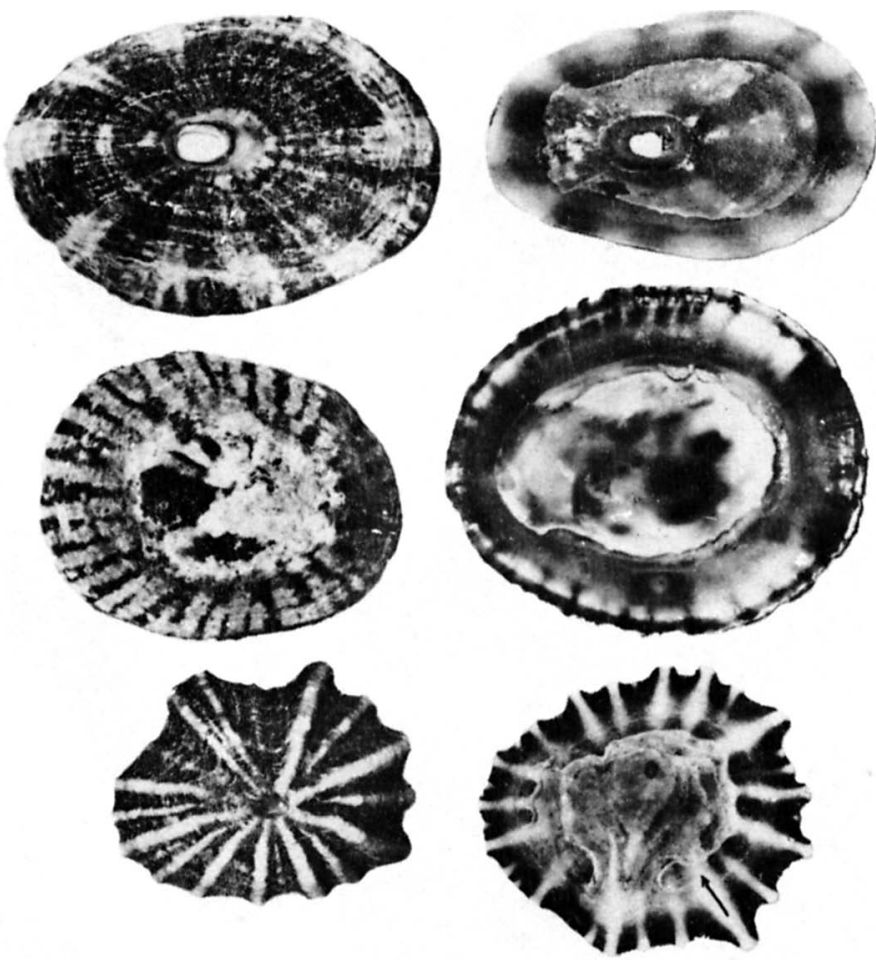
MORFOLOGIA GERAL DOS MOLUSCOS

39 a 42
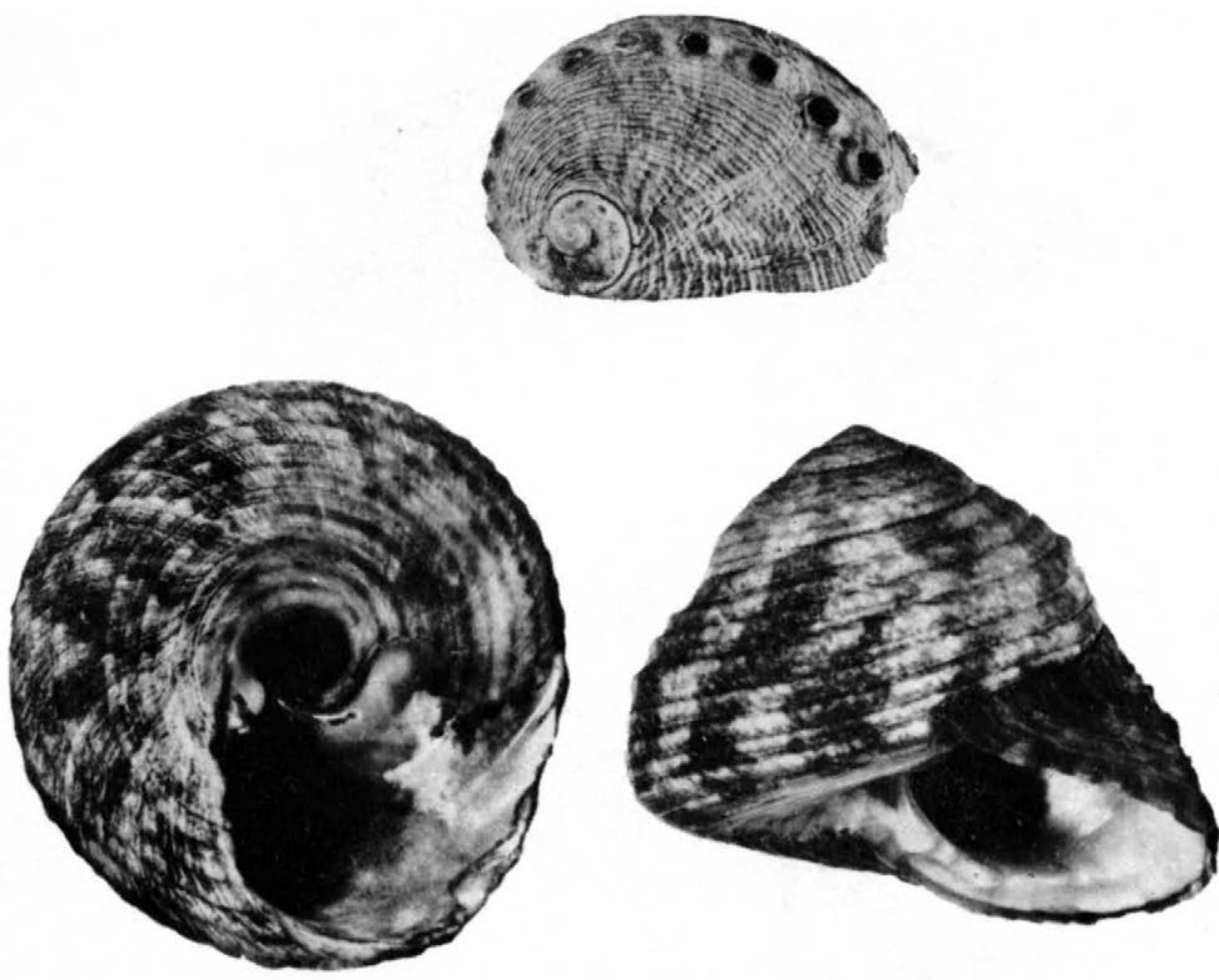

$50 \mathrm{~mm}$

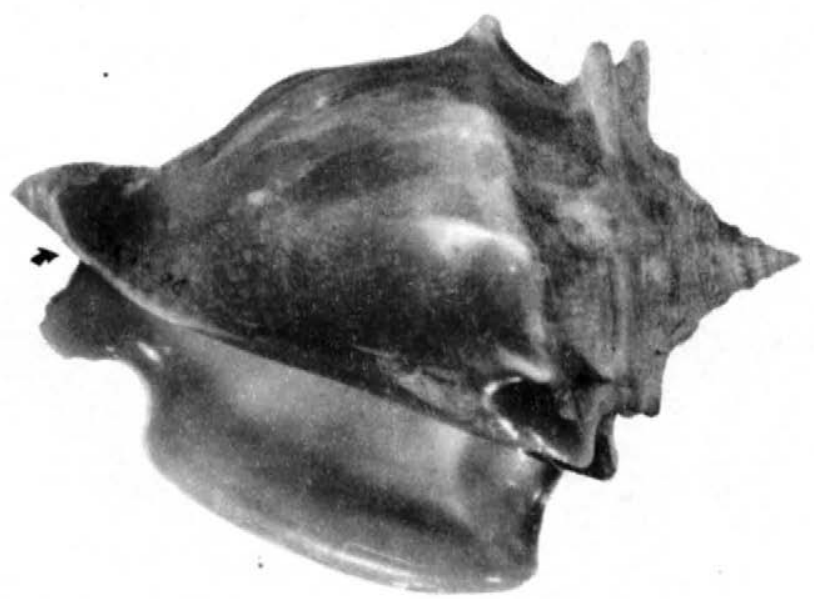


TÓPICOS EM MALACOLOGIA MÉDICA

43
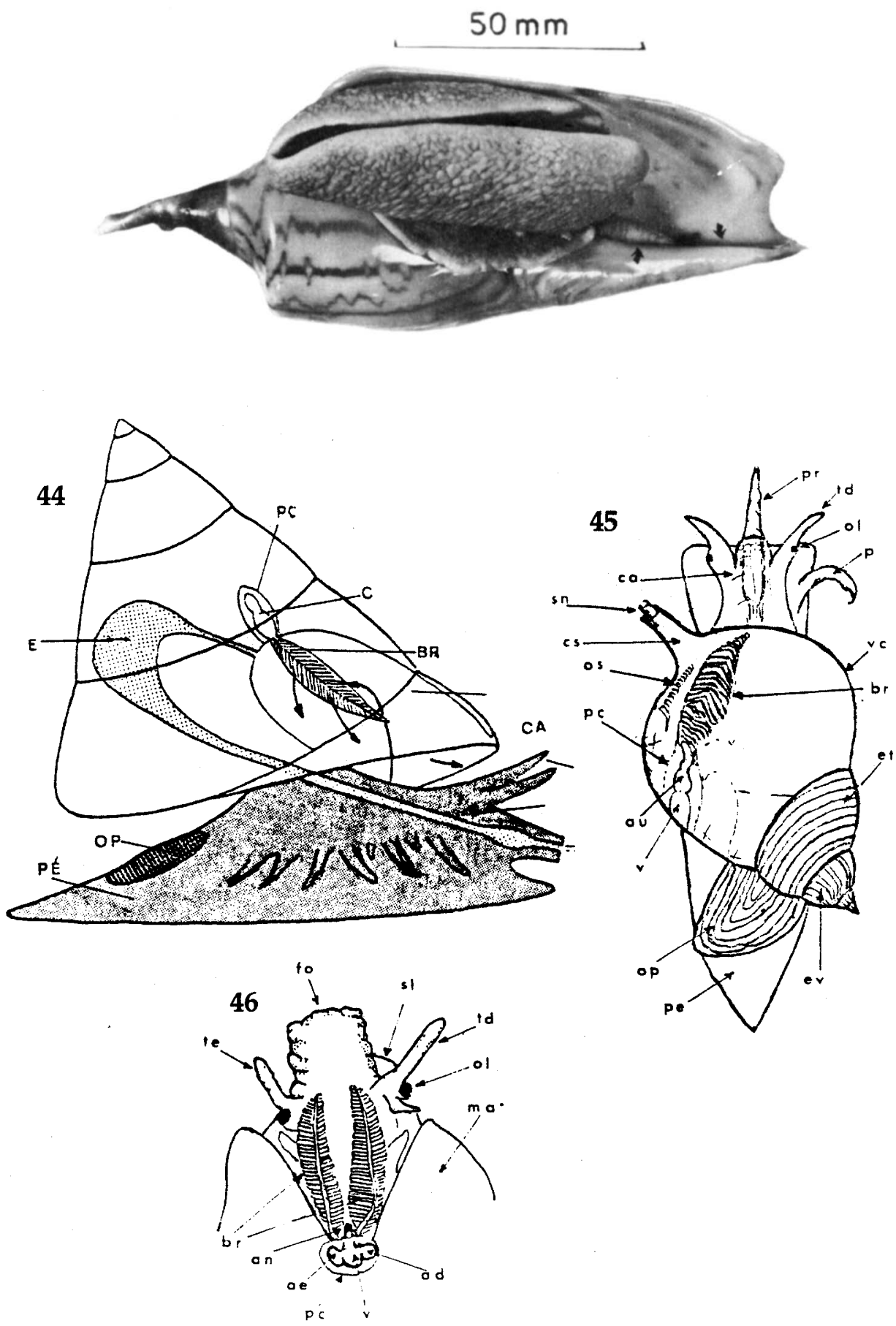
MORFOLOGIA GERAL DOS MOLUSCOS
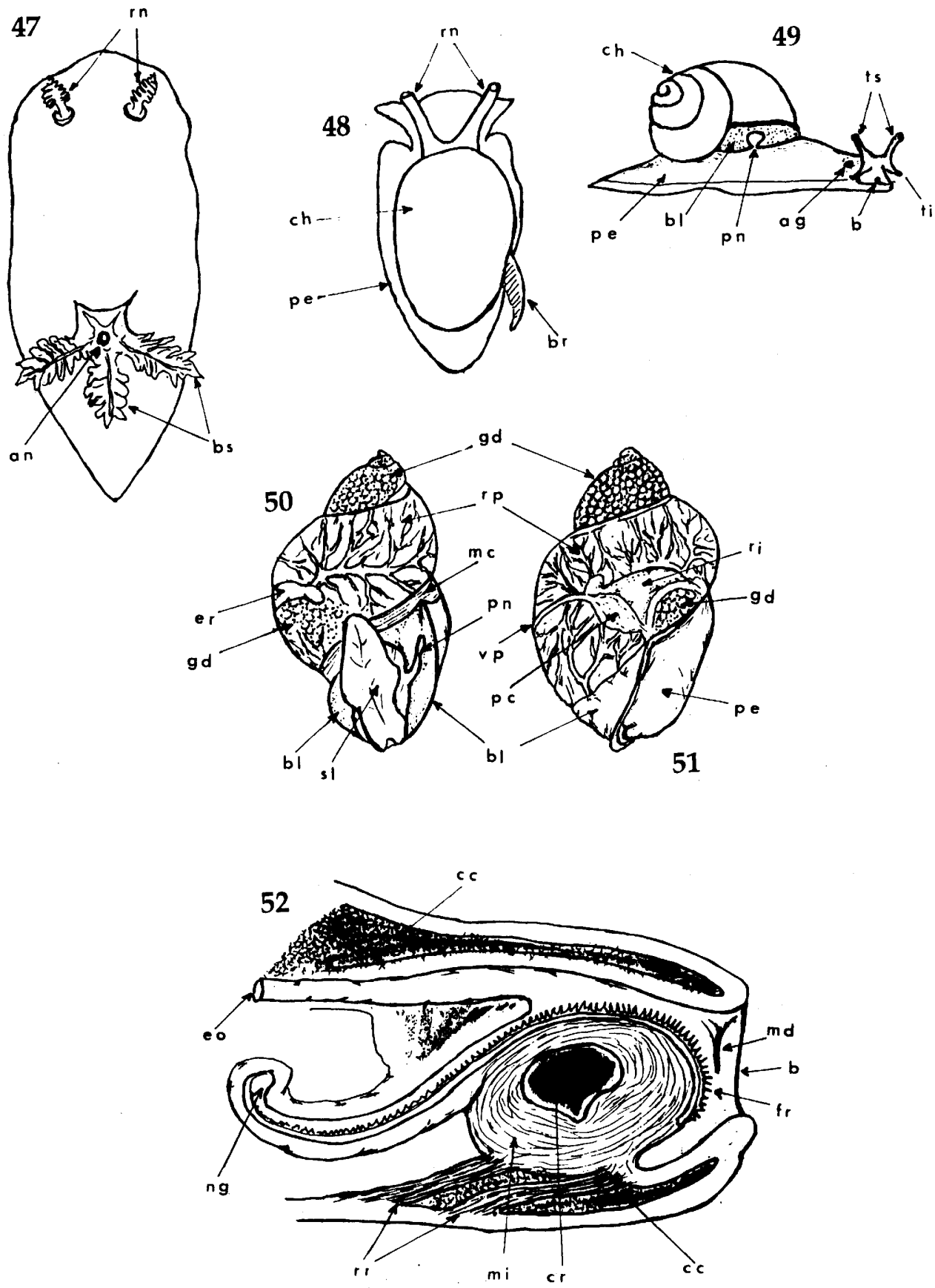

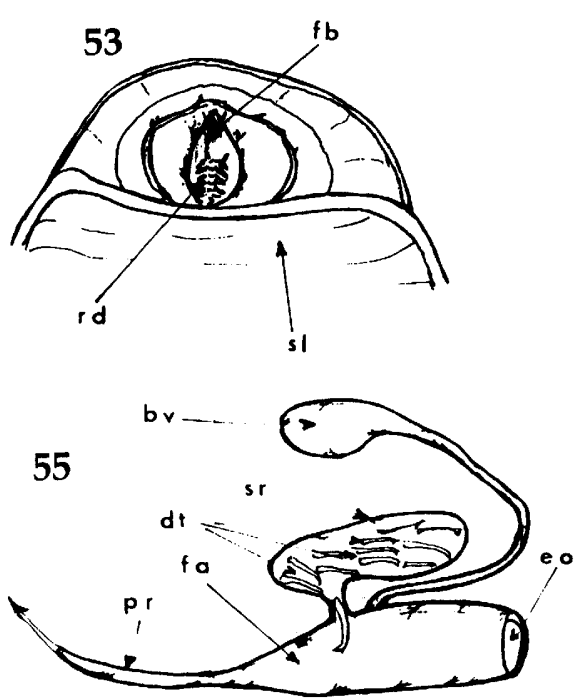

57

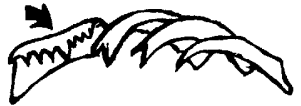

54

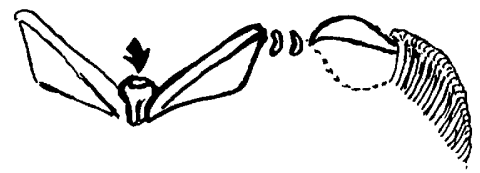

56

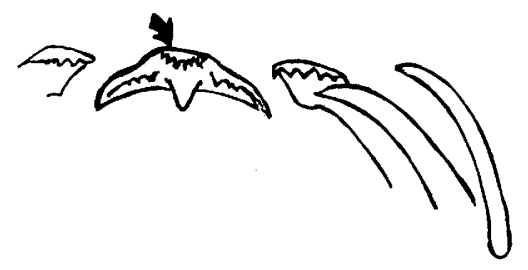

58

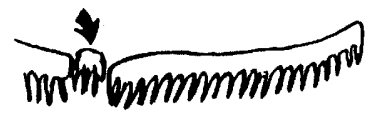

59

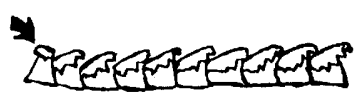

60

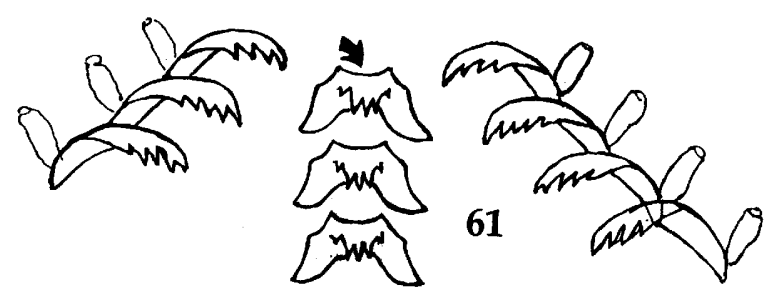

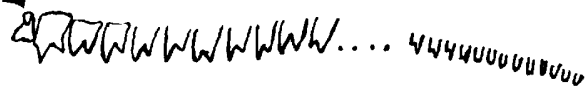

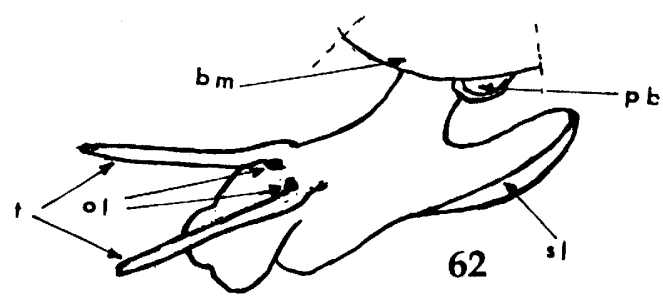


MORFOLOGIA GERAL DOS MOLUSCOS
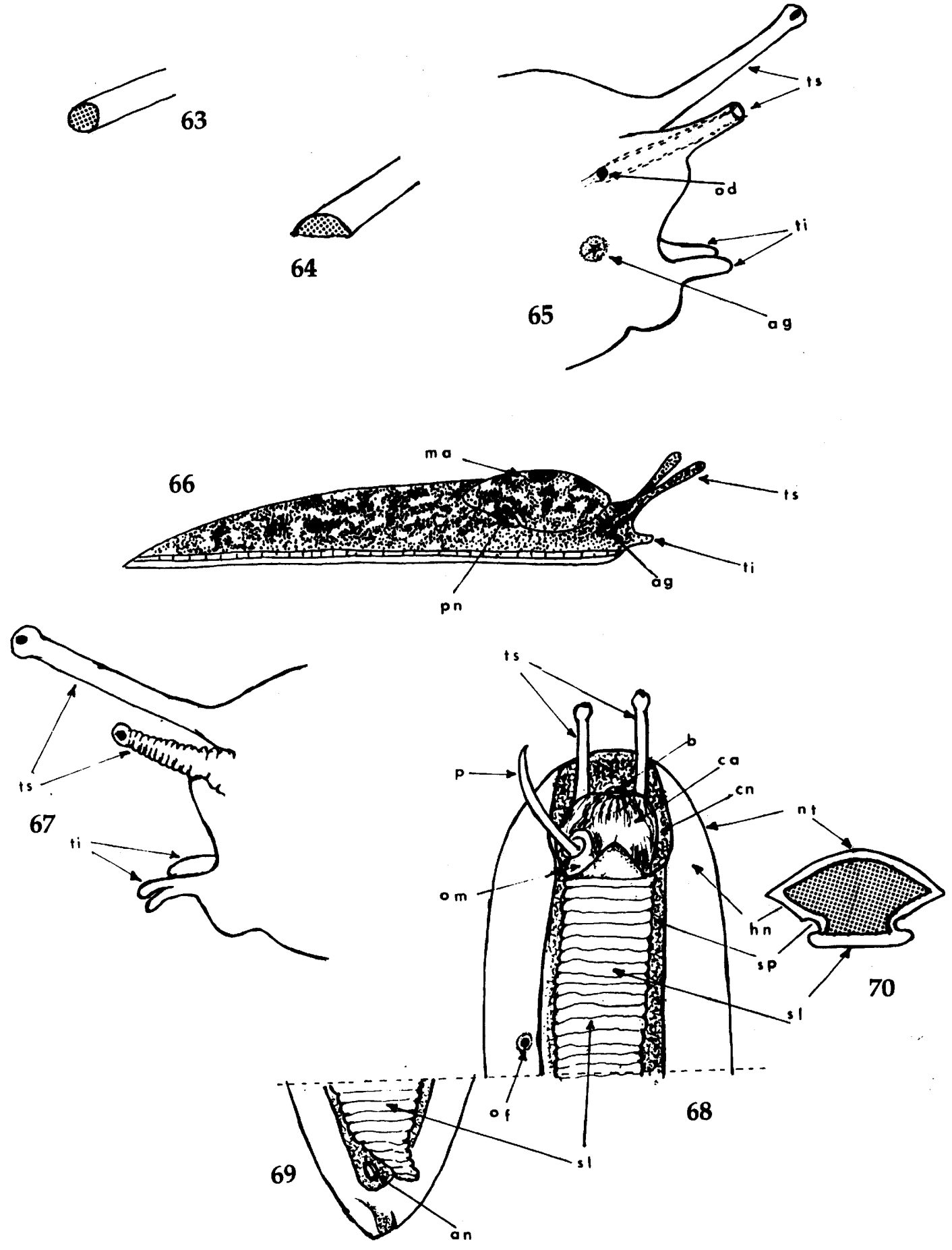

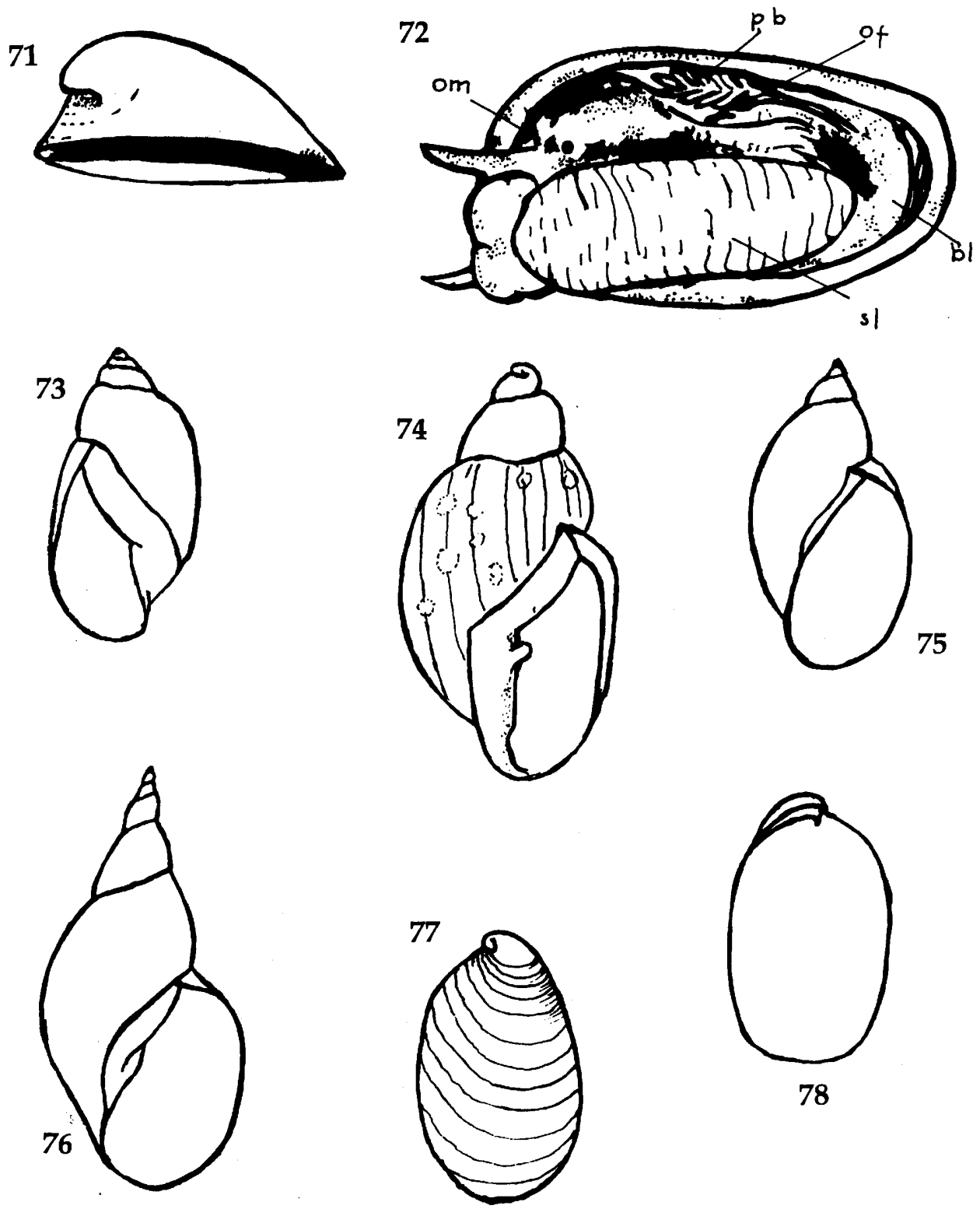

A cabeça bem desenvolvida também reúne as classes Gastropoda e Cephalopo$\mathrm{da}$, enquanto nas demais classes ela é pouco evidente ou ausente como na Bivalvia. Nos Cephalopoda a região cefálica apresenta oito a dez braços alongados dotados de ventosas preensis, utilizados na captura do alimento. Os Gastropoda apresentam dois ou mais pares de tentáculos não-preensis, cujas características peculiares são utilizadas nas interpretações sistemáticas da classe. 
A relação concha/corpo característica dos Bibalvia, isto é, o corpo ser protegido externamente por duas valvas laterais articuladas pela borda dorsal é encontrada também num gênero de Gastropoda, Bertelinia (Crosse, 1875). Mesmo nesse caso a diferenciação é imediata quando se tem um animal completo, isto é, concha e partes moles, pois o desenvolvimento da cabeça assim como do pé é típico dos Gastrópodes. No passado eram conhecidas apenas conchas de espécies desse gênero que eram erroneamente colocadas entre os Bivalvia. Um resumo da posição sistemática e do conhecimento geral sobre os gastrópodes bivalvos é encontrado em Kay (1968).

Outra característica peculiar dos Gastropoda é a assimetria que é devida a dois fenômenos distintos, o enrolamento da concha e da parte mole e sua principal causa que é a torção.

Este fenômeno consiste em um giro de $180^{\circ}$ que a massa visceral sofre em relação a porção basal do animal que é a massa cefalo-pediosa, fazendo com que estruturas e órgãos originariamente de localização caudal venham se alojar na região anterior, logo atrás da cabeça. Em algumas espécies a torção é um fenômeno ontológico, isto é, ocorre durante o desenvolvimento larval do animal, enquanto em outras é um fenômeno filogenético, ocorrido durante a evolução da espécie, que é detectado apenas pelas suas conseqüências, tais como deslocamento, diminuição numérica e desaparecimento de órgãos e o comprometimento parcial ou total da simetria bilateral.

Detalhes e discussões referentes a assimetria e torção podem ser encontrados em todos os livros de texto atualizados que tratam de gastrópodes. Estudos mais aprofundados a respeito da origem da assimetria e das teorias da torção foram feitos, respectivamente, por Verdonk (1979) e Lever (1979).

Em alguns grupos de espécies de gastrópodes marinhos e terrestres a simetria externa do corpo é readquirida, através de processo inverso à torção, chamado "detorção". Estudos anatômicos comprovam a ocorrência da detorção e sugerem a interpretação adaptativa das mudanças morfológicas e fisiológicas e suas implicações sistemáticas e filogenéticas.

As particularidades mais importantes a serem consideradas nessa interpretação são as apresentadas pelo tubo digestivo, pelos gânglios e comissuras nervosas e, principalmente, pela cavidade do manto e suas estruturas componentes, que formam um conjunto denominado complexo palial.

O tubo digestivo dos gastrópodes primitivos teria sido reto, isto é, com os dois orifícios diametralmente opostos, a boca na extremidade anterior e o ânus na posterior. Em decorrência da torção, o ânus foi trazido para as proximidades da cabeça, dando ao tubo a forma de um $U$.

A principal característica do tubo digestivo dos moluscos é a rádula que é exclusiva em a nível de filo, faltando apenas na classe Bivalvia, pela ausência total da cabeça. Consiste ela de um sistema de dentes quitinosos móveis dispostos em séries em uma lâmina de crescimento contínuo. A constituição e forma dos 
elementos que constituem o aparelho radular oferece padrões de organização utilizados na sistemática nos diferentes níveis taxonômicos e na interpretação dos hábitos alimentares das espécies.

A interpretação de tais padrões será feita adiante, quando tratarmos das diferenciações de categorias sistemáticas menores.

Dentro da classe, o sistema nervoso evoluiu no sentido da dininuição das comissuras com a migração e desenvolvimento dos glânglios viscerais e pedais para a cefalização.

Outro caráter exclusivo do filo Mollusca é o manto que é uma dobra do epitélio que se expande e delimita uma cavidade com funções primordiais de respiração, excreção e sensoriais.

$\mathrm{O}$ desenvolvimento e a organização das estruturas da cavidade do manto, oferecem elementos importantes não só para a adaptação do animal ao ambiente como para a aplicação na sistemática em nível de subclasses.

É nas células do manto que se realizam os processos químicos da síntese da concha que é geralmente de constituição calcárea sobre uma matriz proteica. Um excelente estudo sobre a formação da concha foi realizado por Saleuddin (1979).

Quanto à reprodução, a diversidade encontrada nos gastrópodes pode ser considerada extraordinária. São conhecidas: fecundação externa, fecundação interna, fecundação cruzada, autofecundação, partenogênese, hermafroditismo, alternância de sexo, neotenia. O desenvolvimento pode ser direto através de oviparidade, ovoviviparidade e viviparidade ou através de larvas fixas, livre-natantes ou planctônicas.

Em relação às subclasses os gastrópodes são separados em Prosobranchia, Opisthobranchia e Pulmonata. Na primeira subclasse as brânquias estão localizadas anteriormente em relação ao coração, na segunda posteriormente e na última a cavidade palial é modificada para a respiração aérea, transformando-se em cavidade pulmonar.

Os Prosobranchia vivem em todas as condições do ambiente marinho, invadem a água doce e até o ambiente aéreo. Os Opisthotranchia são limitados ao ambiente marinho, que exploram amplamente através de grandes diversidades adaptativas, morfológicas e funcionais apresentadas pelas espécies componentes da subclasse.

A subclasse Pulmonata, cuja grande maioria da espécies é terrestre, explora com grande eficiência a água doce, e ainda algumas de suas famílias habitam limitados nichos ecológicos do ambiente marinho.

\section{Subclasse Prosobranchia}

Nesta subclasse apenas uma família, de formas marinhas do Oceano Índico, Titiscaniidae não apresenta qualquer vestígio de concha. Em todos os demais prosobrânquios a concha é sempre presente, univalva e externa. 
Embora a definição da subclasse seja dada pela condição das brânquias, pela separação dos sexos (dióicos) e pelo padrão estreptonêurico do sistema nervoso, certas características conquiológicas associadas a dados ambientais oferecem condições para o especialista ou para estudiosos amadores estabelecerem a posição sistemática de uma espécie representada apenas pelo seu esqueleto externo, a concha. Assim, muitas espécies são até hoje conhecidas e catalogadas apenas por seus caracteres conquiológicos.

Julgo ser necessário e imprescindível, antes de detalhar as estruturas anatômicas e conquiológicas dos Prosobranchia, dar uma noção das ordens e suas implicações nas conquistas dos ambientes.

Basicamente, a subclasse é dividida em três ordens fundamentadas em um conjunto de estruturas e fenômenos de complexidade menor ou maior, dando como conseqüência origem aos nomes: Archaeogastropoda, Mesogastropoda e Neogastropoda. A ordem Archaeogastropoda reúne espécies cujos padrões conquilógicos, anatômicos, fisiológicos e ecológicos se aproximam mais aos daqueles descritos para o arquétipo. São espécies conservadoras, limitadas ao ambiete bentônico marinho, constituindo elemento importante na fauna e na ecologia dos costões litorâneos.

Nesta ordem são encontrados dois padrões predominantes de conchas. $\mathrm{O}$ primeiro é representado por conchas achatadas com enrolamento perceptível apenas no ápice e abertura ampla, ocupando toda a superfície basal. $O$ enrolamento pode ser evidenciado em algumas famílias apenas nas fases jovens, pois o crescimento e a abrasão (desgaste) causados pelas ondas e associações com outros organismos vivos modificam consideravelmente a região apical das conchas. Outro fato é observado na família Fissurellidae: um fenômeno natural ao longo do crescimento faz com que o ápice seja reabsorvido e em seu lugar apareça um orifício apical característico não só da família, mas com condições diferenciais para permitir a classificação de gêneros e espécies. Através desse orifício, no qual se aloja o ânus, se estabeleceu uma nova e característica corrente circulatória de água.

Em outra família, Haliotidae, as diferentes posições do ânus ao longo do crescimento da concha podem ser notadas por uma série de orifícios que acompanham o perfil.

O mesmo fenômeno de adaptação da concha para abrigar o ânus durante o crescimento é observado nas famílias Pleurotomariidae e Scissurellidae, não através de orifícios isolados, mas sim de uma fenda contínua. Enquanto a família Pleurotomariidae reúne espécies de concha volumosa, que ultrapassam cinco centímetros em suas dimensões, Scissurellidae reune espécies milimétricas.

No segundo padrão são reunidas as famílias que apresentam conchas nãoachatadas, enroladas no sentido conespiral sendo todas as voltas preservadas ao longo da vida do animal.

A característica básica de tais conchas é a abertura que é contínua, sem formas entalhes ou canal, e perfeitamente vedada por um opérculo calcário ou córneo, 
quando as partes moles estão totalmente recolhidas. A esse tipo de boca se dá o nome de holostoma (holo $=$ completo, inteiro + stoma $=$ boca, abertura).

Os Archaeogastropoda, assim reconhecidos, são limitados ao ambiente bentônico marinho, e são raspadores. Reproduzem-se por meio de fecundação externa, sem órgãos sexuais copuladores.

As brânquias e as outras estruturas do complexo palial também oferecem caracteres para a identificação da ordem. Apenas entre os Archaeorgastropoda encontramos gastrópodes com um par de brânquias, um par de aurículas e um par de rins. Mesmo nas famílias que já apresentam a redução numérica de tais órgãos a brânquia se diferencia por ser bipectinada, isto é, apresenta lâminas dos dois lados do eixo central, enquanto nas outras duas ordens as lâminas se distribuem em apenas um lado do eixo branquial.

No primeiro grupo as espécies apresentam um par de brânquias, enquanto no segundo apenas uma ou tansformações adaptativas, às vezes representadas até pela ausência completa dessa estrutura respiratória.

Entre as ordens Archaeogastropoda e Mesogastropoda são colocadas espécies com características intermediárias na concha, na anatomia, na fisiologia e na ecologia que dificultam sua inclusão em uma ou outra ordem. Por essa razão muitos e sérios autores separam as famílias com tais características num grupo chamado "Ordem Ia" Neritoidea (Rafinesque, 1815).

É nesse grupo que se encontram as famílias Titiscaniidae, sem concha; Hydrocenidae e Helicinidae adaptadas à vida terrestre, além de Phenacolepadidae, Neritopsidae e Neritidae marinhas. É também nele que surge a fecundação interna, com o desenvolvimento de órgãos copuladores.

Não há na bibliografia malacológica e parasitológica, qualquer referência sobre a implicação de espécies de Archaeogastropoda com a saúde humana.

A ordem Mesogastropoda é constituída por famílias bastantes diversificadas em todos os aspectos até aqui considerados: morfológicos, fisiológicos e ecológicos. Assim, apresenta representantes em todos os ambientes e com toda a gama de transformações anatômicas adaptativas. Dessa maneira é quase que impossível uma diagnose abrangente e ao mesmo tempo sucinta para a ordem.

Nela se encontram algumas famílias de importância médico-veterinária no Brasil, devido a suscetibilidade pela infestação de cercária de algumas espécies de trematódeos que podem vir a completar seu ciclo no homem ou em animais utilizados pelo homem. São elas: Ampullariidae (ou Pilidae), Thiaridae, Pleurosceridae e Hidrobiidae, todas de água doce $\mathrm{e}$, de alguma maneira, dividindo o hábitat com os planorbídeos.

A primeira reúne um grande número de espécies, de concha lisa e globosa com perióstraco persistente, geralmente de cor castanho-esverdeada, que vivem em águas calmas de lagos, represas e valas de irrigação. São espécies adaptadas a extrema variação de oxigenação da água e até dessecação, o que as possibilita viver em 
ambiente aéreo, graças a adaptação de uma área do teto da cavidade palial, que se transforma num saco aéreo; podendo assim colocar suas posturas fora da linha d'água, mostrando um nítido traçado na conquista do ambiente terrestre.

As espécies da família Ampullariidae são facilmente reconhecidas pelo seu aspecto globoso e pelo seu tamanho que chega a ultrapassar dez centímetros, tendo em geral a maioria mais do que cinco centímetros.

Constitui exceção a isso o gênero Marisa, cujas conchas são planispiraladas como as dos planorbídeos dos quais se distingue pelo tamanho, pelo perióstraco colorido, por faixas espirais e, principalmente, pelo opérculo córneo característico da familia.

Os Hidrobiidae também vivem em águas calmas, mas, aos contrário das ampulárias, são de porte milimétrico e formas globosas ou fusiformes. São adaptados ao ambiente aquático, vivendo geralmente em fundos lodosos, sem adaptações para a vida aérea.

Os Thiaridae e os Pleuroceridae possuem conchas turriformes alongadas, sendo freqüente a perda das voltas apicais, como um meio de adaptação do animal ao ambiente, por um fenômeno biológico chamado autotomia. Através desse processo o animal pode crescer sem o alongamento da concha, que apresenta então, com a idade, um truncamento pronunciado da região apical.

Além desse caráter da anatomia, os Thiaridae e Pleuroceridae se distinguem pela escultura forte e saliente da superfície da concha, não encontrada em outras famílias de água doce do Brasil. Vivem preferencialmente em águas ricas em oxigênio, nas imediações de cachoeiras e corredeiras, muito embora algumas espécies sejam encontradas em águas paradas e poluídas e até em canais litorâneos com um certo grau de salinidade.

Uma característica importante para o reconhecimento dessa ordem é o padrão radular tenioglossa, constituído por um dente central, um par de dentes laterais e dois pares de dentes marginais. Os caracteres diferenciais dos padrões radulares serão discutidos mais adiante.

Aqui cabe dizer que esse grupo de Mesogastropoda de interesse médico é herbívoro, é limitado a água doce, e se reproduz sexuadamente, sendo a grande maioria ovípara, muito embora dentre os Thiaridae se encontre a reprodução por partenogênese, isto é, sem a presença de machos. Apresentam, também, outros processos adaptativos, como o desenvolvimento dos ovos em bolsas incubadoras até a liberação do indivíduo completo.

Dentre os Mesogastropoda se encontram espécies relacionadas com a transmissão da esquistossomose em outros continentes, como a japônica causada por outra espécie de Trematoda.

Em 1959, Rey descreveu uma espécie de Hidrobiidae do gênero asiático Oncomelania, vivendo na região de Aquidauana, Corumbá, Mato Grosso, discutindo a possibilidade da mesma vir a ser um hospedeiro da esquistossomose Japônica no Brasil. Para tal espécie (O. brasiliense Rey, 1959) Davis (1979) criou um gênero 
novo Aquidauania, colocado na família Pomatiopsidae. Na literatura especializada pode-se encontrar polêmica sobre a questão, cuja discussão não cabe no presente texto.

A última ordem dos Prosobranchia, Neogastropoda, reúne formas marinhas de hábitos carnívoros, predadores, que tendem para uma especialização. Assim podem dizer que a tendência dos Archaeogastropoda é o conservadorismo, dos Mesogastropoda é a diversidade adaptativa e a dos Neogastropoda é a especialização.

Um Neogastropoda pode ser reconhecido por meio de uma concha, pela presença de uma interrupção na base da abertura, prolongada por um canal que se alonga para alojar o sifão, daí seu nome, canal sifonal.

Nas partes moles também encontramos elementos para o reconhecimento de um Neogastropoda. O primeiro deles é a presença de um equipamento muscular adaptado ao hábito predatório, não só no deslocamento como também no desenvolvimento de proboscis e tromba que proteja a rádula para sua maior eficiência de ataque à presa.

O topo dessa especialização é alcançado pelos Toxoglossa que sofrem uma transformação no aparelho radular, modificando todo o sistema de fileira de dentes em um dispositivo de armazenamento de um só tipo de dente, em forma de arpão, adaptado a um sistema muscular de propulsão e uma glândula de veneno.

Os animais assim dotados podem lançar seu "dente arpão" e atingir sua presa à distância. Seu potente veneno paralisa a presa, geralmente peixes de pequeno porte, e provoca a lise de seus tecidos, facilitando sua ingestão.

Apenas os Toxoglossa dentre os Neogastropoda apresentam algum interesse à medicina pela potencialidade de seu veneno.

Não existem casos confirmados de acidentes humanos, mas a possibilidade de ocorrência em nosso meio justifica o alerta aqui colocado.

Também não há no Brasil um levantamento das cercárias que se desenvolvem em Prosobranchia marinhos, com ciclos em peixes e aves como o apresentado por Fretter \& Graham (1962), para a fauna britânica.

É um campo aberto para pesquisa em nosso país.

\section{Subclasse Opisthobranchia}

Abriga um grande número de ordens, todas limitadas ao ambiente marinho, apresentando extrema diversidade morfológica adaptativa.

Suas características básicas são a posição das brânquias posteriormente ao coração e o hermafroditismo. Contudo, há grupos de espécies em que as brânquias se tornam externas, em outras palavras, as brânquias são nuas, daí o nome Nudibranchia para distinguir tal grupo. Em outros grupos as brânquias e a própria cavidade do manto podem desaparecer. 
A própria divisão externa do corpo sofre extrema variação, alterando pronunciadamente o aspecto do animal. Assim, nos Cephalopoda os tentáculos se expandem e se reúnem para formar um disco que encobre completamente a região antero-dorsal, o disco cefálico.

A grande maioria das espécies de Opisthobranchia não apresenta concha alguma, enquanto em outras a concha é interna e reduzida.

Não há na literatura referência sobre a importância médica dos representantes dessa subclasse.

\section{Subclasse Pulmonata}

Esta subclasse é importante no Brasil, do ponto de vista médico-parasitológico, por abrigar a família Planorbidae que reúne espécies hospedeiras da esquistossomose mansônica.

A grande maioria das espécies de Pulmonata tem como hábitat o ambiente terrestre, graças ao desenvolvimento de um tecido ricamente vascularizado, que reveste o teto da cavidade palial, a qual se fecha quase totalmente, transformando-se num pulmão, controlado por uma válvula, aberta para o exterior, o pneumóstoma.

Nessa subclasse podemos distinguir quatro ordens distintas: Archaeopulmönatä, Basommatophora, Stylommatophora e Systellommatophora.

Há na literatura especializada em sistemática malacológica outros conceitos, principalmente no que tange à terminologia da última ordem mencionada, que em Franc (1968), por exemplo, é chamada de Gymnophila (Baker, 1955).

Dado o cunho didático deste texto, é mantida aqui a posição dos autores que adotam o termo Systellommatophora.

\section{Ordem Archaeopulmonata}

A ordem Archaeopulmonata reúne algumas famílias consideradas a base da evolução dos Pulmonata (por exemplo Ellobiidae), que explora principalmente as regiões de transição ambiental da zona entre-marés, famílias estas muito bem estudadas por Van Mol (1967) e Mortan (1955). Foi desdobrada da ordem Basommatophora, portanto seus caracteres diferenciais são pouco conspícuos para os não-especialistas.

Tais caracteres são encontrados no desenvolvimento do sistema nervoso, do aparelho digestivo, principalmente na estrutura do estômago e na ausência completa de ureteres. Nos demais caracteres não é possível sua distinção dos Basommatophora.

Nesta ordem se encontra um gênero bastante comum em nossos mangues representado pela espécie Melampus coffeus (Linnaeus, 1758). 


\section{Ordem Basommatophora}

Esta ordem é a principal do ponto de vista do interesse médico. Um estudo básico e ao mesmo tempo resumido sobre ela é apresentado por Hubendick (1978).

As características básicas para o reconhecimento dos componentes dessa ordem são: a presença de apenas um par de tentáculos cefálicos não-invagináveis, com um par de olhos na base; hermafroditismo com aberturas sexuais separadas (ditremia); rim alongado com apenas ureter primário, curto, reto e dirigido para trás; hábito dulciaqüícola, desenvolvimento do estômago em forma de moela.

No Brasil são encontradas as seguintes famílias: Ancylidae, Planorbidae, Physidae, Chilinidae e Lymnaeidae. Esclarece-se que Hubendick (1978) não reconhece a ordem Archaeopulmonata e nem o status da família para os planorbídeos, agrupando-os aos ancilídeos numa só família a qual denominou Ancyloplanorbidae; o que não é seguido aqui por razões didáticas, sem entrar no mérito da questão.

As características das famílias pertencentes à ordem basommatophora serão abordadas de forma mais detalhada no capítulo 1.3.

\section{Ordem Stylommatophora}

Esta ordem reúne a grande maioria dos gastrópodos terrestres dotados de um saco pulmonar desenvolvido e adaptado ao ambiente aéreo.

Os representantes dessa ordem diferem dos das demais ordens pela presença de dois pares de tentáculos retráteis e invagináveis com um par de olhos na extremidade do par superior e por apresentar os orifícios genitais reunidos em um átrio, isto é, são monotrêmicos.

A concha varia extremamente em forma e tamanho, comportando na maioria das espécies toda a parte mole, quando o animal se recolhe, contudo, sem fechar sua abertura com um opérculo como ocorre entre os Prosobranchia. Algumas espécies conseguem vedar completamente a abertura da concha, quando em estivação, com uma secreção mucosa que se solidifica em contacto com o ar, o epifragma. As espécies do gênero Oxystyla conseguem soldar o epifragma nas paredes de cavidades de troncos, constituindo uma tampa resistente impossível de ser destacada sem a destruição da concha.

Em algumas famílias as tendências evolutivas levam à redução da concha que passa a ser uma estrutura vestigial que não abriga mais as partes moles. Duas situações intermediárias entre a concha calcária e protetora e a concha vestigial interna dos Lymacidae e Arionidae encontramos na família Amphibulimidae na qual o gênero Simpulopsis apresenta concha globosa córnea e tênue, enquanto no gênero Peltella ela é parcialmente envolvida por uma expansão circular do manto que deixa no seu centro um orifício. 
A primeira referência ligada ao interesse médico dos Stylommatophora foi dada por Lutz (1921), relacionando o gênero Omalonyx (D'Orbigny, 1835) da família Succineidae com o gênero Urogoninus, fechando o seu ciclo com o frango d'água.

Outras referências esparsas foram surgindo na literatura, ligando outros helmintos parasitas a representantes dessa ordem.

A caracterização das subordens dos Stylommatophora é baseada nas estruturas do aparelho excretor. São reconhecidas quatro ordens, reunindo todas as famílias descritas: Mesurethra, Orthurethra, Heterurethra e Sigmurethra.

Na primeira o rim é aproximadamente triangular e não apresenta ureter, sendo a urina expelida por um poro simples, localizado em seu flanco esquerdo livre.

Os Orthurethra apresentam o rim algo semelhante ao dos Basommatophora com um ureter primário curto.

Os Heterurethra e Sigmurethra apresentam ureteres primários e secundários desenvolvidos, levando a urina para a região do pneumóstoma ou pelo menos se aproximando da mesma. A diferenciação entre essas duas ordens se faz pela análise das dimensões do rim; nos Sigmurethra a maior dimensão do rim é aquela paralela ao eixo longitudinal do animal, nos Heterurethra é a transversal.

\section{Ordem Systellommatophora}

Esta ordem reúne espécies não-enroladas, totalmente sem concha, sem saco pulmonar, sem cavidade palial definida, com a cabeça protegida em uma cavidade de tegumento dorsal externo, contínuo e indiferenciado, chamado noto. $O$ ânus é protegido em uma cavidade caudal do noto, sendo, portanto, terminal; por este caráter as lesmas neotropicais são diferenciadas não só de todos os pulmonata, como dos Prosobranchia e da maioria dos Opistobranchia. Apenas nessa última subclasse são encontradas espécies com ânus terminal, o que acusa a ocorrência de um fenômeno inverso ao da "torção", chamado "detorção".

Devido a tal fenômeno e ao desenvolvimento, as lesmas apresentam uma interessante estrutura anatômica de neoformação, o reto, para demonstrar didaticamente a ocorrência da evolução. Em outras palavras a origem do reto das lesmas não é a mesma do restante do tubo digestivo; ele é formado por uma dobra epitelial.

Externamente a região pleural, que separa o noto da sola rastejante, recebe o nome de hiponoto.

Diferindo dos Stylommatophora e se assemelhando aos Basommatophora, os Systellommatophora apresentam os orifícios genitais separados, não-ditrêmicos. A vagina se abre na porção mediana do hiponoto direito, enquanto o pênis se localiza na região cefálica.

Outra característica diferencial em relação aos Stylommatophora é a nãoinvaginação dos tentáculos para a cavidade do corpo, ficando os olhos sempre na extremidade dos mesmos, também difere por apresentar os tentáculos inferiores bífidos. 


\section{TÓPICOS EM MALACOLOGIA MÉDICA}

Todas as espécies de lesmas brasileiras dessa ordem são reunidas na família Veronicellidae.

Também ao contrário dos outros Pulmonata terrestres, as lesmas põem ovos gelatinosos enfileirados em uma fita, que se enrola e se condensa à medida que cresce. Os Stylommatophora põem ovos isolados, com casca calcária.

\section{Estudo comparado dos caracteres diferenciais}

As Figuras 1 a 4 representam esquemas dos caracteres principais da classe Caudofoveata. Na primeira vê-se a extremidade anterior, com a boca terminal protegida pelo escudo pedioso, apontado pela seta. A Figura 3 representa a extremidade oposta, mostrando a posição do ânus e as brânquias terminais. A Figura 2 representa uma secção transversal, mostrando a distribuição contínua das espículas calcáreas. A Figura 4 representa o aspecto externo do animal.

A classe Solenogastre é representada pelas Figuras 5 a 8 . Na primeira e na segunda vê-se a boca, de localização ventral. O sulco ventral, que dá nome à classe, é apontado pela seta na Figura 5 e representado no corte transversal, Figura 7; a Figura 8 representa a extremidade posterior.

As características básicas externas dos Monoplacophora estão representadas nos esquemas de número 9 a 11 . No primeiro vê-se a concha univalva e pateliforme apoiada sobre o pé. Na Figura 11, que representa a face interna da concha, aparecem as cicatrizes musculares da metamerização que caracteriza a classe. A Figura 10 esquematiza o animal em vista dorsal onde vê-se a boca, de posição ventral (seta) característica dos moluscos raspadores, e o ânus na extremidade oposta. O pé em forma de ventosa de fixação separa duas séries laterais de brânquias externas.

A característica básica da classe Polyplacophora é a fragmentação da concha em oito placas embricadas, como é mostrado nas Figuras 12, 14 e 15, reunidas por um escudo periférico apontado pela seta. A Figura 13 esquematiza um animal em face ventral, mostrando a semelhança com a classe anterior.

A classe Scaphopoda é aqui representada pelos esquemas 16 a 19. Na primeira, vêem-se as partes moles totalmente contidas numa concha univalva cilíndrica em forma de presa de elefante. Nota-se o pé e os tentáculos preensis (captácula), ultrapassando a abertura anterior da concha. Nota-se, também, o intestino em U com o ânus localizado na região anterior, como mostra a seta. As figuras 17 e 18 mostram, respectivamente, a forma da concha no gênero Dentalium e Cadulus. O número 19 representa caracteres diferenciais de três espécies distintas da família Dentaliidae.

A concha formada por duas valvas articuladas pelo dorso, envolvendo completamente as partes moles, o que caracteriza a classe Bivalvia, é mostrada nos esquemas 20 a 22 . Na primeira, vê-se um corte transversal, mostrando no eixo 
mediano o pé, separando duas brânquias laterais. A Figura 21 mostra a valva esquerda rebatida com duas cicatrizes musculares e a massa visceral exposta após a retirada da lâmina esquerda do manto, no interior da valva direita. A seta aponta a região anterior, na qual não se nota qualquer vestígio de cabeça. A Figura 22 mostra a face interna de uma valva direita com alguns elementos utilizados na classificação do grupo, como a região de articulação (charneira) com dentes e fossetas correspondentes, o ápice ou umbo, as cicatrizes musculares e a linha palial; ligando as duas.

Os Cephalopoda atuais, dotados de concha, são representados por seus dois padrões principais nas Figuras 23 e 23a. Na primeira vê-se um esquema de Nautilus com a concha externa e as partes moles alojadas apenas na última volta. Na outra é esquematizada uma lula (Loligo) com a concha córnea interna apontada pela seta.

Vimos na parte inicial que a concha, na classe Gastropoda, pode variar amplamente desde extremamente desenvolvida e enrolada até a ausência completa. Quando existente, pode ser externa ou interna, eficiente como proteção ou apenas vestigial.

A Figura 24 mostra um esquema de concha de um Gastropoda, Prosobranchia, Neogastropoda, com a sinalização de alguns dos principais caracteres utilizados na sua sistemática.

As Figuras 25 a 32 mostram diferentes formas de concha, sendo que a de número 26 distingue-se das demais pelo enrolamento planispiral, que caracteriza a família Planorbidae. As outras todas são conispiraladas.

As Figuras 27, 28, 30 e 31 são relacionadas à condição das voltas se tocarem no eixo central, tornando-o maciço ou não. No primeiro caso a concha não apresenta uma perfuração contínua como mostra a Figura 31. No segundo fica um orifício externo, geralmente circular, o umbílico, representado pela letra U. O umbílico pode ser parcialmente fechado pela columela, como se vê na Figura 27 ou totalmente fechado por um calo parietal. A Figura 29 mostra um tipo de columela truncada característica de algumas famílias. Na Figura 32 é mostrado pelo pontilhado os limites da última volta ou volta do corpo, caráter importante nas diagnoses específicas.

Nas Fotos de números 33 a 39 são representadas quatro espécies de gastrópodes marinhos raspadores adaptados ao ambiente de águas batidas dos costões, pelo achatamento da concha e ao substrato pela modificação do pé para a fixação. A característica principal da família Fissurella (Figuras 33 e 34) é o orifício apical da concha para alojar o ânus. As Figuras 35 e 36 mostram, respectivamente, as faces dorsal e ventral de uma espécie da família Acmaeidae, com ápices corroídos, mas sem o orifício natural.

Outra representante de concha pateliforme, aqui ilustrado pelas Figuras 37 e 38, é Siphonaria, gênero de gastrópode Pulmonata, Archaeopulmonata dotado de cavidade pulmonar fechado, sendo o pneumóstoma apontado pela seta. 
A Figura 39 mostra uma concha do gênero Haliotis, Prosobranchia, Archaeogastropoda, cuja característica conquiológica principal é a série de orifícios que sinalizam as diferentes posições do ânus durante o crescimento.

$O$ outro tipo de concha encontrado nos Archaeopulmonata, discutido na primeira parte, e o enrolamento em espiral é aqui mostrado pelas Fotos 40 e 41 que representam o gênero Tegula. Além do enrolamento, deve ser destacado o caráter importante que é a abertura com lábio contínuo.

O lábio contínuo de abertura, todavia, não é exclusivo dos Archaeogastropoda, sendo também encontrado em muitas famílias de Mesogastroda.

A Foto 42 mostra um representante do gênero Strombus, Mesogastropoda com abertura descontínua, interrompida na base por um entalhe amplo (seta) de acomodação do sifão.

A ordem Neogastropoda é aqui ilustrada pelo gênero Zidona, Volutidae, Figura 43 , onde se vê o sifão desenvolvido e o canal sifonal, assinalados, respectivamente, pelas setas superior e inferior.

Na primeira parte foi dito que a distinção das categorias superiores na sistemática dos gastrópodes é feita, através de caracteres morfológicos internos, muito embora, possam ser reconhecidos os grupos por alguns de seus caracteres conquiológicos, conforme foi demonstrado acima.

$O$ esquema da Figura 44 mostra a organização geral, resumida, de um Prosobranchia, Archaeogastropoda. Além dos caracteres conquiológicos temos a presença de uma brânquia bipectinada (Aspidobranchia), para justificar tal identificação.

Os Archaeogastropoda "mais primitivos" apresentam um par de brânquias bipectinadas (br), um par de aurículas (ae, ad), como é mostrado na Figura 46, além de um par de rins. Outros já apresentam esses órgãos reduzidos numericamente, mas as brânquias permanecem bipectinadas (br).

Nas outras ordens de Prosobranchia, as brânquias já são monopectinadas como mostra o esquema do Neogastropoda, ilustrado na Figura 45. Além do canal sifonal longo e do sifão (cs, sn) outra característica é da probóscide (pr) extroversível que identifica o hábito carnívoro, característico da ordem Neogastropoda. Nos. Archaeogastropoda raspadores encontramos, quando muito, uma projeção anterior da cabeça, formando um focinho (fo) visto na Figura 46, ver também Figura 53.

A presença de uma estrutura musculosa nucal, o pênis (p), sempre visível nos machos, exclui tal exemplar ilustrado dos Archaeogastropoda, que têm fecundação externa e não possuem órgão copulador.

A presença do opérculo (op), mostrado nas Figuras 44 e 45 , nunca é encontrada nos Pulmonata, sendo raríssima entre os Opisthobranchia. Já a presença de escultura vertical ou transversal (ev, et) na superfície da concha tem geralmente valor apenas nas categorias sistemáticas mais baixas. 
As Figuras 47 e 48 ilustram duas formas distintas de Opisthobranchia, dentre as inúmeras variedades que o grupo apresenta. Em comum, vê-se a presença de um par de rinóforos (rn), que são tentáculos olfativos exclusivos dessa classe. Na Figura 48, além da concha (ch), vê-se uma brânquia parcialmente externada, mostrando sua condição de posterior em relação ao pericárdio (pc). Na Figura 47 vê-se uma espécie sem concha que apresenta brânquias secundárias, circundando o ânus (an).

A subclasse Pulmonata é aqui representada pelas Figuras 49 a 51 . No primeiro esquema vê-se um animal completo; concha e partes moles, enquanto nos últimos a concha foi retirada. Como principais características visíveis temos a borda livre do manto (bl), soldada com a porção dorsal da massa cafalopediosa, deixando apenas uma válvula de controle do fluxo de ar para a cavidade pulmonar, o pneumóstama (pn) e a abertura genital hermafrodita (ag) situada à direita entre os tentáculos superior (ts) e inferior (ti).

$\mathrm{Na}$ Figura 50 vê-se a posição da sola, quando a massa cefalopediosa se encolhe para dentro do anel, formado pela borda livre do manto. Vêem-se também, por transparência, os vasos pulmonares. Na Figura 51, em vista lateral esquerda, vê-se a posição dos rins (ri), pericárdio (pc) e da veia pulmonar (vp).

Foi dito na parte geral que um dos poucos caracteres exclusivos do Filo Mollusca é a rádula. A Figura 52 mostra um esquema simplificado do aparelho radular. Vêem-se as duas extremidades da fita radular (fr), a anterior na abertura bucal (b) e sua região geradora (ng) na posterior. Essa fita tem um crescimento contínuo para reposição dos dentes que vão se gastando com o uso. $O$ movimento é dado pela musculatura intrínseca (mi) com o apoio de uma peça cartilaginosa (cr) e por músculos retratores (rr) inseridos ao músculo columelar (Figura $50, \mathrm{mc}$ ). O alimento cortado pela mandíbula (md) é raspado pela rádula e empurrado para o esôfago (eo).

Entre esses padrões acima descritos e a ausência total de aparelho radular, os gastrópodes apresentam uma variedade enorme de padrões, impossíveis de detalhes no espaço do presente texto. São então selecionados alguns esquemas para ilustrar o tema.

A Figura 53 mostra a sola (sl) e a face ventral da regão cefálica de um gastrópode raspador, vendo-se a rádula (rd) exposta na fenda bucal (fb).

A Figura 55 mostra a evolução do aparelho radular em um Neogastropoda, Toxoglossa, onde a fita radular é substituída por um aparelho adaptado à produção, propulsão e inoculação de veneno em animais predados. Os dentes (dt) vão se formando e se isolando no interior do saco radular (sr). Quando perfeitamente formados, são dirigidos para a proboscis (pr), ficando um a um em posição de disparo, ligados a um sistema de condução do veneno armazenado na bolsa de veneno (bv).

As Figuras 54, 56 a 61 mostram partes de fileiras de dentes de fitas radulares de diferentes espécies de famílias de Prosobranchia e Pulmonata, partindo dos dentes centrais, apontados pelas setas: Figura 54 Neritidae, 56 Amnicolidae (Mesogastropo- 
da), 58 Fasciolariidae (Neogastropoda), 59 Ancylidae (Basommatophora), 60 Lymnaeidae, 61 Physidae (a única a apresentar fileiras oblíquas).

Os interessados podem encontrar um interessante estudo sobre rádulas de gastrópodes brasileiros em Calvo (1987).

A separação das ordens da classe Pulmonata é baseada nas diferenças estruturais e funcionais apresentadas pelos tentáculos cefálicos. A Figura 62 mostra o padrão da ordem Basommatophora, com apenas um par de tentáculos (t) com os olhos em sua base; assim é também na ordem Archaeopulmonata. As espécies das duas ordens restantes apresentam um par superior (ts) e um inferior (ti).

O padrão da estrutura tentacular dos Stylommatophora é esquematizado na Figura 65. Nela, vêem-se dois pares de tentáculos, sendo os olhos localizados na extremidade do par superior (ts). Nota-se o tentáculo superior direito parcialmente invaginado com o olho (od) puxado por uma musculatura especial para o interior da cavidade do corpo. A sigla ag aponta a abertura genital hermafrodita, característica dessa ordem.

A Figura 66 mostra um Stylommatophora de concha rudimentar externa protegida pelo manto que delimita a cavidade pulmonar.

Nas Figuras 67 a 70 vêem-se esquemas referentes à ordem Systellommatophora, contituída pelas lesmas neotropicais, sem qualquer vestígio de concha. $\mathrm{Na}$ Figura 67 mostra-se o tentáculo superior esquerdo retraído, mas não invaginado, conservando sempre o olho em sua extremidade.

Outras características exclusivas da ordem são encontradas nas Figuras restantes. A 68 mostra a face ventral da região anterior de um Veronicellidae, cuja secção transversal é esquematizada na Figura 70. São assinalados noto (nt), hiponoto (hn), sulco pedal (sp), cavidade nucal (cn). Destaca-se a localização das aberturas genitais feminina (of), e masculinas (om), vendo-se o pênis se externando através dessa última. A Figura 69 mostra outro importante caráter da ordem, o ânus (an) subterminal.

\section{REFERÊNCIAS BIBLIOGRÁFICAS}

ABBOTT, R. T. \& BOSS, K. J., 1989. A Classification of the Living Mollusca. Melbourne: American Malacologists.

BOOS, K. J., 1982. Mollusca. In: Synopsis and Classification of Living Organisms (S.P. Parker, ed.), Vol. 2, pp. 945-1166, New York: MacGraw Hill.

CALVO, I. S., 1987. Rádulas de Gastrópodes Marinhos Brasileiros. Rio Grande: Furg.

DAVIS, G. M., 1979. The origin and evolution of the Gastropod family Pomatiopsidae with emphasis on the Mekong River Triculinae. Monograph Academy of Natural Sciences of Philadelphia, 20: 1-120.

FRANC, A., 1968. Classe des Gastéropodes (Gastropoda Cuvier 1798). Généralités et définition. In: Traité de Zoologie: Anatomie, Systématique, Biologie, (P.P. Grassé), Vol.5, Fas. 3, pp. 1-1083, Paris: Masson et it Cie Editéurs. 
FRETTER, V. \& GRAHAM, A., 1962. British Prosobranch Molluscs. Their Functional Anatomy and Ecology. London: The Ray Society.

HUBENDICK, B., 1978. Systematics and comparative morphology of the Basommatophora. In: Pulmonates: Systematics, Evolution and Ecology (V. Fretter \& J. Peake), Vol. 2A, Cap. 1, pp.1-47, London: Academic Press.

HYMAN, L. H., 1967. The Invertebrates: Mollusca I. Vol. 7, New York: McGraw Hill Boock Company.

KAY, E. A., 1968. A review of the Bivalved Gastropods and a discussion of evolution within the Sacoglossa. In: Studies in the Structure, Physiology and Ecology of Molluscs (V. Fretter, ed.), pp. 109-134, London: Academic Press.

LEME, J. L. M., 1973. Anatomy and systematics of the Neotropical Strophocheiloidea (Gastropoda, Pulmonata) with the description of a new family. Arquivos de Zoologia, 23: 295337.

LEVER, J., 1979. On torsion in gastropods. In: Pathways in Malacology (S. Van der Spoel, A. C. Van Bruggen \& J. Lever), Cap. 1, pp. 5-23, Amsterdam: Scheltema \& Holkema BV.

LUTZ, A., 1921. Observações sobre o gênero Urogonimus e uma nova forma de Leucochloridium em novo hospedeiro. Memórias do Instituto Oswaldo Cruz, 13: 136-140.

MORTON, J. E., 1955. Molluscs. London: Hutchinson University Library.

MORTON, J. E. \& YONE, C. M., 1964. Classification and structure of the Mollusca. In: Physiology of Mollusca (K. M. Wilbur \& C. M. Yonge, eds.), Vol. 1, Cap. 1, pp. 1-58, London: Academic Press.

PURCHON, R. D., 1968. The Biology of the Mollusca. London: Pergamon Press.

REY, L., 1956. Contribuição para o Conhecimento da Morfologia, Biologia é Ecologia dos Planorbideos Brasileiros Transmissores da Esquistossomose. Sua Importância em Epidemiologia. Rio de Janeiro: Serviço Nacional de Educação Sanitária.

RIOS, E. C., 1985. Seashells of Brazil. Rio Grande: Fundação Universidade do Rio Grande e Museu Oceanográfico.

RUSSELL-HUNTER, W. D., 1969. Uma Biologia dos Invertebrados Inferiores. Sāo Paulo: Editora da Universidade de São Paulo.

SALEUDDIN, A. S. M., 1979. Shell formation in molluscs with special referece to periostracum formation and shell regeneration. In: Pathways in Malacogy (S. Vander Spoel, A. C. Van

Bruggen \& J. Lever, eds.), Cap. 3, pp. 47-81, Amsterdam: Scheltama \& Holkema BV.

Van MOL, J. J., 1967. Étude morphologique et phylogénétique du ganglion cérébroide des Gastéropodes Pulmonés (Mollusques). Memoires Académie Royale de Belgigue - Classe des Sciences: 1-168.

VERDONK, N. H., 1979. Symmetry and asymmetry in the embryonic development of molluscs. In: Pathways in Malacology ( S. Van der Spoel, A.C. Van Bruggen \& J. Lever, eds.) Cap. 2, pp. 25-45, Amsterdam: Scheltema \& Holkema BV.

WILBUR, K. M. \& YONGE, C. M., 1964. Physiology of Mollusca. London: Academic Press. 


\subsection{Família Pilidae Connoly, 1927 (Ampulariidae Gray, 1824)}

Os pilídeos ou ampularídeos são amplamente distribuídos em águas continentais do mundo. Na Região Neotropical encontramos representantes de quatro gêneros: Asolene (Orbigny, 1835); Felipponea (Dall, 1919); Marisa (Gray, 1824) e Pomacea (Perry, 1810), estando incluída neste último Pomacea gigas (Spix, 1827), o maior gastrópode límnico neotropical, podendo alcançar cerca de $150 \mathrm{~mm}$ de comprimento.

Michelson (1961) com base em caracteres morfológicos, biológicos e zoogeográficos, propôs a divisão da família em sete gêneros: Asolene, Pomacea e Marisa para o Novo Mundo e Afropommus (Pilsbry \& Bequaert, 1927), Lanistes (Monfort, 1810), Pila (Roding, 1798) e Saulea (Gray, 1867) para o Velho Mundo. A presença de um sifão longo (exceto em Asolene) e de um canal espermático fechado caracteriza as primeiras, e um sifão curto e um canal espermático aberto é característico das espécies orientais.

O tamanho da concha nesta família varia de médio a grande, sendo espessa ou delgada, sempre globosa (exceto no gênero Marisa, de concha planorbóide), com giros convexos lisos ou finamente estriados, geralmente ornamentados com faixas castanhas; umbílico de tamanho moderado a grande; dextrógiras (levógira em Lanistes), com abertura grande, oval e inteira; opérculo córneo, exceto em Pila que é calcário.

A rádula é do tipo taenioglossa, mas devido às variações intra-específicas sua importância taxionômica fica reduzida em níveis abaixo de família.

As mandíbulas são quitinosas, convexas e unidas dorsalmente.

O animal possui pé grande e lanceolado; probóscide curta, com dois prolongamentos tentaculiformes que correspondem aos palpos labiais; tentáculos longos e finos na base dos quais se encontram os olhos, situados sobre pendúnculos salientes; dois apêndices nucais, o da esquerda, formando um sifão respiratório; cavidade palial dividida em duas partes, a da direita com uma brânquia alongada e a da esquerda, funcionando como um pulmão; osfrádio à esquerda próximo à margem do manto; mandíbulas bemdesenvolvidas, constituídas por fibras córneas finas; dente radular central alargado com uma cúspide principal, um ou dois dentículos laterais; dente lateral moderadamente grande, apresentando além da cúspide principal, um ou dois dentículos internos e dois externos; dentes marginais fortes, acuminados nas extremidades e geralmente com um dentículo secundário interno; glânglios cerebrais unidos por uma comissura dorsal longa e fina e uma 
ventral frágil; cordões pediosos reunidos por uma comissura principal longa e algumas secundárias; glânglio subintestinal fundido ao glânglio pleural direito (Thiele, 1931; Franc, 1968).

Os ampularídeos são dióicos mas geralmente não apresentam dimorfismo sexual externo. As fêmeas apresentam um pênis rudimentar na borda direita do manto. As de Pila e Pomacea depositam cachos de ovos de casca dura em hastes de plantas aquáticas, pilares de pontes, rochas e paredes de concreto, sempre um pouco acima do nível da água. Em Pomacea os ovos são pigmentados, podendo apresentar coloração vermelha, rósea, laranja, amarela ou verde, enquanto que em Pila não possuem pigmento. Nos gêneros Asolene, Lanistes e Marisa as desovas, colocadas dentro d'água, são gelatinosas e incolores.

São principalmente herbívoros. Alimentam-se da vegetação aquática presente no ambiente, mas também do bentos e restos de animais mortos. Em laboratório consomem vorazmente folhas de alface, couve, agrião, serralha e de outras hortaliças oferecidas como alimento.

A presença de um mecanismo respiratório duplo (pulmão e brânquia) torna-os capazes de respirarem no ambiente terrestre e aquático.

Toleram bem a poluição, mesmo a industrial, e a dessecação. Os gêneros Pila e Pomacea são acentuadamente anfíbios, podendo hibernar ou resistir à dessecação, enterrados na lama, emergindo com o início das chuvas. Orbigny (1835) observou tal comportamento em alguns exemplares de Pomacea coletados em La Plata (Argentina) que foram deixados em uma caixa durante 13 meses e que voltaram à atividade quando colocados novamente na água.

Respresentantes do gênero Asolene são encontrados nas regiões Sul e Sudeste do Brasil, no Uruguai e na Argentina. Apresentam sifão respiratório pouco desenvolvido; concha de tamanho médio, arredondada ou ovóide, com espira elevada; abertura oval, com lábio geralmente espesso e opérculo córneo. A discriminação das espécies é feita através de dados conquiliológicos, por falta quase completa de conhecimentos anatômicos.

Apesar de sua abundância e larga distribuição, a morfologia dos pilídeos neotropicais é ainda pouco conhecida, sendo sua classificação baseada, principalmente, em caracteres conquiliológicos. Paraense (1981) adverte sobre a fragilidade do estudo taxionômico baseado apenas em caracteres conquiliológicos, referindo-se ao excessivo número de espécies nominais na malacofauna límnica sul-americana. No caso dos pilídeos neotropicais, cerca de 100 nomes específicos são citados na literatura. 


\section{REFERÊNCIAS BIBLIOGRÁFICAS}

FRANC, A., 1968. Sous classe des Prosobranches. In: Traité de Zoologie: Anatomie, Systematique, Biologie (P. P. Grassé, org.), 5: 40-324, Paris: P. Bertrand.

MICHELSON, E. H., 1961. On the generic limits in the family Pilidae (Prosobranchia: Mollusca). Breviora, 133: 1-10.

ORBIGNY, A. D. Voyage dans L'Amerique Méridionale. Ampullaria, pp. 365-379.

PARAENSE, W. L., 1981. Gastropoda. In: Aquatic Biota of Tropical South America, Part 2: Anarthropoda (S.H. Hulbert, G. Rodriguez \& N.D. Santos, eds.), pp. 200-204, California: San Diego State University.

THIELE, J., 1929-1931. Handbuch der Systematischen weichtierkunde. Vol. 1, Jena: Gustav Fisher. 


\subsubsection{Gênero Pomacea (Perry, 1810)}

As espécies do gênero Pomacea distribuem-se por quase toda a Região Neotropical, geralmente habitando águas de curso lento e estagnadas. Pomacea paludosa (Say, 1829) ocorre na Flórida, Estados Unidos.

Apresentam concha de tamanho médio e grande, de coloração castanhoesverdeada ou amarelada, ornamentada com faixas espirais escuras; espira geralmente curta; umbílico presente, às vezes, bemdesenvolvido; abertura oval ou arredondada, lábio geralmente simples; opérculo córneo (Figuras 1, 2 e 3).

$\mathrm{O}$ animal apresenta probóscide extensível, em cuja extremidade encontra-se a boca. Esta é uma fenda sagital e o epitélio ao seu redor é glandular, apresentando sulcos e pregas. A cada lado da boca há uma projeção tentaculiforme que corresponde ao palpo labial. Em seguida a eles vêm os tentáculos cilíndricos, longos e extensíveis, que durante a locomoção do animal mostram-se distendidos e em movimento. Externamente, na base de cada tentáculo, há uma proeminência globulosa, o omatóforo, na extremidade do qual se encontra o olho.

Os lóbulos cervicais, direito e esquerdo, estão situados lateralmente, atrás dos tentáculos, junto à borda do manto. $\mathrm{O}$ direito é formado por uma pequena dobra da parede do corpo e funciona como um canal de excreção, desembocando nele o ânus, a corrente exalante da brânquia e os produtos de excreção do rim. $O$ lóbulo nucal forma pela aposição de suas bordas um tubo fechado, o sifão, utilizado para bombear o ar atmosférico para dentro do pulmão. Possui grande elasticidade, podendo alcançar, quando totalmente distendido, cerca de quatro vezes o seu comprimento em repouso, quando se mostra como uma pequena formação alongada aberta médioventralmente.

O pé tem a forma de escudo e sua coloração pode variar de cinza escuro à amarelada. Em sua região dorsal posterior encontra-se inserido o opérculo córneo e de linhas concêntricas.

O manto forma na região cervical o anel palial ou borda do manto que é espesso e muitas vezes apresenta faixas castanhas, reproduzindo o ornamento da concha. Posteriormente é mais delgado, deixando ver a maioria dos órgãos por relevo e transparência. Dorsalmente, a área ocupada pelo pulmão e pela brânquia é geralmente pigmentada de negro. $O$ pulmão abre-se na cavidade do manto ou cavidade palial onde estão alojados a brânquia, o osfrádio e partes do sistema digestivo e do reprodutor. Esta cavidade é separada da massa visceral pela dobra palial, que se inicia perto do ânus e da abertura genital, indo até o pericárdio. 
A rádula é do tipo taenioglossa e as mandíbulas são quitinosas, convexas e unidas dorsalmente (Figuras 4 e 5).

FIGURA 1: Concha de $P$. lineata
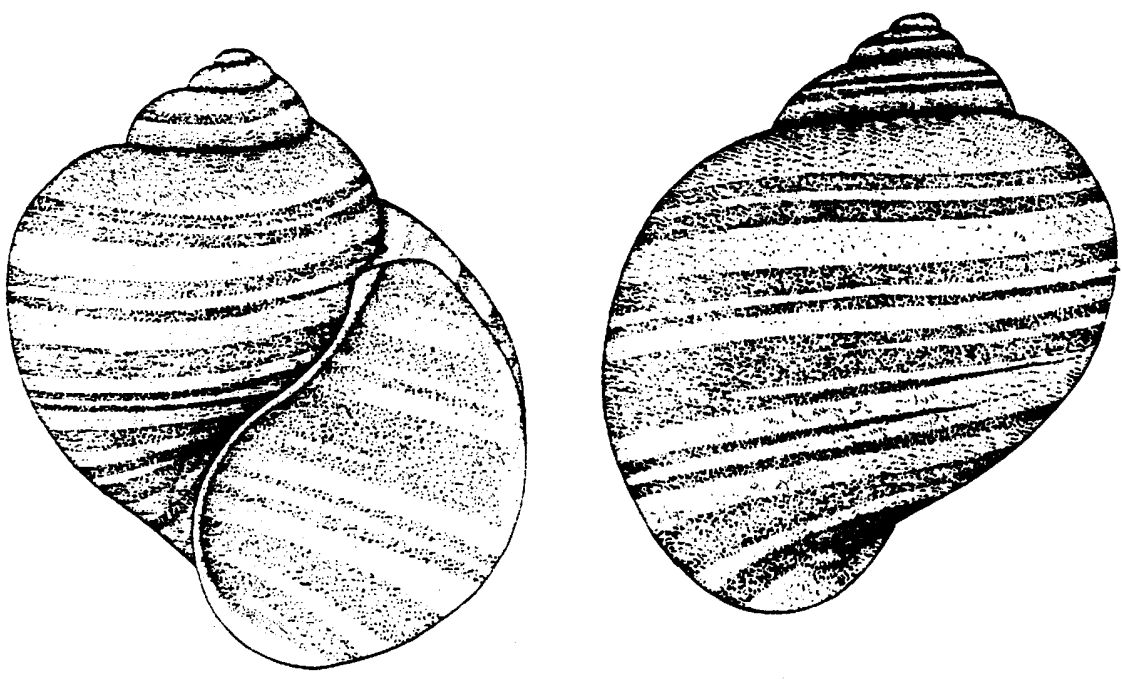

FIGURA 2: Concha de $P$. canaliculata
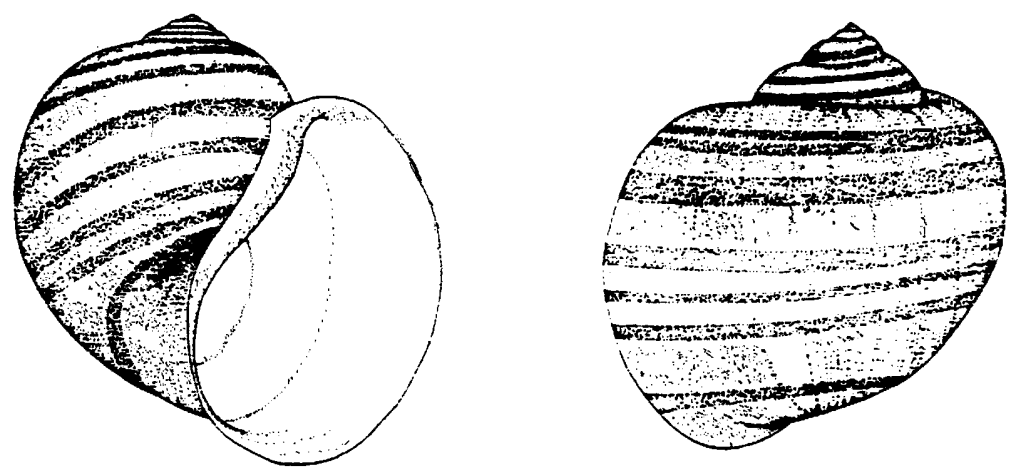
FIGURA 3: Concha de Pomacea sordida
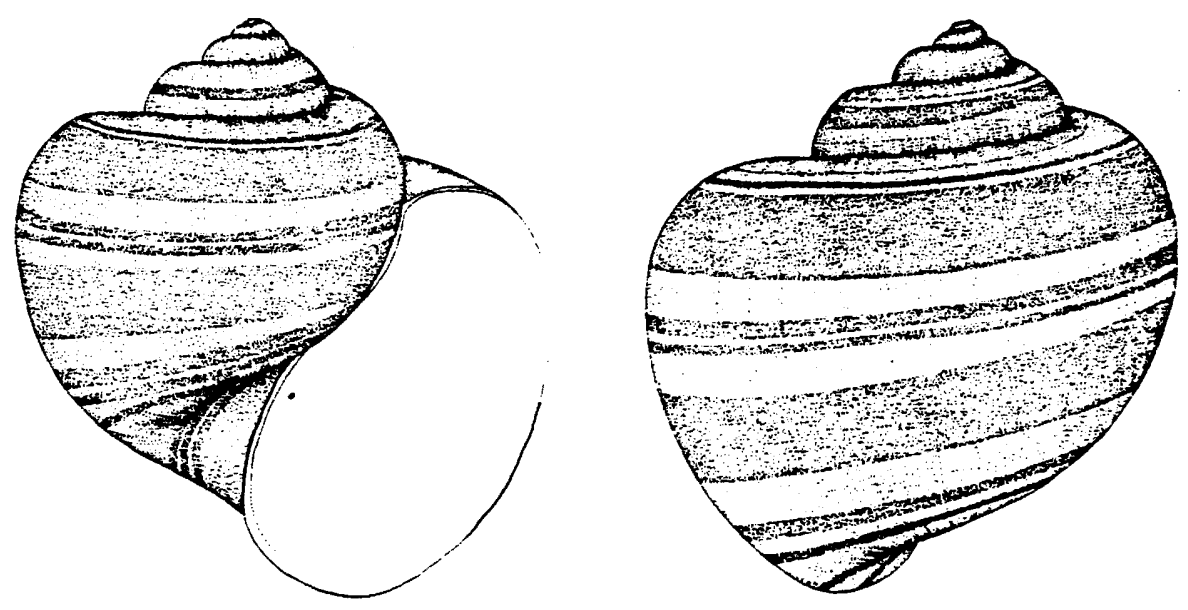

A massa visceral corresponde aos órgãos envolvidos pelo manto, e segue o enrolamento em espiral da concha. $\mathrm{O}$ pericárdio situa-se à esquerda, próximo à borda do manto. Dorsalmente vêem-se o ureter, transversal ao eixo do corpo do animal, o rim e a glândula digestiva, esta última ocupando a maior parte da massa visceral. $O$ estômago apresenta-se como uma mancha circular clara inserida na massa esverdeada da glândula digestiva. A gônada, tanto no macho como na fêmea, ocupa mais ou menos as três primeiras voltas da espira (Figura 6).

Como nos demais ampulariídeos, os sexos são separados. Nos machos, a presença da bainha do pênis na borda đireita do manto permite a distinção dos sexos sem dissecção. Nos casais em cópula, os machos são geralmente menores que as fêmeas. Estas iniciam a oviposição cerca de 24 horas após a cópula, durante a noite ou pela manhã bem cedo. As desovas são postas sempre acima do nível da água, sendo os oyos esféricos, com cerca de $3 \mathrm{~mm}$ de diâmetro e com coloração que pode ser varmelha, rósea, laranja, amarela ou verde.

Os ovos são expelidos um a um pelo orifício genital e deslizam lentamente pelo sulco, formado pelo lóbulo nucal direito e pelo pé. São depositados muito próximos uns aos outros, de forma que alguns se tornam um pouco achatados. À medida que vão amadurecendo, a cor torna-se mais clara, atingindo uma tonalidade esbranquiçada, quando próximo à eclosão. Esta ocorre, geralmente, 15 dias após a ovoposição, em uma temperatura média de $25^{\circ} \mathrm{C}$. 
FIGURA 4: Rádula de $P$ lineata. dc: dente central; dl: dente lateral; dme: dente marginal externo; dmi: dente marginal interno

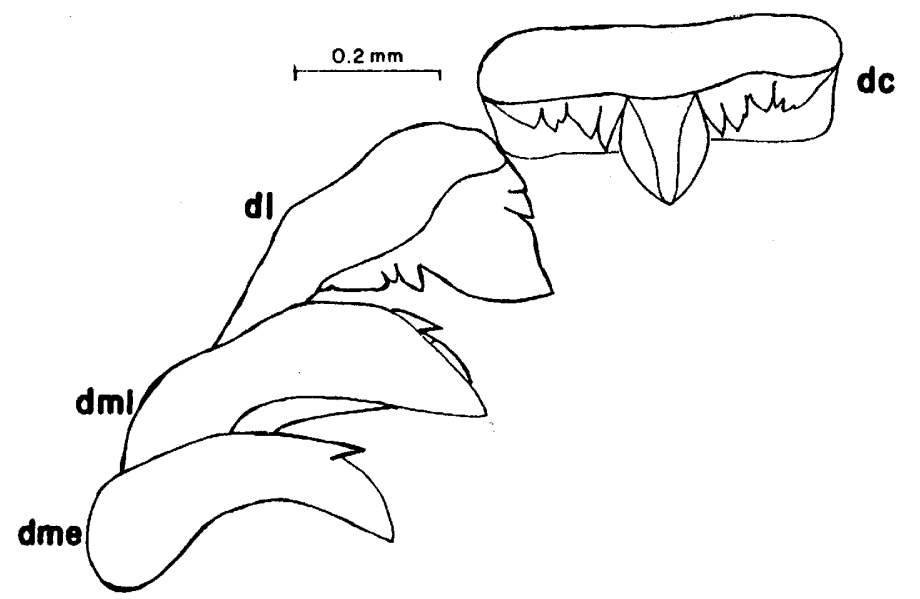

FIGURA 5: Mandíbula de $P$. lineata (ma)

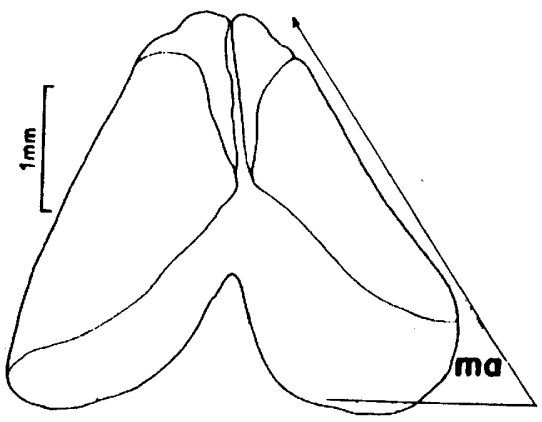

O sistema reprodutor masculino pode ser dividido em quatro partes: o testículo e o ducto deferente; a vesícula seminal; a próstata e o pênis em sua bainha (Figuras 7,8 e 9) 
FIGURA 6: $P$. lineata, animal retirado da concha. bm: borda do manto; ga: glândula anal; gd: glândula digestiva; Ind: lóbulo nucal direito; ol: olho; om: omatóforo; pe: pé; pl: palpo labial; pu: pulmão; re: reto; ri: rim; sp: saco espermático; si: sifāo; te: tentáculo; ur: ureter

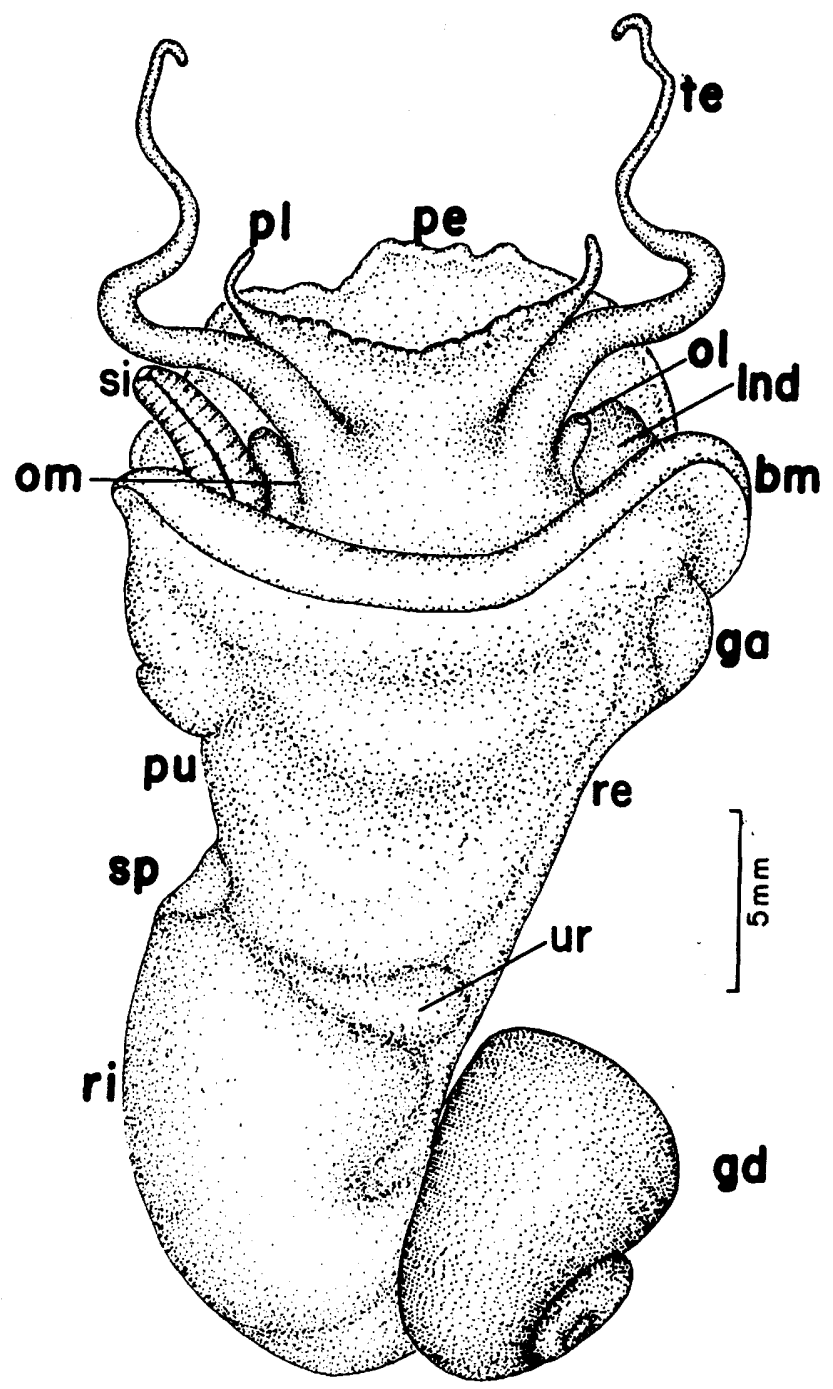

O testículo é uma massa de cor creme recoberta por pigmentação escura, que ocupa as três primeiras volta ou mais da espira. Pequenos e numerosos ductos eferentes se reúnem para formar dois ramos principais, dando origem ao ducto deferente. Este último, muito delgado em todo o seu trajeto, passa pela base espira até o nível do estômago e curva-se para a direita, na altura do saco pericárdio, para penetrar na vesícula seminal. 
FIGURA 7: Aparelho reprodutor masculino de $P$. lineata: bm: borda do manto; bpe: bolsa do pênis; bpn: bainha do pênis; cd: canal deferente; dp: dobra palial; gap: glândula apical; gi: glândula interna da bainha; gmi: glândula mediana interna da bainha; me: membrana; pr: próstata; sb: sulco da bainha; ts: testículo; vs: vesícula seminal

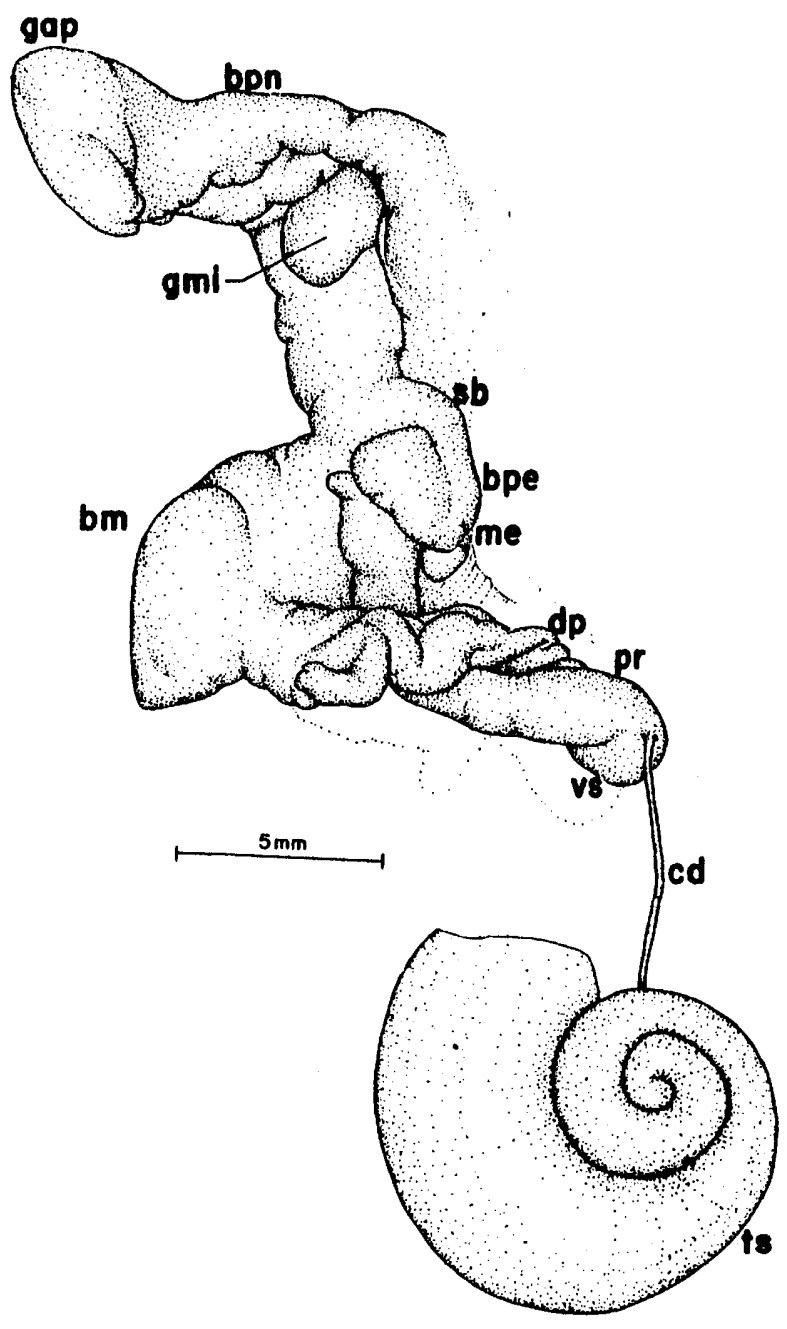




\section{GÊNERO POMACEA}

FIGURA 8: Aparelho reprodutor masculino de $P$. canaliculata: bm: borda do manto; bpe, bolsa do pênis; bpn: bainha do pênis; cd: canal deferente; gbe: glândula basal externa; pr: próstata; ts: testículo; vs: vesícula seminal.

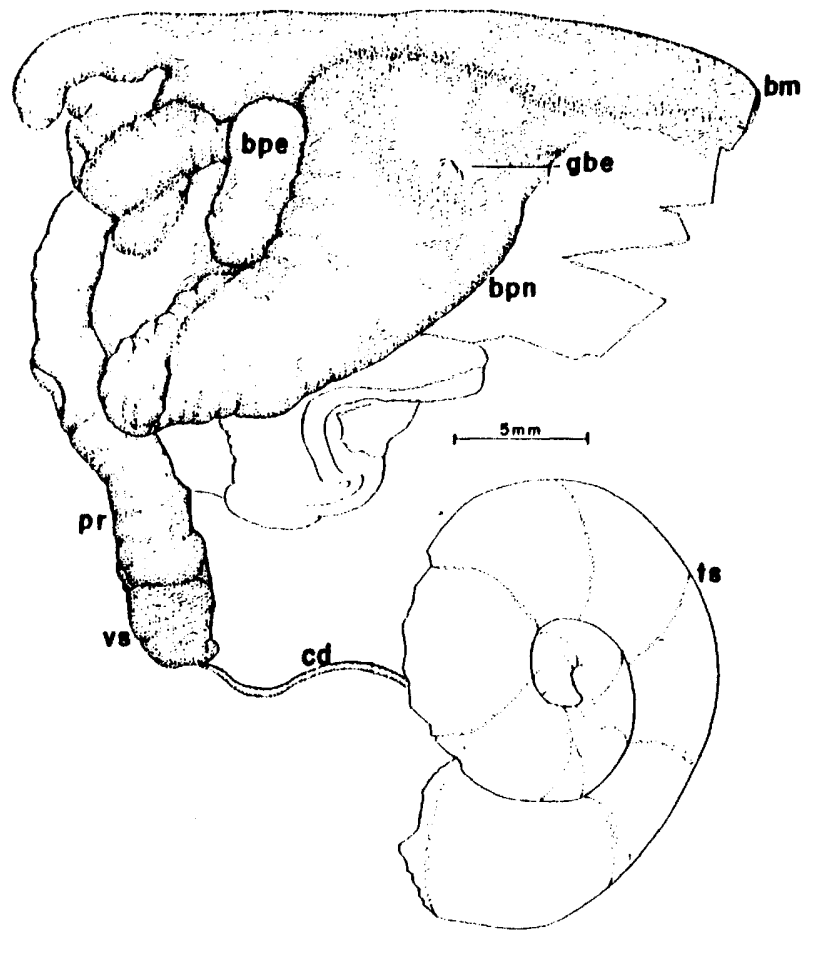

A vesícula seminal apresenta dobras e sulcos internos que convergem em um canal ligado ao canal prostático (Figura 9).

FIGURA 9. $P$. caniculata vesícula seminal: pr: próstata; vs: vesícula seminal

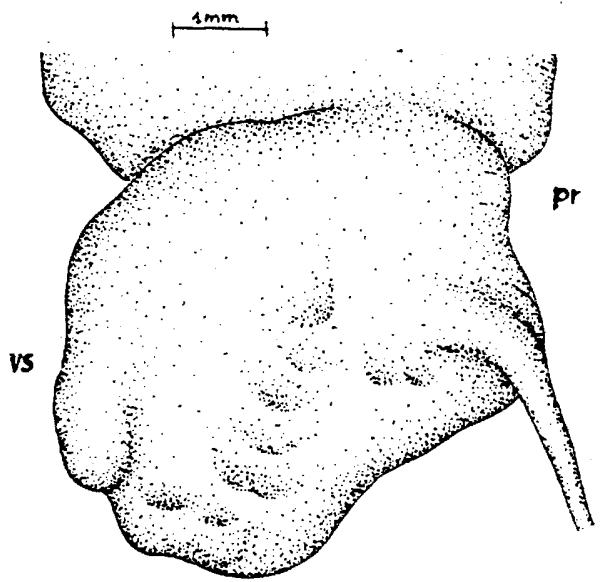


FIGURA 10. Aparelho reprodutor masculino de $P$. sordida: a: ânus; bm: borda do manto; bpe: bolsa do pênis; bpn: bainha do pênis; br: brânquia; cd: canal deferente; gbe: glândula basal externa; pr: próstata; ts: testículo; vs: vesícula seminal

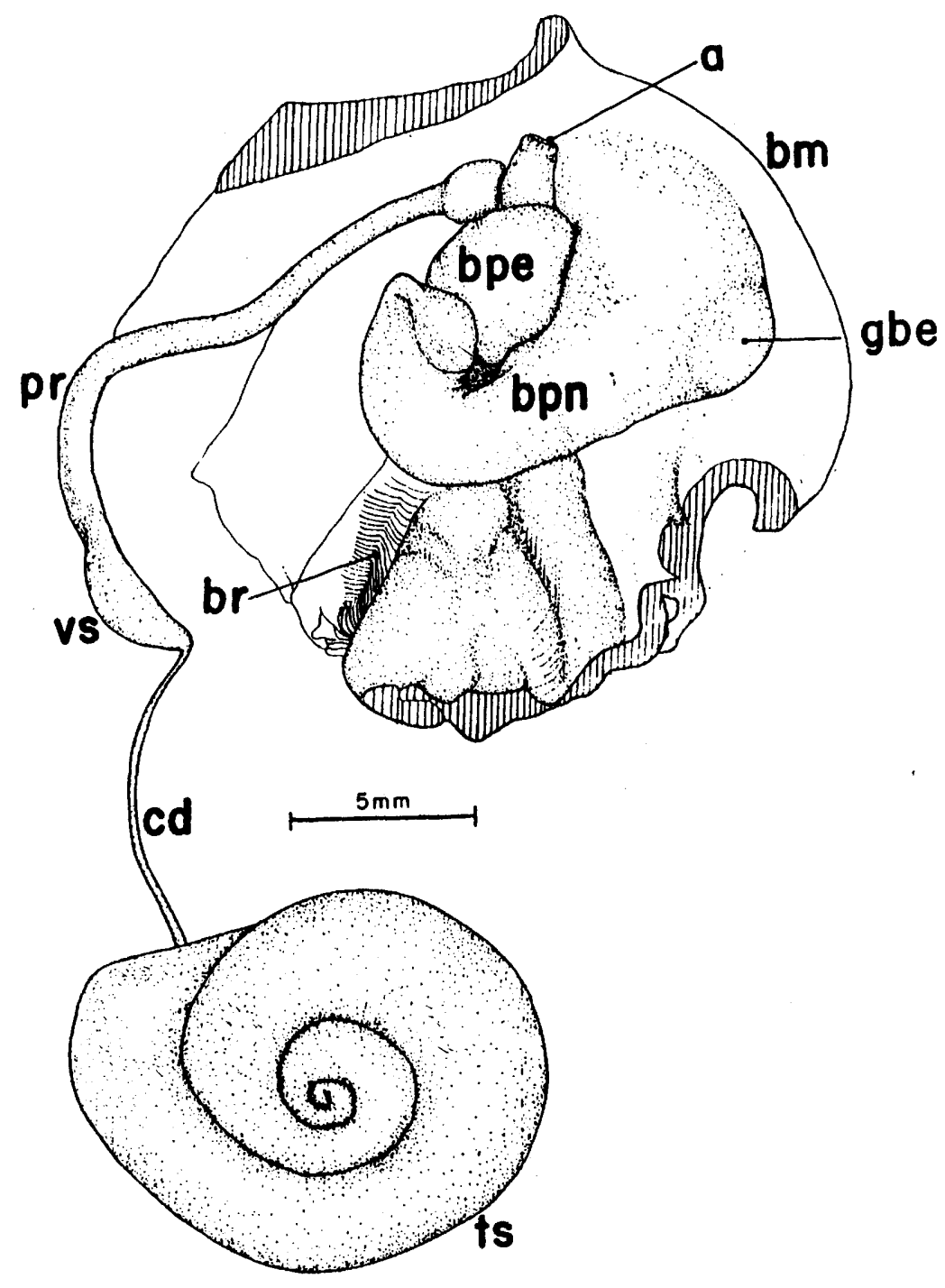


A próstata é cilíndrica e compacta, com coloração semelhante à do testículo. Após a vesícula seminal, segue adiante e à esquerda do reto até alcançar a papila anal. Em seguida, curva-se ligeiramente para a esquerda, abrindo-se na goteira seminal embaixo da bolsa do pênis. O canal prostático, quase central, apresenta uma estreita luz em forma de fenda.

$\mathrm{O}$ pênis (Figuras 11 e 12) é cilíndrico, filiforme e seu diâmetro diminui gradualmente, até terminar em ponta aguda. Quando em repouso, encontra-se enrolado dentro de uma bolsa, a bolsa do pênis, de paredes delgadas, cuja extremidade proximal, que corresponde à base do pênis, é compacta, enquanto que a extremidade distal forma internamente um canal em forma de $U$, por onde o pênis desliza para a cópula. Embaixo dessa bolsa, perto da extremidade distal da próstata, há uma membrana alongada e delicada, que segundo Lopes (1955) teria a função de auxiliar o transporte do líquido espermático da próstata para o pênis.

Durante a cópula, o pênis percorre o canal formado pela bolsa do pênis e pela bainha, emergindo próximo à metade da bainha. Sua extremidade proximal permanece presa pelas bordas da bainha, enquanto a distal penetra no gonoporo feminino até alcançar o oviduto palial.

A bainha do pênis (Figuras 13, 14 e 15), uma estrutura alongada e alargada na base, se localiza perto da borda do manto, à direita, sendo formada por uma dobra do manto, cujas bordas se justapõem longitudinalmente, formando um sulco mediano. A borda direita da bainha dobra-se internamente, dando continuidade ao canal formado pela bolsa do pênis.

FIGURA 11. P. Lineata .Pênis enovelado dentro da bolsa: pn: pênis.

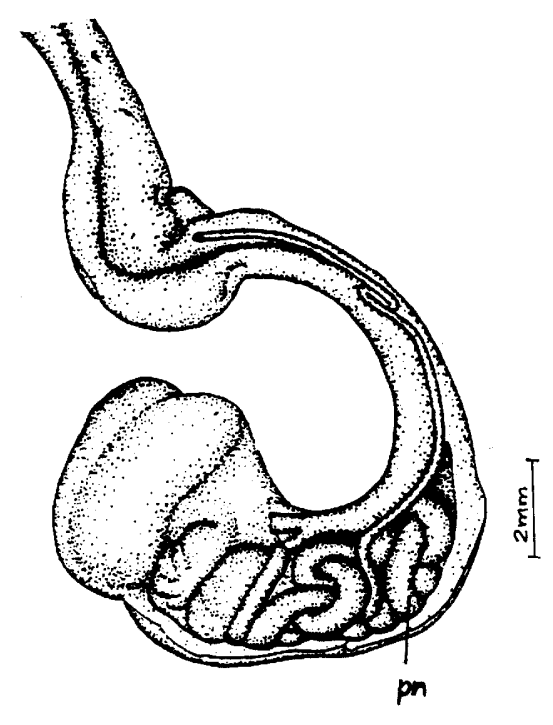




\section{TÓPICOS EM MALACOLOGIA MÉDICA}

FIGURA 12. $P$. Lineata. Pênis parcialmente distendido: pn: pênis.

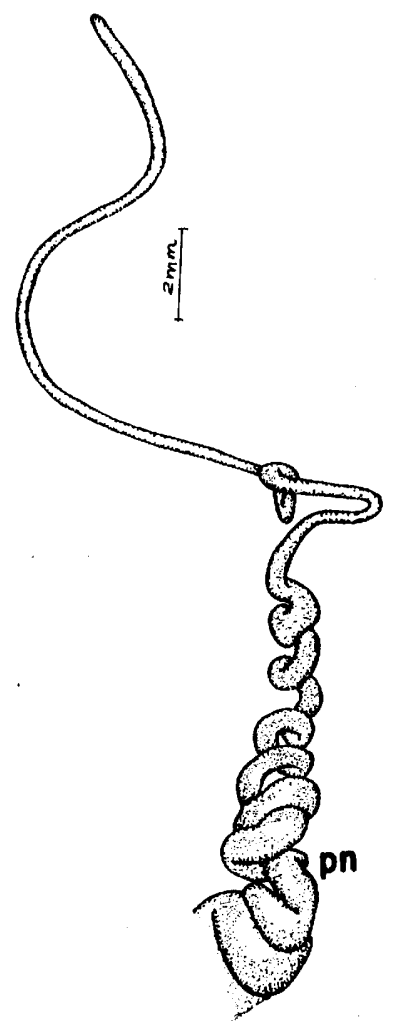

FIGURA 13. $P$. Lineata. Bainha do pênis, voltada para dentro da cavidade palial: agb: abertura da glândula basal; bm: borda do manto; bpn: bainha do pênis; gbe: glândula basal externa.

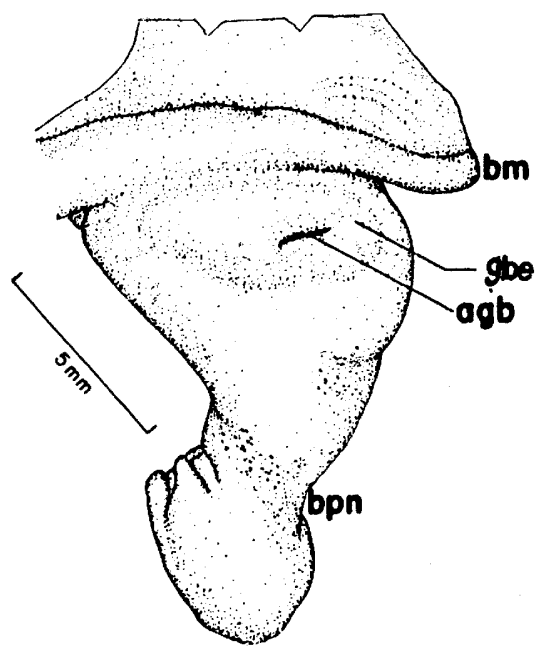




\section{GÊNERO POMACEA}

FIGURA 14. $P$. caniculata. Bainha do pênis, voltada para fora da cavidade palial: gi: glândula interna; bpe: bolsa do pênis; bpn: bainha do pênis; sb: sulco da bainha

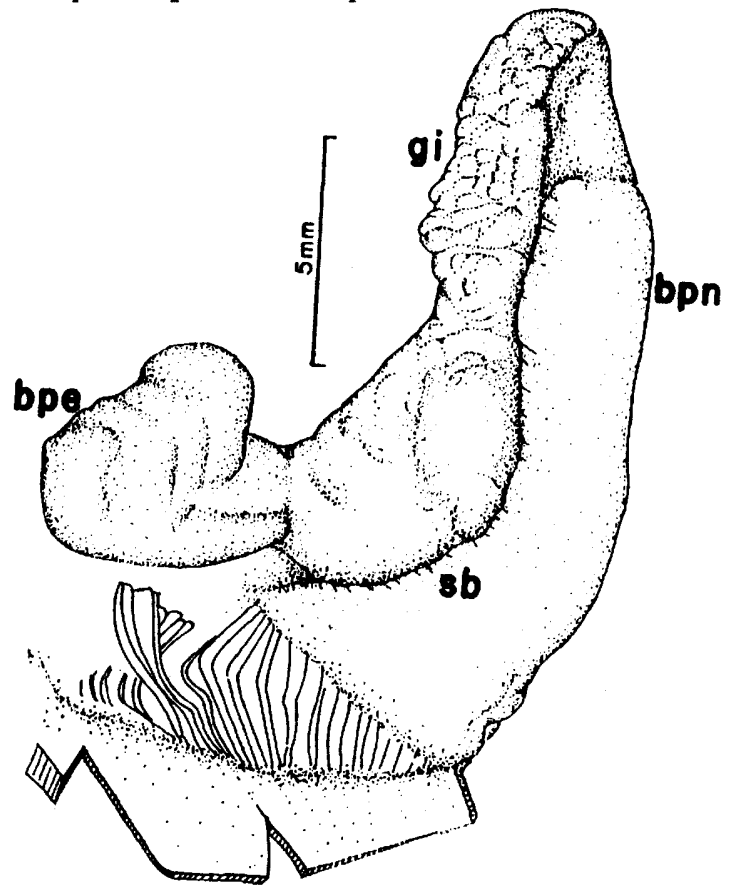

FIGURA 15. $P$. sordida. Bainha do pênis, voltada para fora da cavidade palial: gap: glândula apical; gmi: glândula mediana interna; pn: pênis

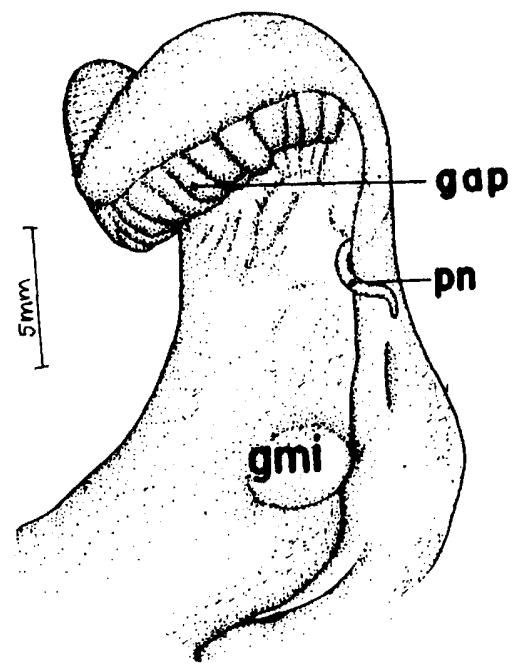


Quando em repouso, a extremidade distal da bainha se projeta para dentro da cavidade palial e durante a cópula ela se volta para fora, penetrando, juntamente com o pênis, na cavidade palial da fêmea. A presença e a disposição de glândulas na bainha são carateres usados em sistemática.

O ovário ocupa posição semelhante à do testículo, sendo constituído por túbulos brancos e ramificados, dispostos superficialmente sobre a glândula digestiva. Apresenta, geralmente, três ou quatro ramificações principais que convergem para formar um ducto muito fino, o oviduto. Este acompanha a espiralação da concha, descrevendo um trajeto semelhante ao do ducto deferente, dobrando-se à direita do pericárdio para penetrar na glândula de albume. $\mathrm{O}$ oviduto palial segue à direita do reto, até abrir-se no gonoporo feminino, ao lado do ânus e nessa região apresenta dobras e sulcos profundos (Figuras 16 e 17).

FIGURA 16: Aparelho reprodutor feminino de $P$. Lineata: ag: abertura genital; an: ânus; bm: borda do manto; br: brânquia; bv: bainha vestigal; gal: glândula de albume; ov: ovário; pnv: pênis vestigal; pu: pulmão; rs: receptáculo seminal.

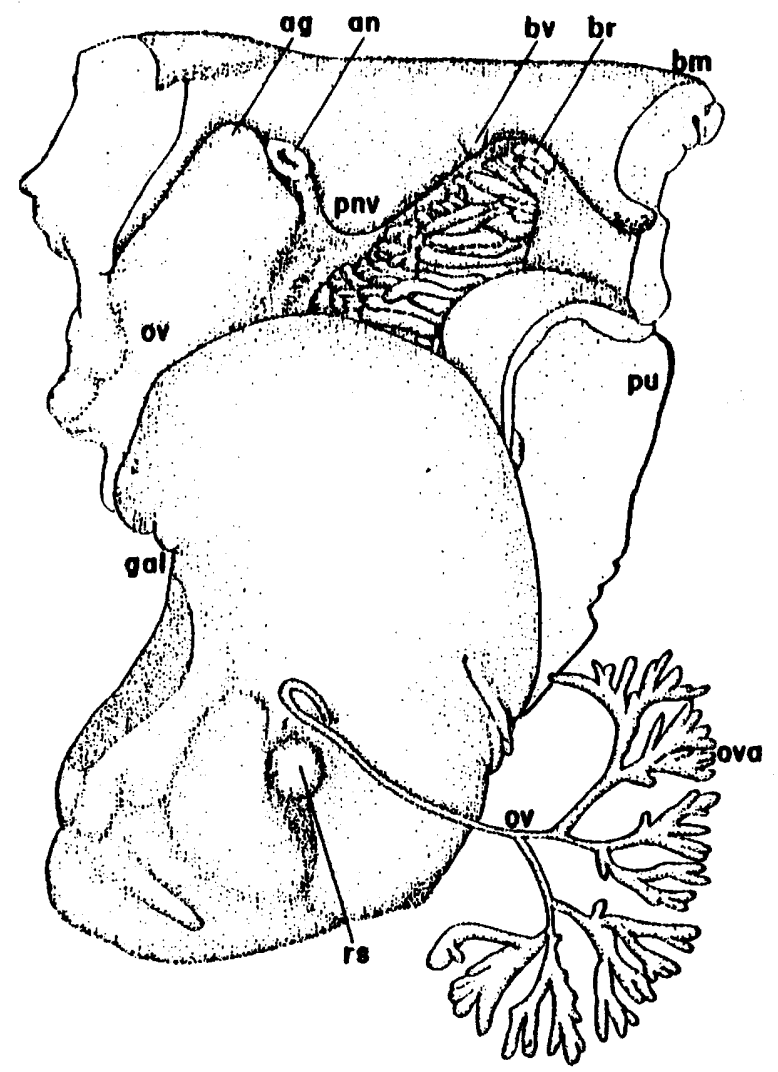




\section{GÊNERO POMACEA}

FIGURA 17: Glândula de albume de $P$. Lineata: gal: glândula de albume; gc: glândula da casca em espiral; ov: oviduto; rs: receptáculo seminal.

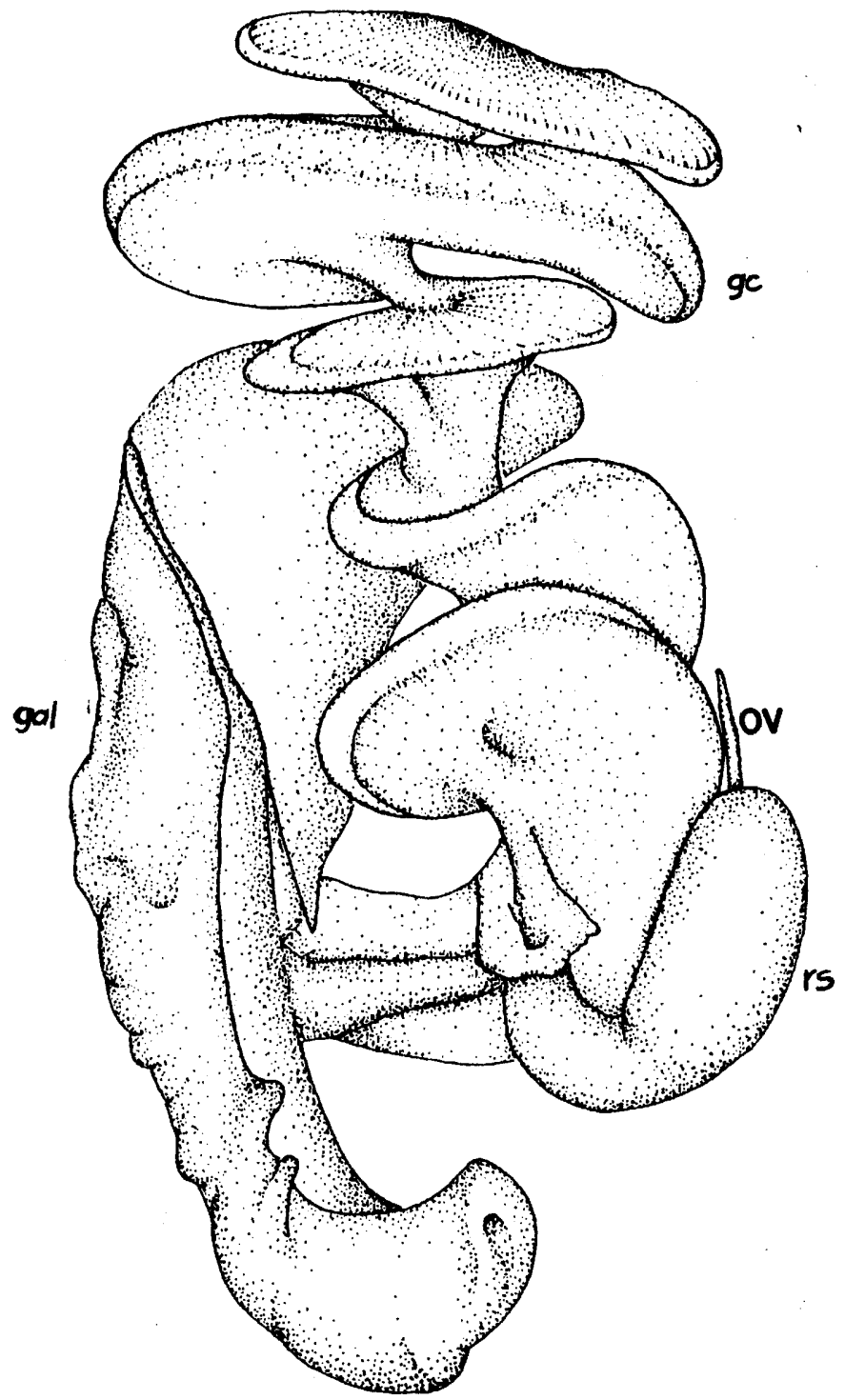

O receptáculo seminal possui paredes fortemente musculares e sua extremidade anterior é, geralmente, mais larga do que a posterior. Encontra-se envolvido pela glândula de albume, ficando visível apenas parte de sua extremidade proximal.

Pela coloração e grande volume, a glândula de albume é o órgão de maior destaque no sistema reprodutor feminino. Na época da reprodução ocupa a maior parte da massa visceral, tornando-se reduzida fora desse período. Sua metade 
proximal encontra-se sobre o ureter e a parede lateral do rim, enquanto que a metade distal projeta-se na cavidade palial. Apresenta internamente um canal em espiral, a glândula da casca, de luz muito estreita, que se extende desde o receptáculo seminal até sua estremid̦ade distal, onde faz relevo.

O canal principal da glândula de albume, localizado na massa glandular adjacente à glândula da casca, apresenta luz estreita e várias aberturas em fendas para a passagem do albume (Figura 17).

As fêmeas apreșentam vestígio do aparelho copulador masculino, pênis e sua bainha. Correspondem, respectivamente, às duas formações, uma maior e outra menor, situadas na margem direita do manto, entre o ânus e a brânquia (Figura 17). A primeira estrutura apresenta internamente um filamento digitiforme, o pênis, localizado em uma dobra que se prolonga até a segunda formação, a bainha.

A anatomia do grupo é ainda pouco conhecida, a despeito de sua ampla distribuição e abundância. A maior parte da literatura diz respeito à conquiliologia e a certos aspectos da biologia, sendo poucos os estudos anatômicos. Dentre estes últimos, podem ser citados: Sachwatkin (1920) sobre Ampullaria gigas (Spix, 1827); Lopes (1955a, 1955b, 1956) sobre Pomacea canaliculata (Lamarck, 1822), Pomacea haustrum (Reeve, 1856), Pomacea lineata (Spix, 1827) e Pomacea sordida (Swainson, 1823); Scott (1957) sobre alguns pilídeos argentinos; Pain (1958) sobre Pomacea falconensis; Andrews (1964, 1965a, 1965b) sobre $P$. canaliculata; Martin $(1980,1984)$ sobre o complexo peniano de pilídeos da Argentina. Catalán \& Moreno (1984) sobre a glândula de albume de $P$. canaliculata; Thiengo $(1987,1989,1993)$ sobre a morfologia de $P$. lineata, $P$. sordida e $P$. canaliculata e Cazzaniga (1987) sobre $P$. canaliculata.

Alguns caracteres dos sistema reprodutor masculino são utilizados na discriminação das espécies, como, por exemplo, tamanho, forma, disposição das glândulas da bainha do pênis e a forma da próstata. $\mathrm{O}$ sistema reprodutor masculino de $P$. lineata, $P$. canaliculata e $P$. sordida estão ilustrados nas Figuras 7,11 e 14, respectivamente. As duas primeiras são espécies próximas, sendo os caracteres diagnósticos observados, principalmente, na bainha do pênis. $P$. sordida, ao contrário, reúne caracteres morfológicos e conquiliológicos que a diferenciam prontamente das demais espécies conhecidas.

Salvo algumas exceções, como no caso de $P$. scalaris na qual as voltas da espira se dispõem como uma escada, em $P$. gigas pelo tamanho avantajado e em $P$. sordida por sua coloração geralmente escura e abertura amarela ou violácea, os caracteres conquiliológicos servem apenas como orientação na identificação das espécies. Como esses são variáveis, uma taxionomia, focalizando apenas este aspecto, pode levar a uma fragmentação excessiva de taxa, o que, provavelmente, 
ocorreu com o gênero Pomacea. Só para o Brasil são citados cerca de cinqüenta nomes específicos.

$P$. lineata apresenta uma distribuição mais setentrional e litorânea, sendo encontrada desde o nordeste até o sudeste do país.

$P$. canaliculata ocorre, principalmente, nas regiões Sul e Sudeste do Brasil, assim como na Argentina, Uruguai, Paraguai e Bolívia, sendo abundante nas bacias dos rios da Prata, Uruguai e Paraguai. Ihering (1968) cita, também, sua ocorrência na bacia Amazônica.

$P$. scalaris é uma espécie comum nas bacias dos rios Paraná, Paraguai e rio da Prata.

P. maculata (= P. gigas) é endêmica na bacia Amazônica.

Os representantes do gênero Pomacea no Brasil são conhecidos popularmente como arauá, aruá-do-banhado, aruá-do-brejo, caramujo-do-banhado, fuá e aruá (Santos, 1982; Ihering, 1968). São utilizados no Nordeste como remédio contra as doenças do peito e na Argentina contra a disenteria (Santos, 1982). No Norte são apreciados como alimento (O. Monte Apud lhering, 1968).

Pomacea lineata e Pomacea glauca são considerados como praga de arrozais no Suriname (Van Dinther, 1956) e $P$. canaliculata foi citada por Olazarri (1979) como praga nos cultivos de agrião, no Uruguai.

Colman (1992), informação pessoal, comentou sobre a introdução e a proliferação de $P$. canaliculata na Austrália e a preocupação das autoridades daquele país na erradicação desta espécie, antes que se torne praga nas plantações de arroz, como vem acontecendo em alguns países no Oriente.

Há algumas décadas vem sendo pesquisada a utilização de pilídeos no controle biológico dos moluscos hospedeiros do Schistossoma mansoni. Autores como Mathiensen (1976), Milward-de-Andrade (1978) e Paulinyi (1971) consideram que Pomacea haustrum e Pomacea lineata podem atuar como predadores-competidores, alimentando-se das desovas e formas jovens de bionfalárias, além de competir por espaço e alimento. Entretanto, a literatura sobre o assunto é ainda controversa. Paraense (1987), entre outros, questiona a validade do uso de pilídeos no controle biológico desses planorbídeos, ressaltando que a ingestão de ovos e de bionfalárias jovens ocorrem em conseqüência do hábito alimentar voraz desses animais e não um processo seletivo, como é defendido por alguns autores, e cita, também, alguns exemplos de co-habitação prolongada de pilídeos e bionfalárias em criadouros naturais.

Pilídeos do gênero oriental Pila podem atuar como hospedeiros intermediários do Angiostrongylus contonensis (Chen), um nematoda parasito de roedores e, acidentalmente, do homem. Quando os pilídeos parasitados são ingeridos crus pelo homem, as larvas migram para a medula e sistema nervoso contral, causando a 
angiostrongilíase (meningoencefalite eosinofílica), podendo resultar em morte. A angiostrongilíase ocorre principalmente no sudeste da Ásia, Malásia e ilhas do Pacífico. Entretanto já foi detectada no Caribe, em Cuba, provavelmente introduzida por ratos transportados em navios procedentes das áreas de ocorrência (Aguiar, 1981).

$P$. paludosa $e P$. canaliculata, espécies americanas, foram encontradas naturalmente infectadas com A. cantonensis na ilha de Oahu (Havaí) e nas ilhas Ryukyu (Japão), respectivamente (Wallace \& Rosen, 1969; Nishimura, 1986). P. paludosa foi encontrada em valas de irrigação e foi introduzida naquela ilha para ser utilizada como alimento pela população.

Até o presidente não há relatos desta doença no país. Entretanto, o grande número de imigrantes orientais, a possibilidade de introdução de ratos infectados e a presença dos hospedeiros intermediários suscetíveis em nosso país possibilitam a ocorrência do ciclo desse parasito no Brasil.

\section{REFERÊNCIAS BIBLIOGRÁFICAS}

AGUIAR, P. H.; MORERA, P. \& PASCUAL, J., 1981. First record of Angiostrongylus cantonensis in Cuba. American Journal of Tropical Disease and Hygiene, 30: 963-965.

ANDREWS, E. B., 1964. The functional anatomy and histology of the reproductive system of some gastropod molluscs. Proceedings of the Malacological Society of London, 36: 121-140.

, 1965a. The functional anatomy of the mantle cavity, kidney and blood system of some pilid gastropods (Prosobranchia). Journal of Zoology, 146: 70-94.

, 1965b. The functional anatomy of the gut of the prosobranch gastropod Pomacea canaliculata and some other pilids. Proceedings of the Malacological Society of London, 145: 19-36.

CATAlAN, N. M. Y. C. \& MORENO, A. R., 1984. Descripción del tracto intrauterino en el gasteropodo Ampullaria canaliculata. Neotropica, 30: 153-160.

CAZZANIGA, N. J., 1987. Expansión de Pomacea canaliculata (Gastropoda: Ampullariidae) en Asia. Un comentario de bibliografia reciente. Comunicaciones de la Sociedad Malacologica del Uruguay, 7: 67-68.

IHERING, R. V., 1968. Dicionário dos Animais do Brasil. São Paulo: Universidade de São Paulo.

LOPES, H. S., 1955. Sobre duas espécies do gênero Pomacea (Perry, 1810) com um estudo da genitália em ambos os sexos (Mesogastropoda, Architaenioglossa, Mollusca). Revista Brasileira de Biologia, 15: 202-210.

1956a. Sobre Pomacea lineata (Spix, 1827) (Mesogastropoda, (Architaenioglossa, Mollusca). Revista Brasileira de Biologia, 16: 375-380.

, 1956b. Sobre Pomaceà canaliculata (Lamarck, 1822) (Mesogastropoda, Architaeniglossa, Mollusca). Revista Brasileira de Biologia, 16: 535-542.

MARTIN, S. M., 1980. Contribuición al estudio histológio del complexo peniano de algunas ampularias argentinas (Mollusca, Ampullariidae). Neotropica, 26: 47-52. 


\section{GÊNERO POMACEA}

1984. Estudio del complejo penial de Asolene platae (Maton) (Mollusca, Prosobranchia, Ampullariidae). Neotropica, 30: 107-110.

MAThIENSEN, F. A., 1976. Pomacea lineata (Spix) (Mollusca, Prosobranchia) e o combate a planorbídeos. Ciência e Cultura, 28: 771.

MILWARD-DE-ANDRADE, R.; CARVALHO, O. S. \& GUIMARÃES, C. T., 1978. Alguns dados biológicos de Pomacea haustrum (Reeve, 1856), predador-competidor de hospedeiros intermediários de Schistosoma mansoni Sambon, 1907. Revista de Saúde Pública de São Paulo, 12: 78-89.

NISHIMURA, K. \& SATO, Y., 1986. Natural infection with Angiostrongylus cantonensis in Ampullarius canaliculatus (Lamarck) in the Ryukyu Island, Japan. Japanese Journal of Parasitology, 35: 469-470.

OLAZARRI, J., 1979. Los moluscos plaga de los cultivos de "berro" en Salto, Uruguay. Comunicaciones de la Sociedad Malacologica del Uruguay, 5: 63-69.

PAIN, T. \& ARIAS, S. C., 1958. Descripción de una especie nueva de Pomacea de Venezuela (Mesogastropoda, Architaeniglossa, Mollusca). Novidades Cientificas del Museo del Historia Naturales la Salle. Zoología, 24: 5-11.

PARAENSE, W. L., 1987. Control of Schistosomiasis mansoni: an outlook from current expectation. Memórias do Instituto Oswaldo Cruz, 82, Supl. IV: 1-12.

PAULINYI, H. M. \& PAULINI, E., 1971. Observações de laboratório sobre o controle biológico de Biomphalaria glabrata pela Pomacea sp. (Ampullaria). Revista Brasileira de Malariologia e Doenças Tropicais, 23: 135-149.

SACHWATKIN, V., 1920. Das Urogenitalsystem von Ampullaria gigas Spix. Acta Zoologica, 1: 67130.

SANTOS, E., 1982. Os Moluscos (Vida e Costumes). Belo Horizonte: Itatiaia.

SCOTT, M. I. H., 1957. Estudio morfologico y taxonomico de los ampullariideos de la Republica Argentina. Revista del Museo Argentino de Ciencias Naturales Bernardino Rivadavia, Zoologia, 3: 233-333.

THIENGO, S. C., 1987. Observations on the morphology of Pomacea lineata (Spix, 1827) (Mollusca, Ampullariidae). Memórias do Instituto Oswaldo Cruz, 84: 563-570.

THIENGO, S. C., 1989. On Pomacea sordida (Swaison, 1823) (Prisobranchia, Ampullariidae). Memórias do Instituto Oswaldo Cruz, 84: 351-355.

THIENGO, S. C.; BORDA, C. E. \& ARAÚJO, J. L., 1993. On Pomacea canaliculata (Lamarck, 1822) (Mollusca, Pilidae=Ampullariidae). Memórias do Instituto Oswaldo Cruz, 88: 67-71.

VAN DINTHER, J. B. M., 1956. Control of Pomacea (Ampuliaria) snails in rice fields. Bulletins van het Landbouwproefstation, 68: 1-20.

WALLACE, G. D. \& ROSEN, L., 1969. Studies on eosinophilic meningitis V-Molluscan hosts of Angiostrongylus cantonensis on Pacific Islands. American Journal of Medicine and Hygiene, 18: 206-216. 


\subsubsection{Gênero Marisa (Gray, 1824)}

As espécies deste gênero distinguem-se daquelas dos demais gêneros de Ampullariidae, principalmente, pelos seguintes aspectos: concha planorbóide, animal com lóbulo nucal esquerdo constituído por longo sifão, ovos com envoltórios gelatinosos, desprovidos de casca calcária e sempre depositados dentro da água (Pilsbry, 1933; Scott, 1957).

Atualmente têm sido citadas e reconhecidas como válidas somente duas espécies deste gênero: Marisa cornuarietis (Linnaeus, 1758) e Marisa planogyra (Pilsbry, 1933).

Dessas duas espécies, sem dúvida a mais conhecida e estudada é $M$. cornuarietis. Provavelmente originária de uma área da América tropical compreendida entre o Panamá e as Guianas e Trinidad (Baker, 1930; Pain, 1950; Oliver-Gonzáles et al., 1956), sua ocorrência tem sido citada para todo o norte da América do Sul, América Central e Flórida; sua presença já foi também registrada para o Texas, Estados Unidos da América, onde foi introduzida acidentalmente por aquaristas (Neck, 1984).

M. cornuarietis tem uma concha discoidal ou planorbóide relativamente grande, com cerca de cinco voltas. A concha é de coloração marrom-escuro avermelhado, com faixas amareladas, uniformemente dura, esculturada com linhas de crescimento regulares e finas e marcada com uma série de faixas castanho-escuras e espessura variada. A abertura da concha é arredondado-lunada ou subovalada. $O$ perístoma é inteiro; seu lábio externo é fino, completo e firmemente aderido à última volta. O plano da abertura faz um ângulo de dez graus com o eixo da cavidade espiral naquele ponto.

A espécie apresenta dimorfismo sexual (Demian \& Ibrahim, 1972). As fêmeas crescem em média um pouco mais do que os machos e têm a abertura da concha relativamente mais estreita, com um lábio peristomial externo reto, pé e cabeça mais pigmentados e escurecidos e uma sola também mais pigmentada. Os machos são caracterizados por terem a abertura da concha mais ampla e quase circular, com um lábio peristomial externo amplamente sulcado, pé e cabeça de colorido mais claro e mais fracamente pigmentados e uma sola amarelada, finamente pigmentada.

A concha de $M$. planogyra, tal como está destacado em sua descrição original por Pilsbry (1933), lembra a de $M$. cornuarietis, mas difere desta principalmente no menor calibre das voltas; a última volta e a abertura são menos expandidas nas partes superior e basal; a espira é moderadamente côncava, as voltas 
internas são achatadas e erodidas nos indivíduos adultos; permanecem cerca de quatro e meia a cinco voltas; a coloração da concha tende a ser mais amarelada ou esverdeada, com três a seis ou mais faixas castanho escuras e linhas castanho amarronzadas sobre a face periférica da última volta; a abertura, menor do que em $M$. cornuarietis, é oblíqua, pela maior saliência da margem basal; o perístoma é espessado internamente e bem arredondado tanto na margem superior como na basal; o opérculo é côncavo externamente, irregularmente periforme, nitidamente côncavo na margem parietal, sendo a parte superior bem mais estreita do que em M. cornuarietis.

A localidade-tipo de $M$. planogyra é Santa Rosa, no estado de Mato Grosso. Segundo Pilsbry (1933), esta espécie teria uma distribuição mais meridional na América do Sul, ocupando principalmente as bacias dos rios Paraguai e Paraná. A distinção entre $M$. cornuarietis e $M$. planogyra, baseada apenas em caracteres de concha é muito difícil, e é agravada em razão da variabilidade morfológica dessas duas espécies. Em função disso, sempre existiu certa controvérsia entre os malacologistas sobre a validade de $M$. planogyra.

Mais recentemente, Mello (1988) comparou a morfologia do aparelho genital de $M$. planogyra e $M$. cornuarietis, utilizando para isso exemplares procedentes respectivamente de Poconé, estado de Mato Grosso, e de Porto Rico, no Caribe, encontrando diferenças entre o aparelho genital masculino das espécies em questão que afirma serem úteis na sua identificação taxonômica; segundo Mello (1988), M. planogyra possui a bainha do pênis relativamente mais curta (relação altura/base 2,0 a 3,0), com apenas duas glândulas em sua superfície (Figura 1), enquanto que $M$. cornuarietis possui a bainha do pênis proporcionalmente mais longa (relação altura/base 4,25 a 5,75), com um total de quatro glândulas em sua superfície (Figura 2).

Todos os trabalhos conhecidos sobre a biologia do gênero Marisa foram desenvolvidos a partir da cepa de $M$. cornuarietis, introduzida aparentemente da Venezuela a Porto Rico, no início de 1950 (Harry \& Cumbie, 1956).

A biologia reprodutiva de $M$. cornuarietis foi estudada por Jobin (1970), Demian \& Ibrahim (1970, 1972a, 1972b, 1975), Meir-Brook (1978), Blackburn \& Sutton (1971), Demian \& Yousif (1972). Esses autores fizeram estudos em campo e em laboratório, abordando vários aspectos referentes à cópula, oviposição e ciclo de vida, e alguns dos principais resultados então obtidos são os seguintes: a cópula tem duração de duas a três horas; o processo de eliminação dos ovos se dá num tempo variável entre uma a três horas, sendo os mesmos depositados abaixo da superfície da água, aderidos a substratos diversos e envoltos em uma massa gelatinosa; de três a quatro ovos são eliminados a intervalos de aproximadamente quatro minutos; os ovos são esféricos, opacos, castanho claros e gradualmente 
tornam-se transparentes; cada massa gelatinosa mede em torno de cinco centímetros e contém em média aproximadamente cem ovos; o tempo de amadurecimento dos ovos varia de setenta e dois a oitenta e três dias; a oviposição é contínua e aumenta progressivamente com o crescimento do molusco; o máximo de oviposição observado foi em fêmeas, medindo aproximadamente quarenta milímetros e com idades, variando entre dois anos e dois anos e meio; a temperatura é um fator físico importante no desenvolvimento embrionário e na eclosão; os ovos se desenvolvem bem entre dezoito e trinta e dois graus centígrados; o desenvolvimento embrionário leva, em média, oito dias em temperaturas, variando entre vinte e cinco a trinta graus centígrados e vinte dias em temperaturas, variando entre quinze e vinte graus centígrados; os moluscos nascem ligeiramente avermelhados, medindo cerca de dois milímetros de diâmetro, têm aspecto globoso e gradualmente tornam-se planorbóides; $M$. cornuarietis demanda grande quantidade de cálcio para o seu crescimento; o ciclo de vida completa-se, aproximadamente, entre 500 e 730 dias.

Os hábitos alimentares de $M$. cornuarietis foram estudados por vários autores, entre os quais Seaman \& Porterfield (1964), Demian \& Lutfy $(1965,1966)$, Demian \& Ibrahim (1969), Jobin et al. (1977) e Cedeño-Leon \& Thomas (1983).

Os resultados desses trabalhos mostraram que $M$. cornuarietis é predominantemente herbívora, mas pode assumir o onivorismo, podendo se alimentar em fontes de origem animal vivas ou mortas e até de toalhas de papel. $O$ número de espécies vegetais testadas e aceitas em seu cardápio alimentar compreende mais de trinta, variando desde vegetação aquática emergente até semiaquática e algumas terrestres como alface, tomate, aipo, etc. Ortiz-Torres (1962), por exemplo, observou no campo exemplares de $M$. cornuarietis se alimentando de plantas jovens de arroz. Geralmente esse molusco tem um comportamento alimentar voraz, mas o consumo é proporcional à idade e ao sexo (Demian \& Lutfy, 1966).

Cedeño-Leon \& Thomas (1983), com o objetivo de aprofundar os estudos sobre o comportamento predatório de $M$. cornuarietis, desenvolveram uma pesquisa para avaliar sua importância sobre o controle de Biomphalaria glabrata, levando em consideração que haviam opiniões completamente contraditórias sobre esse assunto; por exemplo, para Oliver-Gonzáles et al. (1956) e Chemin et al. (1956), a ingestão de ovos de outras espécies de moluscos por $M$. cornuarietis é puramente acidental e decorre do fato desses ovos serem depositados sobre as plantas que são fonte alimentar de $M$. cornuarietis; já para Demian \& Lutfy $(1965,1966)$, o comportamento predatório de $M$. cornuarietis sobre os ovos de outros moluscos é intencional. Os resultados obtidos por Cedeño-Leon \& Thomas (1983) levaram à conclusão de que o comportamento alimentar de $M$. cornuarietis quanto à predação é um fenômeno plástico, influenciado por fatores endógenos e exógenos (genótipo, fisiologia, fatores ambientais, etc.) e também por experiência condicionada por 
aprendizado. Cedeño-Leon \& Thomas (1983) mostraram, ainda, que, há uma associação entre o comportamento de predação e a ingestão de alface, e levantaram, como hipótese, que esta associação poderia ser determinada pela existência, na alface, de kairomona, que atuaria como o fator ativador deste tipo de comportamento alimentar. Cedeño-Leon \& Thomas (1983) demonstraram existir um significativo aumento do comportamento alimentar predatório por parte de fêmeas maduras, fato esse que já tinha sido constatado em outras espécies de moluscos (Bovbjerg, 1968; Eisenberg, 1970), e destacaram a grande necessidade por parte das fêmeas de selecionar alimento rico em galactogênio e proteína, como suplemento à dieta alimentar vegetal para a formação dos ovos.

FIGURA 1: Morfologia do aparelho genital masculino de Marisa planogyra: (A), porção proximal e distal do aparelho genital; (B-D), detalhes da bainha do pênis e saco peniano; (E), detalhes do pênis. bp: bainha do pênis; cb: canal da bainha; de: duto espermático; cgb: glândula da bainha do pênis; gh: glândula hipobranquial; mmt: margem do manto; p: pênis; pg: papila genital; sp: saco peniano; t: testículos; ru: uréter; vd: vaso deferente; vs: vesícula seminal

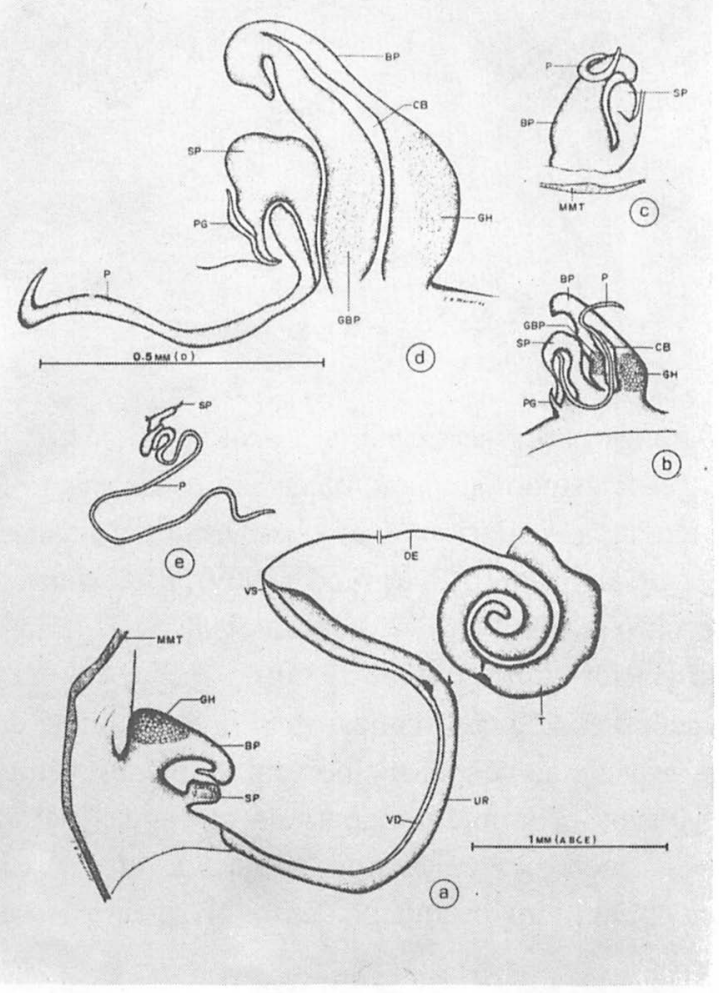


FIGURA 2: Morfologia do aparelho genital masculino de Marisa cornuarietis: a, aparelho completo; $b-e$, detalhes da bainha do pênis e saco peniano; $f$, detalhes do pênis. avd: abertura do vaso deferente; gbp 1-3: glândula da bainha do pênis; demais legendas iguais às da Figura 1

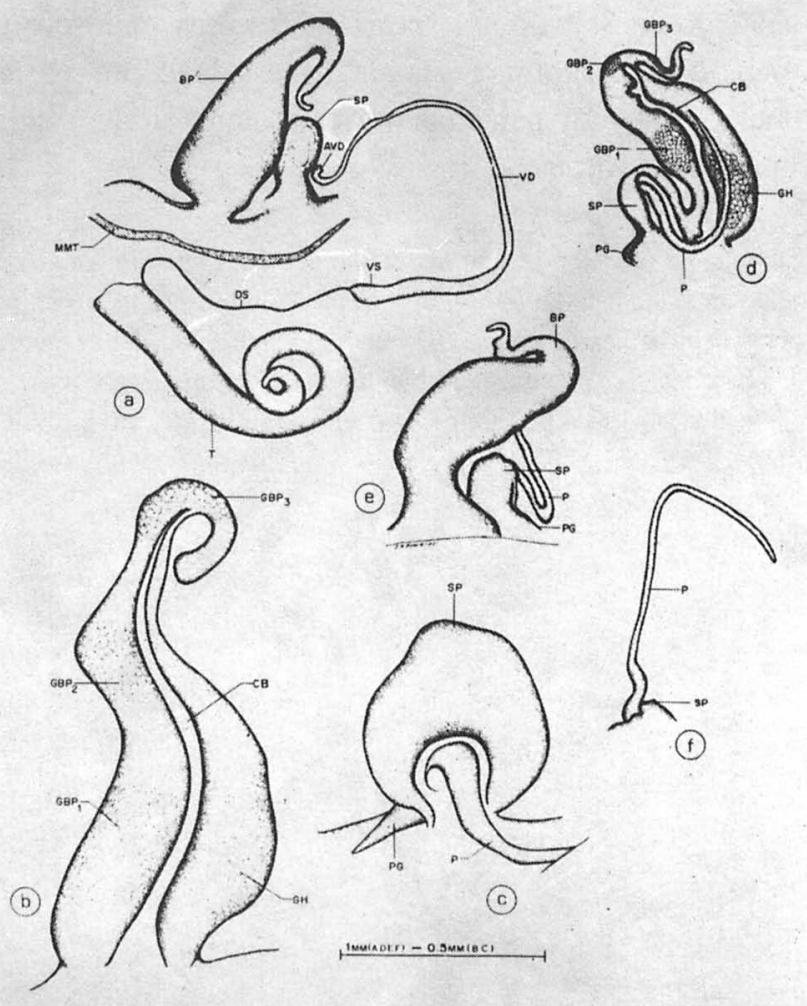

Existem algumas observações sobre a ecologia de $M$. cornuarietis, em sua maioria descritivas, e os estudos populacionais são escassos. Entre os autores que trabalharam em ecologia, resgataríamos as observações e análises conduzidas por Hunt (1961), Butler et al. (1969), Akerlund (1969), Blackburn \& Sutton (1971), Demian \& Ibrahim (1969a, 1969b, 1972) Jobin et al. (1977, 1979), Cedeño-Leon \& Thomas (1983) e Haridi et al. (1985a, 1985b).

As observações ecológicas realizadas sobre o hábitat de $M$. cornuarietis mostraram que esta espécie se adapta melhor em ambientes lênticos, transparentes ou só ligeiramente turvos. Tem sido encontrada em águas paradas, lagos, lagoas naturais ou artificiais, corixos, canais de irrigação, etc. A iluminação parece desempenhar um papel muito importante no desenvolvimento dessa espécie. O limite 
máximo de velocidade da água para a sua permanência no ambiente está ao redor de $0,9 \mathrm{~m} / \mathrm{s}$. Em laboratório, $M$. cornuarietis suporta no ambiente aquático uma amplitude grande de variação de temperatura, que pode oscilar entre nove e quarenta e cinco graus centígrados, mas exposições a temperaturas de cinco graus negativos ou superiores a quarenta e cinco graus levam rapidamente a uma alta mortalidade; em aquários, a temperatura ótima situa-se entre vinte e cinco a vinte e seis graus centígrados, com $\mathrm{pH}$ entre seis e sete e um fotoperíodo de doze horas de luz e doze horas de escuro. Experimentalmente, sabe-se que $\boldsymbol{M}$. cornuarietis pode resistir a níveis de salinidade até ao redor de $2500 \mathrm{mg} / \mathrm{l}$. Os trabalhos sobre a tolerância à dessecação têm mostrado que a capacidade de $M$. cornuarietis baixar os seu metabolismo está relacionada com a idade do animal e com a presença de uma cobertura vegetal que mantenha uma umidade relativa entre $60 \%$ a $80 \%$; como $M$. cornuarietis possui um opérculo espesso e capacidade de respiração pulmonar, sobrevive nessas condições até quatro meses. Os ovos e jovens recém-eclodidos são muito sensíveis à dessecação, dependendo vitalmente da respiração branquial, pois somente após cinco semanas a respiração aérea torna-se funcional.

Vários estudos sobre o comportamento de $M$. cornuarietis no que se refere às interações com outras espécies de moluscos foram realizados em Porto Rico, em 1952, por Oliver-González (1956) e Chemin et al. (1956). Esses autores verificaram que $M$. cornuarietis, tanto em laboratório como em campo, era capaz de limitar o crescimento de Biomphalaria glabrata, vetor importante de Schistosoma mansoni no continente americano. Creditaram o fenômeno ao comportamento alimentar herbivoro de $M$. cornuarietis, que, ao ingerir plantas aquáticas ingeririam também os ovos e os jovens de $B$. glabrata, aderidos a este tipo de substrato.

Muitos outros autores, entre os quais Fergunson et al. (1958), OliverGonzález \& Fergunson (1959), Radke et al. (1961), Ruiz-Tiben (1969), Demian \& Lutfy (1964, 1965a, 1965b, 1966), Demian \& Kamel (1973), Nguma et al. (1982), Jobin \& Laracuente (1979), Cedeño-Leon \& Thomas (1983) e Haridi et al. (1985a, 1985b), seguiram esta linha de pesquisa, demonstrando a capacidade de $M$. cornuarietis de diminuir ou até mesmo de eliminar completamente as populações dos gêneros Biomphalaria, Lymnaea, Bulinus e Oncomelania, todos importantes vetores de trematódeos de interesse para a medicina humana e veterinária.

As pesquisas desenvolvidas por Michelson \& Augustine (1957) em laboratório, com Biomphalaria pfeiferi, vetor da esquistossomose mansônica na África, tiveram resultados semelhantes aos obtidos com B. glabrata no continente americano.

Demian \& Lutfy $(1964,1965 a, 1965 b, 1966)$ e Demian \& Kamel (1973), trabalhando experimentalmente e em condições seminaturais com Bulinus truncatus, B.alexandrina e Lymnaea caillandi, observaram diretamente o efeito predador de 
M. cornuarietis, tanto em adultos de vários tamanhos, como em jovens, recémeclodidos e em massas de ovos; esses mesmos autores verificaram também que a atividade predatória tinha o seu máximo à temperatura de trinta graus centígrados, mas que a atividade diminuía com a presença de vegetação e que a intensidade da predação era mais ou menos proporcional à densidade das presas.

Chi et al. (1971) conduziram experimentos onde demonstraram que $M$. cornuarietis era menos eficiente em controlar populações de Oncomelania formosana, embora esta última fosse deslocada de seu espaço físico por $M$. cornuarietis.

Os resultados das pesquisas em Porto Rico levaram à implantação de um programa de controle biológico das populações de Biomphalaria glabrata por $\boldsymbol{M}$. cornuarietis em várias lagoas naturais existentes na ilha, como alternativa ao controle químico (Palmer et al., 1969; Jordan et al., 1980). O acompanhamento do programa durante vinte anos demonstrou que gradualmente as populações de $B$. glabrata diminuíram, sendo substituídas paulatinamente por $M$. cornuarietis. Os pesquisadores concluíram que o processo de interação biológica estabelecido entre as duas espécies ocorreu em função de predação e deslocamento competitivo por espaço físico e vital.

Jobin \& Laracuente (1979) avaliaram o controle das populações de $B$. glabrata por $M$. cornuarietis, monitorando não somente as populações dos moluscos como também as infeções pelo esquistossomo; o acompanhamento das populações dos moluscos foi efetuado durante quatro anos e os índices de infeção por $S$. mansoni durante dois anos. As populações de $B$. glabrata desapareceram após a introdução de vinte mil exemplares de $M$. cornuarietis. A avaliação financeira do programa mostrou um custo de US $\$ 0,10$ per capita/ano, correspondendo de $5 \%$ a $10 \%$ do custo correspondente a um controle químico.

Por outro lado, os estudos experimentais conduzidos por Cedeño-Leon \& Thomas (1983) sobre a atividade predatória de $M$. cornuarietis levaram à conclusão que do ponto de vista comportamental esta espécie não apresenta atributos suficientes que a indiquem para a utilização contínua no controle de populações de B. glabrata; segundo esses autores, há uma relação de equilibrio entre a atividade predatória e a densidade dos ovos; não há uma resposta de densidade de $M$. cornuarietis em relação à diversidade de substratos onde ficam aderidos os ovos de $B$. glabrata e, finalmente, é duvidoso se $M$. cornuarietis tem uma resposta reprodutiva alta em relação a $B$. glabrata, pois para otimizar o controle parece haver sempre a necessidade de introdução de altas densidades de adultos de $M$. cornuarietis.

Não obstante isso, os trabalhos desenvolvidos por Haridi et al. (1985) e Haridi \& Jobin (1985), no Sudão, África, em áreas de irrigação no vale do Nilo, 
mostraram que $M$. cornuarietis pode se estabelecer em altas densidades onde existir fonte alimentar adequada e em grandes quantidades, necessárias ao crescimento e desenvolvimento populacional.

\section{REFERÊNCIAS BIBLIOGRÁFICAS}

AKERLUND, G., 1969. Oxygen consumption of the ampullariid snail Marisa cornuarietis L. in relation to body weight and temperature. Oikos, 20: 529-533.

BAKER, H. B., 1930. The Mollusca collected by the University of Michigan-Williamson Expedition in Venezuela.Part VI. Occasional Papers of the Museum of Zoology (Michigan), 210: 1-94.

BLACKBURN, R. D. \& SUTTON, D. G., 1971. Temperature tolerance and necessary stocking rates of Marisa cornuarietis for aquatic weed control. Proceedings of the European Weed Research Council, 3rd International Symposium of Aquatic Weed, London.

BOVBJERG, R. V., 1968. Responses to food in lymnaeid snails. Physiology Zoological, 41: 412-423.

BUTLER, J. M. JR.; FERGUNSON, F. F. \& OLIVER-GONZALEZ, J., 1969. A system for mass producing the snail Marisa cornuarietis, for use as a biological control agent of schistosomiasis. Caribbean Journal of Science, 9: 135-139.

CEDEÑO-LEON, A. \& THOMAS, J. D., 1983. The predatory behaviour of Marisa cornuarietis on eggs and neonates of Biomphalaria glabrata, the snail host of Schistosoma mansoni. Malacologia, 24: 289-297.

CHERNIN, E.; MICHELSON, E. H. \& AUGUSTINE, D. C., 1956. Studies on the biological control of schistosome-bearing snails. I. The control of Australorbis glabratus populations by the snail Marisa cornuarietis under laboratory conditions. American Journal of Tropical Medicine and Hygiene, 5: 297-307.

CHI, L. W.; WINKLER, L. R. \& COLVIN, R., 1970. Predation of Marisa cornuarietis and Oncomelania formosana eggs under laboratory conditions. Veliger, 14: 184-186.

DEMIAN, E. S. \& IBRAHIM, A. M., 1969a. Feeding activities of the snail Marisa cornuarietis (L.) under laboratory conditions. Proceedings of the Sixth Arab Science Congress, Damascus, November 1-7, 1969, Part I: 145-165.

, 1969b. Tolerance of the snail Marisa cornuarietis (L.) to desiccation and to continuos submersion, under laboratory conditions. Bulletin of the Zoological Society of Egypt, 22: 73-88., ,1970. The egg mass, egg laying and mating behaviour of the snail Marisa cornuarietis (L.). Bulletin of the Zoological Society of Egypt, 23: 1-12.

1972a. Tolerance of the snail Marisa cornuarietis (L.) to extreme temperatures under laboratory conditions. Bulletin of the Zoological Society of Egypt, 24: 20-30.

DEMIAN, E. S. \& IBRAHIM, A. M., 1972b. Sexual dimorphism and sex ratio in the snail Marisa cornuarietis (L.). Bulletin of the Zoological Society of Egypt, 24: 52-63.

1975. The reprodutive biology of the snail Marisa cornuarietis (L.) under laboratory conditions. Ain Shams Sciences Bulletin, 19: 111-120.

DEMIAN, E. S. \& KAMEL, E. G., 1973. Effects of Marisa cornuarietis on Bulinus truncatus populations under semi-field conditions in Egypt. Malacologia, 14: 439.

DEMIAN, E. S. \& LUTFY, R. G., 1964. Prospects of the use of Marisa cornuarietis in the biological control of Lymnaea cailliaudi in the U.A.R. Proceedings of Egyptian Academy Sciences, 18: 48-50.

1965a. Predatory activity of Marisa cornuarietis against Bulinus (Bulinus) truncatus, the transmitter of urinary schistosomiasis. Annals of Tropical Medicine and Parasitology, 59: 331336. 


\section{TÓPICOS EM MALACOLOGIA MÉDICA}

DEMIAN, E. S. \& LUTFY, R. G., 1965b. Predatory of Marisa cornuarietis against Biomphalaria alexandrina under laboratory conditions. Annals of Tropical Medicine and Parasitology, 59: 337339.

DEMIAN, E. S. \& LUTFY, R. G., 1966. Factors affecting the predation of Marisa cornuarietis on Bulinus (B.) truncatus, Biomphalaria alexandrina and Lymnaea cailliaudi. Oikos, 17: 212-230.

DEMIAN, E. S. \& YOUSIF, F., 1972a. Embryonic development and organogenesis in the snail Marisa cornuarietis (Mesogastropoda: Ampullariidae). 3. Development of the circulatory and renal systems. Malacologia, 12: 175-194.

DEMIAN, E. S. \& YOUSIF, F., 1972b. Embryonic development and organogenesis in the snail Marisa cornuarietis (Mesogastropoda: Ampullariidae). 4. Development of the shell gland, mantle and respiratory organs. Malacologia, 12: 195-211.

EISENBERG, R. M., 1970. The role of food in the regulation of the pond snail Lymnaea elodes. Ecology, 51: 680-684.

FERGUNSON, F. F. \& PALMER, J. R., 1958.Biological nottes on Marisa cornuarietis, a predator of Australorbis glabratus, the snail intermediate host of schistosomiasis in Puerto Rico. American Journal of Tropical Medicine and Hygiene, 7: 649-652.

HARIDI, A. A.; EL SAFI, S. H. \& JOBIN, W. R., 1985. Survival growth and reprodution of the imported ampullariid snail Marisa cornuarietis in Central Sudam. American Journal of Tropical Medicine and Hygiene, 88: 135-144.

HARIDI, A. A. \& JOBIN, W. R., 1985. Estimated risk and benefits from introducing Marisa cornuarietis into Sudam. American Journal of Tropical Medicine and Hygiene, 88: 145-151.

HARRY, H. \& CUMBIE, B. G., 1956.Stream gradient as an criterion of lotic habitats suitable for Australorbis glabratus in Puerto Rico. American Journal of Tropical Medicine and Hygiene, 5: 921 928.

HUNT, B.P., 1961. Tolerance of a freshwater snail, Marisa cornuarietis to salt water. Quartely Journal of the Florida Academy of Sciences, 23: 278-284.

JOBIN, W. R., 1970. Population dynamics of aquatic snails in three farm ponds of Puerto Rico. American Journal of Tropical Medicine and Hygiene, 19: 1038-1048.

JOBIN, W.R.; BROWN, R.A.; VELEZ, S.P. \& FERGUNSON, F.F., 1977. Biological control of Biomphalaria glabrata in major reservoirs of Puerto Rico. American Journal of Tropical Medicine and Hygiene, 26: 1018-1024.

JOBIN, W. R. \& LARACUENTE, A., 1979. Biological control of schistosome transmission in flowing water habits. American Journal of Tropical Medicine and Hygiene, 28: 916-917.

JORDAN, P.; CHRISTIE, J. D. \& UMAN, G. D., 1980. Schistosomiasis transmission with particular reference to possible ecological and biological methods of control. Acta Tropica, 37: 95-135.

MEIR-BROOK, C., 1978. Calcium uptake by Marisa cornuarietis (Gastropoda; Ampulariidae), a predator of schistosome-bearing snails. Archives Hydrobiology, 82: 449-464.

MELLO, M. D. A., 1988. Morfologia do aparelho genital de Marisa planogyra Pilsbry, 1933 e $M$. cornuarietis (Linné, 1767) (Gastropoda, Ampullariidae). Revista Nordestina de Biologia, 6: 7-14.

MICHELSON, E. H. \& AUGUSTINE, D. L., 1957. Studies on the biological control of schistosomebearing snails. V.: The control of Biomphalaria pfeifferi populations by the snail, Marisa cornuarietis, under laboratory conditons. Journal of Parasitology, 43: 135.

NECK, R.W., 1984. Occurrence of the striped ram's horn, Marisa cornuarietis, in Central Texas (Ampullariidae). Nautilus, 98: 119-120. 


\section{GENÊRO MARISA}

NGUMA, J. F.; McCULLOUGH, F. S. \& MASHA, E., 1982. Elimination of Biomphalaria pfeifferi, Bulinus tropicus and Lymanaea natalensis by the ampullarid snail, Marisa cornuarietis, in the manmade dam in northern Tanzania. Acta Tropica, 39: 85-90.

OLIVER-GONZÁLEZ, J; BAUMAN, P. M. \& BENESON, A. S., 1956. Effect of the snail Marisa cornuarietis on Australorbis glabratus in natural bodies of water in Puerto Rico. American Journal of Tropical Medicine and Hygiene, 5: 290-296.

OLIVER-GONZÁLEZ, J. \& FERGUNSON, F. F., 1959. Probable biological control of schistosomiasis mansoni in a Puerto Rico watershed. American Journal of Tropical Medicine and Hygiene, 8: 56-59.

ORTIZ-TORRES, E., 1962. Damage caused by the snail Marisa cornuarietis to young rice seedling in Puerto Rico. The Journal of Agriculture of the University of Puerto Rico, 46: 241-243.

PAIN, T., 1950. Pomacea (Ampullariidae) of British Guiana. Proceedings of the Malacological Society of London, 28: 63-74.

PALMER, J. R.; COLIN, A. E.; FERGUNSON, F. F. \& JOBIN, W. R., 1969. The control of schistosomiasis in Patillas, Puerto Rico. Public Health Reports, 84: 1003-1007.

PILSBRY, H.A., 1933. Zoological results of the Mato Grosso expediton to Brazil in 1931. II. Mollusca. Proceedings Academy of Natural Sciences of Philadelphia, 85: 67-76.

RADKE, M. G.; RITCHIE, L. S. \& FERGUNSON, F. F., 1961. Demonstrated control of Australorbis glabratus by Marisa cornuarietis under field condition in Puerto Rico. American Journal of Tropical Medicine and Hygiene, 10: 370-373.

RUIZ-TIBEN, E.; PALMER, J. R. \& FERGUNSON, F. F., 1969. Biological control of Biomphalaria glabrata by Marisa cornuarietis in 110 irrigation ponds of Puerto Rico. Bulletin of the World Health Organization, 41: 329-333.

SCOTT, M. I. H., 1957. Estudio morfologico y taxonomico de los ampullaridos de $1^{\mathbf{2}}$ Republica Argentina. Revista del Museo Argentino de Ciencias Naturales Bernardino Rivadavia, Zoología, 3: 233-333.

SEAMAN, D. E. \& PORTERFIELD, W. A., 1964. Control of aquatic weeds by the snail Marisa cornuarietis. Weeds, 12: 87-92.

Mªlva A. Mello

Departamento de Saúde Comunitária - CCS/UFC

Rua Prof. Costa Mendes, $1608 / 5^{\circ}$ andar - Rodolfo Teófilo

Fortaleza - CE - 60430-140

Antônio Carlos Marini

Laboratório de Zoologia - Departamento de Biologia

Universidade Federal do Mato Grosso do Sul

Cx. Postal 649 - Campo Grande - MS - 79070-900 


\subsection{Famílias Chilinidae, Ancylidae, Physidae e Lymnaeidae}

A posição sistemática (Quadro 1) e a descrição dos principais moluscos da ordem Basommatophora são apresentadas ressaltando-se os hospedeiros intermediários de helmintos parasitas.

A família Planorbidae é tratada separadamente por englobar os transmissores da esquistossomose mansônica.

QUADRO 1: Molusca, Gastropoda, Pulmonata, Basommatophora

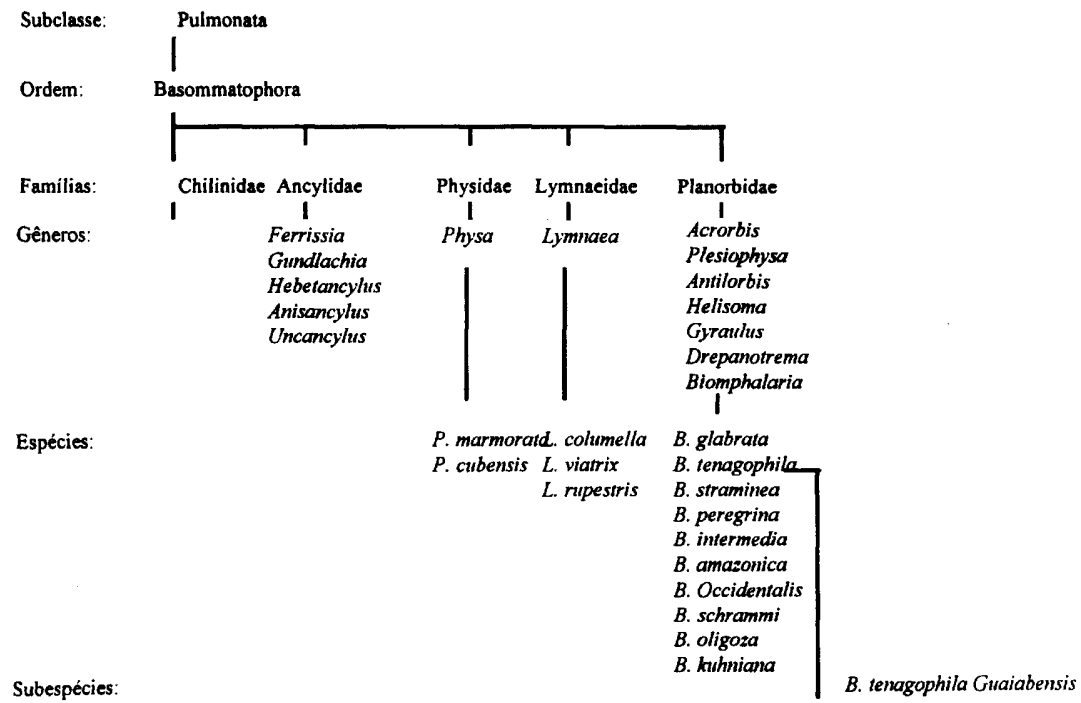

A morfologia interna dos moluscos é de importância fundamental para a sistemática dos mesmos (Paraense, 1961). Variações de conchas em diferentes populações e anomalias (vide Souza \& Lima, 1990, p.7) podem levar a identificações duvidosas na ausência do conhecimento anatômico interno do molusco.

A parte mole de um gastrópodo planorbídeo é mostrada do lado esquerdo, com parte do manto levantada, permitindo a visão dos órgãos internos (Figura 1). A massa cefalopodal (cabeça e pé) (Figura $2 \mathrm{~A}$ e C), exposta quando o molusco se movimenta, é unida pelo colo à massa visceral que é permanentemente protegida pela concha. No colo encontramos a abertura genital masculina, atrás do tentáculo esquerdo e, mais atrás, a feminina. 


\section{FAMÍLIAS}

FIGURA 1. Parte mole de Biomphalaria, vista do lado esquerdo, com o manto parcialmente levantado. an: ânus; c: cabeça; cl: crista dorsolateral; cm: colar do manto; cp: cavidade pulmonar; ct: crista retal; et: estômago; ga: glândula de albúmen; gd: glândula digestiva; ia: intestino anterior; im: intestino médio; ip: intestino posterior; mc: músculo columelar; mf: mufla; ms: massa cefalopodal; om: orifício genital masculino; ot: ovoteste; p: pé, pn: pneumóstoma; ps: pseudobrânquia; rt: reto; te: tentáculo; tr: tubo renal; vp: veia pulmonar; vr: veia renal

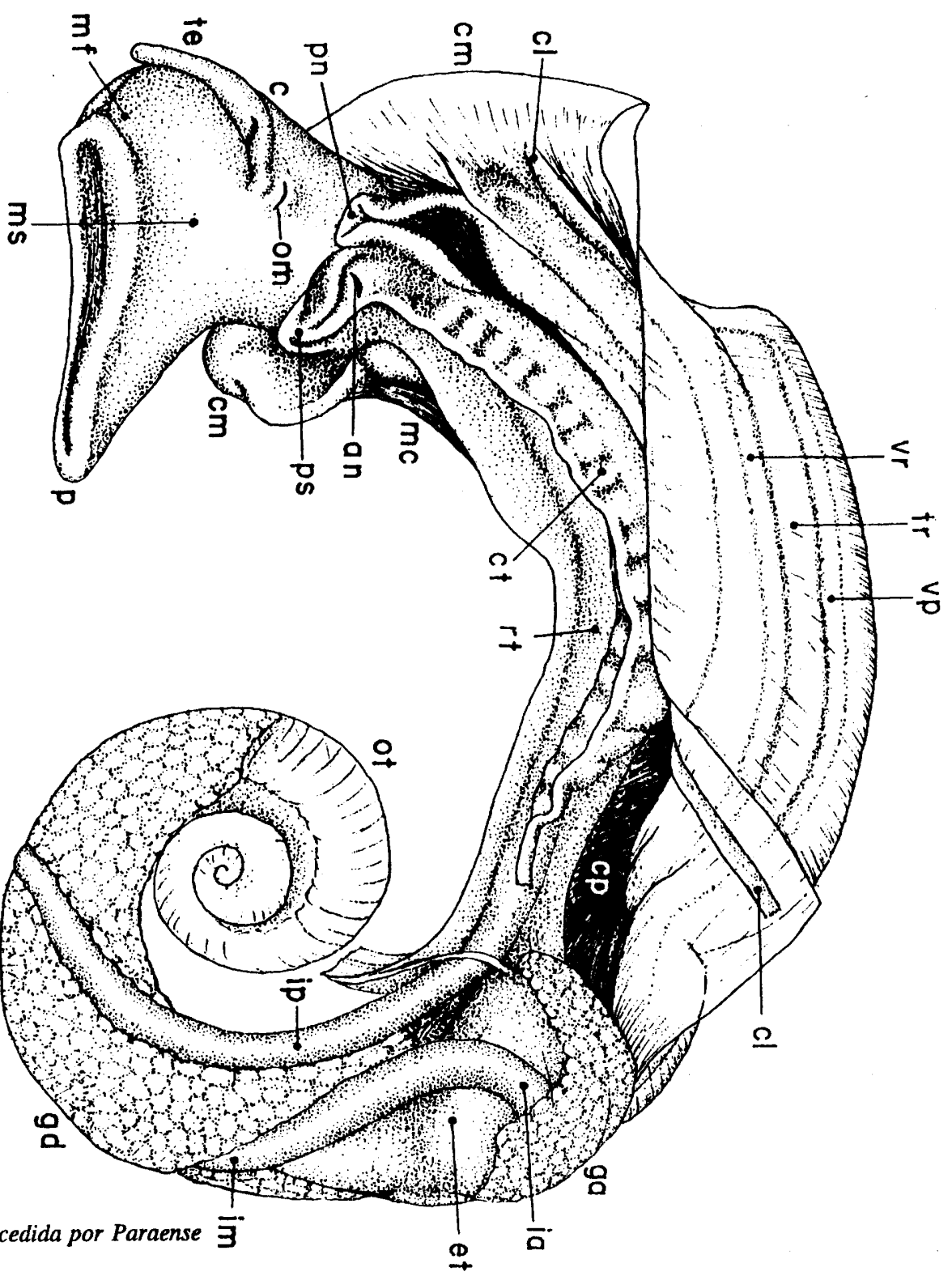




\section{TÓPICOS EM MALACOLOGIA MÉDICA}

FIGURA 2: Biomphalaria. Concha e massa cefalopodal, vistas pela direita (A) e pela esquerda (C). Concha, vista de frente (B). ac: abertura da concha; ag: abertura genital masculina; bm: borda do manto; ca: calo; co: colo; di: diâmetro da concha; ga: giro apical ou interno (primeiro giro); gc: giro corporal ou externo (último giro); lc: largura da concha; ld: lado direito; le: lado esquerdo; mu: mufla; ol: olho; pb: pseudobrânquia; pe: pé; pf: periferia; pl: palpos labiais; pn: pneumóstoma; ps: perístoma; so: sola do pé; su: sutura; te: tentáculo
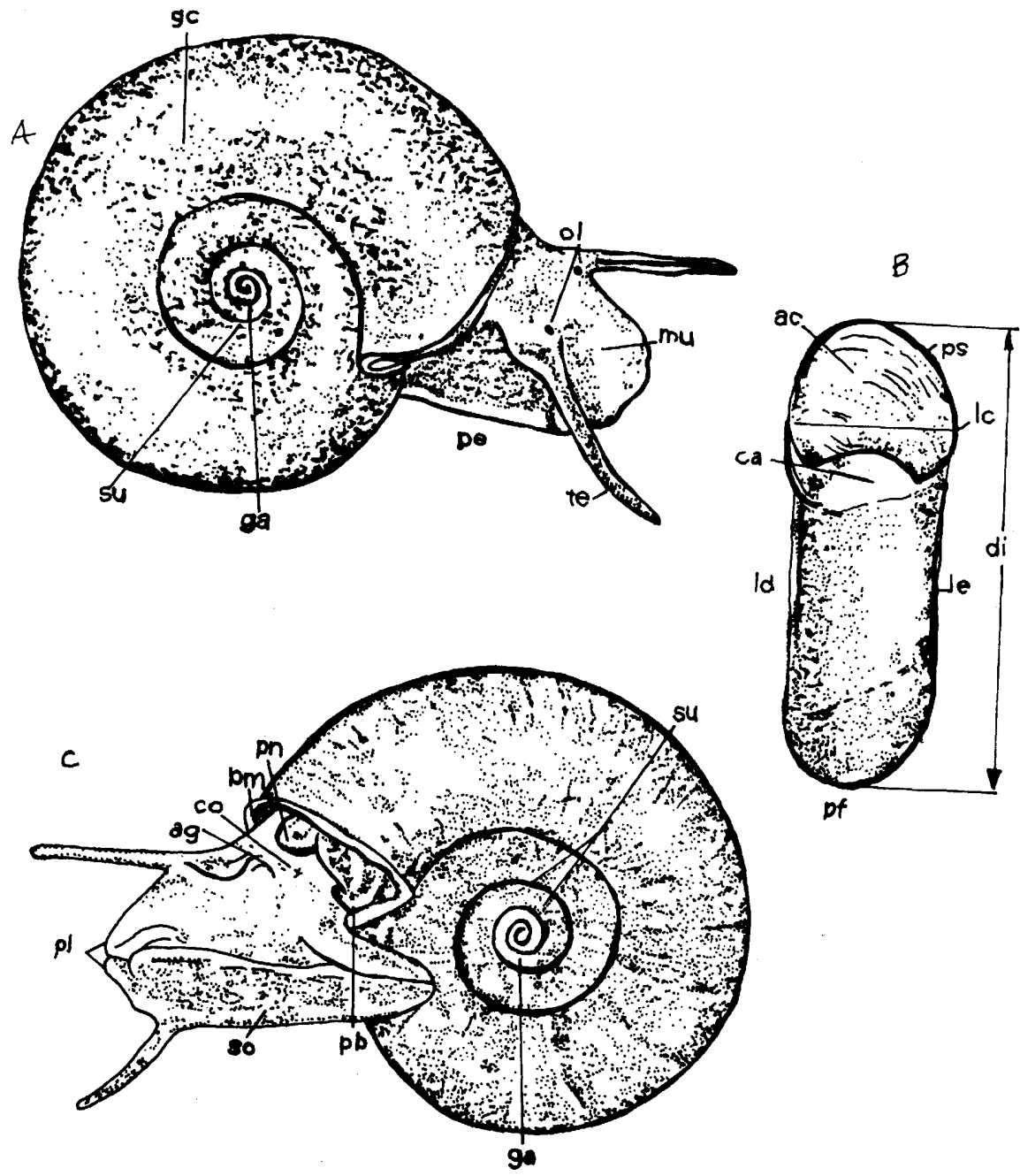

Fonte: Paraense, 1972 


\section{FAMÍLIAS}

FIGURA 3: Aparelho genital de $B$. glabrata. bo: bolsa do oviduto; bp: bainha do pênis; bv: bolsa vaginal; cc: canal coletor do ovoteste; cd: canal deferente; ed: espermiduto; eg: encruzilhada genital; es: espermateca; gn: glândula nidamental; mp: músculo protrator; mr: músculo retrator; od: segmento proximal do ovispermiduto; odd: segmento distal do ovispermiduto; ot: ovoteste; ov: oviduto; pp: prepúcio; pr: prós-tata; ut: útero; va: vagina; vs: vesícula seminal

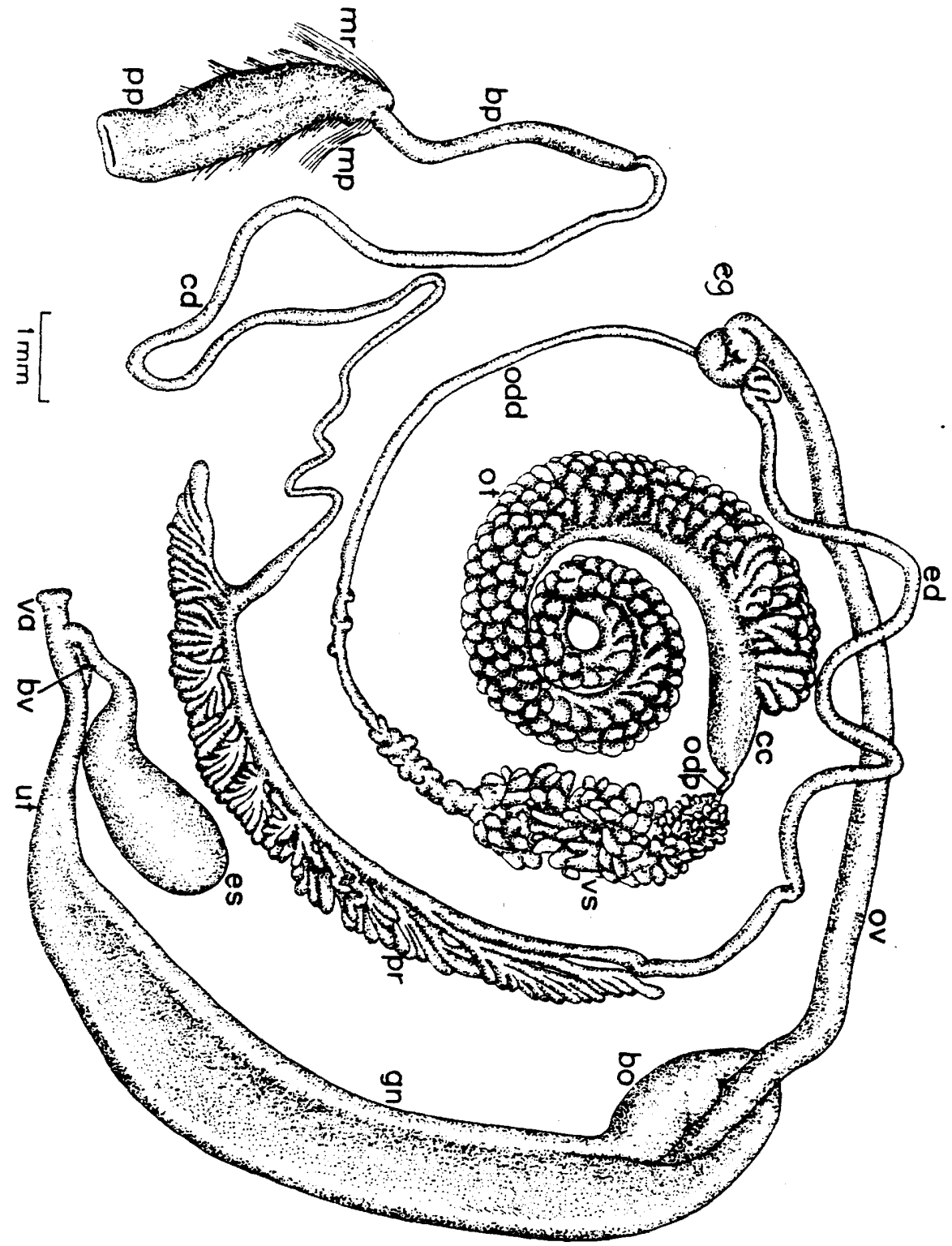

Ilustraçāo cedida por Paraense 
O manto ou pálio é uma membrana que envolve a massa visceral e forma a cavidade pulmonar. Nele está situado o tubo renal.

Quanto a reprodução, estes moluscos são hermafroditas, capazes de se reproduzirem por autofecundação; mas a cópula entre dois indivíduos, um atuando como macho e o outro como fêmea é a forma preferida. O sistema genital é composto basicamente de um ovoteste, que produz óvulos e espermatozóides, seguido de um canal para a passagem dos mesmos, o qual se divide em dois ramos, um masculino e outro feminino, de acordo com a Figura 3.

\section{CHILINIDAE}

Concha entre globosa e cônica, dextrógira, com espira distinta, columela com calo e um a dois dentes na abertura; tentáculos curtos, chatos e triangulares, estando os olhos situados na base externa dos mesmos. Encontrados aderidos a pedras ou ligeiramente enterrados, em águas correntes rápidas e limpas. São encontrados no Chile, Argentina, Uruguai, Sul do Brasil e Peru. Exemplo: Chilina (Paraense, 1981a).

\section{ANCYLIDAE}

Concha pateliforme pequena, com abertura ampla; tentáculos longos e finos; gonoporos (aberturas masculina e feminina) à esquerda (Figura 4). Encontrados na zona de arrebentação dos lagos ou em águas correntes, aderidos a superfícies submersas, em toda a América do Sul. Os gêneros sul-americanos são: Ferrissia, Gundlachia, Hebetancylus, Anisancylus e Uncancylus (Paraense, 1981a).

FIGURA 4: Concha pateliforme de Ancylidae. (A). Vista dorsal. (B). vista lateral
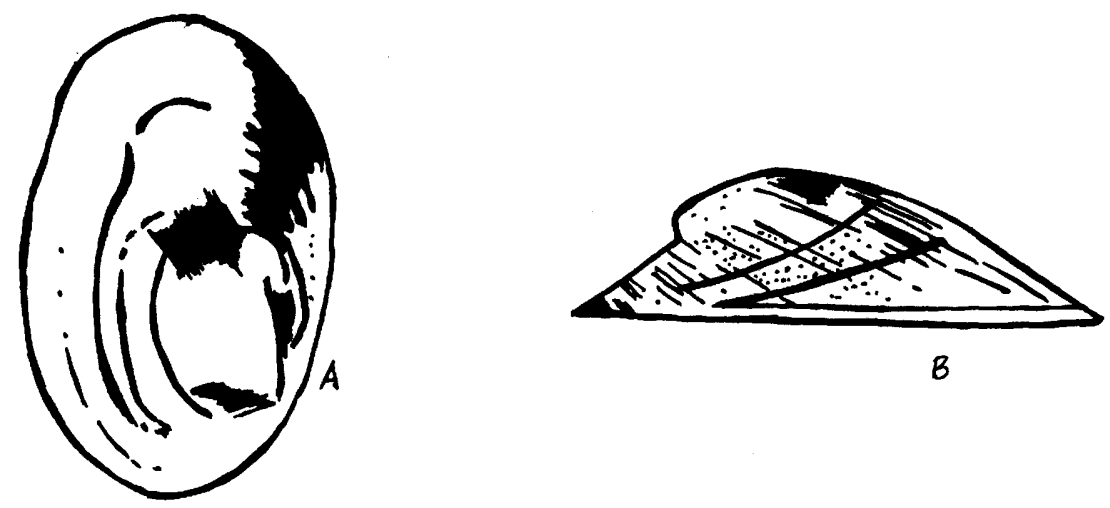

B 


\section{PHYSIDAE}

Concha fina, cônica, sinistrógira, brilhante, com espira distinta (Figura 5); olhos na base interna dos tentáculos, que são longos e finos; pé lanceolado; borda do manto lobulada ou digitada. Encontrados em águas paradas ou de curso lento em todo o território brasileiro. São resistentes a ambientes poluídos (Paraense, 1981). Exemplos: Physa marmorata Guilding, 1828: concha com giros convexos, sem ombros, espira mais alta e mais estreita do que em Physa cubensis, sutura rasa e dobra columelar fraca (Figura 5) (Paraense, 1986a).

FIGURA 5: Conchas de Physa marmorata (Escala Milimétrica)
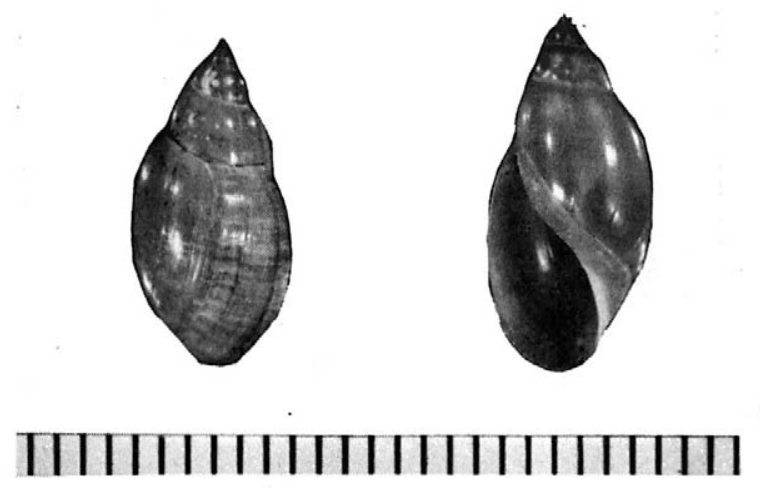

Fonte: Coleção do Laboratório de Malacologia, do Centro de Pesquisas René Rachou, Belo Horizonte, Minas Gerais - Acervo Fotográfico de Lais Clark Lima

FIGURA 6: Conchas de Physa cubensis

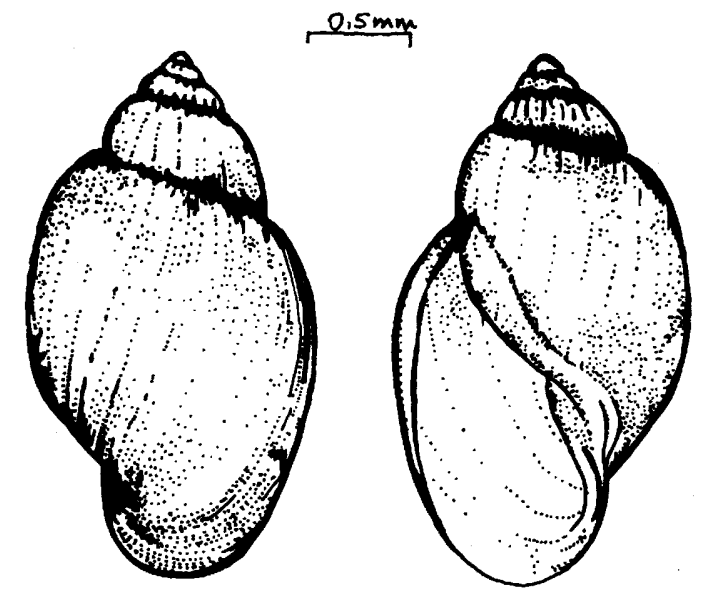

Ilustração cedida por Paraense 
Características da anatomia interna: corpo da espermateca oblongo, mais ou menos cinturado na parte média e um tanto curvo; pênis longo estreito; canal peniano com abertura na junção dos terços médio e inferior; prepúcio com ombro (Paraense, 1986a).

Physa cubensis Pfeiffer, 1839: concha com giros convexos, com ombros moderadamente salientes, sutura e dobra columelar bem marcadas (Figura 7) (Paraense, 1987) .

Características da anatomia interna: corpo da espermateca ovóide ou piriforme; pênis grosso na parte proximal; canal peniano com abertura subterminal; prepúcio com glândula volumosa em um lado de sua metade proximal (Paraense, 1987).

FIGURA 7: Conchas de Physa marmorata*

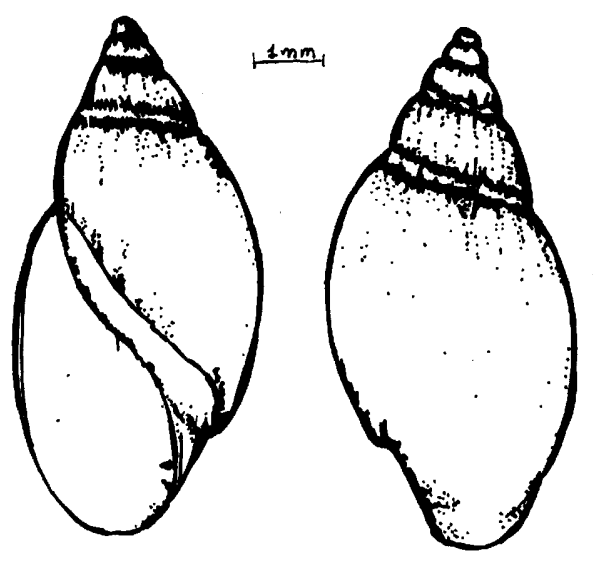

*Ilustração cedida por Paraense

LYMNAEIDAE

Concha semelhante à dos Physidae - porém dextrógira - cônica, alongada, fina, giros convexos, suturas rasas ou profundas, abertura oval ou arredondada, lábio interno refletido sobre o umbigo, mede menos de $11 \mathrm{~mm}$ até mais de $15 \mathrm{~mm}$ de altura (Figura 8); olhos na base interna dos tentáculos, que são achatados e triangulares. Encontrados em águas paradas ou de curso lento. Ocorrem em todo o território brasileiro (Paraense, 1981a). As espécies identificadas até o momento no Brasil são: Lymnaea columella Say, 1817: concha com até $14 \mathrm{~mm}$ de comprimento, 
7,5 mm de largura, cinco giros arredondados, espira pequena com ápice pontiagudo e giro corporal volumoso ocupando três vezes o comprimento da concha (Figura 8). (Paraense, 1983a).

Características da anatomia interna: prepúcio cerca de duas, quatro a seis vezes mais longo que a bainha do pênis e um pouco mais largo; bolsa do oviduto claramente visível; ureter duplamente flexionado (Paraense, 1983a).

FIGURA 8: Conchas de Lymnaea columella (Escala Milimétrica).

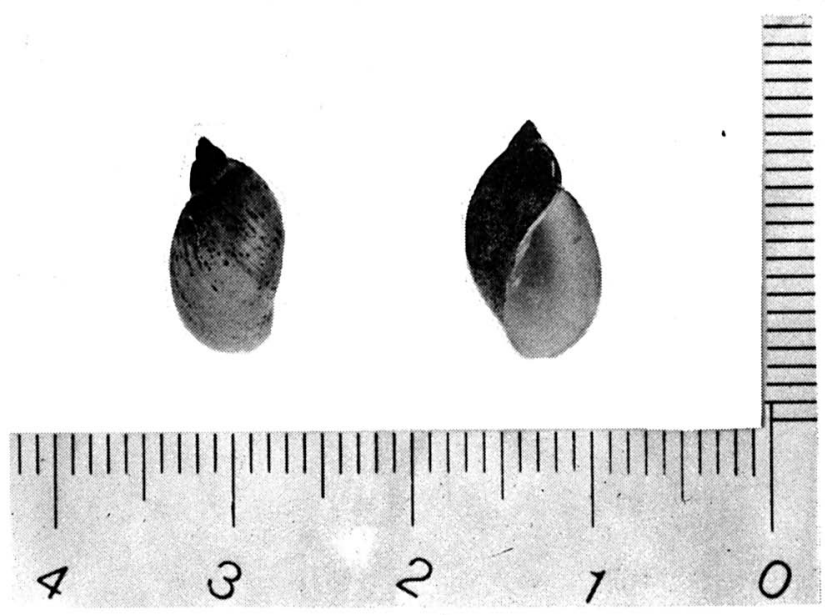

Fonte: Coleção do Laboratório de Malacologia do Centro de Pesquisas René Rachou, Belo Horizonte, Minas Gerais - Acervo Fotográfico de Lais Clark Lima.

Lymnaea viatrix Orbigny, 1835: concha com até $12,6 \mathrm{~mm}$ de comprimento, 7,5 $\mathrm{mm}$ de largura, cinco e meio giros que aumentam lentamente de diâmetro e abertura ocupando metade do comprimento da concha (Figura 9) (Paraense, 1976).

Características da anatomia interna: prepúcio aproximadamente do mesmo tamanho que a bainha do pênis ou até três vezes maior que a mesma; bolsa do oviduto bem desenvolvida; ureter reto (Paraense, 1976, 1982a, 1983a).

Lymnaea rupestris Paraense, 1982: concha com até $6 \mathrm{~mm}$ de comprimento, 3,9 $\mathrm{mm}$ de largura, quatro giros com ombros bem marcados; sutura muito profunda, superfície com linhas de crescimento, abertura ovóide arredondada com mais da metade do comprimento da concha e lábio refletido (Figura 10) (Paraense, 1982b). 
Características da anatomia interna: prepúcio mais ou menos do mesmo comprimento e da mesma largura que a bainha do pênis; bolsa do oviduto rudimentar; ureter reto (Paraense, 1982b, 1983a).

FIGURA 9: Conchas de Lymnaea viatrix*
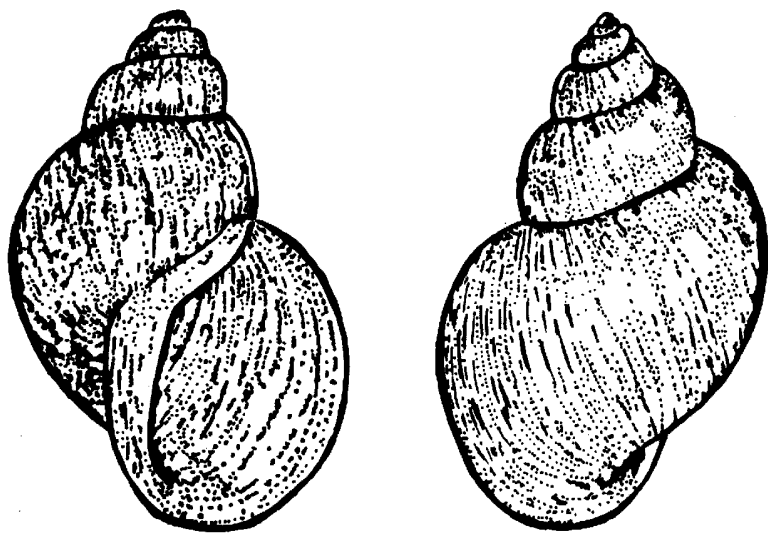

$2 m m$

\section{* Ilustraçāo cedida por Paraense}

FIGURA 10: Conchas de Lymnaea ruspestris*

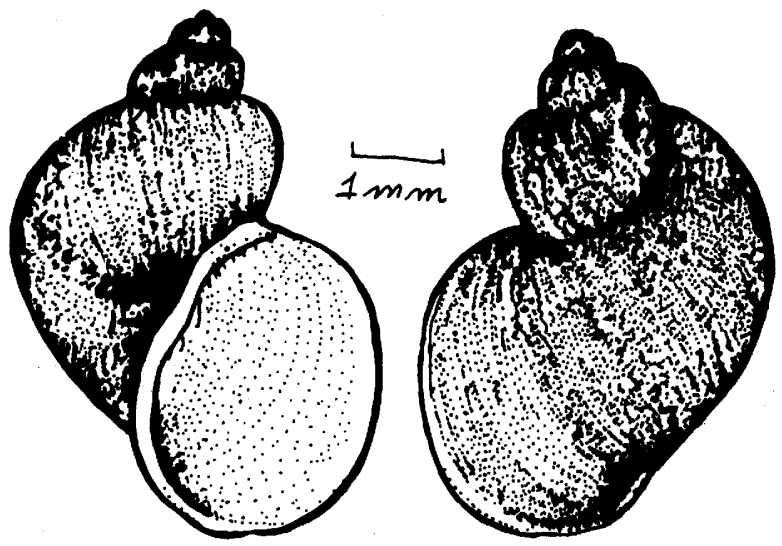

* Iustração cedida por Paraense 
Representantes da família Lymnaeidae são hospedeiros intermediários de trematódeos parasitas do fígado, Fasciola hepatica Linnaeus, 1758 (Trematoda: Fasciolidae), de grande importância econômica em áreas de criação de bovinos e ovinos. A fasciolose humana tem sido registrada em Porto Rico, Cuba, México, Costa Rica, Venezuela, Colômbia, Chile, Argentina, Uruguai e Brasil (Souza \& Lima, 1990).

Distribuição geográfica dos moluscos hospedeiros: $L$. columella é encontrada no Rio Grande do Sul, Santa Catarina, Paraná, São Paulo, Rio de Janeiro, Minas Gerais (Belo Horizonte, Barbacena, Betim, Diamantina, Ferros, Juiz de Fora, Ouro Fino, Sabinópolis, Ubá e Viçosa), Goiás, Distrito Federal, Mato Grosso, Mato Grosso do Sul, Amazonas e Bahia. L. viatrix, em Minas Gerais (população introduzida em Belo Horizonte) e Rio Grande do Sul (Paraense, 1982a, 1983a, 1986b).

A Fasciola hepatica ocorre em Minas Gerais, Paraná, Rio Grande do Sul, Rio de Janeiro, Santa Catarina, São Paulo e Brasil Central. Os hospedeiros definitivos deste trematódeo no Brasil são: eqüinos, bovinos, bufalinos, ovinos, caprinos, suínos, cães e o homem. Casos de fasciolose humana foram registrados na Bahia, São Paulo (Vale do Paraíba) e Paraná (Pessoa \& Martins, 1982).

A distribuição geográfica dos moluscos hospedeiros, as áreas de ocorrência de $F$. hepatica e de casos humanos de fasciolose são mostrados na Figura 11.

FIGURA 11: Ocorrência de fasciolose no Brasil. Distribuição dos limneídeos hospedeiros de Fasciola hepatica (Paraense, 1982a). Área de ocorrência de fasciolose em animais (Costa et al., 1986). \ Área de ocorrência de casos humanos de fasciolose (Pessoa \& Martins, 1982)

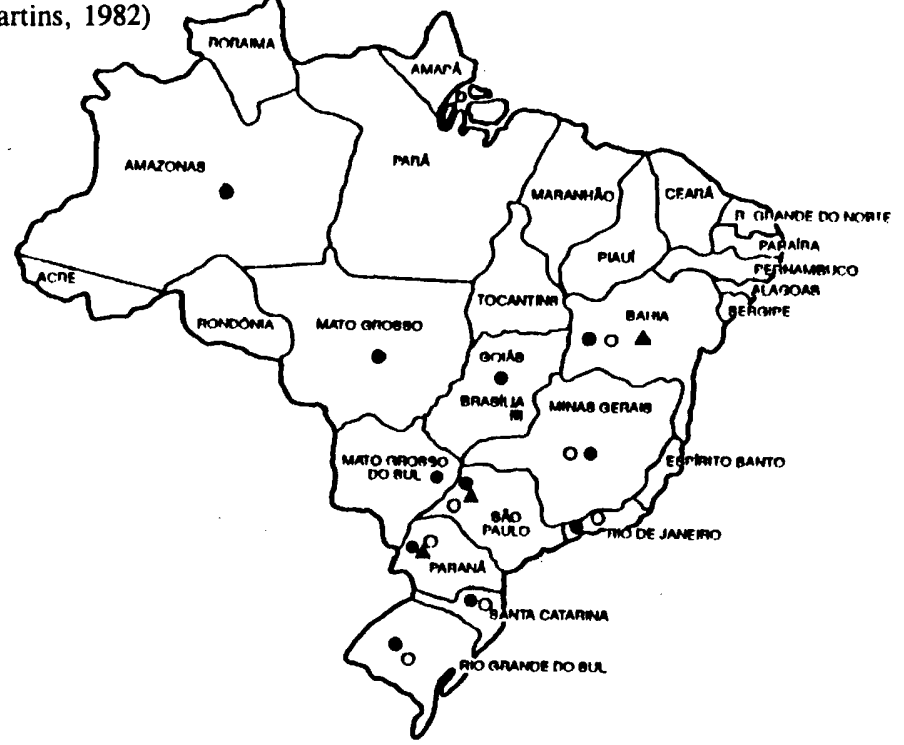




\subsection{Família Planorbidae}

A concha típica de um planorbídeo é planispiral; os olhos estão situados nas bases internas dos tentáculos, que são longos e finos; aberturas genitais à esquerda.

\section{GÊNERO Acrorbis}

Concha pequena, helicoidal, dextrógira, umbilicada; hemolinfa incolor; extremidade posterior do pé arredondada; tubo renal em J; rádula longa. Espécie: Acrorbis petricola Odhner, 1937 - concha com três e meio giros arredondados, 1,6 $\mathrm{mm}$ de comprimento e $2,6 \mathrm{~mm}$ de largura, e espira elevada (Figura 12). Distribuição geográfica: Santa Catarina (Paraense, 1975).

FIGURA 12: Concha de Acrorbis petricola*
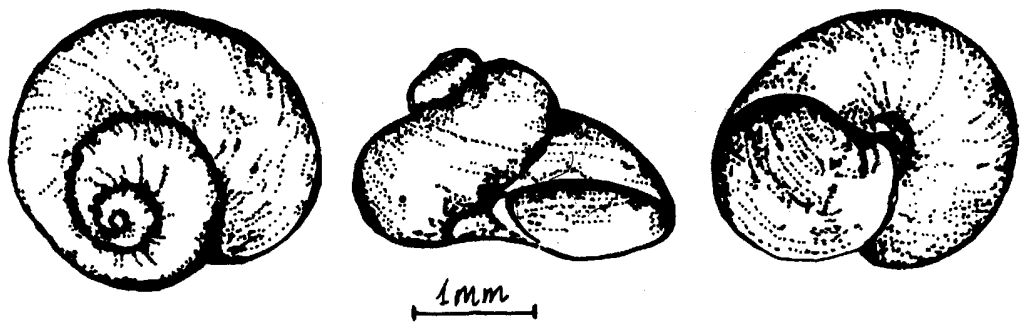

*Ilustração cedida por Paraense

GÊNERO Gyraulus (não existe no Brasil)

\section{GÊNERO Plesiophysa}

Concha pequena, fisóide, sinistrógira, com pelos curtos quando jovem; hemolinfa incolor; tubo renal em S. Espécie: Plesiophysa ornata (Haas, 1938) concha com três e meio giros arredondados, $9 \mathrm{~mm}$ de comprimento e $5 \mathrm{~mm}$ de largura, espira achatada, e com abertura correspondente a $60-75 \%$ do seu comprimento (Figura 13). Distribuição geográfica: Paraíba, Pernambuco, Espírito Santo, Minas Gerais, Goiás (Paraense, 1975; Souza \& Lima, 1990). 
FIGURA 13: Concha de Plesiophysa ornata*

*Ilustração cedida por Paraense

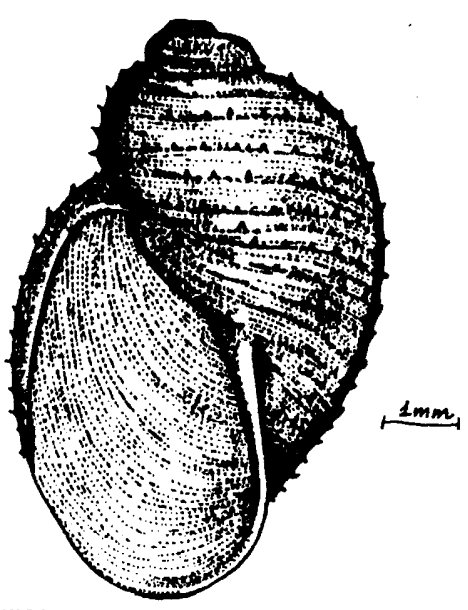

\section{GÊNERO Antillorbis}

Concha discoidal, pequena, com abertura oval; hemolinfa incolor; pé curto com extremidade caudal estreita, tubo renal em J. Espécie: Antillorbis nordestensis (Lucena, 1954) - concha com quatro giros arredondados que crescem rapidamente em diâmetro; lado direito aplanado e esquerdo com cavidade ampla; com $5 \mathrm{~mm}$ de diâmetro e 1,4 mm de largura (Figura 14). Distribuição geográfica: Alagoas, Distrito Federal, Goiás, Minas Gerais, Paraná, Pernambuco, Rio Grande do Sul, Santa Catarina, São Paulo, Pará e Maranhão (Paraense, 1975; Souza \& Lima, 1990).

FIGURA 14: Concha de Antillorbis nordestensis*
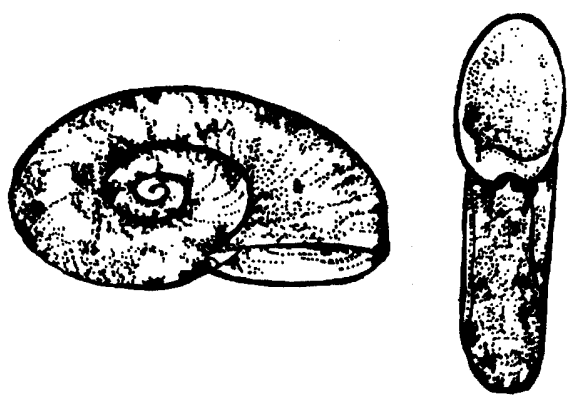

$1 m m$

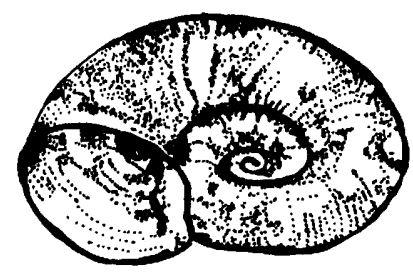

*Ilustração cedida por Paraense 


\section{GÊNERO Helisoma}

Concha discoidal de tamanho médio a grande; hemolinfa vermelha devido à hemoglobina; tubo renal em J. Espécie: Helisoma duryi (Wetherby, 1879) - concha com $18 \mathrm{~mm}$ de diâmetro e $\mathbf{8 , 5} \mathrm{mm}$ de largura; cinco giros, arredondados à direita e subangulosos à esquerda, crescendo rapidamente em diâmetro; abertura cordiforme ou deltóide (Figura 15). Distribuição geográfica: não é autóctone, foi introduzido no Brasil. É encontrado em Goiás, no município de Formosa e em São Paulo em várias localidades (Paraense, 1975; Souza \& Lima, 1990).

FIGURA 15: Conchas de Helisoma duryi (Escala Milimétrica)

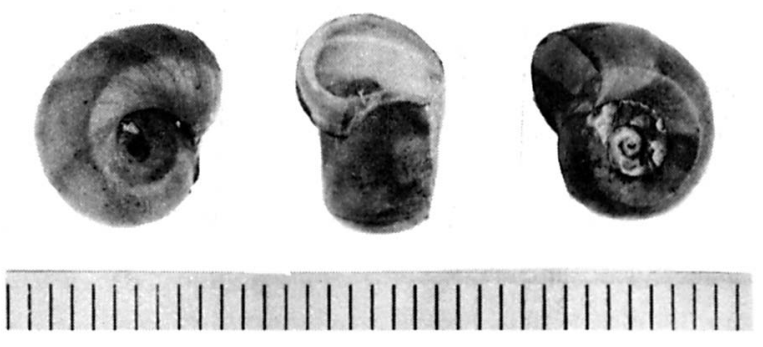

Fonte: Coleção do Laboratório de Malacologia do Centro de Pesquisas René Rachou, Belo Horizonte, Minas Gerais - Acervo Fotográfico de Lais Clark Lima

\section{GÊNERO Drepanotrema}

Concha discoidal, pequena, com abertura falciforme; pé longo, estreito e lanceolar; hemolinfa incolor; tubo renal em J; massa cefalopodal com faixas pigmentadas (Figura 16). Espécies:

FIGURA 16: Massa cefalopodal e parte cefálica do manto de Drepanotrema lucidum, mostrando as faixas pigmentadas. cm: colar do manto; mf: mufla; p: pé; te: tentáculo*

*Ilustração cedida por Paraense
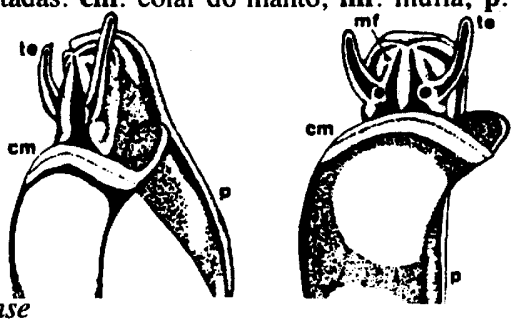
Drepanotrema anatinum (Orbigny, 1835): concha com 4,2 $\mathrm{mm}$ de diâmetro e 1,9 mm de largura; seis giros arredondados, crescendo lentamente em diâmetro e cada um, recobrindo consideravelmente seu antecessor (Figura 17). Distribuição geográfica: em todo o território brasileiro (Paraense, 1975).

FIGURA 17: Conchas de Drepanotrema anatinum (Escala Milimétrica)
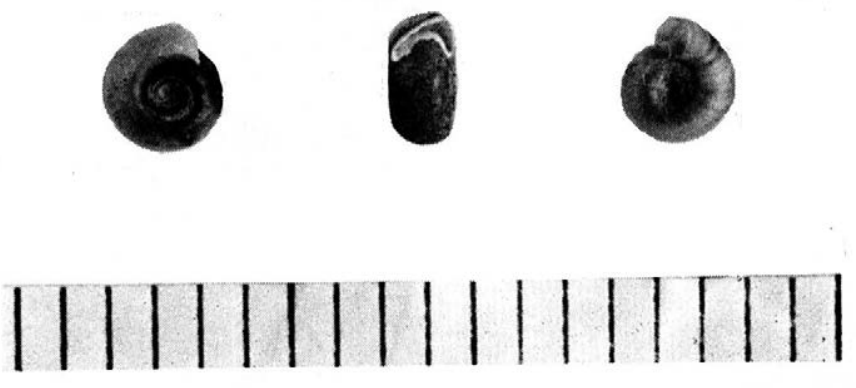

Fonte: Coleçāo do Laboratório de Malacologia do Centro de Pesquisas René Rachou, Belo Horizonte, Minas Gerais - Acervo Fotográfico de Lais Clark Lima

Drepanotrema heloicum (Orbigny, 1835): concha com $8 \mathrm{~mm}$ de diâmetro e $2,2 \mathrm{~mm}$ de largura; cinco e meio giros arredondados, crescendo lentamente em diâmetro. Nesta espécie a abertura é arredondada (Figura 18). Distribuição geográfica: Rio Grande do Sul e Mato Grosso do Sul (Paraense, 1975; Souza \& Lima, 1990).

FIGURA 18: Conchas de Drepanotrema heloicum*
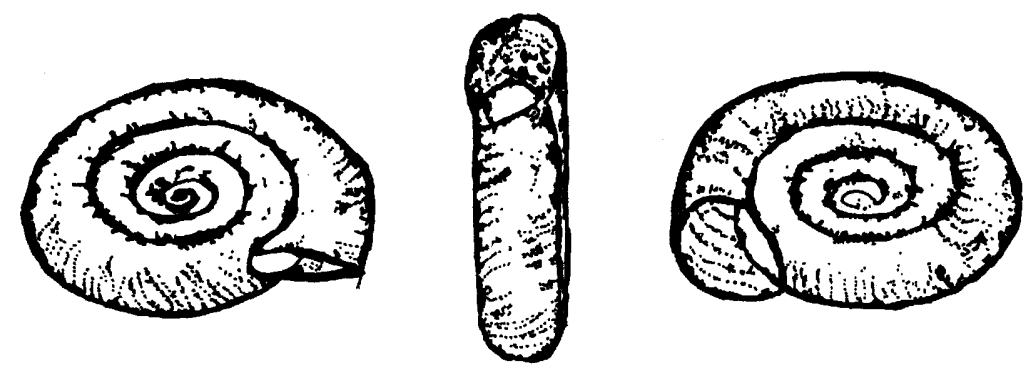

Ilustração cedida por Paraense 
Drepanotrema kermatoides (Orbigny, 1835): concha com 12,5 mm de diâmetro e 1,8 mm de largura; seis e meio giros arredondados à direita e achatados à esquerda, crescendo lentamente em diâmetro; periferia carenada (angulosa); massa cefalopodal sem as faixas características do gênero (Figura 19). Distribuição geográfica: Rio Grande do Sul e Mato Grosso do Sul (Paraense, 1975; Souza \& Lima, 1990).

Drepanotrema lucidum (Pfeiffer, 1839): concha com brilho peculiar, com 8 $\mathrm{mm}$ de diâmetro e $2 \mathrm{~mm}$ de largura, seis giros aplanados, sutura rasa (Figura 20). Distribuição geográfica: todo o território brasileiro (Paraense, 1975).

FIGURA 19: Conchas de Drepanotrema kermatoides (Escala Milimétrica)
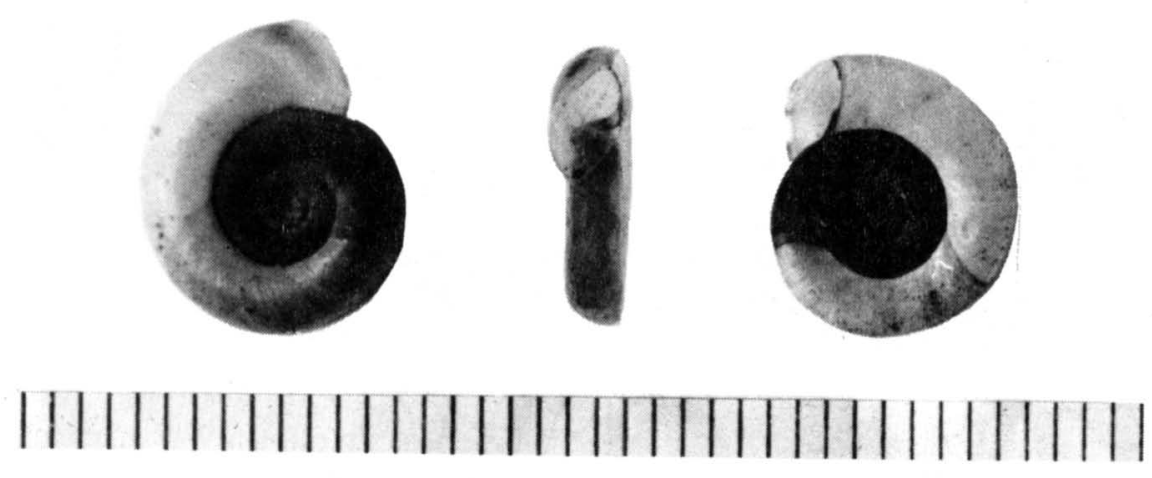

Fonte: Coleção do Laboratório de Malacologia do Centro de Pesquisas René Rachou, Belo Horizonte, Minas Gerais - Acervo Fotográfico de Lais Clark Lima

FIGURA 20: Conchas de Drepanotrema lucidum (Escala milimétrica)
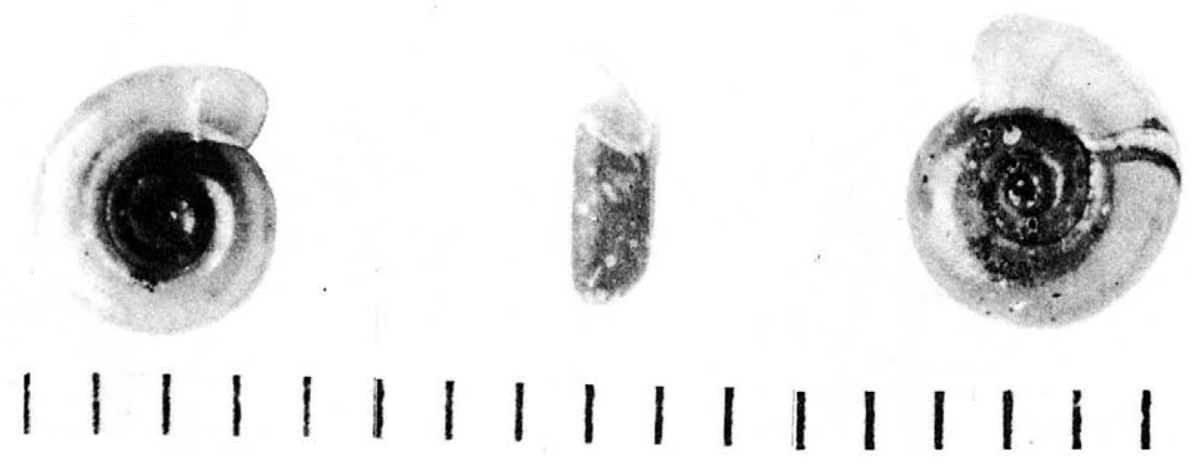

Fonte: Coleção do Laboratório de Malacologia do Centro de Pesquisas René Rachou, Belo Horizonte, Minas Gerais - Acervo Fotográfico de Lais Clark Lima 
Drepanotrema cimex (Moricand, 1839): concha com $8 \mathrm{~mm}$ de diâmetro e $1,1 \mathrm{~mm}$ de largura; sete giros, crescendo lentamente em diâmetro (Figura 21). Distribuição geográfica: em todo o território brasileiro (Paraense, 1975).

FIGURA 21: Conchas de Drepanotrema cimex (Escala milimétrica)
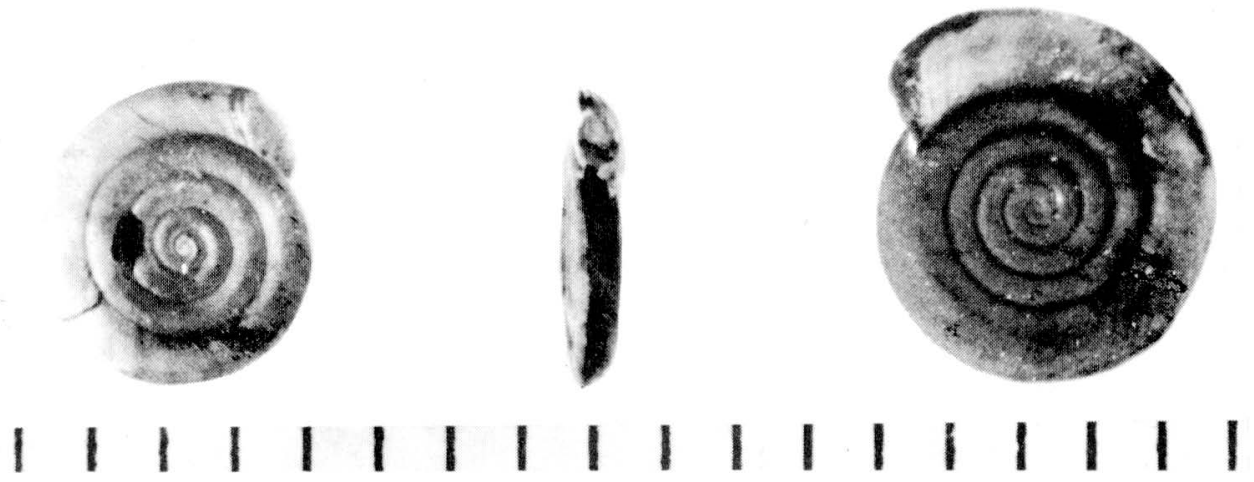

Fonte: Coleção do Laboratório de Malacologia do Centro de Pesquisas René Rachou, Belo Horizonte, Minas Gerais - Acervo Fotográfico de Lais Clark Lima

Drepanotrema depressissimum (Moricand, 1839): concha com $11 \mathrm{~mm}$ de diâmetro e 1,5 mm de largura; sete giros, crescendo lentamente em diâmetro; periferia com carena aguda, bem à esquerda (Figura 22). Distribuição geográfica: em todo o território brasileiro, só não foi assinalado no Paraná e em Santa Catarina (Paraense, 1975).

FIGURA 22: Conchas de Drepanotrema depressissimum (Escala Milimétrica)

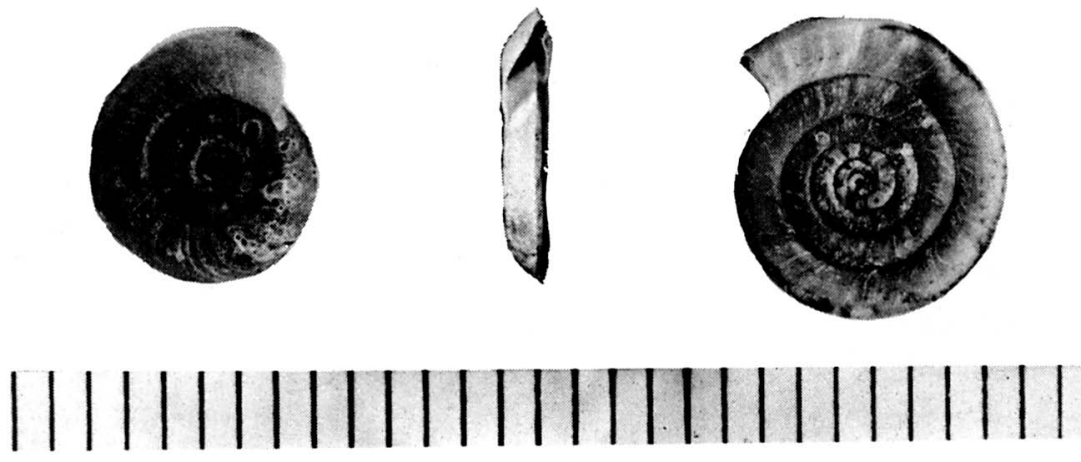

Fonte: Coleçāo do Laboratório de Malacologia do Centro de Pesquisas René Rachou, Belo Horizonte, Minas Gerais - Acervo Fotográfico de Lais Clark Lima 
Drepanotrema pileatum Paraense, 1971: concha com $13 \mathrm{~mm}$ de diâmetro e 4,5 mm de largura; sete giros, crescendo lentamente em diâmetro, recobrindo seu antecessor; lado esquerdo profundamente côncavo (Figura 23). Distribuição geográfica: Bahia e Minas Gerais (Paraense, 1975).

FIGURA 23: Conchas de Drepanotrema pileatum (Escala Milimétrica)

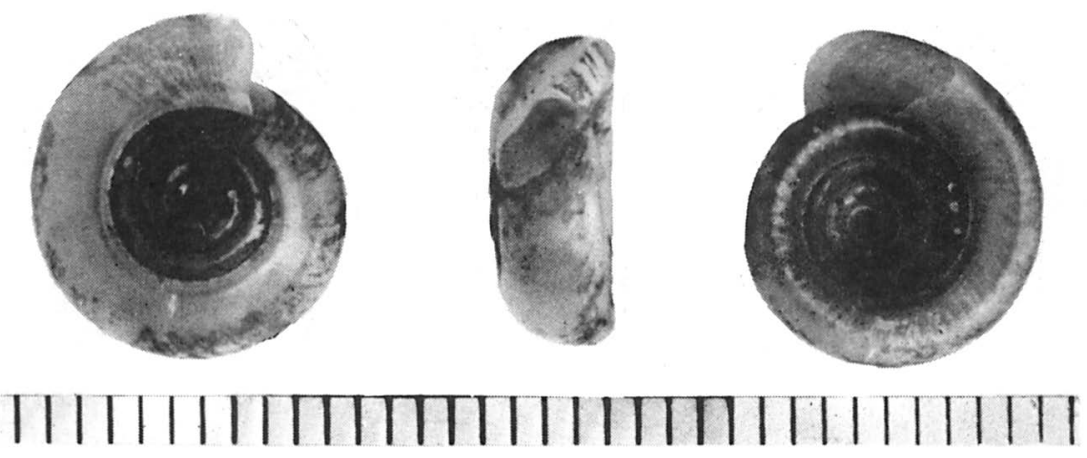

Fonte: Coleção do Laboratório de Malacologia do Centro de Pesquisas René Rachou, Belo Horizonte, Minas Gerais - Acervo Fotográfico de Lais Clark Lima

\section{GÊNERO Biomphalaria}

Concha discoidal, de pequena a grande (de 7 a $40 \mathrm{~mm}$ de diâmetro); hemolinfa vermelha devido à hemoglobina; tubo renal em J. A este gênero pertencem as espécies hospedeiras do Schistosoma mansoni Sambon, 1907 - Trematoda: Schistosomatidae - no continente americano. O S. mansoni é o parasita do sistema sanguíneo do homem que causa a esquistossomose mansônica, doença endêmica que afeta cerca de $\mathbf{2 0 0}$ milhões de pessoas em várias regiões do mundo. A distribuição geográfica do $S$. mansoni no continente americano é ampla. Ele é encontrado em Porto Rico, República Dominicana, Santa Lúcia, Guadalupe, Martinica, St. Kitts, Suriname, Venezuela e Brasil. O nosso país pode ser considerado, atualmente, o maior foco endêmico da esquistossomose mansônica do mundo, com cerca de 8 milhões de indivíduos parasitados. As regiões que apresentam endemicidade mais elevada são o Nordeste do país (Figura 38) e o nordeste de Minas Gerais (Figura 39) (Paraense, 1972, 1975). 


\subsubsection{Espécies e Subespécies do Gênero Biomphalaria}

Biomphalaria glabrata (Say, 1818)

Concha com até $40 \mathrm{~mm}$ de diâmetro e $11 \mathrm{~mm}$ de largura; seis a sete giros arredondados, crescendo lentamente em diâmetro, sendo o central mais à esquerda; lado direito mais escavado que o esquerdo; periferia arredondada, tendendo para a direita (Figura 24). É o maior molusco da família Planorbidae. Como já foi salientado, as características típicas da concha de uma espécie podem não se apresentar em alguns espécimes e populações. Portanto, podemos encontrar indivíduos de $B$. glabrata mais largos e com carena (angulação longitudinal na lateral da concha), que pela morfologia da concha são susceptíveis de ser confundidos com a Biomphalaria tenagophila. Encontramos também indivíduos jovens, de ambientes sujeitos a dessecação, que apresentam lamelas no interior da abertura, tornando as conchas bastantes semelhante às de Biomphalaria schrammi (Paraense, 1961, 1972, 1975).

FIGURA 24: Conchas de Biomphalaria glabrata (Escala Milimétrica)

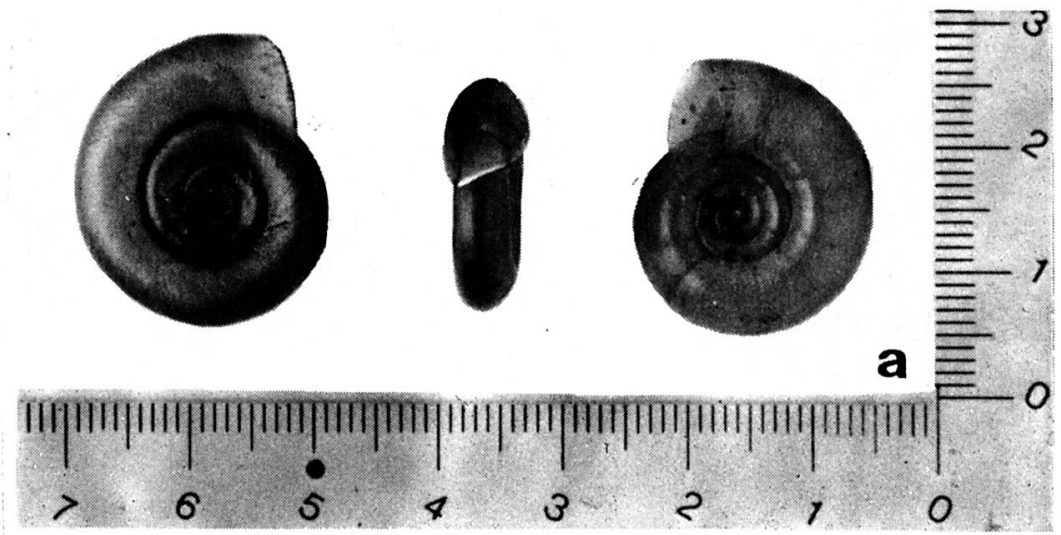

Fonte: Coleção do Laboratório de Malacologia do Centro de Pesquisas René Rachou, Belo Horizonte, Minas Gerais - Acervo Fotográfico de Lais Clark Lima

Características da anatomia interna: presença de crista renal pigmentada (Figura 25 A) ao longo da superfície ventral do tubo renal em indivíduos adultos, e linha pigmentada em indivíduos jovens (Figura 25 B) - nas outras espécies de Biomphala- 
ria não há este caráter (Figura $25 \mathrm{C}$ ); ovoteste com mais de 350 divertículos; presença de bolsa vaginal; porção média da bainha do pênis aproximadamente do mesmo diâmetro que a porção mais larga do canal deferente (Paraense, 1972, 1975).

Distribuição geográfica: Alagoas, Bahia, Ceará, Distrito Federal, Espírito Santo, Goiás, Maranhão, Pará, Paraíba, Paraná, Pernambuco, Piauí, Rio de Janeiro, Rio Grande do Norte, São Paulo, Sergipe e Minas Gerais (Figura 37): Araçaí, Acesita, Água Boa, Águas Vermelhas, Aimorés, Almenara, Alterosa, Alvinópolis, Araxá, Arcos, Ariranha, Baldim, Bambuí, Barão de Cocais, Barbacena, Belo

FIGURA 25: Manto de Biomphalaria, visto do seu lado ventral. A: apresenta a crista renal pigmentada (cr) de $B$. glabrata adulta. B: apresenta a linha renal pigmentada (Ir) de $B$. glabrata jovem. C: apresenta o tubo renal liso das outras espécies de Biomphalaria. cl: crista lateral do manto; cm: colar do manto; co: coração; cr: crista renal; ga: glândula de albúmen; Ir: linha renal pigmentada; mu: meato do ureter; pe: pericárdio parcialmente retirado; pn: pneumóstoma, tr: tubo renal; ur: ureter; vp: veia renal*
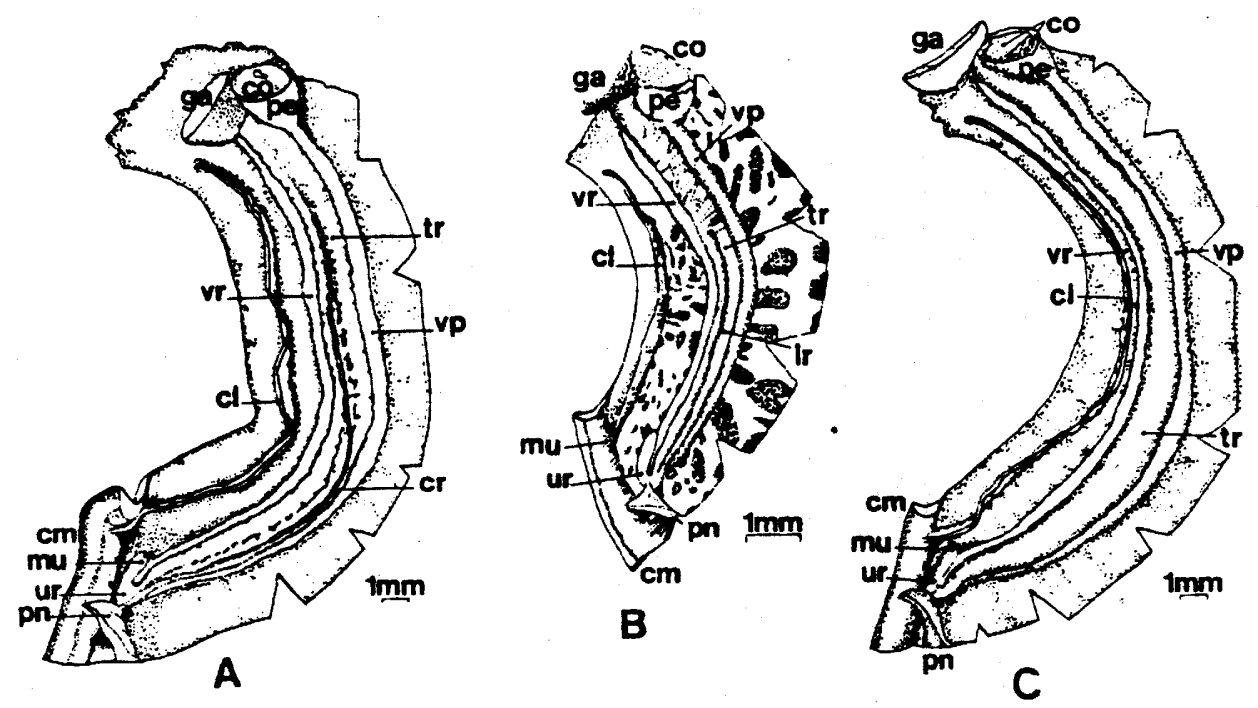

*Ilustração cedida por Paraense 
Horizonte, Bocaiúva, Bom Jesus do Galho, Brasília de Minas, Braúnas, Buenópolis, Buratamena, Caetés, Calciolândia, Campanha, Capoeirão, Capim Branco, Caratinga, Carlos Bernardes, Centenário de Ipanema, Cinco Ilhas, Coluna, Comercinho, Conceição da Aparecida, Conceição do Capim, Conceição do Mato Dentro, Conselheiro Lafaiete, Conselheiro Pena, Contagem, Coração de Jesus, Cordisburgo, Corinto, Coronel Fabriciano, Crenaque, Cuieté, Curvelo, Derribadinha, Desembargador Trindade, Diamantina, Divino, Divinópolis, Dom Joaquim, Dores do Indaiá, Doresópolis, Entre Folhas, Engenheiro Caldas, Espinosa, Ferros, Florestal, Formiga, Francisco Sá, Frei Inocêncio, Galiléia, Governador Valadares, Guanhães, Iapu, Igarapé, Inhapim, Itacarambi, Itabira, Itajubá, Itambacuri, Itanhomi, Itinga, Itueta, Jaboticatubas, Jacinto, Jacuri, Jampruca, Janaúba, Januária, Jequitaí, Jequitinhonha, João Pessoa, Joaíma, José de Melo, Juiz de Fora, Justinópolis, Lagoa Santa, Lagoa da Prata, Lontra, Malacacheta, Machacalis, Mamonas, Manga, Manhuaçu, Mariana, Matozinhos, Medina, Mesquita, Mirabela, Missões, Monlevade, Montalvânia, Montes Claros, Mutum, Nacip Raydan, Neves, Nossa Senhora das Graças, Nova Era, Nova Lima, Novo Cruzeiro, Ouro Preto, Pains, Paracatu, Papagaios, Passos, Peçanha, Pará de Minas, Pedra Azul, Pedro Leopoldo, Penha do Capim, Piau, Pinhões, Pirapora, Ponte Nova, Porteirinha, Resplendor, Retiro, Rio Acima, Rio Casca, Rio Novo, Rio Pardo de Minas, Rio Piracicaba, Rio Vermelho, Sabará, Sabinópolis, Salinas, Salto da Divisa, Santa Bárbara, Santa Luzia, Santa Maria de Itabira, Santa Maria de Suaçuí, Santa Rita, Santo Antônio do Grama, São João do Paraíso, São João Evangelista, São Pedro do Suaçuí, São Raimundo, São Romão, São Sebastião. do Rio Preto, Sapucaia, Sete Lagoas, Tabuleiro, Taquaraçu de Minas, Tarumirim, Teófilo Otoni, Tumiritinga, Tuparecê," Ubá, Vespasiano, Viçosa (Paraense, 1972, 1975; Paraense \& Araújo, 1984; Souza \& Lima, 1990).

Biomphalaria tenagophila (Orbigny, 1835)

Concha com até $35 \mathrm{~mm}$ de diâmetro e $11 \mathrm{~mm}$ de largura, sete a oito giros, crescendo lentamente em diâmetro; com carena em ambos os lados, sendo mais acentuada à esquerda; giro central mais à esquerda; lado esquerdo mais côncavo que o direito; periferia arredondada, tendendo para a direita; abertura deltóide nas conchas mais largas e cordiforme nas mais estreitas (Figura 26). Há populações com carena bastante atenuada e mesmo ausente (Paraense, 1972, 1975).

Características da anatomia interna: semelhante à de $B$. glabrata, diferindo pela ausência de linha ou crista renal (Figura $25 \mathrm{C}$ ) e ovoteste com mais de 150 e menos de 350 divertículos (Paraense, 1972, 1975). 
FIGURA 26: Conchas de Biomphalaria tenagophila (Escala Milimétrica)

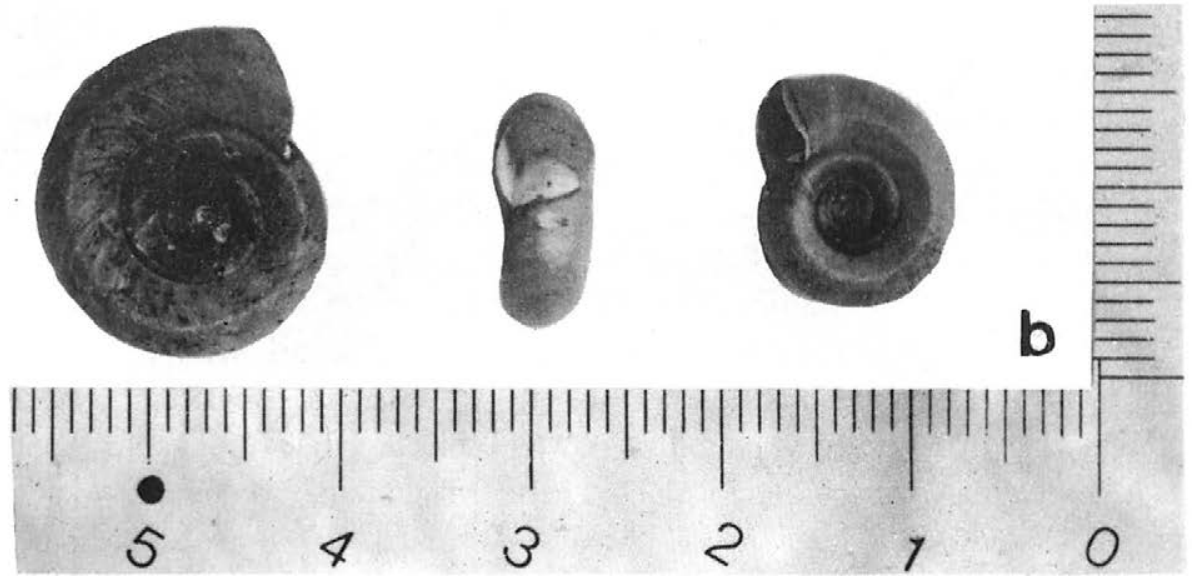

Fonte: Coleção do Laboratório de Malacologia do Centro de Pesquisas René Rachou, Belo Horizonte, Minas Gerais - Acervo Fotográfico de Lais Clark Lima

Distribuição geográfica: Bahia, Distrito Federal, Espírito Santo, Goiás, Paraná, Rio de Janeiro, Rio Grande do Sul, Santa Catarina, São Paulo e Minas Gerais (Figura 37): Juiz de Fora, Nova Era, Itajubá, Cabo Verde, Belo Horizonte, Contagem, Betim, Nova Lima, Aimorés, Retiro, Rio Novo, Ubá, Sabará, Jaboticatubas, Uberlândia, Divinópolis, Bom Despacho, Sete Lagoas, Dom Joaquim, Machacalis, Joaíma, Doresópolis, Taquaraçu de Minas, Barbacena e Passos (Paraense, 1972, 1975; Souza \& Lima, 1990).

Biomphalaria straminea (Dunker, 1848)

Concha com até $16,5 \mathrm{~mm}$ de diâmetro e $6 \mathrm{~mm}$ de largura; cinco giros arredondados, crescendo mais rapidamente em diâmetro, às vezes apresentando leve angulação à esquerda; giro central mais à esquerda; lado direito tendendo a aplanarse; periferia arredondada e medial (Figura 27) (Paraense, 1972, 1975).

Características da anatomia interna: presença de enrugamento na parede dorsal da vagina; ovoteste com mais de 50 e menos de 150 divertículos; próstata com 9 a 18 divertículos; porção média da bainha do pênis aproximadamente do mesmo diâmetro que a porção mais larga do canal deferente (Paraense, 1972, 1975). 
FIGURA 27: Conchas de Biomphalaria straminea (Escala Milimétrica)
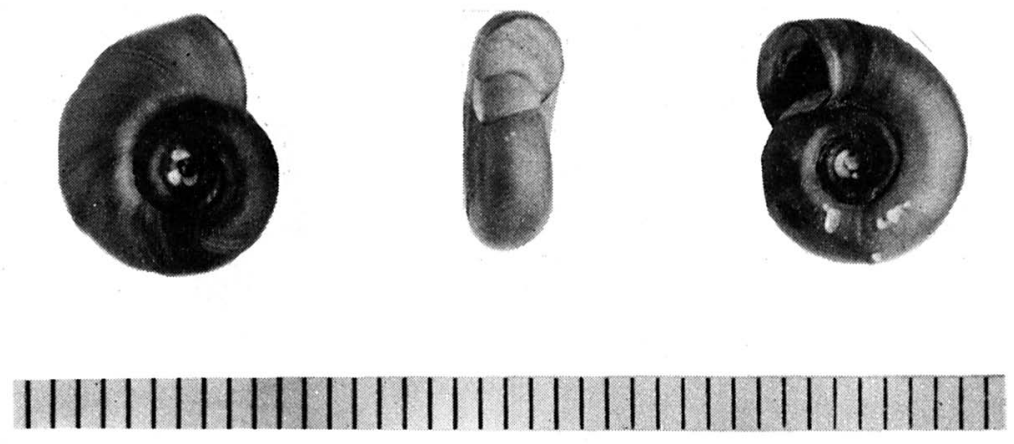

Fonte: Coleção do Laboratório de Malacologia do Centro de Pesquisas René Rachou, Belo Horizonte, Minas Gerais - Acervo Fotográfico de Lais Clark Lima

Distribuição geográfica: Amazonas, Roraima, Acre, Pará, Maranhão, Piauí, Ceará, Rio Grande do Norte, Paraíba, Pernambuco, Alagoas, Sergipe, Bahia, Espírito Santo, Goiás, Distrito Federal, São Paulo, Mato Grosso, Mato Grosso do Sul, Paraná, Rio Grande do Sul, Rio de Janeiro e Minas Gerais (Figura 38): Belo Horizonte, Rio Casca, Governador Valadares, Cordisburgo, Vespasiano, Matozinhos, Baldim, Calciolândia, Arcos, Bocaiúva, Buenópolis, Buratamena, Corinto, Curvelo, Coronel Fabriciano, Derribadinha, Espinosa, Francisco Sá, Itacarambi, Itinga, Jacinto, Jequitaí, Lagoa Santa, Lontra, Mamonas, Montes Claros, Paracatu, Pedro Leopoldo, Pirapora, Porteirinha, São Romão, Sete Lagoas, Teófilo Otoni, Engenheiro Caldas, Nova Lima, Chapada do Norte, Salinas, Salto da Divisa, São Pedro do Suaçuí, Papagaios, Santana de Pirapama, Minas Novas, Frei Inocêncio, Brumadinho, Juramento, Belo Oriente, Jequitibá, Peri-Peri, Capim Branco, Lagoa da Prata, Sobrália, Mateus Leme, Taquaraçu de Minas (Paraense, 1972, 1975; Souza \& Lima, 1990).

Biomphalaria peregrina (Orbigny, 1835)

Concha com até $16,5 \mathrm{~mm}$ de diâmetro e $5,5 \mathrm{~mm}$ de largura, cinco a seis giros arredondados, crescendo lentamente em diâmetro, sendo o central mais à direita; lado direito aplanado; periferia arredondada, tendendo para a direita (Figura 28) (Paraense, 1975). 
FIGURA 28: Conchas de Biomphalaria peregrina (Escala Milimétrica)
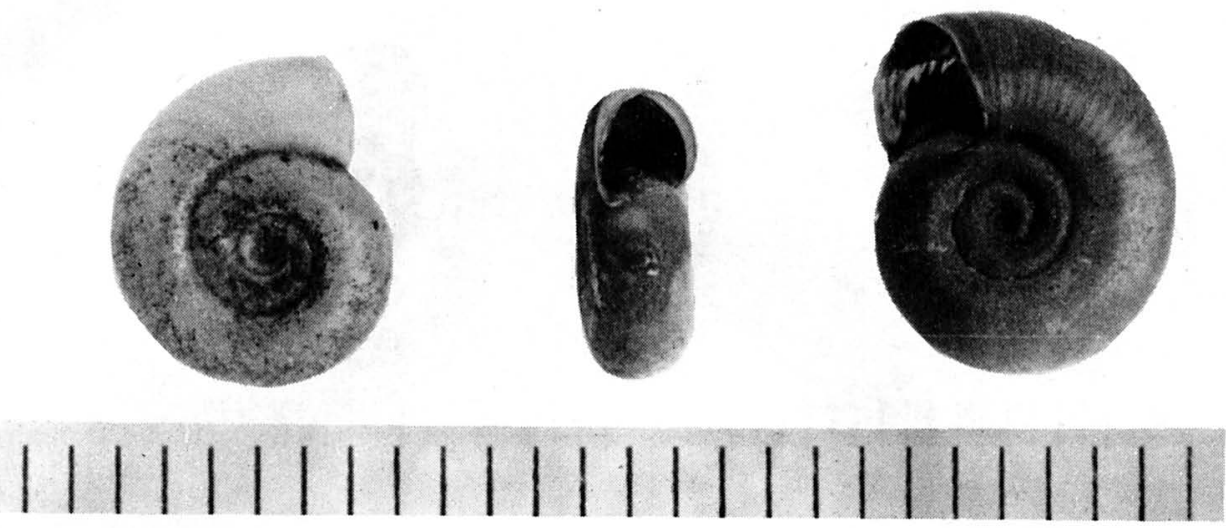

Fonte: Coleção do Laboratório de Malacologia do Centro de Pesquisas René Rachou, Belo Horizonte, Minas Gerais - Acervo Fotográfico de Lais Clark Lima

Características da anatomia interna: presença de bolsa vaginal; ovoteste com mais de 50 e menos de 150 divertículos; porção média da bainha do pênis muito mais larga que a porção de maior diâmetro do canal deferente; divertículo prostático anterior, recobrindo a parte apical do corpo da espermateca (Paraense, 1975).

Distribuição geográfica: Goiás, Mato Grosso do Sul, Rio de Janeiro, São Paulo, Paraná, Santa Catarina, Rio Granide do Sul, Distrito Federal, Mato Grosso e Minas Gerais: Juiz de Fora, Retiro, Barbacena, Borda da Mata, Cachoeira, Ouro Fino, Passos, Pouso Alegre, Itajubá, Santa Rita do Sapucaí, Alfenas, Alterosa, Belo Horizonte, Betim, Campo do Meio, Carmo do Rio Claro, Conceição da Aparecida, Conselheiro Lafaiete, Elói Mendes, Esmeraldas, Fama, Florestal, Juruaia, Lavras, Machado, Monte Belo, Nova Lima, Paraguaçu, Pedra do Indaiá, Pedro Leopoldo, Ponte das Amoras, Ponte de Pedra, Santana da Vargem, Silvianópolis, Três Corações, Três Pontas, Uberlândia, Mutum, Paraisópolis, Areado (Paraense, 1966a, 1975; Souza \& Lima, 1990).

Biomphalaria amazonica Paraense, 1966

Concha com até $8 \mathrm{~mm}$ de diâmetro e 2,5 mm de largura; cinco giros convexos, crescendo rapidamente em diâmetro, sendo o central mais à esquerda; periferia arredondada, com tendência medial; abertura ligeiramente defletida para a esquerda (Figura 29) (Paraense, 1966a, 1975). 
FIGURA 29: Conchas de Biomphalaria amazonica (Escala Milimétrica)

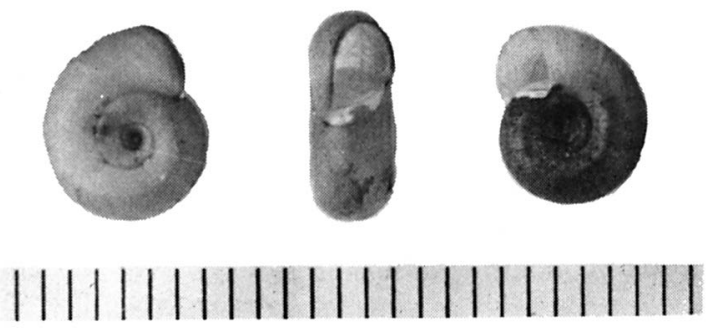

Fonte: Coleção do Laboratório de Malacologia do Centro de Pesquisas René Rachou, Belo Horizonte, Minas Gerais - Acervo Fotográfico de Lais Clark Lima

Características da anatomia interna: presença de bolsa vaginal; ovoteste com mais de 20 e menos de 80 divertículos; bainha do pênis mais curta que o prepúcio; porção média da bainha do pênis mais ou menos do mesmo diâmetro que a porção mais larga do canal deferente (Paraense, 1966b, 1975).

Distribuição geográfica: Acre, Amazonas, Mato Grosso, Mato Grosso do Sul e Rondônia (Paraense, 1975, 1983, 1986c; Souza \& Lima, 1990).

Biomphalaria intermedia (Paraense \& Deslandes, 1962)

Concha com até $12 \mathrm{~mm}$ de diâmetro e $3 \mathrm{~mm}$ de largura; cinco e meio giros convexos, crescendo lentamente em diâmetro, periferia arredondada, medial ou com ligeira tendência para a direita (Figura 30) (Paraense, 1975).

Características da anatomia interna: pode apresentar pequena bolsa vaginal semelhante a de $\boldsymbol{B}$. peregrina, e enrugamento vaginal semelhante ao de $\boldsymbol{B}$. straminea (uma das duas ou as duas características); ovoteste com mais de 50 e menos de 150 divertículos; próstata com 6 a 20 divertículos; porção média da bainha do pênis aproximadamente do mesmo diâmetro que a porção mais larga do canal deferente (Paraense, 1975).

Distribuição geográfica: São Paulo e Mato Grosso do Sul (Paraense, 1975, 1985). 
Biomphalaria occidentalis Paraense, 1981

Concha extremamente semelhente à da de B. tenagophila, com até $21 \mathrm{~mm}$ de diâmetro e $8 \mathrm{~mm}$ de largura, e seis e meio a sete giros (Figura 31) (Paraense, 1981b).

Características da anatomia interna: vagina longa e tubular, podendo apresentar uma projeção da parede que pode ser confundida com uma bolsa; ovoteste com mais de 100 divertículos; bainha do pênis mais larga que a porção mais larga do canal deferente e mais curta que o prepúcio, que mantém aproximadamente o mesmo diâmetro em todo o seu comprimento (Paraense, 1981b).

FIGURA 30: Conchas de Biomphalaria intermedia (Escala Milimétrica)
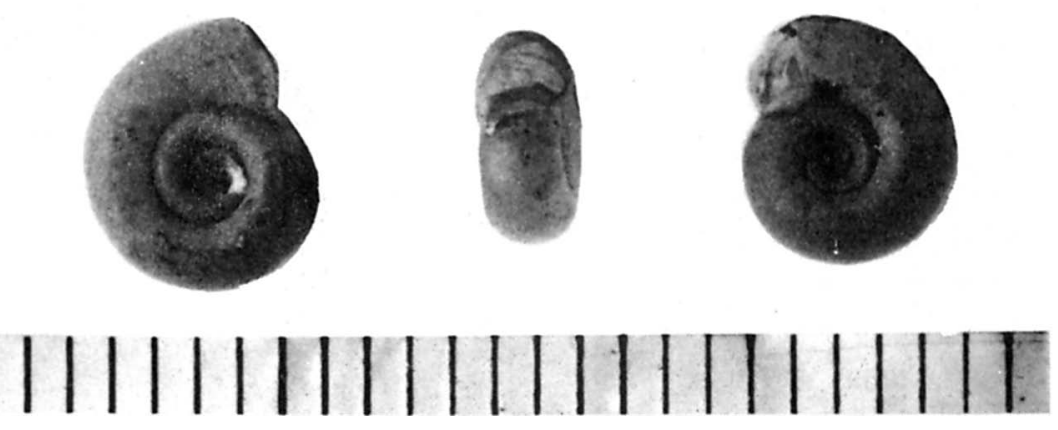

Fonte: Coleçāo do Laboratório de Malacologia do Centro de Pesquisas René Rachou, Belo Horizonte, Minas Gerais - Acervo Fotográfico de Lais Clark Lima

FIGURA 31: Conchas de Biomphalaria occidentalis (Escala Milimétrica)
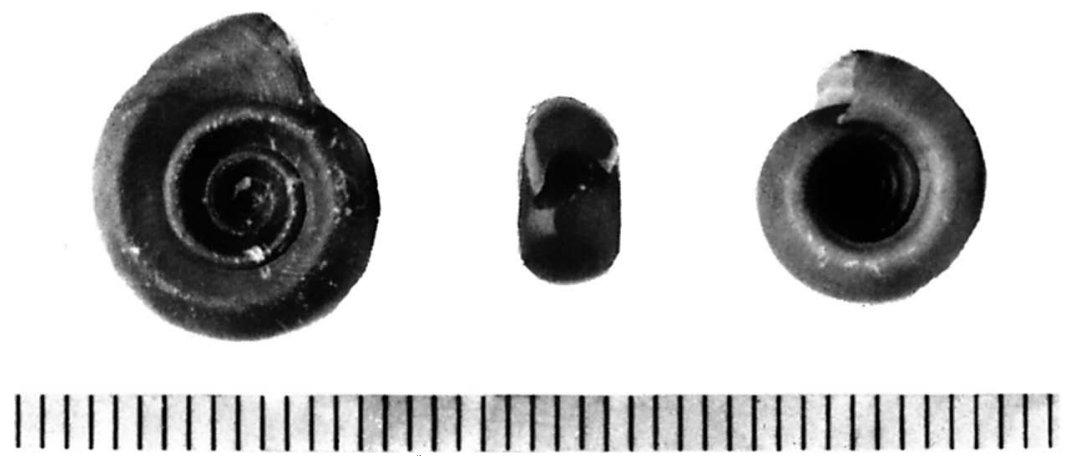

Fonte: Coleção do Laboratório de Malacologia do Centro de Pesquisas René Rachou, Belo Horizonte, Minas Gerais - Acervo Fotográfico de Lais Clark Lima 
Distribuição geográfica: Acre, Amazonas, Rondônia, Mato Grosso, Mato Grosso do Sul, São Paulo, Paraná e Minas Gerais: Contagem (Paraense, 1981b; Souza \& Lima, 1990; Lima, Soares \& Guimarães, 1993).

Biomphalaria schrammi (Crosse, 1864)

Concha com até $8 \mathrm{~mm}$ de diâmetro e $2,2 \mathrm{~mm}$ de largura; cinco giros arredondados, sendo o central mais à esquerda; periferia arqueada, medial, abertura bastante defletida para a esquerda nos indivíduos adultos; apresentam seis lamelas no interior da abertura, sendo o giro externo estreitado na altura das mesmas (Figura 32) (Paraense, 1975).

Características da anatomia interna: útero muito longo; espermateca mais longa que a próstata; ovoteste com mais de 30 e menos de 80 divertículos, bainha do pênis muito longa; prepúcio muito curto (Paraense, 1975).

Distribuição geográfica: todo o território brasileiro, exceto Amazonas, Paraná, Rio Grande do Sul e Santa Catarina. Minas Gerais: Belo Horizonte, Alfenas, Campos Gerais, Itajubá, Lavras, Mercês de Diamantina, Nanuque, Nepomuceno, Ouro Fino, Santa Maria do Suaçuí, Teófilo Otoni, Três Pontas, Bambuí, Governador Valadares, Pouso Alegre, Lassance, Calciolândia, Papagaios, Paraisópolis, Machacalis, Doresópolis (Paraense, 1975; Souza \& Lima, 1990).

FIGURA 32: Conchas de Biomphalaria schrammi (Escala Milimétrica)

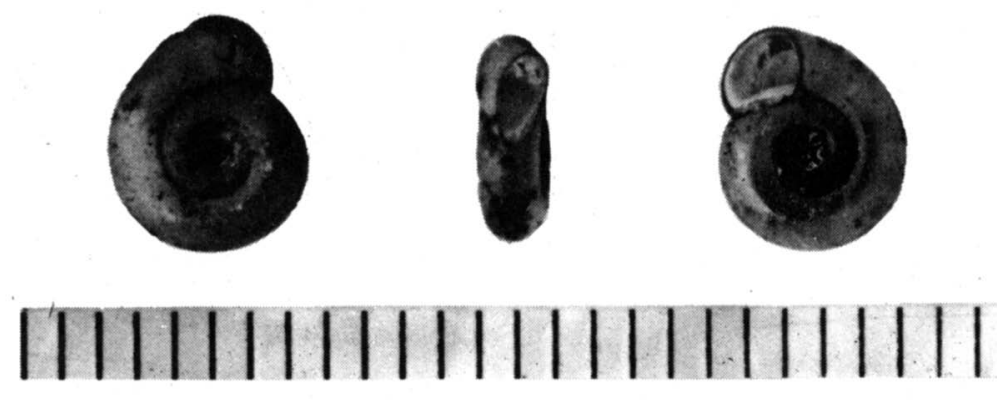

Fonte: Coleção do Laboratório de Malacologia do Centro de Pesquisas René Rachou, Belo Horizonte, Minas Gerais - Acervo Fotográfico de Lais Clark Lima 
Biomphalaria oligoza Paraense, 1975

Concha com até $11 \mathrm{~mm}$ de diâmetro e $3 \mathrm{~mm}$ de largura; cinco giros arredondados, crescendo lentamente em diâmetro, sendo o central mais à esquerda; periferia arredondada, medial (Figura 33) (Paraense, 1975).

Características da anatomia interna: vagina com bolsa às vezes imperceptível; ovoteste com mais de 15 e menos de 50 divertículos; próstata com um a sete (ou mesmo nenhum) divertículos; porção médiá da bainha do pênis de diâmetro igual ou maior que a porção mais larga do canal deferente (Paraense, 1975).

Distribuição geográfica: Mato Grosso do Sul, Paraná, Rio Grande do Sul e Santa Catarina (Paraense, 1975).

FIGURA 33: Conchas de Biomphalaria oligoza (Escala Milimétrica)
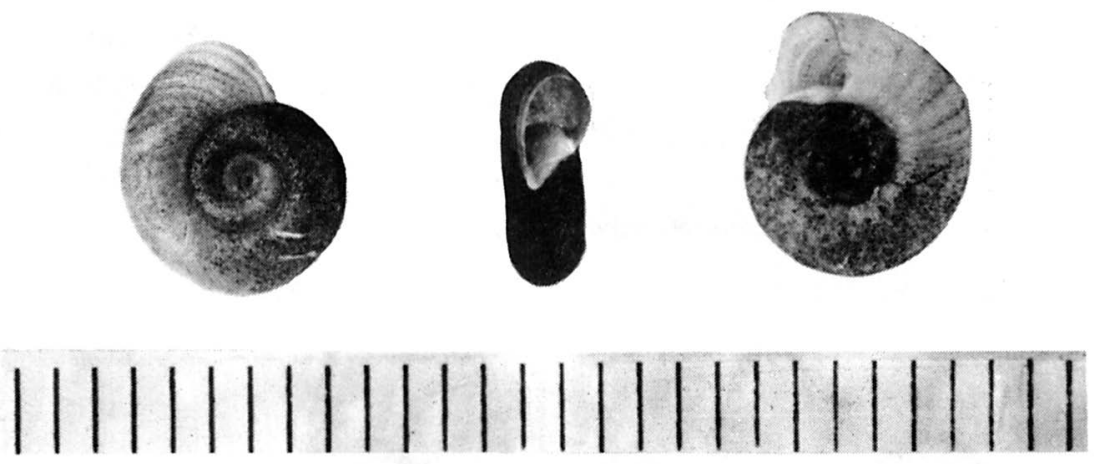

Fonte: Coleção do Laboratório de Malacologia do Centro de Pesquisas René Rachou, Belo Horizonte, Minas Gerais - Acervo Fotográfico de Lais Clark Lima

Biomphalaria kuhniana (Clessim, 1883)

Concha com até 7,4 $\mathrm{mm}$ de diâmetro e 2,8 $\mathrm{mm}$ de largura, quatro e meio giros arredondados, crescendo mais rapidamente em diâmetro e levemente subangulosos do lado esquerdo; lado direito afunilado, com giro central mais à esquerda (Figura 34) (Paraense, 1988). 


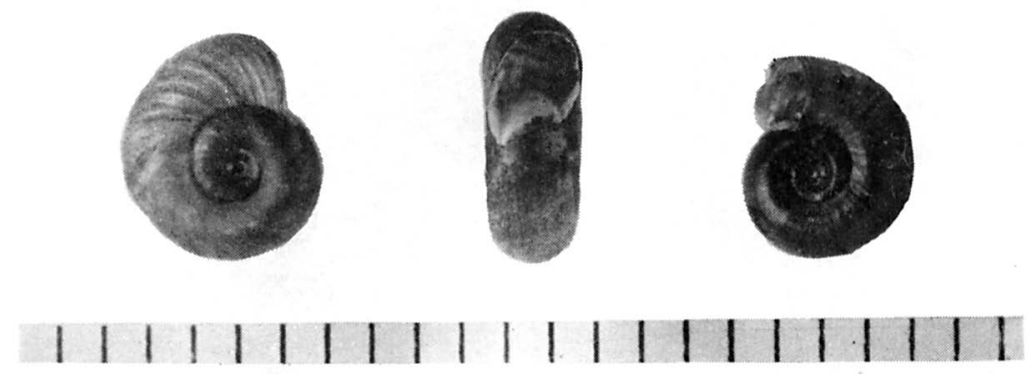

Fonte: Coleção do Laboratório de malacologia do Centro de Pesquisas René Rachou, Belo Horizonte, Minas Gerais - Acervo Fotográfico de Lais Clark Lima

Características da anatomia interna: presença de enrugamento vaginal pouco desenvolvido, que pode ser confundido com o de $B$. straminea e $B$. intermedia; ovoteste com 60 e poucos divertículos; próstata com quatro a nove divertículos; porção mais larga do canal deferente com aproximadamente metade da largura da bainha do pênis (Paraense, 1988).

Distribuição geográfica: Pará (Paraense, 1988).

Biomphalaria tenagophila guaibensis Paraense, 1984

Concha com até $18,5 \mathrm{~mm}$ de diâmetro, 7,5 mm de largura e seis giros; é indistinguível da concha de $B$. tenagophila tenagophila (Figura 35) (Paraense, 1984).

Características da anatomia interna: bainha do pênis mais curta que o prepúcio, sendo este mais longo e mais estreito que o de $B$. $t$. tenagophila; presença de bolsa vaginal (Paraense, 1984).

Distribuição geográfica: Rio Grande do Sul (Paraense, 1984).

A distribuição geográfica dos moluscos do gênero Biomphalaria no Brasil é mostrada na Figura 36. 
FIGURA 35: Conchas de Biomphalaria tenagophila guaibensis (Escala Milimétrica)

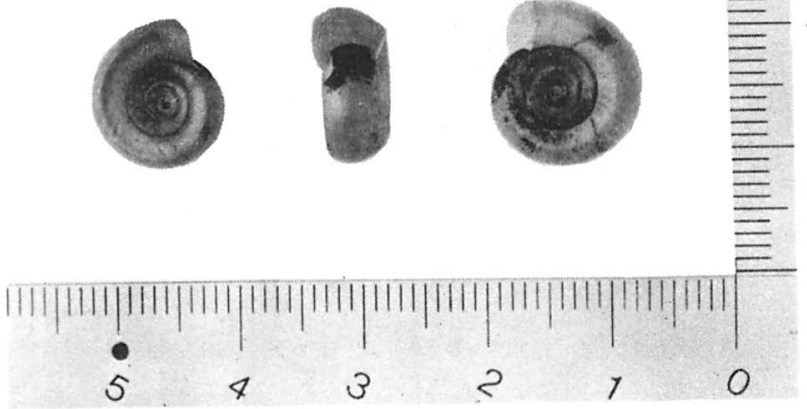

Fonte: Coleção do Laboratório de Malacologia do Centro de Pesquisas René Rachou, Belo Horizonte, Minas Gerais - Acervo Fotográfico de Lais Clark Lima

FIGURA 36: Distribuição geográfica das espécies e subespécie de moluscos do gênero Biomphalaria no Brasil. A: B. amazonica. G: B. glabrata. I: B. intermedia. K: B. Kuhniana. O: B. oligoza. Oc: B. occidentalis. P: B. peregrina. S: B. straminea. Sc: B. schrammi. T: $B$. tenagophila. TG: $B$. tenagophila guaibensis (Souza \& Lima, 1990)

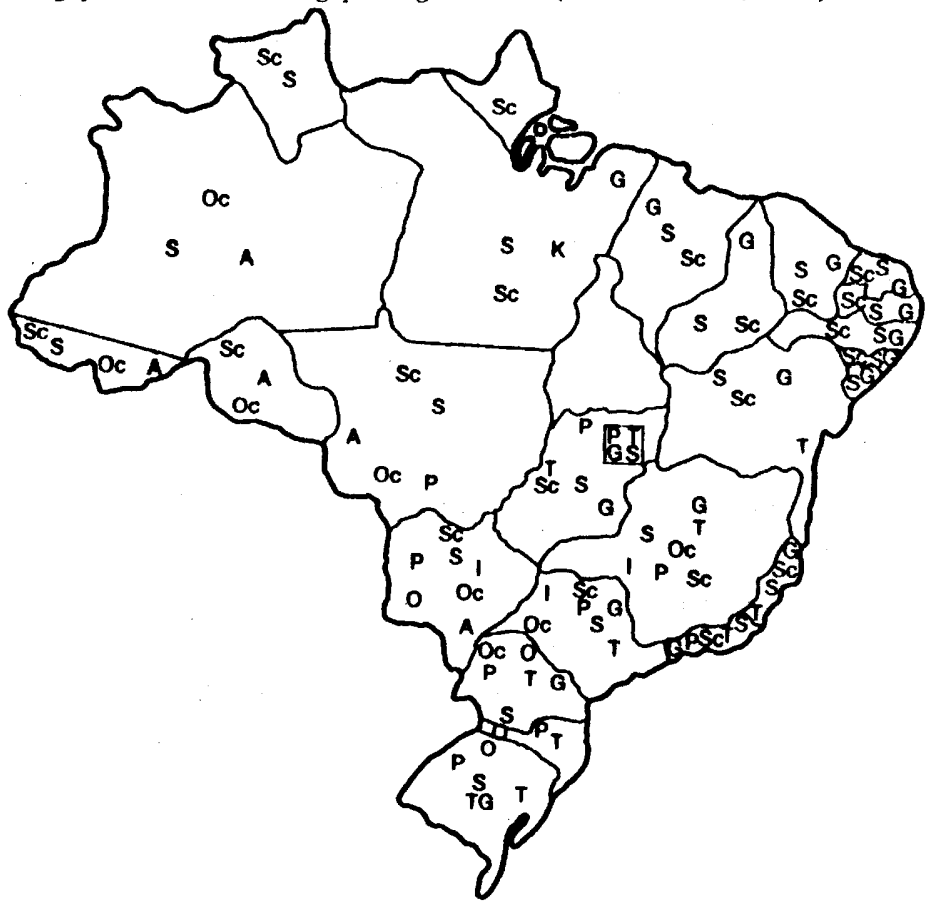




\subsubsection{Espécies Hospedeiras de Schistosoma mansoni no Brasil}

Em nosso país as três espécies hospedeiras do Schistosoma mansoni fazem parte do gênero Biomphalaria: B. glabrata, B. straminea e B. tenagophila. As outras sete espécies de Biomphalaria e uma subespécie, descritas até o momento, não foram encontradas com infecção natural por S. mansoni (Souza \& Lima, 1990). Entretanto, B. peregrina (Paraense, 1973) e B. amazonica (Corrêa \& Paraense, 1971; Paraense $\&$ Corrêa, 1985) mostraram-se suscetíveis ao $S$. mansoni em infecções experimentais, podendo ser consideradas hospedeiras em potencial do trematódeo no Brasil.

B. glabrata: é a principal hospedeira de $S$. mansoni, ocorrendo em quase todo o território nacional (Figura 37). A área de ocorrência de esquistossomose no Brasil (Figura 38) está bastante relacionada à presença de $B$. glabrata.

B. straminea: tem ampla distribuição geográfica no país (Figura 37). É hospedeira de $S$. mansoni na região do Nordeste e em focos isolados no Pará (Fordlândia e Belém) (Paraense, Souza \& Braun, 1984) e Goiás (Goiânia). A densidade deste molusco nos criadouros do Nordeste é alta, mas as taxas de infecção natural por S. mansoni são baixas (Souza \& Lima, 1990).

FIGURA 37: Distribuição geográfica dos moluscos hospedeiros do Schistosoma mansoni no Brasil

Biomphalaria glabrata

Biomphalaria straminea Biomphalaria tenagophila

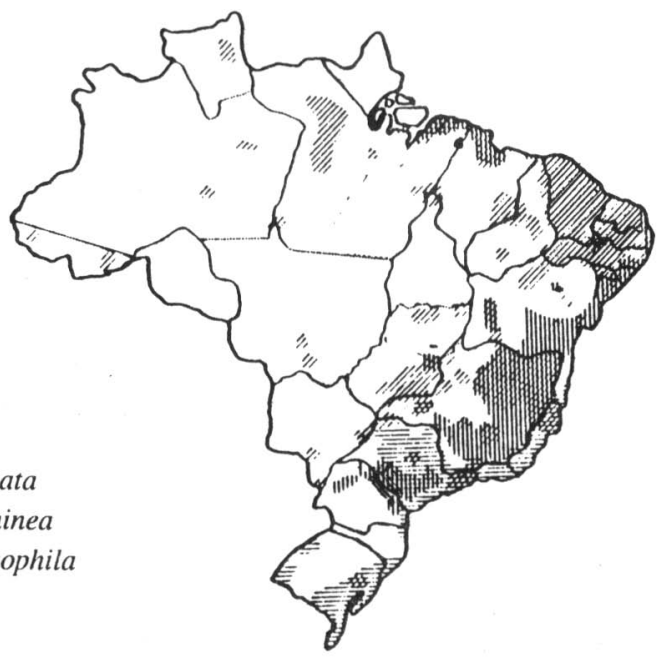

Fonte: Paraense, $1986 \mathrm{c}$ 
B. tenagophila: é hospedeira de S. mansoni nos estados do Rio de Janeiro, Santa Catarina, São Paulo, no Vale do Paraíba; e em Minas Gerais, nos municípios de Jaboticatubas, Itajubá e Belo Horizonte (represa da Pampulha) (Souza \& Lima, 1990). Sua distribuição geográfica no país é mostrada na Figura 37.

A prevalência da esquistossomose por áreas dos Centros Regionais de Saúde, em Minas Gerais, é mostrada na Figura 39.

FIGURA 38: Áreas de ocorrência da esquistossomose no Brasil .

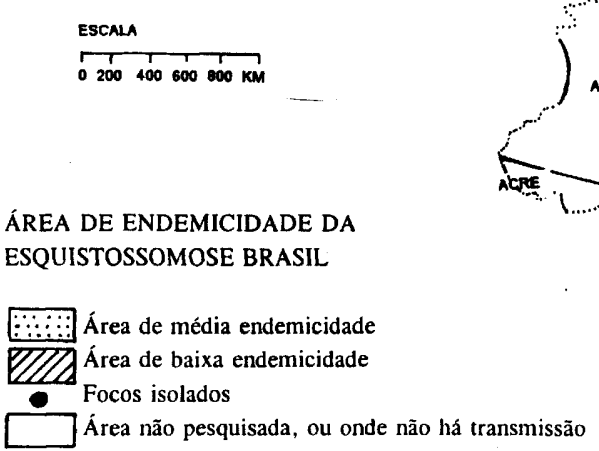

Fonte: Paraense, $1986 \mathrm{c}$

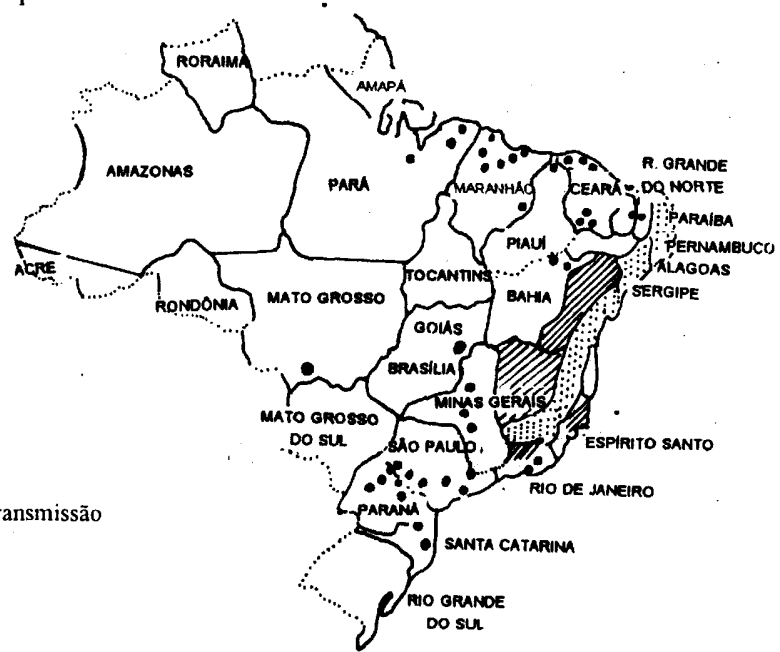

FIGURA 39: Prevalência da esquistossomose nas áreas dos Centros Regionais de Saúde em Minas Gerais

REGIÕES DE SAÚDE

- SEDE DOS CENTROS REgIONAIS DE SAÚDE - PERCENTUAL DE POSITIVIDADE PARA

Schistosoma mansoni TOTAL PARA O ESTADO: $4,69 \%$

Fonte: SES-MG - 1986

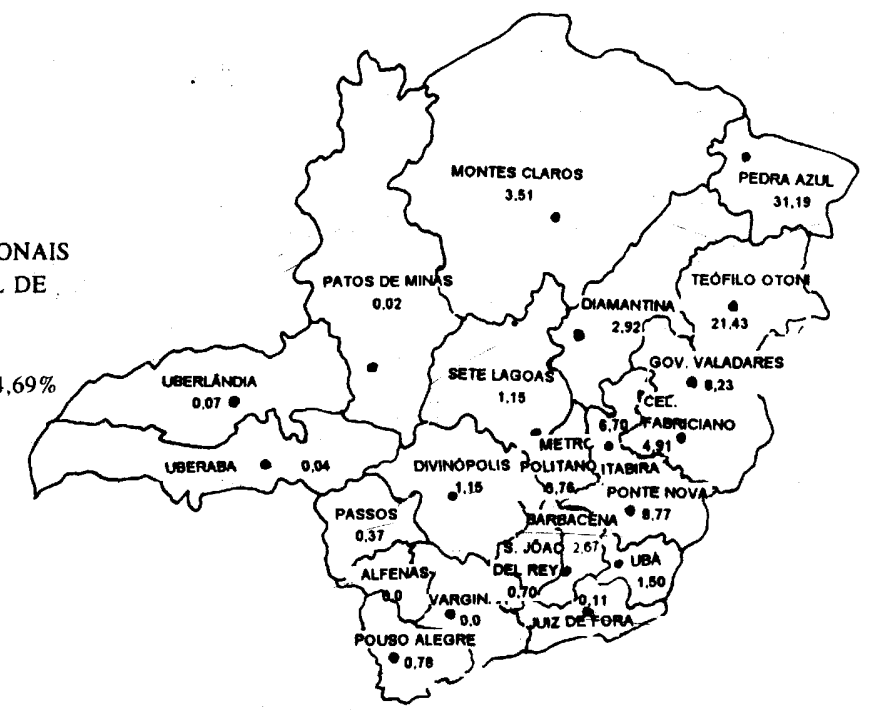




\section{REFERÊNCIAS BIBLIOGRÁFICAS}

CORREA, L. R. \& PARAENSE, W. L., 1971. Susceptibility of Biomphalaria amazonica, to infection with two strains of Schistosoma mansoni. Revista do Instituto de Medicina Tropical. São Paulo, 13: 387-390.

COSTA, H. M. A,; GUIMARÃES, M. P.; LEITE, A. C. R. \& LIMA, W. S., 1986. Distribuição de helmintos parasitos de animais domésticos do Brasil. Arquivo Brasileiro de Veterinária e Zootecnia, 38: 465-579.

LIMA, L. C. ; SOARES, D. M. \& GUIMARÃES, C. T., 1993. Biomphalaria occidentalis Paraense, 1981 in the State of Minas Gerais, Brazil. Memórias do Instituto Oswaldo Cruz, 88: 289-292.

PARAENSE, W. L., 1961. Shell versus anatomy in planorbid systematics. I: Australorbis glabratus. Revista Brasileira de Biologia, 21: 163-170.

, 1966a. The synonymy and distribution of Biomphalaria peregrina in the neotropical region. Revista Brasileira de Biologia, 26: 269-296.

1966b. Biomphalaria amazonica and Biomphalaria cousini, two new species of neotropical, planorbid molluscs. Revista Brasileira de Biologia, 26: 115-126.

1972. Fauna planorbídica do Brasil, p. 213-239. In C. S. Lacaz; R. G. Baruzzi \& J. W. Siqueira, Introdução à Geografia Médica do Brasil. Edgard Blucher \& USP, São Paulo.

, 1973. Susceptibility of Biomphalaria peregrina from Brazil and Ecuador to two strains of

Schistosoma mansoni. Revista do Instituto de Medicina Tropical de São Paulo, 15: 127-130.

, 1975. Estado atual da sistemática dos planorbídeos brasileiros. Arquivo do Museu Nacional,

55: 105-111.

1976. Lymnaea viatrix: a study of topotypic specimens. Revista Brasileira de Biologia. 36: 419-428.

, 1981a. Gastropoda, p. 200-207. In S. H. Hurlbert, G. Rodrigues \& N. D. Santos. Aquatic Biota of Tropical South America, Part. 2: Anarthropoda. San Diego State University, California, $\mathrm{xi}: 298 \mathrm{p}$.

, 1981b. Biomphalaria occidentalis spp n. from South America (Mollusca Basommatophora Pulmonata). Memórias do Instituto Oswaldo Cruz, 77: 437-443.

1982a. Lymnaea viatrix and Lymnaea columella in the neotropical region: a distributional outline. Memórias do Instituto Oswaldo Cruz, 77: 181-188.

, 1982b. Lymnaea rupestris sp.n. from Southern Brazil (Pulmonata: Lymnaeidae). Memórias do Instituto Oswaldo Cruz.

, 1983a. Lymnaea columella in Norther Brazil. Memórias do Instituto Oswaldo Cruz, 78: 477482.

, 1983b. A survey of planorbid molluscs in the Amazonian Region of Brazil. Memórias do Instituto Oswaldo Cruz, 78: 343-361.

, 1984. Biomphalaria tenagophila guaibensis ssp.n. from Southern Brazil an Uruguay

(Pulmonata: Planorbidae). I. Morphology. Memórias do Instituto Oswaldo Cruz, 79: 465-469.

1985. Biomphalaria intermedia in Mato Grosso do Sul, Brazil and Misiones, Argentina

(Pulmonata: Planorbidae). Memórias do Instituto Oswaldo Cruz. 80: 247-250.

1986a. Physa marmorata Guilding, 1828 (Pulmonata: Physidae). Memórias do Instituto Oswaldo Cruz, 81 : 459-469.

, 1986b. Lymanea columella: two new brazilian localities in the states of Amazonas and

Bahia. Memórias do Instituto Oswaldo Cruz. 81: 121-123. 


\section{TÓPICOS EM MALACOLOGIA MÉDICA}

, 1986c. Distribuição dos caramujos no Brasil, p. 117-127. In F. A. Reis, 1. Faria \& N. Katz. Modernos conhecimentos sobre a Esquistossomose mansónica. Suplemento dos Anais de 1983/84 da Academia Mineira de Medicina, Belo Horizonte, vol.4.

, 1987. Physa cubensis Pfeiffer, 1839 (Pulmonata: Physidae). Memórias do Instituto Oswaldo Cruz. 82: 15-20.

, 1988. Biomphalaria kuhniana (Clessim, 1883), planorbidae mollusc from South America.

Memórias do Instituto Oswaldo Cruz, 83:1-12.

PARAENSE, W. L. \& ARAÚJO, M. V., 1984. Biomphalaria glabrata no Estado do Piauí. Memórias do Instituto Oswaldo Cruz, 79: 383-387.

PARAENSE, W. L. \& CORREA, L. R., 1985. Further experiments on susceptibility of Biomphalaria amazonica to Schistosoma mansoni. Memórias do Instituto Oswaldo Cruz, 80: 259-262.

PARAENSE, W. L. ; SOUZA, P. E. F. P. \& BRAUN, R. F., 1984. Novos focos de transmissão do Schistossoma mansoni no Estado do Pará. Memórias do Instituto Oswaldo Cruz, 79: 389-391.

PESSOA, S. B. \& MARTINS, A. V., 1982. Parasitologia Médica. Ed. Guanabara Koogan, Rio de Janeiro, $11^{2}$ ed., 872p.

SOUZA, C. P. \& LIMA, L. C., 1990. Moluscos de Interesse Parasitológico do Brasil. Centro de Pesquisa "René Rachou"/Fiocruz, Belo Horizonte, $1^{\text {a }}$ Ed., 76p. 


\section{Etologia}

2 


\subsection{Catálogo Comportamental de Biomphalaria glabrata (Say, 1818) (Gastropoda; Planorbidae), Caramujo Vetor da Esquistossomose}

Embora o controle da transmissão da esquistossomose, através do combate aos moluscos vetores, freqüentemente empregue métodos eficazes, alguns caramujos conseguem sobreviver e repovoar os criadouros tratados ou manipulados, devido a manifestação de alguns comportamentos denominados de proteção. Estes comportamentos podem favorecer a sobrevivência de poucos exemplares sob condições adversas do meio, devido a causas naturais (chuvas, mudanças de temperatura, superpopulação) ou artificiais (resposta a medidas de controle). Com o posterior retorno às condições normais, os caramujos sobreviventes repovoam os criadouros em pouco tempo. Como exemplo destes comportamentos podemos citar: retração da massa cefalopodal na concha, saída da água, entrada em buracos em respostas a dosagens subletais de moluscicidas (Pieri \& Jurberg, 1981a; Jurberg, 1987). Considerando que as campanhas contra os caramujos não levam em conta estes comportamentos, podemos presumir que o repovoamento dos locais tratados se dá por exemplares que escapam à ação direta dos agentes empregados (Jurberg, 1987, 1990); e por se tratar de animais prolíferos, hermafroditas e capazes de autofecundarem-se, conseguem reconstituir as populações rapidamente (Paraense, 1955).

O estudo comportamental de Biomphalaria glabrata, embora recomendado (WHO, 1965; Ritchie, 1973) não tem sido realizado de maneira condizente com a sua importância. Permanece uma série lacuna no que diz respeito à uniformização dos estudos nesta área. Por esta razão, elaboramos um catálogo comportamental dessa espécie, que, provavelmente, poderá ser usado também para outras espécies do gênero Biomphalaria, tendo em vista que generalizações deste tipo já foram realizadas, com sucesso, em estudos com moluscos dos gêneros Strombus e Lambis (Berg Jr., 1974) e do gênero Aplysia (Leonard \& Lukowiak, 1986).

Para maior compreensão, dividimos este capítulo em tópicos, onde foram descritos qualitativamente alguns comportamentos, relacionando-os com as possíveis causas ou situações nas quais ocorrerem. 


\section{OBSERVAÇÃO E REGISTRO DO COMPORTAMENTO}

\section{CONCEITOS E DESCRIÇÕES REFERENCIAIS}
II.1 - Descrição da concha e da massa cefalopodal de Biomphalaria glabrata.
II. 2 - Descrição do colo como local de referência de movimentos da concha.
II.3 - Descrição dos planos medianos da concha e da massa cefalopodal.

\section{REPERTÓRIO COMPORTAMENTAL DE Biomphalaria glabrata}

III.1 - Movimentos da concha em relação a massa cefalopodal.

III.2 - Posturas da concha em relação a massa cefalopodal.

III.3 - Movimentos e posturas da massa cefalopodal.

III.4 - Deformações posturais da massa cefalopodal.

III.5 - Tipos de deslocamentos.

III.6 - Posturas e movimentos de partes do corpo.

\section{OBSERVAÇÃO E REGISTRO DO COMPORTAMENTO}

O estudo do comportamento de Biomphalaria glabrata foi baseado, principalmente, em observações diretas e indiretas (registradas por fotografias, fotocinematografia com lapso de tempo e videoteipe), realizadas em nosso laboratório e complementadas com dados de campo (Jurberg et al., 1980, 1982, 1985, 1987a, 1988a, 1988b, 1988c; Pieri et al., 1980a, 1980b; Pieri \& Jurberg, 1981b; Schall et al., 1985). As descrições de alguns comportamentos baseiam-se em trabalhos de outros autores. Assim, o comportamento denominado de distress syndrome foi baseado na descrição de Harry \& Aldrich (1963). As descrições da disposição espacial da concha e do tamanho da massa cefalopodal exposta foram baseadas nos trabalhos de Pimentel-Souza et al. (1976a, 1976b).

Os métodos e técnicas empregados na elaboração deste catálogo estão detalhadamente expostos no capítulo anterior a este, por Jurberg, Cunha \& Rodrigues (1990).

Para as descrições, consideramos o observador de frente para o aquário; o caramujo, por sua vez, podia estar localizado em qualquer parte do aquário, proporcionando ao observador uma visão de todas as suas posições. Essas diferentes 
vistas foram registradas, através de desenhos baseados em fotos de caramujos no aquário e de um modelo de caramujo que era constituído de uma concha verdadeira, e a massa cefalopodal moldada em massa plástica flexível. Uma concha foi cortada em um plano mediano para facilitar a confecção do seu desenho, segundo método desenvolvido por Jurberg \& Barth (1965). As diversas posturas da concha em relação a massa cefalopodal foram representadas, através de planos em sistema de coordenadas cartesianas (Bezerra, 1974).

Todos os desenhos são semi-esquemáticos e obedeceram a uma escala de 1:1, 2:1 ou 3:1, indicada em cada desenho. Adotamos este critério, tendo em vista que cada desenho representa uma amostra de um determinado comportamento, apresentada por inúmeros exemplares.

\section{CONCEITOS E DESCRIÇÕES REFERENCIAIS}

Neste capítulo, convencionamos que o comportamento é qualquer atividade de partes do animal ou do animal como um todo. As atividades foram divididas e descritas da seguinte maneira: (a) postura - disposição espacial estacionária de partes articuladas do organismo, uma em relação à outra tomada como referência; (b) movimento - mudança de posição espacial de uma ou mais partes do organismo, em relação a outras tomadas como referência (Cunha, 1974; 1975); (c) deslocamento convencionamos que é a mudança de posição espacial do animal como um todo, em relação ao observador.

Para catalogarmos o repertório comportamental de Biomphalaria glabrata, tomamos como base: (1) - descrição da concha e da massa cefalopodal; (2) descrição do colo como local de referência de movimentos da concha; (3) descrição dos planos medianos da concha e da massa cefalopodal respectivamente.

\section{1 - Descrição da concha e da massa cefalopodal de Biomphalaria glabrata}

Para perfeita compreensão dos comportamentos, é necessário uma descrição pormenorizada dos componentes morfológicos (concha e massa cefalopodal). Para este trabalho, adotamos descrições baseadas nos trabalhos de Key (1956) e Paraense (1972).

Concha - A concha dos planorbídeos possui o formato de um disco bicôncavo plano-espiral e é definida por um cone enrolado em um mesmo plano, ao redor do seu próprio ápice, cujos giros aumentam em diâmetro do centro para a periferia (Figura 1). Do ápice (umbigo) para a base (abertura) da concha, o último giro (giro 
corporal) é mais volumoso e apresenta uma abertura arrendondada, cujo contorno (peristoma) é muito delgado e cortante, representando a última lâmina adicionada durante o crescimento contínuo da concha. O peristoma tem um lábio direito e um esquerdo, entre os quais se estende, sobre a parede do penúltimo giro, uma lâmina calcárea (calo). Considera-se o lado direito da concha, a face do ápice e o lado esquerdo a face do umbigo (Figura 2).

FIGURA 1: Concha de Biomphalaria glabrata em um plano horizontal (ph), com seus giros crescendo em diâmetro no sentido horário em torno do eixo " $y$ "

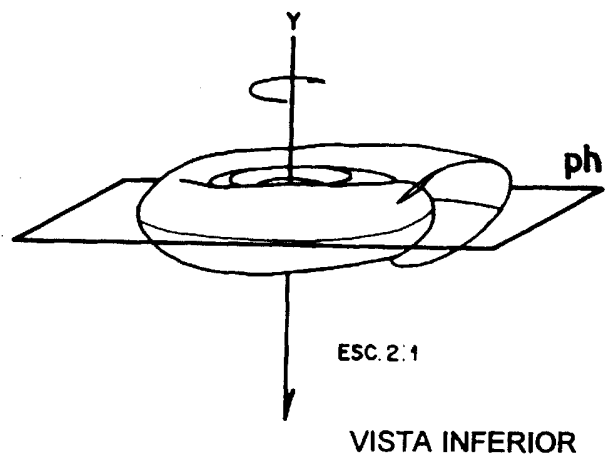

FIGURA 2: Morfologia externa da concha de Biomphalaria glabrata: ápice (a); umbigo (u); abertura da concha (ac); giro corporal (gc); peristoma (p); lábio direito (ld); lábio esquerdo (le); calo (c); suturas (s)

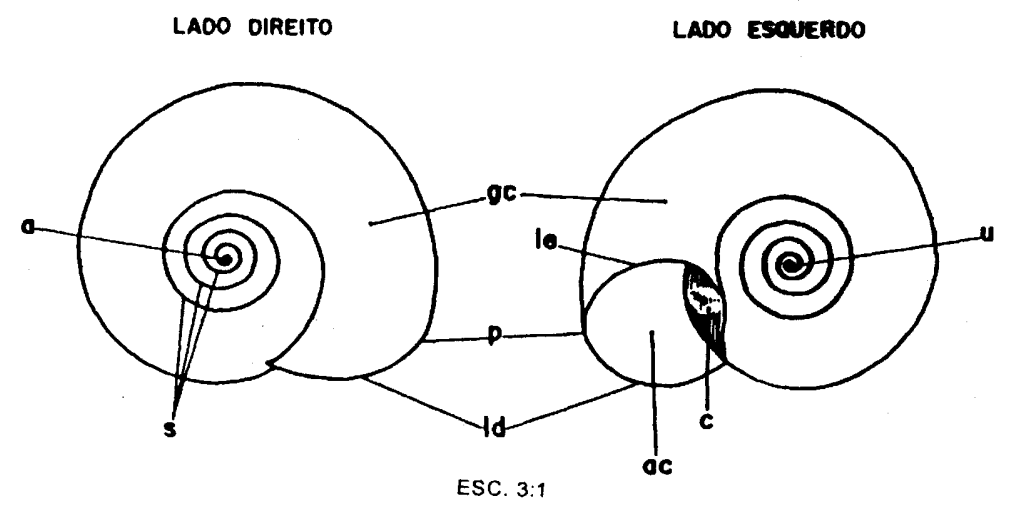

VISTA LATERAL 


\section{CATÁLOGO COMPORTAMENTAL}

Massa Cefalopodal - Divide-se em cabeça e pé. Da parte posterior da cabeça, projetam-se dois tentáculos filiformes, cilíndricos e extensíveis. Os dois olhos estão encravados medialmente, junto às bases dos tentáculos. Na parte anterior da cabeça, entre os tentáculos, situa-se a mufla, que projeta para adiante dois palpos labiais, separados por uma chanfradura medial.

O pé é ablongo e tem a extremidade anterior arredondada nos cantos. A extremidade posterior é mais estreita e de contorno ogival. Sua superfície ventral (sola) é perfeitamente lisa e revestida de cílios.

Pela abertura da concha passa o colo, que pode ficar exposto, e onde se desembocam os aparelhos respiratório, digestivo e reprodutor (do lado esquerdo do animal). Faz a ligação entre a massa cefalopodal e a massa visceral, que é revestida pelo manto, que fica inclusa na concha (Paraense, 1972).

No fundo da cavidade hipopeplar ou palial, o tegumento do manto continua com o tegumento do colo, mas esse prosseguimento é interrompido sobre o lado esquerdo do animal, numa larga fenda, que comunica a cavidade do manto com o meio externo. As bordas dessa fenda estão diferenciadas em duas estruturas: o pneumóstoma e a pseudobrânquia, que são considerados dependências do manto, mas que se inserem realmente na margem interna ou medial da fenda e permanecem aderidos ao colo quando o manto é destacado (Figuras 3 e 4).

\section{2 - Descrição do colo como local de referência de movimentos da concha}

De acordo com Cunha (1976), os movimentos podem ser explicados como mudanças de posição de uma estrutura ou sua parte com referência ao locus de origem dessa mudança: um ponto de articulação, um conjunto de fibras, etc., mas, sempre, um ponto, eixo ou região por onde se transmitem forças reais, dentro do organismo. Baseado nesta explicação, convencionamos que, no caso de Biomphalaria glabrata, as descrições dos movimentos de rotação e inclinação da concha, tomariam como referencial o colo (Figura 5). 
FIGURA 3: Morfologia externa da massa cefalopodal de Biomphalaria glabrata: cabeça (ca); borda o manto (bm); tentáculos (t); cavidade hipopeplar (ch); mufla (m); septo (sp); chanfradura medial (cm); poro genital feminino (pgf); colo (cl); pênis (pn); pé (p); pseudobrânquias (pb); olhos (o); ânus (a); palpos labiais (pl); pneumóstoma (pm); sola (so)

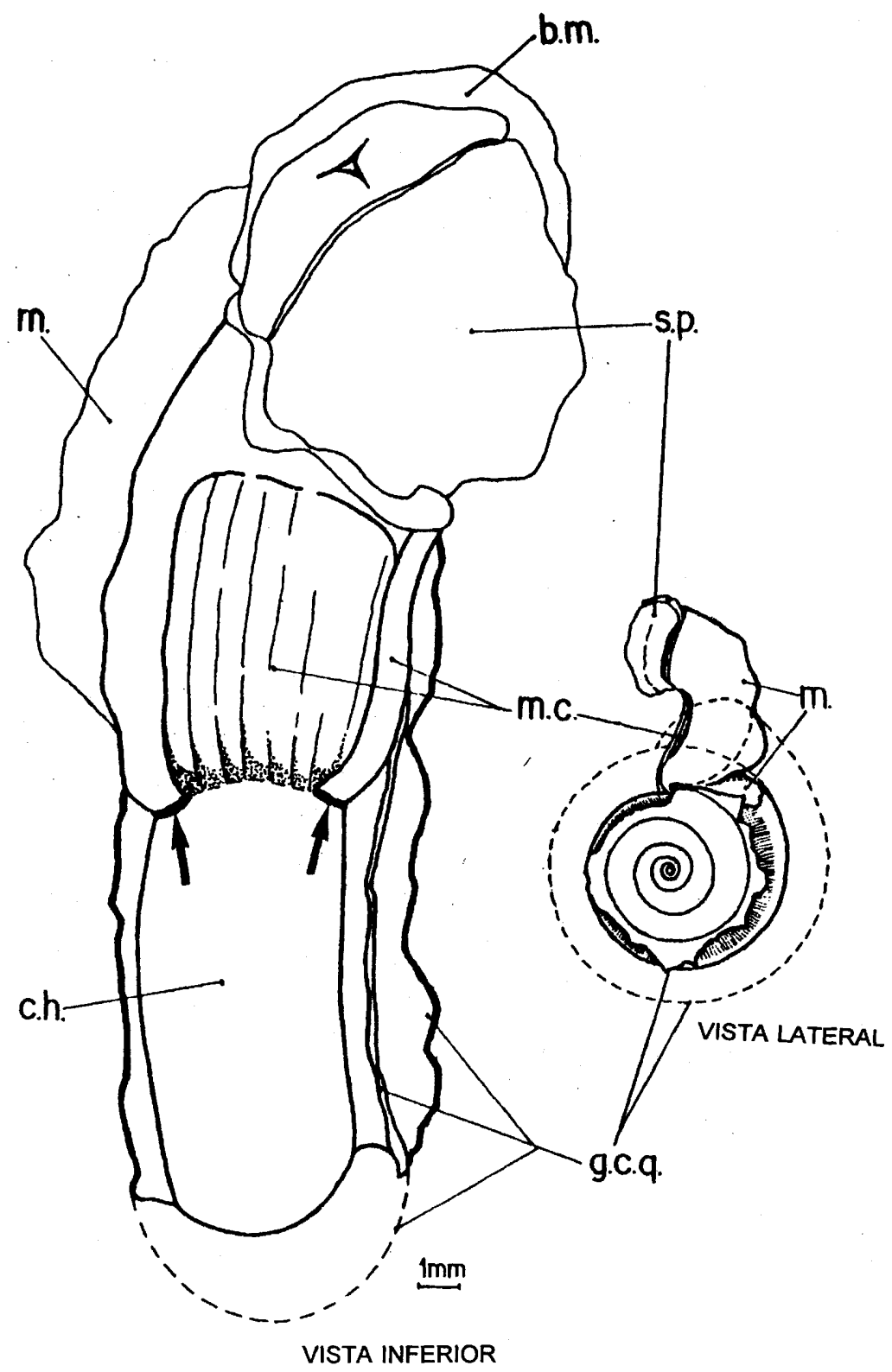




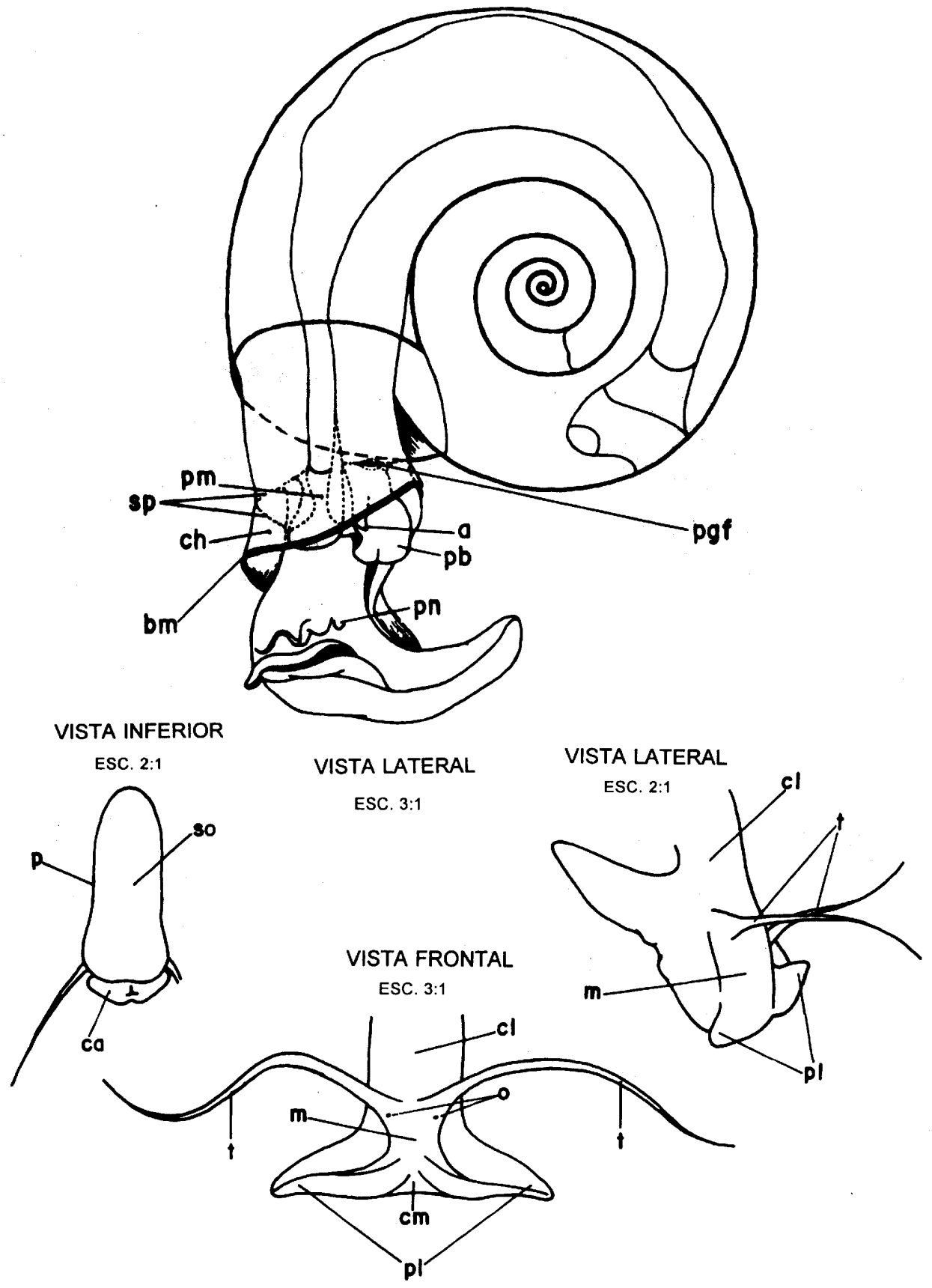




\section{TÓPICOS EM MALACOLOGIA MÉDICA}

FIGURA 4: Morfologia externa e interna das partes moles, com detalhe da abertura do pneumóstoma: massa visceral (mv); septo (sp); massa cefalopodal (mc); pneumóstoma fechado (pmf); manto (palio) (ma); pneumóstoma aberto (pma); cavidade pulmonar (cp); cavidade hipopeplar (ch); coração (co); borda do manto (bm); colo (cl)

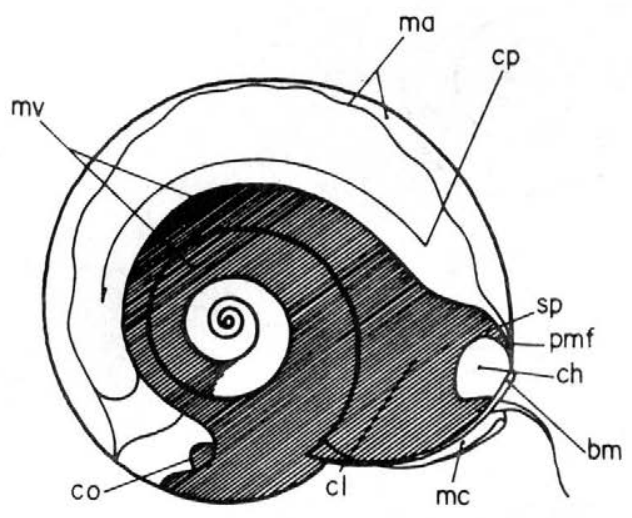

FIGURA 5: O colo (seta indicadora) como local de referência de movimentos da concha em relaçāo à massa cefalopodal

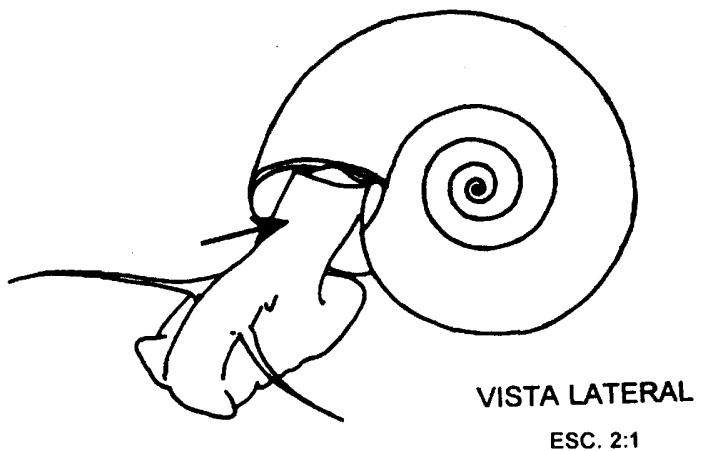


FIGURA 6: Plano mediano (PM) seccionando a concha de Biomphalaria glabrata e dividindo-a em duas partes: direita (D) (esquerda do observador) e esquerda (E) (direita do observador)
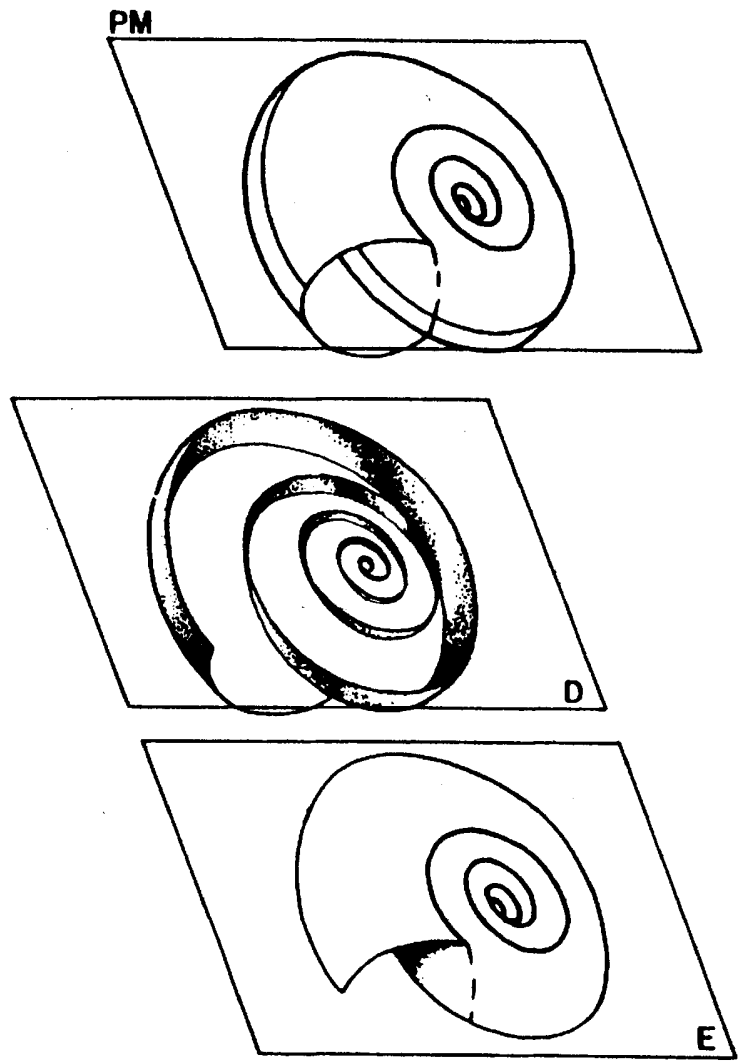

VISTA LATERAL

ESC $3: 1$

\section{3 - Descrição dos planos medianos da concha e da massa cefalopodal}

O plano mediano divide o caramujo (concha e massa cefalopodal) em metades direita e esquerda: o plano mediano corta a concha longitudinalmente, passando pela abertura, umbigo e parte posterior do giro externo (Figura 6). Este mesmo plano corta a massa cefalopodal longitudinalmente, passando pela mufla entre os tentáculos, pelo colo e pela extremidade posterior do pé (Figura 7). 
FIGURA 7: Plano mediano (PM) seccionando a massa cefalopodal de Biomphalaria glabrata e dividindo-a em duas partes: direita (D) (esquerda do observador) e esquerda (E) (direita do observador)

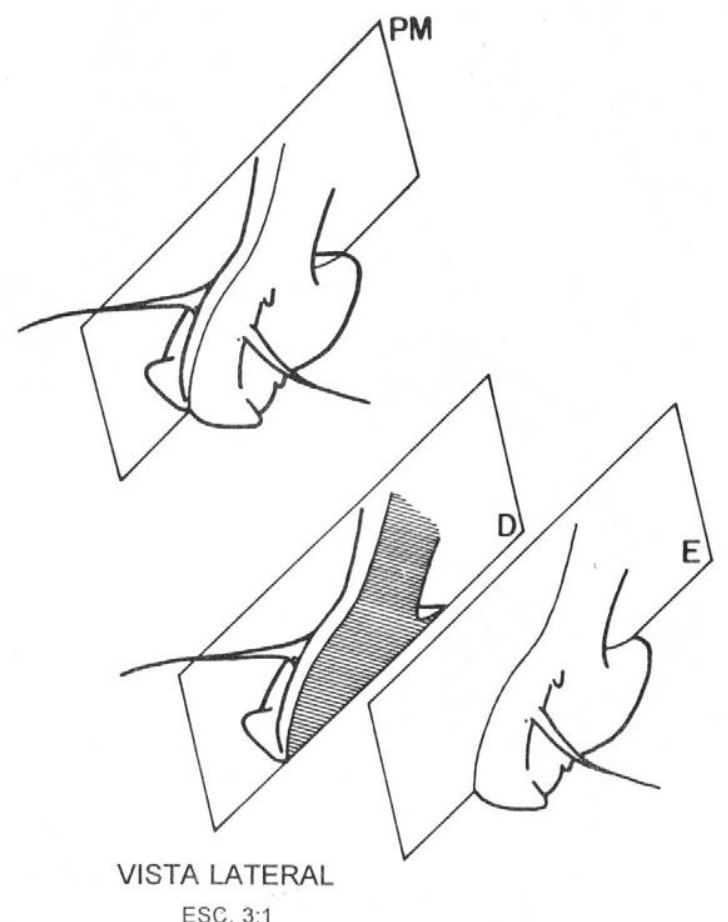

III - REPERTÓRIO COMPORTAMENTAL DE Biomphalaria glabrata

III. 1 - Movimentos da cocha em relação à massa cefalopodal

\section{A - ROTAÇÃO DA CONCHA}

Este movimento é caracterizado pela rotação da concha para os lados esquerdo ou direito da massa cefalopodal, tendo o colo como local de referência.

Utilizamos, como referência inicial de postura, a superposição dos planos medianos da massa e da concha, alinhados longitudinalmente. O plano mediano da concha movimenta-se tanto para a esquerda como para a direita, em relação ao plano mediano da massa cefalopodal (que permanece fixo), produzindo, o primeiro, um movimento giratório, que pode formar vários ângulos em relação ao segundo (Figura 8). 
FIGURA 8: Rotação da concha - Movimento giratório tanto para a esquerda (A), quanto para a direita (B) do observador. Ângulos de: $0^{\prime \prime}, 15^{\prime \prime}, 45^{\circ}, 90^{\prime \prime}$, e 180". PMC - plano mediano da concha; PMM - plano mediano da massa cefalopodal
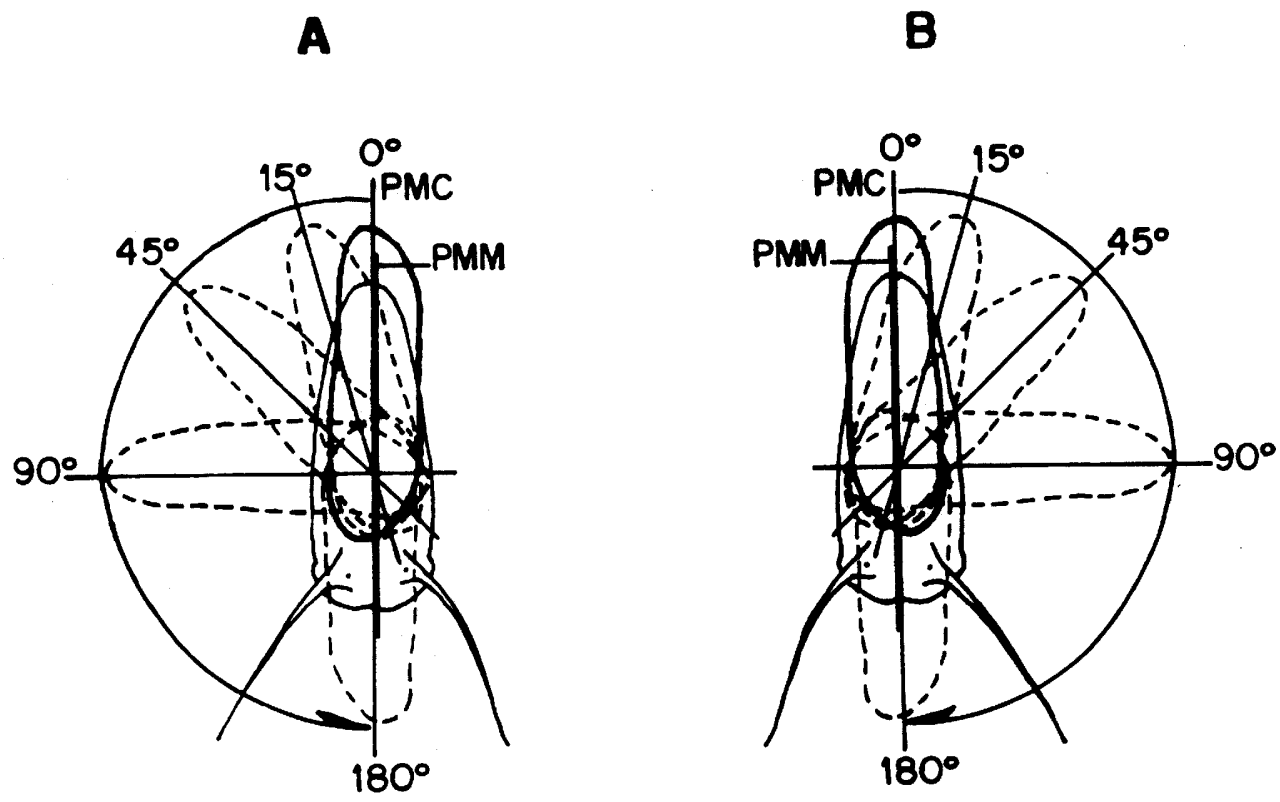

VISTA SUPERIOR

ESC. 1.1

\section{B - INCLINAÇÃO DA CONCHA}

Este movimento é caracterizado pela inclinação da concha para os lados esquerdo ou direito da massa cefalopodal, tendo o colo como local de referência.

Utilizamos como referência inicial de postura, a superposição dos planos medianos da massa e da concha, alinhados longitudinalmente. O plano mediano da concha se movimenta, tanto para a esquerda, quanto para a direita, em relação ao plano mediano da massa cefalopodal (que permanece fixo), produzindo o primeiro um movimento oblíquo, que pode formar vários ângulos em relação ao último (Figura 9). 
FIGURA 9: Inclinação da concha - Movimento oblíquio tanto para a esquerda (A), como para a direita (B) do observador. Ângulos de: $0^{\prime \prime}, 15^{\prime \prime}, 45^{\prime \prime}$, e 90". PMC - plano mediano da concha; PMM- plano mediano da massa cefalopodal

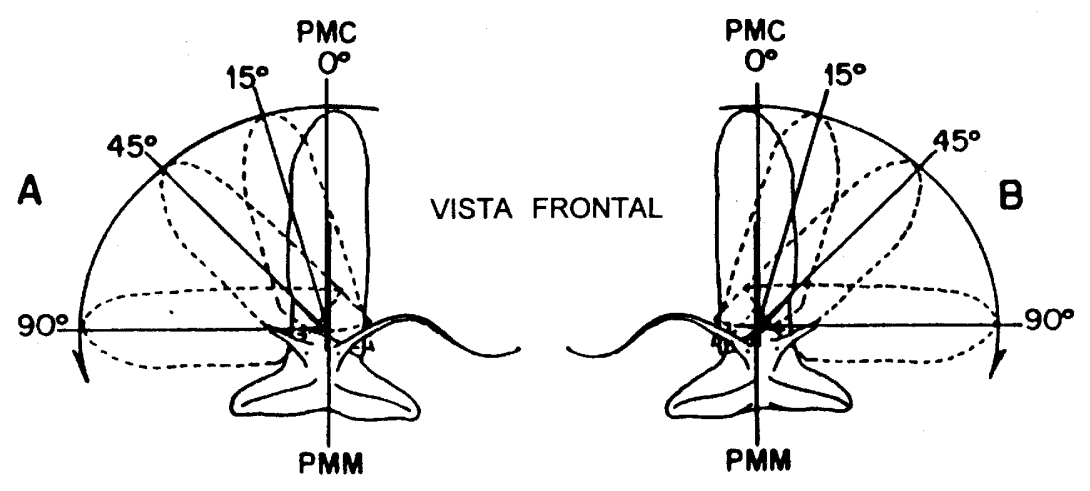

\section{2 - Posturas da concha em relação à massa cefalópodal}

Todas as posturas que definem o posicionamento da concha de Biomphalaria glabrata em relação à sua massa cefalopodal foram estabelecidas, através de seus respectivos planos medianos, fazendo-se todas as combinações possíveis entre os ângulos de rotação $\left(180^{\circ}, 90^{\circ}, 45^{\circ}\right.$ e $\left.15^{\circ}\right)$ e os ângulos de inclinação $\left(90^{\circ}, 45^{\circ}\right.$ e $\left.15^{\circ}\right)$ para ambos os lados do caramujo, sendo que o ângulo de zero grau foi considerado quando os planos medianos da concha e da massa cefalopodal se sobrepunham (concha erecta). Essas posturas foram plotadas em um sistema de coordenadas cartesianas (Bezerra, 1974), sendo cada uma delas identificada pela combinação de um ângulo " $X$ " de rotação (R) e um ângulo " $Y$ " de inclinação (I), ou seja, um par ordenado $(\mathrm{X}, \mathrm{Y})=(\mathrm{R}, \mathrm{I})$. Com este procedimento, conseguimos identificar 63 pares ordenados que representam 63 posturas (Figura 10). Representamos os principais ângulos, porém, consideramos que nas observações é possível a ocorrência dos ângulos intermediários, sendo que, neste caso, os ângulos foram referidos como o mais próximo.

Alguns autores já realizaram trabalhos nesta área. Pimentel-Souza et al. (1976a) descreveram a disposição espacial da concha de Biomphalaria glabrata em relação à sua massa cefalopodal, considerando os seus respectivos planos medianos. Estabeleceram um produto matricial com 42 posturas representadas, formadas pelas diversas combinações dos ângulos de desvio $\left(90^{\circ}, 45^{\circ}, 15^{\circ}\right.$ e $\left.10^{\circ}\right)$ e ângulos de inclinação $\left(90^{\circ}, 45^{\circ}\right.$ e $\left.15^{\circ}\right)$ para ambos os lados do caramujo. Além disso, eles definiram como "sem postura" quando a massa cefalopodal encontrava-se retraída 
na concha. Esses autores correlacionaram estes comportamentos com a luminosidade e alimentação.

Das 63 posturas representadas por nós, apenas quatro foram descritas e denominadas por serem as mais freqüentes, sendo que uma delas (concha invertida) foi considerada uma exceção entre todas, pelo motivo que será exposto a seguir em sua descrição.

FIGURA 10: Sistema de coordenadas cartesianas, apresentando as possíveis posturas de conchas pela combinação de ângulo de rotação e inclinação (pares ordenados)

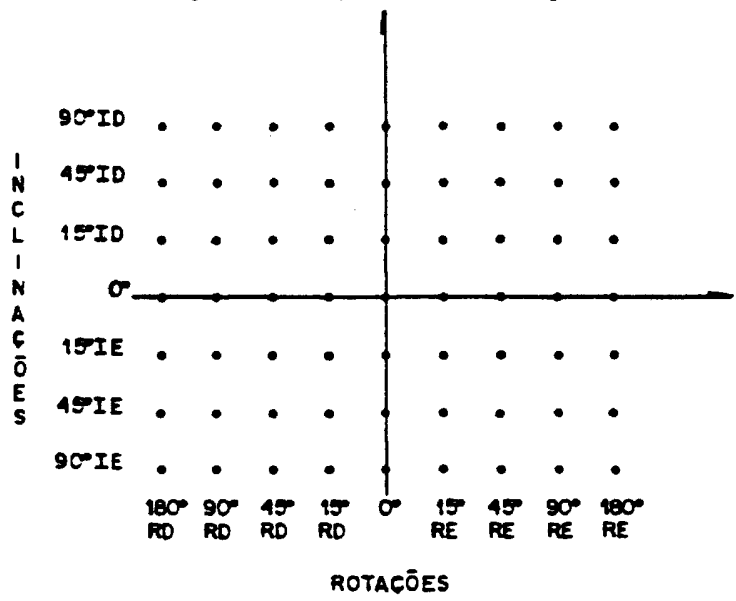

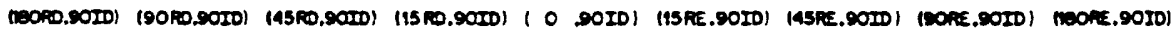

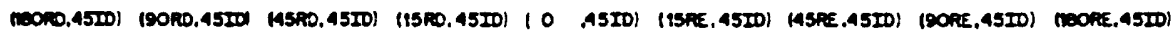

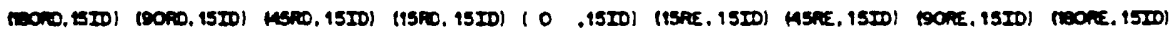

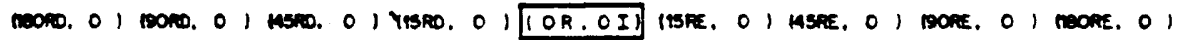

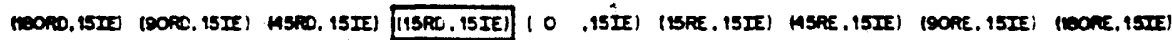

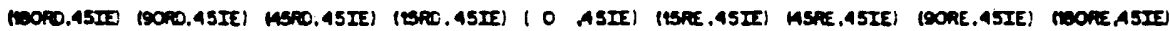

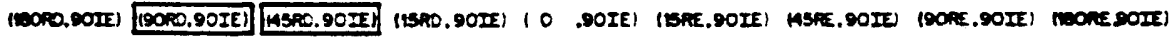
A - CONCHA NORMAL

Essa postura é o resultado final de uma rotação da concha para a esquerda seguida de uma inclinação para a direita em relação à massa cefalopodal.

O posicionamento do plano mediano da concha em relação ao plano mediano da massa cefalopodal é de 15 graus de rotação à esquerda e 15 graus de inclinação à direita.

No sistema de coordenadas cartesianas essa postura é representada pelos pares ordenados (15 RE, 15 ID) (Figura 11). 
FIGURA 11: Concha normal. (A) rotação da concha para a esquerda do observador (ângulo de $15^{\circ}$ );

(B) inclinação da concha para a direita do observador (ângulo de $15^{\circ}$ ). PMC - plano mediano da concha; PMM - plano mediano da massa cefalopodal

A

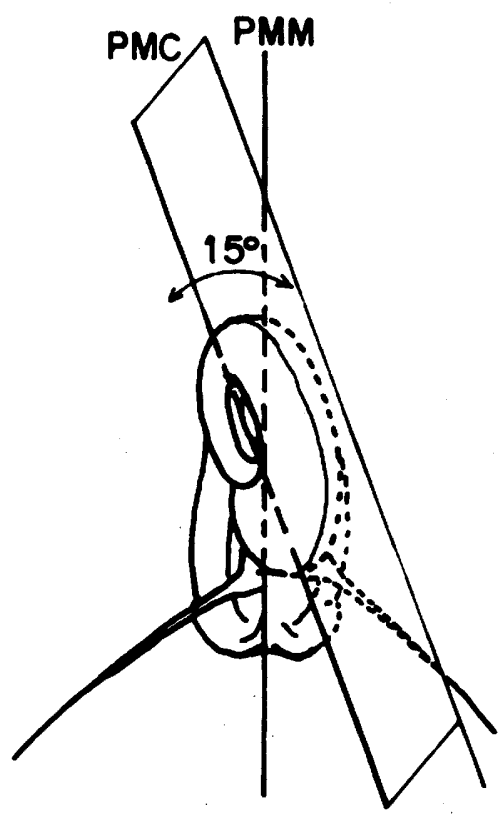

VISTA SUPERIOR
B

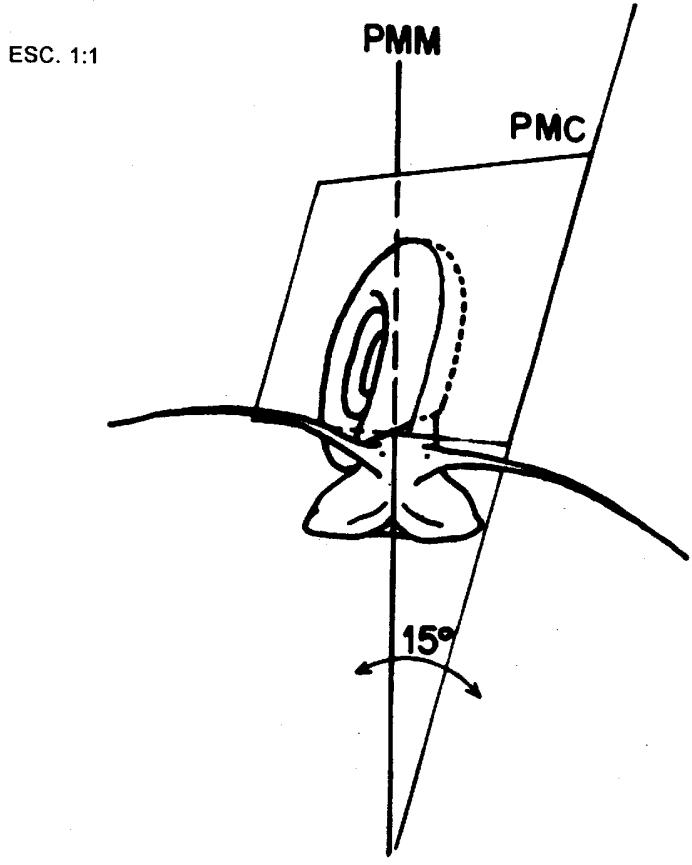

VISTA FRONTAL

Essa postura foi assim denominada por ser a mais freqüentemente observada em condições de laboratório. Pode ser observada no caramujo parado ou em deslocamento (deslizando) com o pé aderido ao vidro do aquário.

Paraense (1970) descreveu a concha de Biomphalaria glabrata, mencionando que o seu lado esquerdo possui uma concavidade denominada de umbigo. Isso, a seu ver, determinaria uma menor massa desse lado e, conseqüentemente, provocaria um giro da concha (rotação) para o lado direito. Considerou, ainda, que o fato dos sistemas respiratórios, reprodutor e digestivo desembocarem do lado esquerdo do corpo, próximo à abertura da concha, a mesma ficaria com menos apoio e tenderia a inclinar-se para esse lado, estabelecendo também um ângulo de inclinação. 
Pimentel-Souza et al. (1976a) confirmaram que a concha de Biomphalaria glabrata apresenta-se mais desviada longitudinalmente para a direita (esquerda do observador) e mais inclinada verticalmente para a esquerda (direita do observador).

Verificamos que esta postura se deve a disposição espacial das três câmaras que compõem a cavidade do manto. A concha tende a ter um peso maior no lado esquerdo do caramujo, onde estão situadas as duas câmaras de água, do que no lado direito onde está situada a câmara que contém ar (Jurberg, 1992).

\section{B - CONCHA PENDENTE}

Esta postura resulta da rotação da concha para a esquerda seguida de uma inclinação para a parte posterior da massa cefalopodal, ficando quase paralela ao substrato.

O posicionamento do plano mediano da concha em relação ao plano mediano da massa cefalopodal é de 45 a 90 graus de rotação à esquerda e 90 graus de inclinação à direita.

No sistema de coordenadas cartesianas essa postura é representada pelos pares ordenados (45 RE, 90 ID) ou (90 RE, 90 ID) Figura 12.

Pimentel-Souza et al. (1976a), embora tenham identificado essa postura em um produto matricial, não as descreveram, apenas correlacionaram essa e as demais posturas à hora do dia, à luminosidade e à temperatura.

Em nossa opinião, a ocorrência dessa postura deve-se ao preenchimento total da cavidade do manto pela água. Tivemos oportunidade de verificar este fato em caramujos submetidos a mudanças bruscas de pressão (Jurberg et al., 1987b), e quando impedidos de irem à superfície por mais de 24 horas (Jurberg et al., 1982).

\section{C - CONCHA ERETA}

Esta postura é caracterizada pela concha alinhada longitudinalmente em relação à massa cefalopodal.

O posicionamento do plano mediano da concha em relação ao plano mediano da massa cefalopodal é de zero grau, isto é, ambos os planos ficam simultaneamente paralelos e superpostos. 
FIGURA 12: Concha pendente. (A) rotação da concha para a esquerda do observador (ângulo podendo variar entre $45^{\circ}$ e $90^{\circ}$ ); (B) inclinação da concha para a direita do observador (ângulo de $90^{\circ}$ ). PMC - plano mediano da concha; PMM - plano mediano da massa cefalopodal

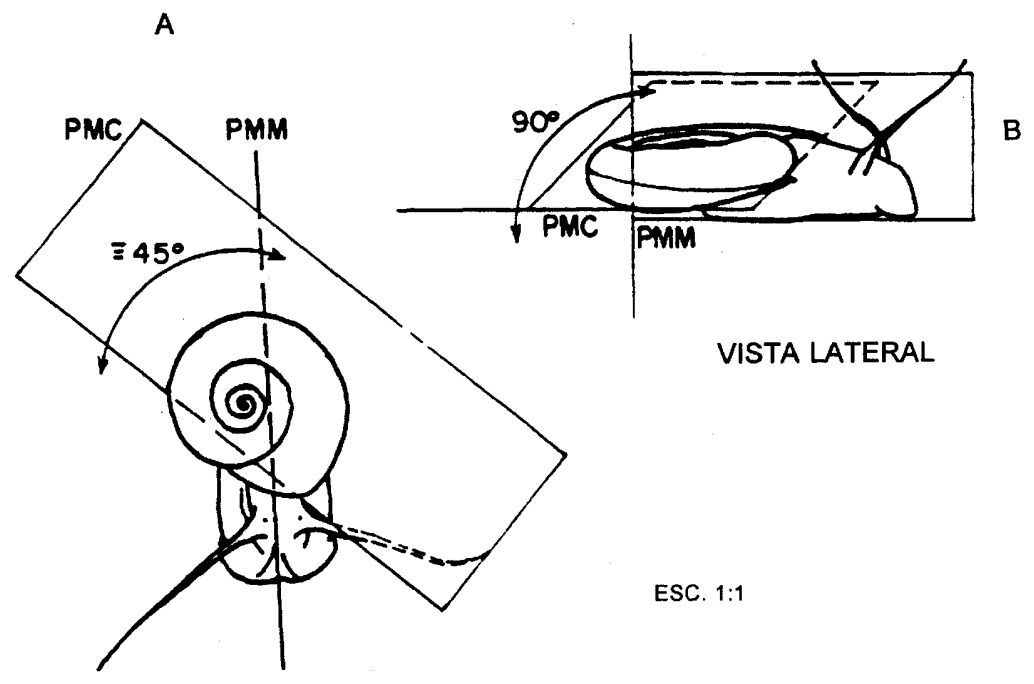

Nos sistemas de coordenadas cartesianas essa postura é representada pelo par ordenado (O, R, O, I) (Figura 13).

É uma postura pouco freqüente de ser observada, por ser transição na seqüência de movimentos da concha, para a direita ou para a esquerda.

FIGURA 13: Concha ereta. (A) ausência de movimento de inclinação (ângulo de 0"); (B) ausência de movimento de rotação (ângulo de $0^{\prime \prime}$ ). PMC - plano mediano da concha; PMM - plano mediano da massa cefalopodal

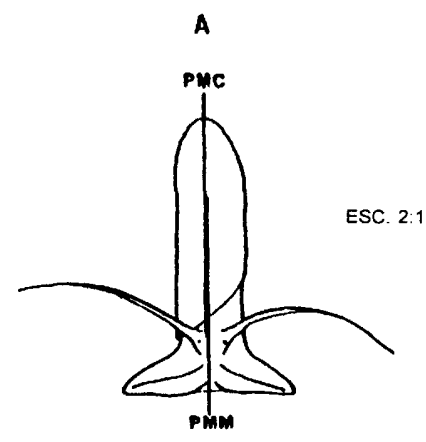

VISTA FRONTAL

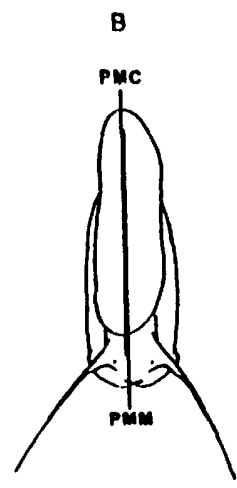

VISTA SUPERIOR 


\section{D - CONCHA INVERTIDA}

Esta postura resulta da rotação da concha para a esquerda ou direita, ficando a mesma com sua parte posterior voltada para a parte anterior da massa cefalopodal, seguida de uma inclinação longitudinal para a parte posterior da massa cefalopodal.

O posicionamento do plano mediano da concha em relação ao plano mediano da massa cefalopodal é de 180 graus de rotação à esquerda ou direita e 90 graus de inclinação longitudinal para a parte posterior.

No sistema de coordenadas cartesianas essa postura não está representada, por ser diferente das demais. A inclinação da concha, nesse caso, ocorre num sentido longitudinal, enquanto que nas outras o sentido da inclinação é lateral (Figura 14).

Incluímos esta postura, por ser a menos freqüente de ser observada, e por ser também a mais complexa.

Nas quatro posturas de concha descritas acima, a massa cefalopodal pode ficar semidistendida ou totalmente distendida, mas sempre aderida ao substrato.

FIGURA 14: Concha invertida. (A) rotação da concha para a esquerda do observador (Ângulo de $180^{\circ}$ ); (B) inclinação longitudinal da concha para a parte posterior da massa cefalopodal. PMC - Plano Mediano da concha; PMM - plano mediano da massa cefalopodal

A

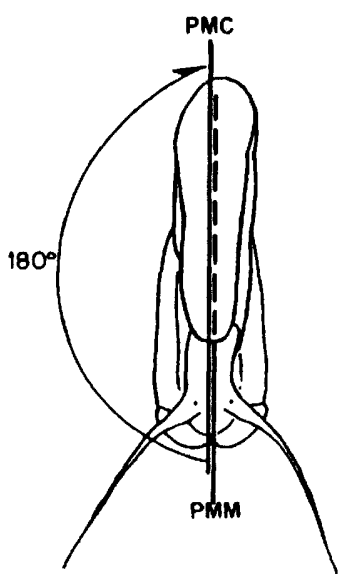

VISTA SUPERIOR
B

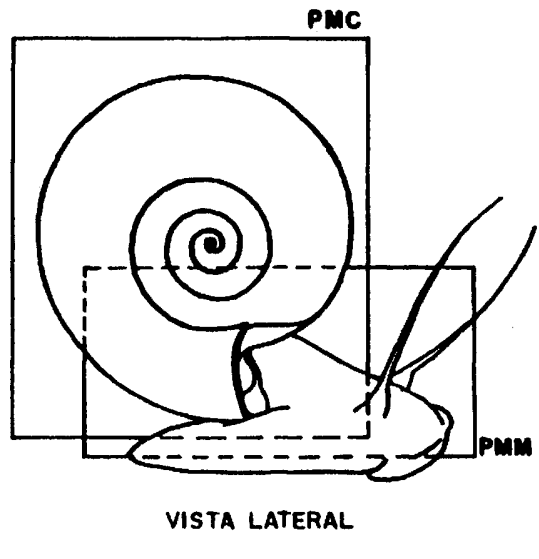

ESC. 2: 1 


\section{3 - Movimentos e posturas da massa cefalopodal}

Os movimentos ocorrem pela exteriorização ou interiorização da massa cefalopodal em relação à concha (Figura 15).

Pode haver também vários tipos de posturas: a) quando exteriorizada, a massa cefalopodal pode ficar total ou parcialmente distendida; b) quando interiorizada, ela pode ficar parcial ou totalmente retraída.

A retração da massa cefalopodal na concha pode ser quantitativa, descrita em função do giro corporal da concha. Por exemplo: $1 / 4$ de giro ou $1 / 8$ de giro, entretanto, preferimos não quantificar, tendo em vista que o critério quantitativo é mais fácil de ser evidenciado.

Pimentel-Souza et al. (1976b) descreveram o tamanho da massa cefalo-podal exposta, estabelecendo, para tanto, percentuais $(100 \%, 70 \%, 30 \%, 0 \%+$ e 0 -). Correlacionaram este comportamento com a temperatura e as variações circa-dianas.

Nós consideramos que a massa cefalopodal pode se apresentar total ou parcialmente distendida quando está para fora da concha, e total ou parcialmente retraída quando está para dentro, por ser mais fácil identificá-las que pelos percentuais apresentados por Pimentel-Souza et al. (1976b).

FIGURA 15: Movimentos da massa cefalopodal. (A) exteriorização da massa cefalopodal, com o pé aderido ao substrato (vidro do aquário); (B) interiorização da massa cefalopodal
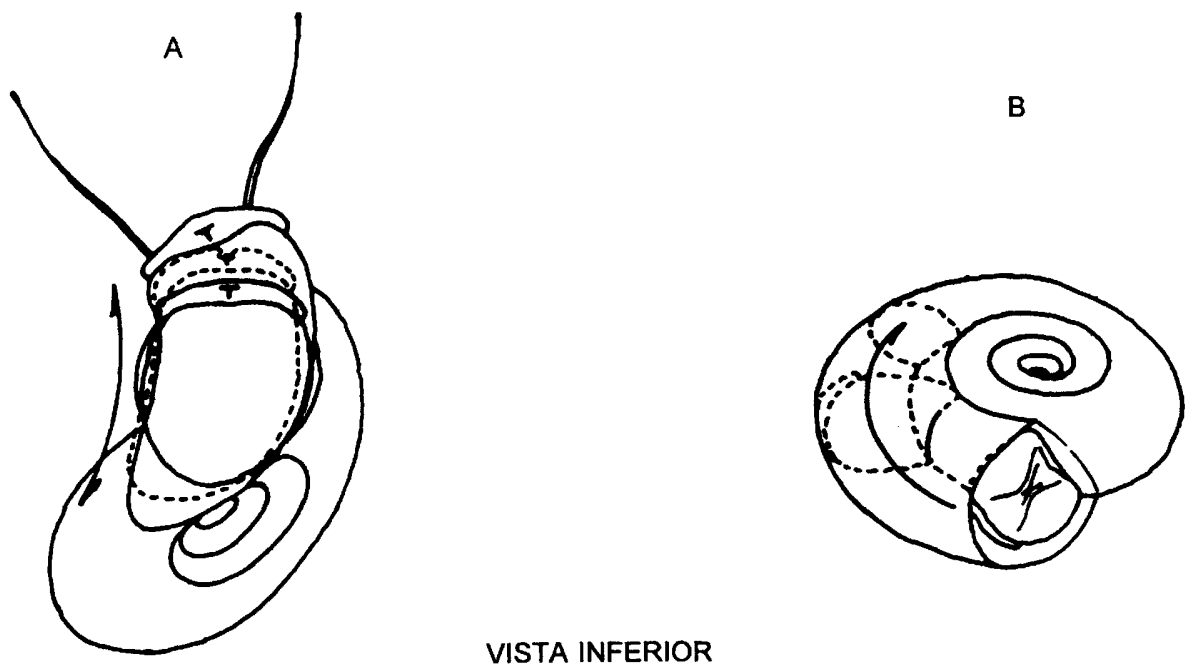

VISTA INFERIOR

ESC. 2:1 


\section{A- MASSA CEFALOPODAL TOTALMENTE DISTENDIDA}

Esta postura é caracterizada pela completa distensão da massa, além da abertura da concha, ficando aderida ou não ao substrato (Figura 16).

FIGURA 16: Massa cefalopodal totalmente distendida

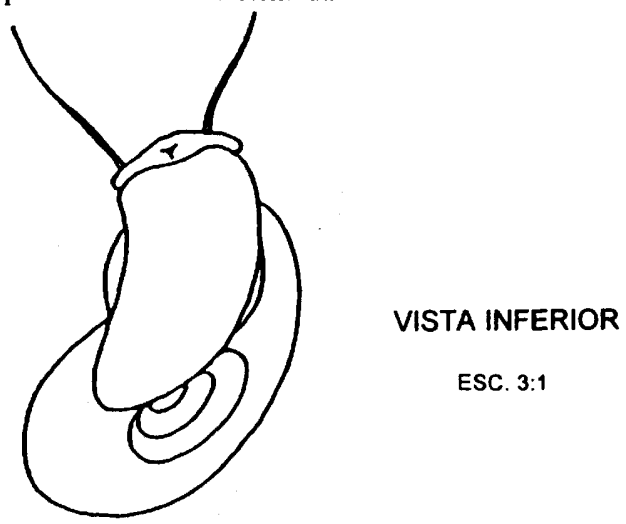

\section{B - MASSA CEFALOPODAL PARCIALMENTE DISTENDIDA}

Esta postura é caracterizada pela semidistensão da massa, além da abertura da concha, estando aderida ou não ao substrato (Figura 17).

A distensão da massa cefalopodal ocorre tanto com o caramujo parado como se deslocando (arrastamento, deslizamento, descidas e subidas súbitas ou boiar).

FIGURA 17: Massa cefalopodal parcialmente distendida

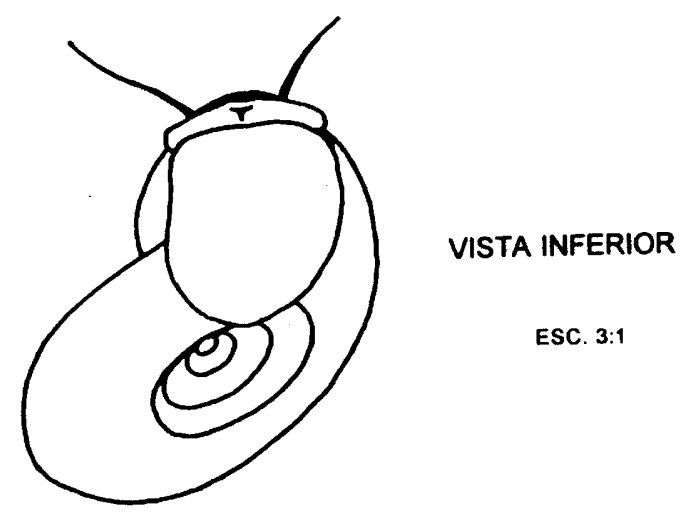

Embora as modificações do volume da massa cefalopodal possam influenciar no peso específico do caramujo, facilitando os seus deslocamentos em diversos níveis de profundidade, tal fato não foi comprovado experimentalmente. 
Embora as modificações do volume da massa cefalopodal possam influenciar no peso específico do caramujo, facilitando os seus deslocamentos em diversos níveis de profundidade, tal fato não foi comprovado experimentalmente.

Pimentel-Souza et al. (1976b) relatam que a expansão da massa cefalopodal fora da concha foi mais freqüente do outono ou verão para o inverno, e foi correlacionada negativamente com a temperatura.

Nas duas posturas da massa cefalopodal descritas acima, a concha pode estar em qualquer posição.

\section{C - MASSA CEFALOPODAL PARCIALMENTE RETRAÍDA}

Nesta postura, a massa fica posicionada aproximadamente no limite da abertura da concha (Figura 18).

FIGURA 18: Massa cefalopodal parcialmente retraída

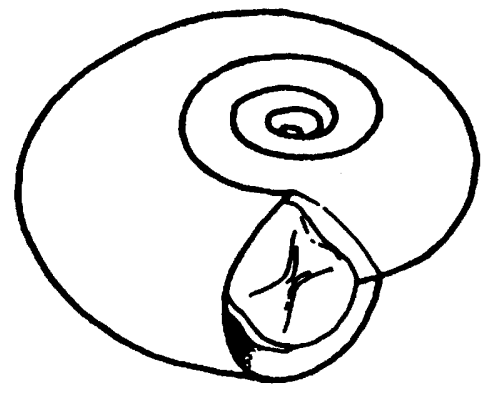

VISTA INFERIOR

ESC. 3:1

\section{D - MASSA CEFALOPODAL TOTALMENTE RETRAÍDA}

Nesta postura, a massa fica posicionada aproximadamente na metade do giro corporal da concha (Figura 19).

A retração na concha pode ser fora ou dentro da água, sendo uma resposta reflexa dos gastrópodes. Em Biomphalaria glabrata pode ser devido a mudanças ambientais, tais como a seca (Olivier \& Barbosa, 1956), o que deve ser relacionado ao comportamento de proteção, pois evita a perda de água, como comprovaram Von Brandt et al. (1957). As vantagens e desvantagens da retração na concha foram discutidas por Dannemann \& Pieri (1989).

Observa-se, também, a retração da massa cefalopodal, como resposta às substâncias tóxicas, dependendo da natureza e concentração desta última (Harry 
\& Aldrich, 1963; Cheng \& Sullivan, 1973a; 1973b), podendo ser, também nesse caso, considerado como comportamento de proteção, pois diminuiria a área de contato da massa cefalopodal do caramujo com a substância tóxica. Maiores detalhes sobre esse comportamento podem ser obtidos em Pieri \& Jurberg (1981a).

III - Deformações posturais da massa cefalopodal

A massa cefalopodal, quando exteriorizada, pode sofrer deformações posturais, a saber:

FIGURA 19: Massa cefalopodal totalmente retraída

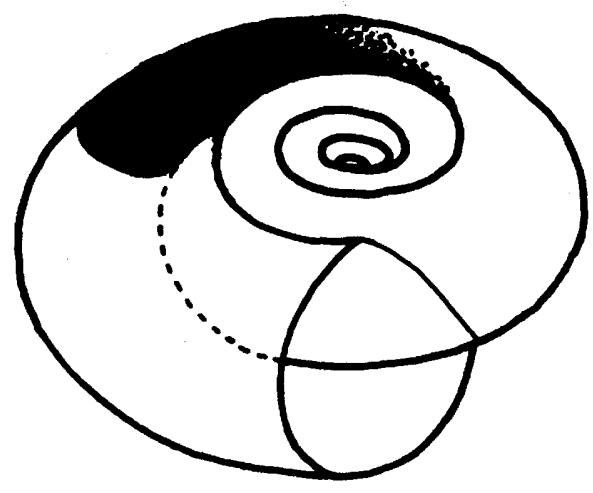

VISTA INFERIOR

\section{A - MASSA CEFALOPODAL CONTORCIDA}

Esta postura se caracteriza pela torção das metades anterior e posterior da massa, uma em relação à outra, sem aderência do pé ao substrato (Figura 20). 


\section{B - MASSA CEFALOPODAL ARQUEADA CÔNCAVA}

Esta postura se caracteriza por apresentar a massa curvada, com as suas extremidades voltadas em direção à concha, com ou sem aderência do pé ao substrato (Figura 21).

FIGURA 20: Massa cefalopodal contorcida (setas)

ESC. $3: 1$

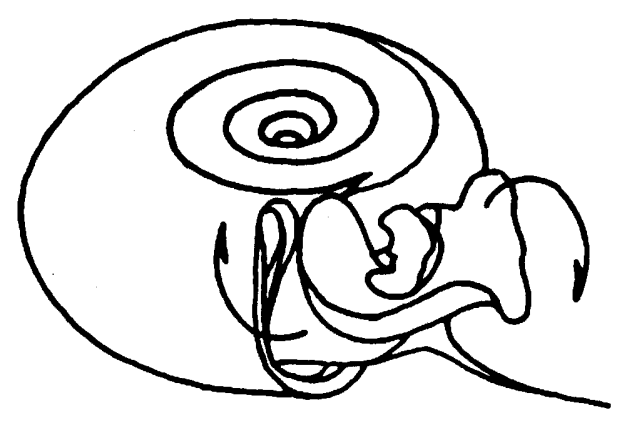

VISTA INFERIOR

FIGURA 21: Massa cefalopodal arqueada côncava. As setas indicam a direção da curvatura

ESC. $3: 1$

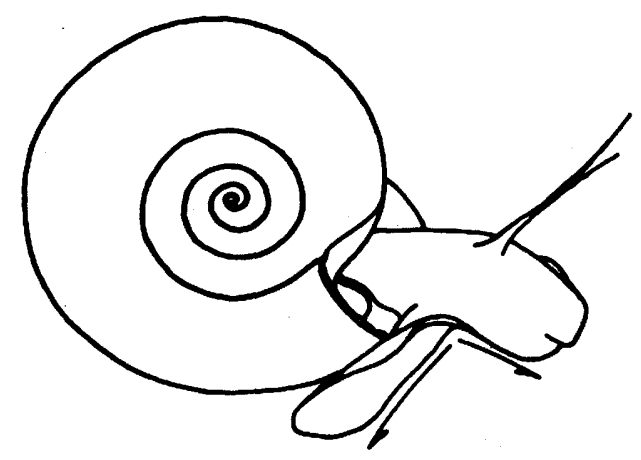

VISTA LATERAL 


\section{C - MASSA CEFALOPODAL ARQUEADA CONVEXA}

Esta postura se caracteriza pela curvatura da massa, com as suas extremidades voltadas em direção oposta à concha, com ou sem aderência da sola ao substrato (Figura 22).

FIGURA 22: Massa cefalopodal arqueada convexa. As setas indicam a direção da curvatura

ESC. 3:1

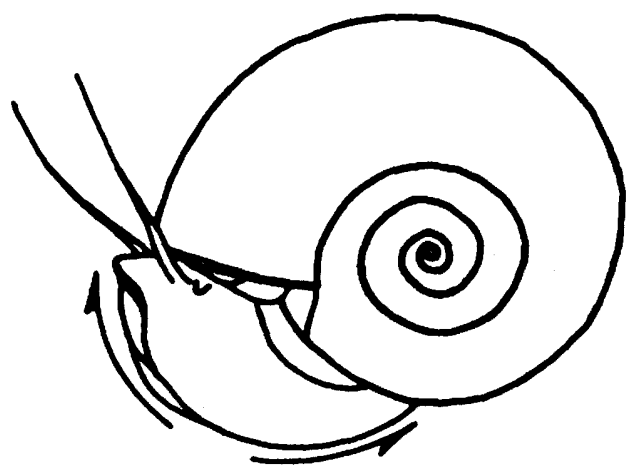

VISTA LATERAL

\section{D - MASSA CEFALOPODAL PREGUEADA}

Esta postura se caracteriza pelas bordas da sola do pé enrugadas, com formação de pequenas ondulações com ou sem aderência da sola ao mesmo (Figura 23).

Em observações não-sistemáticas, foram verificadas as posturas: Massa Cefalopodal Contorcida, Arqueada e Pregueada. Esses comportamentos podem ocorrer durante os deslocamentos do caramujo em condições normais, com o pé aderido ou não ao vidro do aquário ou, ainda, quando submetidos à ação de moluscicidas. Na Distress Syndrome, a massa cefalopodal apresenta-se com todas estas posturas.

Nas quatro últimas posturas da massa cefalopodal descritas acima, a concha pode ficar em qualquer posição. 
FIGURA 23: Massa cefalopodal pregueada. A seta destaca o pregueamento da borda da sola

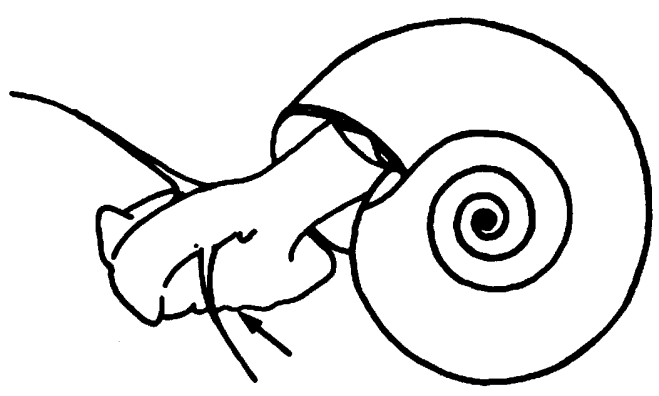

VISTA LATERAL

\section{5 - Tipos de deslocamentos}

Os caramujos podem se deslocar ativamente através de comportamentos denominados deslizar e arrastar - estes dois comportamentos caracterizam-se por ter o pé em contato com o substrato - e o deslizar pode ocorrer na película da água. Quando o pé não está em contato com o substrato temos dois outros deslocamentos passivos que denominamos descida súbita e subida súbita, um outro deslocamento passivo devido a correntes da água foi denominado boiar. A ausência de deslocamentos caracteriza a categoria denominada parar, outro comportamento aqui descrito é a saída da água.

A possibilidade de os moluscos pulmonados controlarem o seu peso específico e, conseqüentemente, sua flutuabilidade através da quantidade de ar contido na cavidade pulmonar ou pela modificação do volume da sua massa cefalopodal, foi postulado por Cheatum (1934) para diversos moluscos, inclusive os da família Planorbidae (Helisoma antrosum percarinatum, Helisoma campanulatum smithi $\mathrm{e}$ Helisoma trivolvis).

Henderson (1963) demonstrou em Lymnaea stagnalis e Planorbarius corneus, que esses caramujos aumentam o seu peso específico pela diminuição do volume gasoso, devido ao tempo de submersão, não tendo encontrado evidências da entrada de água na cavidade pulmonar.

Sullivan \& Cheng (1974) postularam a entrada de água na cavidade pulmonar, o que foi posteriormente demonstrado por Jurberg et al. (1987b), que observaram a entrada de água na cavidade pulmonar de Biomphalaria glabrata submetida a 
variações bruscas de pressão hidrostática, ocasionando a alteração do peso específico da concha.

Considerando o caramujo como um sistema que possui massa cefalopodal passível de modificações no seu volume, e uma cavidade pulmonar, onde pode ocorrer a entrada e saída de ar e de água, é possível tentar explicar os deslocamentos, como veremos mais adiante junto com as descrições.

\section{A- DESLIZAR}

Neste tipo de deslocamento, o caramujo move o conjunto massa cefalopoda1/concha de maneira uniforme, sincronizada e simultânea em relação ao observador (Figura 24A). Eventualmente, o caramujo pode deslizar sob a película da água (Figura 24B).

Neste tipo de deslocamento, o caramujo é capaz de compensar o seu peso específico, podendo ser devido à presença de ar na cavidade pulmonar, o que determinaria a postura de concha normal. A compensação do seu peso específico permite um deslocamento suave, que denominamos de deslizar, pois a concha segue sem aparente esforço a massa cefalopodal.

Townsend (1974) denominou este comportamento de arrastar (to crawl, em inglês). Entretanto, preferimos denominá-lo deslizar (to slide, em inglês), pelo motivo acima exposto. Reservamos o termo arrastar, para denominar outro tipo de deslocamento, como veremos a seguir, que possui características adequadas que $o$ termo evoca. Este tipo de comportamento ocorre tanto para subir, quanto para descer até $1 \mathrm{~m}$ de profundidade.

FIGURA 24: (A) deslizando no substrato; (B) deslizando sob a película da água

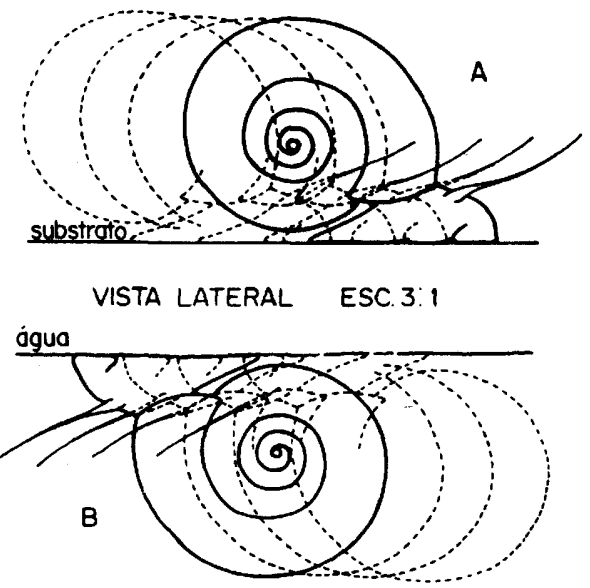




\section{B - ARRASTAR}

Neste tipo de deslocamento, o caramujo move as partes do conjunto massa cefalopodal e concha, independentemente e alternadamente, em relação ao observador. Primeiro a massa cefalopodal move-se para adiante, deixando o colo exposto (Figura 25A); em seguida, a concha é puxada para frente, voltando a encobrir o colo (Figura 25B). Este tipo de comportamento ocorre mais freqüentemente para subir.

Este tipo de deslocamento poderia ocorrer pelo aumento do peso específico do caramujo, devido à saída de ar, consumo de oxigênio pulmonar com difusão de $\mathrm{CO}_{2}$ na água, ou entrada de água na cavidade pulmonar, o que acarretaria também a postura de concha pendente, comum a este movimento (Jurberg et al., 1987a).

Em ambos os deslocamentos analisados acima, a variação do volume da massa cefalopodal exteriorizada, poderá também influenciar no peso específico do animal.

Nos dois tipos de deslocamentos descritos acima, a massa cefalopodal fica totalmente distendida e aderida ao substrato, com a concha assumindo uma postura normal quando o caramujo desliza e pendente quando o caramujo se arrasta.

FIGURA 25: Arrastar. (A) 1 movimento; (B) 2 movimento

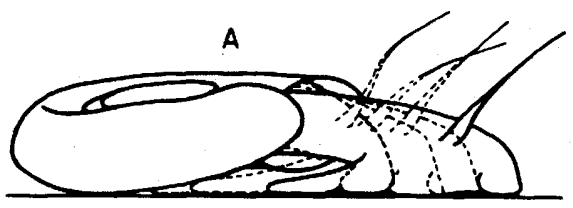

VISTA LATERAL ESC. $3: 1$

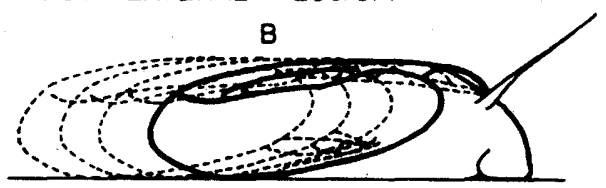




\section{C - SUBIDA SÚBITA}

Neste tipo de deslocamento, o caramujo se desloca repentina e verticalmente em meio à massa d'água, indo em direção à superfície (Figura 26).

A subida súbita pode ser explicada por duas suposições: (1) o caramujo desceria, deslizando pela parede do aquário, com a cavidade pulmonar cheia de ar (o que determina um peso específico menor que o da água); após um curto tempo de permanência no fundo, ele desprenderia a sola do pé do substrato e subiria; (2) estando o caramujo no fundo do aquário, ele distenderia totalmente sua massa cefalopodal, o que determinaria um aumento no seu volume corporal e, em contrapartida, diminuiria o seu peso específico em relação à água, em seguida, com o desprendimento da sola do pé do substrato, ele subiria. Temos que considerar que ambos os mecanismos não são excludentes, podendo funcionar concomitantemente.

FIGURA 26: Subida súbita

ESC. 2:1

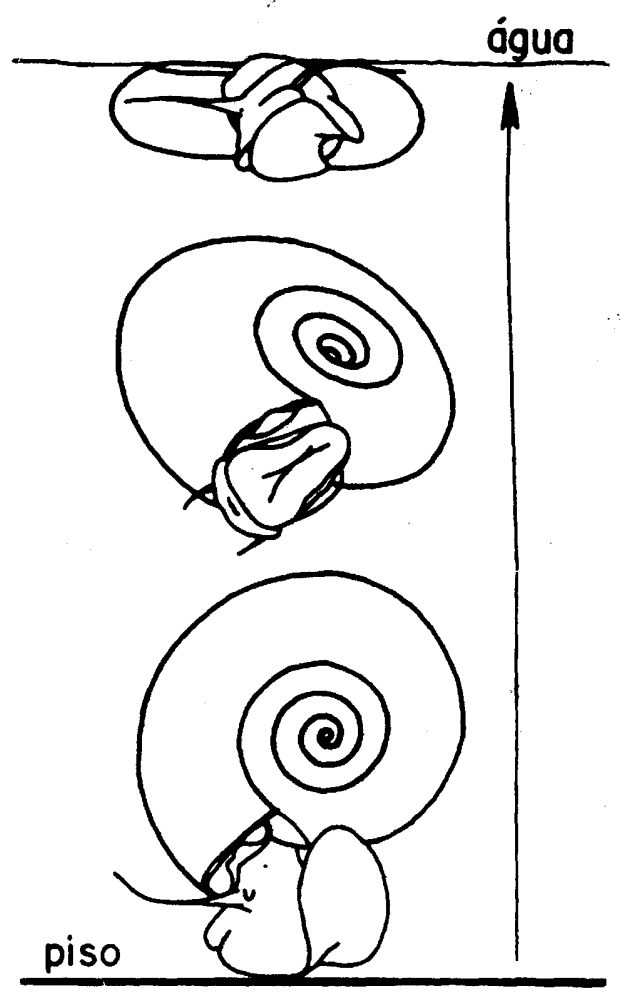

VISTA LATERAL 


\section{D - DESCIDA SÚBITA}

Neste tipo de deslocamento, o caramujo se desloca repentina e verticalmente em meio à massa d'água, indo em direção ao fundo do aquário, podendo ou não ocorrer eliminação de bolhas de ar (Figura 27).

Este tipo de deslocamento poderá ocorrer devido a: (a) saída de bolhas de ar da cavidade pulmonar, conforme citou Rey (1956), causando o aumento do peso específico do caramujo; (b) contração da massa cefalopodal e/ou o consumo do oxigênio da cavidade pulmonar, em tal quantidade, que determinaria o aumento do peso específico e, conseqüentemente, provocaria a perda da flutuabilidade e neste caso não haveria necessidade de sair bolhas de ar. Não podemos descartar a possibilidade de entrada de água na cavidade, embora não tenha sido visualizada nas observações realizadas neste comportamento.

Antes da manifestação desses dois tipos de deslocamentos descritos acima, a massa cefalopodal perde a sua aderência ao substrato, permanecendo exteriorizada ou interiorizada na concha. Esta poderá, por sua vez, ficar com sua abertura voltada para baixo, no primeiro caso; ou, ainda, voltada para cima ou para baixo, no segundo caso. A descida súbita pode ocorrer quando o caramujo está boiando.

\section{Comentários sobre os deslocamentos supracitados}

Jurberg et al. (1987a) verificaram em uma coluna transparente de $8,40 \mathrm{~m}$ que deslizar é o comportamento típico de deslocamentos em torno de $1 \mathrm{~m}$ de profundidade, tanto para descer como para subir. O comportamento de arrastar foi típico dos caramujos que atingiram os níveis mais profundos desta coluna, sendo que a grande maioria das vezes, o comportamento ocorreu no sentido da superfície e com poucas exceções foi observado arrastar para baixo.

Townsend (1975), estudando em Biomphalaria glabratạ a influência da privação alimentar em relação às subidas e descidas dos caramujos em recipientes com $20 \mathrm{~cm}$ de profundidade, com alimento no fundo, verificou que, no total de 420 descidas, $95,5 \%$ foram de deslizar para baixo (crawling down) aderido à parede do aquário e 4,5\% por queda (dropping). Das 420 subidas, $73,3 \%$ foram por deslizar para cima (crawling up) e $26,7 \%$ por subida abrupta (floating up). Corr et al. (1984), em tubos de $15 \mathrm{~cm}$ de altura, verificaram que $21 \%$ da locomoção era passivo (descidas e subidas súbitas). 


\section{E - BOIAR}

Este comportamento é arbitrariamente colocado entre os deslocamentos, o que pode ou não ocorrer, mas é sempre passivo, dependendo exclusivamente das correntes porventura existentes. Apresenta-se de três maneiras (Figura 28): a) com a concha paralelamente sob a película da água, com a abertura voltada para a esquerda ou direita; (b) com a concha perpendicularmente sob a película da água, com a abertura voltada para baixo; (c) com a concha perpendicularmente em meio à massa d'água, com a abertura voltada para baixo ou para cima.

Já a massa cefalopodal, nos três casos, pode ficar desde totalmente distendida até totalmente retraída, mas sem aderência ao substrato.

A possibilidade da Biomphalaria glabrata controlar o seu peso específico, através dos mecanismos já descritos acima, permite-lhe flutuar na superfície ou em qualquer profundidade. Nessas condições, o seu deslocamento é devido aos movimentos da água.

FIGURA 27: Descida súbita

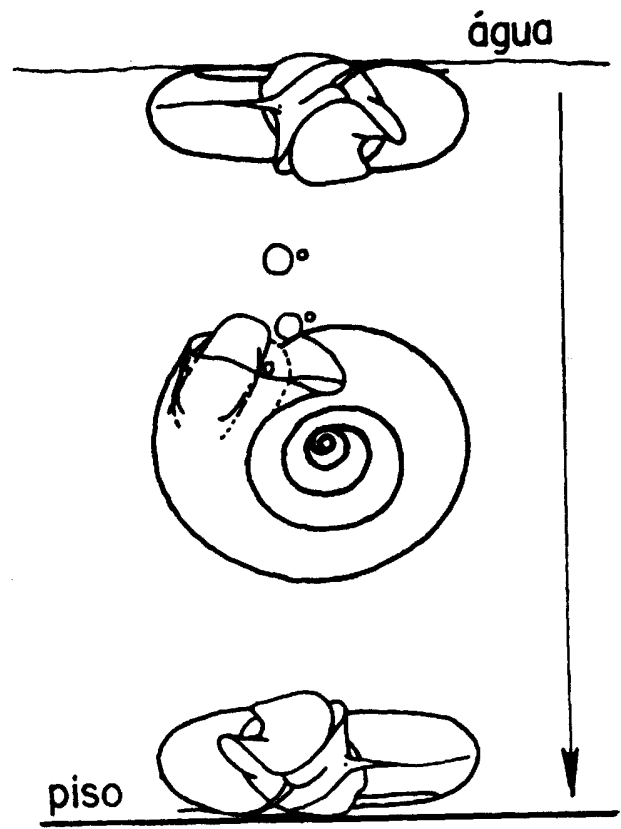

VISTA LATERAL

ESC. 2:1 
FIGURA 28: Boiar. (A) paralelamente sob a película da água; (B) perpendicular sob a película da água; (C) perpendicularmente em meio a massa d'água

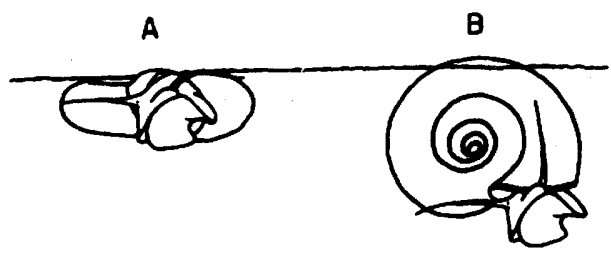

C

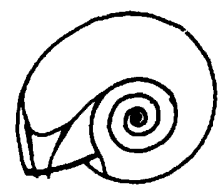

F - SAÍDA DA ÁGUA

Estando na superfície, o caramujo rompe a película da água, ficando com a parte anterior da massa e da concha em contato com o ar. A partir desse momento, a concha assume a postura Pendente. Através de rápidos movimentos de contração muscular de toda a massa cefalopodal e, simultaneamente, arrastando de forma brusca a concha atrás da cabeça, ele tenta transpor totalmente a película da água até sua saída completa. Nesse momento, por vezes o caramujo se desprende do substrato e cai novamente na água, tornando a subir à superfície, até conseguir sua total saída. Uma vez fora da água, o caramujo passa a deslocar-se por arrastamento. Outros comportamentos são também característicos desta fase, tais como: Concha Pendente, Massa Totalmente Exposta, Pseudobrânquia Retraída, Pneumóstoma Retraído e Tentáculos Retraídos. Ao chegar a uma determinada altura, em relação à superfície da água, o caramujo pára de se locomover e aí permanece aderido ao substrato. $\mathrm{O}$ que caracteriza esta última fase é a concha, que fica geralmente com sua face esquerda aderida ao vidro do aquário com a ajuda do muco, permitindo dessa forma ao caramujo permanecer fixo por longo tempo enquanto a massa cefalopodal se destaca do substrato e se retrai lentamente, até a sua Retração Total para dentro da concha. Raramente a concha fica perpendicularmente aderida pela abertura ao substrato. Algumas vezes o caramujo pode, ainda, retornar ao meio líquido (Figura 29). 


\section{CATÁLOGO COMPORTAMENTAL}

FIGURA 29: Seqüência de movimentos, deslocamentos e posturas que caracterizam a saída da água. (A) Estando o caramujo na superficie, ele rompe a película da água. A concha passa a ter uma postura pendente; (B) $O$ caramujo prossegue no seu deslocamento se arrastando, com a concha pendente e a massa cefalopodal aderida a parede lateral do aquário; (C) Uma vez atingida uma certa altura acima do nível da água, o caramujo aí permanece aderido ao vidro lateral do aquário, pela face esquerda da concha

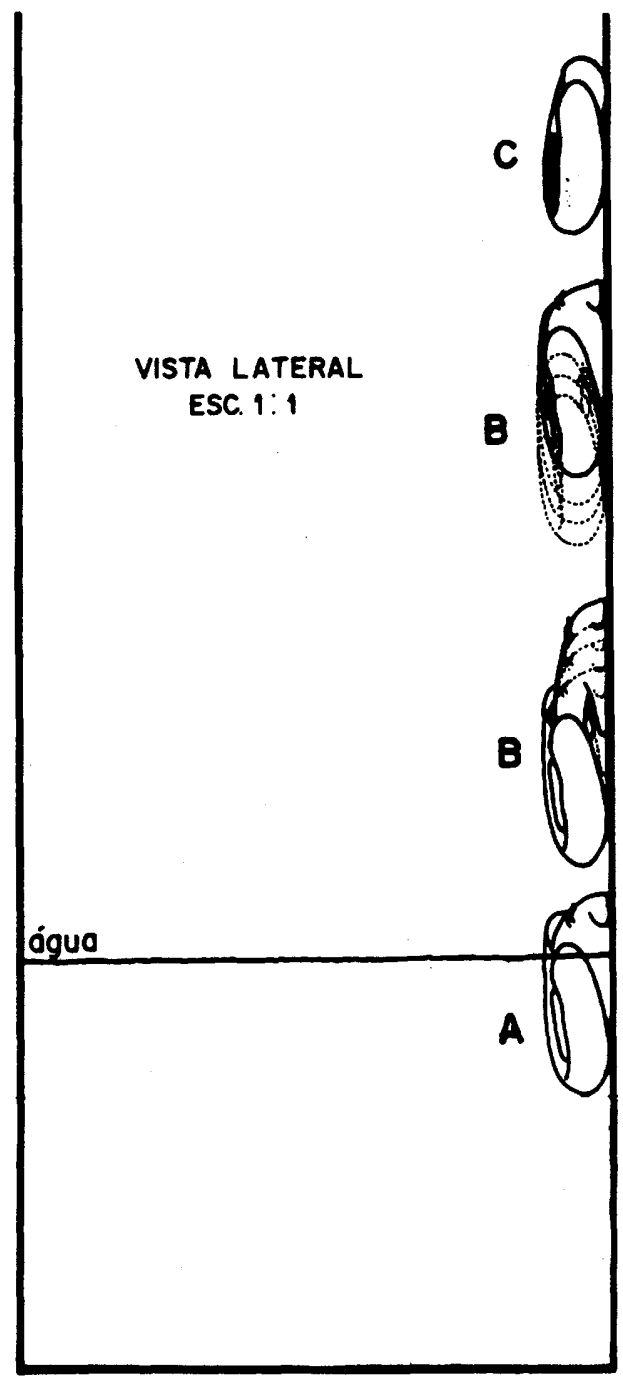


Vários fatores podem estar relacionados à saída da água de Biomphalaria glabrata, tais como: superpopulação, falta de alimentos, temperatura elevada ou apodrecimento da água (Paraense, 1957). Fatores genéticos podem também determinar este comportamento (Richards, 1968).

As substâncias químicas tais como moluscicidas podem ter efeito repelente, fazendo com que os caramujos saiam da água. Entre estas substâncias citamos os compostos fenóicos (Nolan et al., 1953); pentaclorofenato de sódio (Rey, 1973; Souza \& Paulini, 1967) e Phytolacca dodecandra (Jurberg et al., 1988a).

Biomphalaria glabrata também responde às correntes fracas que escorrem pela margem, saindo da água (Jurberg et al., 1988c). Após a saída da água, os caramujos podem retornar, ou permanecer em diapausa (Pieri \& Jurberg, 1981a; Pieri, 1985; Dannemann \& Pieri, 1989).

Existe emigração de caramujos juvenis lamelados na ausência de fatores adversos do meio. Neste caso o comportamento é induzido por fatores genéticos e temperaturas baixas em uma fase do desenvolvimento, de maneira que estes caramujos saem da água nas estações chuvosas, e entram em diapausa, sobrevivendo nestas condições, como estabeleceram os estudos de Pieri \& Thomas (1986) e de Dannemann \& Pieri (1989).

G - PARAR

Este comportamemto foi por nós incluído arbitrariamente dentro de deslocamento, embora seja caracterizado pela ausência de deslocamentos. É caracterizado pelo caramujo aderido ao substrato com a massa cefalopodal estendida e a concha com a postura normal. Movimentos da massa cefalopodal e da concha (rotação e inclinação), asssumindo outras posturas, também podem ocorrer. Neste comportamento, a massa cefalopodal pode estar direcionada para cima, para baixo ou horizontal em relação ao fundo (Jurberg et al., 1987b).

\section{6 - Posturas e movimentos de partes do corpo}

A - Distress Sindrome (Harry \& Aldrich, 1963)

Essa postura é caracterizada por apresentar a concha apoiada paralelamente ao piso do recipiente. A massa cefalopodal por sua vez fica totalmente distendida, perdendo a sua capacidade de aderência ao substrato, embora freqüentemente apoie a, extremidade anterior, em aparente tentativa de aderir totalmente a sola do pé. A massa cefalopodal pode, ainda, apresentar-se com torções e pregueamentos nas bordas da sola (Figura 30). 
Metais pesados como zinco, cádmio e cobre causam esta síndrome (Harry \& Aldrich, 1963). Estudos com estes mesmos metais radioativos sugeriram que eles prejudicam a permeabilidade das membranas celulares na passagem das taxas normais de oxigênio e dos produtos de excreção (Yager \& Harry, 1964). Os caramujos submetidos a anoxia induzida por $\mathrm{N}_{2}$ durante 24 horas de exposição, bem como aos submetidos a $\mathrm{O}_{2}$ puro por igual período, não mostraram este comportamento, mas em presença de $5 \%$ de $\mathrm{CO}_{2}$ aparece uma síndrome mediana, e a $20 \%$ deste mesmo gás aparece uma severa síndrome, sem recuperação, sendo que a $100 \%$ eles se retraem e morrem. Caso haja $5 \%$ de $0_{2}$ e $20 \%$ de $\mathrm{CO}_{2}$ este não produz efeitos deletérios (Harry \& Senturia, 1964).

FIGURA 30: Distress Syndrome. Caramujo no fundo do aquário

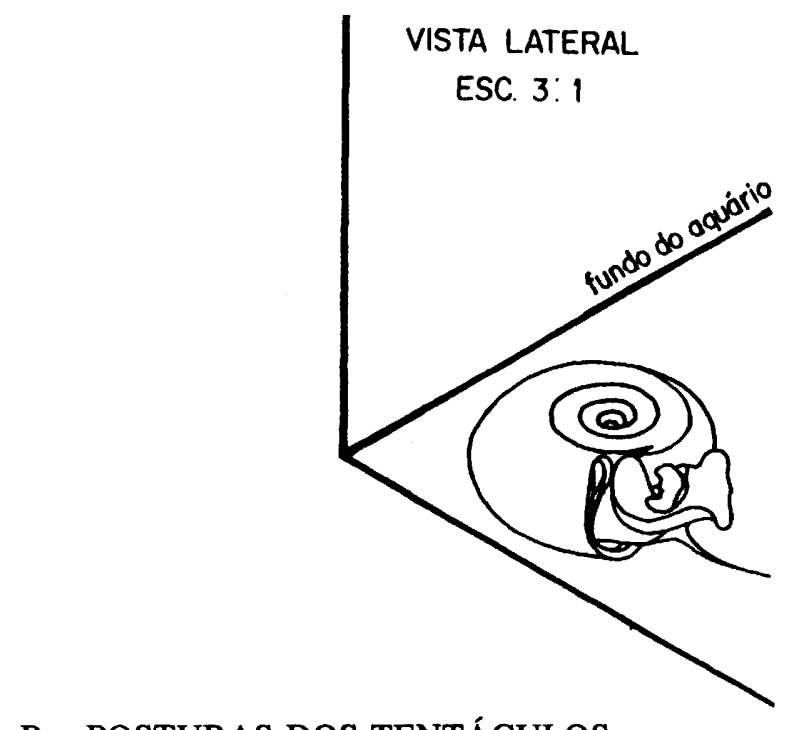

\section{B - POSTURAS DOS TENTÁCULOS}

Caracteriza-se pelo grau de sua distensão em relação à cabeça, podendo ficar desde retraído, até totalmente distendido (Figura 31).

Estudos sobre os tentáculos, realizados por Townsend (1974), demonstraram sua função como direcionadores de correntes de água, graças aos movimentos ciliares de sua extremidade até a base, aonde existem células capazes de detectar os alimentos.

Os tentáculos podem sofrer deformações, quando os caramujos estão submetidos a pressões correspondentes a $50 \mathrm{~m}$ de profundidade (dados inéditos). 
Biomphalaria glabrata pode apresentar variações morfológicas nos tentáculos duplo, ramificado, curto ou ausente, devido a herança multifatorial. Nos exemplares que só tem um tentáculo, existe uma tendência para se locomoverem na direção do tentáculo ausente (Richards, 1969).

FIGURA 31: Posturas dos tentáculos, vista superior. (A) totalmente distendidos; (B) retraídos
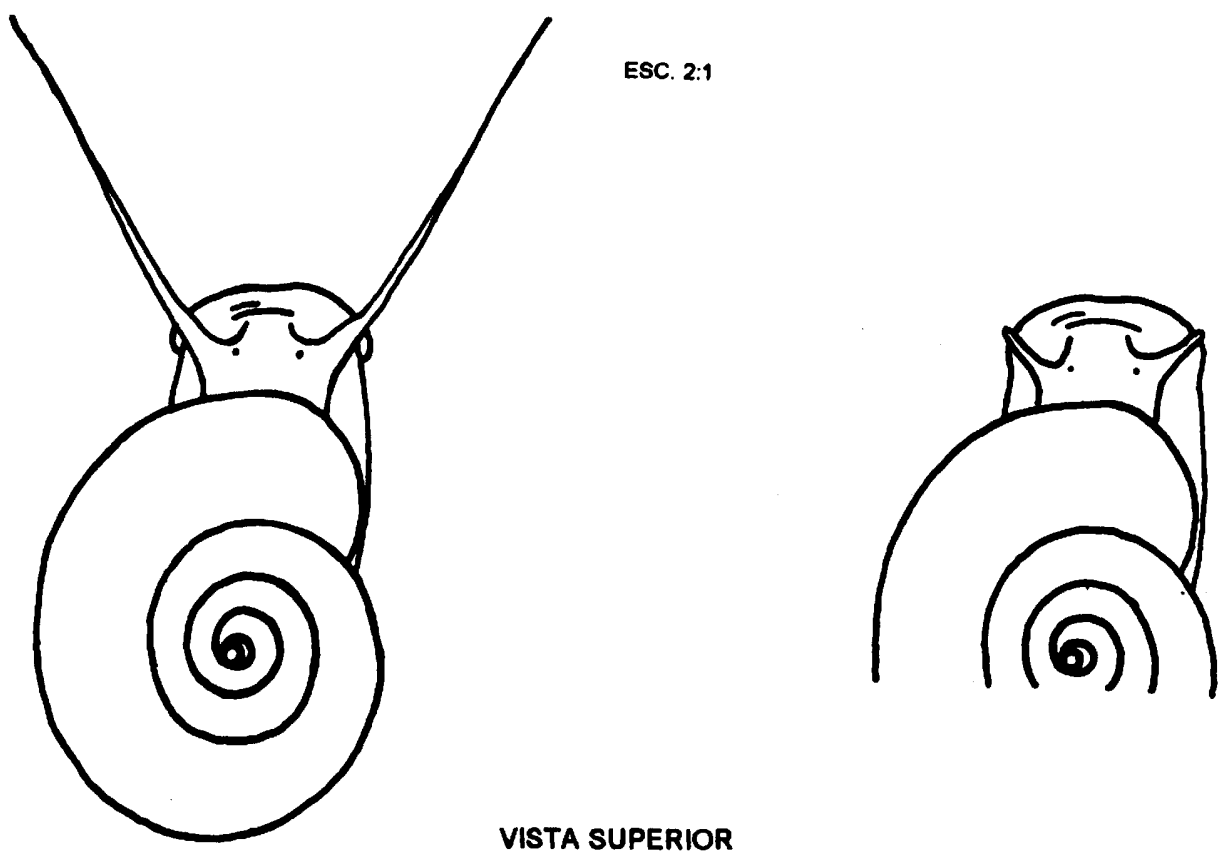

\section{C - POSTURAS DA PSEUDOBRÂNQUIA}

Caracteriza-se pelo seu grau de protração em relação à abertura da concha. Quando retraída ela não é visível, já, quando protraída, além da abertura da concha, ela passa a ser visível ao observador (Figura 32).

Existe controvérsia quanto à função desta estrutura que, para alguns autores, está relacionada com a respiração, (Paraense, 1972; Rey, 1956; Pan, 1958). Para Sullivan \& Cheng (1974), ela é uma válvula que permite a entrada de água na cavidade pulmonar. Entretanto, em caramujos impedidos de virem à superfície, ocorre a expansão da pseudobrânquia (Jurberg et al., 1982), o que nos leva a supor que ela possa ter as duas funções. 
FIGURA 32: Posturas da pseudobrânquia. (A) pseudobrânquia protraída (seta); (B) pseudobrânquia retraída
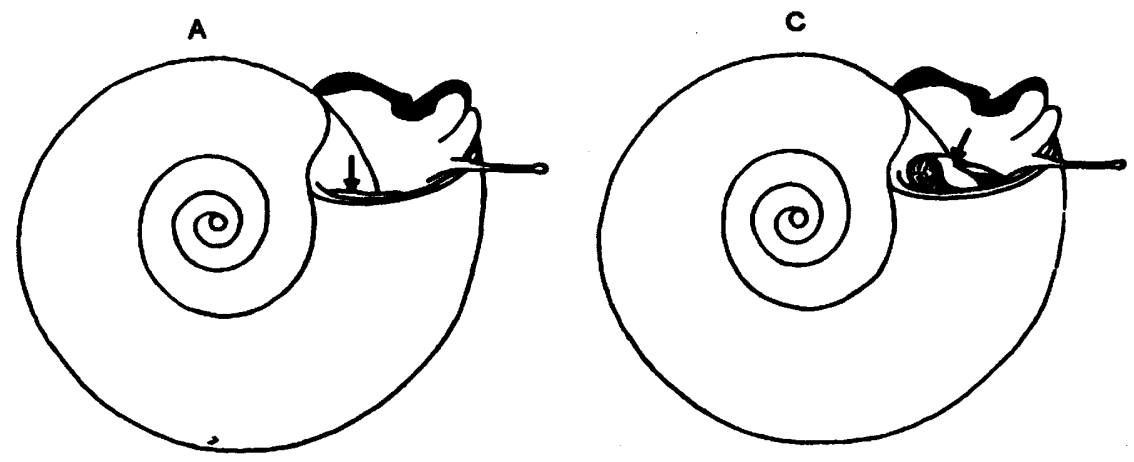

Esc. 3,5: 1
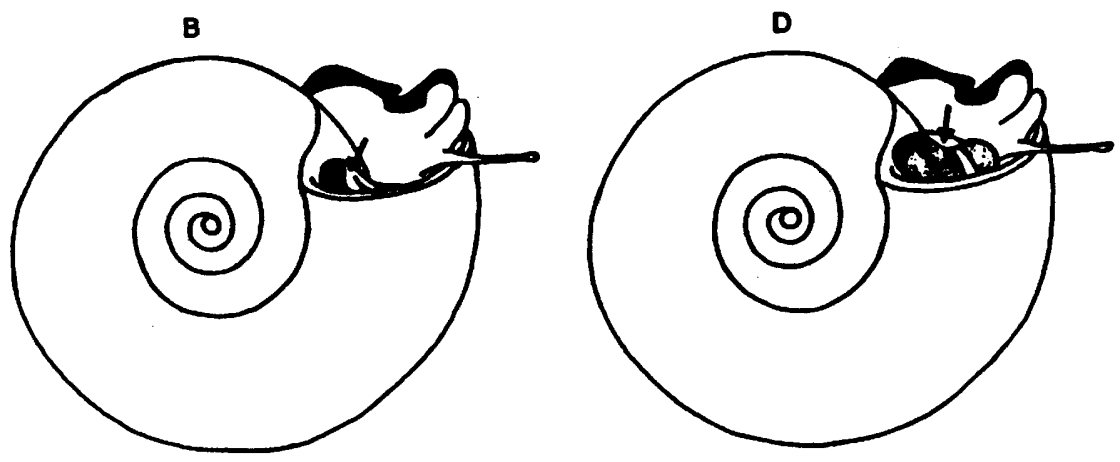

\section{D - MOVIMENTO DE ABERTURA DO PNEUMÓSTOMA}

A borda medial do pneumóstoma projeta-se numa prega semilunar muito extensível que se alonga como uma calha ao mesmo tempo que aproxima os dois bordos, de modo a formar um sifão cuja extremidade livre rompe a película superficial da água para efetuar as trocas gasosas. Quando em repouso, essa prega dobra-se para cima, cerrando o pneumóstoma, (Paraense, 1972) (Figura 33).

Jurberg et al. (1987c) mostraram, através de experimentos de laboratório, que a freqüência com que o caramujo abre o pneumóstoma, e o tempo que ele fica aberto para a tomada de ar na superfície, é inversamente proporcional ao teor de oxigênio dissolvido na água. 
FIGURA 33: Seqüência do movimento de abertura do pneumóstoma de Biomphalaria glabrata. 1pneumóstoma (pm) recolhido no interior da cavidade hipopeplar (ch); 2-5- distensão do pneumóstoma (pm) até a borda da abertura da concha (ac); peristoma (p); 6-8- prolongamento das bordas do peneumóstoma (bp) após rompimento da película da água; (sp) septo; (icp) início da cavidade pulmonar
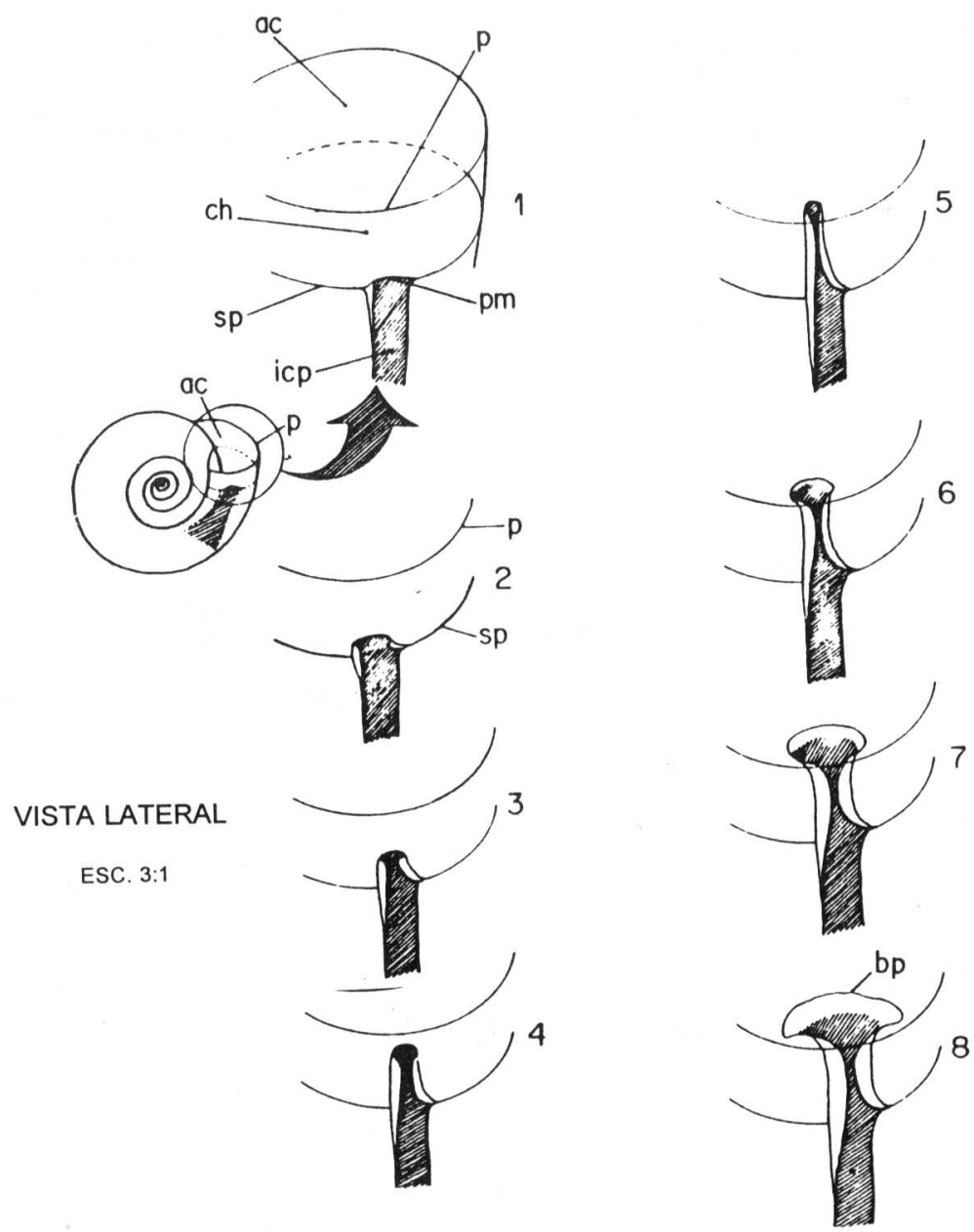

\section{AGRADECIMENTOS}

Queremos externar nossos agradecimentos ao Conselho Nacional de Pesquisa (CNPq), que financiou este trabalho, ao Dr. Otávio S. Pieri e a Dra. Marli Maria Lima. 


\section{CATÁLOGO COMPORTAMENTAL}

\section{REFERÊNCIAS BIBLIOGRÁFICAS}

BERG Jr., C. J., 1974. A comparative ethological study of Strombid Gastropods. Behaviour, 51: 274 322.

BEZERRA, M. J., 1974. Curso de Matemática para os Cursos de Segundo Grau (antigos cursos clássico e científico) Curso Completo. $31^{\mathrm{a}}$ ed., São Paulo: Companhia Editora Nacional.

CHEATUM, E. P., 1934. Limnological investigations on respiration, annual migratory cycle, and ogher related phenomena in freshawater pulmonate snails. Transactions of American Microscopical Society, 53: 348-407.

CHENG, T. C. \& SULLIVAN, J. T., 1973a. The effect of copper on the heart rate of Biomphalaria glabrata (Mollusca: Pulmonata). Comparative General Pharmacology, 4: 37-41.

1973b. A comparative study of the effects of two copper ocmpounds on the respiration and survival of Biomphalaria glabrata (Mollusca: Pulmonata). Comparative General Pharmacology, 4: 315-320.

COOR, M.; COVICH, A \& YOSHINO, T. P., 1984. Vertical movement and time allocation to a freshwater pulmonate snail. Hydrobiologia, 112: 69-72.

CUNHA, W. H. A., 1974. Acerca de um curso pós-graduado destinado ao treino da observação científica no domínio das ciências do comportamento. Ciência e Cultura, 26: 846-853.

, 1975. O estudo etológico do comportamento animal. Ciência e Cultura, 27: 263-268.

, 1976. Alguns princípios de categorização, descrição e análise do comportamento. Ciência e Cultura, 28: 15-24.

DENNEMANN, R. D. A., \& PIERI, 0. S., 1989. Antidrobiose e diapausa em Biomphalaria glabrata (Say), caramujo transmissor da esquistossomose na regiāo nordeste. Biotemas, 2: 57-68.

HARRY, H. W. \& ALDRICH, D. V., 1963. The distress syndrome in Taphius glabratus (say), as a reaction to toxic concentrations of inorganicions. Malacologia, 1: 283-289.

HARRY, H. W. \& SENTURIA, J. B., 1964. The effecct of nitrogen, oxygen and caarbon dioxid in producing the dystress syndrome in Taphisus glabratus. Biological, 127: 271-179.

HENDERSON, A. E., 1963. On the underwater weights of freshwater sanails. Zeitschrift fur vergeichende Physiologie, 46: 467-490.

JURBERG, P., 1987. Why it is diffeicult to control Biomphalaria glabrata, the vector snail of Schistosomiasis. Memórias do Instituto Oswaldo Cruz, 82 (Suppl. 4): 203-207.

1990. Controle de doenças endêmicas através da manipulação comportamental. Biotemas, $3: 1-45$.

1992. Alguns Aspectos do Comportamento de Biomphalaria glabrata (Say, 1818), com Ênfase na Atividade Respiratória. Tese de Doutorado, Rio de Janeiro: Instituto de Biofísica, Universidade Estadual do Rio de Janeiro.

JURBERG, P. \& BARTH, R., 1965. Técnicas utilizadas para evidenciar estrutras de conchas dos moluscos em suas possíveis aplicações. Notas Técnicas do Instituto de Pesquisa da Marinha, 17: $01-$ 21.

JURBERG, P.; PIERI, O. S. \& RAYMUNDO, J. S., 1980. Comportamento de penetração em buracos e sobrevivência sob o solo como meio de proteção de Biomphalaria glabrata (Say, 1818). Suplemento de Ciência e Cultura, 31: 799. 


\section{TÓPICOS EM MALACOLOGIA MÉDICA}

JURBERG, P.; GATTI, M. J.; SOARES, M. S. \& BARBOSA, J/ V., 1982. Comportamento e condições de sobrevivência de Biomphalaria glabrata submetida a imersão prolongada. Ciência e Cultura, 34: (Supl. ?): 802.

JURBERG, P.; CABRAL NETO, J. B. \& SCHALL, V. T., 1985. Molluscicidde activity of the "Avelos" plant (Euphorbia tirucalli, L.) on Biomphalaria glabrata, the mollusc vector of Schistosomiasis. Memórias do Instituto Oswaldo Cruz, 80: 423-427.

JURBERG, P.; SCHALL, V. T.; BARBOSA, J. V.; GATTI, M. J. \& SOARES, M. S., 1987a. Behavior of Biomphalaria glabrata, the intermediate host snail of Schistosoma mansoni, at different depths in water in laboratory conditions. Memórias do Instituto Oswaldo Cruz, 82: 197-208.

JURBERG, P.; RODRIGUES M. L.; CUNHA, R. A.; BARBOSA, J. V., 1987b. Effect of Sudden increase of Hidrostatic Pressure in Biomphalaria glabrata. First International Symposium on Schistossomiasis: 45.

JURBERG, P.; CUNHA, R. A.; RODRIGUES, M. L.; BARBOSA, J. V., 1987c. Respiratory behaviour of Biomphalaria glabrata. First International Symposium on Schistosomiasis: 33.

JURBERG, P.; BARBOSA, J. V. \& ROTEMBERG, L., 1988a. The role of behaviorin the survival of Biomphalaria glabrata in bioassays with the plant molluscicide Phytolacca dodecandra. Memórias do Instituto Oswaldo Cruz, 83: 41-46.

JURBERG, P,; SOARES, M. S.; MASCITELLI, A. C.; FAVRE, T.C. \& BARBOSA, J.V., $1988 \mathrm{~b}$. Studies on survival, biological activities and behavior of Biomphalaria glabrata, the host snall of Schistotomiasis, submitted to increased hydrostatic pressure: a technique. Memórias do Instituto Oswaldo Cruz, 83: 53-61.

JURBERG, P.; COELHO da SILVA, C. L. P. A.; BARRETO, M. G. M. \& SOARES, M. S., 1988c. Rheotaxis of Biomphalaria glabrata on vertical substrates and its role in the recolonization of habitats treated whith molluscicides. Memórias do Instituto Oswaldo Cruz, 83: 165-174.

LEONARD, J. L. \& LUKOWIAK, K., 1986. The behavior of Aplysia californica Cooper (Gastropoda; Opisthobranchia) I. Ethogram. Behaviour, 98: 320-360.

NOLAN, M. O.; BROND, H. W. \& MANN, E. R., 1953. Results of laboratory screening tests of chemical compounds for molluscicidal activity. American Journal of Tropical Medicine and Hygiene, 2: 717-752.

OLIVER, L. \& BARBOSA, F. S., 1956. Observations on vectors of Schistosomiasis mansoni kept out of water in the laboratory. Journal of Parasitology, 42: 277-286.

PAN, C. T., 1958. The general histology and topographic microanatomy of Australorbis glabratus. Bulletin of the Museum of Comparative Zoology, 119: 237-299.

PARAENSE, W. L., 1955. Autofecundação e fecundação cruzada. Memórias do Instituto Oswaldo Cruz. 53: 277-284.

1957. Apertural lamelae in Australorbis glabratus. Proceeding of the Malacological Society London, 32: 175-179.

1970. Planorbídeos hospedeiros intermediários do Schistosoma mansoni. In: Esquistossomose mansoni (A. S. Cunha,...), pp.13-30, São Paulo: Sarvier/Universidade de São Paulo.

1972. Fauna planorbídica do Brasil. In: Introdução à Geografia Médica do Brasil (C. S. Lacaz, R. G. Baruzzi \& W. Siqueira, eds.), pp. 213-239, São Paulo: Blucher/Universidade São Paulo. 


\section{CATÁLOGO COMPORTAMENTAL}

PIERI, O. S.; RAYMUNDO, J. S. \& JURBERG, P., 1980b. Estudos sobre o comportamento dos planorbídeos: II- Enterramento de Biomphalaria glabrata (Say, 1818) como meio de proteção contra a dessecação. Memórias do Instituto Oswaldo Cruz, 75: 83-88.

PIERI, O. S. \& JURBERG, P., 1981a. Aspectos etológicos na sobrevivência dos caramujos vetores da xistosomose ao tratamento com moluscicidas. Memórias do Instituto Oswaldo Cruz, 76: 47-55.

, 1981b. Comportamento de Biomphalaria glabrata (Say, 1818) como critério de toxidade em ensaios biológicos com muluscicidas. Memórias do Instituto Oswaldo Cruz, 76: 174-160.

PIERI, O. S., 1985. Studies on the Host Snail of Schistosomiasis from North-East Brazil, with Special Reference to Diapause in Biomphalaria glabrata (Say). Tese de Doutorado, Sussex: Uiversity of Sussex.

PIERI, O. S., \& THOMAS, J. D., 1986. Polymorphism in a laboratory population of Biomphalaria glabrata from a seasonally drynig habitat in north-east Brasil. Malacologia, 27: 313-321.

PIMENTEL-SOUZA, F.; FERNANDES-SOUZA, N.; V. T. \& COELHO, P. M. Z., 1976a. Comportamento elementar do caramujo Biomphalaria glabrata. I - Disposição espacial da concha. Revista Brasileira de Pesquisas Médicas e Biológicas, 9: 117-122.

PIMENTEL-SOUZA, F.; SCHALL, V. T.; FERNANDES SOUZA, N. \& COELHO, P. M. Z., 1976b. Comportamento elementar do caramujo Biomphalaria glabrata. II - Localização e tamanho da massa cefalopodal exposta. Revista Brasileira de Pesquisas Médicas e Biológicas, 9: 123-127.

PIMENTEL-SOUZA, F.; SCHALL, V. T.; LAUTNER Jr., R.; BARBOSA, N. D. C.; SCHETTINO, M. \& FERNANDES, N., 1984. Behavior of Biomphalaria glabrata (Gastropoda: Pulmonata) under different lighting conditions. Canadian Journal Zoology, 62: 2328-2334.

REY, L., 1956. Contribuição para o Conhecimento da Morfologia, Biologia e Ecologia dos Planorbideos Brasileiros Transmissores da Esquistossomose. Rio de Janeiro: Serviço Nacional de Educaçāo Sanitária.

REY, L., 1973. Parasitologia. Rio de Janeiro: Guanabara Koogan.

RICHARDS, C. S., 1968. Aestivation of Biomphalaria glabrata (Basommatophora; Planorbidae): Genetic studies. Malacologia, 7: 109-116.

RICHARDS, C. S., 1969. Genetic studies on Biomphalaria glabrata: tentacle and eye variations. Malacologia, 9: 327-328.

RITCHIE, L. S., 1973. Chemical control of snails. In: Epidemiology and Control of Schistosomiasis (Bilhariasis) (N. Ansari, ed.), pp. 458-532, Basel: S. Karger.

SCHALL, V. T.; JURBERG, P.; VASCONCELLOS, M. C., 1985. Orientation to light of juvenile and adult forms of melanic and albino populations of Biomphalaria glabrata (Say, 1818). Memórias do Instituto Oswaldo Cruz, 80: 101-111.

SOUZA, C. P. \& PAULINI, E., 1967. Influência da cobertura dos vasos sobre o resultado nos ensaios biológicos com Biomphalaria glabrata. Revista Brasileira de Malariologia, 19: 421-425.

SUllivaN, J. T. \& CHENG., T. C., 1974. Structure and Function of the mantle cavity of Biomphalaria glabrata (Mollusca: Pulmonata). Transactions American Microscopical Society, 93 : 416-420.

TOWNSEND, C. R., 1974. The chemoreceptor sites involved in foodfiding by the freshwater pulmonate snail, Biomphalaria glabrata (Say), with particular reference to the function of the tentacles. Behavioral Biology, 11: 511-523.

, 1975. Strategic aspects of time allocation in the exology of a freshwater pulmonat snail. Oecologia, 19: 105-115.

VON BRANDT, T.; McMAHON, P. \& NOLAN, M. O., 1957. Physiological observations on starvation and desiccation of the snail Australorbis glabratus. Biological Bulletin, 113: 89-102. 


\section{TÓPICOS EM MALACO LOGIA MÉDICA}

WHO (World Health Organization), 1965. Molluscicide screening and evaluation. Bulletin of the World Health Organization, 33: 567-581.

YAGER, C. M. \& HARRY, H. W., 1964. The uptake of radioacctive zinc, cadmium and copper by the freshwater snail. Biological Bulletin, 104: 301-312.

Jurberg, P. ${ }^{l e 2}$; Cunha, R. A. ${ }^{\prime}$; Barbosa, J. V.' ; Soares, M. S. ${ }^{l}$; Schall, V.T.' \& Gatti, M. J.'

'Instituto Oswaldo Cruz, Departamento de Biologia, Laboratório de Comportamento Animal, Caixa Postal 926, 20001, Rio de Janeiro, RJ, Brasil.

${ }^{2}$ Instituto de Psicologia, Universidade do Estado do Rio de Janeiro. 


\section{Embriologia}




\subsection{Embriologia}

\section{INTRODUÇÃO}

O conceito tradicional que define a embriologia é o estudo de embriões. A embriologia estuda o desenvolvimento de uma célula que é um ovo fertilizado, até se tornar um organismo pronto para eclosão como no caso dos moluscos.

Durante o desenvolvimento embrionário, a diversidade celular é determinada através da diferenciação, enquanto o processo da morfogênese é o que organiza diferentes células em tecidos e órgãos, e o crescimento "é o aumento em tamanho e número celular. A segunda maior função no desenvolvimento é a reprodução, isto é, a geração de novos indivíduos.

O ovo inicialmente sofre diversas clivagens (formando células denominadas de blastômeros), até alcançar um estádio de blástula onde, até então, somente ocorrem mitoses sem aumento de volume celular. No estádio seguinte de gástrula, ocorre início da movimentação celular. $\mathrm{Na}$ gastrulação o embrião contém três camadas celulares: a ectoderme, mesoderme e endoderme. Na etapa seguinte de Organogênese, as células interagem e formam os órgãos. Há um grupo de células que são precursoras dos gametas, as células germinativas, responsáveis pela função reprodutora. Por outro lado, todas as outras células são denominadas de somáticas. As células germinativas migram para as gônadas e se diferenciam em gametas. $O$ processo de desenvolvimento dos gametas se chama gametogênese e se completa, quando o organismo se torna fisicamente maduro (Scott, 1994).

A embriologia atualmente faz parte de um ramo da Biologia do Desenvolvimento.

O estudo da embriologia normal de um organismo como a Biomphalaria glabrata (Mollusca, Gastropoda, Planorbidae), se torna importante em razão de se poder comparar o embrião normal com o malformado, já que é um organismo extremamente utilizado em experimentos com diferentes substâncias químicas ou de origem vegetal, para o seu controle na natureza. 


\section{MATURAÇÃO E FERTILIZAÇÃO DO OVO: ASPECTO EXTERNO}

Nos moluscos, em geral, a maturação do ovócito inicia-se independentemente da fertilização e fica bloqueada na metáfase da primeira divisão meiótica (Raven, 1958), continuando o desenvolvimento normal após a fertilização.

Os eventos da fertilização nos ovos de clivagem em espiral incluem três etapas (Longo, 1976):

a) Incorporação do esperma e desenvolvimento do pronúcleo masculino com bloqueio da polispermia.

b) Reinício da meiose do ovócito: quebra da vesícula germinal, formação do primeiro e segundo corpúsculo polar e desenvolvimento do pronúcleo feminino.

c) A associação do pronúcleo masculino e feminino, formação do genoma embriônico e início da mitose.

Logo após a oviposição, tanto em Limnaea stagnalis L. como em Biomphalaria glabrata (Say), a desova apresenta-se com a cápsula externa maleável e com a substância albuminosa opaca. Após alguns minutos, a cápsula torna-se mais rígida e a desova transparente.

A emissão do primeiro corpúsculo polar, ocorre de 15 a 30 minutos após a oviposição; cerca de 50 a 80 minutos depois, o segundo corpúsculo é expulso. Ambos podem permanecer um sobre o outro ou lado a lado, na região do pólo animal do ovo.

Em L. stagnalis, Raven (1945), e B. glabrata, Camey (1968), a emissão dos corpúsculos polares é seguida de movimentos amebóides do ovo que acompanham as divisões de maturação. $O$ contorno do ovo se torna irregular e um processo pseudopseudópodo é formado, acarretando a sua deformação.

O pronúcleo feminino e o masculino se unem formando o genoma do embrião que estará apto a iniciar o cíclo da mitose, em períodos que variam de 60 ( $B$. glabrata) a 100-110 minutos (L. stagnalis), após a emissão do segundo corpúsculo.

\section{Clivagem em espiral ou determinativa}

Com exceção dos cefalópodos, os moluscos apresentam clivagem espiral (helicoidal) ou determinativa; assim é possível traçar o destino de cada blastômero, desde as primeiras clivagens do ovo.

Nos moluscos de clivagem em espiral, determinantes morfogenéticos situados no pólo vegetativo em ovos indivisos, desempenham um papel importante, estabelecendo a organização primordial do futuro embrião. Tais determinantes podem estar localizados em estruturas citoplasmáticas especiais ou estariam ligados no córtex da região vegetativa do ovo e serem distribuídos para certos blastômeros, 
determinando o destino dos mesmos (Verdonk \& Cather, 1983). Os determinantes parecem ser sintetizados e armazenados durante a ovogênese; sua natureza, entretanto, ainda é discutível (Boon-Niermeijer, 1987).

Desde o final do século passado vários pesquisadores realizaram trabalhos em linhagens celulares com diferentes espécies de moluscos. Raven (1958) referiu-se aos estudos de Blochman (1882) com Neritina fluviatilis; de Heymons (1893) com Umbrella mediterranea; de Lillie (1895) com Unionidae; de Kofoid (1895) com Limax sp.; de Meisenheimer (1896 e 1901) com Limax maximus e Dreissensia polymorpha; de Conklin (1897 e 1907) com Crepidula sp. e Fulgur sp.; de Heath (1899) com Ischnochiton sp.; de Holmes (1900) com Planorbis trivolvis; de Robert (1902) com Trochus sp.; de Casteel (1904) com Fiona marina; de Carazzi (1905) com Aplysia sp.; de Wierzejski (1905) com Physa fontinalis; de Delsman (1912) com Littorina obtusata. Mais recentemente trabalhos como de Verdonk (1965) com Limnaea stagnalis; de Camey e Verdonk (1970) com B.glabrata e de Van Dongen (1976) com Dentalium foram descritos.

A abordagem da embriologia neste item será realizada, principalmente, com espécies de moluscos de interesse médico. As espécies estudadas comparativamente são a Limnaea stagnalis (hospedeira intermediária da Fasciola hepatica) e Biomphalaria glabrata (hospedeira intermediária do Schistosoma mansoni). A $L$. stagnalis é um exemplo de clivagem padrão ou dextrorsa (Verdonk, 1965) e a $B$. glabrata é do tipo reversa ou sinistrorsa (Camey, 1968).

\section{Nomenclatura e nota}

A nomenclatura e a notação são padronizadas para o estudo da linhagem celular, o que é essencial para o acompanhamento das etapas sucessivas do desenvolvimento embrionário, bem como do estudo comparativo entre as diferentes espécies.

A nomenclatura e notação utilizadas neste trabalho são as mesmas adotadas por Verdonk (1965) para o estudo de $L$. stagnalis e anteriormente estabelecidas Conklin (1897) para o estudo de linhagem celular de Crepidula.

A clivagem em espiral se caracteriza pela orientação do fuso na divisão dos blastômeros que é oblíqua e alternante: oblíqua, em relação a um eixo que passa pelo pólo animal e vegetativo (Wilson, 1892 apud Raven, 1958) e alternante pela mudança alternada da direção do fuso a cada divisão sucessiva dos blastômeros, do sentido horário para o anti-horário, por uma rotação de $45^{\circ} \mathrm{em}$ torno do eixo vertical do ovo (Kofoid 1895, apud Raven, 1958). 
A notação para designação das gerações sucessivas de micrômeros consiste de uma letra, um coeficiente e um expoente. A letra indica a origem de um micrômero. $\mathrm{O}$ coeficiente indica o número da camada do micrômero e o expoente indica o número de gerações. $\mathrm{O}$ termo quarteto foi adotado por Conklin (1897) apud Raven (1958) para designar os quatro blastômeros e sua descendência que se originam da clivagem dos quatro macrômeros iniciais. $O$ hífen, nesse caso, é utilizado para simbolizar os quatros blastômeros pertencentes a um quarteto, ou seja: $1 \mathrm{a}^{1}-1 \mathrm{~d}^{1}=$ a $1 a^{1}, 1 b^{1}, 1 c^{1}$ e $1 d^{1}$. O primeiro quarteto de micrômeros que se forma na terceira clivagem do ovo terá a seguinte notação $1 \mathrm{a}-1 \mathrm{~d}$ (Figura 2-3). Estes micrômeros, por sua vez, darão posteriormente a geração $1 \mathrm{a}^{1}-1 \mathrm{~d}^{1}$ e $1 \mathrm{a}^{2}-1 \mathrm{~d}^{2}$ (Figura 2-5). $\mathrm{Na}$ geração seguinte o $1 \mathrm{a}^{1}-1 \mathrm{~d}^{1}$ dará origem a $1 \mathrm{a}^{11}-1 \mathrm{~d}^{11}$ e $1 \mathrm{a}^{12}-1 \mathrm{~d}^{12}$ (Figura 2-11). $\mathrm{O}$ quarteto $1 \mathrm{a}^{2}-1 \mathrm{~d}^{2}$ dará: $1 \mathrm{a}^{21}-1 \mathrm{~d}^{21}$ e $1 \mathrm{a}^{22}-1 \mathrm{~d}^{22}$ (Figura 2-12) e assim por diante.

Após uma clivagem o blastômero que se aloja à direita e na parte superior, ou seja, na direção do pólo animal, leva o expoente 1 ; o expoente 2 , portanto, será daquele que se localiza á esquerda e próximo ao pólo vegetativo do embrião. Quando, entretanto, a clivagem é bilateral, utiliza-se o expoente 1 para o blastômero situado à direita e o 2 para 0 da esquerda.

Para distinguir se o tipo de clivagem é dextrorsa ou sinistrorsa, leva-se em conta a orientação do fuso de divisão. Quando o fuso de divisão estiver no sentido oblíquo em relação ao eixo do ovo e no sentido horário, a clivagem é dextrorsa e quando no sentido anti-horário, sinistrorsa. Quando se observa o ovo do pólo animal, considera-se a clivagem dextrorsa se o quarteto superior se encontra à direita do inferior, do qual se originou e sinistrorsa se o quarteto superior se encontra à esquerda.

A notação para os macrômeros foi utilizada segundo Wierzejski (1905). Esta consiste em alterar a numeração do macrômero, de acordo com separação de um quarteto de micrômeros. Com a origem do primeiro quarteto de micrômeros 1a-1d, os macrômeros A-D são designados 1A-1D (Figura 2-3). Após a clivagem do segundo quarteto de micrômeros $2 \mathrm{a}-2 \mathrm{~d}$, os macrômeros passam a ser designados de 2A-2D (Figura 2-4). Assim, na formação do quarteto de micrômeros 3a-3d, os macrômeros passam a ser 3A-3D, (Figura 2-7). Na clivagem do quarto quarteto de micrômeros 4a-4d, os macrômeros passam a ser 4A-4D (Figura 2-10). Finalmente, com a formação da quinta geração de micrômeros $5 \mathrm{a}-5 \mathrm{c}$, os macrômeros são denominados 5A-5C (Figura 2-18).

A descrição da linhagem celular das duas espécies será feita concomitantemente, já que o padrão de clivagem de $B$. glabrata é a imagem especular do padrão de $L$. stagnalis. No decorrer da decrição, só será feita uma observação quando a clivagem em $L$. stagnalis for diferente. 
Técnica de coloração do limite celular

Até o estádio de 12 blastômeros foi observado in vivo, porém nos estádios posteriores foi utilizado o método de Holmes (1900 apud Verdonk, 1965) que estudou em Planorbis trivolvis e em Lymnaea stagnalis, Verdonk (1965), e mais tarde em Biomphalaria glabrata, Camey e Verdonk (1970).

Os ovos foram removidos de suas cápsulas, com um auxílio de duas pinças de extremidades bem agudas, dentro de uma saleirinha contendo água destilada. Com uma pipeta braking foram transferidos para uma outra saleirinha contendo água destilada removendo assim a substância gelatinosa. Em seguida foram transferidos para uma saleirinha contendo $0,75 \%$ de $\mathrm{AgNO} 3$ e expostas ao U.V. por alguns minutos, até o limite celular se tornar nítido (microscópio estereoscópio). Os ovos então foram lavados com água destilada, transferidos em diferentes alcooís: $50 \%$, $70 \%, 80 \%, 96 \%$ ( \pm 10 horas cada), $100 \%$ ( $3 \times 20$ minutos e no xylol (três banhos). Os ovos foram montados individualmente em bálsamo entre uma lamínula colada de um dos lados em cartolina (mesma área da lamínula, porém recortada na sua parte central em forma circular) de modo que os ovos possam permanecer inteiros sem o contato direto entre a lâmina e a lamínula. Após a montagem, os ovos foram movimentados e observados de todos os lados pelo deslocamento da lamínula. No caso do bálsamo endurecer, poderá ser gotejado xylol na extremidade da lamínula para facilitar a movimentação da mesma.

\section{Primeiras clivagens: Antes da primeira clivagem}

O diâmetro do ovo maduro é cerca de 100u para B. glabrata (Camey, 1968) e 120u para L. stagnalis (Raven, 1958).

Na Figura 1-1A observa-se o estádio do ovo antes da primeira clivagem, com o pólo animal e os dois corpúsculos polares.

\section{Primeira clivagem}

Todos os estádios de primeiras clivagens (primeira até quarta) foram fotografadas in vivo, em intervalos de 2 a 5 minutos, em B. glabrata (Kawano et al., 1992); estes estádios são semelhantes os de $L$. stagnalis (Raven, 1946).

Durante todo o desenvolvimento embrionário, as desovas foram mantidas a uma temperatura de $25^{\circ} \mathrm{C}$.

No estádio 1B (Figura 1-1B) verifica-se o aparecimento do sulco da primeira clivagem do ovo, na região do pólo animal. Para qualquer contagem na idade do 
embrião, este estádio 1B (quando $50 \%$ de embriões de uma mesma desova atingem este estádio) é o ponto de partida do desenvolvimento, pois dentro de uma mesma desova o desenvolvimento inicial não é sincrônico em todos os embriões.

No estádio 2 (Figura 1-2) o sulco se apresenta mais profundo; observa-se que a região do pólo animal se cliva mais rapidamente que a do pólo vegetativo, 3 minutos após o estádio $1 \mathrm{~B}$.

No estádio 3 (Figura 1-3) o sulco do pólo animal se apresenta mais profundo que o do pólo vegetativo, 4 minutos.

No estádio 4 (Figura 1-4), observa-se o afastamento máximo dos dois blastômeros, ambos com a superfície bem arredondada, ligados somente com uma pequena superfície citoplasmática, 10 minutos.

A partir do estádio 5 (Figura 1-5) (20 minutos) há aproximação dos blastômeros, aumentando a superfície de contato; os estádios 6 (26 minutos) e 7 (38 minutos) (Figuras 1-6 e 7) possuem os limites dos blastômeros pouco nítidos.

No estádio 8 (Figura 1-8) (45 minutos) observa-se o aparecimento bem discreto da cavidade de clivagem entre os dois blastômeros. Esta cavidade aumenta de tamanho e atinge toda superfície de contato dos dois blastômeros, no estádio 9 (Figura 1-9) (75 minutos). Após este estádio, a cavidade de clivagem se abre e o seu conteúdo flui para o exterior.

\section{Segunda clivagem}

O estádio 10 (Figura 1-10), ou o início da segunda clivagem, ocorre 80 minutos após a primeira clivagem do ovo.

Neste estádio, os blastômeros não se dividem simultaneamente; o sulco de clivagem de um dos blastômeros surge antes do outro, apresentando o aspecto bilobado, enquanto o outro se apresenta inteiro. O sulco de clivagem é total e meridional. No estádio 11 (91 minutos), nota-se que os quatro blastômeros A, B, C e D são arredondados, mas não se encontram no mesmo plano (Figura 1-11). $O$ blastômero A e C estão ligados pelo sulco do pólo animal, enquanto o B e D pelo sulco polar vegetativo. No estádio 12 (98 minutos) observa-se o início do achatamento dos blastômeros e os dois blastômeros opostos se apresentam unidos com maior visibilidade.

Nos estádios que se seguem, 13 (103 minutos) e 14 (123 minutos) (Figuras 1-13 e 14), há o aparecimento da cavidade de clivagem entre os blastômeros. Esta cavidade começa a alargar até se abrir para o exterior expelindo o fluído, o que é acompanhado de uma contração de todo o ovo (Figura 1-15) (134 minutos). 


\section{Terceira clivagem}

O embrião atinge este estádio 16 (Figura 1-16) cerca de 160 minutos após a primeira clivagem. A terceira clivagem é no sentido subequatorial; os quatro micrômeros (1a-1d) nunca jazem sobre os macrômeros, mas sobre os sulcos formados por eles; assim a $B$. glabrata possui a orientação dos micrômeros no sentido anti-horário.

O micrômero 1a está em conexão com o 1c, no pólo animal, enquanto os macrômeros 1B e 1D se ligam no pólo vegetativo.

Quando o micrômero atinge o estádio 17 (Figura 1-17) (165 minutos), observa-se arredondamento máximo dos blastômeros, em seguida, nos estádios 18 (173 minutos) e 19 (181 minutos) (Figuras 1-18 e 19) ocorre o aumento da cavidade de clivagem entre os blastômeros.

\section{Quarta clivagem}

A quarta clivagem ocorre 3 horas e 50 minutos após a primeira clivagem do ovo (Figura 1-20). O segundo quarteto de micrômeros se separa dos macrômeros no sentido sinistrorso (Figura 2-4), atingindo o estádio de 12 blastômeros.

\section{Estádio de 12 a 24 blastômeros}

O primeiro quarteto de ectômeros (1a-1d) é o próximo a clivar, aproximadamente cinco horas após a primeira clivagem. Esta clivagem é dextrorsa e o embrião possui 16 células (Figura 2-5).

Cerca de 6 horas após a primeira clivagem, ocorrem quase simultaneamente a clivagem do segundo quarteto de micrômeros $(2 \mathrm{a}-2 \mathrm{~d})$ e a formação do terceiro quarteto de micrômeros (3a-3d) (Figura 2-6).

Terminadas estas clivagens, que são no sentido sinistroso, o embrião atinge o estádio de 24 blastômeros. Neste estádio, os quatro macrômeros são aparentemente menores que quatro micrômeros, provavelmente porque apresentam ao observador apenas uma parte reduzida de sua superfície externa. $O$ macrômero 3D apresenta-se com o contorno arredondado (Figura 2-7), diferenciando-se dos demais três macrômeros.

A semelhança de Planorbis trinolvis, Physa fontinalis e L. stagnalis, o estádio de 24 células em $B$. glabrata também é um período de "repouso", cuja duração média é de 3 horas. 
O período de "repouso" termina quando o macrômero 3D se divide, dando origem ao mesoblasto primário $M$ (4d). Com esta clivagem, o embrião atinge 25 blastômeros, cerca de 9 horas após a primeira clivagem do ovo. Ela determina, pela primeira vez, a simetria bilateral do embrião (Figura 2-8).

Para se entender a relação entre a posição dos quadrantes e o eixo do futuro embrião, deve-se levar em conta a clivagem reversa de $B$. glabrata.

A posição de $4 \mathrm{~d}(\mathrm{M})$ e o eixo animal-vegetativo determinam o plano mediano de simetria do futuro embrião; a célula $4 \mathrm{~d}$ indica a posição dorsal. Assim, o segundo $(2 \mathrm{a}-2 \mathrm{~d})$ e o quarto $(4 \mathrm{a}-4 \mathrm{~d})$ quartetos de micrômeros são formados no sentido dextrorso, encontrando-se em posição radial $(A=$ direita, $B=$ ventral, $C=$ esquerda e $\mathrm{D}=$ dorsal), Figura 2-10. A geração do terceiro quarteto de micrômeros se origina no sentido sinistrorso, localizando-se na posição inter-radial $(A=$ direita ventral, $\mathrm{B}=$ esquerda ventral, $\mathrm{C}=$ esquerda dorsal e $\mathrm{D}=$ direita dorsal) (Figura 2-10). Porém na clivagem seguinte, que é sinistrorsa em $L$. stagnalis e dextrorsa para $B$. glabrata, as células filhas $1 \mathrm{a}^{2}-1 \mathrm{~d}^{2}$ irão se situar na posição inter-radial, enquanto que $1 a^{1}-1 d^{1}$ se dispõem no sentido radial (Figura 2-9).

Cerca de 10 horas após a primeira clivagem, a camada superior e inferior do segundo quarteto de micrômeros, respectivamente $2 \mathrm{a}^{1}-2 \mathrm{~d}^{1}$ e $2 \mathrm{a}^{2}-2 \mathrm{~d}^{2}$ sofrerão as próximas clivagens no sentido dextrorso em B. glabrata (Figura 2-9), atingindo, desta maneira, o estádio de 33 blastômeros.

Nesse estádio, formam-se as células terminais $2 a^{11}-2 d^{11}$ que tomam parte na formação da cruz observada em $B$. glabrata (Figura 2-11). O estádio de cruz tem sido descrito em Anelídeos e Moluscos (exceto cefalópodos) como sendo um dos estádios mais característicos durante o desenvolvimento embrionário destes animais. Nos moluscos, a cruz constituída por blastômeros que formarão quase toda a região cefálica.

Aproximadamente 11 horas após a primeira clivagem do ovo, o terceiro quarteto de micrômeros se cliva no sentido dextrorso. Em seguida, os macrômeros 3A, 3B e 3C se clivam formando a quarta geração de micrômeros $(4 a, 4 b$, e 4c), em direção ligeiramente dextrorsa, atingindo 40 blastômeros.

No pólo animal, a camada superior do primeiro quarteto de ectômeros $\left(1 \mathrm{a}^{1}\right.$ $\left.1 d^{1}\right)$ se cliva no sentido sinistrorso. Neste período se destaca, pela primeira vez, o inconfundível estádio de cruz (Figura 2-11). As quatro células externas do primeiro quarteto de micrômeros $1 \mathrm{a}^{12}-1 \mathrm{~d}^{12}$ são as bases do braço da cruz, situando-se radialmente na direção das células terminais $2 \mathrm{a}^{11}-2 \mathrm{~d}^{11}$, enquanto que as células apicais $1 \mathrm{a}^{11}-1 \mathrm{~d}^{11}$ formam o centro da cruz, na posição inter-radial. 
Em L. stagnalis, Biggelaar (1971) observou que o blastômero 1d1 se divide 30 minutos após os outros três $\left(1 \mathrm{a}^{1}, 1 \mathrm{~b}^{1}\right.$ e $\left.1 \mathrm{c}^{1}\right)$; nesta espécie, portanto, a simetria bilateral (pólo animal) inicia-se a partir deste estádio. Este mesmo autor constatou que em condições experimentais com LiCl em embriões, ocorreu a sincronia na clivagem deste quarteto $1 a^{1}-1 d^{1}$ e a posterior formação da exogástrula. Esta observação foi de grande importância, pois chegou-se à conclusão de que a simetriabilateral no pólo animal é induzida na estádio de 24 blastômeros e está associada ao processo de gastrulação.

Os blastômeros do segundo quarteto de micrômeros $2 \mathrm{a}^{11}-2 \mathrm{~d}^{11}$ são os que constituem as células terminais dos braços da cruz.

Cerca de 12 horas após a primeira clivagem do ovo, segue-se a clivagem do mesoblasto primário, no sentido meridional, resultando nos blastômeros $\mathbf{M}_{1}$ e $\mathbf{M}_{2}$ (Figura 2-10). Como estas duas células são do mesmo tamanho, o embrião apresenta um aspecto característico na sua parte dorsal. Na Figura 2-11 um embrião com 45 células visto pelo pólo animal. Na Figura 2-10 o mesmo embrião é visto pelo pólo vegetativo.

Um embrião com 45 blastômeros tem a seguinte constituição:

Células do primeiro quarteto:

$$
\begin{aligned}
& 1 a^{11}-1 d^{11} \\
& 1 a^{12}-1 d^{12} \\
& 1 a^{2}-1 d^{2}
\end{aligned}
$$

Células do segundo quarteto:

$$
\begin{aligned}
& 2 a^{11}-2 d^{11} \\
& 2 a^{12}-2 d^{12} \\
& 2 a^{21}-2 d^{21} \\
& 2 a^{22}-2 d^{22}
\end{aligned}
$$

\section{Células do terceiro quarteto:}

$$
\begin{aligned}
& 3 a^{1}-3 d^{1} \\
& 3 a^{2}-3 d^{2}
\end{aligned}
$$


Células do quarto quarteto:

2 mesômeros $M_{1}$ e $M_{2}$

3 endômeros $4 \mathrm{a}-4 \mathrm{c}$

Macrômeros: 4A - 4D

\section{O DESENVOLVIMENTO DO PRIMEIRO QUARTETO DE MICRÔMEROS}

\section{Estádio de cruz}

A Figura 3 ilustra o desenvolvimento do primeiro quarteto de micrômeros, a partir do ovo. A figura em cruz se torna visível pela primeira vez, quando o embrião atinge o estádio de 45 blastômeros (Figura 2-11). 0 quarteto de micrômeros apicais $1 a^{11}-1 d^{11}$ jazem no centro da cruz, enquanto os braços são formados pelas células basais $1 \mathrm{a}^{12}-1 \mathrm{~d}^{12}$. As células terminais são constituídas pelos micrômeros do segundo quarteto $2 \mathrm{a}^{11}-2 \mathrm{~d}^{11}$.

O próximo quarteto a se clivar é o trocoblasto primário $1 \mathrm{a}^{2}-1 \mathrm{~d}^{2}$, cerca de 13 horas após a primeira clivagem. As oito células $\left(1 \mathrm{a}^{21}-1 \mathrm{~d}^{21}\right.$ e $\left.1 \mathrm{a}^{22}-1 \mathrm{~d}^{22}\right)$ secundárias ou trocoblasto definitivo, nunca se dividem, localizando-se nos ângulos entre os braços da cruz.

Formada a cruz, durante três horas não se observam divisões celulares nesta região. Modifica-se, porém, o aspecto da cruz, em razão da penetração das células $\left(1 a^{11}-1 d^{11}\right)$ no interior do embrião (Figura 2-12). Em seguida as células basais $1 a^{12}$ - $1 d^{12}$ começam a se clivar, contando o embrião com cerca de 76 blastômeros, cerca de 16 horas após a primeira clivagem.

Na Figura 2-14 um embrião com 83 blastômeros se apresenta com todas as células basais divididas. A direção da clivagem é ligeiramente sinistrorsa.

As células medianas externas $1 \mathrm{a}^{122}-1 \mathrm{~d}^{122}$ se localizam entre as células terminais $2 a^{11}-2 d^{11}$ e as células basais $1 a^{121}-1 d^{121}$. Com exceção da célula mediana do braço ventral $1 b^{122}$, as células medianas externas dos outros braços não mais se dividem no estádio larvário (Figura 2-25).

A divisão seguinte ocorre nas células apicais do primeiro quarteto de micrômeros $1 \mathrm{a}^{11}-1 \mathrm{~d}^{11}$, no sentido dextrorso (centro da cruz).

A partir desta divisão forma-se a roseta apical $1 a^{111}-1 d^{111}$, cercando o pólo animal do embrião e a roseta periférica $1 \mathrm{a}^{112}-1 \mathrm{~d}^{12}$ situadas nos ângulos entre os braços da cruz (Figura 2-16); neste estádio, o embrião alcança cerca de 97 blastômeros, 18 horas após a primeira clivagem. 
A cruz é constituída por 20 células. A partir deste estádio, as células da cruz não se clivam durante 2 horas.

A seguir a célula mediana basal interna do braço ventral da cruz $\left(1 b^{121}\right)$ se divide, sendo seguida dos braços laterais $1 \mathrm{a}^{121}$ e $1 \mathrm{c}^{121}$ (Figura 2-19). A célula basal do braço dorsal $1 \mathrm{~d}^{121}$ se cliva mais tarde, e a cruz alcança cerca de 24 células assim distribuídas:

\section{Centro:}

células da roseta apical $1 \mathrm{a}^{111}-1 \mathrm{~d}^{111}$

células da roseta periférica $1 \mathrm{a}^{112}-1 \mathrm{~d}^{112}$

\section{Braço dorsal:}

célula basal $1 \mathrm{~d}^{1211}$

célula mediana interna $1 \mathrm{~d}^{1212}$

célula mediana externa $1 \mathrm{~d}^{122}$

célula terminal $2 \mathrm{~d}^{11}$

\section{Braço ventral:}

célula basal $1 b^{1211}$

célula mediana interna $1 b^{1212}$

célula mediana externa $1 b^{122}$

célula terminal $2 b^{11}$

\section{Braço lateral direito:}

célula basal $1 \mathrm{a}^{1211}$

célula mediana interna $1 \mathrm{a}^{1212}$

célula mediana externa $1 \mathbf{a}^{122}$

célula terminal $2 \mathrm{a}^{11}$

\section{Braço lateral esquerdo:}

célula basal $1 \mathrm{c}^{1211}$

célula mediana interna $1 \mathrm{c}^{1212}$

célula mediana externa $1 c^{122}$

célula terminal $2 \mathrm{c}^{11}$

A descrição do desenvolvimento de cada braço a partir deste estádio será realizada separadamente, em razão de diferenças existentes entre cada braço. 


\section{O braço dorsal}

Cerca de 21 horas e 30 minutos após a primeira clivagem, a célula $1 \mathrm{~d}^{121}$ se cliva; a direção de clivagem desta célula forma um ângulo reto com a direção do braço dorsal (Figura 2-19). Assim, as células $1 \mathrm{~d}^{1211}$ e $1 \mathrm{~d}^{1212}$ vão se situar uma sobre a outra.

Em L. stagnalis, entretanto, a clivagem de $1 \mathrm{~d}^{121}$ é paralela em relação à direção do braço dorsal, permanecendo as células $1 \mathrm{~d}^{1211}$ e $1 \mathrm{~d}^{1212}$ uma ao lado da outra (Verdonk, 1965).

A célula mediana externa $1 \mathrm{~d}^{122}$ e a terminal $2 \mathrm{~d}^{11}$ permanecem sem se dividir.

\section{Os braços laterais}

Cerca de 21 horas após a primeira clivagem, as células basais dos braços laterais da cruz $1 a^{121}$ e $1 c^{121}$ se clivam num plano em ângulo reto em relação ao braços laterais (Figura 2-19).

As células basais $1 \mathrm{a}^{1211}$ e $1 \mathrm{c}^{1211}$ estão em contato com as células apicais. As células medianas internas $1 \mathrm{a}^{1212}$ e $1 \mathrm{c}^{1212}$ se localizam entre as células basais e as células medianas externas $1 \mathrm{a}^{122}$ e $1 \mathrm{c}^{122}$ (Figura 2-19).

As células basais $1 \mathrm{a}^{1211}$ e $1 \mathrm{c}^{1211}$ serão as próximas a clivarem cerca de 24 horas após a primeira clivagem. Esta divisão ocorre num plano paralelo ao eixo longitudinal dos braços. Do mesmo modo que as células anteriores, as células medianas internas $1 \mathrm{a}^{1212}$ e $1 \mathrm{c}^{1212}$ se clivam aproximadamente 26 horas após a primeira clivagem (Figura 2-22).

Cerca de 30 horas após a primeira clivagem, as células $1 \mathrm{a}^{1212}$ e $1 \mathrm{c}^{1212}$ entram em divisão. As células $1 \mathrm{a}^{12121} 1 \mathrm{c}^{12122}$ permanecem sem se dividir, até cerca de 36 horas após a primeira clivagem (Figura 2-23).

Cada braço possui sete células por cerca de 6 horas. As células mediana externa $1 a^{122}$ e $1 c^{122}$ e as células terminais $2 a^{11}$ e $2 c^{11}$ não se dividem mais.

A forma conspícua que caracteriza o estádio de cruz começa gradualmente a se modificar. Os braços laterais, que estavam situados em ângulo reto com o eixo dorso-ventral da cruz, vão se dirigindo para a região dorsal do embrião (Figura 2-22).

\section{O braço ventral}

A divisão da célula basal do braço ventral da cruz $1 b^{121}$, ocorre cerca de 20 horas após a primeira clivagem, portanto antes das outras correspondentes $1 \mathrm{a}^{121}$, 
$1 c^{121}$ e $1 d^{121}$. As células $1 b^{1211}$ e $1 b^{1212}$ vão se situar uma sobre a outra na direção longitudinal do braço ventral (Figura 2-19).

Cerca de 21 horas e 30 minutos após a primeira clivagem, a célula terminal do braço ventral $2 b^{11}$ se cliva no sentido meridional (Figura 2-19).

Após a divisão destas células observa-se, pela primeira vez, a simetria bilateral no pólo animal do embrião. A próxima divisão no sentido meridional é da célula mediana interna $1 b^{1212}$, dando origem a $1 b^{12121}$ e $1 b^{12122}$ (Figura 2-20).

Aproximadamente 21 horas após a primeira clivagem, as células $1 b^{12121} \mathrm{e}$ $1 b^{12122}$ se clivam. Até o estádio anterior à divisão, estas duas células estavam em contato, através de uma pequena superfície no plano mediano. Entretanto, após esta clivagem, os respectivos descendentes se separam completamente (Figura 2-23). A célula $1 b^{122}$ é a próxima a se dividir no plano meridional e é única célula mediana externa de cruz que continua se dividindo posteriormente (Figura 2-24).

As células $1 b^{1221}$ e $1 b^{1222}$ se encontram fortemente unidas logo após a divisão (Figura 2-24); aos poucos, porém, elas se afastam uma da outra, ficando unidas por uma pequena superfície (Figura 2-25).

As células terminais $2 b^{111}$ e $2 b^{112}$, que no início estão bem próximas, vão-se separando, alojando-se à direita e à esquerda da região situada acima da boca. Há, entretanto, casos, como ilustrado na Figura 2-27, em que a larva trocófora ainda apresenta as duas células terminais unidas.

As duas células $1 b^{1221}$ e $1 b^{1222}$ nunca se dividirão em $L$. stagnalis, enquanto que em $B$. glabrata continuam a divisão cerca de 43 horas após a primeira clivagem. Até este estádio elas podem facilmente ser distinguidas das outras que as limitam, porque estão ladeando a célula $1 b^{1211}$, permanecendo maiores que as descendentes de $1 b^{1212}$ (Figura 2-26).

\section{O centro da cruz}

Num período de cerca de 10 horas o centro da cruz permanece com as células da roseta apical $1 a^{111}-1 d^{111}$ e as células da roseta periférica $1 a^{112}-1 d^{112}$ em sua posição central, 27 horas após a primeira clivagem, porém, as células da roseta periférica $1 \mathrm{a}^{112}-1 \mathrm{~d}^{112}$ começam a se dividir (Figura 2-23).

As células da roseta periférica dorsal $1 c^{112}$ e $1 d^{112}$ estão situadas entre células basais $1 \mathrm{a}^{1211}$ e $1 \mathrm{c}^{1211}$ e a célula basal dorsal $1 \mathrm{~d}^{1211}$ (Figura 2-19). As duas células filhas $1 a^{1121}$ e $1 b^{1121}$ continuam unidas, enquanto as células $1 a^{1122}$ e $1 b^{1122}$ se deslocam para a periferia (Figura 2-23). Na próxima etapa do desenvolvimento, observa-se o aumento gradativo da superfície das seis células centrais: as células da roseta 
apical $1 \mathrm{a}^{111}-1 \mathrm{~d}^{111} \mathrm{e}$ os descendentes das células da roseta periférica ventral $1 \mathrm{a}^{1121} \mathrm{e}$ $1 b^{1121}$ (Figura 2-24 e 25).

\section{O desenvolvimento do segundo quarteto de micrômeros}

O esquema da divisão deste quarteto se encontra ilustrado na Figura 4.

Quando o embrião atinge o estádio de 24 células (Figura 2-6) há um total de oito blastômeros $\left(2 \mathrm{a}^{1}-2 \mathrm{~d}^{1}\right.$ e $\left.2 \mathrm{a}^{2}-2 \mathrm{~d}^{2}\right)$, pertencentes ao segundo quarteto de micrômeros. Cerca de 9 horas e 15 minutos após a primeira clivagem, as células $2 \mathrm{a}^{1}$ - $2 \mathrm{~d}^{1}$ se clivam (embrião com 29 blastômeros). Cerca de 10 horas após a primeira clivagem o quarteto $2 \mathrm{a}^{2}-2 \mathrm{~d}^{2}$ se cliva (embrião com 33 blastômeros, Figura 2-9). No estádio de 51 blastômeros a clivagem de $2 \mathrm{~d} 21$ é seguida pela $2 \mathrm{a}^{21}, 2 \mathrm{~b}^{21}, 2 \mathrm{c}^{21}$ e $2 \mathrm{a}^{12}$ - $2 \mathrm{~d}^{12}$, todas no sentido sinistrorso.

Terminadas as clivagens assinaladas no parágrafo anterior, o embrião alcança o estádio de 64 blastômeros (Figura 2-12 e 13), sendo 24 células originárias do segundo quarteto de micrômeros.

Os blastômeros $2 \mathrm{a}^{11}-2 \mathrm{~d}^{11}$ formam as células terminais dos braços da cruz. As células dos quadrantes $2 \mathrm{a}^{121}-2 \mathrm{~d}^{121}$ e $2 \mathrm{a}^{211}-2 \mathrm{~d}^{211}$ se localizam lado a lado e na parte inferior (mais próxima ao pólo vegetativo) às descritas anteriormente se encontram $2 a^{122}-2 d^{122}$ e $2 a^{212}-2 d^{212}$, formando a camada mediana. As células do quarteto inferior $2 \mathrm{a}^{22}-2 \mathrm{~d}^{22}$ se acham em conexão com os endômeros e mesômeros (Figura 2-10) no pólo vegetativo.

A próxima clivagem neste quarteto ocorre na camada mediana $\left(2 \mathrm{a}^{212}-2 \mathrm{~d}^{212} \mathrm{e}\right.$ $2 \mathrm{a}^{122}-2 \mathrm{~d}^{122}$ ), o blastômero $2 \mathrm{~d}^{212}$ se cliva no sentido sinistrorso. Neste momento, o embrião atinge 80 blastômeros. Os blastômeros $2 a^{122}$ e $2 c^{122}$ são os que se clivam em seguida. O blastômero $2 \mathrm{c}^{212}$ se cliva no sentido sinistrorso e $2 \mathrm{~d}^{211}$ e $2 \mathrm{~d}^{2122}$ no sentido dextrorso.

As células $2 a^{121}, 2 c^{121}$ e $2 d^{121}$ se clivam no sentido dextrorso, enquanto $2 a^{212}$ no sentido sinistrorso. As clivagens descendentes de quadrantes a, c e d se realizam regularmente, embora não sincromicamente (Figura 4).

A descrição das células descendentes do quadrante b será feita separadamente, em virtude das diferenças encontradas em relação aos outros já descritos.

O embrião no estádio de 64 blastômeros (Figura 2-12) apresenta as duas células $2 b^{211}$ e $2 b^{121}$ na posição superior, enquanto $2 b^{212}$ e $2 b^{122}$ se alojam na parte inferior, mais próxima ao pólo vegetativo.

Com o decorrer do desenvolvimento, observa-se a lenta descida da célula terminal ventral $2 b^{11}$, deslocando-se a posição de $2 b^{211}$ e $2 b^{121}$ para os lados direito e esquerdo do embrião (Figura 2-19). Após a clivagem de $2 b^{11}$, as duas células $2 b^{111}$ 
e $2 b^{112}$ se encontram rodeadas por quatro células na parte ventral, à direita por $2 b^{211}$ e $2 b^{212}$ e à esquerda por $2 b^{122}$ e $2 b^{121}$ (Figura 2-21).

Com o decorrer do desenvolvimento, cerca de 26 horas após a primeira clivagem, as duas células $2 b^{212}$ e $2 b^{122}$ se dividem, dando origem às células filhas $2 b^{2121}$ e $2 b^{2122}$ à direita e $2 b^{1221}$ e $2 b^{1222}$ à esquerda do embrião.

Durante as divisões seguintes, as células que descendem de $2 b^{212}$ e $2 b^{122}$, formam a região ventral da cabeça (Figura 2-26) e as mesmas irão se deslocando lateralmente para os blastômeros $2 b^{211}$ e $2 b^{121}$. A célula $2 b^{211}$ se encontra limitada por $1 a^{21}$ e $1 a^{22}$ à direita e $2 b^{121}$ por $1 b^{21}$ e $1 b^{22}$ à esquerda. Os blastômeros $2 b^{211}$ e $2 b^{121}$ foram observados com nitidez até cerca de 43 horas após a primeira clivagem, por apresentarem uma coloração diferente das células que os rodeiam. Presume-se que estas mesmas células não se dividem mais e irão se situar na região externa da fileira de células constituída pela descendência de $2 b^{122}$ e $2 b^{212}$.

Voltando à descrição geral deste segundo quarteto, observou-se que, desde o estádio de 33 blastômeros (10 horas após a primeira clivagem), o quarteto inferior $2 \mathrm{a}^{22}-2 \mathrm{~d}^{22}$ permace sem clivar, retornando novamente á atividade quando o embrião atinge 92 blastômeros (18 horas após a primeira clivagem). $O$ primeiro a se clivar é o $2 \mathrm{~b}^{22}$, no sentido horizontal; e em seguida, o $2 \mathrm{~d}^{22}$ se cliva no mesmo sentido (20 horas após a primeira clivagem); a célula filha $2 \mathrm{~d}^{221}$ penetra entre os descendentes de $2 d^{212}$ e $2 d^{122}$ (Figura 2-18).

Enquanto $M_{1}$ e $M_{2}$ (mesoblasto primário) estiveram visíveis na região do pólo vegetativo, a célula $2 \mathrm{~d}^{22}$ permaneceu sem se clivar (Figura 2-17). Após o desaparecimento destas células do mesoblasto primário da superfície do embrião, entretanto, ocorreu a clivagem do $2 \mathrm{~d}^{22}$ (Figura 2-18). Cerca de 26 horas após a primeira clivagem, observou-se a divisão meridional da célula $2 \mathrm{~d}^{221}$ na região próxima ao blastóporo.

A clivagem seguinte se verifica em $2 a^{22}$ e $2 c^{22}$ no sentido ligeiramente oblíquo (21 horas após a primeira clivagem), ficando estas células em limite com os endômeros (Figura 2-18).

As células $2 \mathrm{a}^{22}, 2 \mathrm{~b}^{22} \mathrm{e} 2 \mathrm{c}^{22}$ foram consideradas por Holmes (1900) apud Raven (1958) como "estomoblastos", porque fazem parte da região periférica do blastóporo e mais tarde vão formar o estomódeo.

\section{O desenvolvimento do terceiro quarteto de micrômeros}

A seqüência de divisão deste quarteto é representada na Figura 5.

$\mathrm{O}$ terceiro quarteto de micrômeros ( $3 \mathrm{a}-3 \mathrm{~d}$ ) se forma pela primeira vez no estádio de 24 blastômeros (Figura 2-6). A clivagem seguinte ocorre quando o 
embrião atinge 45 células, dando origem a $3 a^{1}-3 d^{1}$ e $3 a^{2}-3 d^{2}$ (Figura 2-11). Estas oito células situam-se inter-radialmente, entre o segundo quarteto de micrômeros descendentes de $2 a^{1}-2 d^{1}$ e $2 a^{2}-2 d^{2}$ (Figura 2-10). O quarteto superior $3 a^{1}-3 d^{1}$ está em conexão com o trocoblasto $1 a^{2}-1 d^{2}$, enquanto que $3 a^{2}-3 d^{2}$ se acha em contato com os macrômeros no pólo vegetativo.

A partir deste estádio, ocorre uma sincronia no desenvolvimento deste quarteto. Os blastômeros $3 a^{1}$ e $3 b^{1}$, situados na parte ventral do embrião, permanecem sem se clivar até cerca de 16 horas após a primeira clivagem (Figura 2-13), enquanto $3 a^{2}$ e $3 b^{2}$ se clivam cerca de 2 horas antes. Na região dorsal, porém, ocorre o oposto: as células $3 c^{1}$ e $3 d^{1}$ (Figura 2-12) se clivam cerca de quatro horas antes de $3 c^{2}$ e $3 d^{2}$ que só se clivam cerca de 18 horas após a primeira clivagem (Figura 2-17).

O primeiro blastômero do quarteto superior a se clivar é $3 \mathrm{~d}^{1}$, que o faz em divisão bilateral, no estádio de 51 blastômeros. Em seguida, $3 a^{2}, 3 b^{2}$ e $3 c^{1}$ se clivam também no mesmo sentido, atingindo o embrião no estádio de 55 blastômeros.

Um aspecto inconfundível no pólo vegetativo é delineado neste estádio, cerca de 15 horas após a primeira clivagem (Figura 2-13), em razão da diferença na direção de clivagem entre as células que se localizam na parte ventral $\left(3 a^{21}, 3 a^{22}\right.$, $3 b^{21}$ e $3 b^{22}$ ) e a parte dorsal $\left(3 c^{2}\right.$ e $\left.3 d^{2}\right)$ deste quarteto. As clivagens que se seguem são nas células $3 a^{1}$ e $3 b^{1}$ no sentido bilateral.

Os blastômeros $3 \mathrm{~d}^{11}$ e $3 \mathrm{~d}^{12}$ se clivam horizontalmente dando origem a células filhas cuja metade superior $3 d^{111}$ e $3 d^{121}$ apresentam a superfície maior que a inferior, $3 d^{112}$ e $3 d^{122}$.

A clivagem continua nos blastômeros $3 a^{21}$ e $3 b^{21}$ no sentido horizontal com ligeiro desvio para a direita, enquanto que em $3 \mathrm{a}^{22}$ e $3 \mathrm{~b}^{22}$ é no sentido sinistrorso. Os blastômeros $3 c^{11}$ e $3 c^{12}$ se clivam do mesmo modo que $3 d^{11}$ e $3 d^{12}$. O embrião neste período atinge o estádio de 76 células, das quais 22 pertencem ao terceiro quarteto de micrômeros.

Os blastômeros $3 \mathrm{c}^{2}$ e $3 \mathrm{~d}^{2}$ se clivam bilateralmente, no estádio de 97 células (18 horas após a primeira clivagem). As células da geração $3 a$ e $3 b\left(3 a^{211}, 3 a^{221}, 3 b^{211}\right.$. e $3 b^{221}$ ) se clivam bilateralmente (Figura 2-18).

A próxima clivagem acontece nas células $3 \mathrm{c}^{111}, 3 \mathrm{c}^{121}, 3 \mathrm{~d}^{111}$ e $3 \mathrm{~d}^{121}$, no sentido horizontal. Neste estádio, o embrião atinge 106 células, das quais 31 pertencem ao terceiro quarteto de micrômeros.

Em seguida, as células $3 b^{11}$ e $3 b^{12}$ se clivam no sentido horizontal, seguida pelas células $3 \mathrm{a}^{11}$ e $3 \mathrm{a}^{12}$ no mesmo sentido, alcançando o embrião um número total de 125 blastômeros. 
Na região ventral do embrião, há um grupo de células pequenas originadas pela divisão de $3 a^{2}$ e $3 b^{2}$ (Figura 2-18). Estas células provalvelmente irão formar o mesoblasto secundário.

O estudo da divisão deste quarteto foi observado até o estádio de 130 células, das quais 36 pertencentes ao terceiro quarteto de micrômeros.

\section{Endômeros}

\section{O quarto quarteto de micrômeros}

A seqüência da divisão do quarto quarteto de micrômeros é apresentada na Figura 5.

No período em que o embrião atinge o estádio de 40 blastômeros, observa-se pela primeira vez a formação dos endômeros $4 \mathrm{a}, 4 \mathrm{~b}$ e $4 \mathrm{c}$, separando-se dos macrômeros 4A, 4B e 4C (11 horas após a primeira clivagem). Na Figura 2-10, um embrião no estádio 45 células se apresenta com os endômeros $4 a, 4 b$ e $4 c$.

Os endômeros $4 \mathrm{a}-4 \mathrm{c}$ se clivam no sentido bilateral, quando o embrião atinge 64 células (Figura 2-13). A partir desta clivagem, as células se organizam em forma de ferradura (4a1, 4a2, 4b1, 4b2, $4 \mathrm{c} 1$ e $4 \mathrm{c} 2$ ), circundando os macrômeros. $O$ primeiro endômero a se clivar é o $4 \mathrm{a}^{1}$ (16 horas após a primeira clivagem) no sentido sinistrorso: 0 embrião atinge o total de 76 células. $O$ próximo a se clivar é $4 c^{2}$ (17 horas após a primeira clivagem) no sentido dextrorso: o embrião atinge $o$ total de 80 células. Em seguida se cliva $4 b^{1}$ (17 horas após a primeira clivagem), no sentido sinistrorso, alcançando o embrião o total de 83 blastômeros.

A clivagem seguinte ocorre em $4 a^{2}$ e $4 b^{2}$, no sentido sinistrorso, enquanto $4 c^{1}$ o faz no sentido dextrorso; o embrião atinge assim 92 células, das quais 12 endômeros pertencentes à geração $4 a-4 c$. A próxima clivagem nesta região ocorre na fase de 130 blastômeros. Os endômeros $4 b^{11}, 4 b^{21}$ e $4 b^{22}$ se cliva bilateralmente.

\section{O quinto quarteto de micrômeros}

Os macrômeros, depois da origem dos endômeros, permanecem sem se clivar até o embrião atingir 92 células. A partir deste momento, o macrômero $4 \mathrm{~A}$ se cliva (18 horas após a primeira clivagem), sendo seguido por 4B. O macrômero $4 \mathrm{C}$ se cliva (20 horas após a primeira clivagem), e o embrião atinge 111 células.

Até o estádio de 130 blastômeros, foi observada apenas a formação da $5 \mathrm{a}, 5 \mathrm{~b}$ e $5 c$ que se destacam entre os macrômeros e os descendentes do quarto quarteto (Figura 2-18).

Em B.glabrata foi observada a divisão de 4D antes da gastrulação. 


\section{O mesoblasto primário}

O período de repouso é uma característica no desenvolvimento embrionário dos moluscos, quando atingem o estádio de 24 blastômeros. Este período se prolonga por cerca de 3 horas, quando o embrião entra novamente em atividade de clivagem com o macrômero 3D. Esta célula dá origem ao mesoblasto primário $\mathbf{M}(4 \mathrm{~d})$, (Figura 2-8). Em B. glabrata esta clivagem é no sentido dextrorso.

A primeira clivagem do mesoblasto primário ocorre quando o embrião atinge 45 células, no sentido ligeiramente oblíquo. No início da clivagem, as células $\mathbf{M}_{1} \mathrm{e}$ $\mathbf{M}_{2}$ mostram a superfície relativamente grande (Figura 2-10). Entretanto, durante o desenvolvimento a superfície destas células vai diminuindo (Figura 2-17).

Em B. glabrata, $\mathbf{M}_{1}$ e $\mathbf{M}_{2}$ permanecem na superfície até o estádio, de 106 blastômeros (Figura 2-17). Neste estádio porém, é visível somente pequena superfície triangular das células que se destacam entre o macrômero $4 \mathrm{D}$ e a célula $2 \mathrm{~d}^{22}$. Em todas as preparações, observou-se que a ausência de $M_{1}$ e $\mathbf{M}_{2}$ da superfície do embrião coincidia com a clivagem de $2 \mathrm{~d}^{22}\left(2 \mathrm{~d}^{221}\right.$ e $\left.2 \mathrm{~d}^{222}\right)$ (Figura 2-18).

Em $B$. glabrata e L. stagnalis, a linhagem celular de todos os quartetos de micrômeros foi estudada até o estádio de 130 blastômeros respectivamente. A partir deste estádio estudou-se especificamente a região cefálica do molusco.

\section{Gastrulação}

A gastrulação é uma etapa do desenvolvimento embrionário que nclui o final da clivagem das células; há, portanto, o início do crescimento, da diferenciação e da movimentação celular.

A gastrulação ocorre, tanto em $B$. glabrata quanto em $L$. stagnalis, por invaginação ou endobolia, 26 horas após a primeira clivagem. Inicialmente, 0 embrião sofre um achatamento na região do pólo animal em direção ao pólo vegetativo.

A princípio, verifica-se a penetração dos macrômeros $5 \mathrm{~A}-5 \mathrm{C}$, seguida pelos endômeros $5 \mathrm{a}-5 \mathrm{c}$ e os descendentes de $4 \mathrm{a}$ - $4 \mathrm{c}$. À medida que as células vão-se movimentando para o interior, a concavidade irá aumentando, formando inicialmente uma abertura esférica que vai-se fechando gradualmente. A abertura, que é o blastóporo, com o desenvolvimento vai sendo reduzida, pela aproximação lateral dos lábios, transformando-se mais tarde numa fenda. Esta abertura se comunica com o exterior até cerca de 39 horas após a primeira clivagem. Então, fecha-se completamente, permanecendo só a imagem virtual da abertura. Mais tarde, no final da gastrulação haverá o aparecimento da boca nesta região. 
No estádio inicial da gastrulação, o blastóporo se encontra situado ao lado oposto da figura em cruz, no pólo vegetativo original. Com o decorrer do desenvolvimento, ele será deslocado para a região ventral do embrião, sob as células $2 b^{2211}$ e $2 b^{2212}$. Na Figura 2-22, um embrião no estádio de gástrula é apresentado. A característica da fase inicial da gastrulação é a deformação da figura em cruz, em razão do alargamento do braço ventral da cruz.

\section{Trocófora}

Nesta fase larvária a $B$. glabrata apresenta-se com uma dupla fileira celular situada na região acima da boca, o prototroco (Figura 2-27 e 28). Observa-se uma série de cílios que recobrem a super-fície destas células e que auxiliam na movimentação da larva. O prototroco separa o corpo em duas partes, a região prétrocal e a pós-trocal. Assim, ele circunda a parte ventral e lateral da região pré-trocal. A região dorsal, porém, é formada por um grupo de células, a vesícula cerebral, que se apresenta sem cílios.

A Figura 3 ilustra a linhagem celular da região cefálica do molusco.

A região pré-trocal é contituída por um conjunto de células, na parte mediana central, a placa apical. Lateralmente a esta placa apical, se encontram as placas cefálicas (conjunto de células pequenas). A parte dorsal destas formações é margeada por células maiores que constituem a vesícula cerebral. Esta vesícula cerebral se encontra em contato com ambos os braços laterais da fileira superior do prototroco. A boca está situada na parte ventral do prototroco. Distingue-se, também, na região logo abaixo da boca, "a banda ciliar pós-trocal", que separa duas regiões de células pequenas que formarão o pé. Na região dorsal oposta à boca, encontra-se a glândula da concha, com uma delgada concha já formada, localizandose numa posição simétrica á boca. Este estádio larvário em Biomphalaria transcorre, ainda, dentro da cápsula do ovo, como no caso de outros pulmonados. As diferentes partes que constituem a região cefálica da larva, serão descritas em seguida.

\section{Prototroco (Pr.)}

Em B. glabrata o prototroco é constituído por uma dupla fileira de células, uma superior formada pelas células terminais do braço ventral da cruz $2 b^{111}$ e $2 b^{112}$, situadas no centro e na parte ventral do prototroco e que estão ligadas à direita com $1 \mathrm{a}^{21}, 1 \mathrm{a}^{22} \mathrm{e}$ à esquerda com as células $1 \mathrm{~b}^{21}$ e $1 \mathrm{~b}^{22}$ (Figura 2-27). A segunda fileira, inferior, que está situada logo acima da boca, constituída pelos descendentes das células $2 b^{212}$ e $2 b^{122}$ e pelas células $2 b^{211}$ e $2 b^{121}$. 
Logo após a clivagem da célula terminal do braço ventral $2 b^{11}$, cerca de 23 horas após a primeira clivagem, $2 b^{111}$ e $2 b^{112}$ se localizarão entre as duas células $2 b^{121}$ e $2 b^{211}$ (Figuras 2-21 e 22). Com o decorrer do desenvolvimento, há um alargamento na superfície das células $2 b^{212}$ e $2 b^{122}$. Aproximadamente 28 horas após a primeira clivagem, $2 b^{212}$ e $2 b^{122}$ entram em segmentação, deslocando as células $2 b^{121}$ e $2 b^{211}$ para um nível mais inferior em relação $a b^{111}$ e $2 b^{112}$.

Cerca de 30 horas após a primeira clivagem, observa-se uma reduzida área de ligação entre as células de $2 b^{111}$ e $2 b^{211}$ à direita e $2 b^{112}$ e $2 b^{121}$ esquerda da larva. A conexấo vai desaparecendo entre as duas células, em ambos os lados, à medida que a larva atinge cerca de 34 horas, após a primeira clivagem (Figura 2-24).

As células terminais da cruz $2 b^{111}$ e $2 b^{112}$, que inicialmente também se encontravam ligadas entre si com grande superfície de contato (Figuras 2-21 e 22) vão aos poucos sendo afastadas pela descida do blastômero $1 b^{1211}$ (Figuras 2-25 e 26). A descida desta célula tem início após a segmentação de $1 b^{122}$, em $1 b^{1221}$ e $1 b^{1222}$. Os blastômeros $1 b^{1221}$ e $1 b^{1222}$ permanecem interligados ventralmente acima das células $2 b^{111}$ e $2 b^{112}$, até aproximadamente 40 horas após a $1^{\text {a }}$ clivagem do ovo.

$O$ afastamento das células $1 b^{1221}$ e $1 b^{1222}$ é sempre completo, porém as células terminais do braço ventral $2 b^{111}$ e $2 b^{112}$ ou podem permanecer ligadas até um estádio bem mais avançado (Figura 2-27) ou serem completamente afastadas pela célula apical $1 b^{1211}$ (Figura 2-28). Quando unidas formam a fileira superior do prototroco, que é a seguinte: $1 a^{21}, 1 a^{22}, 2 b^{111}, 2 b^{112}, 1 b^{21} e 1 b^{22}$.

A camada inferior do prototroco, contudo, é constituída pelos descendentes de $2 b^{212}$ e $2 b^{122}$ e pelas células $2 b^{211}$ e $2 b^{121}$ (estas últimas permanecem durante vários estádios posteriores, sem indicação de clivagem formada de nove células de cada lado).

Em comparação com a larva de L.stagnalis que só possui oito células $\left(1 b^{1221}\right.$, $1 b^{1222}, 2 b^{111}, 2 b^{112}, 1 a^{21}, 1 a^{22}, 1 b^{21}$ e $1 b^{22}$ ) esta estrutura em B.glabrata é bem mais desenvolvida.

\section{EM B. glabrata, PRIMEIRA FILEIRA:}

Células terminais do braço ventral da cruz:

$2 b^{111}$ e $2 b^{112}$

\section{Células do trocoblasto anterior:}

$$
\begin{aligned}
& 1 a^{21} \text { e } 1 a^{22} \\
& 1 b^{21} \text { e } 1 b^{22}
\end{aligned}
$$




\section{SEGUNDA FILEIRA:}

Células do segundo quarteto de micrômeros:

$$
2 b^{121} \text { e } 2 b^{211}
$$

\section{Descendentes das células:}

$$
2 b^{122} \text { e } 2 b^{212}
$$

Em alguns casos, as células que compõem a segunda fileira do prototroco estão em contato com a região das placas cefálicas, separando, portanto, o $2 b^{111}$ ou $2 b^{112}$ de sua conexão com $01 a^{21}$ ou $1 b^{21}$. Isto foi possível distinguir em razão da coloração transparente das células que constituem a primeira fileira, em contraste com cor escura dos componentes da segunda fileira do prototroco.

\section{Placa apical (P.A)}

A placa apical é composta por sete células, com revestimento ciliar, e são relativamente volumosas, situadas entre as placas cefálicas no meio da região da cabeça (Figura 2-28).

As quatro células dorsais são as células da roseta apical $1 a^{111}-1 d^{111}$, as quais permanecem sem se dividir desde a formação das células da roseta periférica. As duas células $1 a^{1121}$ e $1 b^{1121}$ estão na parte ventral destas quatro células e "são originadas pela clivagem das células da roseta periférica. A célula basal do braço ventral $1 b^{1211}$ é o último componente da placa apical. Situa-se quase sempre na parte superior dos descendentes de $2 b^{212}$ e $2 b^{122}$, isto é, acima da boca da larva. Contudo, há casos em que $2 b^{111}$ e $2 b^{112}$ podem estar na parte inferior do $1 b^{1211}$ e acima dos descendentes de $2 b^{212}$ e $2 b^{122}$. A disposição destas células pode sofrer variação em diferentes larvas mas, em geral, a posição das células da roseta apical é constante: $1 a^{111}$ se encontra em conexão com $1 c^{111}$, enquanto que $1 b^{111}$ e $1 d^{111}$ são separados.

\section{Células que constituem a placa apical:}

As células da roseta apical:

$$
1 \mathrm{a}^{111}-1 \mathrm{~d}^{111}
$$

Células da roseta periférica:

$$
1 a^{1121}-1 b^{1121}
$$

Célula basal do braço ventral da cruz: 
Placas cefálicas (P.C.)

O rudimento destas placas se origina interinamente da primeira geração de ectômeros (Figura 2-28). Acompanhando-se o seu desenvolvimento desde o estádio inicial da cruz, observa-se que a parte dorsal destas placas é constituída pelas gerações das células da roseta periférica $1 \mathrm{~d}^{112}$ à direita e $1 \mathrm{c}^{112}$ à esquerda da larva, (estas células são visíveis nos embriões vistos nas Figuras 2-19 e 20). Mais para o centro, à direita, é formada pelos descendentes da célula basal $1 a^{1211}$ e da geração da célula mediana interna, $1 \mathrm{a}^{1212}$. No lado esquerdo tem-se o equivalente: a geração de $1 \mathrm{c}^{1211}$ e $1 \mathrm{c}^{1212}$. Na parte ventral, nota-se o desligamento das células $1 \mathrm{a}^{1122}$ e $1 \mathrm{~b}^{1122}$ que irão se localizar respectivamente à direita e à esquerda da larva, para formação das placas cefálicas (Figura 2-23).

Seguindo-se o desenvolvimento da célula mediana interna do braço ventral da cruz 1 b1212, verifica-se que, logo após a sua primeira clivagem, as células filhas $1 b^{12121}$ e $1 b^{12122}$ se limitam por grande superfície de contato (Figuras 2-20 e 21). Com o decorrer do tempo, porém, elas são gradativamente separadas, pela descida da célula básica ventral $1 b^{1211}$ (Figura 2-22). Portanto, antes da próxima clivagem elas se encontram completamente separadas indo localizar-se lateralmente (Figura 2-23). Finalmente, do braço ventral da cruz, a célula medina externa $1 b^{122}$ é a primeira a se segmentar. Seguindo-se a esta divisão $1 b^{1221}$ e $1 b^{1222}$ permanecem em contato íntimo (Figura 2-24); aos poucos, as mesmas começam a se separar pela descida da célula $1 b^{1211}$ (Figura 2-25) até serem completamentedesligadas um da outra, aproximadamente 40 horas após a primeira clivagem (Figura 2-26). Cerca de 42 horas após a primeira clivagem, as células $1 b^{1221}$ e $1 b^{1222}$ se segmentam pela primeira vez e são pressionadas para a direção lateral da larva, fazendo parte portanto das placas cefálicas.

Em L. stagnalis (Verdonk, 1965) estas duas células $1 b^{1221}$ e $1 b^{1222}$ pertencem ao prototroco. Em B. glabrata a linhagem celular destas células foi cuidadosamente observada.

\section{Cada placa cefálica se compōe de:}

\begin{tabular}{|c|c|c|}
\hline \multirow{3}{*}{$\begin{array}{l}\text { parte } \\
\text { dorsal }\end{array}$} & lado direito & lado esquerdo \\
\hline & $1 d^{1121}$ & $1 c^{1121}$ \\
\hline & $11 d^{1122}$ & $1 c^{1122}$ \\
\hline trte & $1 a^{12111}$ & $1 c^{12111}$ \\
\hline ntral & $1 \mathrm{a}^{12112}$ & $1 c^{12112}$ \\
\hline & $1 \mathrm{a}^{12121}$ & $1 c^{12121}$ \\
\hline
\end{tabular}


$1 \mathrm{a}^{12122}$

parte

ventral
$1 \mathrm{a}^{1122}$

$1 b^{12121}$

$1 b^{1221}$
$1 b^{1122}$

$1 b^{12122}$

$1 b^{1222}$

Observando-se o tamanho, o número e a posição das células que compõem as placas cefálicas, elas parecem ser completamente simétricas, embora tenham sido derivadas diferentemente. Assim, a placa cefálica ao lado direito se origina dos três quadrantes ( $a, b$ e d) enquanto que a do lado esquerdo somente de dois (b e c). Isto devido a posição do quadrante que está situado à direita do eixo mediano da larva.

\section{Vesícula cerebral (V.C.)}

Abrangendo a parte dorsal da placa apical e das placas cefálicas, encontram-se 12 céluluas maiores, componentes da vesícula cerebral (Figura 2-28). O embrião no estádio de 83 células (18 horas após a primeira clivagem) já possui todos os constituintes da vesícula cerebral (Figura 2-14), exceto o blastômero $1 \mathrm{~d}^{121}$ que se cliva posteriormente (aproximadamente 21 horas e $30 \mathrm{~min}$. Após a primeira clivagem), originando as células filhas $1 \mathrm{~d}^{1211}$ e $1 \mathrm{~d}^{212}$.

Todas as células que constituem o braço dorsal da cruz vão contribuir para formação da vesícula cerebral.

As células $1 \mathrm{~d}^{1212}$ (célula mediana interna) e $1 \mathrm{~d}^{122}$ (célula mediana externa) são

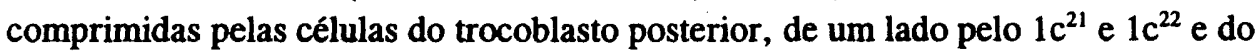
outro pelo $1 \mathrm{~d}^{21}$ e $1 \mathrm{~d}^{22}$. Esta situação se prolonga durante cerca de 15 horas (no intervalo a partir de 28 até 43 horas após a primeira clivagem). Depois deste periodo, as células se alargam e se comprimem uma sobre a outra.

Para o lado esquerdo do braço posterior da cruz, as células do trocoblasto posterior $1 \mathrm{c}^{21}$ e $1 \mathrm{c}^{22}$, a célula mediana externa $1 \mathrm{c}^{122}$ e a célula terminal do braço lateral $2 c^{11}$, irão formar a vesícula cerebral. Do lado direito da larva, as células do trocoblasto posterior, $1 \mathrm{~d}^{21}$ e $1 \mathrm{~d}^{22}$, a célula mediana externa $1 \mathrm{a}^{122}$ e a célula terminal do braço lateral $2 a^{11}$ completarão o conjunto que formará a vesícula cerebral.

Em geral, as quatro células $1 \mathrm{a}^{122}, 1 \mathrm{~d}^{22}, 1 \mathrm{c}^{22}$ e $1 \mathrm{c}^{122}$ são fortemente coradas com o nitrato de prata, destacando-se das demais.

Em algumas larvas foi observada divisão da célula $1 d^{122}$, que normalmente não se segmenta, elevando a 13 o número total de células. 
Formação da vesícula cerebral:

Células do braço dorsal da cruz:

$$
\begin{aligned}
& 1 d 1^{211} \text { e } 1 d^{1212} \\
& 1 d^{122} \text { e } 2 d^{11}
\end{aligned}
$$

\section{Trocoblasto posterior:}

$$
\begin{aligned}
& 1 c^{21} \text { e } 1 c^{22} \\
& 1 d^{21} \text { e } 1 d^{22}
\end{aligned}
$$

Células dos braços laterais da cruz:

$$
\begin{aligned}
& 1 \mathrm{a}^{122} \text { e } 2 \mathrm{a}^{11} \\
& 1 \mathrm{c}^{122} \text { e } 2 \mathrm{c}^{11}
\end{aligned}
$$

\section{Veliger}

Em B. glabrata esta fase do desenvolvimento larvário ocorre dentro da cápsula do ovo.

O estágio de "veliger jovem" ocorre de 96 horas após a primeira clivagem (Figura 2-29). O prototroco se transforma no órgão mais evoluído, o velum, havendo também desenvolvimento maior da concha e do pé. A concha no estágio de trocófora situa-se simetricamente em relação à boca.

No veliger, porém, verifica-se o início da assimetria pelo desvio da concha, que sofre torção para o lado direito. Neste estádio, as células que compõem o velum se encontram comprimidas entre as células das placas cefálicas e as células que se encontram acima da região da boca. Em geral, na parte ventral há uma fileira de células (geração de $2 b^{212}$ e $2 b^{122}$ ). As duas células terminais do braço ventral da cruz se separam, alojando-se lateralmente. Os blastômeros que formam a placa apical e a vesícula cerebral permanecem sem se alterar, desde o estádio de trocófora. Os das placas cefálicas, porém, continuam a se dividir, mostrando a presença de várias células pequenas na futura região, onde se formarão os tentáculos e os olhos. $\mathrm{Na}$ parte ventral do velum, observa-se uma parte característica que compreende a região do pé.

No veliger mais evoluído, ou "hippo stage" (Raven, 1949), o aparecimento dos olhos, que, a princípio, se evidenciam como um halo pigmentado na região das placas cefálicas (região tentacular, Figura 2-30). Em $L$. stagnalis também o gânglio cerebral tem origem na região tentacular. A região pré-trocal se apresenta mais desenvolvida com o esboço dos tentáculos que se formam na região tentacular. $\mathrm{Na}$ região pós-trocal, contudo, o pé se encontra bem mais diferenciado, aumentando de 
tamanho. O velum vai sendo comprimido cada vez mais, principalmente na sua parte lateral.

Nesta fase, se observa o início do enrolamento da concha e mais tarde o seu crescimento. Neste estádio há a formação quase completa de um caramujo jovem.

O estádio de veliger mais evoluído ou "hippo stage" foi o período final no estudo do desenvolvimento normal. Ainda neste período, certas estruturas larvárias se encontram distintas. A $25^{\circ} \mathrm{C}$ o caramujo pode eclodir, a partir do sexto dia após primeira clivagem.

Principais diferenças entre as linhagens celulares das espécies Limnaea stagnalis e Biomphalaria glabrata

1. Em L. stagnalis a clivagem é dextrorsa ou padrão e em $B$. glabrata é sinistrorsa ou reversa.

2. Em L. stagnalis, Verdonk (1965) observou que a divisão dacélula basal do braço dorsal da cruz $1 \mathrm{~d}^{121}$ se faz no sentido paralelo á direção do braço dorsal da cruz; os blastômeros ( $1 \mathrm{~d}^{1211}$ e $1 \mathrm{~d}^{1212}$ ) se alojam um ao lado do outro. Em B. glabrata, entretanto, esta mesma célula $1 \mathrm{~d}^{121}$ se divide num plano em ângulo reto em relação ao braço dorsal (Camey \& Verdonk, 1970) e os blastômeros se alojam um acima do outro.

3. Em $L$. stagnalis as células medianas externas do braço ventral da cruz, $1 b^{1221}$ e $1 b^{1222}$, irão fazer parte do prototroco, permanecendo sem se dividir. Em $B$. glabrata, estas células $1 b^{1221}$ e $1 b^{1222}$ irão tomar parte na formação das placas cefálicas e, portanto, se dividem diversas vezes.

\section{AGRADECIMENTOS}

A autora agradece:

Ao Prof. Dr. N.H. Verdonk que foi orientador do trabalho de Embriologia de B. glabrata, realizado na Holanda. A Dra. Maria Nazareth Rabello-Gay, pela leitura, críticas e sugestões do texto.

A parte de datilografia a Cristina Antonia Albuquerque das Chagas. 


\section{TÓPICOS EM MALACOLOGIA MÉDICA}

\section{FIGURAS}

FIGURA 1-1A: Ovo indiviso de $B$. glabrata, com os dois corpúsculos polares

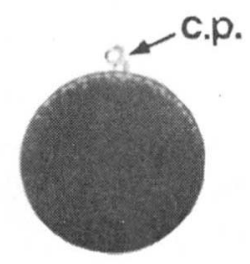

FIGURA 1-1B: Início do sulco de clivagem no pólo animal (hora 0)

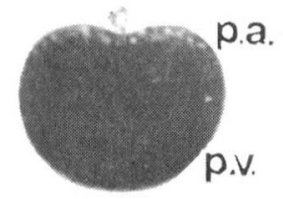

FIGURA 1-2: Sulco de clivagem, 3 minutos após o estádio 1B ou primeira clivagem

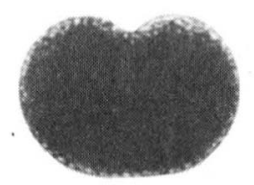

FIGURA 1-3: Sulco de clivagem, 4 minutos

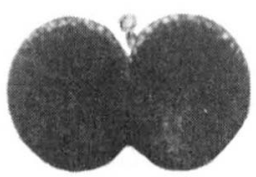




\section{EMBRIOLOGIA}

FIGURA 1-4: Os dois blastômeros ligados somente por uma pequena superfície citoplasmática, 10 minutos

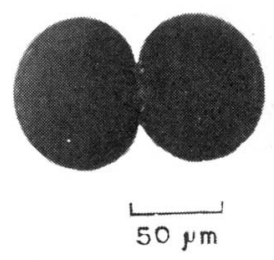

FIGURA 1-5: Os dois blastômeros com maior superfície de contato, 21 minutos

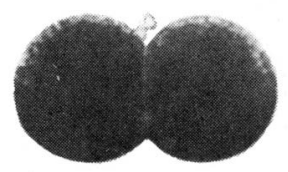

FIGURA 1-6/7: Os dois blastômeros continuando com a superfície de contato, 26 e 38 minutos respectivamente
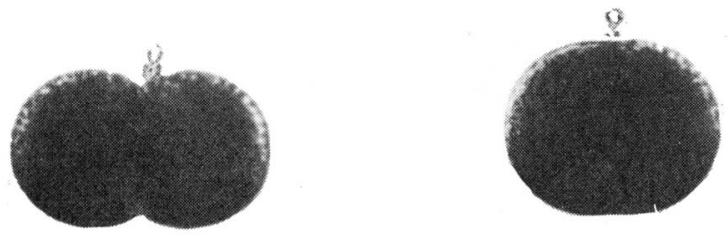


\section{TÓPICOS EM MALACOLOGIA MÉDICA}

FIGURA 1-8: Início da cavidade de clivagem, 45 minutos

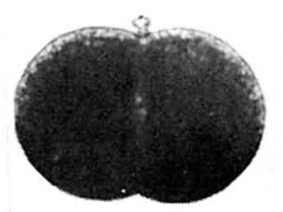

FIGURA 1-9: Cavidade de clivagem mais nítida, 75 minutos

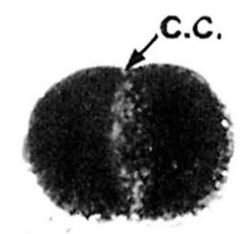

FIGURA 1-10: Segunda clivagem, 80 minutos após a primeira clivagem

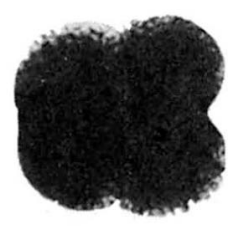




\section{EMBRIOLOGIA}

FIGURA 1-11: Os quatro blastômeros nítidos, 91 minutos

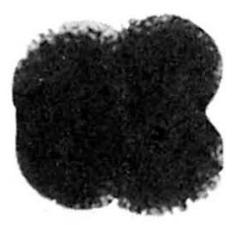

FIGURA 1-12/13: Início da cavidade de clivagem entre os dois blastômeros, 98 a 103 minutos respectivamente
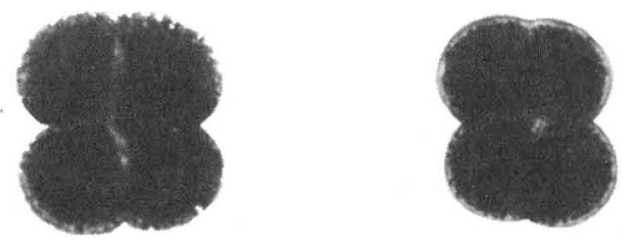

FIGURA 1-14/15: Superfície quase arredondada dos blastômeros, 123 e 134 minutos respectivamente
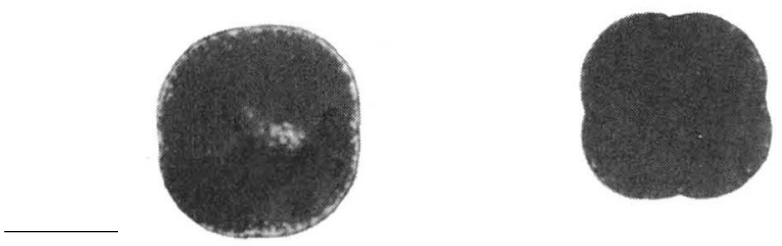


\section{TÓPICOS EM MALACOLOGIA MÉDICA}

FIGURA 1-16: Início da terceira clivagem - formação do primeiro quarteto de micrômeros, 160 minutos após a primeira clivagem

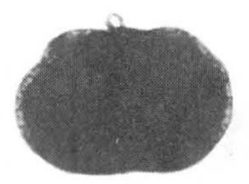

FIGURA 1-17: Terceira clivagem, 165 minutos

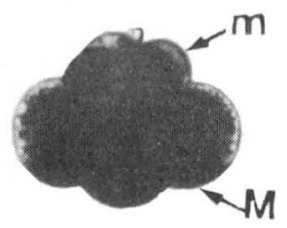

FIGURA 1-18/19: os blastômeros unidos, 173 e 181 minutos respectivamente
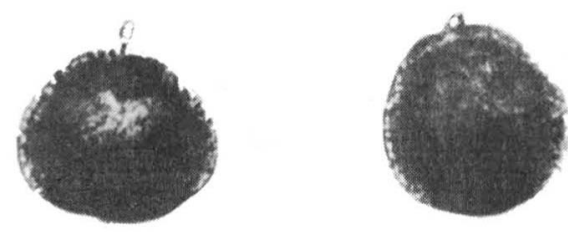
FIGURA 1-20: Quarta clivagem, 230 minutos após a $1^{\text {a }}$ clivagem
c.p. $=$ corpúsculo polar
p.a. $=$ pólo animal
p.v. = pólo vegetativo
c.c. $=$ cavidade de clivagem
$\mathrm{m} .=$ micrômero
M. = macrômero

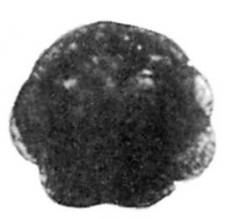

FIGURA 2-1: Primeira clivagem, estádio de dois blastômeros

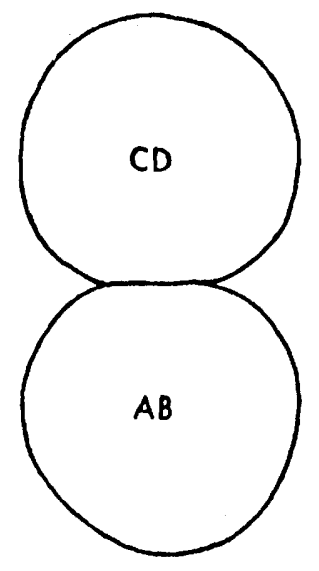

FIGURA 2-2: Segunda clivagem, estádio de quatro blastômeros, 80 minutos após a primeira clivagem

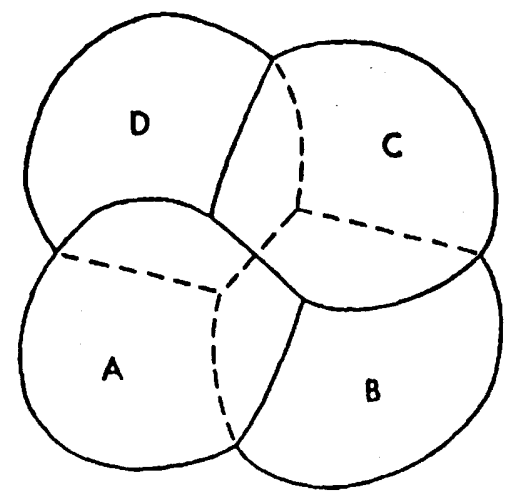


FIGURA 2-3: Terceira clivagem, estádio de oito blastômeros, primeiro quarteto de micrômeros (1a-1d) 160 minutos após a primeira clivagem

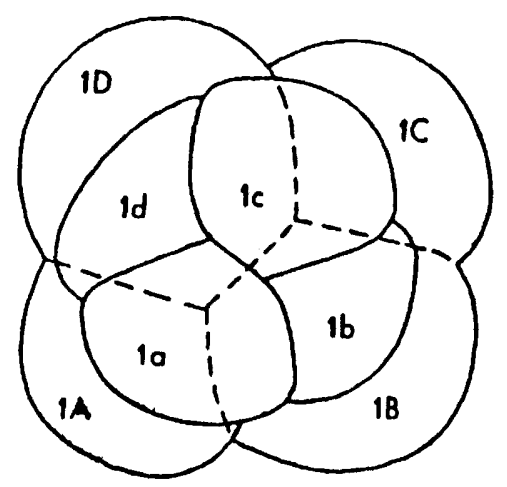

FIGURA 2-4: Quarta clivagem, estádio de 12 blastômeros, o segundo quarteto (2a - 2d) está situado na posição dexiotrópica com relação aos macrômeros (2A - 2D)

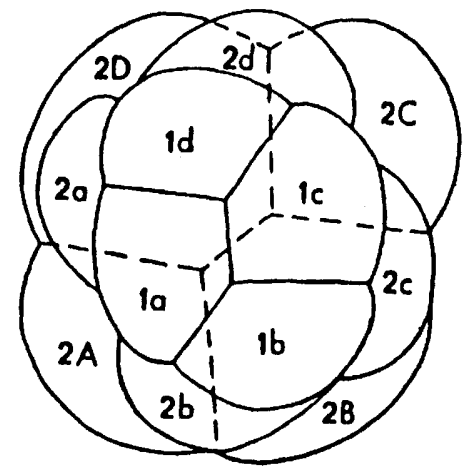

FIGURA 2-5: Quinta clivagem, estádio de 16 blastômeros, o trocoblasto primário $1 \mathrm{a}^{2}-1 \mathrm{~d}^{2}$ é formado, 5 horas após a primeira clivagem

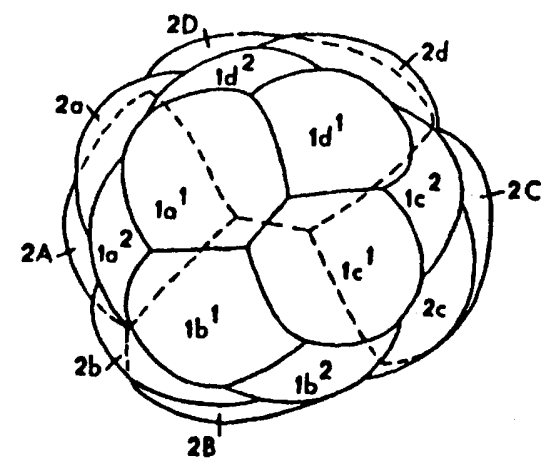




\section{EMBRIOLOGIA}

FIGURA 2-6: Estádio de 24 blastômeros, 6 horas após a primeira clivagem

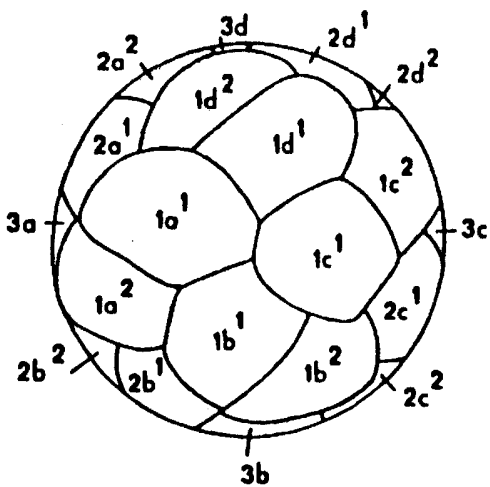

FIGURA 2-7: Estádio de 24 blastômeros, vista pelo pólo vegetativo. O macrômero 3D é caracterizado pela forma arredondada, 7 horas após a primeira clivagem

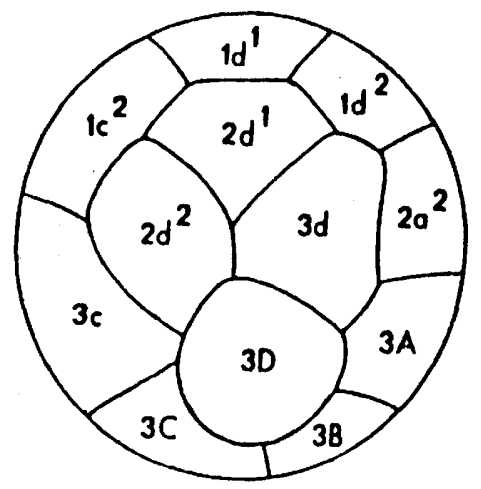

FIGURA 2-8: Estádio de 25 blastômeros (pólo vegetativo). $\mathrm{O}$ mesoblasto primário $4 \mathrm{~d}$ ou $\mathrm{M}$ se forma, 9 horas após a primeira clivagem do ovo

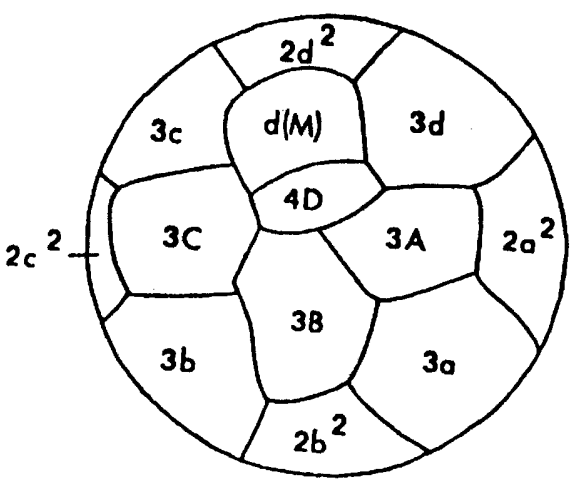




\section{TÓPICOS EM MALACOLOGIA MÉDICA}

FIGURA 2-9/10: Estádio de 33 blastômeros (pólo animal), 10 horas após a primeira clivagem. Estádio de 45 blastômeros (pólo vegetativo). $\mathrm{O}$ mesoblasto primário sofreu a clivagem $\left(M_{1}-M_{2}\right), 12$ horas após a primeira clivagem
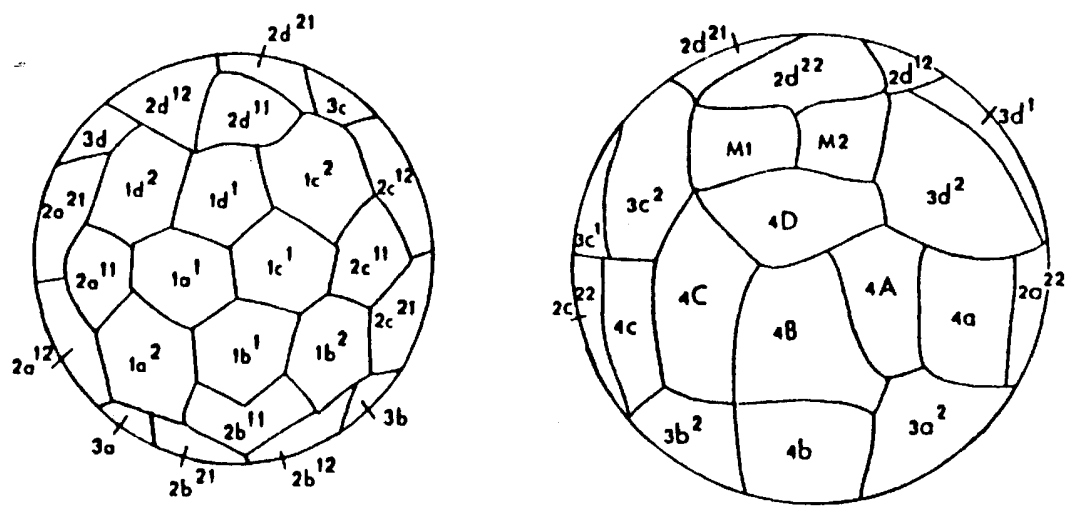

FIGURA 2-11: Estádio de 45 blastômeros (pólo animal), primeira indicaçāo da figura em Cruz

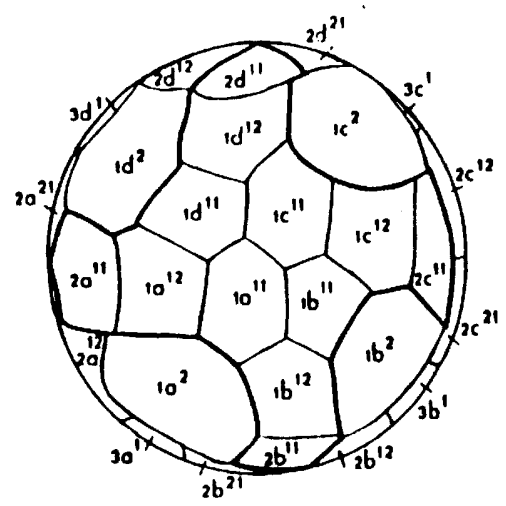

FIGURA 2-12: Figura em Cruz no estádio de 64 blastômeros, 15 horas após a primeira clivagem, (pólo animal)

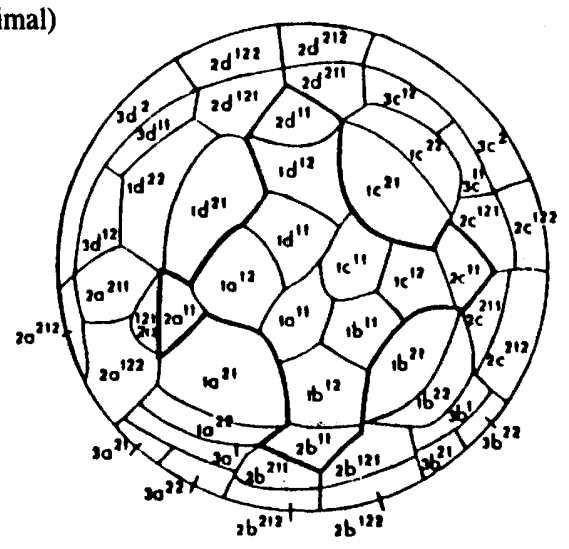




\section{EMBRIOLOGIA}

FIGURA 2-13: Estádio de 64 blastômeros (pólo vegetativo)

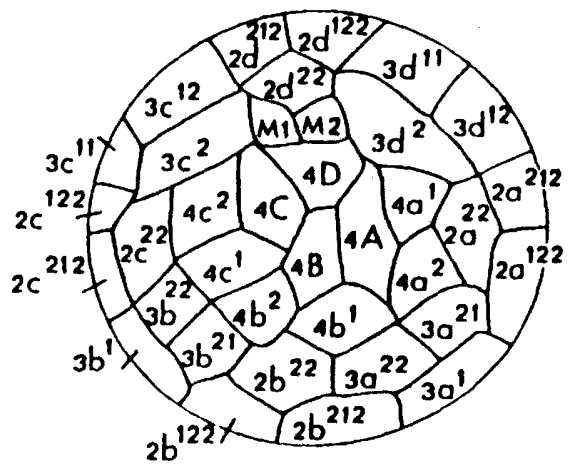

FIGURA 2-14: Estádio de 83 blastômeros (pólo animal), 17 horas após a primeira clivagem

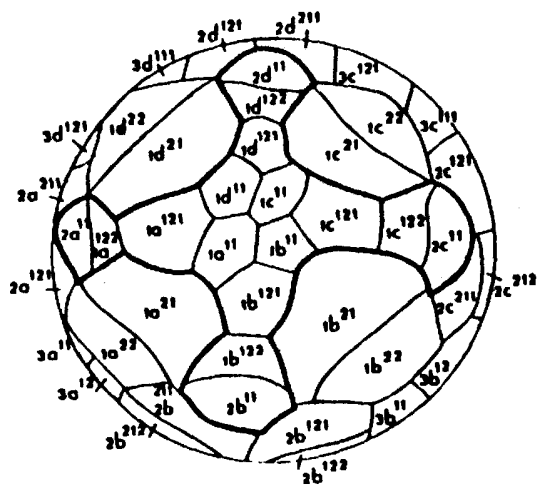

FIGURA 2-15: Mesmo estádio de 14, vista lateral. Células do segundo quarteto estão inseridas entre as do terceiro quarteto

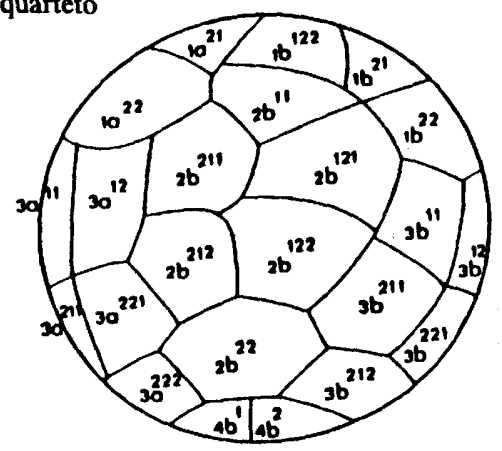




\section{TÓPICOS EM MALACOLOGIA MÉDICA}

FIGURA 2-16: Estádio de 97 células, 18 horas após a primeira clivagem

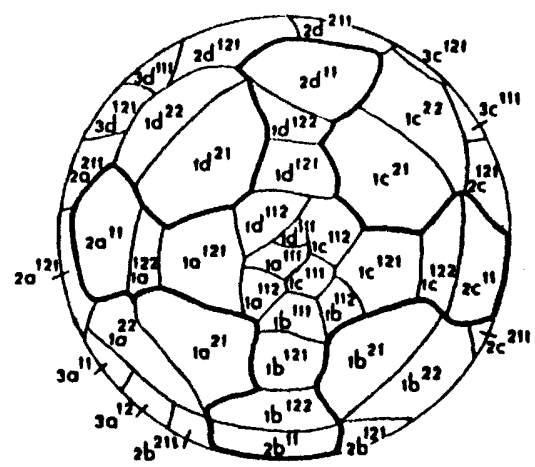

FIGURA 2-17: Estádio de 106 blastômeros (pólo vegetativo), 19 horas após a primeira clivagem. $O$ mesoblasto primário $M_{1}$ e $M_{2}$ com pequena superficie externa

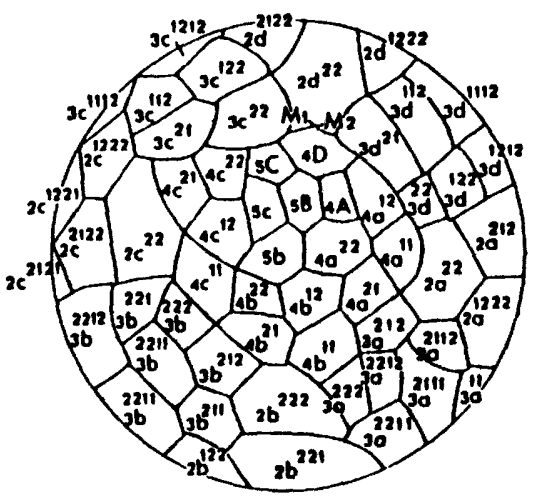

FIGURA 2-18: Estádio de 125 blastômeros (pólo vegetativo). $O$ mesoblasto primário $M_{1}$ e $M_{2}$ já não visível na superfície, 21 horas após a primeira clivagem

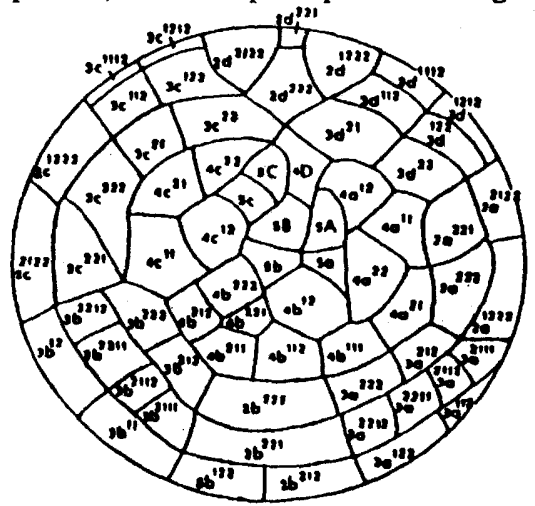




\section{EMBRIOLOGIA}

FIGURA 2-19: Estádio de 130 blastômeros (pólo anịmal), 21:30 horas após a primeira clivagem

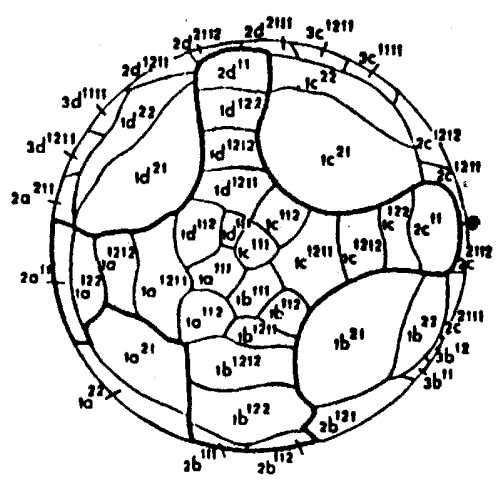

FIGURA 2-20: Divisão do $1 \mathrm{~b}^{1212}, 22$ horas após a primeira clivagem

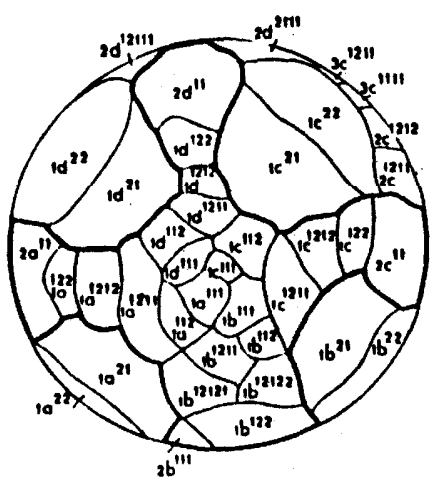

FIGURA 2-21: As quatro células do segundo quarteto $2 b^{211}, 2 b^{212}, 2 b^{122}$ e $2 b^{121}$, que formará o prototroco, 24 horas após a primeira clivagem

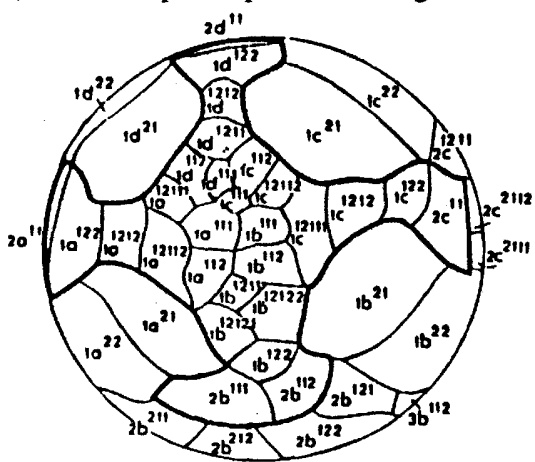


FIGURA 2-22: Estádio de 26 horas após a primeira clivagem, gástrula

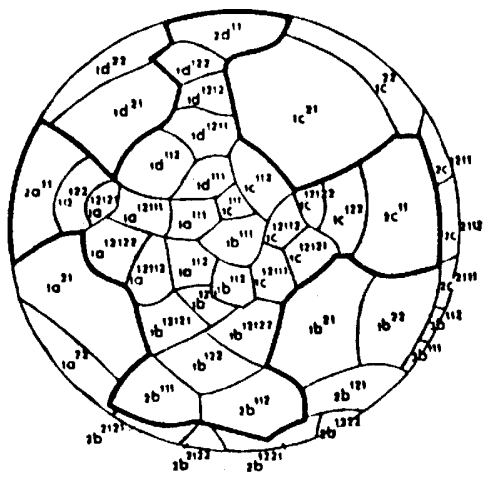

FIGURA 2-23: Estádio de 30 horas após a primeira clivagem, gástrula

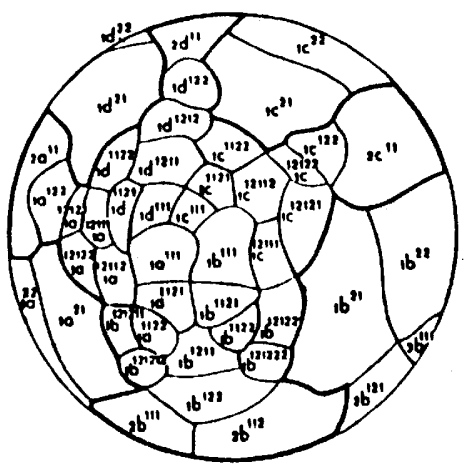

FIGURA 2-24: Estádio de 34 horas após a primeira clivagem, gástrula

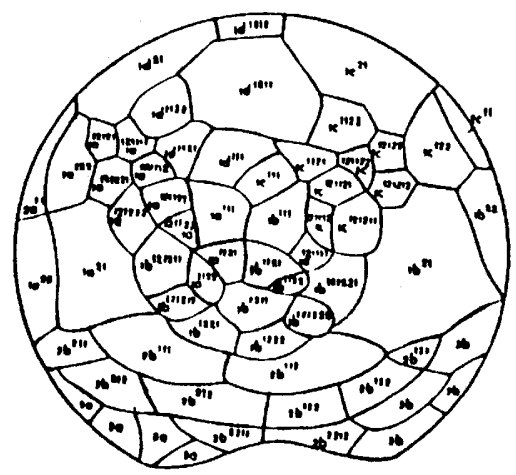


FIGURA 2-25: Estádio 36 horas após a primeira clivagem, gástrula

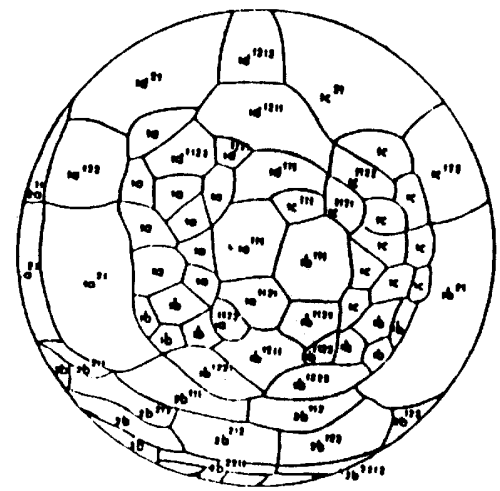

FIGURA 2-26: Estádio de trocófora jovem, 43 horas após a primeira clivagem

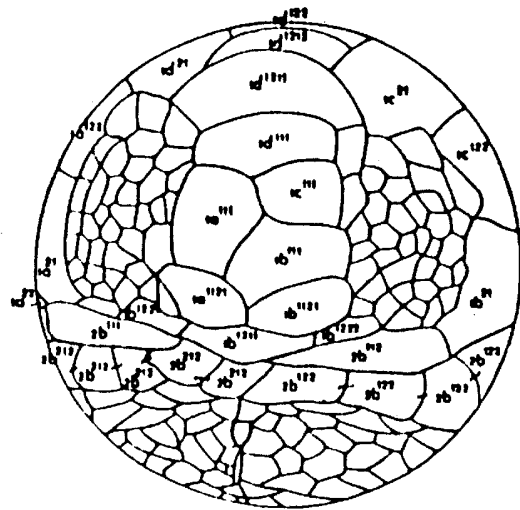

FIGURA 2-27: Estádio de trocófora, 66 horas após a primeira clivagem

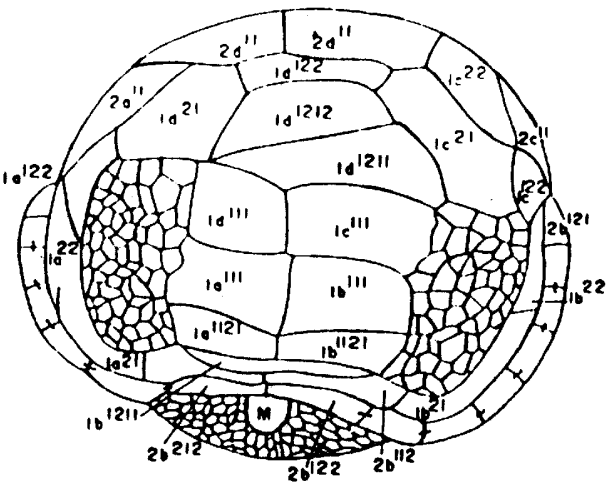




\section{TÓPICOS EM MALACOLOGIA MÉDICA}

FIGURA 2-28: Estádio de trocófora, 74 horas após a primeira clivagem

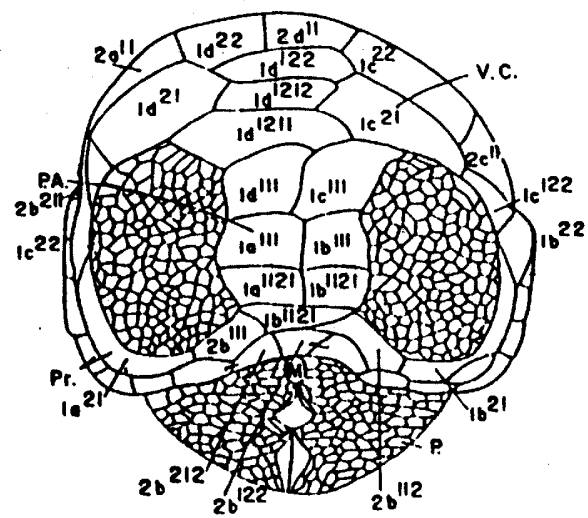

FIGURA 2-29: Veliger jovem. Delimitação do pé, 96 horas após a primeira clivagem

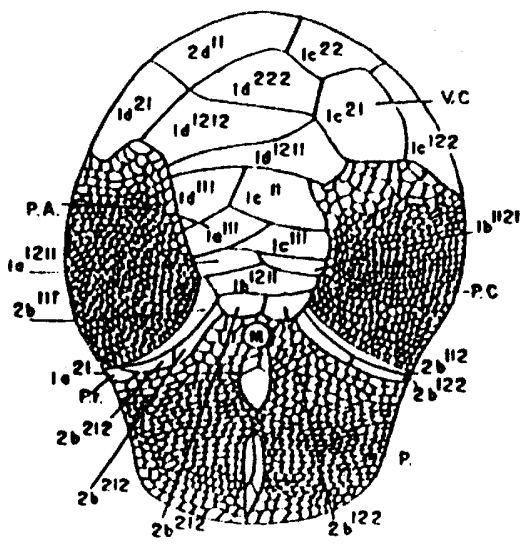

FIGURA 2-30: Veliger, com estruturas larvárias como a placa apical, vesícula cerebral e velum presentes. Duas regiões tentaculares com os olhos e tentáculos, 120 horas após a primeira clivagem

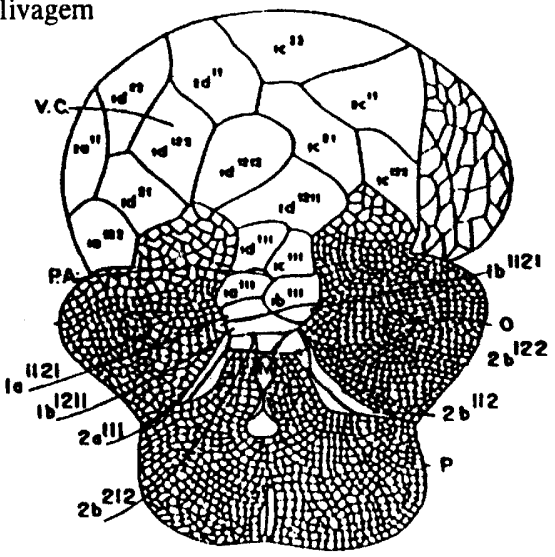


EMBRIOLOGIA

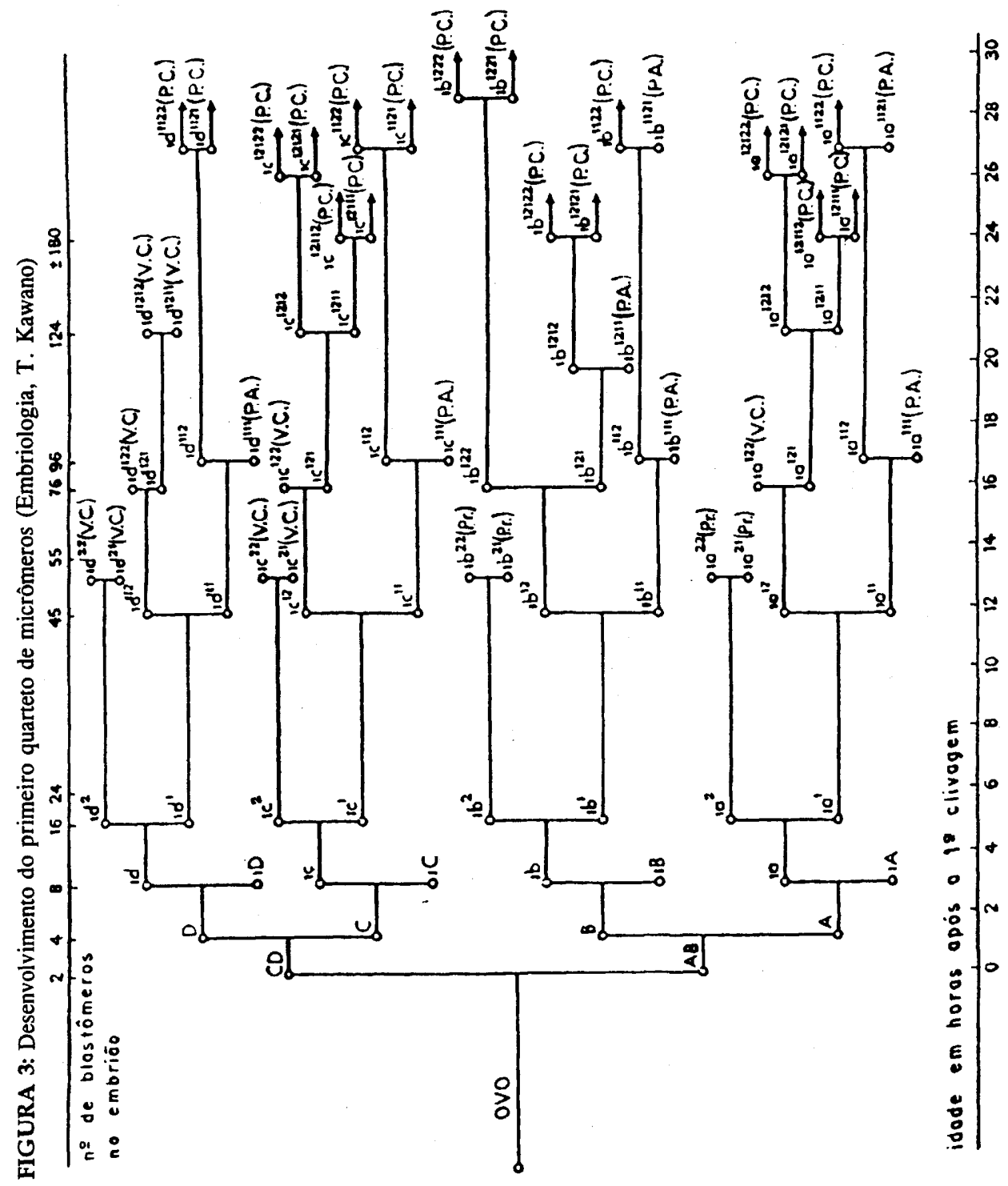




\section{TÓPICOS EM MALACOLOGIA MÉDICA}

FIGURA 4: O desenvolvimento do segundo quarteto de micrômeros (Embriologia, T. Kawano)

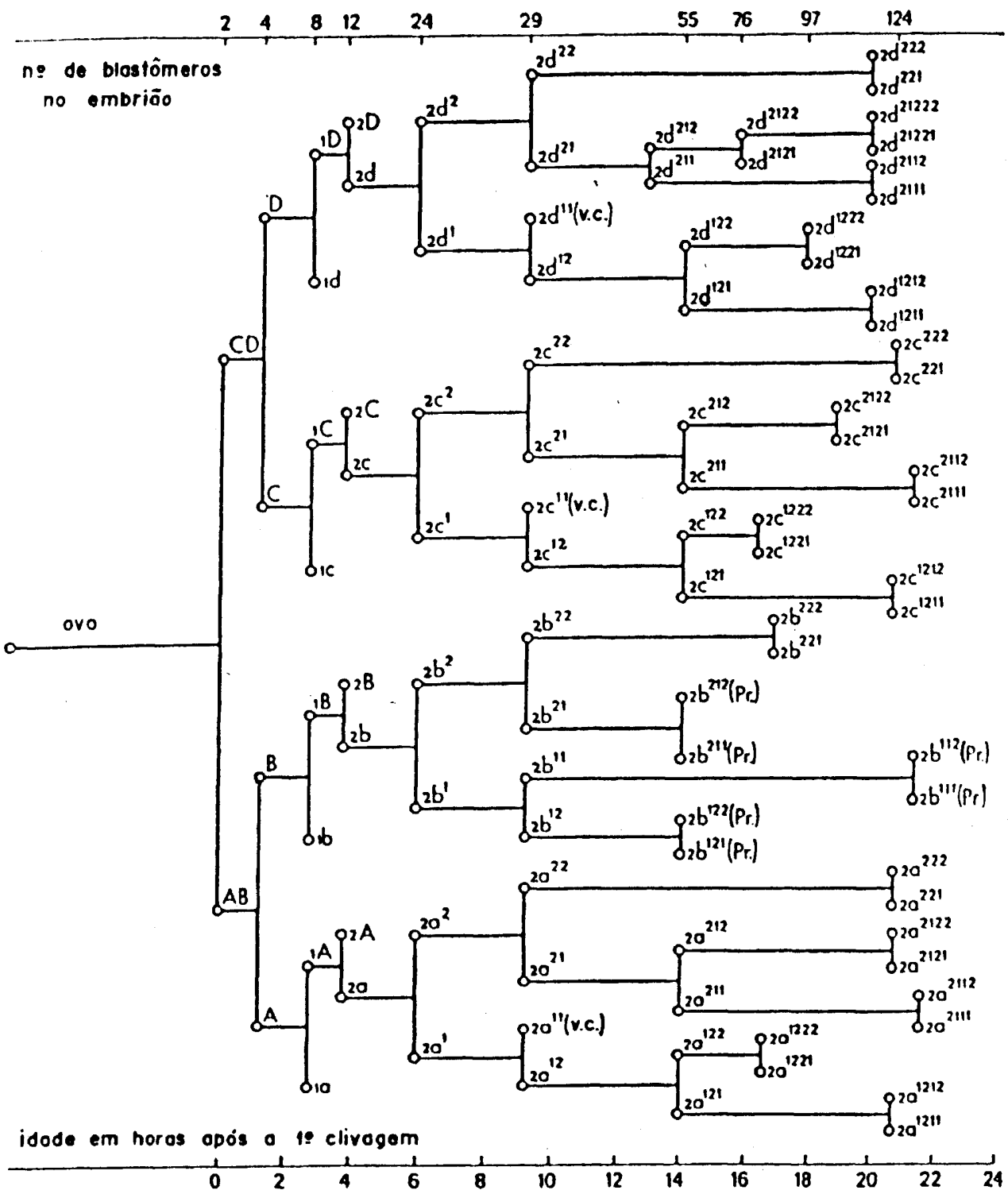


FIGURA 5: O desenvolvimento do terceiro e quarto quarteto de micrộmeros (Embriologia, T. Kawano)

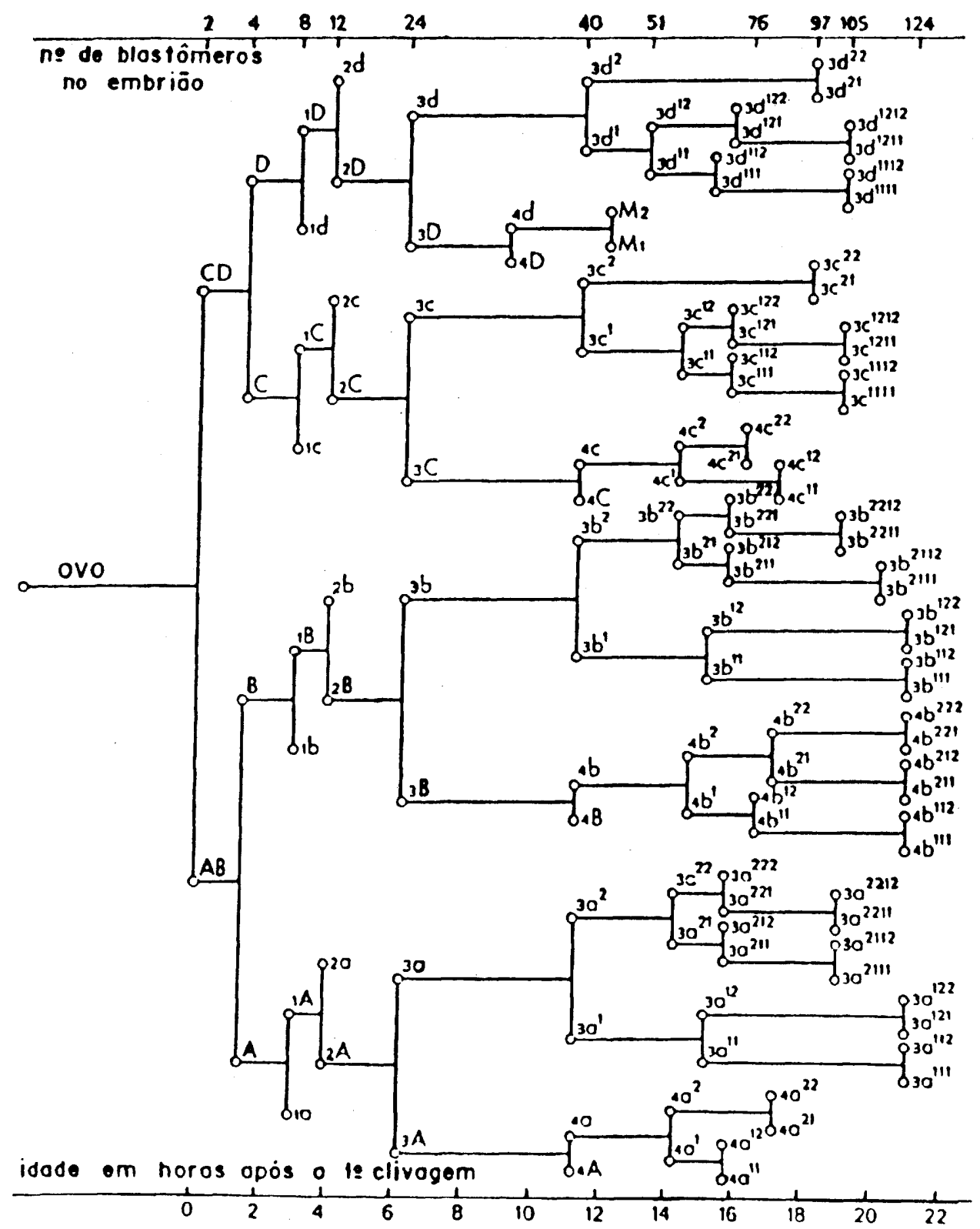




\section{TÓPICOS EM MALACOLOGIA MÉDICA}

\section{REFERÊNCIAS BIBLIOGRÁFICAS}

BIGGELAAR, J. A. M. van den, 1971. Development of division synchrony and bilateral symmetry in the first quartet of micromeres in eggs of Lymnaea. Journal of Embryology and Experimental Morphology, 26:

393-399.

BOON-NIERMEIJER, E. K., 1987. Responses of a developing organism upon heat stress. Ph. D. Thesis, Utrecht: University of Utrecht.

CAMEY, T., 1968. Estágios iniciais do desenvolvimento embrionário da Biomphalaria glabrata (Say, 1818). Tese de Doutorado, Belo Horizonte: Universidade Federal de Minas Gerais.

CAMEY, T. \& VERDONK, N. H., 1970. The early development of the snail Biomphalaria glabrata (Say) and the origin of the head organs. Netherlands Journal of Zoology, 20: 93-121.

DONGEN, C. A. M. van, 1976. The development of Dentalium with special reference to the significance of the polar lobe. Ph. D. Thesis, Utrecht: University of Utrecht.

KAWANO, T.; OKAZAKI, K. \& RÉ, L., 1992. The principal stages of the embryonic development of Biomphalaria glabrata (Mollusca, Planorbidae): practical guide. Malacologia, 34: 33-40.

LONGO, F. J., 1976. Ultrastructural aspects of fertilization in spiralian eggs. American Zoologist, 16: 375-394.

RAVEN, C. P., 1945. The development of the eggs of Limnaea stagnalis L. from oviposition till first cleavage. Archives Neerlandaises de Zoologie, 7: 91-121.

, 1946. The development of the eggs of Limnaea stagnalis $\mathrm{L}$. from the firsicleavage till the trochophore stage, with special reference to its' chemical embryology. Archives Neerlandaises de Zoologie, 7: 353-434.

1949. On the structure of cyclopic, synophthalmic and anophthalmic embryos, obtained by the

action of lithium Limnaea stagnalis. Archives Neerlandaises de Zoologie, 8: 1-30.

, 1958. Morphogenesis: The analysis of molluscan development. London: Pergamon Press.

SCOTT, F. G., 1994. Developmental Biology. $4^{\text {th }}$ Edition, Sunderland: Sinauer Associates Inc. Publishers.

VERDONK, N. H., 1965. Morphogenesis of the head region in Limnaea stagnalis $L$. Ph.D. Thesis, Utrecht: University of Utrecht.

VERDONK, N. H. \& CATHER, J. N., 1983. Morphogenetic determination and differentiation. In: The Mollusca, Vol. 3. Development (N. H. Verdonk, J. A. M. van den Biggelaar \& A. S. Tompa, eds.), New York: Academic Press.

WIERZEJSKI, A., 1905. Embryologie von Physa fontinalis L. Zeitschrift für Wissesnchaftliche Zoologie, 83: 502-706. 
Relação Molusco/Parasita 


\subsection{Ciclo Biológico Do Parasita No Molusco}

\section{INTRODUÇÃO}

Nos trematódeos Digenea encontramos os mais complexos ciclos biológicos do reino animal. A presença de um molusco, principalmente gastrópode, como primeiro hospedeiro intermediário é, quase sempre, regra geral. Entretanto, Linton (1917) encontrou anelídeos que eliminavam cercárias, funcionando, assim, como verdadeiros primeiros hospedeiros intermediários. Estes resultados foram, posteriormente, confirmados por Martin (1952).

Na subclasse Digenea existem milhares de espécies, parasitando inúmeros vertebrados, sendo que algumas destas espécies são parasitoses de importância para o homem. Podemos relacionar as seguintes espécies que, freqüentemente, parasitam o homem em diversas regiões do mundo: Schistosoma mansoni, Schistosoma haematobium, Schistosoma japonicum, Schistosoma intercalatum, Paragonimus westermani, Paragonimus peruvianus, Clonorchis sinensis, Fasciolopsis buski, Heterophyes heterophyes, Metagonimus yokogawi, Gastrodiscoides hominis e Fasciola hepatica. Dentre as seguintes espécies que eventualmente podem parasitar o homem encontram-se: Schistosoma matthei, Schistosoma bovis, Echinostoma revolutum, Dicrocoelium dendriticum, Ophisthorchis tenuicollis, Pseudamphistomum truncatum, Nanophyetus schichobalowi e Eurytrema pancreaticum.

No Brasil, duas espécies de trematódeos Digenea podem parasitar o homem: o Schistosoma mansoni, com milhões de casos, e a Fasciola hepatica, com registro de apenas poucas dezenas de casos, o que torna esta afecção uma ocorrência de muito pouca importância em Saúde Pública. Assim sendo, ateremo-nos, neste capítulo, à evolução do $S$. mansoni em seus hospedeiros intermediários, pelo seu inegável peso no contexto da Saúde Pública no Brasil.

Os hospedeiros suscetíveis pertencem ao gênero Biomphalaria, sendo que somente as espécies $B$. glabrata, $B$. tenagophila e $B$. straminea têm importância epidemiológica no Brasil.

A manutenção do ciclo vital do $S$. mansoni em seus hospedeiros intermediários sofre influências do ambiente natural onde ele ocorre, do comportamento biológico do miracídio e dos moluscos hospedeiros, dos mecanismos de defesa dos caramujos 
potencialmente transmissores e, também, dos mecanismos de adaptação do parasito aos hospedeiros intermediários.

\section{Descrição do miracídio}

O miracídio apresenta forma cilíndrica, com dimensões médias de 180 micrômetros de comprimento por 64 micrômetros de largura. Apresenta, ademais, células epidérmicas, onde implantam-se os cílios, os quais permitem o movimento no meio aquático. Várias estruturas internas estão contidas no meio líquido do interior da larva. A extremidade anterior apresenta uma papila apical, ou terebratorium, que pode se amoldar em forma de uma ventosa. No terebratorium encontram-se as terminações das glândulas adesivas, anteriormente denominadas "glândulas de penetração" e "sacos digestivos", e as terminações da glândula de penetração, anteriormente denominada "tubo digestivo primitivo". Também encontram-se no terebratorium um conjunto de cílios maiores e espículos anteriores, provavelmente importantes no processo de penetração nos moluscos e, finalmente, terminações nervosas, que teriam funções tácteis e sensoriais (Ottolina, 1957).

O aparelho excretor é composto por solenócitos, também chamados "células em labareda" ou "células em chama". Estás são em número de quatro, apresentando-se em pares, e estão ligadas por um sistema de canalículos que são drenados para uma ampola excretora, a qual termina no poro excretor.

O sistema nervoso é muito primitivo, estando representado por uma massa celular nervosa central, que se ramifica e se conecta com células nervosas periféricas por meio de cordões nervosos formados de células bipolares. A contratilidade $\mathrm{e}$ motilidade da larva são comandadas por este sistema, que aciona a camada muscular subepitelial.

As células germinativas, em número de 50 a 100 , que darão continuidade ao ciclo no caramujo, encontram-se na parte anterior do corpo da larva.

\section{Quimiotaxia e quimiocinese do miracídio}

Alguns autores apresentaram resultados que sugeriam existir uma atração miracidiana em relação aos moluscos (Leiper \& Atkinson, 1975; Lutz, 1919; Brumpt, 1940; Kloetzel, 1958). Esta atração seria decorrente da detecção, pelo miracídio, de substâncias que seriam produzidas pelos moluscos e que se difundiriam pelo meio aquático, sendo detectadas através das terminações sensoriais da papila apical, ou terebratorium. Esta questão foi definitivamente solucionada por trabalhos posteriores (Chernin, 1970, 1974), que demonstraram realmente existir uma emissão 
de substâncias dos caramujos que modifica o comportamento dos miracídios. Estas substâncias estimulariam sua concentração e movimentação próximo ao estímulo, isto é, o caramujo. Ao mesmo tempo, exerceriam um papel significativo no processo de penetração. Estas substâncias, genericamente denominadas miraxone (Chernin, 1970), entretanto, não exerceriam uma ação seletiva em relação ao alvo da infecção - os caramujos Biomphalaria - pois estes miracídios, excitados, tentariam penetrar em moluscos de outros gêneros ou, mesmo, em substrato gelatinoso (Chernin, 1972, 1974).

\section{Luminosidade e temperatura}

A luminosidade natural vem, juntamente com a energia calorífica, através dos raios solares, ocorrendo, assim, efeitos somatórios de ambos os estímulos nas diversas etapas do ciclo evolutivo, tanto nas fases extramolusco como nas fases intramolusco. Assim, observa-se que a eclosão do miracídio no meio aquático é fortemente influenciada pela luminosidade e temperatura ambientais. A eclosão seria quase inibida na obscuridade e não ocorreria em temperaturas inferiores a $10^{\circ} \mathrm{C} \mathrm{e}$ superiores a $37^{\circ} \mathrm{C}$ (Standen, 1951).

A penetração do miracídio no molusco seria, também, fortemente dependente da temperatura. De fato, os resultados de Maldonado \& Acosta-Matienzo (1947) mostram que a redução de $1^{\circ} \mathrm{C}$ na temperatura (de $26^{\circ} \mathrm{C}$ para $25^{\circ} \mathrm{C}$ ) levaria a uma redução na taxa de infecção dos moluscos de $80 \%$ para $40 \%$. A evolução das formas intramolusco, até a emergência das cercárias para o meio externo, também sofre notável influência da temperatura e da luminosidade. Em temperaturas abaixo de $20^{\circ} \mathrm{C}$ ocorre um nítido retardamento da evolução do parasito intramolusco. A emergência das cercárias é também regida por estes dois fatores, isto é, temperatura e luminosidade (Valle et al., 1971).

A atração do miracídio em relação a uma fonte luminosa (fototaxia) foi bem estabelecida por diversos autores (Maldonado \& Acosta-Matienzo, 1947; Standen, 1949; Chaia, 1956). Por outro lado, Williams \& Coelho (1975) mostraram a ocorrência de fototaxia positiva em $B$. glabrata, fenômeno este confirmado por outros trabalhos (Pimentel-Souza et al., 1976a, 1976b, 1984). A fototaxia positiva que ocorre entre miracídios e $B$. glabrata vai, sem dúvida, favorecer o encontro dos dois organismos no ambiente aquático. Por outro lado, o trabalho de Pimentel-Souza et al. (1976b) mostra que a luminosidade também estimula a exposição da massa cefalopodal do molusco no meio aquático, o que, sem dúvida, favoreceria o processo de infecção, já que são estas as partes preferidas para a penetração miracidiana (Coelho, 1957). A seleção natural exerce sua ação na relação $S$. mansoni e Biomphalaria, utilizando, marcadamente, as variáveis temperatura e luminosidade. 
Como já visto, estas duas variáveis influenciam a eclosão do miracídio. A luminosidade exerce uma atração sobre o miracídio e sobre a Biomphalaria. A temperatura constitui fator fundamental no processo de evolução do parasito intramolusco, enquanto ambos os estímulos atuam sobre a emergência das cercárias. Considerando-se, ainda, que temperaturas altas e sol forte são atrativos para que o homem - o principal hospedeiro definitivo - sinta-se atraído para se banhar nas coleções naturais, fica fácil entender porque a transmissão da esquistossomose ocorre, na maioria dos países tropicais, em quase todos os meses do ano e em áreas próximas à linha do equador, em todo o período anual.

\section{Efeito da densidade populacional dos moluscos sobre a evolução do parasito intramolusco}

O trabalho de Wright (1960) mostrou que caramujos vivendo em populações densas apresentavam reprodução e crescimento reduzidos, bem como altas taxas de mortalidade. Por outro lado, Gazzinelli et al. (1970) e Coelho et al. (1975) mostraram que caramujos infectados, em populações densas, incorporavam menos ferro radioativo, enquanto Coelho et al. (1977) mostraram uma diminuição na captação de oxigênio nestes moluscos, quando em altas densidades populacionais. Estes resultados, associados aos de Barbosa \& Coelho (1955), que mostraram que, quando ocorre estivação do caramujo (anidrobiose), o parasito também cessa sua evolução intramolusco, evidenciam um fino ajuste do metabolismo do $S$. mansoni ao do seu hospedeiro intermediário. Assim, Coles (1973) demonstrou que caramujos de populações densas eliminam um número significativamente menor de cercárias, quando comparados a caramujos de populações com densidade baixa. Finalmente, Carlos \& Coelho (1978) mostraram que caramujos infectados e mantidos em densidades populacionais altas, além de eliminarem menor quantidade de cercárias, apresentavam também taxas de infecção significativamente menores.

\section{Penetração dos miracídios nos moluscos hospedeiros}

A capacidade de penetração restringe-se a cerca de oito horas após a eclosão e é notavelmente influenciada pela temperatura (Maldonado \& Acosta-Matienzo, 1947).

A penetração miracidiana, após o contato com o caramujo hospedeiro, é constituída de várias etapas. Esta penetração dos miracídios de $S$. mansoni não ocorre exclusivamente no tegumento de Biomphalaria, pois observou-se que eles penetram indiscriminadamente em moluscos de outros gêneros, como Helisoma e Lymnea, e também èm substrato gelatinoso (Chernin, 1972). 
O contato com o tegumento do molusco faz com que o terebratorium assuma a forma de ventosa, ocorrendo, quase que simultaneamente, a descarga do conteúdo das glândulas de adesão. O miracídio agita-se intensamente, com movimentos contráteis e rotatórios, comandados pelas vibrações ciliares e pela ação da musculatura subepitelial. Neste meio tempo, o conteúdo da glândula de penetração é descarregado e as enzimas proteolíticas iniciam sua ação de digestão dos tecidos. A ação combinada dos intensos movimentos do miracídio e da ação enzimática constitui o elemento que permite a introdução do miracídio nos tecidos do molusco. O epitélio é ultrapassado e a larva se estabelece no tecido subcutâneo. O local de penetração pode ser representado por qualquer ponto das partes expostas do caramujo, sendo, porém, a base das antenas e o pé os pontos preferidos (Coelho, 1957). O processo de penetração tem duração entre 10 e 15 minutos. Neste processo, cerca de apenas $30 \%$ dos miracídios são capazes de penetrar e evoluir em B. glabrata; $30 \%$ penetram mas não evoluem; e $40 \%$ são incapazes de até mesmo penetrar no molusco (Chernin \& Antolics, 1975).

\section{Efeitos da dessecação dos moluscos na evolução do Schistosoma mansoni}

Os trabalhos de Barbosa (1960), Barbosa \& Coelho $(1953,1955)$ Coelho \& Chaia (1960) e Oliver et al. (1954) mostram o interessante fenômeno de parada temporária do desenvolvimento parasitário, quando o molusco, por desidratação, entra em anidrobiose (estivação). Nestas condições, os caramujos contraem-se para o interior da concha, ficando reduzidos de $1 / 6$ a $1 / 7$ do seu volume normal, e segregam uma camada de muco que obstrui a abertura da concha, evitando maiores perdas de água. Ademais, seu metabolismo cai acentuadamente. Este estado de anidrobiose só ocorre de forma lenta e progressiva na natureza. O parasito, na fase de esporocisto I nestes caramujos, acompanha o metabolismo do hospedeiro, gastando o mínimo de energia vital. Quando a infecção está mais adiantada, na fase de esporocisto II (acima de 21 dias), ocorre cura parasitológica. Ao voltar às condições ideais de sobrevivência dos moluscos, isto é, com a chegada de água nos criadouros no período das chuvas, os caramujos retornam rapidamente à sua atividade biológica normal, sendo acompanhados pela retomada da evolução daqueles esporocistos na fase inicial da infecção. 


\subsection{Resistência e suscetibilidade à infecção por Schistosoma mansoni em caramujos do gênero Biomphalaria}

O fenômeno da adaptabilidade dos trematódeos da subclasse Digenea aos seus hospedeiros intermediários apresenta, de maneira geral, alta especificidade. Verifica-se que, na maioria das espécies de parasitos desta subclasse, o hospedeiro intermediário adequado situa-se num único gênero ou acha-se restrito a uma única espécie de molusco, ou mesmo a determinadas linhagens geográficas. Por exemplo, no caso de $S$. mansoni, os hospedeiros intermediários estão restritos a determinadas espécies e cepas geográficas de moluscos do gênero Biomphalaria (Abdel-Malek, 1950; Paraense \& Correa, 1963a,1963b; Richards et al., 1992), ao passo que encontramos inúmeras espécies de mamíferos, pertencentes a vários gêneros, podendo funcionar como hospedeiros definitivos.

Esta especificidade na relação entre parasito e hospedeiro intermediário sugere complexos mecanismos adaptativos. Recentemente, alguns dos mecanismos que regem esta interação parasito-hospedeiro intermediário foram, em parte, esclarecidos.

Fatores ligados ao hospedeiro

A resistência de caramujos refratários à infecção por $S$. mansoni acha-se intimamente ligada à capacidade das células da hemolinfa - denominadas amebócitos, hematócitos ou granulócitos - de envolverem as formas parasitárias recém penetradas, formando uma verdadeira encapsulação em torno destas. Pelo fato de os trabalhos mais recentes terem optado pelo termo " hemócito", esta denominação será a empregada na presente revisão (Newton, 1952; Brooks, 1953; Coelho \& Barbosa, 1956; Coelho, 1957,1962; Liu et al., 1987; Knaap \& Locker, 1990). Estas células apresentam morfologia e conteúdo enzimático variáveis, o que permite diferenciá-las em categorias distintas. Também apresentam subpopulações com capacidade de adesão e fagocitose diferenciadas (Knaap \& Locker, 1990). Fatores humorais são importantes para estimular não só a quimiotaxia em relação à forma parasitária, mas também o processo de fagocitose.

A interação das células fagocitárias - os hemócitos - encapsulando o miracídio recém-penetrado, é um fenômeno que ocorre num espaço de poucas horas, sendo o mesmo fundamental para se determinar a sorte do parasito nos moluscos hospedeiros. 
Existe uma estreita interação entre fatores plasmáticos presentes na hemolinfa e os hemócitos no processo de encapsulação e fagocitose do miracídio ou esporocisto. Deste modo, hemócitos de $B$. glabrata suscetiveis podem ter sua capacidade citotóxica aumentada contra o parasita, na presença de hemolinfa de caramujos resistentes, isto tanto em experimentos in vitro (Bayne et al., 1980; Locker \& Bayne, 1982) como em experimentos in vivo, por transferência de plasma (Granath \& Yoshino, 1984). Foram detectadas, na hemolinfa de duas linhagens de B. glabrata resistentes, aglutininas (opsoninas) que se ligavam a esporocistos de $S$. mansoni; entretanto, estas aglutininas estavam ausentes em três linhagens de B. glabrata suscetíveis (Locker et al., 1984).

Recentemente, o interessante trabalho de Fryer \& Bayne (1990a) mostra que a incubação de miracídios de $S$. mansoni em hemolinfa de caramujos resistentes e suscetíveis modifica a capacidade fagocitária dos hemócitos. Observa-se um nítido contraste no comportamento entre as células de caramujos resistentes e as de caramujos suscetíveis. Assim, a capacidade fagocitária dos hemócitos, medida pela fagocitose de levedura, estava deprimida nos hemócitos de $B$. glabrata suscetíveis e exacerbada nos provenientes de caramujos resistentes. Este trabalho mostra que substâncias provenientes do miracídio diminuem a ação fagocitária dos hemócitos dos caramujos suscetíveis, favorecendo, assim, a sobrevivência do parasito no molusco, enquanto ativariam a capacidade fagocitária dos hemócitos das linhagens resistentes, provocando um ataque mais intenso do sistema de defesa contra as formas parasitárias invasoras. Fryer \& Bayne (1990b) mostraram que hemócitos de $B$. glabrata com três horas de infecção com miracídios de $S$. mansoni apresentavam capacidade fagocitária dos hemócitos alterada. Hemócitos de linhagens resistentes ao $S$. mansoni apresentaram fagocitose exacerbada, enquanto nos hemócitos de linhagens suscetíveis esta estava deprimida. Recentemente, Sullivan \& Spence (1994) demonstraram a transferência de resistência, por transplante do órgão hematopoiético, tendo como doadores caramujos $B$. glabrata resistentes e como receptores $B$. glabrata suscetíveis.

\section{Resistência adquirida}

Os primeiros autores a demonstrar a resistência adquirida contra $S$. mansoni na B. glabrata foram Lie et al., em 1983. Os autores observaram que caramujos $B$. glabrata juvenis previamente infectados com miracídios de $S$. mansoni irradiados apresentavam aumento da sua resistência natural contra infecções por miracídios não-irradiados. 


\section{Fatores ligados à adaptação do parasito ao molusco hospedeiro}

Os parasitos necessitam de determinados artifícios para se evadirem da resposta protetora do organismo do molusco hospedeiro. As revisões sobre o assunto dividem estes verdadeiros mecanismos de escape à resposta protetora do molusco em (1) antígenos comuns e (2) interferência parasitária no sistema de defesa do caramujo suscetível.

\section{Antígenos comuns}

A presença de determinantes antigênicos semelhantes ao do hospedeiro na superfície do parasito levaria a um não-reconhecimento, pelo sistema de defesa do hospedeiro, da presença de antígenos estranhos. Esta teoria, bem comprovada nas formas parasitárias do hospedeiro vertebrado, também apresenta resultados que indicam fortemente sua aplicação na fase intramolusco (Damian, 1987). Recentemente, Cheng \& Dougherty (1990) mostraram que a lesão da superfície dos esporocistos provavelmente promoveria a exposição de antígenos non self. Este fato resultaria em destruição das estruturas parasitárias, pela ação das enzimas dos lisossomas de hemócitos ativados. Zelck \& Becker (1990) demonstraram a fixação de diferentes lecitinas na superfície de $S$. mansoni e na superfície de $B$. glabrata.

Dois mecanismos básicos levam à aquisição destes determinantes antigênicos do hospedeiro pelo parasito (Benex \& Tribouley, 1974; Yoshino et al., 1979; Yoshino \& Cheng, 1978; Yoshino \& Bayne, 1983; Damian, 1987): o chamado mimetismo molecular, que tem como princípio a síntese, por parte do parasito, de determinantes antigênicos semelhantes aos do hospedeiro (Yoshino \& Bayne, 1983; Damian, 1987),e o mascaramento antigênico, através do qual os esporocistos podem absorver, em sua superfície, antígenos do plasma do hospedeiro, como hemaglutininas (Stein \& Basch, 1979) e componentes plasmáticos solúveis (Yoshino \& Bayne, 1983).

\section{Interferência parasitária no sistema de defesa do caramujo suscetível}

Esta interferência pode atuar tanto contra o sistema de resistência natural do molusco como sobre a resistência adquirida (Lie, 1982). Algumas linhagens de $B$. glabrata resistentes ao $S$. mansoni podem se infectar quando previamente parasitadas com espécies do gênero Echinostoma (Lie \& Heyneman, 1979; Lie et al. 1977, 1982). Por outro lado, os miracídios de $S$. mansoni inibem a capacidade fagocitária natural dos hemócitos de linhagens suscetíveis de B. glabrata (Fryer \& Bayne, 1990b). 


\section{Evolução do Schistosoma mansoni após penetração no molusco}

A larva, após a perda das glândulas de adesão e penetração, continua a perder outras estruturas no processo de penetração. Desta forma, o passo seguinte seria a perda do epitélio ciliado e a degeneração do terebratorium. Em seguida dar-se-ia o desaparecimento da musculatura subepitelial e, por último, do sistema nervoso, que pode persistir por mais alguns dias. Com exceção do desaparecimento do sistema nervoso, todas as alterações citadas ocorrem num período de $\mathbf{4 8}$ horas. Assim sendo, o miracídio transforma-se, na verdade, em um saco com paredes cuticulares, contendo a geração das células germinativas ou reprodutivas.

No princípio, o miracídio apresenta movimentos amebóides, que diminuem com o tempo, até a completa imobilidade da larva. As células germinativas, em número de 50 a 100, iniciam, então, um intenso processo de multiplicação, fazendo com que, após 72 horas, a larva, agora chamada esporocisto primário, esporocisto mãe ou, simplesmente, esporocisto I, dobre de tamanho. Na segunda semana da infecção, observa-se no interior do esporocisto, uma série de ramificações tubulares, que preenchem todos os espaços intercelulares do tecido conjuntivo. No interior destas ramificações, as células germinativas encontram-se em franca multiplicação. Em condições ideais de temperatura - entre 25 e $28^{\circ} \mathrm{C}$ - ocorre a formação dos esporocistos secundários, que se inicia a partir do $14^{\circ}$ dia após a penetração do miracídio. Esta evolução pode ser significativamente retardada a temperaturas abaixo de $20^{\circ} \mathrm{C}$. A cinética da evolução e as transformações morfológicas nesta fase do ciclo intracaramujo foram estudadas por vários autores (Faust \& Hoffmann, 1934; Maldonado \& Acosta-Matienzo, 1947; Oliver \& Mao, 1949; Pan, 1965). A formação do esporocisto secundário inicia-se com um aglomerado de células germinativas nas paredes do esporocisto primário, verificando-se uma vacuolização acentuada na parte central da larva. Estes aglomerados se reorganizam e dão origem a septos, ficando o esporocisto primário dividido em 150 a 200 camadas, cada septo ou camada já podendo ser considerado um esporocisto secundário, esporocisto filho ou esporocisto II. As paredes deste esporocisto apresentam uma dupla camada muscular logo abaixo da camada cuticular, apresentando fibras musculares longitudinais e transversais. Esta musculatura, associada à formação de espinhos na parte mais extrema da cutícula, terá papel fundamental na motilidade e na capacidade de migração intratissular das larvas. A migração dos esporocistos secundários inicia-se em torno do $18^{\circ}$ dia, após a saída da estrutura do esporocisto primário por um hipotético poro de nascimento, ainda não identificado com precisão. A migração processa-se ativamente através dos tecidos do molusco. A saída dos esporocistos do local de penetração do miracídio, onde a maioria se desenvolve, até as glândulas digestivas, ou hepato pâncreas, leva de dois a três dias. A localização 
final dos esporocistos será nos espaços intertubulares da glândula digestiva, local com riqueza nutritiva. $O$ ovotesti, ou glândula reprodutiva, poderá também abrigar os esporocistos migrantes, mas com freqüência menor, principalmente nas infecções com poucos miracídios.

Os esporocistos secundários começam, então, a sofrer profundas modificações anatômicas no seu conteúdo de células germinativas. A histogênese da formação cercariana foi estudada com mais detalhe por Pan (1965) e, posteriormente, por Lang (1983), Fournier \& Theron (1985) e Kechermir \& Combes (1988).

Os esporocistos secundários, algum tempo depois de terem atingido o seu destino final, apresentam três áreas estruturais bem definidas. A primeira seria o chamado poro de nascimento. A segunda área apresentaria cercárias desenvolvidas ou em desenvolvimento. Por fim, a terceira teria formas embrionárias, que poderão representar um outro tipo de reprodução.

Esta última geração de células embrionárias originaria novos esporocistos, que seriam então chamados esporocistos III (Jourdane et al., 1980). De acordo com estes autores, os esporocistos III forneceriam a única explicação plausível para uma prolongada eliminação de cercárias nos caramujos infectados, pois isto não ocorrendo, deveria haver uma exaustão no processo de formação cercariana nos esporocistos II. Nesta mesma linha de investigação, Lang, em 1983, demonstrou, por transplante de esporocistos filhos, que seria possível o aparecimento de até seis novas gerações destes mesmos esporocistos, sucedendo-se umas às outras. Este autor admite que, no gênero Schistosoma, esta sucessão de gerações de esporocistos filhos pode ser teoricamente ilimitada. Posteriormente, Kechermir \& Combes (1988) levantaram a hipótese de que o embrião que se desenvolve para esporocisto filho pode se diferenciar em cercárias ou em novas gerações de esporocisto, mas sempre originando-se de um único tipo de célula germinativa.

Pan (1965) verificou que a formação cercariana inicia-se com a disposição das células germinativas em uma mórula, em cujo centro encontra-se uma grande célula basófila, com um núcleo grande e vesicular. Com o crescimento da mórula, esta célula central se multiplica, constituindo o primórdio das glândulas de penetração. As células externas da mórula vão originar as duas camadas celulares da cercária, constituída de fibras longitudinais e circulares. Ao mesmo tempo, observa-se a formação de uma cutícula acelular, bem como das duas ventosas. A formação completa da cercária, até sua emergência para o meio aquático, pode ocorrer dentro de um período de 27 a 30 dias, em condições ideais de temperatura (cerca de $28^{\circ} \mathrm{C}$ ).

Um único miracídio pode gerar cerca de 300 mil cercárias (Faust \& Hoffmann, 1934), sendo que cada miracídio já leva definido o sexo das cercárias que serão produzidas. Schwanbek et al. (1986) mostraram que existe uma regulação da evolução das formas parasitárias intramolusco em função da carga infectante dos 
miracídios. De fato, os autores demonstraram a existência de uma massa significativamente maior de tecido parasitário em caramujos infectados por dois miracídios, quando comparados àqueles infectados por um único miracídio. Entretanto, não se observou aumento significativo do tecido parasitário em caramujos infectados com cargas crescentes de miracídio (5, 10 e 20). Estes achados sugerem algum tipo de mecanismo regulador para prevenir uma carga parasitária excessiva no hospedeiro.

As cercárias apresentam a seguinte morfologia: comprimento total de 500 micrômetros, cauda bifurcada medindo 230 por 50 micrômetros e corpo cercariano com 190 por 70 micrômetros. Duas ventosas estão presentes. A ventosa oral apresenta as terminações das chamadas glândulas de penetração, quatro pares pré-acetabulares e quatro pares pós-acetabulares, e abertura que se conecta com o chamado intestino primitivo, primórdio do sistema digestivo. A ventosa ventral, ou acetábulo, é maior e possui musculatura mais desenvolvida. É principalmente através desta ventosa que a cercária fixa-se na pele do hospedeiro no processo de penetração. Verifica-se um sistema excretor constituído de quatro pares de células flama. Como a cauda é uma estrutura que irá se perder rapidamente no processo de penetração, ela não apresenta órgãos definidos, servindo apenas para a movimentação da larva no meio líquido.

A emergência das cercárias ocorre com a saída dos organismos dos esporocistos filhos. A migração das cercárias faz-se tanto pelos espaços intercelulares, cheios de hemolinfa, como através do sistema venoso do caramujo. A passagem para o meio exterior processa-se pela formação de vesículas no epitélio do manto e pseudobrânquia. Entretanto, algumas cercárias migram por muito tempo nos tecidos antes da emergência (Pan, 1965; Duke, 1952). Gordon \& Griffiths (1951) descreveram glândulas que só existem na cercária intracaramujo. Estas glândulas, acreditam os autores, atuam na emergência cercariana, sendo por eles denominadas glândulas de escape.

Desde Lutz (1919) sabe-se que esta emergência pode ser nitidamente influenciada por estímulos externos como luminosidade e temperatura. Valle et al. (1971) observaram que a emergência segue um ritmo circadiano. Estes autores, variando e alternando as variáveis temperatura e luminosidade, verificaram que a emergência cercariana é regida por fatores exógenos, cujos elementos sincronizadores são a luz e a temperatura, bastando, porém, a ação isolada de um destes fatores para ,a manutenção do ritmo circadiano. A luz parece exercer um papel mais marcante na manutenção do controle deste ritmo.

A infecção por $S$. mansoni nos moluscos leva a uma série de problemas no hospedeiro intermediário. A localização do parasitismo na glândula reprodutiva (ovotesti) ocasiona uma inibição da reprodução, a qual, na verdade, não resulta em verdadeira castração parasitária, pois aqueles que se autocuram voltam à oviposição 
(Coelho, 1954). A infecção no período pré-patente leva a uma grande mortandade dos moluscos. Após a emergência cercariana, muitos caramujos morrem também pela perda de hemolinfa no processo de saída das cercárias.

Embora já se tenha observado a sobrevivência de caramujos infectados por mais de 150 dias em condições de laboratório, a média de sobrevida no laboratório foi de 39 dias (Barbosa et al., 1954).

Na natureza, a sobrevida média de caramujos $B$. glabrata infectados não parece ser longa, apesar de um exemplar ter sobrevivido por um período de quatro meses (Barbosa, 1963).

\section{REFERÊNCIAS BIBLIOGRÁFICAS}

ABDEL-MALEK, E. T., 1950. Susceptibility of snail Biomphalaria boissyi to infection with certain strains of Schistosoma mansoni. American Journal of Tropical Medicine, 30: 887-894.

BARBOSA, F. S., 1960. Alguns aspectos das relaçōes hospedeiro-parasito entre as fases larvárias do trematodeo Schistosoma mansoni e o molusco Australorbis glabratus. Boletim da Fundação Gonçalo Muniz, 15: 1-44.

1963. Survival in the field of Australorbis glabratus infected with Schistosoma mansoni. Journal of Parasitology, 49: 149.

BARBOSA, F. S. \& COELHO, M. V., 1953. Ação de dessecação sobre as fases larvárias intracaramujo de Schistosoma mansoni em Australorbis glabratus. Publicaçōes Avulsas do Instituto Aggeu Magalhães, 11: 159-162.

1955. Comportamento das formas larvárias de Schistosoma mansoni em Australorbis glabratus (Mollusca, Planorbidae) sujeitos a estivação. Publicações Avulsas do Instituto Aggeu Magalhāes, 4: 51-60.

BARBOSA, F. S.; COELHO, M. V. \& DOBBIN, J. E., 1954. Qualidade de vetor dos hospedeiros de Schistosoma mansoni no Nordeste do Brasil. II - Duração da infestaçāo e eliminaçāo de cercárias em Australorbis glabratus. Publicaçōes Avulsas do Instituto Aggeu Magalhães, 3: 19-92.

BAYNE, C. J.; BUCLEY, P. M. \& DE WAN, P. C., 1980. Schistosoma mansoni citotoxicity of hemocytes from susceptible snail host for sporocysts in plasma from resistent Biomphalaria glabrata. Experimental Parasitology, 50: 409-416.

BENEX, J. \& TRIBOULEY, J., 1974. Mise en evidence a la surface de la cercaria de Schistosoma mansoni d'antigene possedant le caractere planorbe. Comptes rendus des séances de la Societé de biologie, 279:683.

BROOKS, C. P., 1953. A comparative study of Schistosoma mansoni in Tropicorbis glabratus. Journal of Parasitology, 39: 159-163.

BRUMPT, E., 1940. Confirmation des observations de A. Lutz sur les lesions tentaculaires de Planorbis glabratus (P. guadelon pensis) determiné para l'evolution des muracidies de Schistosoma mansoni. Comptes rendus des séances de la Societé de biologie, 133: 625-628.

CARLOS, M. A. \& COELHO, P. M. Z., 1978. Crowding effect in Biomphalaria glabrata affecting the intramolusca Schistosoma mansoni. Journal of Parasitology, 64: 1137-1138.

CHAIA, G., 1956. Técnica para concentração de miracídios. Revista Brasileira de Malariologia e Doenças Tropicais, 8: 355-357. 


\section{RELAÇÃO MOLUSCO/PARASITA}

CHENG, T. C. \& Dougherty, W. J., 1990. Ultrastructural evidence for the destruction of Shistosoma mansoni sporocysts associated with elevated lysosomal levels in Biomphalaria glabrata. Journal of Parasitolology, 75:928-941.

CHERNIN, E., 1970. Behavioral responses of miracidia of Schistosoma mansoni and other trematodes to substances emitted by snails. Journal of Parasitology, 56: 287-296.

1972. Penetrative activity of Schistosoma mansoni miracidia stimulated by exposure to snail-conditioned water. Journal of Parasitology, 58: 209-212.

1974. Some host-finding attributes of Schistosoma mansoni miracidia. American Journal of Tropical Medicine and Hygiene, 23: 320-327.

CHERNIN, E. \& ANTOLICS, V. M., 1975. Penetrative capacity of Schistosoma mansoni miracidia. Journal of Parasitology, 63: 560-561.

COELHO, M. V., 1954. Ação das formas larvárias do Schistosoma mansoni sobre a reprodução de Australorbis glabratus. Publicações Avulsas do Instituto Aggeu Magalhães, 3: 39-54.

1957. Aspectos do desenvolvimento de formas larvais de Schistosoma mansoni em Australorbis nigricans. Revista Brasileira de Biologia, 17: 325-337.

1962. Susceptibilidade de Australorbis tenagophilus a infecção por Schistosoma mansoni.

Revista do Instituto de Medicina Tropical de São Paulo, 4: 289-295.

COELHO, M. V. \& BARBOSA, F. S., 1956. Qualidade de vetor dos hospedeiros de Schistosoma mansoni no Nordeste do Brasil. 3 - Duraçāo da infestação e eliminaçāo de cercárias em Tropicorbis centimetralis. Publicações Avulsas do Instituto Aggeu Magalhães, 5: 21-30.

COELHO, M. V. \& CHAIA, M. V., 1960. Equilíbrio hospedeiro-parasita em Australorbis glabratus de Belo Horizonte, infectados por Schistosoma mansoni e sujeitos à estivaçāo em laboratório. Revista Brasileira de Malariologia e Doenças Tropicais, 12: 351-354.

COELHO, P. M. Z.; FIGUEIREDO, Y. P.; PELlEGRINO, J. \& MELO, G. R., 1977. Crowding effect related to aquarium water components. Journal of Parasitology, 63: 284.

COELHO, P. M. Z.; GAZZINELLI, G.; PELLEGRINO, J. \& PEREIRA, L. H., 1975. Aspects of the crowding effect in Biomphalaria glabrata (Say, 1818) evaluated by $59 \mathrm{Fe}$ uptake. Revista do Instituto de Medicina Tropical de São Paulo, 17: 129-134.

COLES, G. C., 1973. The effect of diet and crowding on the shedding of Schistosoma mansoni cercariae by Biomphalaria glabrata. Annals of Tropical Medicine and Parasitology, 67: 419-424.

DAMIAN, R. T., 1987. Molecular mimicry revisited. Parasitology Today, 3: 263-266.

DUKE, B. O. L., 1952. The route of emergence of the cercariae of Schistosoma mansoni from Australobis glabratus. Journal of Helminthology, 55: 133-146.

FAUST, E. C. \& HOFFMANN, W. A., 1934. Studies on schistosomiasis mansoni in Puerto Rico. I - The extramamalian phases on lyfe-cycle. Puerto Rico Journal of Public Health and Tropical Medicine, 10: 1-47.

FOURNIER, A. \& THERON, A., 1985. Sectorisation morpho-anatomique et fonctionnelle du sporocyst-fils de Schistosoma mansoni. Zeitschrift für Parasitenkunde, 71: 325-336.

FRYER, S. E. \& BAYNE, C. J., 1990a. Opsonization of yeast by the plasma of Biomphalaria glabrata (Gastropoda): a strain-specific, time-dependent process. Parasite Immunology, 11: 269-278.

1990b. Shistosoma mansoni modulation of phagocytosis in Biomphalaria glabrata. Journal of Parasitology, 76: 45-52.

GAZZINELLI, G.; RAMALHO-PINTO, F. J.; PELLEGRINO, J. \& GILBERT, B., 1970. Uptake of ${ }^{59} \mathrm{Fe}$ as a tool for the study of the crowding effect in Biomphalaria glabrata. American Journal of Tropical Medicine and Hygiene, 19: 1034-1037. 
GORDON, R. M. \& GRIFFITHS, R. B., 1951. Observations on the means by which the cercariae of Schistosoma mansoni penetrate mammalian skin together with an account of certain morphological changes observed in the newly penetrated larvae. Annals of Tropical Medicine, 45: 227-243.

GRANATH, W. O. Jr. \& YOSHINO, T. P., 1984. Schistosoma mansoni passive transfer of resistance by serum in the vector snail Biomphalaria glabrata. Experimental Parasitology, 58: 188-193.

JOURDANE, J.; THERON, A. \& COMBES, C., 1980. Demonstration of several sporocysts generations as a normal pattern of reproduction of Schistosoma mansoni. Acta Tropica, 37: 177-182.

KECHERMIR, N. \& COMBES, C., 1988. Up to what point are cercariogenesis and sporocystogenesis reversible in schistosomes? Journal of Helminthology, 62: 261-264.

KLOETZEL, K., 1958. Observações sobre o tropismo do miracídio do Schistosoma mansoni pelo molusco Australorbis glabratus. Revista da Sociedade Brasileira de Biologia, 18: 223-232.

KNAAP, van der W. P. W. \& LOCKER, E. S., 1990. Immune mechanism in trematode-snail interaction. Parasitology Today, 6: 175-182.

LANG, M., 1983. Analyse des Entwicklungsmuster der intramosluskären Stadien von Schistosoma mansoni. Tese. Würzburg, Germany: University of Würzburg.

LEIPER, R. T. \& ATKINSON, E. L., 1975. Observations in the spread of Asiatic schistosomiasis. British Medical Journal, 1: 201-203.

LIE, K. J., 1982. Survival of Schistosoma mansoni and other trematode larvae in the snail Biomphalaria glabrata. A discussion of the interference theory. Tropical and Geographical Medicine, 34: 111-122.

LIE, K. J.; JEONG, K. H. \& HEYNEMAN, D., 1982. Further characterization of acquired resistance in Biomphalaria glabrata. Journal of Parasitology, 68: 529-531.

, 1983. Acquired resistance in snails. Induction of resistance to Schistosoma mansoni in Biomphalaria glabrata. International Journal for Parasitology, 13: 301-304.

, 1987. Molluscan host reactions to helminthics infections. In: Immune Responses in Parasitic Infections: Immunology, Immunopathology, and Immunoprophylaxis. Vol. IV- Protozoa, Arthropods, and Invertebrates. (E.J.L. Soulsby), Vol. IV, Boca Raton, Florida: CRS Press Inc.

LIE, K. J.; HEYNEMAN, D. \& RICHARDS, C. S., 1977. Studies in resistance in snails. Interference by non-irradiated echinostoma larvae with natural resistance to Schistosoma mansoni in Biomphalaria glabrata. Journal of Investigative Pathology, 29: 118-125.

LINTON, E., 1917. Sporocysts in an annelid. The Biological Bulletin, 28: 115-118.

LOCKER, E. S. \& BAYNE, C. J., 1982. In vitro encounters between Schistosoma mansoni primary sporocysts and hemolymph components of susceptibilities and resistant strains of Biomphalaria glabrata. American Journal of Tropical Medicine and Hygiene, 31: 999-1006.

LOCKER, E. S.; YUI, M. A. \& BAYNE, C. J., 1984. Schistosoma mansoni: agglutination of sporocysts, and formation of gels on miracidia transforming in plasma of Biomphalaria glabrata. Experimental Parasitology, 58: 56-62.

LUTZ, A., 1919. O Schistosoma mansoni e a schistosomatose segundo observações feitas no Brasil. Memórias do Instituto Oswaldo Cruz, 11: 121-155.

MALDONADO, J. F. \& ACOSTA-MATIENZO, J., 1947. Evolution del Schistosoma mansoni dentro de su hosped intermediario, el caracol Australorbis glabratus. Puento Rico Journal of Public Health and Tropical Medicine, 22: 374- 404.

, J., 1948. Biological studies on the miracidium of Schistosoma mansoni. American Journal of Tropical Medicine and Hygiene, 28: 645-657.

MARTIN, W. E., 1952. Another annelid first intermediate host of a digenetic trematode. Journal of Parasitology, 38: 356-359. 


\section{RELAÇÃO MOLUSCO/PARASITA}

NEWTON, W. L., 1952. The comparative tissue reaction of two strains of Australorbis glabratus to infection with Schistosoma mansoni. Journal of Parasitology, 38: 362-366.

OLIVER, L.; BARBOSA, F. S. \& COELHO, M. V., 1954. The influence of infection with Schistosoma mansoni on survival of Australorbis glabratus. Publicaçōes Avulsas do Instituto Aggeu Magalhães, 3: 63-71.

OLIVER, L. \& MAO, C. P., 1949. The early larval stages of Schistosoma mansoni (Sambon, 1907) in the snail host, Australorbis glabratus (Say, 1818). Journal of Parasitology, 35: 267-275.

OTTOLINA, C., 1957. El miracidio del Schistosoma mansoni. Revista de Sanidade y Assistencia Sociale, 22: 1-411.

PAN, C., 1965. Studies on the host-parasite relationship between Schistosoma mansoni and the snail Australorbis glabratus. American Journal of Tropical Medicine and Hygiene, 14: 931-976.

PARAENSE, W. L. \& CORREA, L. R., 1963a. Variation in susceptibility of populations of Australorbis glabratus to a straion of Schistosoma mansoni. Revista do Instituto de Medicina Tropical de São Paulo, 5: 15-22.

1963b. Susceptibility of Australorbis tenagophilus to infection with Schistosoma mansoni. Revista do Instituto de Medicina Tropical de São Paulo, 5: 23-29.

PIMENTEL-SOUZA, F.; FERNANDES-SOUZA, N.; SCHALL, V. T. \& COELHO, P. M. Z., $1976 a$. Comportamento elementar do caramujo Biomphalaria glabrata. I: Disposição espacial da concha. Revista Brasileira de Pesquisas Médicas e Biológicas, 9: 117-122.

1976b. Comportamento elementar do caramujo Biomphalaria glabrata. II: Localização e tamanho da massa cefalopodal exposta. Revista Brasileira de Pesquisas Médicas e Biológicas, 9: 123-127.

PIMENTEL-SOUZA, F.; SCHALL, V. T.; LAUTNER, R. Jr.; BARBOSA, N .D. C.; SCHETTINO, M. \& FERNANDES, N., 1984. Behavior of Biomphalaria glabrata under different lithening conditions. Canadian Journal of Zoology, 62: 2328-2334.

RICHARDS, C. S., 1975. Genetic factors in susceptibility of Biomphalaria glabrata for different strains of Schistosoma mansoni. Parasitology, 70: 231-241.

RICHARDS, C. S.; KNIGHT, M. \& LEWIS, F. A., 1992. Genetic of Biomphalaria glabrata and its effect on the outcome of Schistosoma mansoni infection. Parasitology Today, 8: 171-174.

SCHWANBEK, A.; BECKER, W. \& RUPPRECHT, H., 1986. Quantification of parasite development in the host-parasite system Biomphalaria glabrata and Schistosoma mansoni. Zeitschrift für Parasitenkunde, 72: 365-373.

STANDEN, O. D., 1949. Experimental schistosomiasis: Maintenance of Schistosoma mansoni in the laboratory, with somes notes on experimental infections with Schistosoma haematobium. Annals of Tropical Medicine and Parasitology, 43: 268-283.

1951. The effect of temperature, light, and salinity upon the hatching of the ova of Schistosoma mansoni. Transactions of the Royal Society of Tropical Medicine and Hygiene, 45: 225-241. STEIN, P. C. \& BASCH, P. F., 1979. Purification and binding properties of hemagglutinin from Biomphalaria glabrata. Journal of Invertebrate Pathology, 33: 10-14.

SULLIVAN, J. T. \& SPENCE, G. V., 1994. Transfer of resistance to Schistosoma mansoni in Biomphalaria glabrata by allografts of amoebocyte-producing organ. Journal of Parasitology, 80: 449-453.

VAlle, C. M.; PELlegrino, J. \& AlVARENGA, N., 1971. Ritmo circadiano de emergência de cercárias (Schistosoma mansoni - Biomphalaria glabrata). Revista Brasileira de Biologia, 31: 53-63.

YOSHINO, T. P. \& BAYNE, C., 1983. Mimicry of snails host antigens by miracidia and primary sporocyst of Schistosoma mansoni. Parasite Immunology, 5: 317-323. 
YOSHINO, T. P. \& CHENG, T. C., 1978. Snail host-like antigens associated with the surface membranes of Schistosoma mansoni miracidia. Journal of Parasitology, 64: 752-760.

YOSHINO, T. P.; RENWRANTZ, L. R. \& CHENG, T. C., 1979. Binding and redistribution of surface membrane receptors for concanavalin A on oyester hemocytes. Journal of Experimental Zoology, 207: 439.

WILLIAMS, P. \& COELHO, P. M. Z., 1975. The attraction of snails to betalights. Transactions of the Royal Society of Tropical Medicine and Hygiene, 67: 616-617.

WRIGHT, C. A., 1960. The crowding phenomenon in laboratory colonies of fresh-water snails. Annals of Tropical Medicine and Parasitology, 54: 224-232.

ZELCK, V. \& BECKER, W., 1990. Lectin binding cells of Schistosoma mansoni sporocystis and sorrounding Biomphalaria glabrata tissue. Journal of Invertebrate Pathology, 55: 91-99.

Prof. Paulo Marcos Zech Coelho Departamento de Parasitologia, Instituto de Ciências Biológicas

Universidade Federal de Minas Gerais Caixa Postal 486, 30161-970, Belo Horizonte, MG, Brasil. 
Controle

5 


\subsection{Controle Biológico dos Moluscos}

\section{Transmissores da Esquistossomose:}

A Competição Interespecífica Biomphalaria glabrata x Biomphalaria straminea

\section{INTRODUÇÃO}

A preocupação com o controle biológico dos moluscos transmissores da esquistossomose vem de muitos anos. A busca de soluções alternativas, não poluidoras, para o controle dessa endemia tem sido uma preocupação constante dos técnicos em Saúde Pública. Michelson (1957) faz uma revisão sobre competidores predadores e parasitos dos caramujos, utilizando-se, na época, de 148 citações bibliográficas. Esta revisão foi importante para dar início a investigações neste campo, realizadas na Escola de Saúde Pública da Universidade de Harvard (Chernin et al.).

A partir desta data, a literatura conta com numerosas publicações que tratam, a maioria das vezes, de observações ocasionais de laboratório sobre ações patogênicas, predadoras e competitivas de diferentes tipos de animais sobre os moluscos, particularmente os planorbídeos. Revisões compreensivas deste tema foram feitas por Ferguson (1972 e 1978), Hairston et al. (1975) e McCullogh (1981). Este assunto é também tratado em várias publicações da Organização Mundial da Saúde (OMS) (WHO, 1975, 1987, entre outras) e mais recentemente foi revisto por Madsen (1990) e por Coimbra Jr. (1991).

\section{Competição Biológica}

A competição biológica é um fenômeno largamente generalizado na natureza e, como tal, a base explicativa da distribuição e da abundância dos seres vivos, na natureza.

O potencial biótico levaria as populações ao crescimento exponencial - o que só excepcionalmente acontece na natureza -, não fora o papel desempenhado pela coexistência de populações da mesma espécie ou de espécies correlatas.

Os trabalhos de Gause (1932) e Hardin (1960) sobre teorias de competição animal, são sintetizados por De Bach (1966), que explica o mecanismo pelo qual duas espécies de semelhança ecológica não poderiam coexistir em um mesmo 
hábitat: "Espécies diferentes que coexistem indefinidamente no mesmo hábitat devem ter nichos ecológicos diferentes, ou seja, elas não devem ser ecologicamente homólogas".

Segundo Pianka (1982) as espécies ecologicamente homólogas são estreitamente aparentadas, em especial as pertencentes ao mesmo gênero, ou congêneres, que apresentam fortes semelhanças morfológicas, fisiológicas, comportamentais e ecológicas. Em conseqüência, a competição seria intensa entre congêneres simpátricos.

Lotka (1925) e Voltera (1926) foram os pioneiros no desenvolvimento de teorias e métodos matemáticos para fundamentar o princípio da competição. A partir daí, diversos outros autores se propuseram a criar modelos para estudos da competição animal, como: Andrewartha \& Birch (1954), Chiang (1954), Williamson (1957), Leslie \& Gower (1958), Pileou (1968), Robson (1972), McGehee \& Armstrong (1977), Hutchinson (1978) e MacCulloch (1985). Essas teorias podem predizer fenômenos da substituição de uma espécie por outra em um ambiente uniforme, porém os rumos e o produto final da competição vão depender da influência dos fatores determinantes e requerem investigação experimental.

Hutchinson (1978) discute as interações competitivas como resultantes da sobreposição dos nichos das espécies em questão, concluindo que nos locais de sobreposição deverá se desencadear um processo competitivo que poderia ter como resultado final a exclusão de uma espécie pela outra. Em relação aos vetores da esquistossomose, vale citar Hubendick (1958), que pela primeira vez emitiu o conceito de que a seleção natural poderia favorecer uma cepa de caramujo nãosuscetível a Schistosoma mansoni, levantando a possibilidade do desenvolvimento de um método de controle biológico entre cepas resistentes e suscetíveis; e Richard (1970), que desenvolveu técnicas para seleção de cepas resistentes de Biomphalaria glabrata e Biomphálaria straminea e sugeriu que a combinação de certas condições genéticas poderiam favorecer o processo de seleção natural da cepa não-suscetível, afirmando que tais estudos constituem a base mais importante para o controle biológico dos caramujos transmissores da esquistossomose.

\section{A Exclusão Competitiva Biomphalaria straminea X Biomphalaria glabrata}

O presente trabalho restringe seu âmbito à análise dos trabalhos recentemente publicados sobre a competição interespecífica entre os dois planorbídeos hospedeiros de $S$. mansoni no nordeste do Brasil, $B$. glabrata e $B$. straminea.

A distribuição geográfica destas espécies no nordeste do Brasil é conhecida graças aos trabalhos de Lucena (1963), Barbosa \& Figueiredo (1969) e Paraense (1972). Embora as duas espécies possam se sobrepor territorialmente, B. glabrata 
está limitada à região da mata, enquanto $B$. straminea é espécie de larga distribuição tanto nesta região como nas regiões do agreste e da caatinga.

A despeito de $B$. glabrata e $B$. straminea poderem conviver em uma mesma região (simpatrismo) dificilmente elas vivem em sintonia (Barbosa \& Olivier 1958; Barbosa, 1962). Paraense \& Deslandes (1955) assinalam a coexistência destas duas espécies em Minas Gerais mencionando, entretanto, a raridade de tal ocorrência.

B. straminea é a espécie com distribuição mais ampla em todo o território brasileiro. Considerada por Gerken (1975) como a mais primitiva das espécies de planorbídeos americanos, tem-se expandido e se adaptado aos mais diversos ecótopos do país e do mundo.

Estas observações sobre a ocupação espacial diferenciada das duas espécies de Biomphalaria (que se aplicam também a $B$. tenagophila) têm levado diversos pesquisadores a admitir o princípio da exclusão competitiva como importante fator, influenciando a distribuição das populações das três espécies de moluscos (Paraense, 1970).

Em relação às interações populacionais entre $B$. glabrata e $B$. straminea vale mencionar as observações iniciais de Barbosa (1973), que durante três anos consecutivos (1952-1954) acompanhou um experimento natural no qual $B$. straminea, ocasionalmente introduzida em área circunscrita, habitada exclusivamente por B. glabrata, substituiu totalmente esta última espécie. Quatro formas mistas foram interpretadas como híbridos interespecíficos que, entretanto, desapareceram nos anos seguintes às observações, mostrando, assim, sua inabilidade em perpetuarem-se na natureza. A substituição de B. glabrata por $B$. straminea foi interpretada como um caso de exclusão competitiva. Duas possibilidades foram sugeridas, naquela ocasião, para explicar a quebra da estabilidade populacional de B. glabrata: a maior suscetibilidade desta espécie à infecção por $S$. mansoni que produz danos severos à vida dos caramujos infectados, e a mais alta resistência de $B$. straminea à dessecação, fenômeno que ocorria, sazonalmente, na área de estudo.

Segundo Guyard \& Pointier (1979 e 1982) e Pointier (1982 e 1983), B. glabrata é uma espécie rara atualmente em Martinica, e que está sendo substituída gradualmente por $B$. straminea em numerosos cursos de água que antes se constituíam em sítios de transmissão da esquistossomose. A substituição progressiva de $B$. glabrata por $B$. straminea foi, sem dúvida, o fator responsável pela interrupção na continuidade da parasitose na ilha. Vale ressaltar que $B$. straminea de Martinica, tem-se mostrado resistente à infecção por S. mansoni.

Em estudos de laboratório, Michelson \& Dubois (1979) concluem ser $B$. straminea uma espécie que, em condições artificiais, mostrou-se mais agressiva e com maior vagilidade ao invadir território ocupado por $B$. glabrata, competindo com esta última espécie. 
A partir de 1976, face aos resultados observados em campo (Barbosa, 1973), fundos específicos foram atribuídos pela Fundação Oswaldo Cruz ao Centro de Pesquisa Aggeu Magalhães, em Recife, para o desenvolvimento de um programa, a longo prazo, de controle biológico por competição interespecífica dos Biomphalaria da região, B. glabrata e B. straminea (Barbosa et al., 1983). Para a finalidade acima foram instaladas, em salas isoladas, dez canaletas com renovação contínua de água. Atualmente estas instalações estão funcionando na Estação de Biologia Experimental em São Lourenço da Mata, Pernambuco, unidade de campo do Centro de Pesquisa Aggeu Magalhães.

A idéia central foi a de criar um ambiente uniforme no qual os caramujos viessem a competir tanto quanto possível, fora da influência de algumas variáveis naturais que pudessem interferir na dinâmica das populações de moluscos. $\mathrm{O}$ objetivo deste trabalho de laboratório foi, assim, de estudar a interação populacional das duas espécies em condições controladas.

Diante o ineditismo da proposta, podem-se calcular as dificuldades surgidas no período inicial, pré-operacional, da pesquisa. As instalações físicas do laboratório, com a montagem e funcionamento das canaletas, foram completadas em período relativamente curto de oito meses (maio - outubro de 1976). As dificuldades maiores surgiram com a organização e treinamento do pessoal que iria operar o projeto. Isso incluía o maior rigor na gerência de todo o processo. Para detalhes ver Barbosa et al. (1983).

Em maio de 1977, as dez canaletas foram semeadas com os caramujos para estudos preliminares de dinâmica das populações de $B$. glabrata e $B$. tenagophila. A despeito de todas as preocupações tomadas, o trabalho não foi conduzido satisfatoriamente o que obrigou a mudança de parte do staff e o retreinamento do pessoal. De fato, somente ao final de 1979 a fase operacional do projeto teve início. Em seguida, a metodologia detalhada do projeto foi publicada (Barbosa et al., 1983).

Simultaneamente, faziam-se alguns estudos observacionais em campo e partiase para um estudo experimental de campo, controlado, no município de Alhandra, estado da Paraíba. Alguns fatores que pudessem influir no processo competitivo, foram também estudados.

Observações de campo foram feitas nos municípios de Olinda e Paulista, Pernambuco, onde coletas sistemáticas de moluscos, realizadas em 1979/80, foram comparadas com coletas efetuadas em período anterior, 1951/56. Os resultados mostraram claramente a ocupação por $B$. straminea do espaço reconhecidamente habitado há muitos anos, com exclusividade, por B. glabrata (Barbosa et al., 1981).

Outro estudo observacional foi feito no estado do Sergipe, onde coletas sistemáticas foram realizadas em 1968 . Nessa ocasião, B. glabrata estava limitada 
à zona da mata e costeira, enquanto $B$. straminea habitava quase com exclusividade as zonas do agreste, do sertão e do vale do São Francisco (Mello \& Barbosa, 1969). Em 1988, 20 anos depois, novas coletas foram feitas nas mesmas localidades percorridas em 1968 . Os resultados desta observações mostraram que $B$. straminea havia ocupado com sucesso áreas da faixa úmida do estado, tendo, algumas vezes, deslocado a espécie nativa $B$. glabrata. As duas espécies foram encontradas sempre em criadouros separados, com uma única exceção, o que indica que elas são mutuamente excludentes. Em três localidades houve substituição total de $B$. glabrata por $B$. straminea. A conclusão mais geral foi a de que parece estar ocorrendo um processo natural de substituição de uma espécie pela outra (Figueiredo, 1989a), no estado de Sergipe.

A dinâmica das populações de $B$. glabrata e $B$. straminea foi estudada em condições seminaturais (Barbosa et al., 1992). Curvas de crescimento de duas cepas de $B$. straminea (R3 e PT) e da cepa PA de B. glabrata foram estudadas. A pesquisa teve duração de 120 semanas e foi realizada em canaletas de $4,5 \mathrm{~m}$ de comprimento. Os resultados mostraram que as cepas de $B$. straminea (particularmente a cepa R3) atinge maiores níveis de sustentação (carrying capacity) do que $B$. glabrata. A análise de co-variância da linha reta mostrou diferença significativa entre as cepas estudadas. Em outros termos ficou demonstrado que $B$. straminea (cepa R3) é capaz de viver em condições satisfatórias, em metade do volume de água exigido por $B$. glabrata (Barbosa et al., 1992). Estes estudos mostram que $B$. straminea tem melhor desempenho reprodutivo, o que the confere maior vantagem competitiva.

A superioridade competitiva de $B$. straminea foi demonstrada, em condiçð̃es de laboratório, em interações populacionais diretas com $B$. glabrata. No período de 100 semanas, $B$. glabrata foi totalmente substituída por $B$. straminea. A maior capacidade de dispersão e de vagilidade desta espécie em relação à população de $B$. glabrata foi também demonstrada em estudos experimentais (Barbosa et al., 1984). Em outro tipo de experimento de laboratório, B. straminea mostrou maior capacidade de resistência à dessecação do que $B$. glabrata (Barbosa et al., 1985). Ao final de seis meses de observação, nenhum $B$. glabrata havia sobrevivido, enquanto $10,7 \%$ dos $B$. straminea estavam vivos ( $p<0,001$ ).

\section{O Estudo Experimental de Campo}

A pesquisa experimental de campo teve início em janeiro de 1980 na pequena bacia hidrográfica do rio Junçara, Vale do Abiai, município de Alhandra, Paraíba (Figueiredo, 1989b). 
A área escolhida possui características muito próprias para tal tipo de experimento por constituir uma pequena bacia hidrográfica isolada. A oeste, a bacia é limitada por pequenas colinas. A leste estendem-se vastos manguesais onde deságua o rio Junçara. Em seu percurso, no vale, ele recebe dez pequenos riachos tributários.

Um riacho de nome Popocas, situado nas proximidades do sistema Junçara foi escolhido como área de comparação, caracterizando, assim, a pesquisa como um estudo experimental controlado.

Durante o período de 12 meses (1981/82), a área experimental e de comparação foram pesquisadas regularmente, a cada três meses, com finalidade de se conhecer a distribuição e a abundância dos Biomphalaria nativos. De fato, como já se conhecia de estudos anteriores, realizados na área, a única espécie encontrada foi $B$. glabrata que passou a ser referida como população-alvo.

B. straminea, já conhecida por sua capacidade competitiva face a B. glabrata, foi tomada como competidor e a cepa escolhida foi a R3, albina e resistente à infecção por $S$. mansoni.

Os caramujos coletados, em todo o trabalho de campo, foram referidos por homem/minuto, segundo metodologia descrita por Olivier \& Schneiderman (1956).

Em 1982, começaram a ser introduzidos na área, caramujos da espécie $B$. straminea albinos e resistentes à infeção por $S$. mansoni, cultivados na Estação de Biologia Experimental do Centro de Pesquisas Aggeu Magalhães (Fiocruz) e segundo metodologia descrita (Barbosa, 1992).

A avaliação dos criadouros em competição e do controle foi feita, inicialmente, a cada três meses. Posteriormente, os mesmos passaram a ser analisados a cada seis meses, considerando-se ser este o tempo mínimo para que se pudesse observar alguma mudança no comportamento das populações. Os caramujos foram contados, identificados e devolvidos aos criadouros de origem. A introdução de $B$. straminea resistente (R3) era efetuada logo após a avaliação dos criadouros. Aqueles riachos onde $B$. glabrata havia sido totalmente substituída por $B$. straminea foram considerados como dominados e, em conseqüência, foram suspensas as introduções dos caramujos competidores. O número de caramujos introduzidos em cada riacho variou de acordo com o tamanho do mesmo e o número de moluscos disponíveis em laboratório na época da ida ao campo. Durante este período, foram introduzidos 139.120 caramujos $B$. straminea resistentes nos diversos riachos da área em estudo.

É preciso salientar que uma vez o riacho dominado por $B$. straminea, em nenhum caso houve regressão do processo competitivo. Em outras palavras, jamais B. glabrata foi encontrado em riachos dominados por $B$. straminea. Considere-se ainda o fato de que, na época das chuvas (o inverno), as água sobem a ponto de 
inundar as áreas mais baixas, cobrindo os riachos e permitindo a disseminação dos caramujos.

Das 11 coleções de água trabalhadas, sete tiveram as populações de $B$. glabrata totalmente substituídas pelo caramujo competidor $B$. straminea, (criadouros $\mathrm{n}^{\text {os }} 2,3,4,7,8,10$ e 11), duas (criadouros 5 e 9) sofreram modificações na metade do experimento (o que prejudicou suas avaliações) e duas (criadouros 1 e 6) conservaram os estoques originais de $B$. glabrata, embora $B$. straminea tenha aparecido em números baixos esporadicamente no riacho número 1. O riacho escolhido como controle manteve as populações de $B$. glabrata em níveis elevados durante todo o período do trabalho.

Os resultados desta pesquisa estão condensados na Tabela 1 e na Figura 1.

Cada um dos criadouros trabalhados merece um comentário detalhado porque, embora o fenômeno da exclusão competitiva tẹnha acontecido em 7/9 dos riachos trabalhados e avaliados, o comportamento das populações de cada criadouro variou, tanto no que se refere à densidade populacional, como à extensão do prazo necessário para a substituição de uma espécie pela outra.

$\mathrm{O}$ criadouro $\mathrm{n}^{0} 1$, riacho Junçara, foi o único onde, além de não ter ocorrido a fixação do caramujo competidor, níveis altos da população autóctone de $B$. glabrata foram mantidos em todos os anos de trabalho. Este criadouro possui características especiais em relação aos outros, pelo fato de não estar sujeito a períodos de seca durante o verão (o que poderia ter favorecido a população-alvo, que é menos resistente à dessecação do que o caramujo competidor) e de ser constantemente manipulado para lavagens de roupas.

$O$ criadouro $\mathrm{n}^{\circ} 2$, riacho da Lavadeira, manteve a população original de $B$. glabrata nos dois primeiros anos do experimento. Por ser uma coleção de água de acesso não muito fácil à comunidade local, é pouco usada para lavagens de roupas. Sua utilização prioritária é fundamentalmente a irrigação de lavoura e banhos. $\mathrm{O}$ processo de colonização e estabelecimento de caramujo foi lento. Durante os anos de 1982 e 1983, o número de caramujos resistentes coletados foi insignificante, e somente em 1984 é que se deu a fixação definitiva da colônia. Em 1986, B. straminea já havia dominado totalmente o riacho, sendo a única espécie ali existente em 1986 e 1987. Seca parcialmente.

O criadouro $\mathrm{n}^{\circ} 3$, córrego da Batata, forma na sua nascente uma pequena lagoa resguardada de interferência humana que se constitui, desde o início, um excelente hábitat para o molusco introduzido. Esse córrego está sujeito a dessecações em grande parte de sua extensão, havendo períodos de estiagem em que a água fica restrita a uma pequena poça ao redor da nascente. Logo no primeiro ano de experimento, em $1982, B$. straminea estabeleceu aí sua colônia, proliferou com 
TÓPICOS EM MALACOLOGIA MÉDICA

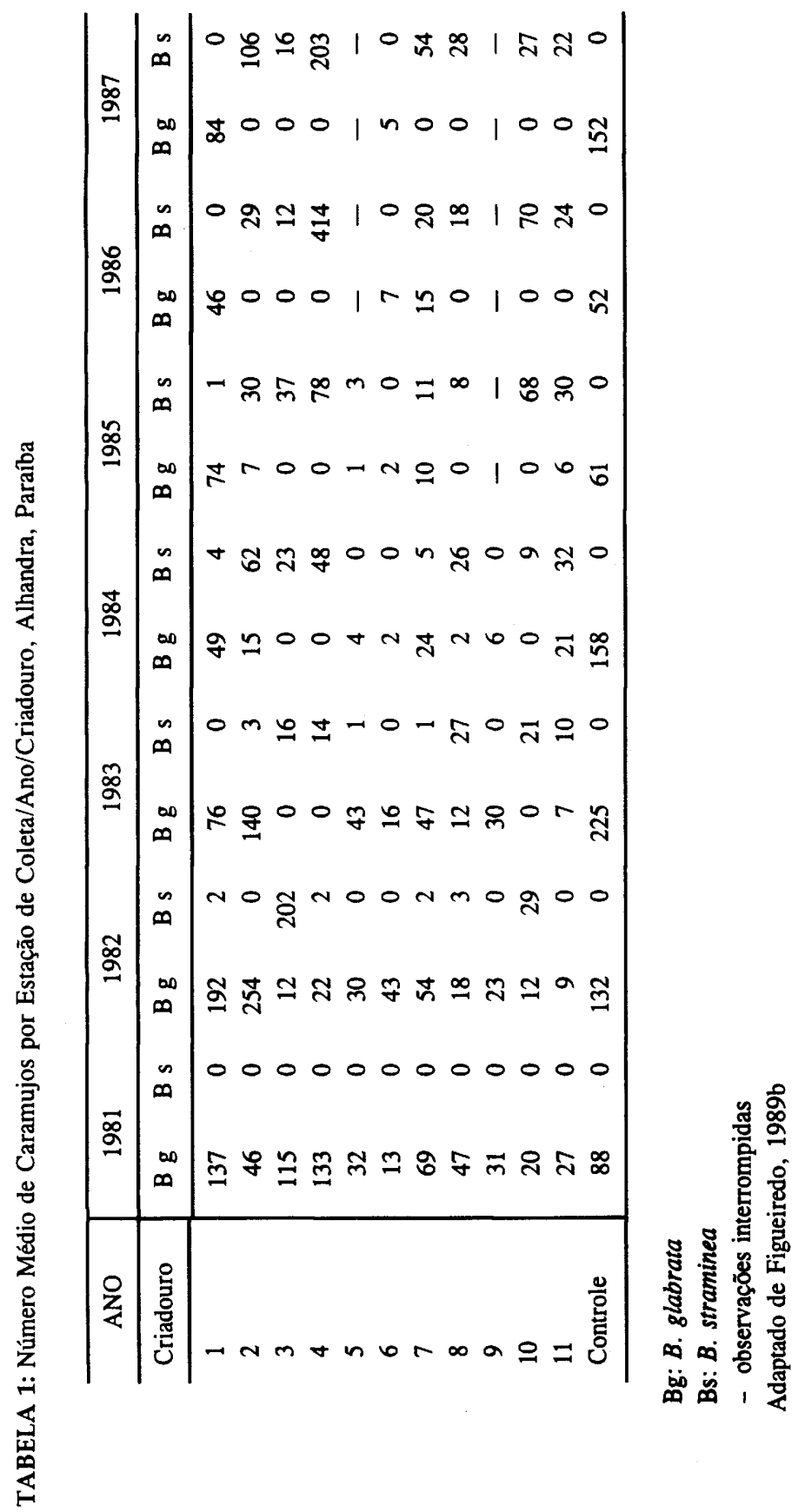


CONTROLE BIOLÓGICO

FIGURA 1
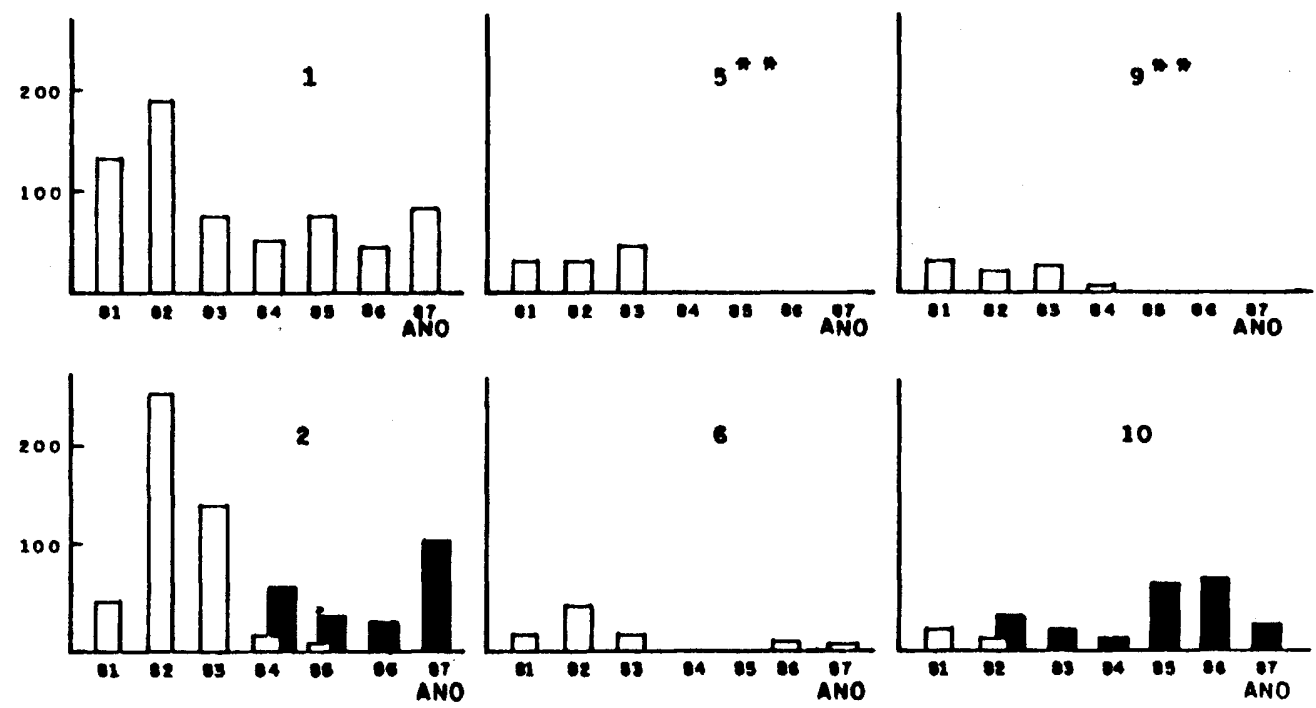

$n$
0
3
3
0
0
0
0
$w$
0
0
0
0
4
$z$
2
$z$
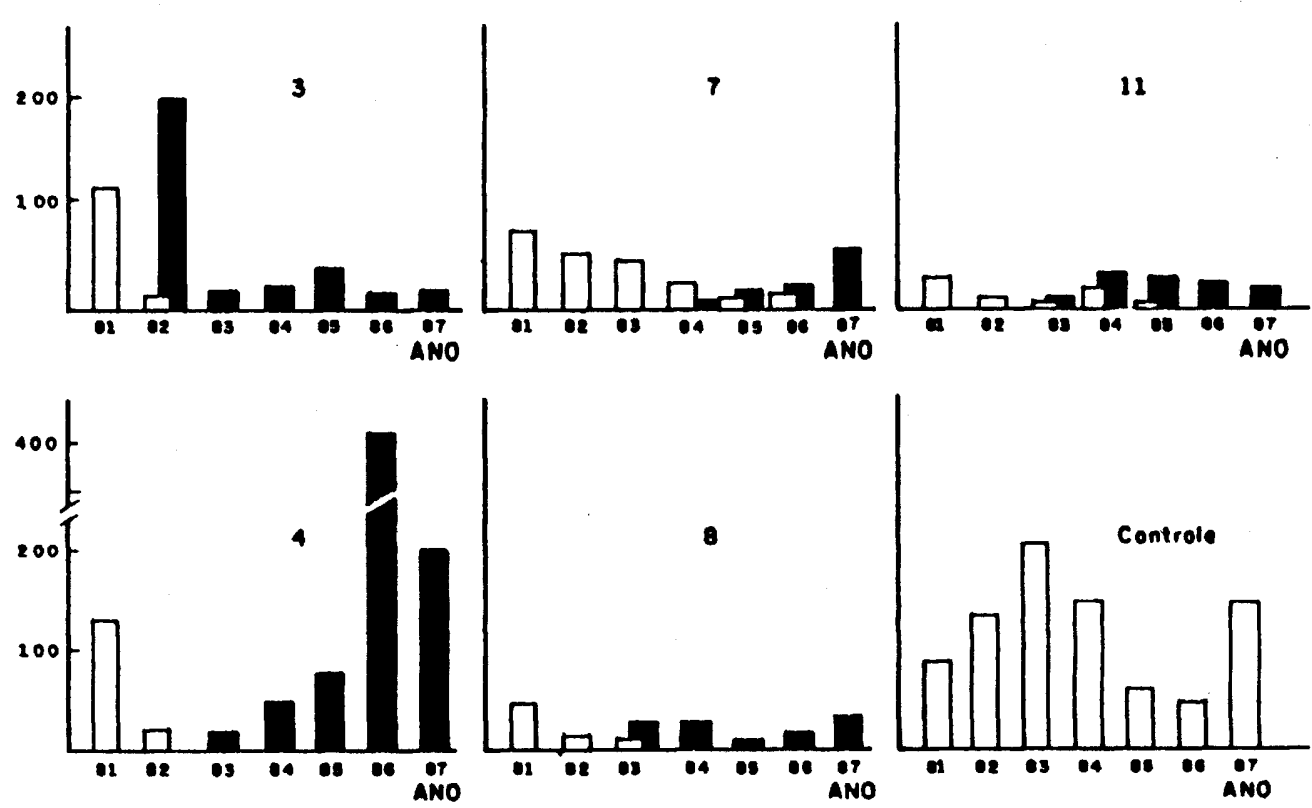

B. golobrate

- adaptado de Figuelredo, 1989

B. etromineo

* ovallogses interrompldas 
abundância e se disseminou em toda a extensão do córrego. Em 1983, já não se encontrava mais nenhum $B$. glabrata e até o final das avaliações, em 1987, o caramujo resistente dominou totalmente esta coleção de água. Fato interessante a assinalar é a existência em abundância, neste logradouro, de um outro tipo de molusco, do gênero Pomacea, que conviveu pacificamente com $B$. straminea.

$O$ criadouro $n^{\circ} 4$, riacho da Venda, tem na sua nascente uma bica adaptada para coleta de água, o que proporciona uma oxigenação abundante ao poço aí formado. Na estação seca, parte do riacho desaparece, ficando a água restrita ao poço da nascente. Neste local, B. straminea começou a se fixar, tendo já em 1983 eliminado a espécie local, sendo, a partir daí, o único molusco a habitar o riacho. Em 1987, ocorreu uma explosão populacional desses caramujos, fato que poderia ser atribuído a um incremento protéico na sua dieta, ocasionado pela lavagem de pratos de uma quitanda instalada nas imediações, que ao despejar os resíduos de alimento na água, fornecia uma ração extra aos caramujos.

O criadouro $n^{0} 5$, riacho do Curral, utilizado para irrigação de lavoura, foi desviado de curso em várias oportunidades, o que provocou um desequilíbrio constante do hábitat dos caramujos. Em 1982 e 1983, B. glabrata ainda dominava o ambiente aquático, em 1984 e 1985 as duas espécies aí sobreviveram sempre com pouquíssimos indivíduos, por causa dos constantes desvios do curso da água. Com a continuação dessa situação, em 1986 e 1987, nenhum caramujo foi encontrado neste criadouro. Parece que, neste caso, a manipulação ambiental ao destruir os refúgios dos moluscos, funcionou como estratégia de controle dos mesmos. Este criadouro não pôde ser avaliado.

$O$ criadouro $n^{\circ} 6$, poço da Jia, não conseguiu ser dominado pela espécie invasora e mesmo a população autóctone de $B$. glabrata, aí se manteve sempre com poucos indivíduos. É um logradouro manipulado pelos moradores locais para pastagem de gado e lavagens de cavalos. Forma, na sua nascente, uma lagoa de água cristalinas, sombreada e que nunca desseca. Essas características foram aproveitadas pela comunidade local, para estabelecer aí um cultivo de tilarias, que se constitui no elemento inibidor para o desenvolvimento dos moluscos, através da predação aos mesmos. Podemos observar que, no momento em que eram feitas as introduções dos caramujos competidores no criadouro, eles eram imediatamente devorados pelos peixes.

O criadouro $\mathrm{n}^{\circ} 7$, riacho do Feijão, só foi dominado por $B$. straminea em 1987 , tendo passado por um lento processo de competição entre as duas espécies. Nos dois anos iniciais do experimento, em 1982 e 1983, B. glabrata se manteve praticamente como a única espécie do hábitat. Somente em 1984, quando o riacho sofreu uma dessecação parcial, é que $B$. straminea começou a se fixar. Sobrepôs-se à população de $B$. glabrata em 1985 e 1986 e, finalmente, em 1987, colonizou todo 


\section{CONTROLE BIOLÓGICO}

o criadouro, estabelecendo-se como espécie absoluta. É um logradouro relativamente isolado do convívio humano, sendo utilizado para coleta de água e irrigação de lavoura por alguns moradores locais, sendo a quase totalidade do seu percurso recoberto por gramíneas e Commelina.

O criadouro $\mathrm{n}^{\circ} 8$, córrego da Porteira, também densamente recoberto por vegetação rasteira, é unicamente utilizado para irrigação de lavoura. Já em 1983, $B$. straminea havia sobrepujado, em quantidade, a população-alvo de $B$. glabrata e, de 1984 a 1987, passou a ser o habitante exclusivo do criadouro. Seca parcialmente.

O criadouro $\mathrm{n}^{\circ} 9$, córrego da Urtiga, não pôde ser avaliado até o final do experimento, por ter seu curso d'água desviado em 1984, para o criadouro de $\mathrm{n}^{\circ}$ 8. Até essa época, o caramujo aí predominante era $B$. glabrata.

O criadouro $\mathrm{n}^{\mathrm{o}} 10$, córrego da Forma, tem sua nascente escavada e adaptada para a coleta de água, formando um remanso de águas tranqüilas, o que se constitui, desde o início, um excelente criadouro para os caramujos. Durante a época de estiagem, fica sujeito a dessecações parciais no seu curso. $B$. straminea teve adaptação imediata neste logradouro, se sobrepondo à população de $B$. glabrata logo no primeiro ano do experimento e dominado o ambiente com exclusividade, de 1983 a 1987.

O criadouro $\mathrm{n}^{\circ} 11$, riacho da Bica, situado nas proximidades de residências de moradores locais, é bastante manipulado, tanto para lavagens de roupas, como para irrigação. Sofre desmatamentos periódicos e está sujeito a dessecações parciais. A ação do sabão utilizado nas lavagens de roupa, não parece ter tido influência sobre os caramujos, uma vez que, neste local, a água esteve sempre corrente. $\boldsymbol{B}$. straminea começou a aparecer em quantidades expressivas em 1983, nos dois anos subseqüentes, conviveu com a espécie-alvo e em 1986 e 1987, já havia dominado totalmente o criadouro.

A maioria dos riachos da área seca na época da estiagem (verão). Uns secam mais intensa, extensa e freqüentemente, enquanto em outros o fenômeno da dessecação é menos acentuado. Os primeiros foram classificados como de dessecação acentuada (que pode chegar a ser anual e total), e os segundos de dessecação moderada (secando, em geral, parcialmente e com menos frequiência). Os demais (diminuem apenas de volume no verão) são considerados perenes. Na Tabela 2 os nove riachos avaliados são classificados de acordo com a espécie e as condições de secura dos riachos. Nos dois únicos riachos perenes $\left(n^{\text {os }} 1\right.$ e 6) $B$. glabrata não conseguiu se fixar. Nos demais nove riachos, tanto os de dessecação moderada $\left(n^{\text {os }} 2,7,8,10\right.$ e 11$)$, como os de dessecação acentuada ( ${ }^{\text {os }} 3$ e 4), a dominação por $B$. straminea foi total. Note-se que nos dois riachos de dessecação acentuada $\left(n^{\text {os }} 3\right.$ e 4$)$, a substituição da população nativa deu-se precocemente (no 
segundo ano de observação). Nos demais cinco riachos, com dessecação moderada, a substituição de $B$. glabrata ocorreu em dois anos $\left(n^{\circ} 10\right)$, quatro anos $\left(n^{\circ} 8\right)$, cinco anos $\left(n^{\text {os }} 2\right.$ e 11$)$ e seis anos $\left(n^{\circ} 7\right)$.

TABELA 2: Distribuição dos Nove Riachos Avaliados, de Acordo com as Espécies Presentes e as Condiçōes de Dessecação dos Criadouros, Alhandra, Paraíba, 1982 a 1987*

\begin{tabular}{lccc}
\hline $\begin{array}{l}\text { condiçōes e } \mathrm{n}^{\circ} \text { dos } \\
\text { criadouros }\end{array}$ & $\begin{array}{l}\text { mantido o estoque } \\
\text { original B. glabrata }\end{array}$ & $\begin{array}{c}\text { dominados } \mathrm{p} / \\
\text { B. straminea }\end{array}$ & TOTAIS \\
\hline Perene (1 e 6) & 2 & - & 2 \\
$\begin{array}{l}\text { Dessecação moderada } \\
7,8,10,11)\end{array}$ & - & 5 & 5 \\
$\begin{array}{l}\text { Dessecação acentuada } \\
(3 \text { e 4) }\end{array}$ & - & & \\
\hline TOTAIS & 2 & 7 & 2 \\
\hline
\end{tabular}

* Verificar observações no texto original

\section{Fatores Condicionantes da Exclusão Competitiva}

B. straminea, sem dúvida, possui ampla valência ecológica, comprovada pela sua considerável distribuição geográfica (Paraense, 1977 e 1986) e pelo fato de que vem ocupando, com sucesso, regiões de ecótopos os mais diversos. No nordeste do Brasil, Barbosa (1973) e Barbosa et al. (1981) acompanharam em localidades da Zona da Mata, o deslocamento progressivo de populações de $B$. glabrata por $B$. straminea. Em 1980, Santos et al. detectaram pela primeira vez a presença de $B$. straminea no Vale do Paraíba, estado de São Paulo. Recentemente, Telles (1988) informa estar esta espécie disseminada por todo o estado, o que atesta, mais uma vez, a sua dispersão e fixação em regiões até então consideradas inóspitas para a espécie.

As observações de Guyard \& Pointier (1982), sobre a substituição de $B$. glabrata por $B$. straminea, em Martinica, e as de Woodruff et al. (1985), sobre a introdução e expansão desta última espécie na China e na Austrália, confirmam a capacidade deste molusco em ocupar os mais diversos ambientes. Essa capacidade invasora estaria associada às características específicas, tais como: vagilidade e agressividade (Michelson \& Dubois, 1979; Barbosa et al., 1984); resistência à 
dessecação (Oliver \& Barbosa, 1956; Barbosa et al., 1985); alta taxa de locomoção e poder de exploração do ambiente (Schall et al., 1986). Acrescenta-se a estes atributos a maior capacidade de sustentação (Carrying capacity) de $B$. straminea em comparação a B. glabrata (Barbosa et al., 1992).

Tais atributos comportamentais se fundamentam na maior variabilidade genética detectada em $B$. straminea em relação à outras espécies de Biomphalaria, conforme os estudos feitos por Woodruff et al. (1985). Essa variação genética, provavelmente, estaria associada a uma melhor capacidade de adaptação às diversas condições ambientais e, conseqüentemente, a um desempenho mais eficaz no sentido de usufruir melhor dos recursos ambientais disponíveis e vitais à sua sobrevivência.

Hutchinson (1978) fazendo a análise do que poderia ocorrer a uma população de espécies diferentes, que vivendo juntas disputam os recursos do meio ambiente, considera que a capacidade competitiva de uma espécie depende de fatores fisiológicos intrínsecos à mesma, tais como: vitalidade (capacidade de deixar descendência viável); longevidade fisiológica e ecológica (tempo de vida real em condições ambientais específicas); agressividade; vagilidade e tolerância a variações ambientais. Duas espécies similares raramente ocuparão o mesmo nicho, uma tende a deslocar ou eliminar a outra de maneira a tomar posse de um recurso comum essencial a ambas.

Tendo em vista os fatores acima expostos, atribuídos à $B$. straminea, pode-se considerar que esta espécie tenha tido vantagem competitiva dentro de um processo de competição indireta como o que poderia ter ocorrido nos experimentos de Alhandra, Paraíba. A posse das características inerentes a essa espécie teriam permitido melhor adaptação ao hábitat, fazendo com que ela pudesse melhor explorar e ocupar o nicho com exclusividade, eliminando assim a espécie local.

Essa linha de raciocínio reforça a teoria de Hutchinson (1978) sobre nichos ecológicos: uma determinada espécie vivendo sem interferência de outra espécie ocupa o seu "nicho fundamental"'. Na presença de um competidor, esse nicho irá ser restringido a um "nicho real"2, ou seja, a espécie competidora irá ocupar com mais eficiência os recursos disponíveis, determinando àquela mais fraca uma redução da fecundidade e da sobrevivência.

${ }^{1}$ Definido como combinação de recursos que permitiriam àquela espécie manter uma população viável. O nicho fundamental é hipotético, idealizado como um conjunto de condições ótimas nas quais os organismos não encontrariam inimigos como competidores e conseguiriam explorar os recursos do meio ambiente com exclusividade.

$2 \mathrm{O}$ "nicho real" seria um subconjunto do "nicho fundamental". 
Begon et al. (1986) afirmam que a coexistência das duas espécies passa a ser associada à diferenciação dos nichos reais de cada uma, pela maneira de como a espécie agredida irá se adaptar à restrição quanto à exploração do ambiente.

Essa diferenciação dos nichos, que pode ocorrer face a um enfrentamento interespecífico, é fundamental para a coexistência de congêneres homólogos em um mesmo hábitat.

Uma vez que houve, na maioria dos criadouros deste experimento, a substituição total de $B$. glabrata por $B$. straminea, seria possível inferir que a espécie agredida, participando de um processo competitivo muito intenso, não conseguiu ser hábil o suficiente para diferenciar o seu nicho, mesmo porque o tempo que durou o processo teria sido escasso para permitir que alterações fisiológicas e comportamentais permitissem à $B$. glabrata explorar outros recursos, garantindo, assim, a sua sobrevivência. Neste caso, esta espécie menos favorecida perdeu o seu nicho real quando em disputa com um competidor mais eficiente que foi capaz de saturar inteiramente esse nicho.

Vale salientar que as duas espécies possuem preferências similares quanto a determinados tipos de refúgios dentro do hábitat, não se distribuindo uniformemente pelo ambiente.

Tais considerações levam a acreditar que essas espécies devem ser ecologicamente homólogas e poderíamos até admitir que tenham uma exigência fundamental em comum no que se refere à exploração dos recursos do hábitat, ou seja, que tenham nichos que se sobrepõem. Tal pressuposto partiu da constatação de que $B$. glabrata e $B$. straminea são organismos excludentes tanto quanto vivendo naturalmente em sintopia, como quando forçadas a coexistir em um mesmo criadouro em condições experimentais.

O estudo de Alhandra cumpriu seus objetivos, ao elucidar as interações das duas espécies de moluscos, quando convivendo em um mesmo ambiente. Os possíveis mecanismos causais do deslocamento competitivo de $B$. glabrata por $B$. straminea, discutidos acima, serão motivo e incentivo para trabalhos futuros.

A aplicação prática da metodologia de introdução de uma cepa resistente em criadouros naturais de $B$. glabrata, visando ao controle desse molusco, mostrou-se eficiente nas condições específicas durante o decorrer do experimento. Entretanto, os fatores limitantes desta tecnologia devem ser levados em consideração, como, por exemplo, uma eventual adaptação da cepa resistente a uma outra cepa do parasito que, porventura, venha a se estabelecer na área de aplicação. Sabe-se, além disso, que a superioridade competitiva de um organismo depende, também, de fatores de ordem ecológica, sendo assim, o que ocorreu em determinàda área pode não ser reproduzível em outra, com condições ecológicas diversas. 


\section{CONTROLE BIOLÓGICO}

No momento em que novas tecnologias de laboratório (Barbosa et al., 1983, 1992) e de campo (Figueiredo, 1989b) estão disponíveis e se discutem conceitos teóricos favoráveis ao fenômeno de deslocamento competitivo entre duas espécies de Biomphalaria, vale refletir sobre a continuidade destas investigações.

Em conclusão pode-se afirmar que os resultados das investigações feitas sobre a competição interespecífica $B$. glabrata $\times$ B straminea, relatadas no presente trabalho, indicam claramente que esta última espécie tem condições de superioridade competitiva. Além de fatores favoráveis sugeridos para $B$. straminea, como capacidade de adaptação, dispersão, vagilidade, dois outros fatores parecem ter importância direta sobre o fenômeno competitivo em favor de $B$. straminea: a maior resistência à dessecação e a maior "capacidade de sustentação" (carrying capacity) de suas populações.

Estes dois fatores podem, ainda, se conjugar no ambiente natural, quando os hábitats dessecam parcialmente, forçando as duas espécies a saturação populacional ("capacidade de sustentação"), condição esta que comprovadamente favorece $\boldsymbol{B}$. straminea.

Os estudos realizados até então devem ser complementados por novas observações e experimentos para melhor compreensão do fenômeno.

Por outro lado, ficou demonstrado que o fenômeno de exclusão competitiva $B$. glabrata $\times$ B. straminea pode ser induzido em condições experimentais no campo.

O desenvolvimento de novas cepas de moluscos, obtidas por cruzamentos inter ou intra-específicos e seleção genética, seria do maior interesse na procura de um competidor eficaz a ponto de poder ser utilizado em larga escala no controle da esquistossomose. A este respeito, as observações e estudos de Hubendick (1958), Richard (1970) e Wright (1960 e 1971) devem ser consideradas.

Os estudos correntes não apenas avançaram na geração do conhecimento sobre a dinâmica do processo competitivo entre duas espécies de Biomphalaria, como abriram uma larga linha de investigação neste campo.

\section{REFERÊNCIAS BIBLIOGRÁFICAS}

ANDREWARTHA, H. G. \& BIRCH, L. C., 1954. The Distribuition and Abundance of Animals. Chicago: University of Chicago Press.

BARBOSA, C. S., 1995. Cultivo em massa de Biomphalaria straminea.

BARBOSA, F. S., 1962. Aspects of the ecology of the intermediate hosts of Schistosoma mansoni interfering with the transmission of bilharziasis in north-eastern Brazil. In: Ciba Foundation Symposium Bilharziasis (G. E. W. Wolstenholme \& Maeve O' Connor, eds.), pp. 23-35, Londres: J. \& A. Churchill. 


\section{TÓPICOS EM MALACOLOGIA MÉDICA}

1973. Possible competitive displacement and evidence of hybridization between two brazilian species of planorbid snails. Malacologia, 14: 401-408.

BARBOSA, F. S. \& FIGUEIREDO, T., 1969. Geographical distribution of the snail hosts of schistosomiasis mansoni in Northeastern Brazil. Revista do Instituto de Medicina Tropical de São Paulo, 2: 285-289.

BARBOSA, F. S. \& OLIVIER, L. J., 1958. Studies on the snail vectors of bilharziasis mansoni in northeastern Brazil. Bulletin of the World Health Organization, 18: 895-908.

BARBOSA, F. S.; PEREIRA DA COSTA, D. P. \& ARRUDA, F., 1981. New field observations on the competitive displacement between two species of planorbid species living in northeastern Brazil. Memórias do Instituto Oswaldo Cruz, 76: 361-366.

1983. Competitive interactions between species of freshwater snails. I Laboratory: Ia General Methodology. Memórias do Instituto Oswaldo Cruz, 78: 335-341.

1984. Competitive interactions between of freshwater snails. I Laboratory: Ib Comparative studies of the dispersal and the vagility capabilities of Biomphalaria glabrata and B. straminea. Memórias do Instituto Oswaldo Cruz, 79: 163-167.

, 1985. Competitive interactions between species of freshwater snails. I Laboratory: Ic Comparative survival of Biomphalaria glabrata and $B$. straminea kept out of water. Memórias do Instituto Oswaldo Cruz, 80: 155-157.

1992. Dynamics of snails population of Biomphalaria glabrata and B. straminea under seminatural conditions. Cadernos de Saúde Pública, 8: 157-167.

BEGON, M.; HARPER, J. L. \& TOWSEND, C. R., 1986. Individuals Populations and Communities. London: Blackwell Scientific Publications.

CHERNIN, E.; MICHELSON, E. H. \& AUGUSTINE, D. L., 1956a. Studies on the biological control of schistosome-bearing snails. I. The control of Australorbis glabratus populations by the snails Marisa cornuarietis, under laboratory conditions. American Journal of Tropical Medicine and Hygiene, 5: 297-307.

1956b. Studies on the biological control of schistosome-bearing snails II. The control of Australorbis glabratus populations by the leech, Helobdella fusca, under laboratory conditions. American Journal of Tropical Medicine and Hygiene, 5: 308-314.

CHIANG, L. C., 1954. Competition and other interactions between species. In: Statistics and Mathematics in Biology, Ames, Iowa: Iowa State College Press.

COIMBRA Jr., C. E. A., 1991. Biological control for freshwater snails. Parasiology Today, 7: 124.

DE BACH, P., 1966. The competitive displacement and coexistence principles. Annales de la Revue de Entomologie, 2: 183-212.

FERGUSON, F. F., 1972. Biological control of schistosomiasis snails. Proceedings of the Symposium on Future Schistosomiasis Control. New Orleans: Max Miller.

1978. The role of biological agents in the control of schistosome-bering snails. Atlanta: Center for Disease Control.

FIGUEIREDO, C. C. S. B., 1989a. Dispersāo de Biomphalaria straminea no estado de Sergipe: um estudo comparativo com dezenove anos de intervalo. Memórias do Instituto Oswaldo Cruz, 84: 383387.

1989b. Interações entre espécies de Biomphalaria, moluscos transmissores da esquistossomose no nordeste do Brasil. Tese de mestrado em Zoologia, Paraíba: Universidade Federal da Paraíba.

GAUSE, G. F., 1932. Ecology of populations. The Quarterly Review of Biology, 7: 27-46. 
GERKEN, S. E.; ARAÚJO, M. P. T. \& FREITAS, J. R., 1975. Suscetibilidade de Biomphalaria straminea da região de Lagoa Santa (MG) ao Schistosoma mansoni. Revista do Instituto de Medicina Tropical de São Paulo, 17: 338-343.

GUYARD, A. \& POINTIER, J. P., 1979. Faune malacologique dulçaquicole et vecteurs de la schistosome intestinale en Martinique. Annales de Parasitologie Humaine et Camparée, 54: 193-205. 1982. Le role de la competition avec Biomphalaria straminea et $B$. glabrata dans le declin de la schistosomose intestinale en Martinique (Antilles Françaises). Budapest: Proceedins of the 8th International Malacological Congress.

HAIRSTON, N. G.; WURZINGER, K. H. \& BURCH, J.B., 1975. Non-chemical methods of snails control. Who document VBC75.573. Genebra: WHO.

HARDIN, G., 1960. The competitive exclusion principle. Science, 131: 1292-1297.

HUBENDICK, B., 1958. A possible method of schistosome-vector between resistant an susceptible strains. Bulletin of the World Health Organization, 18: 1113-1116.

HUTCHINSON, G. E., 1978. An Introduction to Population Ecology. New Haven: New Haven and London University Press.

LESLIE, P. H. \& GOWER, J. C., 1958. The properties of stochastic model for two compenting species. Biometrika, 45: 316-330.

LOTKA, A. J., 1925. Elements of Physical Biology. Baltimore: Williams and Wilkins Co.

LUCENA, D. T., 1963. Planorbídeos transmissores da Esquistossomose no Nordeste do Brasil. Revista Brasileira de Malariologia e Doenças Tropicais, 15: 16-26.

MADSEN, H., 1990. Biological Methods for the Control of Freshwater Snails. Parasitology Today, 6: 237-241.

McCULLOCH, C. E., 1985. Variance tests for species association. Ecology, 66: 1776-1781.

McCULLOGH, F. S., 1981. Biological Control of the snail intermadiate hosts of human Schistosoma spp: a review of its present status and future prospectus. Acta Tropica, 38: 5-13.

McGEHEE, R. \& ARMSTRONG, R. A., 1977. Some mathematical problems concernin the ecological principle of competitive exclusion. Journal of Differential Equations, 23: 30-52.

MELlO, D. A. \& BARBOSA, F. S., 1969. Estudo sobre os planorbídeos transmissores da Esquistossomose Mansônica no Estado de Sergipe. Gazeta Médica da Bahia, 69: 123-136.

MICHELSON, E. H., 1957. Studies on the biological control of schistosome-bearing snails. Predators and parasites of freshwater mollusca: a review of the literature. Parasitology, 47: 413-426.

MICHELSON, E. H. \& DUBOIS, L., 1979. Competitive interactions between two snails hosts of $S$. mansoni. Laboratory studies on B. glabrata and B. straminea. Revista do Instituto de Medicina Tropical de São Paulo, 21: 246-253.

OLIVIER, L. \& BARBOSA, F. S., 1956. Observations on vectors of schistosomiasis mansoni kept out of water in the laboratory. The Journal of Parasitology, 42: 277-286.

OLIVIER, L. \& SCHNEIDERMAN, M., 1956. A method for estimating the density of aquatic snail populations. Experimental Parasitology, 5: 109-117.

PARAENSE, W. L., 1970. Planorbídeos hospedeiros intermediários do Schistosoma. In: Esquistossomose Mansônica (A. S. Cunha, org.), pp. 13-30, São Paulo: Sarvier/Edusp. 1972. Fauna planorbídica do Brasil. In : Introdução a Geografia Médica do Brasil (C. S. Lacaz, R. G. Baruzzi \& E.W. Siqueira Jr., orgs.), pp. 213-239, São Paulo: Edgar Blücher/Edusp. , 1977. Distribuição geográfica dos vetores da xistossomose no Nordeste do Brasil. In: Painel Programa Especial de Controle da Esquistossomose (P. A. Machado, coord.), Brasília: VI Conferência Nacional de Saúde, Ministério da Saúde. 


\section{TÓPICOS EM MALACOLOGIA MÉDICA}

1986. Distribuição dos Caramujos no Brasil. In: Modernos conhecimentos sobre esquistossomose mansônica. Anais Mineiros de Medicina, 12 (Supl.): 117-128.

PARAENSE, W. L.. \& DESLANDES, N., 1955. Studies on Australorbis glabratus. I: Bioespecific characterization. II: Genetic status. Revista Brasileira de Biologia, 15: 341: 348.

PIANKA, E. R., 1982. Ecologia Evolutiva. Barcelona: Ediciones Omega.

PIELOU, D. P.. \& PIELOU, E. C., 1968. Association among species of infrequent occurence: the insect and spider fauna of Polyporus hetulinus. The Journal of Theoretical Biology, 21: 202-216.

POINTIER, J. P., 1982. Etude de la croissance de Biomphalaria glabrata mollusque hôte intermediaire de la Schistosomose intestinale dans le forete marecagneses a Pterocarpus de Guadeloupe (Antilles Françaises). Malacologia, 22: 395-398.

, 1983. La lutte biologique contre les mollusques hôtes intermediaires des bilharzioses a Láide de molusques competiteurs. Symbioses, 15: 85-91.

RICHARD, C. S., 1970. Genetics of a mollusan vector of schistosomiasis. Nature, 227: 806-810.

ROBSON, D. S., 1972 Statistical tests of significance. The Journal of Theorical Biology, 34: 350-352.

SANTOS, L; COSTA, I. B. \& FIGUEIREDO, C. C. S. B., 1980. Primeiro encontro de $B$. straminea (Dunker, 1948) no município de Cruzeiro, Vale do Paraíba, Estado de São Paulo, naturalmente infectada por cercárias de Schistosoma mansoni. Revista do Instituto Adolfo Lutz, 40: 165-166.

SCHALL, V. T.; JURBERG, P. \& ROZEMBERG, B., 1986. Orientation to the snail Biomphalaria straminea (Dunker, 1848) in response to stimulation with light in a situation of selection. Memórias do Instituto Oswaldo Cruz, 81: 255-263.

TELLES, H. M. S., 1988. Aspectos ecológicos de Biomphalaria, Preston, 1910 (Basommatophora, Planorbidae) no Estado de São Paulo, Brasil. I - Sintopia. Ciência e Cultura, 40: 374-379.

VOLTERRA, V., 1926. Variations and Fluctuations of the Number of Individuals in Animal Species Living Together. New York: MacGraw-Hill.

WHO (World Health Organization), 1975. Ecology and control of vectors in public health. Technical Report Series. No. 561, Genebra: WHO.

, 1987. Report of an informal consultation on the detection, isolation, identification and ecology of biocontrol agents of disease vectors. Documento TDR/BVC/IC-GE/87.3, Genebra: TDR/WHO.

WILLIAMSON, M. H., 1957. An elementary theory of interspecific competition. Nature, 180: 442-425. WOODRUFF, D. S.; MULVEY, M. \& YIPP, M. W., 1985. Populations genetics of Biomphalaria straminea in Hong-Kong. The Journal of Heredity, 76: 355-360.

WRIGHT, C. A., 1960. The crowding phenomenon in laboratory colonies of freshwater snails. Annals of Tropical Medicine and Parasitology, 54: 224-232.

, 1971. Comments on the paper by C. A. Richards. Tropical Diseases Bulletin, 68: 33.

Constança Simōes Barbosa

Frederico Simões Barbosa

Estaçāo de Biologia Experimental, CPqAM, Fiocruz.

R. Dr. Francisco Correa, 1114 (54735-000) São Lourenço da Mata - PE. 


\subsection{Perspectivas No Controle Ambiental Dos Moluscos Vetores Da Esquistossomose}

\section{INTRODUÇÃO}

Controle ambiental de moluscos consiste no combate às condições que propiciam a instalação ou permanência dos caramujos, por meio de modificações físicas nos criadouros. As medidas de controle ambiental empregadas nas campanhas de controle, geralmente, envolvem alterações drásticas nos hábitats, a ponto de eliminar as coleções de água (drenagem ou aterro) ou torná-las inviáveis como criadouros de moluscos (canalização). $\mathrm{O}$ exemplo mais espetacular de controle ambiental dos caramujos vetores da esquistossomose é o do Japão, onde o progresso socioeconômico pós-guerra permitiu eliminar os locais de transmissão da doença e impedir o aparecimento de novos focos (Paraense, 1987). Na maioria dos países endêmicos, entretanto, não há perspectivas a curto ou médio prazos de melhoria das condições de vida da população a ponto de eliminar todos os focos de transmissão.

Como a aplicação das medidas de controle ambiental em larga escala envolve altos custos, as campanhas de combate aos caramujos nas áreas endêmicas têm dado preferência ao uso de moluscicidas (controle químico). No entanto, a aplicação de moluscicidas nem sempre é eficaz ou recomendável. Nesses casos, o controle ambiental pode ser uma estratégia complementar necessária, ou mesmo a única alternativa viável para combater os moluscos vetores. Uma resenha detalhada das principais técnicas empregadas para o controle ambiental dos vetores da esquistossomose pode ser encontrada no excelente texto de McMullen (1973), onde ênfase é dada às medidas de engenharia. Informações práticas sobre o emprego dessas medidas também podem ser obtidas nos trabalhos de McJunkin (1975), Cairncorss \& Feachem (1983) e Pike (1987).

No presente capítulo serão abordados exemplos concretos de problemas encontrados pelo pesquisador de campo em nosso país. Ênfase será dada a aspectos particulares do hábitat que podem ser alterados para diminuir as chances de sobrevivência e reprodução dos caramujos, sem exigir mudanças radicais nos criadouros como um todo. A premissa é que pequenas manipulações nos fatoreschaves do meio podem ser eficientes nos casos em que a aplicação de moluscicidas é desaconselhável e o custo de medidas ambientais de amplo espectro, proibitivo.

Atenção especial será dada às perspectivas de controle ambiental dos vetores na área endêmica da região Nordeste, onde as condições socioeconômicas das comunidades atingidas são precárias, e os órgãos públicos locais dispõem de verbas 
irrisórias para a saúde e o saneamento. Trata-se de uma área onde a prevalência da doença tem aumentado preocupantemente nos últimos anos, apesar do tratamento quimioterápico em massa das populações atingidas.

Espera-se que dois pontos básicos fiquem bem claros para o leitor: (a) a escolha adequada das medidas de controle dos moluscos vetores deve ser precedida por estudos locais sobre as variáveis ecológicas e epidemiológicas, e (b) o controle dos caramujos deve fazer parte de um conjunto integrado de medidas de combate à esquistossomose.

\section{Características dos Criadouros da Área Endêmica do Nordeste}

Há várias décadas que se dispõe de informações básicas sobre a ecologia e a distribuição geográfica das espécies vetoras da esquistossomose no Nordeste, bem como sobre as características gerais dos criadouros de importância epidemiológica (Rey \& Pessoa, 1953; Barbosa \& Olivier, 1958; Paraense, 1977). No entanto, só recentemente foram feitas observações quantitativas detalhadas sobre as relações entre os moluscos vetores e aspectos relevantes de seu microhabitat, tais como as características físico-químicas da água, a vegetação macrofítica, o tipo de habitat e o tipo de substrato que prevalecem nos criadouros de importância epidemiológica daquela área (Pieri, 1985). Essas observações permitem identificar fatores-chaves no microhabitat dos moluscos vetores e sugerir manipulações que inviabilizem ou dificultem sua ocorrência nos locais de contato das pessoas com a água.

Embora os moluscos vetores possam colonizar uma grande variedade de coleções de água corrente (desde rios até pequenas valas) e parada (de lagoas e pequenas poças), os focos de transmissão mais importantes na área endêmica do Nordeste têm características topográficas e hídricas bem semelhantes entre si (Pieri \& Thomas, 1987; Kloetzel \& Vergetti, 1988). Em geral, esses focos são localizados em áreas peridomiciliares das comunidades urbanas ou rurais que não dispõem de água encanada ou saneamento básico. Consistem tipicamente em pequenas coleções de água estagnada ou com baixa correnteza, alimentadas por nascedouros e água doméstica servida. Mesmo nas regiōes sujeitas a secas sazonais, esses criadouros podem albergar plantas subaquáticas e populações de caramujos o ano todo, ainda que sua densidade e distribuição variem marcadamente. As principais características desses hábitats, descritas por Pieri (1985), são resumidas a seguir.

\section{Aspectos físico-químicos da água}

A composição química da água é variável, porém dentro das características dos sistemas dulcícolas. Os valores da condutividade estão abaixo de $800 \mu \mathrm{ho} / \mathrm{cm}$, 
havendo predominância dos ions sódio e bicarbonato. A ocorrência dos demais ânions e cátions é similar à obtida na maioria das coleções naturais de água doce. A razão cálcio/magnésio é maior que 1 . Os valores de nitrogênio (amônia) são relativamente elevados (de $0,6 \mathrm{mg} / 1$ a $2,2 \mathrm{mg} / \mathrm{l}$ em média), provavelmente pela alta concentração de matérias orgânicas nos criadouros. Os níveis de oxigênio são abaixo de $50 \%$ do ponto de saturação, e a turbidez pode chegar a valores acima de 100 FTU. O pH varia pouco $\left(6,9 \mathrm{em}\right.$ média), assim como a temperatura $\left(29^{\circ} \mathrm{C} \mathrm{em}\right.$ média).

Esses fatores estão bem dentro dos limites de tolerância das espécies vetoras encontradas naquela região. Biomphalaria glabrata, por exemplo, é capaz de colonizar coleções de água, contendo grandes diferenças nos valores de seus aspectos físico-químicos, como pode ser visto na Tabela 1. Por este motivo, dificilmente alguma medida de controle ambiental daquela espécie baseada exclusivamente na manipulação desses fatores teria a eficácia desejada. Mais difícil ainda seria em relação a Biomphalaria straminea, cuja tolerância a fatores ambientais extremos é maior que a de $B$. glabrata.

\section{Vegetação macrofítica}

As plantas mais comumente encontradas são gramíneas, ciperáceas e outros grupos herbáceos típicos das várzeas úmidas ou alagadas e das áreas onde a vegetação natural foi destruída ou alterada por interferência humana. São poucas as espécies de plantas verdadeiramente aquáticas encontradas nos criadouros, destacando-se as ninfeáceas. Os caramujos associam-se positivamente apenas a espécies de Commelina e Cyperus (Tabela 2). Como essas espécies subaquáticas têm ampla distribuição na área endêmica, elas podem servir como indicadores bióticos da ocorrência de vetores nas coleções de água sob investigação.

$\mathrm{O}$ conhecimento dos mecanişmos causais das associações entre moluscos e macrófitas é de especial interesse para uma compreensão adequada dos aspectos da ecologia dos caramujos vetores que possam ser relevantes para seu controle. Já exisem evidências seguras de que as relações entre caramujos e plantas aquáticas são predominantemente mutualísticas, o que pode explicar as associações positivas encontradas entre determinadas espécies (Thomas, 1987). É menos provável, porém, que tais associações sejam comuns entre os caramujos e as espécies macrófitas subaquáticas. No entanto, plantas com Commelina e Cyperus, que crescem na zona ecótona dos criadouros rasos, podem proporcionar aos caramujos condições microclimáticas especialmente favoráveis. Essas plantas oferecem proteção contra fatores adversos como a radiação solar, altas temperaturas e correntezas, além de 
servir como um substrato fixo para a oviposição dos caramujos e sua locomoção para a superfície (trocas gasosas) ou o fundo (alimentação).

TABELA 1: Valores máximos e mínimos de alguns fatores físicos e químicos da água, obtidos por vários autores em diferentes hábitats, colonizados por Biomphalaria glabrata. (a) Luttermoser \& Castellanos, 1945; (b) Rey \& Pessoa, 1953; (c) Harry et al., 1957; (d) Pimentel \& White, 1959; (e) Sturrock, 1974; (f) Pointier et al., 1977; (g) Freitas, 1978; (h) Mckillop \& Harrison, 1980; (i) Michelson \& Mota, 1982; (j) Patience Thomas \& Sterry, 1983; (k) Pieri, 1985

\begin{tabular}{|c|c|c|}
\hline \multirow{2}{*}{$\begin{array}{c}\text { FATORES } \\
\text { FISICO-QUIMICOS }\end{array}$} & \multicolumn{2}{|c|}{ VALORES } \\
\hline & MÍNIMO & MÁXIMO \\
\hline CONDUTIVIDADE $(\mu \mathrm{mho} / \mathrm{cm})$ & $117(\mathrm{~g})$ & $2000+(e)$ \\
\hline CÁLCIO(mg/l) & $2,4(h)$ & 129 (c) \\
\hline SÓDIO (mg/l) & $6,7(h)$ & $750(h)$ \\
\hline POTÁSSIO (mg/l) & $0,1(h)$ & $54,5(\mathrm{~h})$ \\
\hline FERRO(mg/l) & $0,0(h)$ & $5,4(f)$ \\
\hline $\begin{array}{l}\text { ALCALINIDADE }(\mathrm{mg} / 1 \\
\left.\mathrm{CaCO}_{3}\right)\end{array}$ & 20(a) & 415(c) \\
\hline CLORETO(mg/l Cl) & $1(\mathrm{~g})$ & $3500(b)$ \\
\hline $\begin{array}{l}\text { DIÓXIDO DE } \\
\text { CARBONO(mg/l) }\end{array}$ & $2,3(\mathrm{~g})$ & $90(i, k)$ \\
\hline $\begin{array}{l}\text { NITROGÊNIO } \\
(\text { AMÔNIA)(mg/l) }\end{array}$ & $0,1(\mathrm{~g})$ & $2,6(k)$ \\
\hline SÍLICA (mg/1 $\left.\mathrm{SiO}_{4}\right)$ & $3,1(\mathrm{k})$ & $77(\mathrm{e})$ \\
\hline $\begin{array}{l}\text { \% DE SATURAÇÃO DE } \\
\text { OXIGÊNIO }\end{array}$ & $0,0(j)$ & $86,4(f)$ \\
\hline TURBIDEZ (FTU) & $3,7(\mathrm{~g})$ & $230(e)$ \\
\hline TEMPERATURA( $\left({ }^{\circ} \mathrm{C}\right)$ & 18(i) & 41(f) \\
\hline $\mathrm{pH}$ & $5,6(b, e, j)$ & $9,1(c, d)$ \\
\hline
\end{tabular}




\section{CONTROLE}

\section{Tipo de substrato}

Os moluscos vetores tendem a ocorrer significativamente mais em substratos de depositação, ricos em argila fina e detritos orgânicos, do que em substratos de erosão, sem lama ou material orgânico depositados (Tabela 3). Substratos com depósitos orgânicos são encontrados na maioria dos criadouros da área endêmica do Nordeste, tanto em pequenos charcos e poças quanto em valas e riachos, e constituem provavelmente os indicadores mais importantes da microdistribuição dos moluscos vetores.

TABELA 2: Ocorrência de moluscos vetores em relação às macrófitas aquáticas e subaquáticas mais comumente encontradas nos focos de transmissão da esquistossomose da área endêmica do Nordeste. Os dados são percentagens relativas à presença ou ausência de caramujos e plantas em 56 locais de amostragem (Piere, 1985). As associaçōes positivas estatisticamente significativas estão assinaladas por asterisco

\begin{tabular}{llcc}
\hline \multirow{2}{*}{ PLANTAS } & & \multicolumn{2}{c}{ MOLUSCOS VETORES } \\
& & PRESENTE & AUSENTE \\
\hline Amaranthus spp. & PRESENTE & 8,8 & 12,2 \\
& AUSENTE & 61,4 & 17,6 \\
Commelina spp. & PRESENTE & 62,5 & 16,1 \\
& AUSENTE & 8,9 & $12,5^{*}$ \\
Cyperus spp. & PRESENTE & 42,8 & 3,6 \\
& AUSENTE & 28,6 & $25,0^{*}$ \\
Ipomea sp. & PRESENTE & 12,5 & 1,8 \\
& AUSENTE & 58,8 & 26,9 \\
& PRESENTE & 8,9 & 0,0 \\
Nymphea sp. & AUSENTE & 62,5 & 28,6 \\
\hline
\end{tabular}

A ocorrência preferencial dos caramujos em substratos de depositação pode ser devida a vários fatores. Primeiro, trata-se de um substrato rico em detritos vegetais e em microorganismos epifíticos e epilíticos, que são a principal fonte de alimento dos caramujos (Thomas, 1987). Segundo, esse tipo de substrato inclui pequenas partículas de areia, que são ingeridas pelos caramujos e usadas para triturar o 
alimento (Thomas \& Tait, 1984). Terceiro, esses sedimentos geralmente proporcionam um substrato denso e macio no qual os caramujos podem se enterrar ao menos parcialmemte, evitando assim a luz solar direta em hábitats com pouca cobertura vegetal (Barbosa \& Olivier, 1958). Quarto, substratos de erosão são geralmente associados com correntes acima de $29 \mathrm{~cm} / \mathrm{s}$, que impedem a fixação dos caramujos vetores no solo (Scorza et al., 1961).

\section{Tipo de hábitat}

Os hábitats dos moluscos vetores podem ser classificados como lóticos ou lênticos. Os criadouros lóticos de importância epidemiológica no Nordeste são geralmente riachos ou valas de pequena profundidade, pouca largura e baixa correnteza. Os hábitats lênticos são formados, na maioria, por pequenos pântanos ou coleções de água empoçada. Os hábitats lóticos e lênticos nas áreas de transmissão se assemelham tanto nas características físico-químicas da água quanto na vegetação macrofítica. Além disso, ambos são geralmente ricos em depósitos de material orgânico, proporcionando bom suprimento alimentar para os caramujos. Assim, não é de surpreender que a abundância relativa dos moluscos seja semelhante nos dois tipos de habitat (Pieri, 1985).

TABELA 3: Ocorrência dos moluscos vetores em substratos de depositação (com lama e detritos orgânicos), ou de erosāo (sem argila ou matéria orgânica depositada). Os dados são percentagens relativas à presença ou ausência de caramujos num total de 468 quadrats de $5 \mathrm{~cm}^{2}$, em focos de transmissão da área endêmica da esquistossomose no Nordeste (Pieri, 1985). A proporção de moluscos é significativamente maior em substratos de depositação do que de erosão

\begin{tabular}{lcc}
\multicolumn{1}{c}{ TIPO DE } & \multicolumn{2}{c}{ MOLUSCOS VETORES } \\
SUBSTRATO & PRESENTE & AUSENTE \\
\hline DE DEPOSITAÇÃO & 35,9 & 36,3 \\
DE EROSÃO & 2,1 & 25,7 \\
TOTAL & 38,0 & 62,0 \\
\hline
\end{tabular}

As nascentes e áreas alagadas nas cabeceiras dos riachos, em geral ocupadas por densa vegetação subaquática, constituem um importante refúgio ecológico para os moluscos vetores em áreas elevadas e de relevo irregular. Nessas áreas o solo é 
geralmente sujeito à erosão, em particular durante a estação chuvosa; além disso, gradientes de inclinação acima de $0,02^{\circ}$ são comuns, o que impede a fixação dos moluscos vetores (Harry \& Cumbie, 1956). Em alguns casos, no entanto, os caramujos podem migrar para as cabeceiras e colonizar os refúgios. Assim, embora estejam ausentes da maioria das coleções de água das áreas elevadas, eles ocorrem persistentemente junto às nascentes, mais planas e protegidas.

\section{Uma Estratégia Para Controle Integrado de Moluscos Vetores}

Tendo em vista as características acima descritas, fica claro que as coleções de água da área endêmica de esquistossomose na região Nordeste oferecem condições bem favoráveis à instalação e à permanência dos moluscos vetores. Assim, a escolha das medidas de controle a serem usadas contra os caramujos numa dada situação depende de estudos prévios detalhados que levem em conta a eficácia e o custobenefício das mesmas.

Dentro da estratégia atual de controle da esquistossomose o combate aos moluscos vetores não pode ser considerado isoladamente, mas sim como parte de um conjunto integrado de medidas (OMS, 1985). Nos casos em que abastecimento adequado de água e o saneamento básico são inexeqüíveis, a enfase é na quimioterapia e na educação em saúde. A escolha da melhor combinação de medidas para controle dessa doença em uma área específica depende de informações epidemiológicas detalhadas. A aplicação de medidas contra os caramujos, em particular, necessita de estudos prévios que a justifiquem (McCullough, 1986).

Um exemplo dessa abordagem na área endêmica do Nordeste será visto a seguir, em três etapas: (a) levantamento do histórico epidemiológico de uma áreaproblema, (b) detalhamento das condições propícias para a transmissão da esquistossomose numa localidade específica da área, e (c) descrição das coleções de água epidemiologicamente importantes, seguida de sugestões específicas de medidas integradas para controle dos caramujos naquela localidade.

\section{Histórico epidemiológico de uma área-problema}

O município de São Lourenço da Mata $\left(35^{\circ} \mathrm{W}, 8^{\circ} \mathrm{S}\right)$ localiza-se na zona canavieira de Pernambuco, e pertence à região metropolitana de Recife. Cerca de $22 \%$ da população de 77 mil habitantes vive na área rural. De acordo com o censo de $1980,75 \%$ dos $60 \mathrm{~km}^{2}$ de área cultivada são dedicados à Cultura da cana-deaçúcar. A prevalência da esquistossomose atingia $17,4 \%$ em setembro de 1978 , quando o Programa Especial de Controle da Esquistossomose (Pece) do Ministério da Saúde foi iniciado naquela municipalidade. Durante a fase intensiva de trabalho 
do Pece, $32 \%$ da população foi tratada com oxamniquine. Nessa fase, 642 coleções de água foram localizadas na área, 105 das quais contendo caramujos vetores; $50 \%$ destas foram tratadas com moluscicida (niclosamide). Como resultado das medidas empregadas, a prevalência diminuiu para $11,5 \%$ em 1982; porém, em março de 1986 , a prevalência chegou a atingir $24,6 \%$, ou seja, $14,2 \%$ acima do nível prétratamento.

O único estudo detalhado na área rural do município foi realizado entre 1966 e 1978 por Barbosa \& Costa (1981), em que sete engenhos de cana-de-açúcar foram submetidos a um estudo piloto, visando avaliar o efeito da aplicação de moluscicida no controle da doença. A área é sujeita a um ciclo anual de chuvas, permitindo a identificação de três fases: inverno (abril-julho), pós-inverno (agosto-novembro) e verão (dezembro-março). A única espécie hospedeira intermediária do Schistosoma mansoni é a Biomphalaria straminea, que prolifera durante todo o ano nas pequenas coleções de água que formam um sistema natural de drenagem ao longo do rio Capibaribe. A abundância dos caramujos vetores é maior no pós-inverno do que no resto do ano. A infectividade das coleções de água também varia com a época do ano, sendo significativamente menor durante a estação seca (verão). Os índices de prevalência obtidos a partir de 1973 nesses engenhos estão na Tabela 4.

Desde 1979 essa área tem sido trabalhada pela Superintendência de Campanhas de Saúde Púbica (Sucam). Apesar da aplicação focal de moluscicida e de quatro medicações em massa da população (maio de 1980, outubro de 1982, março de 1984 e março de 1986), em 1990 ultrapassou o nível pré-tratamento (1979) em seis dos sete engenhos (Tabela 4). Esta situação mostra claramente que a esquistossomose ainda está fora de controle nessa área, o que justifica a necessidade de uma conjugação mais eficiente da quimioterapia com o controle de caramujos para o combate efetivo da doença.

\section{Dados relevantes sobre uma localidade da área-problema}

Dentre as sete localidades referidas na Tabela 4, o engenho General apresenta um quadro epidemiológico dos mais preocupantes. Trata-se de um povoado à margem direita do rio Capibaribe, distante cerca de $4 \mathbf{k m}$ da cidade de São Lourenço da Mata, sede do município. A principal atividade da população economicamente ativa é o plantio e o corte da cana-de-açúcar. Até 1979 a prevalência da esquistossomose se mantinha em torno de $26 \%$. Após três tratamentos quimioterápicos da população feitos pela Sucam de 1980 a 1984 , a prevalência desceu a um patamar aceitável de $8 \%$. O índice de $75.6 \%$ obtido em 1990 é, portanto, alarmante, ainda que a intensidade de infecção tenha sido baixa: apenas $7,9 \%$ das pessoas positivas 
para S. mansoni apresentaram mais de 100 ovos do parasita por grama de fezes (J. F. Gonçalves, comunicação pessoal).

Um levantamento realizado em setembro de 1990 (dados inéditos) registrou uma população de 428 pessoas, $33 \%$ das quais tendo menos de 12 anos de idade. A percentagem de analfabetos é superior a $50 \%$. As famílias têm em média seis membros, dos quais apenas dois trabalham. Somente $10 \%$ dos que trabalham ganham mais de dois salários mínimos. As habitações são na maioria geminadas, construídas de alvenaria, com cobertura de telha e piso de cimento. Entretanto, nenhuma dispõe de água encanada, e pouco mais da metade conta com latrinas. Os excretas e o lixo doméstico são, geralmente, atirados no fundo dos quintais, ou jogados diretamente nas coleções de água. Por outro lado, em quase $90 \%$ das famílias há pessoas que têm conhecimento da doença, e sabem que podem preveni-la com um abastecimento adequado de água e saneamento. Em cerca de $30 \%$ dessas famílias sabe-se que a doença é transmitida por caramujos e que pode ser tratada com remédios.

TABELA 4: Evolução da prevalência (\%) da esquistossomose em sete engenhos da cana-de-açúcar em São Lourenço da Mata, município da área endêmica em Pernambuco*, dados de J. F. Gonçalves (comunicação pessoal); 1979-86, dados da Sucam (relatório interno); 1990 , dados inéditos

\begin{tabular}{lcccccccc}
\hline ENGENHOS & $1973^{*}$ & $1974^{*}$ & $1976^{*}$ & $1978^{*}$ & 1979 & 1982 & 1986 & 1990 \\
BELA ROSA & 44,0 & 28,9 & 35,5 & 34,3 & 31,5 & 45,0 & 83,8 & 69,0 \\
CAIRÁ & 43,0 & 34,9 & 32,0 & 39,0 & 28,6 & 25,0 & 74,7 & 85,7 \\
CAMORIM & 44,3 & 19,4 & 27,4 & 34,2 & 49,6 & 73,3 & 63,5 & $90,8^{*}$ \\
GENERAL & 31,0 & 22,4 & 27,3 & 25,2 & 25,8 & 12,5 & 8,0 & $75,6^{*}$ \\
MARTINICA & 34,6 & 25,8 & 24,5 & 15,5 & 24,2 & 7,9 & 14,0 & 31,3 \\
QUIZANGA & 27,0 & 14,4 & 10,6 & 9,0 & 27,1 & 14,6 & 22,4 & 0,0 \\
SÃO JOÃO & 44,0 & 28,6 & 32,9 & 22,7 & 25,9 & 23,4 & 40,7 & 40,6 \\
\hline
\end{tabular}

A localização das moradias, bem como dos elementos topográficos, hídricos e agrários mais importantes da área, está esquematizada na Figura 1. Nela também estão assinalados os locais de contato mais freqüente dos moradores com a água. A principal fonte de água potável é uma cacimba próxima ao núcleo habitacional. $\mathrm{O}$ rio Capibaribe e os riachos que nele desembocam têm trechos que são intensivamente usados para coleta de água, banho, lavagem de roupa, pesca e recreação. 
Dos 17 locais de contato das pessoas com a água identificados no pós-inverno de 1990 , oito albergavam populações de $B$. straminea, onde foram coletados $0,78 \pm$ 0,41 caramujos por pessoa por minuto (média e desvio-padrão).

\section{Descrição dos hábitats e sugestões para controle dos caramujos}

No trecho do rio Capibaribe (1 na Figura 1) usado com freqüência pelos moradores do povoado, a largura média é de $50 \mathrm{~m}$, e a profundidade varia de alguns centímetros nas margens a vários metros no centro. O fluxo da água é controlado por uma comporta instalada a montante. Com isso, na maior parte do ano formamse remansos junto às margens e entre pedras no leito do rio, o que oferece condições favoráveis tanto ao contato das pessoas com a água quanto ao desenvolvimento de populações de $B$. straminea, principalmente no verão. No pós-inverno (setembro) de 1990, o número de caramujos coletados por pessoa por minuto não ultrapassou a 0,3 nos locais usados pelos moradores para banho e lavagem de roupa; já no verão (dezembro) foram coletados até 100 caramujos por pessoa por minuto nos mesmos locais. Por isso, dificilmente a mera aplicação de moluscicidas daria resultados ali. Essa medida deveria ser complementada com a abertura periódica das comportas, aumentando bruscamente o volume e a velocidade da água e destruindo assim os criadouros já estabelecidos.

Os riachos que cortam os canaviais (2, 3 e 4 na Figura 1) têm uma largura média de $2,5 \mathrm{~m}$, uma profundidade menor que $1 \mathrm{~m}$ e uma vazão de água inferior a $0,2 \mathrm{~m}^{3} / \mathrm{s}$. Eles são relativamente livres de vegetação aquática e subaquática, com os substratos de erosão predominando nos trechos mais retilíneos. Somente nas curvas e nos remansos mais fundos (usado para banho e lavagem de roupa) o substrato é de depositação. Os locais de contato da população com a água desses riachos varia durante o ano, não só em função das alterações sazonais no volume de água, como também das freqüentes modificações antrópicas (escavações para coleta de areia, pequenas barragens para pesca, banho e lavagem de roupa). Assim, a melhor medida para controle dos moluscos vetores nesses riachos é a aplicação de moluscicida, precedida pela remoção da vegetação marginal e dos detritos nos trechos mais críticos.

A cacimba usada como principal fonte de água para beber está situada junto à nascente de um riacho ( 2 na Figura 1). No local usado para coleta de água a terra é plana, freqüentemente alagada e coberta por gramíneas e ciperáceas. Trata-se, portanto, de um excelente refúgio ecológico para os moluscos vetores, além de um foco de transmissão em potencial. A medida mais adequada para controle dos caramujos nesse local seria aterrar e drenar a pequena área em volta da cacimba, 


\section{CONTROLE}

de modo a evitar o empoçamento da água. O riacho propriamente dito, que desemboca logo adiante no Capibaribe, pode ser tratado com moluscicida.

FIGURA 1: Representação esquemática dos principais elementos hidrográficos, topográficos e agrários próximos ao núcleo habitacional do Engenho General, município de São Lourenço da Mata, Pernambuco. Círculos grandes indicam os locais de contato freqüente da população com a água. O círculo menor mostra a localizaçāo da única cacimba de água potável da área. $\mathrm{O}$ número 1 identifica o rio Capibaribe. Os demais números identificam os riachos, sendo que o 2 e o 5 têm suas nascentes na área. As habitaçōes geminadas estão representadas por retângulos escuros; as casas isoladas, por quadrados escuros (residenciais) ou claros (não-residenciais). A escola primária está representada por um quadro com um ponto. As pontes estão representadas por colchetes (][). A comporta no rio Capibaribe está indicada por um C. As setas indicam o sentido do fluxo de água

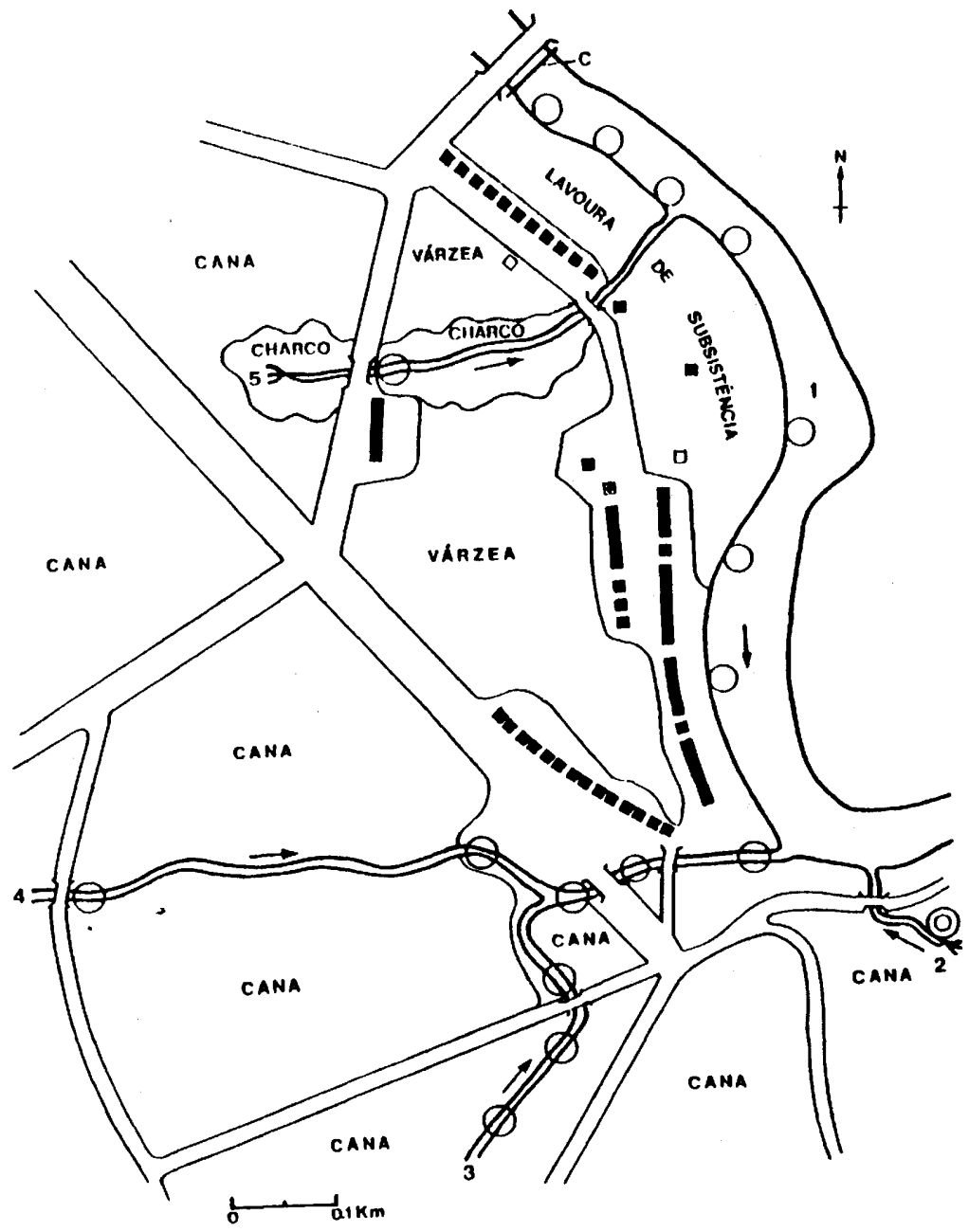


As práticas de irrigação usadas para a lavoura não são um problema sério para o controle dos moluscos vetores nessa localidade. As extensas plantações de cana são irrigadas por aspersão da calda resultante da destilação do álcool pela usina vizinha ao engenho; assim, não oferecem condições propícias para os caramujos. Apenas as lavouras de subsistência (mandioca, feijão e batata) necessitam de atenção especial, pois ocupam pequenas áreas nas medições do núcleo habitacional (Figura 1), e são irrigadas pela água acumulada em pequenas valas. Estas constituem ótimos criadouros de caramujos, o que requer constante limpeza para remover a vegetação e os detritos, além da aplicação periódica de moluscicida.

O curso de água mais problemático para o controle dos moluscos vetores é um riacho formado pela captação da água de chuva e de nascentes em uma depressão de terreno próximo à estrada (5 na Figura 1). A área tem uma vegetação herbácea densa, típica das várzeas úmidas ou encharcadas, propiciando um microclima favorável para a sobrevivência dos caramujos mesmo durante as fases de seca. A elevação do terreno combinada com a abertura de valas de drenagem eleminaria as áreas alagadas; o custo relativamente elevado dessas medidas poderia ser compensado com aproveitamento da área para o plantio de cana.

\section{COMENTÁRIOS FINAIS}

O exemplo acima ilustra situações comumente encontradas na área endêmica da esquistossomose no Nordeste, notadamente na zona canavieira. Assim, as medidas aqui propostas podem ser válidas para outras localidades com características semelhantes. No entanto, cada área-problema dever ser previamente estudada sob os pontos de vista epidemiológico e ecológico tão detalhadamente quanto possível: em primeiro lugar, consultando os órgãos nacionais e regionais de saúde pública sobre o histórico epidemiológico da área; em seguida, coletando dados demográficos e parasitológicos das populações envolvidas; depois, levantando os elementos topográficos, hídricos e aquales relacionados com o uso da terra; por fim, identificando e caracterizando ecologicamente os criadouros de importância epidemiológica.

É claro que as medidas recomendadas para controle dos moluscos vetores precisam ser conjugadas com a quimioterapia para que tanto a transmissão quanto a infecção sejam controladas. Entretanto, mesmo a combinação dessas medidas terá efeito pouco duradouro se as comunidades envolvidas não participarem do processo. Uma vez alcançados níveis mínimos aceitáveis da doença, é necessário que os sistemas de cuidados primários da saúde sejam acionados para evitar o recrudescimento do problema. 


\section{CONTROLE}

O combate à esquistossomose envolve, portanto, o trabalho articulado de diferentes especialistas junto às populações atingidas. Nesse contexto, os especialistas em malacologia médica têm um papel fundamental, pois o controle de moluscos vetores é, ainda, a arma mais imediatamente efetiva contra a transmissão da doença. Além disso, as medidas para controle dos caramujos, sejam químicas, biológicas ou ambientais, ainda precisam ser aperfeiçoadas, o que exige conhecimentos mais detalhados sobre as espécies implicadas. Para a Organização Mundial da Saúde (OMS), uma compreensão integral da ecologia dos moluscos vetores é um requisito básico para se alcançar êxito nas medidas de controle que dependem, basicamente, de tecnologia implementada pela própria comunidade (Who, 1980).

\section{REFERÊNCIAS BIBLIOGRÁFICAS}

BARBOSA, F. S. \& COSTA, D.P.P., 1981. A long term schistosomiasis control project with molluscicide in a rural area of Brazil. Annals of Tropical Medicine and Parasitology, 75: 41-52.

BARBOSA, F.S. \& OLIVIER, L., 1958. Studies on the snail vectors of bilharziasis mansoni in North-Eastern Brazil. Bulletin of the World Health Organization, 18: 895-908.

CAIRNCROSS, S. \& FEACHEM, R.G., 1983. Environmental Health Engineering in the Tropics: an Introductory Text. London: Jonh Willey \& Sons.

FREITAS J. R., 1978. Descrição do Hábitat de Biomphalaria glabrata. Belo Horizonte: Fundação de Desenvolvimento da Pesquisa.

HARRY, H. W. \& CUMBIE, B.C., 1956. Stream gradient as a criterion of lotic habitats suitable for Australorbis glabratus in Puerto Rico. American Journal of Tropical Medicine and Hygiene, 5: $921-928$.

HARRY, H. W.; CUMBIE, B.C \& JESUS.M., 1957. Studies on the quality of fresh waters of Puerto Rico relative to the occurrence of Australorbis glabratus (Say). American Journal Tropical Medicine and Hygiene, 6: 313-322.

KLOETZEL, K \& VERGETTI, A.M.A., 1988. Repeated mass treatment of schistosomiasis mansoni: experience in hyperendemic areas of Brazil. II Micro-level evaluation of results. Annals of Tropical Medicine and Parasitology, 82: 367-376.

LUTTERMOSER G. W. \& CASTELLANOS, J.V., 1945. Observaciones sobre la propagacion y la destruccion del caracol, Australorbis glabratus Say, 1818, vector de Schistosoma mansoni (Bilharzia) en El Valle, D.F. Revista de Sanidad y Assistencia Social, 10: 109-148.

MCCULLOUGH, F., 1986. Snail control in relation to a strategy for reduction of morbidity due to schistosomiassis. Tropical Medicine and Parasitology, 37: 181-184.

MCJUNKIN, F. E., 1975. Water Engineers, Development and Disease in the Tropics. Washington: Agency for International development, Department of State.

MCKILLOP, W. B. \& HARRISON, A.D., 1980. Hydrobiological studies of EasternLesser Antillean Island. V - St. Lucia: freshwater habitats, water chemistry and distribution of freshwater molluscs. Archiv für Hydrobiologie., 57: 251-290.

MICHELSON, E. H. \& MOTA, E., 1982. Malacological observations bearing on the epidemiology of schistosomiasis in a rural Bahian community. Revista do Instituto Medicina Tropical de São Paulo, 24: 75-82. 


\section{TÓPICOS EM MALACOLOGIA MÉDICA}

MCMULLEN, D. B., 1973. Biological and evironmental control of snails. In: Epidemiology and Control of Schistosomiasis (N. Ansari, ed.), pp. 533-591, Basel: Karger.

OMS (Organização Mundial da Saúde), 1985. Control de la Esquistosomiasis. Informe de um Comite de Expertos de la OMS. Serie de Informes Tecnicos 728, Ginebra: Organización Mundial de la Salud.

PARAENSE, W. L., 1977. Distribuição geográfica dos vetores da xistosomose no Nordeste do Brasil, In: Painel Programa Especial de Controle da Esquistossomose (P.A. Machado, ed.), pp. 47-51, Brasília: Ministério da Saúde.

, W. L., 1987. Control of schistosomiasis: an outlook from current expectation. Memórias do Instituto Oswaldo Cruz, 82: 1-12.

PATIENCE, R. L.; THOMAS, J .D. \& STERRY, P.R., 1983. Production and release of carboxilic acids during oxic and anoxicmetabolism by the pulmonate snail Biomphalaria glabrata. Comparative Biochenistry and Physiology, 76: 253-263.

PIERI, O. S., 1985. Studies on the Host Snails of Schistosomiasis from North-east Brazil, with Special Reference to Diapause by Biomphalaria glabrata (Say). D. Phil. thesis, Brighton: University of Sussex.

PIERI, O. S. \& THOMAS, J.D., 1987. Snail control in the eastern coastal areas of North-east Brazil. Memórias do Instituto Oswaldo Cruz, 82: 197-201.

PIKE, E. G., 1987. Engineering Against Schistosomiasis/Bilharzia: Guidelines Towards Control of the Disease. London: Macmillan Publishers.

PIMENTEL, D. \& WHITE, P.C., 1959. Physiochemical environment of Australorbis glabratus, the snail intermediate host of Schistosoma mansoni in Puerto Rico. Ecology, 40: 533-541.

POINTIER, J. P., SAlVAT, B., DELPLANQUE, A. \& GOLVAN, Y., 1977. Principaux facteurs regissant la densite des populations de Biomphalaria glabrata (Say, 1818), mollusque vecteur de Ia schistosomose en Guadeloupe (Antilles francaises). Annals of Parasitology, 52: 277-323.

REY, L. \& PESSOA, S.B., 1953. Contribuição ao estudo dos focos de Australorbis glabratus (transmissor da esquistossomose mansonica) em Sergipe. Revista Clínica de São Paulo, 29: 85-108.

SCORZA, J.V.; SILVA, J.; GONZALEZ. L \& MACHADO, R., 1961. Stream velocity as a gradient in Australorbis glabratus (Say, 1818). Zeitschrift Für Tropenmendizin Und Parasitologie, 12: 191196.

STURROCK, R. F., 1974. Ecological notes on habitats of the freshwater snail Biomphalaria glabrata, intermediate host of Schistosoma mansoni on St. Lucia, West Indies. Caribbean Journal of Science, 14: 149-161.

THOMAS, J. D., 1987. A holistic view of schistosomiasis and snail control. Memórias do Instituto Oswaldo Cruz, 82: 183-192.

THOMAS, J. D. \& TAIT, A., 1984. Control of the snail hosts of schistosomiasis by environmental manipulation. A field and laboratory appraisal in the Ibadan area in Nigeria. Philosophical Transactions of the Royal Society of London, 305: 201-253.

WHO (World Health Organization), 1980. Epidemiology and control of schistosomiasis. Report of a WHO expert committee. Geneva: Technical Report Series 643, Geneva: Who. 


\section{Técnicas Malacológicas}




\subsection{Coleta; Remessa de Exemplares Vivos; Fixação e Dissecção}

\section{COLETA}

Os moluscos límnicos podem ser encontrados em vários tipos de coleções hídricas, tais como rios, riachos, lagoas, açudes, valas e alagados, preferindo geralmente águas tranqüilas ou de curso lento. Nesses ambientes devem ser procurados sob a vegetação aquática, no fundo do criadouro ou aderidos a pedras e a objetos flutuantes.

Material necessário para a coleta: pinças longas; conchas de captura (Figura 1); pequenos sacos de tecidos ou recipientes plásticos para acondicionar os moluscos; luvas e botas de borracha; caderneta de campo, lápis e fita adesiva ou similar, para a identificação do material coletado. São também muito úteis no campo os coletes utilizados por pescadores, pois, como possuem muitos bolsos, facilitam tanto o transporte do equipamento de trabalho, como também o do material coletado.

\section{FIGURA 1}

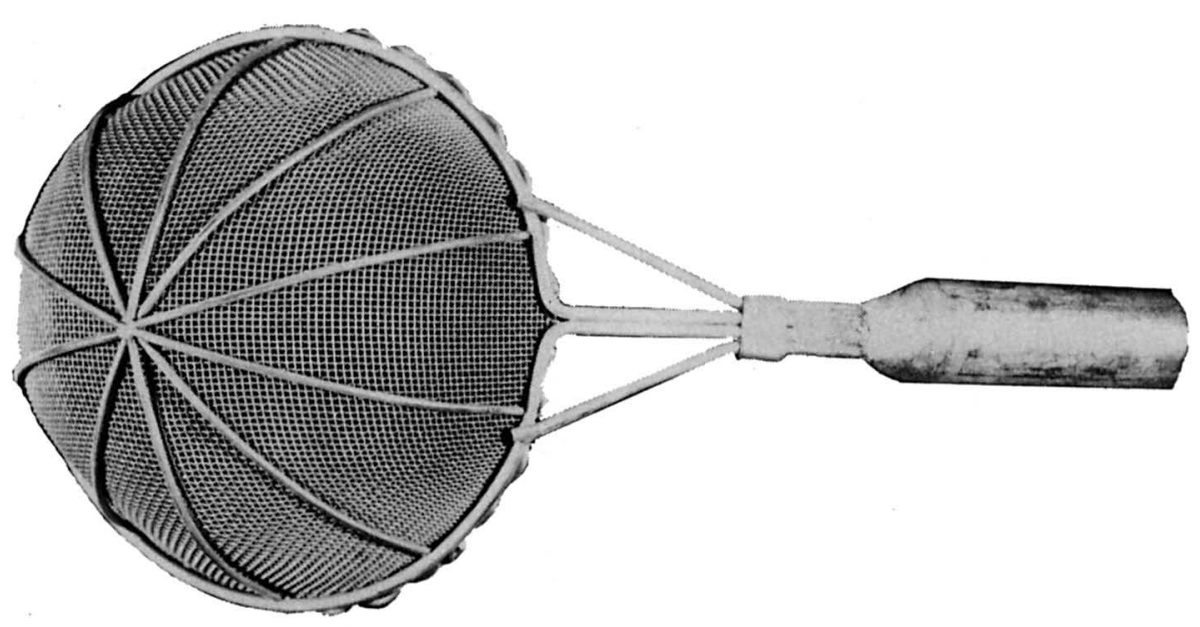


A concha de captura consiste em um cabo de madeira com aproximadamente $1 \mathrm{~m}$ de comprimento acoplado a uma peneira ou concha de metal perfurada. Uma boa concha de captura deve ter o espaço entre as malhas ou os furos em torno de $2 \mathrm{~mm}$, para que exemplares pequenos como Antillorbis e Drepanotrema, sejam também retidos.

A técnica consiste em raspar com a concha de captura a vegetação submersa e o fundo do criadouro, levá-la à superfície, lavando cuidadosamente o material recolhido e procurar pelos moluscos que, eventualmente, tenham ficado retidos. Pegar os exemplares com a pinça e colocá-los nos saquinhos de tecido umedecidos ou nos recipientes plásticos sem água e afixar a etiqueta de identificação para o transporte até o laboratório.

Repete-se várias vezes esta operação em diferentes pontos do criadouro, para se obter uma boa amostragem.

\section{REMESSA DE MOLUSCOS VIVOS}

Paraense recomenda a técnica que se segue para o transporte de moluscos vivos:

- Cortar uma faixa de gaze com uns 30 a $50 \mathrm{~cm}$ de comprimento e $20 \mathrm{~cm}$ de largura, molhar em água da torneira e espremer bem para retirar o excesso de água. Pode ser usado outro tipo de tecido, desde que se preste para a finalidade.

- Estender a faixa de gaze, apenas úmida, sobre uma superfície plana.

- Colocar uma fileira transversal de moluscos a uns $3 \mathrm{~cm}$ da extremidade da gaze próxima ao operador, deixando um espaço de $1 \mathrm{~cm}$ entre moluscos pequenos ou de $2 \mathrm{~cm}$ entre moluscos grandes.

- Dobrar sobre a fileira de moluscos a extremidade da gaze próxima ao operador.

- Colocar adiante outra fileira de moluscos e dobrar sobre ela a parte da gaze, contendo a fileira anterior.

- Colocar adiante outra fileira de moluscos, dobrar a gaze sobre ela, e prosseguir até chegar próximo à extremidade mais distante da gaze, ou até esgotar a provisão de moluscos.

- Entre a última fileira de moluscos e a extremidade da gaze deve sobrar uma margem de tecido suficiente para dar pelo menos uma volta completa sobre o cilindro de gaze que se formou.

- Introduzir o cilindro de gaze úmida em um saco plástico de tamanho adequado, ou envolver o cilindro em uma folha de plástico, devendo ficar o cilindro bem protegido (envoltório de plástico bem fechado) para evitar o secamento da gaze.

- Colocar dentro do envoltório plástico, mas fora de contato com a gaze, uma etiqueta com os seguintes dados: localidade onde foi feita a coleta, tipo de 
criadouro (córrego, lagoa, brejo, vala de irrigação ou drenagem, etc.), nome do coletor, data da coleta, e qualquer outra informação que seja considerada útil.

- Colocar o conjunto em recipiente resistente ao amassamento (caixa de madeira, lata, tubo de metal, etc.), que não deve ser perfurado.

- Não submeter os moluscos à refrigeração, durante o manuseio ou durante o transporte.

- Durante o manuseio dos moluscos, evitar exposição a moscas, que depositam ovos, cujas larvas devoram os animais.

\section{FIXAÇÃO}

Para um bom estudo anatômico, os moluscos devem ser previamente anestesiados e fixados adequadamente. A técnica descrita a seguir, desenvolvida por Paraense, é utilizada na rotina de trabalho do Departamento de Malacologia do Instituto Oswaldo Cruz:

- Colocar os espécimes em recipiente com água limpa.

- Transferir aqueles que estiverem movimentando-se livremente para outro recipiente com solução de nembutal a $0,05 \%$ em água comum $(0,1$ de nembutal $+200 \mathrm{ml}$ de água), onde ficarão durante a noite. Na manhã seguinte deverão estar bem relaxados e imóveis. À falta de nembutal, pode ser usado outro barbitúrico, desde que seja estabelecida a dose adequada.

- Imergir os espécimes, um a um ou reunidos em coador de plástico ou metal (tipo coador de chá), em água aquecida a $70^{\circ} \mathrm{C}$, durante um tempo proporcional ao tamanho do exemplar (cerca de 45 segundos para planorbídeos com cerca de $20 \mathrm{~mm}$ de/ diâmetro, ou outros moluscos de tamanho equivalente; cerca de 30 segundos para planorbídeos pequenos, aucilídeos, etc.). Ter cuidado para não ultrapassar a temperatura adequada $\left(70^{\circ} \mathrm{C}\right)$ e o tempo de imersão, para evitar que o cozimento do sangue e dos tecidos prejudique a dissecção.

- Imergir o animal morto em água fria e retirá-lo da concha, segurando-o pela parte posterior da cabeça com uma pinça adequada e puxando-o com suave tração a fim de desprender a inserção do músculo columelar. À medida que se retira o animal, a concha vai sendo ocupada pela água, dilui o resíduo de sangue, evitando sua putrefação dentro da concha.

- Colocar o animal no fixador (líquido de Railliet-Henry, modificado para animais de água doce): 


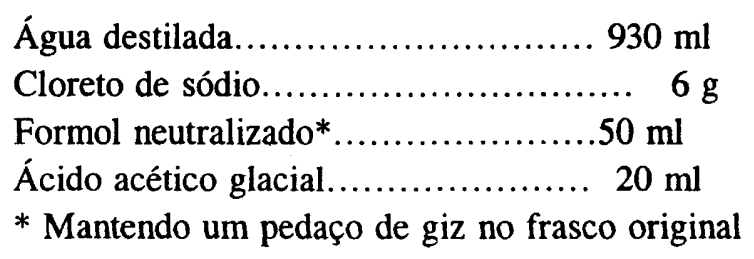

A quantidade de fixador não deve ser menor que dez vezes o volume do material a ser fixado. Deve-se trocar o fixador depois de 24 horas. Uma vez bem fixado o material, a quantidade de fixador pode ser reduzida para conservação ou remessa.

- Limpar a superfície das conchas com um pincel de pelo macio e deixá-las secar.

- Deixar as partes moles no fixador por pelo menos 24 horas antes de dissecar. O material conserva-se indefinidamente no fixador. Havendo urgência na dissecção, fazer a fixação na estufa a $40^{\circ}-45^{\circ} \mathrm{C}$ durante 12 horas.

- Em espécimes de concha lamelada, ou de tamanho muito pequeno, ou em drepanotremas com muitos giros, o animal arrebenta facilmente quando se tenta extraí-lo da concha. Nestes casos o animal, depois de imergido na água quente por 15-30 segundos, é colocado diretamente no fixador sem ser retirado da concha. Devido à produção de $\mathrm{CO}_{2}$ resultante da reação entre o ácido acético do fixador e o carbonato de cálcio da concha, o fixador deve ser trocado várias vezes para evitar o destapamento do frasco pela pressão do gás.

- Na impossibilidade de usar um relaxante adequado, proceder como segue: tomar com uma pinça um espécime que esteja movimentando-se livremente, com a cabeça e o pé bem expostos, tendo muito cuidado para que não se retraia na concha durante a manipulação. Mantendo a abertura da concha para cima, imergir gradualmente o molusco em água quente, como descrito no item 3. Manter a concha imersa na água quente até quase ao nível da abertura durante os primeiros 15 segundos, submergindo inteiramente o espécime pelo tempo restante.

Prosseguir conforme as recomendações dos itens 4 a 8 . Animais fixados sem prévio relaxamento apresentam desvantagens para um bom estudo anatômico.

\section{DISSECÇÃO}

Material necessário: uma placa de Petri rasa, duas pinças com pontas bem finas e retas ou dois estiletes, um pincel com cerdas finas e macias e um bom microscópio estereoscópico.

A técnica de dissecção descrita a seguir é utilizada no Departamento de Malacologia do Instituto Oswaldo Cruz e foi desenvolvida por Paraense e Deslandes. 
- Numa placa de Petri rasa, contendo um pouco de líquido fixador, colocar o caramujo apoiado pelo lado direito, de modo que o lado esquerdo, onde estão os gonoporos masculino e feminino, fique para cima.

- Com a pinça vai-se despregando aos poucos a junção entre o manto e o músculo columelar, sempre pelo lado esquerdo, até a altura do estômago, onde o músculo termina.

- Feito isto, vira-se o animal sobre sua face esquerda, deixando para cima a face direita e, cuidadosamente, separa-se a parte anterior do manto, presa ao pescoço, deixando então todo o manto preso apenas ao longo do lado direito do músculo columelar. Desprega-se depois o lado direito, como se fez com o esquerdo, obtendo-se então todo o manto destacado e os órgãos paliais (coração, pulmão e tubo renal) em condições de serem examinados.

- O gonoporo masculino se encontra logo abaixo do tentáculo esquerdo, e o feminino se localiza posteriormente, sob o colar do manto, próximo à abertura anal. O prepúcio e parte do delicado duto deferente podem ser vistos, por transparência, próximo ao gonoporo masculino. A dissecção do complexo peniano inicia-se nesta região, retirando-se pele e músculos cuidadosamente com a pinça, até que o prepúcio e duto deferente fiquem completamente expostos.

- Em seguida secciona-se os músculos que prendem o prepúcio à parede do corpo e com a pinça puxa-se cuidadosamente o prepúcio e o duto deferente até que fiquem completamente liberados.

- Depois, para facilitar a dissecção do restante do sistema reprodutor, corta-se a cabeça-pé, o esôfago, o reto e todo o músculo columelar, restando então na placa apenas o sistema reprodutor e parte do sistema digestivo (estômago, intestino e glândula digestiva).

- Com a pinça retira-se aos poucos as membranas, o muco e o sangue que geralmente recobrem o sistema reprodutor. Para a limpeza dos sistemas reprodutores é preciso redobrado cuidado para que nada seja rompido. A limpeza é necessária para visualizar pequenas estruturas de importância taxionômica, como, por exemplo, bolsa e enrugamento vaginal.

- A glândula de albume encontra-se sobre o carrefour ou encruzilhada genital e ligase ao oviduto por um pequeno canal, que pode ser visto rebatendo-se o estômago, de forma que este fique com a face ventral para cima.

- Após o carrefour seguem-se o delicado ovispermoduto, que se dilata mais adiante, formando a vesícula seminal, e o ovoteste ou glândula hermafrodita, que ocupa os giros mais internos da concha. O ovispermoduto pode ser visto facilmente em seu trajeto até a vesícula seminal, passando pela face ventral do estômago e da glândula digestiva. Para dissecá-los basta ir retirando aos poucos a glândula digestiva e o estômago. Tanto a glândula digestiva quanto o ovoteste 
encontram-se recobertos pelo manto, que deve ser retirado para facilitar a observação das duas glândulas. Os divertículos do ovoteste são menores do que aqueles da glândula digestiva e geralmente apresentam cor branca-amarelada, contrastando com a coloração verde-oliva dos divertículos da glândula digestiva.

- Quando se fizer necessário distinguir com clareza as ramificações e o número exato de divertículos prostáticos e do ovoteste, utiliza-se o lugol como corante.

O sistema reprodutor completo de Biomphalaria tenagophila.

\section{PREPARAÇÃO DA RÁDULA}

Colocar o saco bucal inteiro em um tubo de hemólise $(8 \times 75 \mathrm{~mm})$, contendo solução de hidróxido de sódio a $10 \%$ e lavá-lo ao aquecimento em banho-maria até se obter apenas a rádula e os maxilares. Retirar o tubo do banho-maria e derramar seu conteúdo numa placa de Petri. Em seguida lavar a rádula e os maxilares, transferindo-os para outra placa, contendo água. A montagem temporária é feita colocando-se a rádula e os maxilares em uma lâmina histológica com algumas gotas de glicerol, cobrindo-as com lamínula, afixada com esmalte de unhas. Não é necessário corar.

\subsection{Coleção Malacológica}

As coleções malacológicas remontam aos tempos pré-lineanos e, durante muito tempo, reuniram apenas conchas, as quais constituíram a base da taxionomia malacológica até, aproximadamente, o final do século passado. A partir de então o estudo das partes moles do animal foi adquirindo prioridade, passando a integrar o acervo das coleções e tornando-se fundamental na atual sistemática malacológica. Lotes contendo séries de indivíduos são utilizados, preferencialmente, nas coleções atuais, possibilitando ao taxionomista o exame de amostras de populações.

Seja como fonte de material para estudo ou como documentação da pesquisa pregressa, é relevante o papel das coleções na pesquisa malacológica.

No Brasil, as principais coleções malacológicas científicas encontram-se nas seguintes instituições:

Fundação Zoobotânica do Rio Grande do Sul . . . . . 33000 lotes

Instituto Oswaldo Cruz . . . . . . . . . . . . . . . 4000 lotes

Museu Nacional/UFRJ . . . . . . . . . . . . . . . 16000 lotes

Museu Oceanográfico da Fundação Universidade

do Rio Grande . . . . . . . . . . . . . . . . . . . 30000 lotes

Museu de Zoologia da USP . . . . . . . . . . . . . . . . 17000 lotes

Universidade Federal de Juiz de Fora . . . . . . . . . 7000 lotes 


\section{ORGANIZAÇÃO DA COLEÇÃO}

Os procedimentos descritos neste tópico referem-se àqueles adotados na coleção malacológica do Instituto Oswaldo Cruz.

A coleção deve ser ordenada de forma a assegurar o bom estado do material e a simplificar e agilizar o manuseio.

Nas Figuras 1-6 podem ser observados os armários, as gavetas, os frascos e as etiquetas utilizadas na coleção malacológica do Instituto Oswaldo Cruz. As conchas são acondicionadas em vidros ou sacos plásticos de diferentes capacidades (dependendo do tamamho do lote), e são colocadas em gavetas de acrílico $(15 \mathrm{~cm}$ x $7 \mathrm{~cm} \mathrm{x} 4 \mathrm{~cm}$ ), encaixadas em prateleiras de metal afixadas na parede. As partes moles do animal após serem colocadas em vidros de 5 a $100 \mathrm{ml}$, contendo líquido fixador de Railliet-Henry, vedados com tampa plástica hermética, são acondicionados dentro de gavetas em armários de metal. Dentro dos vidros ou sacos plásticos com lotes de conchas (parte seca da coleção), são colocadas etiquetas de $6 \mathrm{~cm} \times 2 \mathrm{~cm}$, nas quais são anotados o número de registro, a identificação específica e à procedência do material. Dentro dos frascos da parte líquida da coleção devem ser colocados apenas o número de registro do lote em duas etiquetas, uma em papel vegetal escrita a nanquim, e outra com fita rotuladora de boa qualidade, para não descorar. Externamente, na tampa, é também afixada uma etiqueta adesiva com o número do lote, para facilitar a inspeção.

Para a estocagem de conchas maiores, como a dos ampulariídeos (=pilídeos), utilizamos um armário de madeira com gavetas maiores.

Armários de madeira, caixas de papelão, madeira ou plástico de vários tamanhos e recipientes plásticos com tampas herméticas, podem também ser utilizados. O mais importante e que sejam práticos e seguros.

\section{INCLUSÃO DE LOTES NA COLEÇÃO}

1. amostras com exemplares vivos;

1.1 separação das espécies pelas conchas;

1.2 investigação de possível infecção por helmintos ou outros parasitos;

1.3 relaxamento dos animais da amostra em solução de nembutal, seguida de fixação e após $\mathbf{4 8}$ horas dissecção, para se confirmar a identificação;

1.4 numeração das amostras e confecção de etiquetas: além do número do lote, identificação e procedência, a etiqueta pode também conter a data de coleta ou entrada do material na coleção, o criadouro ou ambiente, o nome do coletor ou remetente e o nome de quem identificou o material;

1.5 lançamento no livro de registro (Figura 7): em geral, o registro contém número 
do lote, data da coleta ou entrada na coleção, país ou estado, município, localidade, criadouro ou ambiente, coletor ou remetente, número de exemplares, tamanho do maior exemplar, identificação, a natureza do material (concha e anatomia, só concha ou só anatomia) e observações;

1.6 acondicionamento das conchas e das partes moles para o depósito na coleção: as conchas são colocadas entre duas camadas de algodão, em frascos contendo etiqueta, enquanto as partes moles são acondicionadas em frascos herméticos, contendo líquido fixador e etiqueta em papel vegetal e/ou fita rotuladora.

2. Para amostras com exemplares já fixados, após a dissecção e identificação, devem-se seguir os procedimentos indicados nos itens $1.4,1.5$ e 1.6 .

Devido à evaporação do fixador, a parte líquida da coleção deve ser revista semestralmente.

As solicitações de identificação de material podem ser respondidas em fichas semelhantes à da ilustração 8 .

Para facilitar o manuseio da coleção, é recomendável manter-se um fichário dividido por estados, listados pelos municípios, em ordem alfabética, registrando-se o nome específico, a natureza da material e o número de registro do lote na coleção. O ideal é informatizar a coleção, meio mais seguro e prático para simplificar e agilizar o seu manuseio. No Brasil, a coleção do Museu Nacional foi informatizada através do Sistema de Gerenciamento de Coleções do Museu Nacional/Universidade Federal do Rio de Janeiro, que vem assessorando a informatização de outras coleções, entre elas a do Instituto Oswaldo Cruz.

\section{FIGURAS}

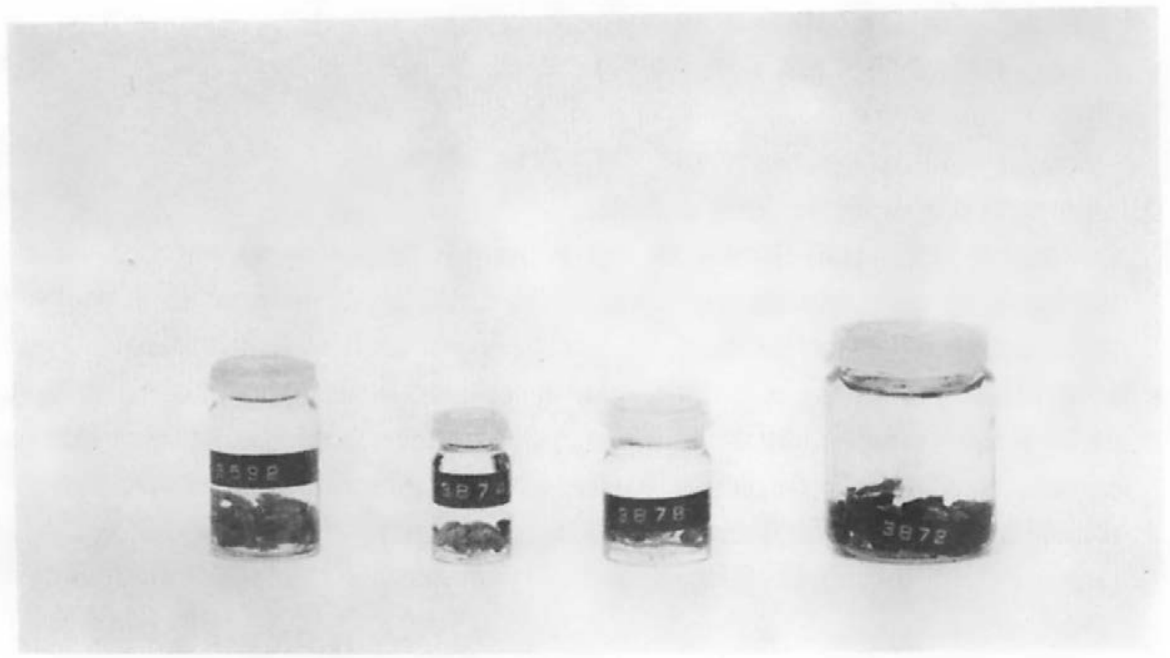




\section{COLETA; REMESSA DE EXEMPLARES VIVOS}
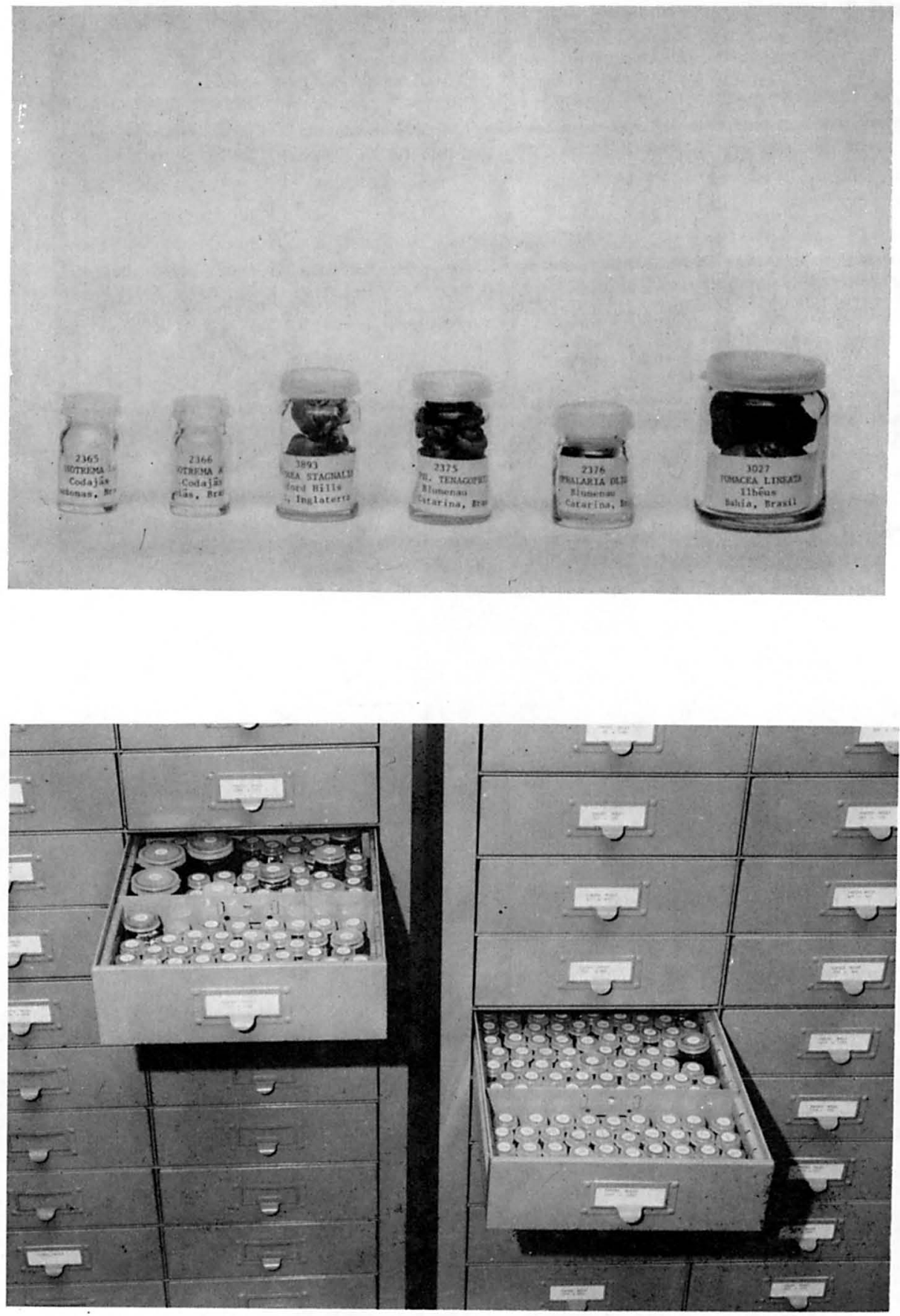
TÓPICOS EM MALACOLOGIA MÉDICA
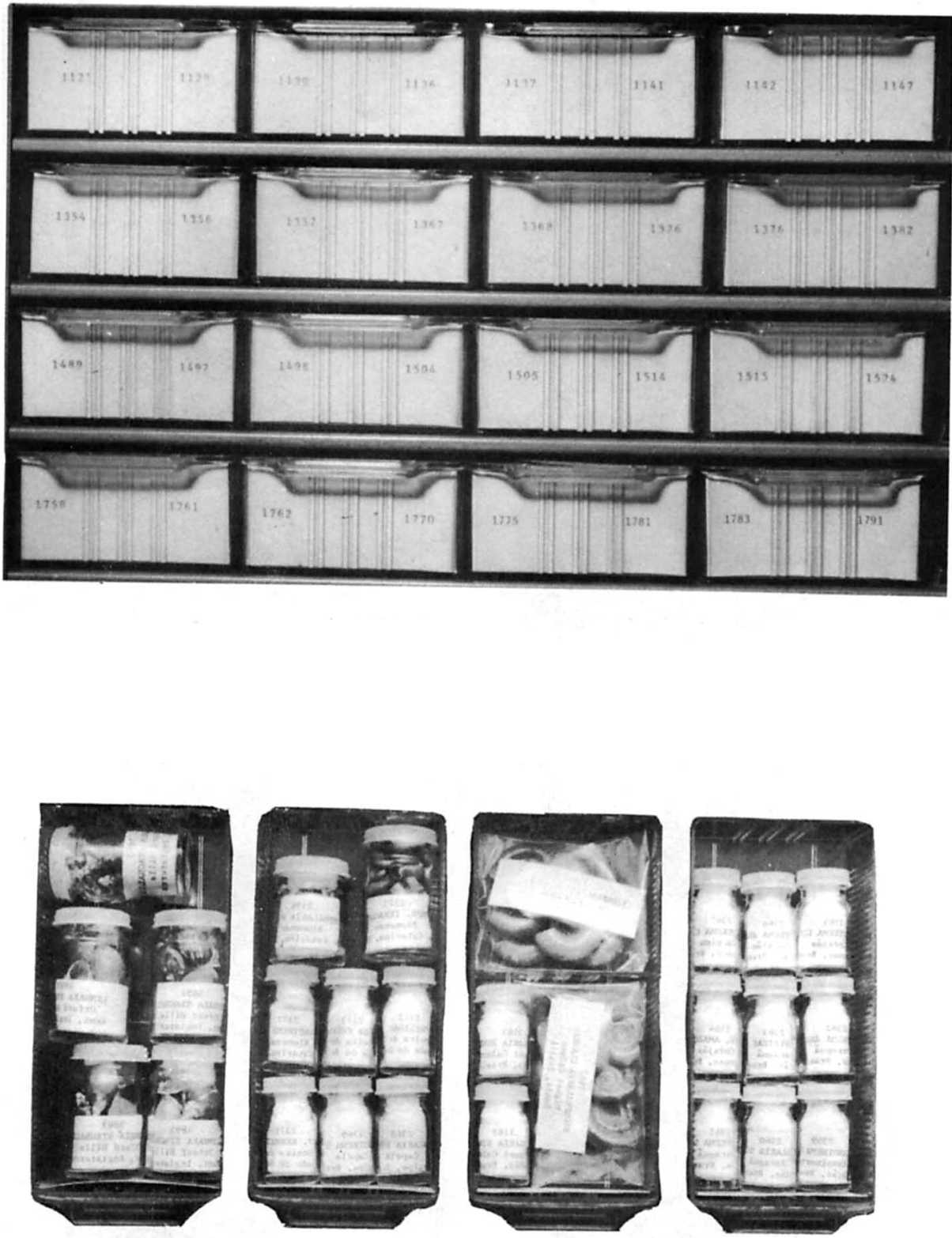


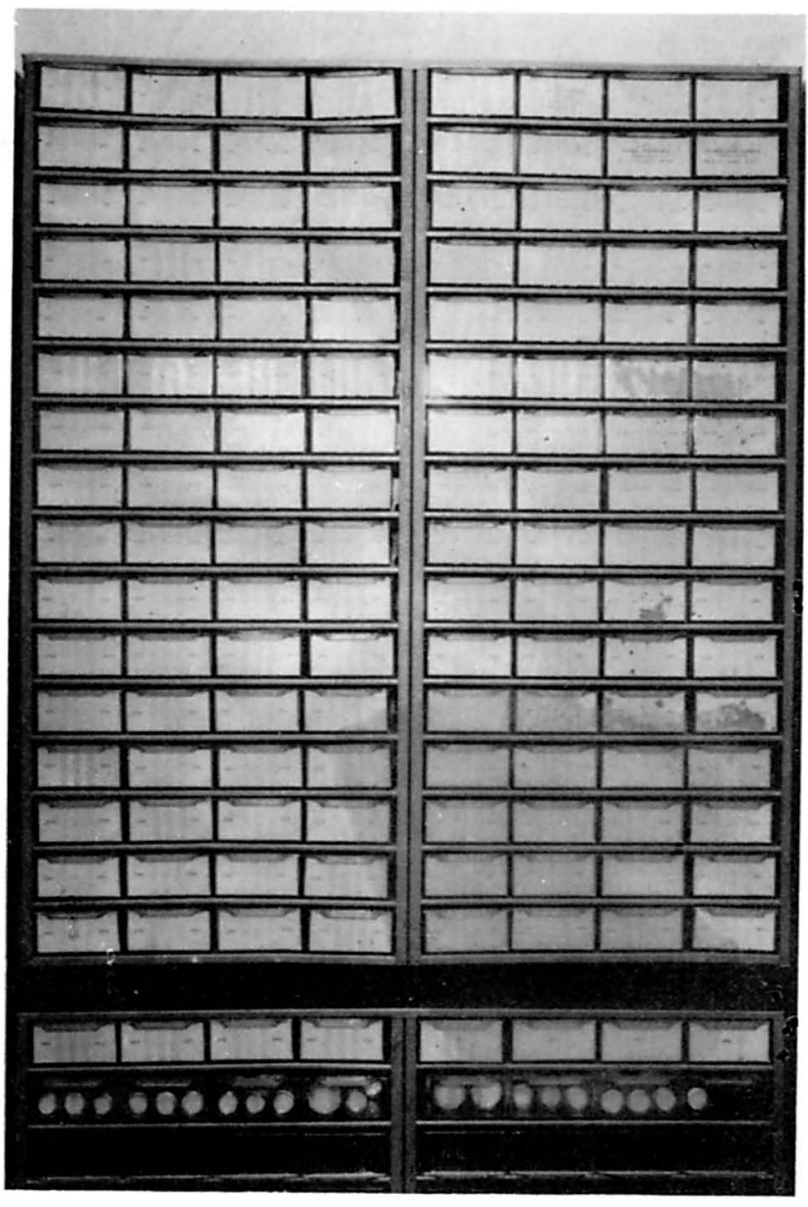




\subsection{Infecção de Moluscos em Laboratório ${ }^{1}$}

Para infecçao de moluscos em laboratório necessita-se de um concentrado de miracídios. Este pode ser obtido de fezes ou de extratos de órgãos de animais infectados, de acordo com a técnica descrita abaixo.

\section{Técnica de concentração de mirocídios:}

1) As fezes são vigorosamente trituradas e diluídas em água, na proporção de 1 parte do material fecal para 9 partes do líquido.

2) A mistura é então passada através de tamiz de malhas finas para dentro de um grande cálice cônico de vidro. O volume é elevado ao dobro com água. Por exemplo, se as fezes pesam cerca de $100 \mathrm{~g}$, a primeira diluição irá a 1 litro, e a segunda elevará o volume do líquido a 2 litros. Portanto, o cálice de vidro terá forçasamente que possuir capacidade acima deste volume.

3) O cálice é colocado na parte mais baixa do refrigerador (temperatura de cerca de $8^{0}-10^{0} \mathrm{C}$ ) e aí permanecerá durante $1 / 2$ hora. Em seguida o líquido sobrenadante é desprezado e o volume reposto com água. Esta manobra é repetida mais 3 ou 4 vezes, até que o líquido sobrenadante esteja incolor.

4) O sedimento da última lavagem é então distribuído em placas de Petri de grande diâmetro, de modo que a superfície do líquido seja bastante extensa e exposta à luz artificial ou natural durante 1 hora e a temperatura de $28^{\circ} \mathrm{C}$.

5) Após a exposição à luz, o lavado fecal é transferido para o balão de Kitasato, que será descrito no final deste item. É conveniente colocar, para um balão de 500 $\mathrm{ml}$, quantidade de líquido correspondente a cerca de $150 \mathrm{~g}$ de fezes sólidas.

6) Junta-se ao balão água, lentamente, até que as primeiras gotas escorram pelo tubo de borracha que é então pinçado.

1 Adaptação de trecho do capítulo Relações Hospedeiro/Parasito, originalmente publicado em Manual de Malacologia Médica (Barbosa, F. S.; Carneiro, e. \& Barbosa, I.). Salvador, Fundação Gonçalo Muniz, 1960. 
7) Deita-se em seguida, $20 \mathrm{ml}$ de água pelas paredes do colo do balão $(10 \mathrm{ml}$ nos balões de $250 \mathrm{ml}$ ). Ilumina-se o aparelho e após 15 minutos de exposição à luz colhem-se os 10 ou $20 \mathrm{ml}$ de água fazendo simplesmente abrir a pinça que fecha o tubo de borracha. Pinçado novamente o tubo, mais 10 ou $20 \mathrm{ml}$ de água são colocados no balão e coletas periódicas poderão ser assim feitas.

8) A contagem dos miracídios é feita em amostras de $1 \mathrm{ml}$ do líquido obtido do balão em cada coleta. A água pode ser distribuída em gotas dentro dos orifícios de uma placa de toque e os miracídios contados a lupa.

\section{Descrição do balão de Kitasato}

O aparelho é de fácil construção e pode ser fabricado com material comumente utilizado em laboratório de química.

Consta simplesmente de um balão de Kitasato de $250 \mathrm{ml}$ ou $500 \mathrm{ml}$. Este balão é pintado de preto até o nível inferior do tubo lateral ao qual está adaptado um curto tubo de borracha. Uma pinça, do tipo Mohr, serve para fechar ou abrir o tubo de borracha.

O foco luminoso é colocado paralelamente logo acima da parte do balão pintado de preto, a uma distância de $15 \mathrm{~cm}$ do aparelho.

\section{INFECÇÃO DOS MOLUSCOS}

Uma vez concentrados, os miracídios podem ser utilizados para infecção e moluscos, de acordo com o seguinte processo:

1) Contagem dos miracídios - retire uma amostra de $1 \mathrm{ml}$ de água contendo os miracídios. A quantidade de água pode variar de acordo com a precisão desejada na tomada da amostra e as condições de planejamento da experiência. Distribua a amostra da água colhida, em pequenas gotas sobre uma placa de vidro. Conte diretamente os miracídios em cada gota. Se houver grande concentração de miracídios por gota, tornando a contagem difícil, dilua o material convenientemente e faça novas contagens.

2) Sabido o número de miracídios por ml do líquido, procede-se a infecção dos moluscos fazendo com que estes entrem em contato com aqueles. Os moluscos podem ser infectados individualmente, i.e., colocando-se em um pequeno recipiente um caramujo isolado para o número desejado de miracídios. Ou então, 
como é mais prático, colocar todos os animais de uma mesma espécie a infectar em um único recipiente. Juntar, logo em seguida, água contendo os miracídios tendo sido calculada previamente a média por caramujo. Para trabalhos de rotina 10 miracídios por caramujo satisfazem plenamente. Em moluscos altament suscetíveis, como Biomphalaria glabrata, obtêm-se, quando o trabalho é ben conduzido, cerca de $100 \%$ de infecções.

3) Deixe os miracídios em contato com os moluscos, sob um foco luminoso, durants 6 horas, que é tempo máximo de vitalidade daqueles.

4) Em seguida, transfira os moluscos para aquários bem balanceados e examine-os a partir do vigésimo dia após a exposição aos miracídios. 


\subsection{Métodos e Técnicas Empregadas para o Estudo do Comportamento de Biomphalaria glabrata (Say, 1818), (Gastropoda; Planorbidae), Caramujo Vetor da Esquistossomose}

Neste capítulo, apresentamos os métodos e técnicas utilizadas para estudar o comportamento da Biomphalaria glabrata, considerado o principal vetor da esquistossomose no Brasil, pela sua ampla distribuição geográfica e por estar sua ocorrência quase sempre associada à doença (Paraense, 1972). Tais fatos são responsáveis pelas inúmeras publicações sobre aspectos biológicos ecológicos e anatômicos deste caramujo (Rey, 1956; Perlowagora-Szumlewicz, 1958; Andrade, 1959; Paraense, 1972; Appleton, 1978; Paraense, 1987). Estes trabalhos, embora contenham descrições pormenorizadas das atividades desta espécie, não podem ser considerados como estudos comportamentais, devido à ausência de análise causal, que é uma característica da abordagem etológica. Assim, seria mais correto considerar aquelas descrições como sendo referentes aos hábitos e não ao comportamento da espécie (Jurberg, 1985, 1990).

No estudo comportamental baseado na abordagem etológica, procura-se inicalmente, através da observação das atividades do animal, descrever e categorizar os comportamentos. Posteriormente quantificam-se as categorias e, por meio de experimentos em laboratório ou no campo, estas são analisadas quanto às suas possíveis causas e funções. Através da comparação de comportamentos de indivíduos de diferentes idades, pode se estabelecer como determinado comportamento surge nestes indivíduos (análise ontogenética). Assim, o estudo do comportamento de espécies do mesmo gênero ou da mesma família permite compreender como o comportamento surge na espécie (análise filogenética) (Hinde, 1966; Tinbergen, 1969; Baerendes, 1975).

A observação, por ser enfatizada neste capítulo, foi por nós considerada como método juntamente com a experimentação, sendo que a primeira descreve os fatos e a segunda estabelece relação de causa e efeito. As técnicas são os procedimentos, com ou sem o uso de instrumentos utilizados para operacionalizar os métodos. Como não temos conhecimentos sobre os dados pormenorizados do estudo comportamental 
de espécies do mesmo gênero, o método comparativo não será tratado aqui. Maiores detalhes sobre experimentação em comportamento animal poderá ser visto em Aspey \& Blankenship (1977) e Lèhner (1979).

ASSUNTOS ABORDADOS NESTE CAPÍTULO:

1. Observação

2. Descrição comportamental

3. Categorização comportamental

4. Catálogo comportamental

5. Técnicas de registro do comportamento e quantificação

6. Descrição das circunstâncias

7. Uso de instrumentos registradores e aparelhos para evidenciar o comportamento

8. Análise causal

9. Análise funcional

10. Validade dos estudos na natureza e no laboratório

Ressaltamos que antes de se iniciar, efetivamente, o estudo sobre o comportamento de um animal, é necessário conhecer a sua morfologia, fisiologia e biologia.

\section{OBSERVAÇÃO}

A observação é o primeiro passo para se iniciar um estudo comportamental. No contato do pesquisador com o animal, embora surjam perguntas relevantes, a despeito do conteúdo teórico do pesquisador (behaviorista ou etologista), é preciso que as atividades do animal sejam observadas sem preconceitos e desprovidas de antropomorfismo.

\section{DESCRIÇÃO COMPORTAMENTAL}

Quando observamos o comportamento animal, na natureza ou no laboratório, devemos descrevê-lo, relatando tudo que conseguirmos captar através dos nossos sentidos.

Cunha (1976) citou algumas das qualidades que as descrições precisam ter para que sejam adequadas e objetivas, tais como: ser direta, explícita, completa e incluir apenas os elementos essenciais. Baseado nisto, a descrição comportamental poderá ser feita de duas maneiras: 


\subsection{Pela Forma}

a) posturas - disposição espacial estacionária de partes do organismo, uma em relação às outras. No caso dos bionfalarídeos podemos nos referir às posições da concha em relação à massa cefalopodal tais como: concha normal, concha pendente, concha ereta, concha invertida; b) movimentos - mudanças de posição espacial de uma ou mais partes do organismo em relação à outra tomada como referência; exemplo: abertura do pneumóstoma, exteriorização, interiorização da massa cefalopodal em relação a concha, rotação e inclinação da concha em relação a massa cefalopodal; c) estados fisiológicos - aspectos funcionais do organismo, como batimentos cardíacos. Os exemplos citados neste parágrafo estarão minuciosamente descritos no capítulo sobre catálogo comportamental de B. glabrata.

\subsection{Por Conseqüência}

A descrição por consequiência é caracterizada pelas alterações que causam as atividades do animal no ambiente, ou em indivíduos da mesma ou de outra espécie. Dentre elas citamos alimentação, defecação, cópula, respiração.

Ela apresenta algumas vantagens segundo Hinde (1966):

a) reunião de várias categorias descritas pela forma com um objetivo comum; b) ser mais detectável por alteração do meio; c) mostra geralmente a interação entre o organismo e o meio.

\subsection{Alguns Comentários Sobre Descrição Comportamental}

Nos trabalhos sobre comportamento de bionfalarídeos - que citamos como exemplo neste capítulo - verificamos que os autores não esclarecem se as descrições foram feitas pela forma ou pela consequiência, fazendo com que alguns comportamentos se tornem difíceis de se enquadrarem neste tipo de classificação. Entretanto, esta confusão é comum nas descrições comportamentais de outros animais como ressalta (Lehner, 1979). Podemos citar como exemplo a "Dormência", comportamento descrito por Pieri \& Thomas (1986) e Dannemmann \& Pieri (1989) em que o caramujo encontra-se foram d'água aderido ao substrato com a massa cefalopodal totalmente retraída.

$\mathrm{Na}$ descrição pela forma, poderiam ser consideradas somente as posturas, por estas estarem mais adequadas ao vocábulo forma. No entanto, se assim fosse, os aspectos dinâmicos do comportamento do caramujo não seriam levados em conta. 
Por isto, devemos incluir os movimentos e as alterações fisiológicas mais evidentes, para melhor esclarecimento das atividades do animal.

Thomas et al. (1985), ao descrever o comportamento alimentar de Biomphalaria glabrata, optaram pela descrição da forma, mas poderam ter optado também pela conseqüência, uma vez que neste tipo de comportamento fica evidente a alteração que ocorre no meio, onde em um primeiro instante o alimento está presente e logo em seguida deixa de estar, ao ser ingerido pelo caramujo. Outros exemplos de comportamentos descritos pela forma podem ser encontrados em Pimentel et al. (1976a, 1976b) e em Jurberg et al. (1987a), com descrições de postura da concha em relação à massa cefalopodal, e no capítulo seguinte deste livro, sobre o Catálogo Comportamental de $B$. glabrata.

Os estados fisiológicos dizem respeito às alterações funcionais dos animais, que em caramujos são pouco evidenciáveis, a não ser a batida cardíaca, que é bem visível nos albinos, e foi utilizada como medida de toxicidade de diferentes doses de moluscicidas (Cheng \& Sullivan, 1973a). O estado de privação alimentar também altera as batidas cardíacas (Williams \& Gilbertson, 1983a), mas não é alterado pela emergência de Schistosoma mansoni (Williams \& Gilbertson, 1983b).

Esclarecemos que há diferença entre os termos movimentos, deslocamentos e locomoções. O primeiro se restringe à mudança de posição espacial de partes do organismo e o segundo e terceiro à mudança espacial do animal como um todo.

\section{A CATEGORIZAÇÃO COMPORTAMENTAL}

Comportamento é toda atividade de um animal e, por ser complexo, pode ser dividido em unidades mais simples (categorias comportamentais), que são identificadas pelos pontos de transição entre eles e pela forma ou consequeência com que se manifestam (Cunha, 1974; 1975). Por exemplo, observamos o caramujo parado e com a sola do pé aderida à parede vertical de um aquário, em seguida desloca-se para cima até a superfície da água e solta o pé do substrato. Podemos arbitrar três categorias, as quais denominaremos de: parado, deslocando para cima e boiando. Os pontos de transição observados serão, respectivamente: 1) ausência de movimento, 2) com movimento mas aderido ao substrato e 3) com movimento mas não aderido ao substrato. Estas, como as demais categorias comportamentais, são arbitrárias e dependem do pesquisador que as seleciona pela relevância que possam ter para o âmbito do seu trabalho.

Quando estabelecemos comportamentos, devemos designá-los por nomes que estejam de acordo com as suas respectivas descrições, para que possam ser identificadas e diferenciadas umas das outras. 
Cunha (1976) menciona que os comportamentos devem ser designados por vocábulos que possam prontamente evocá-los. Slater (1978) recomenda que se evitem termos que insinuem causa ou função do comportamento. Pieri (1979) exemplificou com a preferência da expressão "saída da água" em vez de "fuga para fora da água" para denominar o comportamento que o caramujo tem de abandonar o meio aquático. A segunda denominação continha inferências que necessitariam ser comprovadas experimentalmente.

Hutt \& Hutt (1974) propuseram o uso do dicionário (Oxford English Dictionary) para denominação das atividades comportamentais em inglês. Nós utilizamos o Novo Dicionário da Língua Portuguesa (Ferreira, 1975) nos estudos comportamentais dos bionfalarídeos (Jurberg et al., 1987a, 1988a), como já havíamos feito também para o estudo do comportamento do caramujo gastrópode terrestre Thaumastus (Thaumastus) taunaisii Férussac, 1822 (Jurberg et al., 1988b).

\section{CATÁlOGO COMPORTAMENTAL}

Em qualquer estudo de comportamento baseado na abordagem etológica, faz-se necessário a elaboração de um catálogo comportamental, contendo as categorias comportamentais que o observador conseguiu estabelecer e descrever. Este é um registro parcial do comportamento e é diferente de um etograma, que se caracteriza por conter um registro completo do repertório comportamental de um animal durante toda a sua vida, o que se torna mais difícil de ser realizado conforme enfatizou EiblEibesfeldt (1974). Este catálogo comportamental pode ser estabelecido através das técnicas descritas no próximo tópico.

\section{TÉCNICAS DE REGISTRO DO COMPORTAMENTO E QUANTIFICAÇÃO}

\subsection{Registro cursivo}

Segundo Fagundes (1982), o registro cursivo é um relato do que é presenciado, na seqüência em que os fatos se sucedem; é chamado também de "registro contínuo". A linguagem utilizada neste tipo de registro deve ser a mais objetiva possível, clara e concisa, descrevendo-se o que acontece de maneira direta ou afirmativa.

Esse tipo de registro preliminar do comportamento é importante, na medida em que facilitará a posterior descrição, categorização e análise comportamental, impedindo que as informações sejam esquecidas, e deverá ser feito em um protocolo que conterá as seguintes informações: a) Situação de observação: descreve-se o local 
onde está sendo feito a observação, informando as condições físico-químicas do meio; b) Sujeito: características do animal (espécie, procedência, tamanho, idade e alimentação); c) Início da observação; d) Término; e) Duração; f) Data; g) Técnica de observação.

A grande vantagem desse tipo de registro é permitir a inclusão de uma ampla variedade de comportamentos, sem requerer deles definição e quantificação prévia. Devido a isso, é muitas vezes utilizado numa fase inicial de trabalhos e pesquisas. Nesta fase, desenhos esquemáticos ou fotografias facilitam a clareza do registro. Além disso, em vez de escrever, podemos registrar o comportamento através de um gravador. Neste caso, tendo marcado a hora de início da gravação, é possível posteriormente estabelecer o tempo que durou toda a observação, bem como o período de tempo da ocorrência de qualquer atividade registrada, bastando para isso ouvir a fita e acionar um cronômetro.

Após vários registros cursivos feitos com diversos exemplares, verificamos que eles ocorrem com certa repetição. Neste caso, é possível estabelecer um catálogo comportamental com comportamentos mais freqüentes, para posterior quantificação e tentativa de análise causal.

Nos trabalhos de Vance-Hall (1973), Altmann (1974) e Fagundes (1982), encontramos algumas técnicas de quantificação de comportamentos em seres humanos e em outros mamíferos, mas que podem ser aplicadas para outros animais, e que adotamos para caramujos.

Para registrar a quantificação do comportamento, organiza-se um outro protocolo com as categorias comportamentais já descritas pela relevância para 0 pesquisador e adota-se uma das técnicas para quantificação. Um modelo de protocolo aparece no anexo 1.

\subsection{Registro de evento}

Anotamos o número de vezes que a categoria comportamental escolhida ocorreu durante a sessão de observação, que foi dividida em intervalos de tempo idênticos. Exemplo: quando submetemos Biomphalaria glabrata a diferentes teores de oxigênio dissolvido, podemos quantificar o número de vezes que ela abre o pneumóstoma na superfície da água, durante cada minuto da sessão de observação (Jurberg et al., 1987b). 


\subsection{Registro de duração}

Anotamos o tempo desde o início até o término da categoria comportamental escolhida, sempre que esta ocorrer durante uma sessão de observação. Exemplos: 1) tempo que o pneumóstoma permanece aberto em relação a diferentes teores de oxigênio dissolvido (Jurberg et al., 1987b); 2) tempo que os caramujos permanecem fora da água, quando submetidos a diferentes concentrações de moluscicidas (Pieri \& Jurberg, 1981; Jurberg et al., 1988c).

\subsection{Registro de ocorrência}

Anotamos a ocorrência ou a não ocorrência da categoria comportamental escolhida, durante a sessão de observação, que neste caso não é dividida em intervalos e sim considerada integralmente. Exemplo: Jurberg et al. (1985) e Jurberg et al.(1988c) verificaram o índice de saída de Biomphalaria glabrata, que é expresso pelo número de caramujo que saíram e permaneceram fora das soluções, contendo diferentes concentrações de moluscicidas após 24 horas de experimentos. Esse comportamento poderia indicar o nível de repelência do moluscicida.

\subsection{Registro por amostragem de tempo}

Dividimos a sessão de observação em intervalos de tempos iguais, e as categorias comportamentais escolhidas só são registradas no período final de cada intervalo, pela sua freqüência ou ocorrência. Exemplo: Jurberg et al. (1987a) estudaram os comportamentos (posturas, deslocamentos e alimentação de Biomphalaria glabrata em diferentes niveis de profundidade em tubos plásticos transparentes de $8,40 \mathrm{~m}$ e $10,20 \mathrm{~m}$ de altura. Observaram o comportamento somente nos últimos 10 min de cada intervalo de 1 hora da sessão de observação (que durou 24 horas), anotando se o comportamento ocorreu ou não, ou a sua freqüência neste período.

\subsection{Outros critérios de quantificação}

Outros critérios de registro de quantificação podem ser adotados, como: velocidade e magnitude da resposta.

A velocidade dos caramujos foi medida, individualmente, por Etges (1963), por determinação da distância percorrida em período de tempo fixos em relação a substâncias químicas. Este procedimento mostrou ser melhor do que manter a distância fixa. 
Temos medido a velocidade do caramujo Biomphalaria glabrata, anotando o tempo e traçando o trajeto percorrido pelo caramujo em superfícies transparentes (placa de vidro ou acrílico), colocadas acima do recipiente que contém o animal, ou na parede do recipiente, quando possível. Marcamos inicialmente com um ponto na coluna, tomando como referência a extremidade da cabeça do caramujo. Do momento em que o mesmo iniciou a locomoção (tempo zero), desenhamos o trajeto com caneta hidrográfica ou para retroprojetor, anotando-se minuto a minuto, sucessivamente, até completar o tempo total da sessão de observação. Em seguida, medimos com uma régua cada espaço percorrido entre os pontos correspondentes aos minutos, tiramos a média aritmética em relação ao tempo total, obtendo, desta forma, a velocidade média (Jurberg et al., 1987a).

Outros exemplos sobre quantificação da velocidade em caramujos, em diferentes situações experimentais, poderão ser encontrados em Pimentel \& White (1959); Simpson et al. (1973); Sodeman (1973); Pieri et al. (1980a); Schall et al. (1985; 1986a; 1986b).

Outros comportamentos podem ser medidos pela magnitude ou intensidade do comportamento, como a ingestão de alimento (Townsed, 1974); a espessura da camada de muco (Cheng \& Sullivan, 1973b); os ângulos de inclinação da concha e tamanho da massa cefalopodal exposta (Pimentel-Souza et al., 1976a; 1976b); o grau de retração da massa para dentro da concha (Pieri et al. 1980b). A estes comportamentos podemos acrescentar também o grau de expansão da pseudobrânquia, observado por Jurberg et al. (1982), que submeteram caramujos a imersão por período prolongado.

\section{DESCRIÇÃO DAS CIRCUNSTÂNCIAS}

Juntamente com o registro quantitativo, feito no protocolo, deve-se elaborar uma lista de circunstâncias em meio as quais o comportamento que está sendo registrado ocorreu. Isto facilitará uma posterior análise do comportamento, pois é possível que determinado comportamento esteja associado a algumas dessas circustâncias. Esta lista deverá abranger os seguintes fatores: a) ambientais temperatura, luminosidade, umidade, composição físico-química da água, etc.; b) do organismo - sua procedência, fase de desenvolvimento, alimentação, etc.; c) comportamentais - relacionar os comportamentos que antecederam e sucederam a determinada categoria comportamental escolhida (Cunha, 1976). 


\subsection{Comentários gerais}

Nos registros, embora a escolha dos intervalos seja arbitrária, é aconselhável que se adotem intervalos curtos para comportamentos cuja freqüência é alta, e intervalos longos para os de freqüência baixa.

$\mathrm{Na}$ quantificação é necessário que se identifique cada caramujo dentro do seu grupo, marcando-os com esmaltes (Jurberg et al., 1987a) ou colocando-os em aquários providos de compartimento individuais (Jurberg et al., 1988c). Com este procedimento, evitamos generalizações incorretas, além de facilitar o uso de estatística adequada. Por exemplo: se em dez indivíduos observados sem identificação, somente um fosse à superfície 30 vezes, durante uma sessão de observação, poderíamos concluir que a média por indivíduo foi de três subidas. A vantagem da observação com caramujos identificados é que ela permitiria fornecer o desvio padrão e, portanto, uma estimativa adequada da variação estatística da resposta. No exemplo anterior, fazendo-se os cálculos de média estatístiva e desvio padrão (3+9.49), percebemos que este último é maior do que a média, indicando alta variabilidade da resposta. Para maiores detalhes de técnicas estatísticas veja Miller (1975).

\section{USO DE INSTRUMENTOS REGISTRADORES}

A cinematografia é muito empregada, pois é possível registrar e posteriormente quantificar as categorias comportamentais, sem ser preciso estar presente (Michaelis, 1955; Eibl-Eibesfeldt, 1974). O registro quadro a quadro, com intervalos de tempo escolhidos previamente, permite uma análise das atividades dos animais e do meio, bastando para isso colocar medidores adequados (termômetros, relógios) junto ao animal (Newell, 1965; Jurberg, 1978).

A cinematografia com lapso de tempo é um registro por amostragem de tempo que a cada período (1 minuto por exemplo) expõe um fotograma, registrando, naquele instante, a atividade do indivíduo ou do grupo e as condições ambientais.

Com Biomphalaria glabrata, utilizando-se câmeras super 8 ou $16 \mathrm{~mm}$, providas de intervalômetros, foram realizados vários trabalhos: Townsend $(1973 ; 1974)$ registrou os deslocamentos em relação aos estímulos alimentares e à trilha de muco; Townsend (1975) também estudou a localização dos caramujos em presença de alimento no fundo de recipentes; Simpson et al. (1973) estudaram as inter-relações sociais; Sodeman \& Dowda (1974) estudaram a localização do caramujo em relação à temperatura, luminosidade e disponibilidade alimentar. Pieri et al. (1980a) fizeram uma caixa com luminosidade e temperatura controlada em que o registro por 
cinematografia com lapso de tempo era feito simultaneamente com o registro das condições ambientais (Figura 1). Posteriormente, Pieri \& Jurberg (1981a) estudaram o efeito subletal do sulfato de cobre em Biomphalaria glabrata nesta mesma câmara; e Rotembeg et al. (1989) estudaram o efeito do ciclo claro-escuro nesta espécie. Também foi empregada esta técnica, porém sem a caixa, para estudar o papel do comportamento na sobrevivência de Biomphalaria glabrata, quando submetida a diferentes dosagens da planta moluscicida Phytolacca dodecandra (Jurberg et al., 1988c).

Posteriormente, Jurberg et al. (1988d) estudaram, no laboratório e no campo, a reotaxia em Biomphalaria glabrata com fotocinematografia por lapso de tempo e videoteipe.

FIGURA 1: Caixa para registrar o comportamento de $B$. Glabrata em aquários através de filmadora super 8 a intervalos pré fixados e flash. O ciclo claro-escuro é obtido através de programador de tempo. A, vista superior; B, vista lateral; aq. = aquário; $\mathbf{f} .=$ flash; $\mathbf{f s i} .=$ filmadora super 8 com relógio para fotografar a intervalos pré-fixados; $1 .=$ lâmpada; pt. $=$ programador de tempo; $\mathbf{s .}=$ suporte; $\mathbf{v} .=$ ventilador

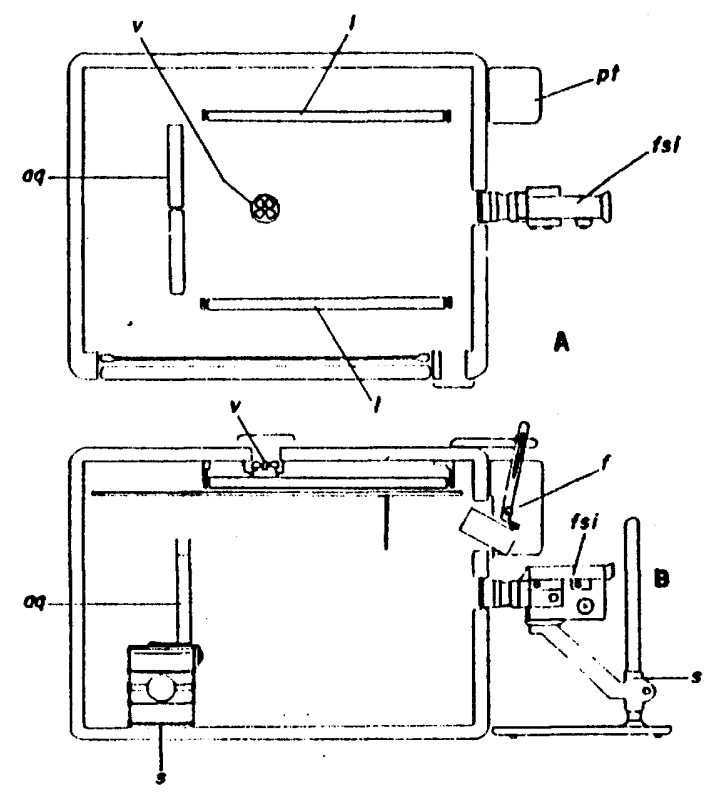


O uso do de videoteipe recorder, com câmera amadora, pode ser utilizado para registros contínuos com luminosidade até 3 lux. Posteriormente, a análise poderá ser feita em intervalos escolhidos, de maneira a se ter uma amostra dos comportamentos ocorridos, podendo, ainda, se desenhar ou fotografar diretamente da tela do televisor. Aparelhos mais sofisticados podem fazer registros a intervalos previamente escolhidos. O uso de sistemas integrados a computadores e registradores de infravermelho permite análises complexas do comportamento individual ou das interrelações grupais, automaticamente no fim das sessões de observações (Hendrié \& Bennett, 1983); entretanto, não temos conhecimento do uso deste instrumental em moluscos.

\subsection{Técnicas fotográficas}

O recurso da fotografia também é empregado para registrar comportamentos, sendo possivel fazer desenhos baseados nesse tipo de registro, ressaltando os aspectos considerados importantes para o pesquisador (Haefelfinger, 1964).

Para fotografar os comportamentos dos caramujos, usamos aquários de acrílico ou de vidro, colocado com silicone para diminuir as sombras formadas pelas junções das paredes. Quanto mais estreito for o aquário, mais fácil se torna a focalização do caramujo. Em aquários grandes deve-se isolar o local que se quer fotografar com um anteparo de plástico ou vidro (Figura 2).

A iluminação é um fator importante e alguns artifícios evitam a formação de sombras do próprio caramujo, com a utilização de duas ou mais lâmpadas e a suspensão do aquário, de forma que a sombra fique projetada fora do campo da fotografia. Neste caso, o uso de folhas de papel de diferentes cores no fundo melhora o contraste (Figura 3).

O uso de filtro de polarização evita os reflexos nas paredes do aquário ou da superfície da água.

Para se estudar movimentos, utiliza-se, se possível, a máquina com o obturador aberto (tempo variável) e o flash deverá ser acionado de tempo em tempo, de maneira que se registrem os movimentos feito pelo animal (Nielsen, 1975; Gage, 1966). Máquinas que possuem intervalômetros e motor podem ser acionadas em tempos determinados, registrando-se os movimentos (Amos, 1975). Embora estas técnicas sejam exeqüiveis para caramujos, preferimos o uso de fotocinematografia, conforme foi descrito acima, em vez de fotografia para estudar movimentos, podem ser muito mais simples. 
FIGURA 2: Aquário com anteparo para fotografia de B. glabrata. A máquina fotográfica (mf) está situada na frente e o flash (f) em cima do aquário

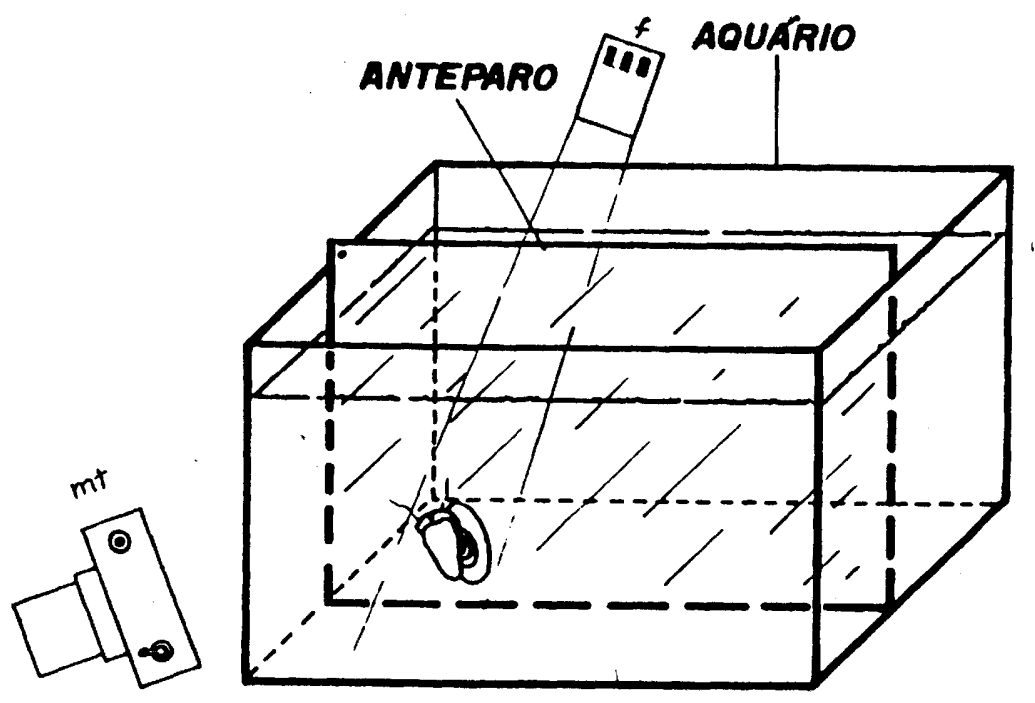

FIGURA 3: Aquário apoiado em calços para evitar "sombras" nas fotografias de B. glabrata

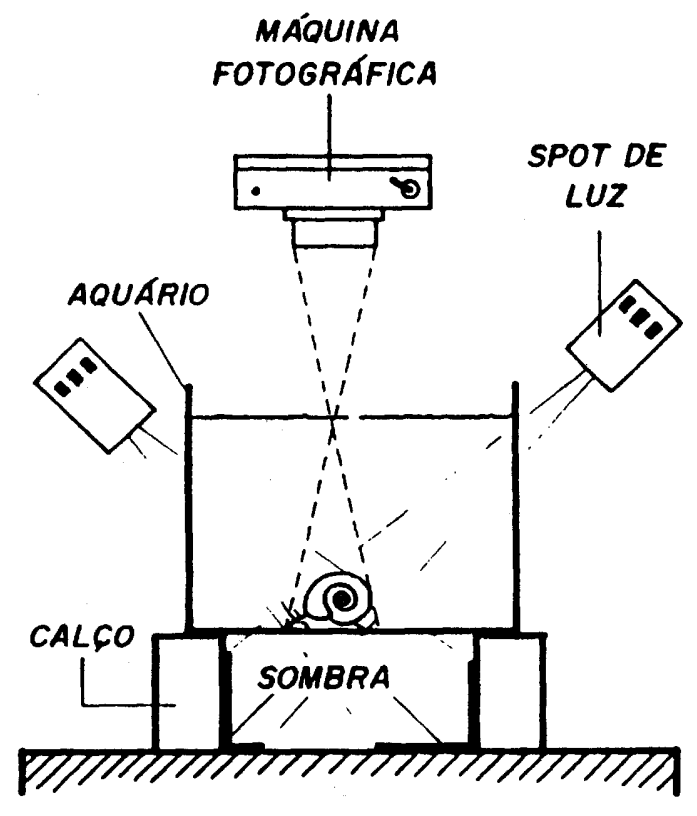




\subsection{Alguns aparelhos para estudar o comportamento dos bionfalarídeos}

Além dos instrumentos registradores, pode-se construir uma série de outros aparelhos para se evidenciar o comportamento, de acordo com os estímulos que se queria estudar.

\section{LUZ}

Para estudar a orientação de $B$. glabrata, $B$. tenagophila e $B$. straminea em relação a uma fonte luminosa, construímos, em nosso laboratório, labirintos em forma de $\mathrm{Y}$ com calhas de P.V.C. rígido. O braço central, onde eram colocados os caramujos, tinha $50 \mathrm{~cm}$ de extensão e os braços laterais, onde podia se colocar alternadamente a fonte luminosa, $70 \mathrm{~cm}$ de extensão (Figura 4) (Schall et al., 1985, 1986a, 1986b).

FIGURA 4: Representação esquemática de um aquário em forma de $Y$ usado para estudar a orientação de $B$. glabrata em relação à luz. bc. $=$ braço central; bd. $=$ braço direito; be $=$ braço esquerdo; $\mathbf{b l .}=$ caixa $\operatorname{com}$ luz; $\mathbf{f} .=$ fundo; ie. $=$ identificação externa das áreas; $\mathbf{p .}=$ parede; $\mathbf{s .}=$ sítio de medição de temperatura; va. $=$ vasilhame de acrílico; vf. $=$ vista frontal

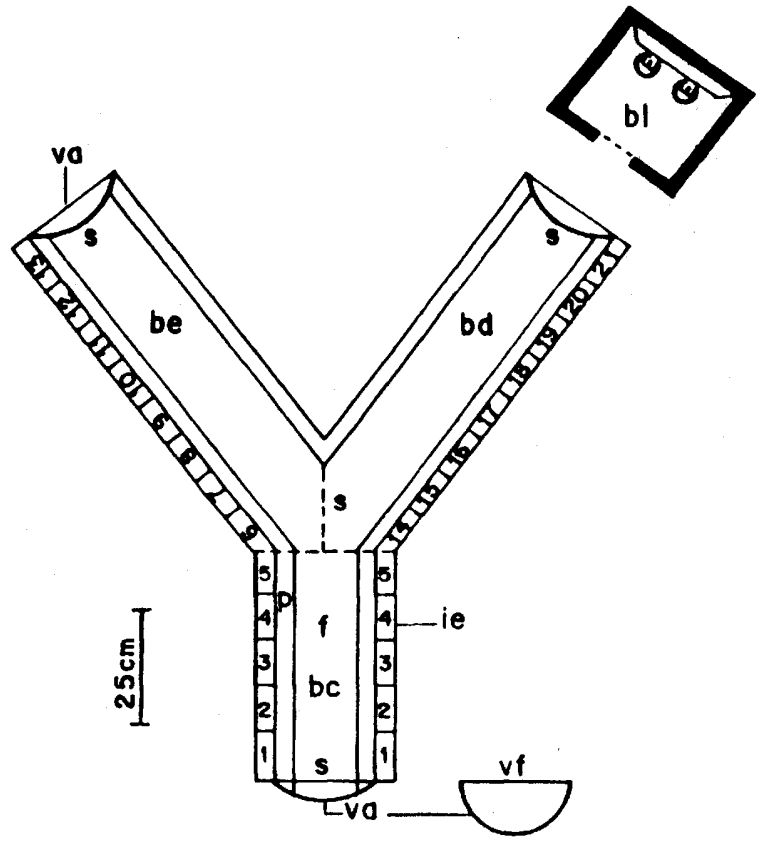


Outros experimentos foram feitos por Sodeman (1973) em uma caixa de atividade, de maneira a estudar a velocidade de $B$. glabrata em relação à intensidade luminosa. Sodeman \& Dowda (1974) fizeram uma câmara em forma de 8 para estabelecer a preferência entre claro e escuro. Pimentel-Souza et al. (1984), em aquário com gradiente de luminosidade, estudaram a distribuição de caramujos. Rotemberg et al. (1989), em aquários com compartimentos individualizados, estudaram o efeito de claro e escuro na atividade dos caramujos.

\section{TEMPERATURA}

Chernin (1967) construiu um recipiente retangular com gradiente de temperatura que se distribuíra horizontalmente, obtido através de circulação em serpentina de água fria e quente nas extremidades, para estudar a preferência de $\boldsymbol{B}$. glabrata. Shiff (1966a) construiu um aquário que era atravessado por tubos em toda a sua altura de forma que a circulação de água fria e quente fazia um gradiente vertical. Este aparelho foi utilizado para estudar efeito na distribuição vertical de $\boldsymbol{B}$. pfeifferi em relação à temperatura.

\section{ATRAENTES E REPELENTES}

Para o estudo do efeito de substâncias atraentes (alimentos, plantas e substâncias) ou repelentes (moluscicidas), no comportamento de bionfalarídeos, foram usadas desde longas caixas de madeiras de 4,0 a 9,0 metros (Etges, 1963; Etges \& Gilbertson, 1966) até pequenas câmaras de plástico com $11 \mathrm{~cm}$ de diâmetro, denominadas de olfatômetros, nas quais podiam ser testadas as substâncias quando se difundissem (Thomas et al., 1980; Thomas \& Assefa, 1979; Thomas, 1986).

A repelência devido a plantas moluscicidas foi determinada em aquários com compartimentos individualizados tendo a parte superior inclinada, de forma que os caramujos que saíssem pudessem permanecer neste local (Jurberg et al., 1988c) (Figura 5).

\section{PRESSÃO}

O estudo do comportamento de $B$. glabrata em pressões correspondentes a até $50 \mathrm{~m}$ de profundidade foi realizado em duas câmaras de acrílico transparente, ligadas a um reservatório de água (Figura 6), através de válvulas que permitiam substituir a água sem variar a pressão exercida nas câmaras, de maneira a manter o mesmo nível de oxigênio dissolvido (Jurberg et al., 1988a). 
FIGURA 5: Dois aquários com compartimentos individualizados e com as bordas inclinadas. Para registrar o comportamento de $B$. Glabrata através de filmadora super 8 com intervalômetro e flash. aq. $=$ aquário; cs. $=$ câmera super 8 ; dre. $=$ dados relativos ao experimento; $\mathbf{f} .=$ flash $\mathbf{m}$. margem; $\mathbf{r} .=$ relógio

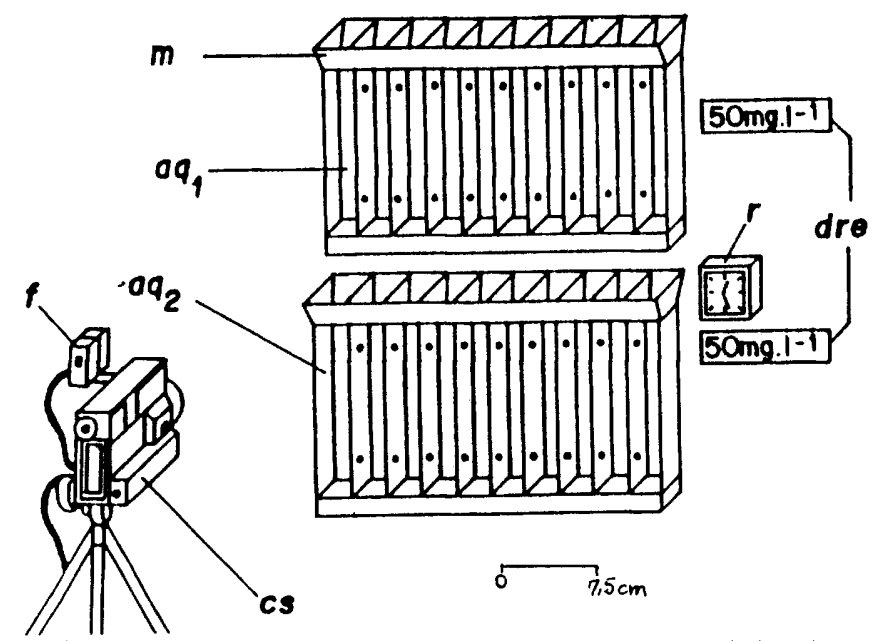

Para estudarmos os deslocamentos dos caramujos e atividades biológicas em diferentes profundidades (Jurberg et al., 1987a), foram construídas colunas transparentes medindo $1,10 \mathrm{~m}, 8,40 \mathrm{~m}$ e $10,40 \mathrm{~m}$ (Figura 7). Estes mesmos deslocamentos foram estudados por Townsend (1975), em aquários com $20 \mathrm{~cm}$ de altura, e por Corr et al. (1984), em colunas de $15 \mathrm{~cm}$ de altura.

FIGURA 6: Câmaras de acrílico para observação do comportamento de B. Glabrata submetida a pressões equivalentes a $50 \mathrm{~m}$ de profundidade. As setas indicam o fluxo da água. co.= câmara de observação; e. = êmbolo; m. = manômetro; v. = válvulas. Explicações no texto

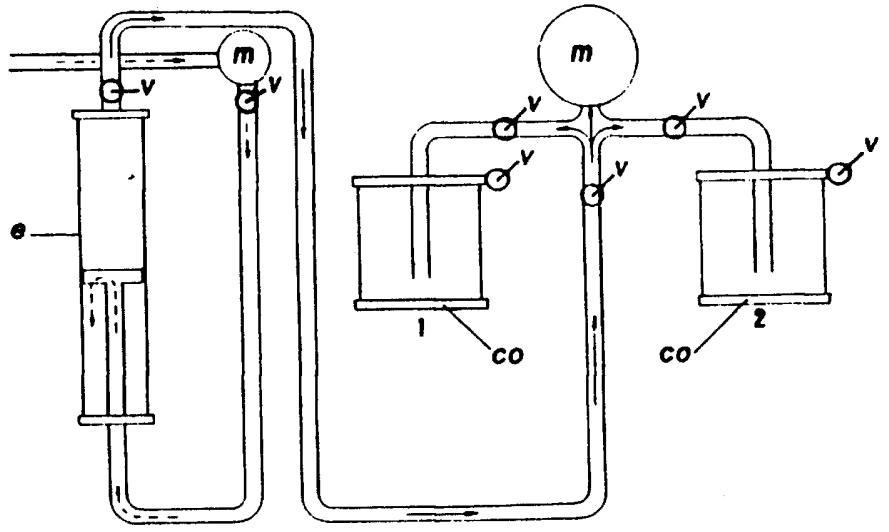


FIGURA 7: A. tubo de plástico transparente $(10,40 \mathrm{~m})$ para observação dos deslocamentos verticais de

B. glabrata com duas caixas de água e uma bomba. $\mathbf{b}_{\mathbf{2}}=$ bomba; $\mathbf{c} .=$ coluna; $\mathbf{c a} .=$ caixa de água; e. = escada. B. coluna de vidro transparente para estudar os deslocamentos verticais de $B$. glabrata $. \mathbf{a} .=$ anteparo $($ para retirar os exemplares); $\mathbf{c} .=$ coluna; $\mathbf{f} .=$ fio; $\mathbf{r} .=$ registro
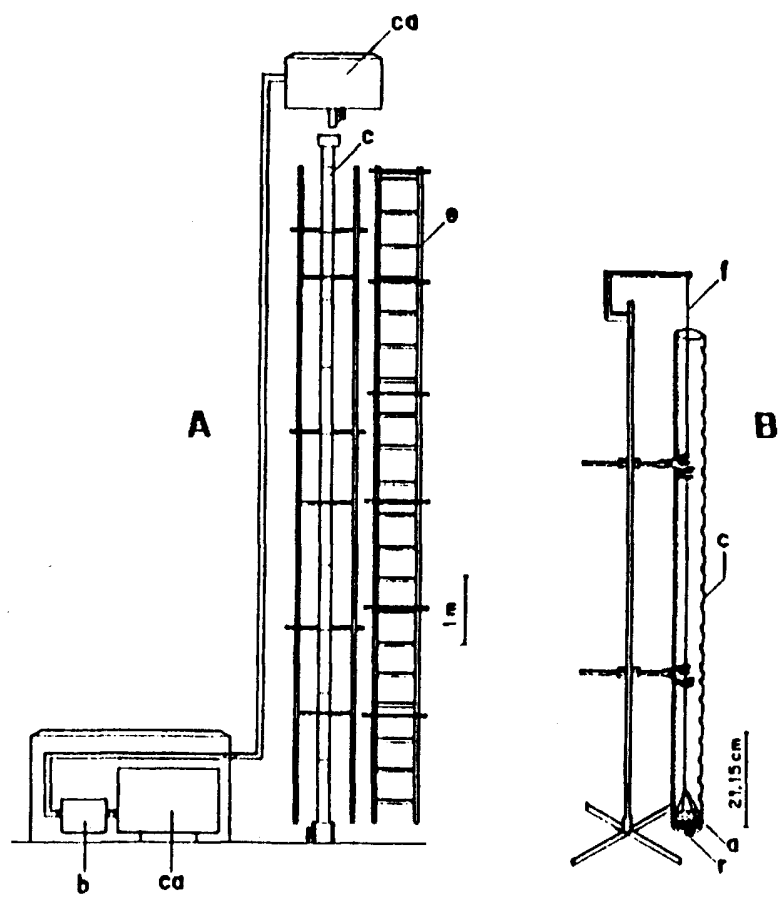

\section{CORRENTE}

Luttermoser (1944) construiu pequenos canais de madeira em que escorria água para evidenciar o comportamento de reotaxia. Bousfield $(1978,1979)$ fez este tipo de estudo em câmaras de plástico circular $(23 \mathrm{~cm}$ de diâmetro), em que a corrente era formada graças ao jato de ar comprimido que saía na superfície junto à margem. A resposta reotáxica também foi evidenciada em superfícies verticais nos aquários com anteparo que escorria água, formando uma corrente na parede (Jurberg et al., 1988d) (Figura 8). 
FIGURA 8: Representação esquemática de um aquário para monitoramento de reotaxia vertical e habituação em B. glabrata. A, B e C compartimentos; 1. parede controle com água gotejante; 2. parede experimental com água formando corrente

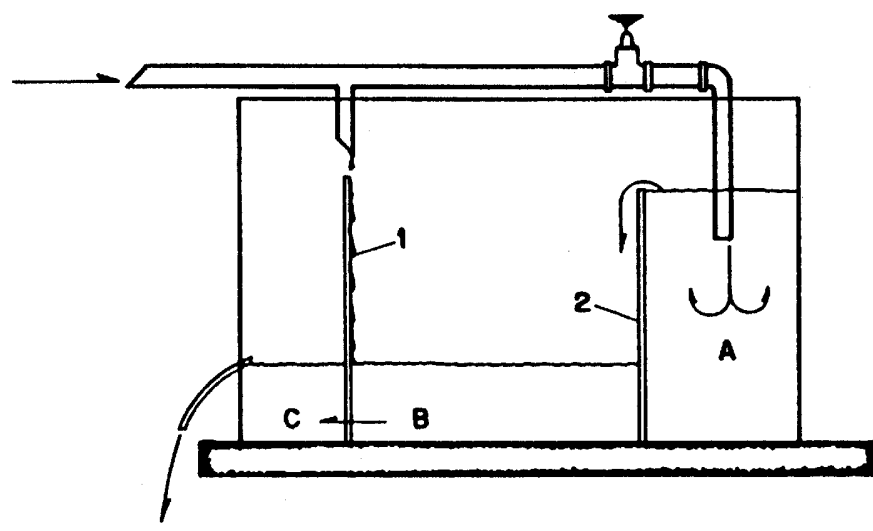

$9,2 \mathrm{~cm}$

\section{ANÁLISE CAUSAL DO COMPORTAMENTO}

Após a quantificação, é possível determinar as causas do comportamento, através de uma análise em que se procura relacionar os estímulos causais das atividades. Entre estas causas podemos citar os estímulos externos: do meio (temperatura, luz, composição química), de outro exemplar da mesma espécie (feromônio) ou de outra espécie (alomônio). Além de estímulos internos, como hormônios responsáveis pelo comportamento sexual.

Por se tratar de estudo de causa e efeito, ressaltamos que nesta fase é imprescindível o uso do método experimental com grupo de controle adequado e amostras representativas seguidas de testes estatísticos bem escolhidos. Biomphalaria glabrata é uma espécie muito variável (Bair \& Etges, 1973; Henriksen \& Jelnes, 1980; Mulvey \& Vrijenhoek, 1981; Corr et al., 1984), e só experimentos bem conduzidos permitem afirmações categóricas. É necessário, ainda, lembrar sempre que as relações de causa e efeito, que a princípio parecem óbvias, podem não corresponder à realidade (Pieri, 1979).

A análise causal pode ser realizada pela apresentação de um estímulo ou variação de sua intensidade, e, verificando a ocorrência da modificação no comportamento do animal, é possível que mais dé uma causa possa estar envolvida, 
contribuindo para o desencadeamento do comportamento em questão. Como exemplo, podemos citar a diapausa que, segundo Pieri (1985), pode ser causada por certos estímulos do meio externo, como a temperatura (causa imediata); ou por modificações internas verificadas em certa fase do desenvolvimento do caramujo, como o aparecimento de lamelas no estágio juvenil (causa ontogenética); ou ainda por diferença de raças geográficas (causa filogenética). Os fatores causais ontogenéticos podem ser estabelecidos através de comparações entre indivíduos da mesma espécie, porém de idades diferentes (ontogenéticos) ou comparações entre indivíduos de raças próximas ou espécies do mesmo gênero (filogenéticos).

$\mathrm{Na}$ natureza, usa-se variar a intensidade do estímulo ou suprimi-lo quando possível, para verificar as modificações comportamentais. No estudo da resposta reotáxica dos caramujos no campo, a corrente de água sofreu variação até a supressão, e verificamos que os caramujos deixaram de subir nas superfícies verticais da vala por onde escorria a água. Quando testado no laboratório, este fato foi comprovado (Jurberg et al., 1988d).

Pode ocorrer, também, de um comportamento ter relação causal com outro comportamento que o antecedeu no tempo imediato (Slater, 1973), podendo ser determinado pela observação do fluxo comportamental, no qual aquele comportamento está inserido. Este tipo de análise caracteriza uma análise causal seqüêncial. Lehner (1979) mencionou que: (a) quando uma categoria comportamental segue-se a outra com uma determinada freqüência, a seqüência é considerada probabilística. Exemplo: Dannemann \& Pieri (1989) verificaram que alguns caramujos, após a saída da água, retraem-se nas conchas e entram em dormência enquanto outros retornam para a água; (b) quando a ocorrência de uma categoria comportamental estiver sempre associada a uma outra, a seqüência é considerada determinística. Exemplo: Pieri (1985) verificou que os caramujos provenientes de ovos originários de pais lamelados, quando mantidos em temperaturas de 19 a 21 graus centígrados, ao atingirem de 3 a $5 \mathrm{~mm}$ de diâmetro, saem da água, retraem-se nas conchas e entram em diapausa em 100\% dos casos. Posteriormente Dannemann \& Pieri (1992), em estudos mais acurados, demonstraram que este, fenômeno não era determinístico, pois havia uma percentagem pequena de caramujos que não correspondem as expectativas (27\%).

\section{ANÁLISE FUNCIONAL DO COMPORTAMENTO}

Em Biomphalaria glabrata, a maioria dos comportamentos é esteriotipados e pré-programados geneticamente (instintivos), havendo poucas modificações de comportamento através da aprendizagem, a não ser a habituação. Esta é comum aos 
moluscos (Willows, 1973; Carey \& Samley, 1986) e já foi constatada em Biomphalaria glabrata, que deixa de subir às superfícies verticais, não mais respondendo reotaxicamente às correntes de água, após 24 horas de exposição a esse estímulo (Jurberg et al., 1988d).

Estes comportamentos instintivos, assim como os órgãos, são resultantes da seleção natural que atua sobre ambos. Sendo assim, é possível estudarmos o comportamento através de uma análise funcional na qual procura-se, não os estímulos causais, mas a sua função em relação à sobrevivência do animal.

Tinbergen (1965) propôs dois procedimentos para este tipo de análise: a) isolar o estímulo ambiental que é o desencadeador do comportamento que se quer estudar, e submeter um grupo experimental ao estímulo, enquanto o controle não é submetido, verificando qual dos dois grupos tem uma taxa de sobrevivência maior. Exemplo: No caso do ressecamento do solo, verificamos que os caramujos que conseguiam se cobriam com areia, sobreviviam em maior proporção do que os caramujos que não se cobriam (Pieri et al., 1980); b) tentar relacionar o comportamento, cuja vantagem adaptativa seja desconhecida, com a sobrevivência, de tal modo que se ela ocorrer em algum grupo, este grupo deverá ter uma taxa de sobrevivência maior. Exemplo: Etges \& Gilbertson (1966) verificaram que uma linhagem de Biomphalaria glabrata era menos suscetível aos moluscicidas, por terem a tendência natural de permanecer fora da água por períodos consideráveis.

A análise funcional permite descobrir como estes comportamentos ajudam a sobrevivência e a reprodução. Estes estudos, em vez de se deterem nas causas, detêm-se nos efeitos, ou seja, em vez de se preocuparem com os estímulos causais, eles visam apenas elucidar o que resulta como conseqüência da ocorrência da categoria observada, necessitando, além da observação com a descrição, a experimentação, sem a qual o estudo tem pouco valor. Mas também é possível usar a especulação para a compreensão dos fenômenos envolvidos, como escreveu Tinbergen (1965). Para demonstrar como este tipo de raciocínio pode ser válido, apresentamos, a seguir, alguns exemplos de trabalhos, em que a observação de fatos na natureza foi seguida de experimentos em laboratório e interpretação especulativa.

O encontro por Paraense et al. (1955) de bionfalarídeos vivos, enterrados 2 ou 3 metros acima da margem da coleção de água, foi contestado pela impossibilidade destes caramujos se manterem vivos após 24 horas cobertos com argila úmida em laboratório (Perlowagora-Szumlewica \& Dias, 1955). Assim, o achado de caramujos enterrados foi atribuído, por estes autores, à ação mecânica do pisoteio de gado.

Para elucidar este paradoxo, fizemos três trabalhos: no primeiro, verificamos que Biomphalaria glabrata foi capaz de se cobrir com areia dentro d'água. Após um período de dessecação provocada pelo esgotamento de água, os caramujos que 
permaneceram cobertos se recuperaram em maior número quando colocamos água, o que evidencia uma vantagem adaptativa deste comportamento (Pieri et al., 1980b).

No segundo trabalho, realizamos uma série de experimentos, registrados através de cinematografia por lapso de tempo e verificamos que: (1) a penetração ativa em buracos faz parte do repertório comportamental da espécie, após o esgotamento da água; (2) a sobrevivência de indivíduos em estivação, enterrados no solo, é possível por longos períodos, e que; (3) os indivíduos são capazes de se desenterrarem com o retorno da água, após vários meses sob o solo (Jurberg et al., 1980).

Posteriormente, verificamos a ocorrência de resposta reotáxica positiva a correntes moderadas de água, fazendo com que Biomphalaria glabrata suba por superfícies verticais (Jurberg et al., 1988d).

Baseado nestes dados obtidos experimentalmente, podemos tentar deduzir uma explicação para o paradoxo apresentado: os caramujos na natureza, ao terem seus criadouros invadidos por água da chuva que escorre pelas margens, subiriam por reotaxia. Após o término das chuvas, procurariam orifícios ou fendas onde penetrariam, mantendo-se estivados por longo período.

Este exemplo também é válido para demonstrar o valor de experimentos realizados em laboratório para o entendimento de fatos observados na natureza.

\section{Classificação dos comportamentos}

Após a análise causal e funcional, é possível reunir diferentes comportamentos quando eles têm a mesma causa ou função, constituindo uma classificação causal ou funcional respectivamente (Hinde, 1966).

A ida à superfície de $B$. glabrata, e a saída da água e permanência fora desta, quando em contato com doses subletais de moluscicidas, tendo os três comportamentos o mesmo estímulo causal, podem ser reunidas com o nome de "respostas aos moluscicidas" (Pieri \& Jurberg, 1981; Jurberg et al., 1988c). Como exemplo de classificação funcional citamos os comportamentos de proteção que, pela sua ocorrência, possibilita os caramujos escaparem de condições adversas, tais como saída da água, retração na concha e entrada em buracos (Pieri \& Jurberg, 1981a).

$\mathrm{Na}$ prática, como chamou atenção Hinde (1966), é muito comum determinado comportamento estar classificado entre causas e funções. Entretanto, reunir os comportamentos por essas duas classificações em comum permite-nos ter uma visão mais ampla das atividades. 


\section{VALIDADE DOS ESTUDOS NA NATUREZA E NO LABORATÓRIO}

Altmann (1974), comparando estes dois tipos de estudos, chamou atenção para o fato de que os testes de laboratório possuem alta validade interna, pois estabelecem as relações causa e efeito nas condições de estudo, mas podem ter baixa validade externa, quando as conclusões do laboratório são levadas e aplicadas no campo, verificando-se que as generalizações podem não ser as mais adequadas.

Nos nossos trabalhos de resistência à pressão, verificamos que a Biomphalaria glabrata sobrevive a pressões correspondentes a $50 \mathrm{~m}$ de profundidade. No entanto, no campo eles são encontrados preferencialmente na superfície (Jurberg et al., 1988a). Este dado de laboratório não permitiu uma generalização para o campo, mas permitiu evidenciar como os caramujos podem sobreviver em açudes profundos, e verificar também a entrada de água na cavidade pulmonar, passando de respiração aérea para aquática. Um exemplo de como uma generalização poderia ser inadequada, é quanto ao comportamento de deslocamento, em que a categoria "deslizar", em Biomphalaria glabrata, é a mais freqüente nas condições de laboratório (coluna e aquário), no entanto, no campo, em coleções d'água rasas, a mais freqüente é "arrastar", pois a concha fora da água, torna-se mais pesada, devido a um peso específico maior (Jurberg et al., 1987a).

Estes exemplos demonstraram o cuidado que se deve ter nas generalizações dos dados obtidos no laboratório para o campo. É aconselhável que se iniciem os estudos em condições naturais, através de observações e registros acurados, para, posteriormente, identificar, no laboratório, as causas e as funções do comportamento, através de experimentação.

\section{AGRADECIMENTOS}

Queremos externar nossos agradecimentos ao Conselho Nacional de Pesquisa (CNPq) que financiou este trabalho, ao Dr. Otácio Pieri, a Dra. Marli Maria Lima e ao Sr. Newton de Azevedo (in memoriam) por ter nos ensinado as técnicas fotográficas empregadas neste trabalho. 


\section{ANEXO 1}

TEMP. AMBIENTE: $25^{\circ} \mathrm{C}$ TEMP. DA AGUA: $24^{\circ} \mathrm{C} \quad \mathrm{O}_{2}$ DISSOLVIDO: $5,8 \mathrm{mg} / \mathrm{l}$ DIA DA OBSERVAÇÃO: 25-07-90 ESPÉCIE: Biomphalaria glabrata HORA: 9:00 ÀS 10:00H IDADE: 12 meses TAMANHO: de $1,3 \mathrm{~cm}$ a $1,8 \mathrm{~cm}$ NOME DO OBSERVADOR:

TÉCNICA DE OBSERVAÇÃO: REGISTRO DE EVENTO ALIMENTAÇÃO: C/ALFACE

\begin{tabular}{|c|c|c|c|c|c|c|c|c|c|c|c|c|c|c|c|}
\hline \multirow[t]{2}{*}{$\begin{array}{l}\mathrm{S} \\
\mathrm{U} \\
\mathrm{J}\end{array}$} & \multirow[t]{2}{*}{$\begin{array}{l}\text { PROFUN- } \\
\text { DIDADE }\end{array}$} & \multicolumn{4}{|c|}{$\begin{array}{c}\text { POSTURAS DA } \\
\text { CONCHA }\end{array}$} & \multicolumn{4}{|c|}{$\begin{array}{l}\text { POSTURAS DA } \\
\text { MASSA } \\
\text { CEFALOPODAL }\end{array}$} & \multicolumn{5}{|c|}{ DESLOCAMENTOS } & \\
\hline & & $\mathrm{CN}$ & CP & CE & $\mathrm{Cl}$ & MTD & MPD & MPR & MTR & SA & DA & $\mathrm{DZ}$ & AR & $B$ & $\mathbf{P}$ \\
\hline 1 & & & & & & & & & & & & & & & \\
\hline 2 & & & & & & & & & & & & & & & \\
\hline 3 & & & & & & & & & & & & & & & \\
\hline 4 & & & & & & & & & & & & & & & \\
\hline 5 & & & & & & & & & & & & & & & \\
\hline 6 & & & & & & & & & & & & & & & \\
\hline 7 & & & & & & & & & & & & & & & \\
\hline 8 & & & & & & & & & & & & & & & \\
\hline 9 & & & & & & & & & & & & & & & \\
\hline 10 & & & & & & & & & & & & & & & \\
\hline 11 & . & & & & & & & & & & & & & & \\
\hline 12 & & & & & & & & & & & & & & & \\
\hline 13 & & & & & & & & & & & & & & & \\
\hline 14 & & & & & & & & & & & & & & & \\
\hline 15 & & & & & & & & & & & & & & & \\
\hline
\end{tabular}

\section{CATEGORIAS}

$\mathrm{CN}=$ Concha normal $\mathrm{CP}=$ concha pendente $\mathrm{CE}=$ concha erecta $\mathrm{Cl}=$ Concha invertida $\mathrm{MTD}=$ Massa totalmente distendida $M P D=$ Massa parcialmente distendida MPR= Massa parcialmente retralda MTR= Massa totalmente retraida $S A=S u b i d a$ súbita $\quad \mathrm{DA}=$ descida súbita $\mathrm{DZ}=$ Deslizar $\mathbf{A R}=$ Arrastar $\mathbf{B}=\mathbf{B}$ oiar $\mathbf{P}=\mathbf{P a r a d o}$ 


\section{ANEXO 2}

Diagrama de fluxo relativo aos deslocamentos de $B$. glabrata submetida a variação de 0 atm a 5 atm e retorno a 0 atm. Os retângulos representam os comportamentos; os números dentro destes representam o número de caramujos em cada comportamento; as setas indicam as mudanças de comportamento; os números nas setas, quantos caramujos passaram de um comportamento para outro. As setas mais grossas indicam as principais mudanças

\section{DESLOCAMENTOS}

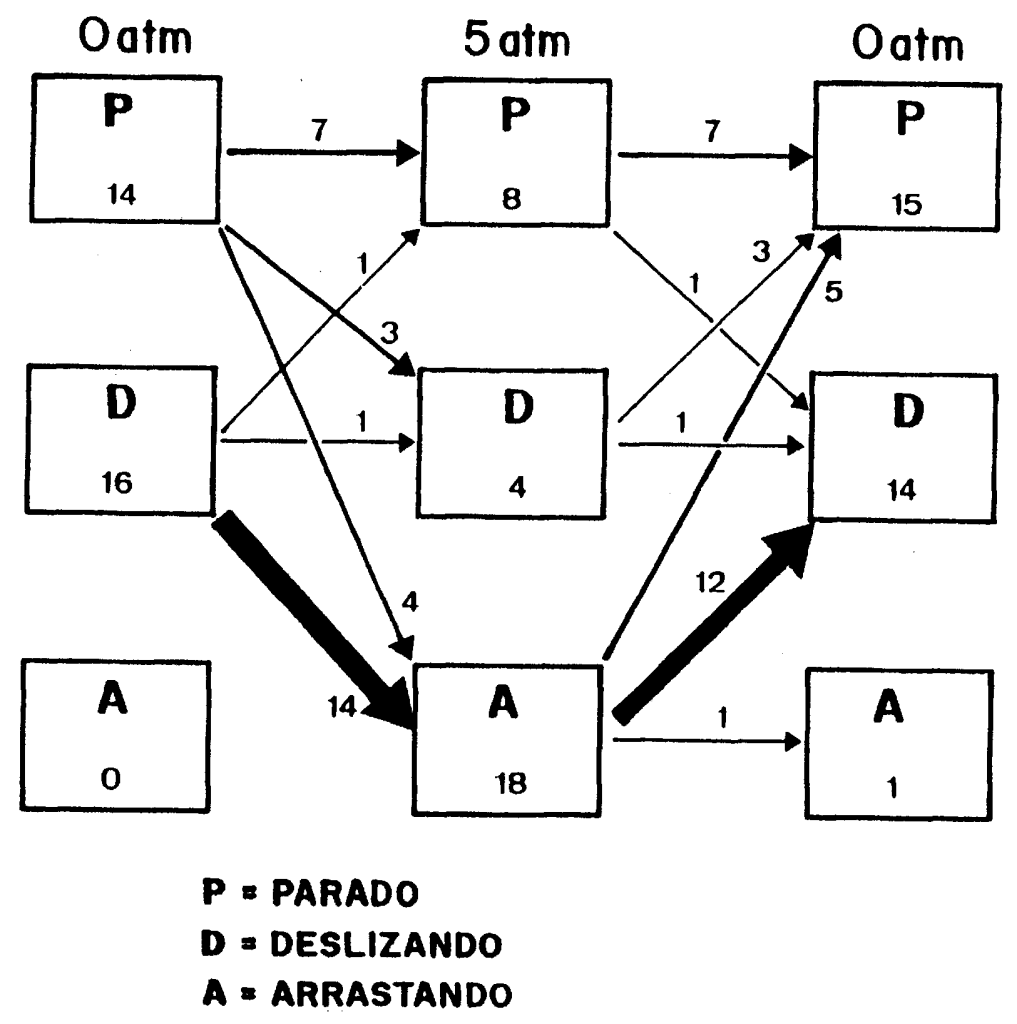




\section{TÓPICOS EM MALACOLOGIA MÉDICA}

\section{REFERÊNCIAS BIBLIOGRÁFICAS}

ALTMANN, J., 1974. Observational study of behavior: sampling methods. Behaviour, 49: 227-265.

AMOS, T. G., 1975. Time lapse photography with synchorized eletronic flash for recording insect behaviour. Animal Behaviour, 13: 558-560.

ANDRADE, R. M., 1959. Ecologia in monografia sobre a esquistossomose mansoni. Revista Brasileira de Malariologia e Doenças Tropicais, 11: 171-217.

APPLETON, C. C., 1978. Review of literature on abiotic factors influencing the distribution and life cycle of bilharziasis intermediate host snails. Malacological Review, 11: 1-25.

ASPEY, W. P. \& BLANKENSHIP, J. E., 1977. Spiders \& Snails \& Statistical Tales: application of multivariate analyses to diverse ethological data. In: Quantitative Methodos in the Study of Animal Behavior (A. Hazlett, ed.), pp.75-120, London: Academic Press London.

BAERENDS, G. P., 1975. The methods of Ethology. Ciência e Cultura, 27: 938-942.

BAIR, R. D. \& ETGES, F. J., 1973. Differences in esterase frequencies in five strains of Biomphalaria glabrata (SAY). International Journal of Parasitology, 3: 43-46.

BOUSFIELD, J. D., 1978. Rheotaxis and chemoreception in the freshwater snail Biomphalaria glabrata (Say). Estimation of the molecular weight of active factors. Biological Bulletin, 154: 361-372.

J. D., 1979. Plant extralts and chemically triggered positive rheotaxis in Biomphalaria glabrata (Say), snail intermediate host of Schistosoma mansoni (Sambon). Journal Applied Ecology, 16: 681-690.

CAREY, J. T. \& SAMLEY C. M., 1986. Invertebrate learning and memory from behavior to molecule. Annual Review Neuroscience, 9: 435-487.

CHENG, T. C. \& SULLIVAN, J. T., 1973a. The effect of copper onthe heart-rate of Biomphalaria glabrata (Mollusca: Pulmonata). Comparative General Pharmacology, 4: 37-41.

1973b. A comparative study of the effects of two copper compounds on the respiration and survival of Biomphalaria glabrata (Mollusca: Pulmonata). Comparative General Pharmacology, 4: $315-320$.

CHERNIN, E., 1967. Behavior of Biomphalaria glabrata and other snails in a thermal gradient. Journal of Parasitology, 53: 1233-12440.

CORR, M.; COVICH, A. \& YOSHINO, T. P., 1984. Vertical movement and time allocation of a freshwater pulmonate snail. Hydrobiologia, 122: 69-72.

CUNHA, W. H. A., 1974. Acerca de um curso pós-graduado destinado ao treino da observação científica no domínio das ciências do comportamento. Ciência e Cultura, 26: 846-853.

1975. O estudo etológico do comportamento animal. Ciência e Cultura, 27: 262-268.

1976. Alguns princípios de categorização, descrição e análise do comportamento. Ciência e Cultura, 28: 15-24.

DANNEMANN, R. D. A. \& PIERI, O. S., 1989. Anidrobiose e diapausa em Biomphalaria glabrata (Say), caramujo transmissor da esquistossomose na região nordeste. Biotemas, 2: 57-68.

1992. Lamella formation and emigration from the water by a laboratory colony of Biomphalaria glabrata (Say) in a flow-through system. Memórias do Instituto Oswaldo Cruz, Vol. 87, Supplement I: 87-90.

EIBL-EIBESFELDT, I., 1974. Etologia - Introducción al Estudio Comparado del Comportamento. Barcelona: Ediciones Omega S.A. 


\section{TÉCNICAS MALACOLÓGICAS}

ETGES, F. J., 1963. Effects of some molluscicidal chemical on chemokinesis in Australorbis glabratus. American Journal of Tropical Medicine and Hygiene, 12: 701-704.

ETGES, F. J. \& GILBERTSON, D. E., 1966. Repellent action of some chemical mollusccides on schistosome vector snails. American Journal of Tropical Medicine and Hygiene, 15; 618-624.

FAGUNDES, A. J. F. M., 1982. Descrição, Definição e Registro de Comportamento. São Paulo: Edicon.

FERREIRA, A. B. H., 1975. Novo Dicionário da Lingua Portuguesa. Editora Nova Fronteira.

GAGE, J., 1966. Photographic method of recording the activity of small animals using repetitive eletronic flash. Nature, 209: 933-934.

HAEFELFINGER, H. R., 1964. La photographie et la cinematographie techniques de documentation puor l'étude des Opphisthobranches. Vie et Millieu, 17. 251-262.

HENDRIÉ, C. A. \& BENNETT, S., 1983. A microcomputer technique for detailed analysis of animal behaviour. Physiology \& Behaviour, 30: 233-235.

HENRIKSEN, V. B. \& JELNES, J. E., 1980. Experimental taxonomy of Biomphalaria (Gastropoda: Planorbidae). 1. Methods for experimental taxonomic studies on Biomphalaria carried out by horizontal starch gel electrophoresis and staining of twelve enzymes. Journal of Chromatrography, 188: $169-176$.

HINDE, R. A., 1966. Animal behaviour. A synthesis of Ethology and Comparative Psychology. New York: McGraw-Hill Book Company.

HUTT, S. J. \& HUTT, C., 1974. Observação Direta e Medida do Comportamento. São Paulo: Pedagógica e Universitária/Universidade de São Paulo.

JURBERG, P., 1978. Contribuição para o Conhecimento da Conquiologia, Anatomia de Thaumastus (Taumastus) taunaisii (Ferussac, 1822). Tese de mestrado, Rio de Janeiro: Museu Nacional. 1990. Controle das doenças endêmicas através da manipulação comportamental.

Biotemas, 3: 1-45.

JURBERG, P.; PIERI, O. S. \& RAYMUNDO, J. S., 1980. Comportamento de penetração em buracos e sobrevivência sob o solo como meio de proteção de Biomphalaria glabrata (Say, 1818). Suplemento de Ciência e Cultura, 31: 799.

JURBERG, P.; GATTI, M. J.; SOARES, M. S. \& BARBOSA, J. V., 1982. Comportamento e condiçōes de sobrevivência de Biomphalaria glabrata submetida a imersão prolongada. Ciência e Cultura, 34: 802.

JURBERG, P.; CABRAL-NETO, J.B. \& SCHALL, V.T., 1985. Molluscicide activity of the "Avelos" plant (Euphorbia tirucalli, L.) on Biomphalaria glabrata, the mollusc vector shcistosomiasis. Memórias do Instituto Oswaldo Cruz, 80: 423-427.

JURBERG, P.; SCHALL, V. T.; BARBOSA, J. V.; GATTI, M. J. \& SOARES M. S., 1987a. Behaviour of Biomphalaria glabrata, the intermediate host snail of Schitosoma mansoni, at different dephts in water in laboratory conditions. Memórias do Instituto Oswaldo Cruz, 82: 197-208

JURBERG. P.; CUNHA, R. A.; RODRIGUES, M. L. \& BARBOSA, J. V. 1987b. Respiratory behaviour of Biomphalaria glabrata. First International Symposium on Schistosomiasis: 33

JURBERG, P.; SOARES, M. S.; MASCITELLI, A. C.; FAVRE, T. C. \& BARBOSA, J. V., 1988a Studies on survival, biological activites and behaviour of Biomphalaria glabrata, the host snail of Schistosomiasis, submitted to increased hydrostatic pressure: a technique. Memórias do Instituto Oswaldo Cruz, 83: 53-61.

JURBERG, P.; BARROS, H. M.; GOMES, L. A. L. \& COELHO, A. C. S., 1988b. Superfamília Bulimuloidea do Brasil. Bulimulidae thaumastus (Thaumastus) taunaisii (Ferussac, 1982), com dados 


\section{TÓPICOS EM MALACOLOGIA MÉDICA}

biológicos e aspectos comportamentais (Mollusca, gastropoda, Pulmonata). Boletim do Museu Nacional, Nova Série Zoologia, 317: 01-40

JURBERG, P.; BARBOSA, J. V. \& ROTEMBERG, L., 1988. The role of behaviour in the survival of Biomphalaria glabrata, in biossays with the plant molluscicide Phytolacca dodecandra. Memórias do Instituto Oswaldo Cruz, 83: 41-46.

JURBERG, P.; COELHO DA SILVA, C. L. P. A.; BARRETO, M. G. M. \& SOARES, M. S., 1988 d. Rheotaxis of Biomphalaria glabrata on vertical substrate and its role in the recolonization of habitats treated with molluscicides. Memórias do Instituto Oswaldo Cruz, 83: 165-174.

LEHNER, P. N., 1979. Handbook of Ethological Methods. New York: Garlard. STPM Press.

LUTTERMOSER, G. M., 1944. The possibility of eliminating the schistosome snail, Australorbis glabrata from canals by control of water flow. Journal of Parasitology, 30 (Supl.): 15.

MICHAELIS, A. R., 1955. Research Films. In: Biology, Anthropology, Psychology and Medicine. New York: Academic Press Incorporation Publishers.

MILLER, S., 1975. Planejamento Experimental e Estatística. Rio de Janeiro: P. Herriot/Zahar.

MULVEY, M. \& VRIJENHOEK, R. C., 1981. Genetic variation among laboratory strains of the planorbid snail Biomphalaria glabrata. Biochemical Genetic, 19: 1169-1182.

NEWELL, P. F., 1965. Time lapse ciné recording the soil surface activity of slugs. Animal

Behavior, 13: 583.

NIELSEN, E. T., 1975. Use of the electronic flash to record the activity of small animals. Nature, 179: 1308.

PARAENSE, W. L.; PEREIRA, O. \& PINTO, D. B., 1955. Um aspecto da ecologia do Australorbis glabratus que favorece a reinfestação dos criadouros. Revista do Serviço Especial de Saúde Pública, 7: 573-581.

PARAENSE, W. L., 1972. Fauna planorbídica do Brasil. In: Introdução à Geografia Médica do Brasil (C. S. Lacaz, R. G. Baruzzi \& W. Siqueira, eds.), PP.213-239, São Paulo: Blücher/Universidade de São Paulo.

1987. Control of Schistosomiasis mansoni: an outlook from current expectation. Memórias do Instituto Oswaldo Cruz, 82 (Suppl. IV): 1-12.

PERLOWAGORA-SZUMLEWICZ, A. \& DIAS, G. O., 1955. Experiências de laboratório sobre a possibilidade de os planorbídeos viverem dentro da lama ou nela se enterrarem na ocasiāo do tratamento com planorbiscidas. Revista Brasileira de Malariologia e Doenças Tropicais, 7: 375-383.

PERLOWAGORA-SZUMLEWICZ, A., 1958. Studies on the biology of Australorbis glabratus Schistosome-bearing Brazilian snail. Revista Brasileira de Malariologia e Doenças Tropicais, 10 : 459-529.

PIERI, O. S., 1979. Comportamento de Biomphalaria glabrata (Say, 1818), caramujo vetor da xistosomose, em relação aos moluscicidas. Tese de Mestrado, Rio de Janeiro: Departamento de Psicologia, Pontifícia Universidade Católica do Rio de Janeiro.

PIERI, O. S.; JURBERG, P. \& RAYMUNDO, J. S., 1980a. Estudos sobre o comportamento dos Planorbídeos: I- Uma técnica de observação e registro comportamental por cinematografia. Memórias do Instituto Oswaldo Cruz, 75: 57-63.

PIERI, O.; RAYMUNDO, H. S. \& JURBERG, P,; 1980b. Estudos sobre o comportamento dos Planorbídeos: II- Enterramento de Biomphalaria glabrata (Say, 1818) como meio de proteção contra a dessecaçāo. Memórias do Instituto Oswaldo Cruz, 75: 83-88. 


\section{TÉCNICAS MALACOLÓGICAS}

PIERI, O. S. \& JURBERG, P., 1981a. Comportamento de Biomphalaria glabrata (Say, 1818) como critério de toxidade em ensaios biológicos com moluscicidas. Memórias do Instituto Oswaldo Cruz, 76: $147-160$.

1981b. Aspectos etológicos na sobrevivência dos caramujos vetores da xistosomose ao tratamento com moluscicidas. Memórias do Instituto Oswaldo Cruz, 76: 47-55.

PIERI, O. S., 1985. Studies on the Host Snail of Schistosomiasis from North-East Brazil, with Special Reference to Diapause in Biomphalaria glabrata (Say). D. PHIL. thesis, Susex: University of Susex.

PIERI, O. S. \& THOMAS, J. D., 1986. Polymorphism in a laboratory population of Biomphalaria glabrata from a seasonally drying habitat in north-east Brasil. Malacologia, 27: 313-321.

PIMENTEL, D. \& WHITE, P. C., 1959. Biological environment and habits of Australorby glabratus, 40: $541-550$.

PIMENTEL-SOUZA, F.; FERNANDES-SOUZA, N.; SCHALL, V. T. \& COELHO, P. M. Z., 1976a. Comportamento elementar do caramujo Biomphalaria glabrata. I- Disposição espacial da concha. Revista Brasileira de Pesquisas Médicas e Biológicas, 9: 117-122.

PIMENTEL-SOUZA, F.; SCHALL, V. T.; FERMANDES-SOUZA, N. \& COELHO, P. M. Z.,1976b. Comportamento elementar do caramujo Biomphalaria glabrata. II- Localização e tamanho da massa cefalopodal exposta. Revista Brasileira de Pesquisas Médicas e Biológicas, 9: 123-127.

PIMENTEL-SOUZA, F.; SCHALL, V. T.; LAUTNER Jr. R; BARBOSA, V. D. C.; SHETTINO, M. \& FERNANDES, N., 1984. Behavior of Biomphalaria glabrata (Gastropoda: Pulmonata), under different ligyting conditions. Canadian Journal of Zoology, 62: 2328-2334.

REY, L., 1956. Contribuição para o conhecimento da morfologia, biologia e ecologia dos planorbídeos brasileiros transmissores da esquistossomose. Rio de Janeiro: Serviço Nacional de Educação Sanitária.

ROTENBERG, L. P. \& PIERI, O. S., 1989. Relationship between lighting conditions and behavior of the freshwater snail Biomphalaria glabrata. Hydrobiologia, 174: 111-116.

SCHALL, V. T.; JURBERG, P. \& VASCONCELLOS, M. C., 1985. Orientation to light of juvenile and adult forms of melanic and albino populations of Biomphalaria glabrata (Say, 1818). Memórias do Instituto Oswaldo Cruz, 80: 101-111.

, 1986a. Behavioral responses to light by the snail Biomphalaria tenagophila (ORBIGNY, 1835). Revista Brasileira de Biologia, 46: 127-138.

SCHALL, V. T.; JURBERG, P. \& ROZEMBERG, B., 1986b. Orientation of the snail Biomphalaria straminea (Dunker, 1848) in response to light in a situation of selection. Memórias do Instituto Oswaldo Cruz, 81: 255-262.

SHIFF, C. J., 1966a. The influence of temperature on the vertical movement of Bulinus (hysopsis) globosus in the laboratory and in the field. South African Journal Science, 622: 210-214.

1966b. The influence of temperature on the vertical movement of Bulinus (hysopsis) globuosus (Moulet) and Biomphalaria pfeifferi (Kraus) (Mollusca: Gastropoda), Proceeding First International Congress of Parasitology, 2: 1057-1058.

SIMPSON, A. W.; THOMAS, J. D. \& TOWNSEND, C. R., 1973. Social Behavior in the freshwater pulmonate snail Biomphalaria glabrata (Say). Behavioral Biology, 9: 731-740.

SLATER, P. J. B., 1973. Describing sequences of behaviour. In: Perspective in Ethology. (P.P.G. Bateson \& P.H. Klopfer, orgs.), pp. 131-153, New York: Plenum Press.

, 1978. Data collection. In: Quantitative, Ethology (P.W. Colgan, ed.), PP. 7-24, New York:

John Wiley \& Sons. 


\section{TÓPICOS EM MALACOLOGIA MÉDICA}

SODEMAN, W. A. Jr., 1973. The influence of light on Biomphalaria glabrata. Nautilus, 87: 103-106. SODEMAN, W. A. Jr. \& DOWDA, M. C., 1974. Behavioral responses of Biomphalaria glabrata. Physiology Zoological, 47: 198-206.

THOMAS, J. D., 1986. The chemical ecology of Biomphalaria glabrata (Say) sugars as attractants and arrestants. Comparative Biochemical Physiology, 83-A: 457-460.

THOMAS, J. D. \& ASSEFA, B., 1979. Behavioural responses to amino acids by juvenile Biomphalaria glabrata, a snail host of Schistosma mansoni. Comparative Biochemistry Physiology, 63: 99-108.

THOMAS, J. D.; COWLEY, C.; OFUSU-BARKO, J., 1980. Behavioural responses to amino and carboxilic acids by Biomphalaria glabrata, one of the snail hosts of Schistosoma mansoni. In: Controlled Release of Bioactive Materials. (R. Baker, ed.), pp. 433-448, New York: Academic Press.

THOMAS, J. D.; NWANKO, D. I. \& STERRY, P. R., 1985. The feeding strategies of juvenile and adult Biomphalaria glabrata (Say) under simulated natural conditions and their relevance to ecological theory and snail control. Proceeding Royal Society London, 226: 117-209.

TINBERGEN, N., 1965. Behaviour and natural selection. In: Ideas in Modern Biology (J. A. Moore, ed.), pp. 521-542, New York: Naty. Hist. Press.

, 1969. El estudio del instinto. Siglo XXI Editores México.

TOWNSEND, C. R., 1973. The food-finding orientation mechanism of Biomphalaria glabrata (Say). Animal Behavior, 21 : 544-548.

1974. The chemoreceptor sites involved in food-fiding by the freshwater pulmonate snail, Biomphalaria glabrata (Say), with particular reference to the function of the tentacles. Behavioral Biology, 11: 511-523.

, 1975. Strategic aspects of time allocation in the ecology of a freshwater pulmonate snail. Oecologia Berlim, 19: 1105-115.

VANCEHALL, R., 1973. Manipulação de comportamento. São Paulo: EPU-Editora Pedagógica Universitária/Edusp.

WILLIAMS, C. L. \& GILBERTSON, D. E., 1983a. Altered feeding response as a cause for the altered hearbeat rate and locolotory activity of Schistosoma mansoni-infected Biomphalaria glabrata. Journal of Parasitology, 69: 671-676.

, 1983b. Effects of alterations in the heartbeat rate and locomotory activity of Schistosoma mansoni-infected Biomphalaria glabrata on cercarial emergence. Journal of Parasitology, 69: 67 681 .

WILLOWS, A. O. D., 1973. Learning in Gastropod mollusc. In: Invertebrate Learning (W. C. Corning, J. A. Dyal \& A. O. D. Willowseds, eds.) pp. 187-274, Vol.2, New York: Plenum.

Pedro Jurberg ${ }^{1} 2$

Rodolfo Armando da Cunha', Marcelo Luis Rodrigues'

' Instituto Oswaldo Cruz, Departamento de Biologia, Laboratório de Comportamento Animal. Caixa Postal 926, Cep. 21045-900, Rio de Janeiro, RJ, Brasil.

${ }^{2}$ Instituto de Psicologia, Uerj. 


\subsection{Cultivo em Massa de Biomphalaria straminea}

Um sistema para produção em massa do caramujo Biomphalaria straminea, hospedeiro intermediário de Schistosoma mansoni, foi implantado em 1980, na Estação de Biologia Experimental, do Centro de Pesquisas Aggeu Magalhães - Fiocruz.

A experiência do grupo de pesquisas da Estação em trabalhos malacológicos permitiu estabelecer a padronização de condições ideais para o cultivo de bionfalárias, com risco insignificante de oscilações negativas, um mínimo de mão-de-obra, espaço físico limitado e custo operacional muito baixo.

O sucesso de uma técnica de cultivo está vinculado à prática do manejo de fatores que afetam a reprodução e o crescimento dos moluscos: qualidade da água, tipo de alimentação, iluminação, temperatura, controle de predadores e do efeito crowding, entre outros.

Algumas técnicas de cultivo em massa de moluscos já foram descritas (Freitas, 1973; Freitas et al., 1974; Milward de Andrade \& Carvalho, 1972; Rowan, 1958; Sandt et al., 1965; Standen, 1951; Ward et al., 1947), geralmente associadas ao tipo de alimentação fornecida e quase todas com referência ao cultivo de $B$. glabrata. Esta é a primeira descrição de cultura em massa de $B$. straminea.

O conhecimento e o domínio na manipulação destes fatores propiciaram a manutenção, em laboratório, de condições ambientais favoráveis ao cultivo de uma cepa de $B$. straminea, albina e resistente a infecção pelo $S$. mansoni, nomeada $B$. straminea $\mathrm{R} 3^{1}$, sendo possível, assim, assegurar uma produção bimensal de alguns milhares de caramujos que foram utilizados em experimentos de campo de controle biológico, em Alhandra, Paraíba.

Em 1980 foram isoladas três salas, nas dependências da Estação de Biologia Experimental, para o cultivo em massa da cepa R3 de B. straminea. As salas dispõem de amplas janelas e, conseqüentemente, de bastante aeração e iluminação naturais. Foram instaladas lâmpadas fluorescentes para os dias mais escuros, e montados vários balcões e estantes que servem de suporte para os aquários. Estes são do tipo pirex, transparentes, com capacidade para 2 litros d'água cada, medindo $25 \mathrm{~cm}$ de diâmetro por $11 \mathrm{~cm}$ de profundidade. As instalações comportaram 470

1 Esta cepa nos foi remetida pelo Dr. C. S. Richards (Biomedical Research Institute, Rockville, Md, USA). Originária de Sete Lagoas, MG, e cultivada no laboratório do Dr. W. L. Paraense, Fiocruz, RJ, foi tomada resistente por seleção genética no laboratório do Dr. Richards, a partir de 1971. 


\section{TÓPICOS EM MALACOLOGIA MÉDICA}

aquários até dezembro de 1985 , quando as coletas de caramujos eram bimensais e diminuindo para 348, em 1986, quando as mesmas passaram a ser semestrais.

Os aquários foram preparados com uma camada de areia de rio lavada e esterilizada, água natural (não-clorada) de poço escavado na própria Estação, sendo a oxigenação da mesma feita com plantas aquáticas do gênero Elodea, coletadas em um açude próximo à Estação. Não havendo necessidade de aeração artificial. As plantas, antes de serem introduzidas nos aquários, passavam por rigorosa inspeção, em três sucessivos estágios de exames em lupa manual, ate estarem totalmente livres de moluscos, hirudíneos, larvas de culicídeos, microcrustáceos, e outros. As salas são mantidas fechadas e as janelas protegidas por telas de malhas finas.

Em cada aquário foram colocados, inicialmente, 15 caramujos com diâmetro médio de $4 \mathrm{~mm}$, já em idade reprodutiva.

Os moluscos eram alimentados diariamente com alface fresca e uma vez por semana recebiam suplementação protéica na forma de ração para alimentação de aves, fornecida pelo Dr. Luís Malta, veterinário e proprietário do Grupo Avimalta - Pernambuco. ${ }^{2}$

A temperatura média anual da água dos aquários foi de $26,09+0.803$. As salas foram mantidas em temperatura ambiental.

A cada dois meses era feita uma coleta geral nos aquários, retirando-se todos os caramujos com mais de $4 \mathrm{~mm}$, que eram, em seguida, contados e embalados para serem transportados ao campo. A água era renovada, sendo os aquários reabastecidos de plantas. Os moluscos que restavam, com menos de $4 \mathrm{~mm}$, eram suficientes para restabelecer uma nova população de indivíduos adultos, utilizados no programa de controle biológico, a cada dois meses.

O cultivo em massa da cepa de $B$. straminea R3 foi mantido na Estação de Biologia Experimental, durante todo o Projeto do Controle Biológico de $B$. glabrata x B.straminea (oito anos), com absoluto sucesso reprodutivo da cepa.

O manuseio dos criadouros é muito simples e executado por um só técnico, devidamente treinado.

A distribuição dos caramujos em aquários pequenos facilita a inspeção diária e a limpeza, assim como permite a visualização e o controle imediato de qualquer forma de contaminação, sem prejuízo de toda a cultura.

Este esquema forneceu, inicialmente, para um total de 470 aquários, a cada dois meses, uma média de 5.777 caramujos. Posteriormente, com 348 aquários, a cada seis meses era coletada uma média de 4.800 moluscos com diâmetro igual ou superior a $4 \mathrm{~mm}$.

O declínio da produtividade, observado quando a coleta passou a ser semestral é justificado pelo efeito crowding. A quantidade de caramujos por aquário está condicionada à necessidade vital da espécie em relação ao espaço físico disponível. 
Quando a população atinge o número crítico de indivíduos, a freqüência reprodutiva passa a ser controlada e a densidade populacional se mantém em equilíbrio.

\section{Agradecimentos}

A manoel Alexandre Neto, pelo apoio técnico, paciência e dedicação.

\section{REFERÊNCIAS BIBLIOGRÁFICAS}

FREITAS, J. R., 1973. Ritmo de crescimento de Biomphalaria glabrata (Say, 1818). Padronização da técnica de criaçāo. Tese de Doutorado, Belo Horizonte: Instituto de Ciências Biológicas, Universidade de Minas Gerais.

FREITAS, J. R.; RESENDE, E. S.; JUNQUEIRA, D. V.; COSTA A. M. \& PELLEGRINO, J., 1974. Criação em massa e ritmo de crescimento de Biomphalaria glabrata. Ciência e Cultura, 27: 968-974.

MILWARD de ANDRADE, R. \& CARVALHO, O. S, 1972. Alimentação e fecundidade de planorbídeos criados em laboratório. I- Biomphalaria tenagophila. Revista Brasileira de Biologia, 32: 225-233.

ROWAN, W. B, 1958. Mass cultivation of Australorbis glabratus intermediate host of Schistosoma mansoni in Puerto Rico. Journal of Parasitology, 44: 247.

SANDT, D. G.; BRUCE, J. I. \& RADKE, M. G, 1965. A system for mass producing the snail Australorbis glabratus and cercariae of Schistosoma mansoni. Parasitology, 51: 1012-1013.

STANDEN, O., 1951. Some observations upon the maintenance of Australorbis glabratus in the laboratory. Annals Tropical Medicine and Parasitology, 45: 80-83.

WARD, P. A.; TRAVIS, D. \& RUE, R. E. 1947. Studies on Shistosomiasis: Methods of stablishing and maintaining in the laboratory. National Institute of Health Bulletin, 189: 70-80. 


\subsection{Alimentação}

\section{INTRODUÇÃO}

Os gastrópodes são os moluscos de maior sucesso na radiação adaptativa, sendo encontrados em vários tipos de ambientes devido, principalmente, a multiplicidade de seus hábitos alimentares. Ocorrem como herbívoros, pastadores, detritívoros, filtradores de plâncton e também como carnívoros, parasitas e predadores. A presença de rádula, na massa bucal (átrio), ornada com numerosas fileiras de minúsculos dentes quitinosos, confere aos pulmonados dulcícolas características de animais essencialmente raspadores.

Uma das dificuldades na criação e manutenção dos caramujos em laboratório resulta da falta de melhor conhecimento de seus hábitos alimentares. Em décadas anteriores, a demanda de grandes quantidades de moluscos para estudos do ciclo evolutivo do parasita, biologia reprodutiva, sistemática, genética, comportamento e principalmente para screening de drogas, deu origem a numerosos trabalhos, visando aprimorar as técnicas de criação em massa. Eram adotados alimentos de eficiência já conhecida e usados comumente na manutenção de animais em cativeiro. No caso dos planorbídeos, eram oferecidos principalmente alimentos usados pelos aquaristas em quantidade indicada para manutenção de boa qualidade da água.

Brumpt (1941) usou na sua técnica de criação, alface crua macerada. Alface seca ou fresca continuou sendo oferecida, principalmente para manutenção de caramujos paralelamente ao uso de outras hortaliças (Barbosa \& Silva, 1951; Chernin \& Michelson, 1957; Szumlewic, 1958; Souza et al., 1985; Thomas, 1987). Também foram usadas rações de fórmulas bastante eficientes como a de Standen (1951) que sofreu modificações significativas, dentre elas as de Moore et al. (1953) e Pellegrino \& Katz (1968).

O Gide (Grupo Interdepartamental de Estudos de Esquistossomose - Universidade Federal de Minas Gerais) mantinha uma bem-sucedida criação de moluscos em mais de 100 aquários de armação metálica e paredes de vidro $(30 \times 30 \times 60 \mathrm{~cm}) \mathrm{com}$ cerca de 150 Biomphalaria glabrata, adultos, por aquário, alimentados com ração própria, a fórmula de Standen (1951), modificada (Pellegrino \& Katz, 1968). A grande demanda de caramujos para screening de drogas, levou o Gide a montar uma sala especial para criação dos recém-eclodidos, "o berçário". A existência desta sala se impunha devido as altas taxas de mortalidade dos recém-nascidos, um problema crucial das criações em massa. Apesar de algum sucesso nas técnicas de criação, 
ainda pouco se sabe sobre o alimento natural e sua capacidade em promover o crescimento dos planorbídeos no campo. Sabe-se, contudo, que se alimentam de algas perifíticas, detritos, bactérias e qualquer material orgânico aderido em plástico, pedras, madeiras, troncos, folhas e frutos de macrófitas, vivas ou mortas. Raspam com a rádula e ingerem tudo que se encontra agarrado em órgãos de plantas, inclusive seus tecidos em decomposição (Freitas et al., 1975; Russel \& Hunter, 1978; Santos, 1985).

Neste capítulo tenta se fazer uma síntese sobre os alimentos usados em laboratório, para criação e manutenção de caramujos, principalmente planorbídeos americanos e sobre os estudos desenvolvidos relativos à sua preferência alimentar no hábitat natural com ênfase nas associações moluscos-macrófitas. Procura-se com este conhecimento tentar compreender as suas relações com os recursos alimentares, e os mecanismos responsáveis pela dispersão e fixação dos moluscos nos hábitats naturais. A meta principal é encontrar subsídios ao controle das populações de moluscos de interesse epidemiológico, baseados no seu comportamento em relação aos alimentos.

\section{Alimentação em laboratório. Técnicas de criação}

O uso da alface na alimentação iniciado na década de quarenta vem sendo adotado até hoje. Assim como a alface, outras hortaliças como couve, agrião ou cenoura, alimentos naturais de moluscos nas hortas, têm sido usadas em laboratório, juntamente com ração para peixes ou para animais domésticos, mesmo após o desenvolvimento de fórmulas mais específicas (Pimentel-Souza et al., 1990; Pointer et al., 1991; Barbosa et al., 1992; Rosemberg et al., 1992; Baptista et al., 1993; Theron \& Gerard, 1994).

A primeira fórmula, ainda hoje muito usada, foi a de Standen (1951). Era composta de Bemax, alginato de sódio, alface seca e leite em pó, nas proporções de 1,0:1,0:1,0 e 0,5, respectivamente. Foi modificada por Moore et al. (1953) que substituíram a alface seca por "Cerofil", um alimento para peixes, e acrescentaram Glandex (10\%). Outra alteração resultou na fórmula do Gide (Pellegrino \& Katz, 1968). Consistiu na substituição da alface por alfafa seca, introdução de ração para cobaia, Testitur, germe de trigo e leite em pó integral, nas seguintes proporções:

\footnotetext{
Alfafa seca $330 \mathrm{~g}$

Testitur 300g

Germe de trigo $100 \mathrm{~g}$

Leite em pó $70 \mathrm{~g}$
} 
À fórmula do Gide eram acrescentados $200 \mathrm{~g}$ de carbonato de cálcio, $60 \mathrm{~g} / \mathrm{kg}$ de glicerina ou $40 \mathrm{~g} / \mathrm{kg}$ de polvilho, para melhor consistência dos comprimidos. A fórmula de Standen modificada é a que tem sido mais adotada desde seu desenvolvimento em 1951. Muitas vezes ela é complementada com alface ou agrião (Chernin \& Michelson, 1957; Rey, 1959; Ritchie et al., 1963; Gerken, 1977).

Outras fórmulas têm sido usadas, tendo como componentes básicos principais alguns tipos de rações comerciais para cães, peixes ou ratos (Andrade \& Carvalho, 1972; Souza et al., 1979) ou alimento semi-sintético (caseína e polissacarídeos) em culturas axênicas (Senna \& Vieira, 1970). Xavier et al. (1968) adotam alimento natural, de solo úmido, alǵas cianofíceas, a Oscillatoria formosa na criação de Bulinus contortus. Malek (1985) recomenda a alface mas que deve ser suplementada com germe de trigo ou ração para peixe, algas e folhas de algumas árvores, principalmente frutíferas.

Nota-se que muitos tipos de alimentos são adequados para a produção e manutenção de planorbídeos em laboratório. Mas há evidências de que estes moluscos deveriam ter um ritmo de crescimento bastante superior no campo em relação aos obtidos em laboratório (Barbosa \& Olivier, 1958; Etges \& Ritchie, 1966). Experimentos de campo, com caramujos em gaiolas submersas, desenvolvidos por Freitas (1973) em duas represas, tendo como alimento organismos perifíticos e detritos, suplementados ou não com alface, mostraram que $B$. glabrata cresceu mais de $10 \mathrm{~mm}$ em 33 dias no campo e ainda produziu descendentes que atingiram 3 a $5 \mathrm{~mm}$ neste período. A marca de $10 \mathrm{~mm}$ com um mês de idade, pareceu um bom parâmetro para avaliar as técnicas de criação. Aliás, alguns pesquisadores (Gerken, 1977; Chiquiloff et al., 1978), usando a técnica desenvolvida por Freitas (1975), conseguiram um crescimento de $B$. glabrata superior a $12,00 \mathrm{~mm}$ de diâmetro, aos 30 dias de idade (Tabela 1).

Gerken (1977) compara a eficiência da ração do Gide, pura ou com alface, no crescimento e fecundidade de $B$. glabrata. O crescimento e o número de ovos/desovas foram diretamente relacionados, em testes estatísticos significativos, com a quantidade de alimento oferecida. A autora lista numerosos trabalhos, onde pode-se ver que mesmo oferecendo como alimento alguma fórmula e alface, os caramujos atingiam a maturidade, geralmente, em dois a quatro meses e alcançavam 9 ou $10 \mathrm{~mm}$ em dois a seis meses e, às vezes, em um ano.

$\mathrm{O}$ sucesso da criação depende não só da alimentação, como também de outros fatores. O alimento deve ser suficiente e em quantiđade apropriada e disponível aos caramujos recém-nascidos. Para tanto os aquários devem apresentar teores de Oxigêniô Dissolvido (OD) iguais ou próximos de $50 \%$ de saturação. O início da criação deve ser com caramujos da mesma idade, um ou dois dias. Outra variável de alta relevância é a introdução de ração pulverizada nos aquários, sete ou oito dias 


\section{ALIMENTAÇÃO}

antes do início do experimento. Forma-se uma camada de fungos e detritos orgânicos, que parecem os preferidos pelos recém-eclodidos. Nestas condições, tanto em aquários de 30 litros de água e 150 caramujos, como em cubas de plástico com capacidade para 4 litros e 20 caramujos, tem-se conseguido resultados satisfatórios com uso de qualquer tipo de ração (para ratos, aves, cobaia, suínos etc.) ou mesmo com a própria alface seca pulverizada.

TABELA 1: Crescimento de Biomphalaria glabrata, no período de 30 a 150 dias, de acordo com as técnicas de criaçāo (autor), alimento e volume de água (Modificado de Gerken, 1977)

\begin{tabular}{|c|c|c|c|c|c|c|}
\hline \multirow[t]{2}{*}{ Autor (es) } & \multirow{2}{*}{$\begin{array}{l}\text { Diâmetro no início do } \\
\text { experimento (mm) }\end{array}$} & \multirow{2}{*}{$\begin{array}{l}\text { Duraçāo do } \\
\text { experimento } \\
\text { (dias) }\end{array}$} & \multicolumn{2}{|c|}{ Final do experimento } & \multirow{2}{*}{$\begin{array}{l}\text { Volume de agua } \\
\text { por } \\
\text { caramujo }(\mathrm{ml})\end{array}$} & \multirow[t]{2}{*}{ Alimento } \\
\hline & & & $\begin{array}{l}\text { Diâmetro (mm) } x \\
(\operatorname{mim}-\max )\end{array}$ & $\begin{array}{l}\text { Idade* } \\
\text { (dias) }\end{array}$ & & \\
\hline $\begin{array}{l}\text { Szunlewicz, } \\
1958\end{array}$ & $8,1-9,4$ & 90 & $13,4(11,9-15,0)$ & $150^{*}$ & $300-500$ & Alface \\
\hline $\begin{array}{l}\text { Pereira \& } \\
\text { Deslandes, } \\
1957\end{array}$ & - & 60 & $7,2(6,6-9,8)$ & 120 & $25-100$ & Alface \\
\hline Barreto, 1960 & - & 115 & $7,8(7,1-8,5)$ & 115 & 50 & $\begin{array}{l}\text { Standen, } \\
195+\mathrm{Al}- \\
\text { face }\end{array}$ \\
\hline $\begin{array}{l}\text { Pointier et al. } \\
1991\end{array}$ & 1,0 & 90 & $10,0--$ & 90 & 250 & Alface \\
\hline \multirow{2}{*}{$\begin{array}{l}\text { Chernin \& } \\
\text { Michelson, } \\
1957\end{array}$} & 3,4 & 45 & $9,4(8,3-13,0)$ & $75^{*}$ & $25-100$ & Agriāo \\
\hline & 5,9 & 40 & $13,1(11,3-15,5)$ & $70^{*}$ & $50-400$ & Agrião \\
\hline $\begin{array}{l}\text { Ritchie et al. } \\
1963\end{array}$ & Recém eclodidos & 40 & $14,6 \ldots$ & 40 & 200 & $\begin{array}{l}\text { Moore et } \\
\text { al.,19+ } \\
\text { Alface }\end{array}$ \\
\hline Freitas, 1973 & 1,0 & 30 & $13,6(8,0-16,7)$ & 30 & $60-150$ & $\begin{array}{l}\text { Gide mo- } \\
\text { dificaçōes } \\
+ \text { Alface }\end{array}$ \\
\hline Gerken, 1977 & 1,0 & 30 & $13,9(7,0-21,0)$ & 30 & $75-300$ & $\begin{array}{l}\text { Gide mo- } \\
\text { dificaçōes } \\
+ \text { Alface }\end{array}$ \\
\hline $\begin{array}{l}\text { Chiquiloff, } \\
1978\end{array}$ & 1,0 & 30 & $13,1(5,0-18,0)$ & 30 & 200 & $\begin{array}{l}\text { Gide mo- } \\
\text { dificaçōes } \\
+ \text { Alface }\end{array}$ \\
\hline
\end{tabular}

* Idade real ou estimada

Os melhores resultados, contudo, têm sido obtidos com uso de ração e alface, outras plantas e perifiton com complementação (Santos, 1985; Bronmark, 
1989; Barbosa et al., 1992; Souza et al., 1985). O efeito crowding, resultante da elevada densidade de moluscos, nos recipientes de criação, responsabilizado pela queda de crescimento e de fecundação nas colônias, pode ter sido confundido com falta de OD e de alimento em quantidade adequada, pois quanto maior a densidade menor a disponibilidade de perifiton por caramujo. Freitas (1973) mostrou que mesmo com 500 ou $1000 \mathrm{~B}$. glabrata por aquário de 30 litros, parece não ter ocorrido o fenômeno crowding.

\section{Preferência de alimento no hábitat natural - Associação moluscos/macrófitas}

A observação de moluscos se deslocando contínua e lentamente sobre ramos e folhas de macrófitas ou sobre as paredes de vidro de aquários, em atitude de "pastagem" tem levado a generalização de que eles se utilizavam de organismos aquáticos e de perifiton como alimento. Por outro lado, as informações sobre as estreitas relações entre a distribuição dos moluscos e os tipos de substrato em que vivem e sobre as numerosas plantas aquáticas indicadoras de condições de hábitat favoráveis (Sturrock, 1974) reforçam as hipóteses sobre a importância das plantas aquáticas como alimento e tem conduzido a diversos experimentos de laboratório na tentativa de detectar tais relações (Harman, 1972; Sterry et al., 1983; Kolodziejczyk, 1984; Santos, 1985; Pieri \& Thomas; 1987; Thomas, 1987; Freitas et al., 1990).

Estas associações trazem numerosos benefícios para os caramujos, além de abrigo e alimento, sendo que um dos mais importantes é a manutenção das condições de hábitat, muitas vezes dependente das plantas, mas raramente se alimentam dos tecidos vivos destas plantas (Pimentel \& White, 1959; Teesdale, 1962; Pip \& Stwart, 1976; Klump et al., 1980; Pointer \& McCullough, 1989; Thomas, 1990). No entanto, $B$. glabrata tem apresentado respostas positivas a extratos de macrófitas vivas (Michelson, 1960; Etges \& Frick, 1966; Thomas, 1987) e B. tenagophila está presente naquelas valas onde se concentra mais vegetação. Quando trechos destas valas são capinados os moluscos desaparecem. Com a volta da vegetação recomeça a colonização do planorbídeo (Santos, 1985).

Outro bom exemplo do papel da vegetação aquática na manutenção de população de moluscos no Brasil pôde ser observado na lagoa central de Lagoa Santa, Minas Gerais, região metropolitana de Belo Horizonte. O junco ocupava toda a orla da lagoa e parecia não apresentar condições de hábitat a $B$. straminea que colonizava, principalmente, as comunidades de Chara spp. e Nitella spp., nas profundidades de $2,0 \mathrm{a} 5,0 \mathrm{~m}$. O junco nas margens servia de barreira às carófitas e ao caramujo na sua tentativa de invadir as praias (Freitas, 1976). Com o desaparecimento total, em 1979, da larga faixa e contínua de junco, contornando toda a orla 
da lagoa (mais de $4 \mathrm{~km}$ ), extinguiu-se a população da bionfalária. Até hoje, nem as macrófitas aquáticas nem $B$. straminea retornaram.

A Pomacea haustrum, também dizimada quase totalmente naquela época, após a destruição do junco, continua presente na lagoa, mas não encontra mais as hastes cilíndricas dos Eleocharis spp. para depositar suas desovas acima da lâmina d'água e nem os abundantes detritos das macrófitas e seu perifiton, ambos fonte de alimento. Para reduzir ainda mais a disponibilidade de alimento para a fauna autóctone, a lagoa foi invadida em 1986/87 pelo Melanoides tuberculata, que em poucos anos ocupou toda sua orla em grandes densidades. O desaparecimento de $B$. straminea da lagoa poderia ser até interpretado, como resultado de exclusão competitiva se sua extinção tivesse coincidido com a invasão de $M$. tuberculata. Mas a invasão do tiarídeo só ocorreu sete anos após a extinção das plantas e de $B$. straminea e a redução de $P$. haustrum. As represas da Pampulha e da Serra Verde e a lagoa do Sumidouro todas na região metropolitana de Belo Horizonte foram também invadidas pelo $M$. tuberculata no final da década de oitenta, mas as espécies de bionfalárias autóctones ou invasoras, continuam presentes. Não parece ter havido, também nestes casos, qualquer indicação de exclusão competitiva de $B$. glabrata por M. tuberculata, apesar da sobrecarga de demanda de alimento pelo tiarídeo.

No entanto, Barbosa et al. (1985) e Paraense (1970) relatam ocorrência de exclusão competitiva entre bionfalárias no Nordeste, e em Belo Horizonte. Os longos experimentos de campo de Guimarães (1981) no Alto São Francisco demonstraram a eficiência de $P$. haustrum na redução da população de $B$. glabrata. No Caribe, diversas observações e experimentos de campo de longa duração, levaram os pesquisadores a atribuírem à exclusão competitiva a substituição de bionfalárias por tiarídeos (Pointer \& McCullough, 1989).

Estes e outros exemplos mostram que há necessidade de melhor conhecimento das relações plantas/caramujos e da competição por recursos alimentares em diversas situações de hábitat. De três comunidades bem-definidas de macrófitas existentes na lagoa Olhos d'Água em Lagoa Santa, a presença de $B$. straminea, com elevadas densidades, foi registrada em duas delas (na de Chara spp. e de Elodea spp.). No entanto esteve ausente, durante três anos consecutivos, da extensa e compacta comunidade de junco (Eleocharis squamigera) que faz limites com essas duas (Freitas et al., 1990). O fato do junco não ter apresentado condições adequadas à colonização de $B$. straminea, pode nos levar a supor que os organismos que compõem esta comunidade, tanto os predadores como os competidores de bionfalária, associados ao junco, seriam espécies mais eficientes do que as existentes ou as associadas aos stands de Chara spp. e de Elodea spp. Outra hipótese seria a existência de substâncias químicas liberadas pelo junco, que se apresentou, pelos testes estatísticos, negativamente associado a $B$. straminea. Neste caso o junco 
exerceria ação de repelência contra o planorbídeo, o que não pareceu ocorrer pelo menos temporariamente, em relação a $B$. glabrata no hipódromo Serra Verde (Nogueira et al., 1980).

\section{Atração dos moluscos por macrófitas e perifiton}

As associações positivas entre moluscos e macrófitas podem ser motivadas pelo encontro de abrigo e alimento e podem ser concretizadas através de sua habilidade em encontrá-los, graças a percepção química que desempenha importante papel na seleção e localização de itens alimentares (Kohn, 1961). Há evidências de que a percepção de substâncias químicas seja a principal forma de reconhecimento do ambiente, favorecendo uma não-aleatoriedade na associação macrófitas/moluscos (Croll, 1983). No entanto, Bovbjerg (1968) sugere que moluscos herbívoros de água doce, por viverem em vegetação densa, não sofrem pressão de seleção pàra identificar o alimento à distância. Tal condição favoreceria o encontro ao acaso e o seu reconhecimento se daria pelo contato. Esta interpretação é diferente da de Croll e parece não se aplicar também às associações macrófitas/ $B$. straminea de Lagoa Santa (Freitas et al., 1990). As diferenças na capacidade de atração dos moluscos podem estar ligadas aos diversos tipos de substâncias que são liberadas nas águas pelas macrófitas e perifiton (Thomas et al., 1983).

Estudos quantitativos sobre atração de moluscos brasileiros por macrófitas e seus perifitons foram realizados por Santos (1985) com espécies provenientes do hábitat natural. As macrófitas que apresentaram as maiores taxas de atração em laboratório foram as mesmas que no campo estavam positivamente associadas a $B$. tenagophila. A ordem de preferência na atração pelas plantas foi a seguinte Nasturtium pumilum $>$ Polygonum acre $>$ Commelina spp. $=$ E. crusgali $>$ controle. Tanto os perifitons raspados destas plantas aquáticas, como os colonizados em lâminas de vidro apresentaram o mesmo forte grau de atração aos caramujos, mas não houve, de maneira geral, nenhuma ordem de preferência por perifiton de determinada macrófita (Santos \& Freitas, 1988).

Em todos os testes os moluscos permaneceram mais de $60 \%$ do tempo junto aos substratos de gelatina (=iscas), contendo extratos de macrófitas ou o perifiton, proveniente delas. Mais de $75 \%$ dos caramujos avançaram $40 \mathrm{~cm}$ em direção às iscas de perifiton nas extremidades de um tubo de $114 \mathrm{~cm}$, a partir do centro dos tubos, nas duas primeiras horas de teste. No entanto, no controle, quase $70 \%$ dos moluscos permaneceram no meio do tubo, durante as $\mathbf{5}$ horas de observações. Estes animais adotaram a atitude de inércia na ausência da isca de perifiton que libera substâncias químicas atrativas (Santos, 1985). 
Trabalhos de Calow (1974) e Hunter (1983) evidenciaram que as substâncias excretadas pelos moluscos, após decomposição, serviriam de nutrientes ( $\mathrm{N}$ e $\mathrm{P}$ ) para o perifiton, aumentando sua produção em até $88 \%$. Daí advém a hipótese de simbiose para explicar a associação moluscos/perifiton, apesar da predação que este sofre. Segundo Porter (1977), a pastagem não seletiva no perifiton favorece a coexistência de algas competidoras com outras menos competitivas, mantendo todas em baixa densidade, evitando assim a exclusão competitiva entre elas.

\section{Consumo de macrófitas}

A suspeita de que numerosas espécies de plantas associadas aos pulmonados de água doce pudessem servir de alimento levou alguns pesquisadores a testar macrófitas aquáticas na sua alimentação. Experimentos de Kolodziekczyk (1984) mostraram que os gastrópodes testados consumiam, principalmente, plantas mortas em decomposição (50\%) e perifiton (30\%). Plantas vivas foram rejeitadas. Apenas uma espécie de molusco, das sete testadas, Lymnae stagnalis, se alimentou de uma das plantas oferecidas - Elodea canadensis. L. stagnalis ingeriu 5,2 a $14,6 \mathrm{mg}$ de alimento/dia, tendo assimilado, em média, 52\%, enquanto o Planorbis corneus consumiu 1,5 a $3,2 \mathrm{mg}$ e assimilou, em média, $34 \%$ do alimento ingerido. $\mathrm{O}$ coeficiente de assimilação dependeu do tipo de alimento e da espécie de molusco.

Exames de tubo digestivo de $B$. pfeifferi do lago Itta, Ibadan, Nigéria, mostraram que eram muito escassos tecidos vivos de macrófitas no seu trato digestivo. De nove espécies testadas, apenas duas: Lemna paucicostada e Salvinia nymphellula foram consumidas. Mesmo assim, da última espécie, só $33 \%$; as outras espécies (sete) foram rejeitadas por $B$. pfeifferi e Helisoma duryi. O H. duryi ingeriu maior quantidade das duas plantas e a Nymphaea lotus, quando fervida, foi também normalmente consumida. Houve, contudo, maior abundância relativa de detritos orgânicos no estômago de $B$. glabrata (cerca de $2 / 3$ do conteúdo) do que de algas ou de tecidos de L. paucicostada (Thomas \& Tait, 1984).

O interessante é que, apesar da forte correlação positiva de $B$. pfeifferi com Ceratophillum demersum, esta e outras macrófitas se apresentaram negativamente associadas a várias espécies de caramujo e os extratos de Nasturtium sp., Elodea sp. e $C$. demersum foram repelentes a $B$. glabrata. Santos (1985) observou o contrário em relação ao Nasturtium pumilum, cujos extratos foram os mais atraentes para a $\boldsymbol{B}$. tenagophila. 


\section{Consumo de perifiton no hábitat natural}

Até recentemente estudos quantitativos sobre consumo de perifiton por bionfalárias americanas eram quase inexistentes, principalmente em seu hábitat natural. Santos (1985) foi o primeiro a medir a quantidade de perifiton consumida por $B$. tenagophila no campo. No entanto desde o início de setenta tem sido realizados diversos experimentos que têm fornecido informações quantitativas sobre o impacto da pastagem do perifiton por diversos moluscos que não as bionfalárias (Kehde \& Wilhm, 1972; Calow, 1973; McMahon et al., 1974; Townsend, 1975; Cuker, 1983 e Cattaneo, 1983).

Nos experimentos realizados no campo por Santos (1985), o consumo de alimento variou de acordo com a produção de perifiton colonizado nas gaiolas de plástico e expostas em tanques escavados na área rural de Brasília. Nos meses de verão (fevereiro/março) a produção e o consumo de perifiton foram quase a metade da dos meses de maio e junho. No período quente, o consumo foi de 4,5 a 8,1 $\mathrm{mg} /$ caramujo/dia e no período frio, de 10,4 a $13,1 \mathrm{mg} /$ caramujo/dia. As médias foram de 9,7 e $8,5 \mathrm{mg} /$ caramujo/dia nas gaiolas transparentes e pretas. Foram contudo semelhantes, conforme análise de variância - teste de " $t$ ". As médias mensais estão na Tabela 2 .

TABELA 2: Consumo médio de perifiton por Biomphalaria tenagophila em $30 \mathrm{dias}$ ( $\mathrm{mg} /$ peso seco) nos meses de fevereiro a julho e média de perifiton por gaiola transparente (Santos, 1985)

\begin{tabular}{llll}
\hline Montagens no datas & $\begin{array}{l}\text { Perfiton por caramu- } \\
\text { jo/dia }(\mathrm{ng} \pm \mathrm{DP})\end{array}$ & \multicolumn{2}{c}{$\begin{array}{c}\text { Média (mg/ps) de perifiton produzido por } \\
\text { gaiola }\end{array}$} \\
\cline { 3 - 4 } & & sem caramujo & com caramujo \\
\hline 1 fev-março & $6,3 \pm 1,6$ & $191 \pm 36$ & $29 \pm 18$ \\
2 março-abril & $5,7 \pm 2,3$ & $97 \pm 3$ & $30 \pm 8$ \\
3 maio & $12,6 \pm 1,7$ & $259 \pm 35$ & $137 \pm 37$ \\
4 junho-julho & $11,3 \pm 1,6$ & $245 \pm 76$ & $115 \pm 43$ \\
\hline
\end{tabular}

Houve sempre sobras nas gaiolas, indicando que o consumo foi proporcional a produção do perifiton. Esta proporcionalidade foi refletida na alta correlação observada entre consumo/disponibilidade de alimento. Alguns autores relatam fatos semelhantes em relação a outros alimentos e observam que as taxas de crescimento dependem também da quantidade de alimento oferecida adequadamente (Freitas et al, 1975; Townsend, 1975; Thomas et al, 1983). Comportamento diferente foi relatado por Calow (1975), em relação a $H$. fluviatilis e $P$. contortus. 
O autor destaca contudo que quando há redução do alimento os caramujos apresentam adaptações fisiológicos para suprir a falta. Utilizam estratégias comportamentais para solucionar seus problemas alimentares, possuindo um considerável potencial adaptativo face a disponibilidade de alimento. Basta lembrar que em muitas criações são necessários três a seis meses para os caramujos atingirem a maturidade, mas que com alimentação e OD suficientes, iniciam a postura em três ou quatro semanas (Gerken, 1977).

Quanto à qualidade do perifiton parece que as mesmas espécies que colonizaram as gaiolas pretas se instalaram também nas transparentes. Em três montagens, mais de $70 \%$ dos organismos perifíticos vegetais eram constituídos por espécies de Stigeoclonium spp. e Oedogonium spp. e em uma delas, cerca de 59\% dos organismos eram representados por Oedogonium spp., Euglena spp. e Oscillatoria spp., gêneros estes com muitas espécies indicadoras de ambientes eutróficos. A proporção numérica dos organismos perifíticos vegetais nas gaiolas transparentes foi de 80 a $92 \%$ em relação a dos animais; mas nas gaiolas de plástico preto as Charchesium spp. foram os organismos de maior abundância e a sua participação e de outros organismos na comunidade perifítica animal foi também superior a $90 \%$ (Santos \& Freitas, 1986). Análise de variância entre o número total de perifitons das gaiolas controle, sem molusco, e daquelas com moluscos, mostrou uma correlação positiva acima de $89 \%$. Também o índice de similaridade de Raabe, entre as gaiolas pastadas e não-pastadas foi superior a $80 \%$.

\section{Manejo de macrófitas e controle de caramujos}

Baseados nas generalizações de que detritos orgânicos e perifiton constituem a principal fonte de alimento para os caramujos, foram testados no passado moluscicidas sistêmicos considerados de "alta especificidade" contra moluscos e inócuos para as algas e macrófitas. Faltava na ocasião conhecimento básico sobre o perifiton como alimento de planorbídeos. Sabia-se contudo que $B$. glabrata cresce e se reproduz no campo, em gaiolas submersas, sem outro alimento senão o produzido dentro da própria gaiola (Freitas, 1973) e que este alimento foi identificado como perifiton e quantificado o seu consumo por $B$. tenagophila (Santos, 1985). Os dados indicaram que não houve seletividade dos caramujos por espécies de perifitons.

Fato semelhante foi observado por Nogueira et al. (1980). As algas mais frequientes e mais abundantes nas macrófitas foram as mesmas encontradas no trato digestivo de $B$. glabrata. Não houve seletividade, mas variação mensal no número de gêneros de perifiton e uma sucessão contínua no número e na estrutura em espécies. Houve meses em que os caramujos ingeriram cerca de dez gêneros de 
algas perifíticas e em outros meses 40; sendo que o número de gêneros por macrófita no ano, variou de 74 a 82 . Por outro lado, as altas densidades de $M$. tuberculata na Pampulha e de $B$. straminea no Nordeste seriam dificilmente explicadas se houvesse seletividade, ou se a pastagem dos moluscos não estimulasse a produção de perifiton e ainda mais se não houvesse uma relação simbiótica entre estes organismos (Thomas \& Tait, 1984; Santos, 1985).

Há necessidade de melhor conhecimento da dieta a fim de contribuir para elucidar os mecanismos que envolvem a regulação e controle das populações de caramujos, inclusive conhecimento sobre as algas tóxicas do hábitat e as plantas terrestres de seus arredores, que podem lançar folhas ou frutos tóxicos no meio aquático. Há necessidade também de revisão da importância que é dada a cadeia alimentar. Parte-se do princípio de que todos os organismos obtêm energia, através da ingestão de outros organismos. Este enfoque é simplista e pode dar informações equivocadas. Bastaria examinar os conteúdos estomacais e saber como funcionam os sistemas modulares aquáticos. No entanto, pequenos organismos permanecem viáveis após terem sido ingeridos e a matéria orgânica dissolvida ("DOM" - Thomas, 1990) é também importante componente da dieta. Por outro lado, algas e bactérias não-digeridas têm uma relação simbiótica com os caramujos e fungos que se desenvolvem à custa de detritos que servem de alimento para os jovens.

Tem-se que ter uma visão holística dos sistemas modulares que leve em conta tanto as interações positivas como as negativas como predação e competição para entender os mecanismos nos sistemas modulares ou nos ecossistemas (Thomas, 1990). Por último, ao se usarem moluscos como competidores, levando-se em conta sua alta capacidade de ingerir e assimilar detritos orgânicos, matéria orgânica dissolvida e algas de águas poluídas, poder-se-ia pensar em estender sua ação ao controle da qualidade da água. Para tanto seria necessário acrescentar mais um elo na cadeia alimentar dos corpos d'água, hábitats de moluscos hospedeiros de Schistosoma spp. Tal elo poderia ser representado por peixes, aves ou outro organismo eficiente predador destes moluscos.

\section{REFERÊNCIAS BIBLIOGRÁFICAS}

ANDRADE, R. M. \& CARVALHO, O. S., 1972. Alimentação e fecundidade de planorbídeos criados em laboratório. I. Biomphalaria tenagophila (D'Orbigny, 1835). Pulmonata, Planorbidae. Revista Brasileira de Biologia, 32: 225-233.

BAPTISTA, D. F. \& JURBERG, P., 1993. Factors conditioning the habitat and the density of Biomphalaria tenagophila (Orbigny, 1835) in an isolated schistosomiasis focus in Rio de Janeiro City. Memórias do Instituto Oswaldo Cruz, 88: 457-464. 
BARBOSA, F. S. \& SILVA, G. M., 1951. Curvas de crescimento de Australorbis glabratus e sua aplicação à epidemiologia e à profilaxia da esquistossomose. Publicações Avulsas do Instituto Aggeu Magalhães, 1: 35-42.

BARBOSA, F. S.; PEREIRA da COSTA , D. P. \& ARRUDA, F., 1985.Competitive interactions between species of freshwater snails I. laboratory. I. C. Comparative survival of Biomphalaria glabrata and B. straminea kept out of water. Memórias do Instituto Oswaldo Cruz, 80: 155157.

BARBOSA, F. S. \& OLIVIER, L., 1958. Studies on the snail vectors of bilharziasis mansoni in northeastern Brazil. Bulletim of the World Health Organization, 18: 895-908.

BARBOSA, F. S.; SANCHES, O.; BARBOSA, C. S. \& ARRUDA, F., 1992. Dynamics of snail populations of Biomphalaria glabrata and $B$. straminea under semi-natural conditions. Cadernos de Saúde Pública, 8: 157-167.

BOVBJERG, R. V., 1968. Response to food in Lymnaeid snails. Physiological Zoology, 41 : 412 423.

BRONMARK, C., 1989. Interactions between epiphytes, macrophytes and freshwater snails: a review. Journal of Molluscan Studies, 55: 299-311.

BRUMPT, E., 1941. Observations biologiques diverses concernant Planorbis (Australorbis) glabratus hôte intermédiaire de Schistosoma mansoni. Annals of Parasitology, 18: 9-45.

CHERNIN, E. \& MICHELSON, E. H., 1957. Studies on the biological control of schistosome bearing snails. III. The effects of populations density on growth and fecundidty in Australorbis glabratus. American Journal of Hygiene, 65: 57-71.

CALOW, P., 1974. Some observations on locomotory strategies and their metabolic effects in two species of freshwater gastropods, Ancylus fluviatilis Müll. and Planorbis contortus Linn. Oecologia, 16: 146-161.

, 1975. The feeding strategies of two freshwater gastropods, Ancylus fluviatilis Müll. and Planorbis contortus Linn. (Pulmonata), in terms of ingestion rates and absorption efficiencies. Oecologia, 20: 33-49.

CATTANEO, A., 1983. Grazing on epiphites. Limnology and Oceanography, 28: 124-132.

CHIQUILOFF, M. A. G.; SCHERRER, J. F. \& FREITAS, J. R., 1978. Estudo preliminar das variedades xadrezadas de Biomphalaria glabrata (Say, 1818) em confronto com as variedades pigmentada e albina. Revista do Instituto de Medicina Tropical de São Paulo, 20: 22-30.

CROLL, R. P., 1983. Gastropod chemoreception. Biological Reviews of the Cambridge Philosophical Society, 58: 293-319.

CUKER, E. B., 1983. Competition and coexistence among the grazing snail Lymnaea, Chironomidae, and microcustacea in an Arctic epilithic lacustrine community. Ecology, 64: 1015.

ETGES, F: J. \& RITCHIE, L. S., 1966. Comparative observations on growths rate and reprodution of Australorbis glabratus in field and laboratory conditions. Bulletim of the World Health Organization, 34: 963-967.

ETGES, F. J. \& FRICK, L. P., 1966. An experimental field study of chemoreception and response in Australorbis glabratus (say) under rheotactic conditions. American Journal of Tropical Medicine and Hygiene, 15: 434-438. 


\section{TÓPICOS EM MALACOLOGIA MÉDICA}

FREITAS, J. R., 1973. Ritmo de Crescimento da Biomphalaria glabrata. Padronização da Técnica de Criação. Tese de doutorado, Belo Horizonte: Instituto de Ciências Biológicas, Universidade Federal de Minas Gerais.

FREITAS, J. R., 1976. Ecologia dos vetores de doenças, o hábitat primitivo da Biomphalaria glabrata. Ciência e Cultura, 28: 212-217.

FREITAS, J. R.; RESENDE, E. S.; JUNQUEIRA, D. V.; COSTA, A. M. \& PELEGRINO, J., 1975. Criação em massa e ritmo de crescimento da Biomphalaria glabrata. Ciência e Cultura, 27: 968-974.

FREITAS, J. R.; ALVES, C. W.; JÚNIOR P. DE MARCO; ROCHA, L. A. \& SANTOS, M. B. L., 1990. Preferência de hábitat da Biomphalaria straminea. Ciência e Cultura, 42: 667-68. (ANAIS DA SBPC).

GERKEN, S. E., 1977. Efeitos da Alimentação e da Densidade Populacional sobre o

Crescimento, a Sobrevivencia e a Fecundidade de Biomphalaria glabrata (Say, 1818). Tese de mestrado, Belo Horizonte: Universidade Federal de Minas Gerais.

GUIMARÃES, C. T., 1981. Algumas observações de campo sobre biologia ecologia de Pomacea haustrum. Memórias do Instituto Oswaldo Cruz, 76: 343-51.

HARMAN, W. N., 1972. Benthic substrates: their effect on freshwater mollusca. Ecology, 53: 271-277.

HUNTER, R. D., 1980. Effects of grazing on the quantity and quality of freshwater aufwuchs. Hidrobiologie, 69: 251-259.

HUNTER, R. D., 1983. Bioenergetic and community changes in intertidal aufwuchs grazed by Littorina Littorea. Ecology, 64: 761-769.

KEHDE, P. M. \& WILHM, J. L., 1972. The effects of grazing by snails on community structure of periphyton in laboratory streams. American Midland Naturalist, 87: 8-24.

KLUMP, R. K. \& CHU, K. Y., 1980. Importance of the aquatic weed Ceratophylum to transmission of Schistosoma haematobium in the Volta Lake, Ghana. Bulletin of the World Health Organization, 58: 791-799.

KOHN, A. J., 1961. Chemoreception in gastropod molluscos. American Zoologist, 1: 291-309.

KOLODZIEJCZYK, A., 1984. Occurrence of gastropoda in the lake littoral and their role in the production and transformation of detritus. I. Snails in the littoral of Mikolajskie Lake - general characteristics of occurrence. Ekologia Polska, 32: 441-488.

MALEK, E. A., 1985. Snail hosts of Schistomiasis and other snail transmitied diseases in Tropical América: a manual. OMS. Washington, DC: Scientific Publication $n^{\circ} 478$.

McMAHON, R. F.; HUNTER, R. D. \& RUSSEL-HUNTER, W. D. 1974. Variation in aufwuchs at six freshwater habitats in terms of carbon biomass and of carbon: nitrogen ratio.

Hydrobiologia, 45: 391-404.

MICHELSON, E. H., 1960. Chemoreception in the snail Australorbis glabratus. American Journal of Tropical Medicine and Higiene, 9: 480-487.

MOORE, D. V.; THILLET, C. J.; CARNEY, D. M. \& MELENEY, H. E., 1953. Experimental infection of Bulinus truncatus with Schistosoma haematobium. Journal of Parasitology, 39: 215-22.

NOGUEIRA, M. L. R.; CAVENAGHI, T. M. C. M.; GONTIJO, T. A. \& FREITAS, J. R., 1980. Perifiton de macrohidrófitas como alimento de Biomphalaria glabrata. Ciência $e$ Cultura, 32 (Supl.): 500. 
PARAENSE, W. L., 1970. Planorbídeos hospedeiros do Schistosoma mansoni. In: Esquistossomose mansoni (A.S. Cunha, ed.), $1^{2}$ ed., pp. 13-30, São Paulo: USP.

PELLEGRINO, J. \& KATZ, N., 1968. Experimental chemoterapy of Schistosomiasis mansoni. In: Advances in Parasitology (D. Ben, ed.), pp. 233-290, London: Academic Press.

PIERI, O. S. \& THOMAS J. D., 1987. Snail host control in the eastern coastal areas of North East Brasil. Memórias do Instituto Oswaldo Cruz, 82: 197-201.

PIMENTEL, D. \& WHITE, P. C., 1959. Biological environment and habits of Australorbis glabratus. Ecology, 40: 541-549.

PIMENTEL-SOUZA, F.; BARBOSA, N. D. C. \& RESENDE, D. F., 1990. Effect of temperature on the reproduction of the snail Biomphalaria glabrata. Brazilian Journal of Medical and Biological Researche, 23: 441-449.

PIP. E. \& STEWART, J. M., 1976. The dynamics of two aquatic plant - snail associations. Canadian Journal of Zoology, 54: 1192-1205.

POINTIER, J. P. \& MCCULLOUGH, 1989. Biological control of the snail hosts of Schistosoma mansoni in the Caribbean area using Thiara spp. Acta Tropica, 46: 147-155.

POINTIER, J. P.; TOFFART, J. L. \& LEFEVRE, M., 1991. Life tables of freshwater snails of the genus Biomphalaria (B. glabrata, B. alexandrina, B. straminea) and of one of its competitors Melanoides tuberculata under laboratory conditions. Malacologia, 33: 43-54.

PORTER, K. G., 1977. The plant animal interface in freshwater ecosystems. American Scientist, 65: $159-170$.

REY, L., 1959. Monografia sobre Esquistossomose mansoni. Biologia. Condiçōes gerais de vida. Revista Brasileira de Malariologia e Doenças Tropicais, 11: 151-170.

RITCHIE, L. S.; BERRIOS-DURAN, L. A. \& DEWEESSE, R., 1963. Biological potencials of Australorbis glabratus growth and maturation. American Journal of Tropical Medicine and Hygiene, 12: 264-68.

ROSEMBERG, B.; REY, L. \& PIERI, O. S., 1992. Fecundity of Biomphalaria straminea and B. glabrata in the laboratory: a twelve-month comparative study. Memórias do Instituto Oswaldo Cruz, 87: 223-32.

RUSSEL-HUNTER, W. D., 1978. Ecology of freshwater Pulmonates. In: Pulmonates. Systematics, Evolution and Ecology (V. Fretter \& J. Peake cols.), Cap. 8, Vol. 2A, London: Academic Press.

SANTOS, M. B. L., 1985. Preferência Alimentar e Consumo de Perifiton do Caramujo B. tenagophila (Gastropoda Planorbidae). Tese de mestrado, Brasília: Instituto de Ciências Biológicas, Universidade de Brasília.

SANTOS, M. B. L. \& FREITAS, J. R., 1986. Consumo quantitativo e qualitativo e qualitativo de perifiton colonizado em substrato Artificial, por Biomphalaria tenagophila. Memórias do Instituto Oswaldo Cruz, 81: 359-364.

SANTOS, M. B. L. \& FREITAS, J. R., 1987. Biomphalaria tenagophila feedind Behavior. Memórias do Instituto Oswaldo Cruz, 82: 307-309.

SANTOS, M. B. L. \& FREITAS, J. R., 1988. Preference of Biomphalaria tenagophila among macrophytes and their periphytons determined through the degree of attractiveness. Revista do Instituto de Medicina Tropical de São Paulo, 30: 264-269.

SENNA, I. A. \& VIEIRA, E. C., 1970. Culture of the snail Biomphalaria glabrata ou a simplified medium. American Journal of Tropical Medicine and Hygiene, 19: 568-70. 
SOUZA, C. P.; DIAS, E. P.; AZEVEDO, M. L. L. \& PAULINI, E., 1979. Observações sobre alguns fatores que influem na manutenção do Schistosoma mansoni em laboratório. Revista Brasileira de Pesquisas Médicas e Biológicas, 12: 411-419.

SOUZA, C. P.; GAZZINELLI, G.; ARAÚJO, N.; CRUZ, O. F. R. \& SILVA, C. R. T., 1985. Criação de caramujos infectados para obtenção em massa de cercárias e esquistossômulos. Memórias do Instituto Oswaldo Cruz, 80: 55-81.

STANDEN, O. D., 1951. Some observation upon maintenance of Australorbis glabrata in the laboratory. Annals of Tropical Medicine and Parasitology, 45: 80-83.

STERRY, P. R.; THOMAS, J. D. \& PATIENCE, R. L., 1983 - Behavioural responses of Biomphalaria glabrata to chemical factors from aquatic macrophytes includind decaying Lemna paucicostada. Freshwater Biology, 13: 466-476.

STURROCK, R. F., 1974. Ecological notes on hábitats of the freshwater snail Biomphalaria glabrata intermediate host of Schistosoma mansoni on St. Lúcia, West Indies. Caribbean Journal of Science, 14: 149-162.

SZUMLEWIC, A. P., 1958. Studies on the biology of Australorbis glabratus, a schistosomebearing brazilian snail. Revista Brasileira de Malariologia e Doenças Tropicais, 10: 459-529.

TEESDALE, C., 1962. Ecological observations on the molluscs of significance in the transmission of Bilharziasis in Kenya. Bulletin of the World Health Organization, 27: 759-782.

THERON, A. \& GERARD, C., 1994. Development of accessory sexual organs in Biomphalaria glabrata (planorbidae) in relation to timing of infection by Schistosoma mansoni. Consequences for energy utilization patterns by the parasite. Journal of Molluscan Studies, 60: 25-31.

THOMAS, J. D.; GREALY, B.\& FENNELL, C. F., 1983. The effects of varying the quantity and quality of various plants on feeding and growth of Biomphalaria glabrata (gastropoda). Oikos, $41: 77-90$.

THOMAS, J. D., 1987. An evoluation of the interactions between freshwater pulmonate snail hosts of human schistosomes and macrophytes. Philosophical Transactions of the Royal Society of London, 315: 75-125.

THOMAS, J. D., 1990. Mutualist interations in freshwater modular sistems with molluskan components. Advances in Ecological Research, 20: 125-178.

THOMAS, J. D. \& TAIT, A. J., 1984. Control of the snail hosts of Schistosomiasis by environmental manipulation: a field and laboratory appraisal in the Ibadan Área, Nigéria. Philosophical Transactions of the Royal Society of London, 305: 201-253.

TOWNSEND, C. R., 1975. Strategic aspects of time allocation in the ecology of a freshwater pulmonate snail. Oecologia, 19: 105-115.

XAVIER, M. L. S. \& FRAGA DE AZEVEDO, J. A., 1968. Importance d'Oscillatoria formosa dans la culture au laboratoire des molusques vectors du Schistosoma haematobium. Bulletin de la Societé de Pathologie Exotique, 61: 52-66.

*José Rabelo de Freitas

*Mairy Barbosa Loureiro dos Santos

*Departamento de Biologia Geral, ICB, Universidade Federal de Minas Gerais Av. Antônio Carlos, 6627, Belo Horizonte, Minas Gerais, Brasil 